
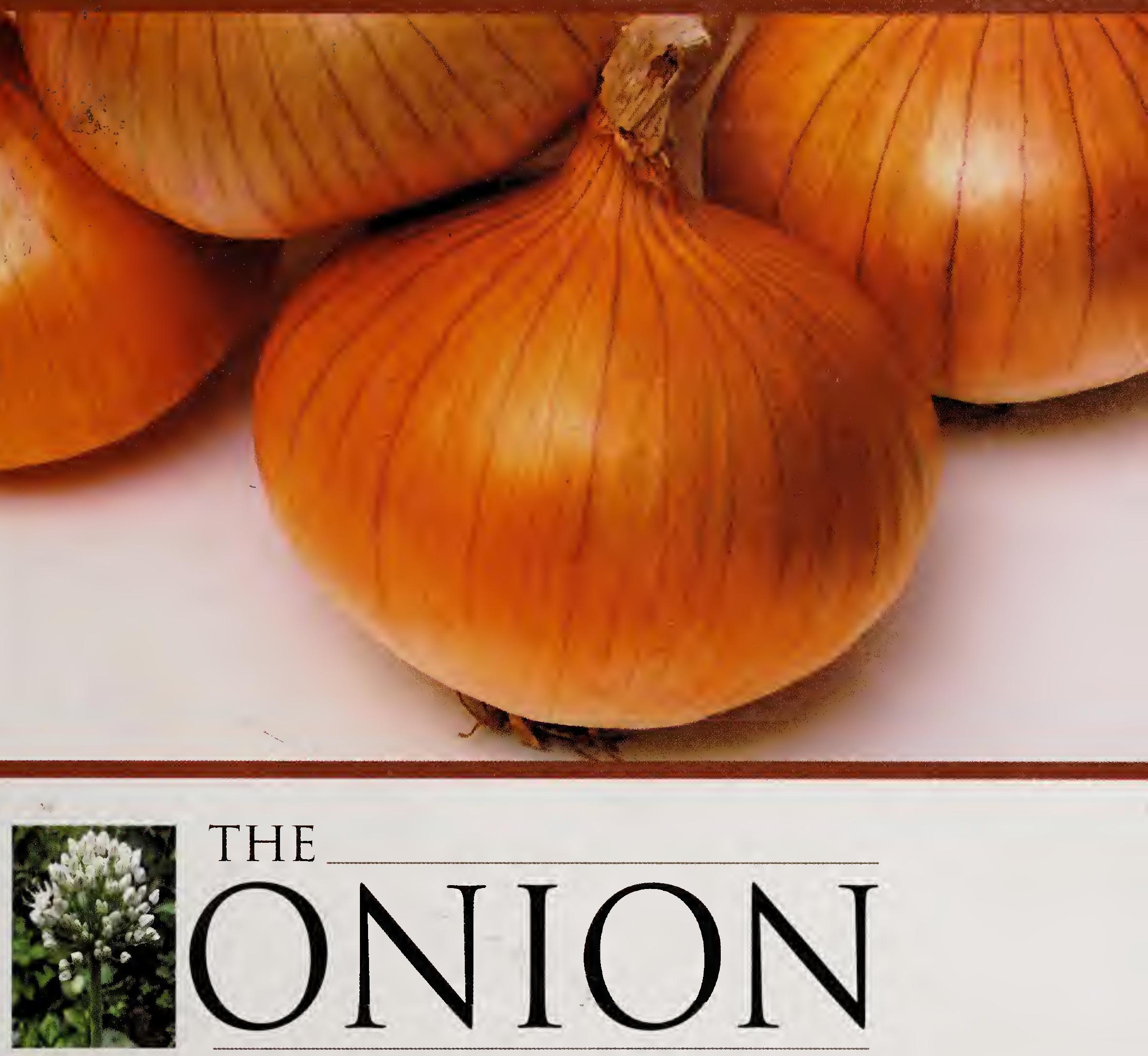

THE

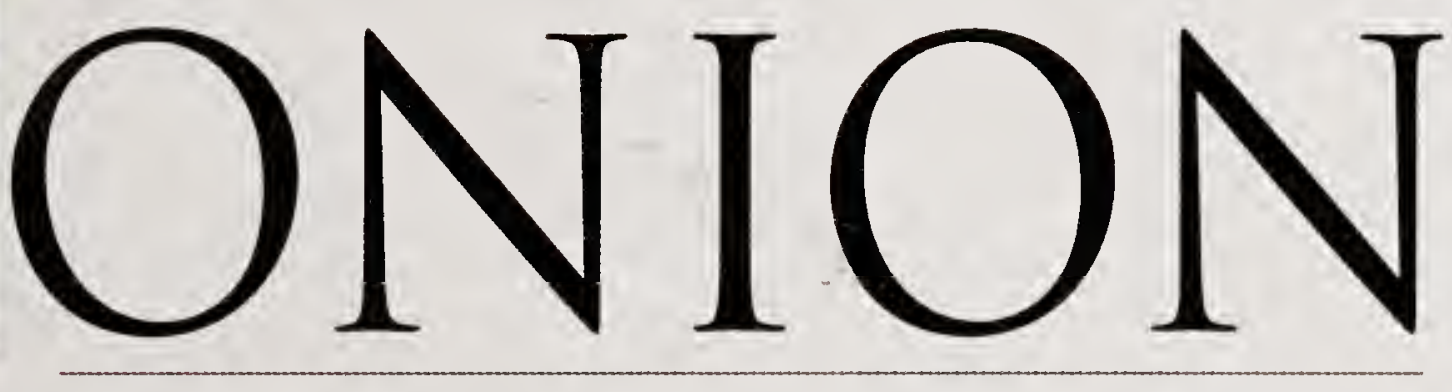

- N K Krishna Kumar - Jai Gopal - V A Parthasarthy

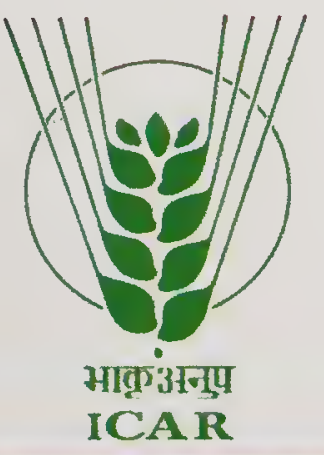

Indian Council of Agriculfural Research

New Delhi 

.

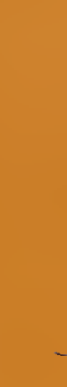



The Onion 



\section{The Onion}

Editors

N. K. Krishna Kumar

Jai Gopal

V. A. Parathasarathy

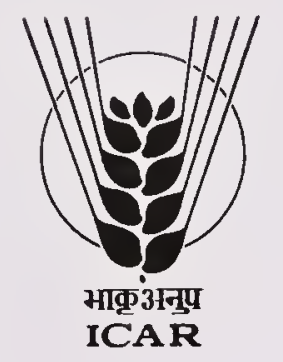

Published by

ICAR-Directorate of Knowledge Management in Agriculture Indian Council of Agricultural Research

Krishi Anusandhan Bhavan, Pusa

New Delhi 110012 


\author{
Project Director (DKMA) : Dr Rameshwar Singh \\ Incharge (English Editorial Unit) : Dr Aruna T. Kumar \\ Editor (English) : Shashi A. Verma \\ Chief Production Officer : Dr V. K. Bharti \\ Assistant Chief Technical Officer : Ashok Shastri
}

\author{
All Rights Reserved \\ (C)2015, Indian Council of Agricultural Research \\ New Delhi
}

ISBN: $978-81-7164-159-8$

Price: ₹ 900

\title{
DISCLAIMER
}

While every attempt has been made to publish reliable data and information. Neither the scientists involved nor the editorial board and ICAR assume any responsibility for the consequences arising as a result of this monograph.

Published by Dr Rameshwar Singh, Project Director, ICAR-Directorate of Knowledge Management in Agriculture, Indian Council of Agricultural Research, Pusa, New Delhi 110 012, lasertypeset at M/s Xpedite Computer Systems 201, Patel House B-11, Ranjeet Nagar, Commercial Complex, New Delhi 110 008, and printed at M/s Chandu Press, D-97, Shakarpur Delhi 110092. 


\section{Foreword}

Onion is an important vegetable-cum-condiment. Humorously said "Onion brings tears to policy-makers when it is absent (in the market) and rocks administration". Thus is the importance of this crop.

Onion belongs to the genus Allium, which is one of the oldest cultivated plant species. Onion and garlic are the most important crops in use as an ingredient in various dishes since ages by many cultures across the world. India is the second largest producer of onion after China. It is estimated that onion is grown in India over 9.92 lakh hectares (22.4\% of the world area) with a total production of 166.54 lakh tonnes. Maharashtra, Karnataka, Gujarat, Bihar, Madhya Pradesh, Rajasthan, Andhra Pradesh and Tamil Nadu are the main onion-growing states. In general, barring north-easten states and Kerala, all other states grow onion. Onion consumption is very common in our daily dietary habits and any fluctuation in its price has great ramifications at the National level.

Systematic research on onion was started in 1960 at Pimpalgaon, Baswant and Nashik and later at the Indian Agricultural Research Institute (IARI), New Delhi, and Indian Institute of Horticultural Research (IIHR), Bengaluru. With the establishment of the National Research Centre for Onion and Garlic (NRCOG), later christened as the Directorate of Onion and Garlic Research (DOGR), the research on onion intensified further. The DOGR is also the nodal agency for the All-India Network Research Project on Onion and Garlic (AINRPOG). The National Horticultural Research and Development Foundation (NHRDF), Nashik, is another organization contributing significantly in research and development of onion in the country. These all efforts have led to the development of a very strong research base in India. The DOGR at Rajgurunagar (Maharashtra) coupled with AINRPOG is doing yeoman service to onion-growers.

I congratulate Dr N.K. Krishna Kumar, Dr Jai Gopal and Dr V.A. Parthasarathy for editing this great monograph on onion. The chapters have been contributed by well-known experts in the field. I congratulate the DKMA for bringing out this publication. The book has been thoughtfully organized, covering all aspects of onion. I am sure this would be of great interest to all onion-workers around the world as well as students, researchers and policy-makers in India.

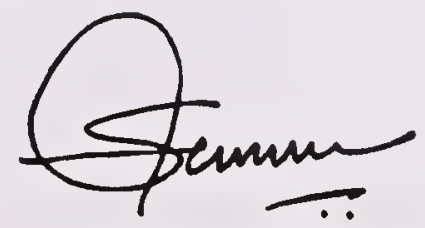

(S. Ayyappan)

Secretary, DARE and Director General, ICAR 
Digitized by the Internet Archive in 2018 


\section{Preface}

Onion is an important component of the daily intake throughout the world, particularly in the South Asia, where no culinary preparation is complete in itself if onion is not included. Onion believed to have originated in the Central Asia (around Turkmenistan-Afghanistan) is currently cultivated all-over the world under the short-day and long-day conditions. It is the single commodity exported in large quantities from India, and is also one among the market-sensitive items that can create ripples in the trade. However, it does not mean that it is less important in the domestic market; its demand is increasing day-by-day in India too as consumers are realizing its multiple utilities-medicinal, therapeutic, etc. It is a common food item for the rich and the poor, but its price volatility often renders it beyond the reach and means of the common man. Low productivity, poor seed quality, skewed cultivation and artificial scarcity are some of the pointers, which since long are demanding attention.

Onion has been in cultivation in India for decades but formal efforts on its R\&D were initiated in 1960 at Pimpalgaon, Baswant and Nashik by the State Department of Horticulture, Government of Maharashtra. Later systematic research was conducted and is still continuing at the Indian Agricultural Research Institute, New Delhi; Indian Institute of Horticultural Research, Bengaluru and the National Horticultural Research and Development Foundation, Nashik. To give further impetus to research on onions, the Indian Council of Agricultural Research established a National Research Centre for Onion and Garlic in 1994 and an AllIndia Network Research Project (AINRP) on Onion and Garlic was initiated in 2009 to validate stability and adoptability of different production technologies. Over the years, R\&D efforts have made significant impact through development of varieties, and various production/protection and post-harvest management technologies. Innovative farmers and private sector undertakings have also contributed significantly in production and overall development of onion-crop in India. Still large gaps do exist in overall understanding of onion production, protection, post-harvest handling, marketing and value-addition.

In the National Workshop of All-India Network Research Project on Onion and Garlic at the Bidhan Chandra Krishi Vishwa Vidyalya, Kalyani, West Bengal, in April 2013, a need was felt for an Indian publication on the Onion, capturing significant research findings with comprehensive presentation. This book "The Onion" is the translation of that vision. This compilation is perhaps the first of its kind and covers most of the R\&D on the onion in India.

This volume has been divided into 18 Chapters focussing on different aspects 
of topical interest-Genetic Resource Management, Genetics, Breeding, Biotechnology and Development of Varieties; Technologies on Crop Production and Protection; Post-harvest Management and Value-addition; and Marketing and Export. A highlight has been the market analysis and the factors influencing onion price stability. Relevant data in all the chapters have been suitably supplemented with tables and graphical presentations. Efforts have also been made to bring uniformity in the contents of the chapters. The information contained here is a reflection of the decades of painstaking research. The editorial board is especially indebted to all the authors who have put in their best efforts in gathering relevant information from all possible sources.

We are extremely thankful to Dr S Ayyappan, Secretary, DARE, Government of India and Director General, ICAR, for his support and encouragement. We are highly thankful to the Directorate of Knowledge Management in Agriculture, ICAR, New Delhi, for publishing this valuable tome. We acknowledge the valuable suggestions of our colleagues, Drs Ranvir Singh, B.K. Pandey and Vikramaditya Pandey at the Horticultural Science Division of the ICAR Headquarters, New Delhi. The help rendered by Dr E. Srinivas Rao, IIHR, Bengaluru; Shri Dhiraj K. Sharma, CISH, Lucknow and Mrs Shashi A. Verma, DKMA, New Delhi, was invaluable. The technical support provided by Shri Shaikh, Horticultural Science Division, in day-to-day handling of the manuscript is duly acknowledged.

Although we have tried our best to present this treasure of information in as perfect a manner as possible, it is open to improvement. As editors, we have tried to make the presentation comprehensive and error-free, but should the readers find any lacunae, we would be happy to address them in revised editions.

N. K. Krishna Kumar Jai Gopal

V. A. Parathasarathy 


\section{Acronyms}

\begin{tabular}{|c|c|}
\hline AFLP & : Amplified Fragment Length Polymorphism \\
\hline AINRP & : All-India Network Research Project \\
\hline AINRPOG & : All-India Network Research Project on Onion and Garlic \\
\hline ANS & : anthocyanidin synthase \\
\hline $\mathrm{BAC}$ & : Bacterial Artificial Chromosome \\
\hline BBF & : broad-based furrow \\
\hline CA & : Controlled Atmosphere \\
\hline CAPS & : Cleaved Amplified Polymorphic Sequences \\
\hline CERRA & : Centre Régional de Recherche Agronomique \\
\hline CGMS & : Cytoplasmic-genic male-sterility system \\
\hline $\mathrm{CHI}$ & : Chalcone Isomerase \\
\hline $\mathrm{CISH}$ & : Central Institute for Subtropical Horticulture \\
\hline CMIE & : Centre for Monitoring Indian Economy \\
\hline CMS & : Cytoplasmic Male Sterility \\
\hline CNRA & : Centre National de Recherche Agronomique \\
\hline COMAV & : Centre for the Conservation and Breeding of the Agrodiversity \\
\hline CPE & : Cumulative Pan Evaporation \\
\hline CRA & : Centre de Recherche Agronomique \\
\hline CRREA & : Centre Régional de Recherches Environnementales et Agricoles \\
\hline CTD & : Cumulative Thrips Days \\
\hline $\mathrm{CV}$ & : Coefficient of Variation \\
\hline DARE & : Department of Agricultural Research and Education \\
\hline DAS & : Days After Storage \\
\hline DFR & : Dihydroflavonol 4-reductase \\
\hline DKMA & : Directorate of Knowledge Management in Agriculture \\
\hline DOGR & : Directorate of Onion and Garlic Research \\
\hline EST & : Expressed Sequence Tags \\
\hline FAA & : Free Amino Acids \\
\hline FOS & : Fructo-oligosaccharides \\
\hline GAP & : Good Agricultural Practices \\
\hline GBNV & : Groundnut Bud Necrosis Virus \\
\hline GC & : Galanthum-Cytoplasmic \\
\hline GCA & : General Combining Abilities \\
\hline $\mathrm{GCV}$ & : Genotypic Coefficient of Variation \\
\hline GISH & : Genome In-situ Hybridization \\
\hline HRI & : Horticulture Research International \\
\hline IARI & : Indian Agricultural Research Institute \\
\hline
\end{tabular}




\begin{tabular}{|c|c|}
\hline IASRI & : Indian Agricultural Statistics Research Institute \\
\hline ICAR & : Indian Council of Agricultural Research \\
\hline IDM & : Integrated Disease Management \\
\hline IIHR & : Indian Institute of Horticultural Research \\
\hline INM & : Integrated Nutrient Management \\
\hline IPGRI & : International Plant Genetic Resources Institute \\
\hline IR & : Infrared Radiation \\
\hline ISSR & : Inter Simple Sequence Repeat \\
\hline IWM & : Integrated Weed Management \\
\hline IYSV & : Iris Yellow Spot Virus \\
\hline KVK & : Krishi Vigyan Kendra \\
\hline $\mathrm{MBC}$ & : Minimum Bactericidal Concentration \\
\hline MH & : Maleic Hydrazide \\
\hline MIC & : Minimum Inhibitory Concentration \\
\hline MPKV & : Mahatma Phule Krishi Vidyapeeth \\
\hline NAFED & $\begin{array}{l}\text { National Agricultural Co-operative Marketing Federation of } \\
\text { India Ltd }\end{array}$ \\
\hline NCBI & : National Centre for Biotechnology Information \\
\hline NHRDF & : National Horticultural Research and Development Foundation \\
\hline NPC & : Nominal Protection Coefficients \\
\hline NRCOG & : National Research Centre for Onion and Garlic \\
\hline NSSO & : National Sample Survey Organization \\
\hline $\mathrm{OP}$ & : Open Pollinated \\
\hline ORF & : Open Reading Frames \\
\hline OYDV & : Onion Yellow Dwarf Virus \\
\hline PCV & : Phenotypic Coefficient of Variation \\
\hline PEG & : Polyethylene Glycol \\
\hline PHL & : Post-harvest Losses \\
\hline $\mathrm{PMC}$ & : Pollen Mother Cell \\
\hline PMI & : Phosphomannose Isomerase \\
\hline PPP & : Public Private Partnership \\
\hline PSB & : Phosphorus-solublizing Bacteria \\
\hline QTL & : Quantitative Trait Loci \\
\hline RAPD & : Random Amplified Polymorphic DNA \\
\hline RFLP & : Restriction Fragment Length Polymorphism \\
\hline RILs & : Recombinant Inbred Lines \\
\hline SCA & : Specific Combining Abilities \\
\hline SCAR & : Sequence Characterized Amplified Region \\
\hline SDD & : Stimulo-deterrent-diversion \\
\hline SEM & : Scanning Electron Microscope \\
\hline SNP & : Single Nucleotide Polymorphism \\
\hline SSC & : Soluble Solids Content \\
\hline SSR & : Simple Sequence Repeat \\
\hline TNAU & : Tamil Nadu Agricultural University \\
\hline WGRU & : Warwick Genetic Resources Unit \\
\hline
\end{tabular}




\section{Contents}

Foreword

Preface vii

Acronyms ix

Chapter 1 Origin, History and Distribution 1

- K.E. Lawande

Chapter 2 Onion R\&D in India-Status and Prospects 9

- J. Gopal and A.A. Murkute

Chapter $3 \quad$ Biosystematics, Botany and Genetic Resources 30

- Vijay Mahajan, K.S. Negi and A.J. Gupta

Chapter 4 Genetics and Breeding of Open-pollinated Varieties

- E. Sreenivasa Rao, Vijay Mahajan and C.S. Pathak

Chapter 5 Breeding for Hybrid Technology

- Amar Jeet Gupta, R. VeereGowda and Vijay Mahajan

Chapter 6 Aggregatum Onion and Shallots

- P. Paramaguru, M. Velmurugan and L. Pugalendhi

Chapter 7 Biotechnology

- D.C. Lakshmana Reddy, S. Anandhan and C. Aswath

Chapter 8 Production Technology

- V. Sankar, P.C. Tripathi, K.E. Lawande and A.N. Ganeshamurthi

Chapter 9 Nutrient Management

- R. Palaniappan and A. Thangasamy

Chapter 10 Seed Production

- R.P. Gupta and H.P. Sharma

Chapter 11 Onion Seed Industry and Trade

- Suresh O. Agrawal

Chapter 12 Fungal Diseases

- S.J. Gawande 
Chapter 13 Viral Viruses

- K.S. Ravi, Muktha Raghuram and Mahesh Shekar

Chapter 14 Insect and Nematode Pests

- P.S. Srinivas and N.K. Krishna Kumar

Chapter 15 Post-harvest Management and Processing

- A.A. Murkute and Kalyani Gorrepati

Chapter 16 Biochemistry and Nutraceutical Properties

- Shamina Azeez and K.S. Shivashankara

Chapter 17 Marketing and Export

- T.M. Gajanana and D. Sreenivasa Murthy

Chapter 18 Onion Production and Price Volatility: Implications for Technology and Policy

- Ramesh Chand, Raka Saxena and Sanjay Chayal

Contributors

Subject Index 


\title{
Origin, History and Distribution
}

\author{
K.E. Lawande
}

Many of the oldest cultivated plant species belong to genus Allium. Onion and garlic are important vegetable crops of this genus, and are used as ingredients in many of the dishes around the world since thousands of years back. World's onion production has steadily increased, and onion has become the most important horticultural crop, after tomatoes. There are several varieties of onion-red, brown, yellow, white and green, ranging from very strong smelled to mild and sweet. Onions can be eaten raw, and can be cooked, fried, dried or roasted. Besides, being used as a food item, onions are valued for their therapeutic effects. Onions were described by Charak in Charak Samhita (300 BC) and in Shusruta (AD 300) as medicine for diuretic, for good digestion and heart, and for eyes and joint problems. In Chinese medicine, onions are being used to treat angina, cough, bacterial infection and breathing problems. Early American settlers used wild onions to treat cold, cough and asthma, and also to repel insects. Modern concept of medicine also recognizes importance of onions in the following, such as lowering blood sugar, curing cardiovascular problems, improving gastrointestinal health, fighting cholera, preventing hair loss, improving bone health, curing tooth disorders and urinary disorders, and in prevention of blood-clot formation. Onions are also used as an antibacterial and aphrodisiac substance.

\section{Historical perspective}

The onion is being cultivated for the last 5,000 years the worldover. It was grown in Chinese gardens almost 5,000 years back. In Egypt, onions are traced back to $2500 \mathrm{BC}$. There is a clear evidence that the Sumerians were cultivating onions as early as 2500 BC. One Sumerian report dating back $2500 \mathrm{BC}$, indicates someone sloughing over city-governor's onion patch. Egyptians worship onions since it symbolizes eternity; they burned onions along the Pharaohs. Paintings of onions are on the inner walls of the pyramids and in tombs of both Old and New Kingdoms. Onions have been mentioned as a funeral offering, and are depicted on the banquet tables of great feast.

In the Bible, onions are mentioned to have been eaten by the Israelites. In numbers 11: 5 of the New International Version of Holy Bible, the children of Israel lament meagre desert diet enforced by the Exodus: "We remember the fish, which we eat in Egypt freely, the cucumbers, and the melons and the leeks and the onions and garlic". In ancient Greece, athletes ate large quantities of onions as it was believed to lighten balance of blood. Roman gladiators were rubbed down with onions to give firmness to their muscles. 
In Bhagavad Gita, Krishna narrates foods which are too bitter, too sour, salty, hot, pungent, dry and burning are dear to those in the mode of passion (those who are Rajasic). Such food causes distress, misery and diseases. Onion and garlic are in this category. They excite baser instincts and make it difficult for one to control senses. The prohibition on onion and garlic is implicit by virtue of their characteristics. Historical and cultural significance of onions have been well documented in Garuda Purana (Shastri, 1995) where it is regarded as Rajasic (of aphrodisiac quality).

While describing ancient recorded history of onion in India, Swarup (2006) gave the following chronological order of events.

\begin{tabular}{ll}
\hline Period & Record \\
\hline Vedic period 15,000-1,000 BC & Rigveda, Yajurveda, Atharvaveda \\
Apastamba 860-300 BC & Apastamba Dharma Sutra I \\
Charak 600 BC & Charak Samhita \\
Patanjali 200 BC & Patanjali \\
Shusruta AD 300-400 & Shusrut Samhita \\
Gupta period AD 606-648 & Chinese travelers' memoirs \\
Insting AD 671-695 & Chinese travelers'memoirs \\
Mughal period AD 1556-1605 & Ain-i-Akbari \\
\hline
\end{tabular}

An old Turkish legend says that when Satan was thrown out of heaven, garlic sprouted where he first placed his left foot, and onions grew where he placed his right foot.

\section{Origin and distribution}

The name "onion" originated from the classical period when it was given the Latin name unio, meaning oneness or unity, or a kind of single onion. The French called it oignon. Martin Elcort in his book, "The Secret Life of Food", wrote, "The word onion was created by adding the onion-shaped letter $\mathrm{O}$ to the word union, yielding a new spelling ounion. The letter ' $u$ ' has been dropped to create modern spelling - onion" (Anonymous, 2013).

Onion is native to Central Asia of temperate region (between Turkmenistan and Afghanistan) where some of its wild relatives still grow. The closest among them are Allium vavilovii Popov \& Vved from Turkmenistan and northern Iran and Allium asarense R.M. from Iran. Allium oschaninii O. Fedtsch, from Uzbekistan and neighbouring countries, is considered to be the ancestor of $A$. cepa, the present-day onion. From Central Asia, the supposedly onion ancestor migrated first towards Mesopotamia [onion has a mention in the Sumerian literature (2500 BC) ], then to Egypt (1600 BC), India and South East Asia. From Egypt, A. cepa was introduced into Mediterranean area, and from there to all Roman Empire. According to Vavilov (1926), South-West Asian gene centre was proposed as the primary centre of onion domestication and variability. Vavilov and Burkinich (1929), based on ecotypes and wild forms, further confirmed that Afghanistan and adjacent countries are the genetic centre of origin of the cultivated forms of 
onion and garlic. More than 600 species of Allium are distributed in Afghanistan, Turkey, Iran and Central Asia, comprising Turkmen SSR, Uzbek SSR, Tadzhik SSR, Kirgiz SSR and Kazakh SSR, and Mongolia (Kotlinska et al., 1990).

The secondary centre of its origin in Mediterranean gene centre represents the area from which onions with large bulbs were selected (Castell and Portas, 1994). Onions have since been cultivated for a long time, so their bulbs and inflorescences must have been adapted closely to temperature and photoperiod where they grow. A huge range of cultivars and landraces exist, developed over the centuries, to fit diverse climate and food preferences of the world (Brewster, 1994). The genetic material developed and being cultivated is of a long-day type, requiring longer photoperiod and moderately cool temperature for development of bulbs and a very low temperature for flowering.

In India, onions were adapted from a very early time, before Christian era. Originally, native of Central Asia of temperate region with perennial-biennial habit and a long-day character, they have established well under the tropical environment and short-day (11-11.5 hours) photoperiod (Seshadri and Chatterjee, 1996).

During acclimatization of different vegetable crops and their varieties, farmers had applied selection pressures involuntarily to meet market preferences. In case of onion, the need to produce seeds indigenously has played an important role in adaptation. Out-breeding mechanism of the onion has promoted its selection suiting to diverse environments during the process of adaptation and diversification.

At the centre of origin and between 25 and $40^{\circ} \mathrm{N}$ latitude, onion is biennial in seed production and requires more than 14 hours day-length for bulb production. In subtropical and tropical parts of India, between 12 and $25^{\circ} \mathrm{N}$ latitude, it is biennial only but produces bulbs under comparatively shorter photoperiod (1111.5 hours) in winter. Winter-season crop accounts for $60 \%$ of the total production in India. Onion cultivation is predominant in western Maharashtra and Gujarat, where two crops, one in a rainy season (kharif) and the other in winter season (rabi) are taken regularly. Its tropicalization progressed further southwards to Bellary region of north Karnataka, and finally vegetatively propagated multiplier onions or shallot-type onions were established in Tamil Nadu at 6 to $8^{\circ} \mathrm{N}$ latitude. The adaptations to hardy conditions of high rainfall, high temperature and short photoperiod, typical of rainy season (kharif) crop of western India, could not be chronologically documented (Seshadri and Chatterjee, 1996). Export from Mumbai and Kandla ports, mainly to Gulf countries, predominantly during November to April, coincides with the harvest of rainy season and late rainy season crop. This is a unique example where largely market forces have influenced domestication and diversification of the crop. Demand for highly pungent pink-skinned bulbs from Gulf countries resulted in the selection of such types by the farmers of the western India, and even seeds could be produced under similar climatic conditions. This adaptation made onion to be an annual crop. The phenomenon led to loss of short dormancy of onion-bulbs. This aspect of onion domestication in western India was unnoticed, and was not even recorded (Seshadri and Chatterjee, 1996)

In Africa, tropical cultivars may have been introduced either from southern 
Egypt, or from India via Sudan to Central and West Africa (Messiaen and Rouamba, 2004). Onion trade from India made it possible to select adapted types. Selection from genetically heterogeneous seeds or bulb-lots by local farmers facilitated adaptation of seed-propagated onions. A. cepa as bulb-onion and/or shallot is cultivated probably in all countries of tropical Africa. Mali, Senegal, Burkina Faso, Ghana, Niger, Nigeria, Chad, Sudan, Ethiopia, Kenya, Uganda, Zambia and Tanzania are chief onion-producing countries. In the lowlands, between $10^{\circ}$ $\mathrm{N}$ and $10^{\circ} \mathrm{S}$, shallots replace onions as temperature is too high for vernalization and seed production and climate is too humid. The short vegetative cycle of shallot (60-75 days) makes possible two crops of this in a year. The spicy taste and high dry matter content (15-18\%) of shallots have made them attractive for growers further down the equator; in many areas where common onions are also produced. Red or purple onions, grown in East Africa, named Bombay Red or Red Globe, symbolize Indian origin, routed through Bombay (now Mumbai) and Kandla ports of Maharashtra and Gujarat, respectively.

There are no native Allium species in Latin America. They were first introduced there at the end of 14th century. The most important Allium species in the region are: A. cepa, A. sativum, A. ampeloprasum; and A. fistulosum to some extent (Jaramillo, 1994). Onions were taken to North America by the first settlers from European continent. The first pilgrims brought onions with them on the Mayflower. They found, however, that strains of wild onions were growing across North America. Native American Indians were using wild onions in a variety of wayseating them raw or cooked, for seasoning or as a vegetable. According to diaries of colonists in 1648, bulb-onions were planted as soon as the pilgrim-farmers could clear the land.

A. fistulosum originated in Asia, probably in Siberia or China, grown predominantly in Japan as welsh onions or Japanese bunching onions, and is adapted to severe winter and moist soils. Welsh onion produces long slender white stem, which is consumed; it does not produce bulb. By the end of $18^{\text {th }}$ century, Japan started growing bulb-onion varieties adapted to extreme long-day conditions.

\section{Global scenario}

\section{Production - productivity}

Onion is grown over an area of 43.64 lakh ha with a total production of 863.44 lakh tonnes, and a productivity of 19.79 tonnes per ha (Anonymous, 2013). World area under onion over a decade has increased from 28.43 lakh ha to 43.64 lakh ha; an increase of $53.49 \%$. Production has increased $72.87 \%$, from 499.46 lakh tonnes to 863.44 lakh tonnes, and productivity from 17.57 to 19.79 with a percentage increase of 12.63 (Fig.1.1).

Among various onion-producing countries, India leads in the area (11.10 lakh ha), followed by China (10. 15 lakh ha), and in production, China produces the maximum (247.65 lakh tonnes), followed by India (159 lakh tonnes). Highest productivity of onion has been reported from Republic of Korea (66 tonnes/ha), followed by the USA ( 56 tonnes/ha), Spain ( 53 tonnes/ha), Netherlands ( 51 tonnes/ ha), Egypt (36 tonnes/ha), Iran (35 tonnes/ha) and Turkey (32 tonnes/ha) (Figs 1.2a, 1.2b). 


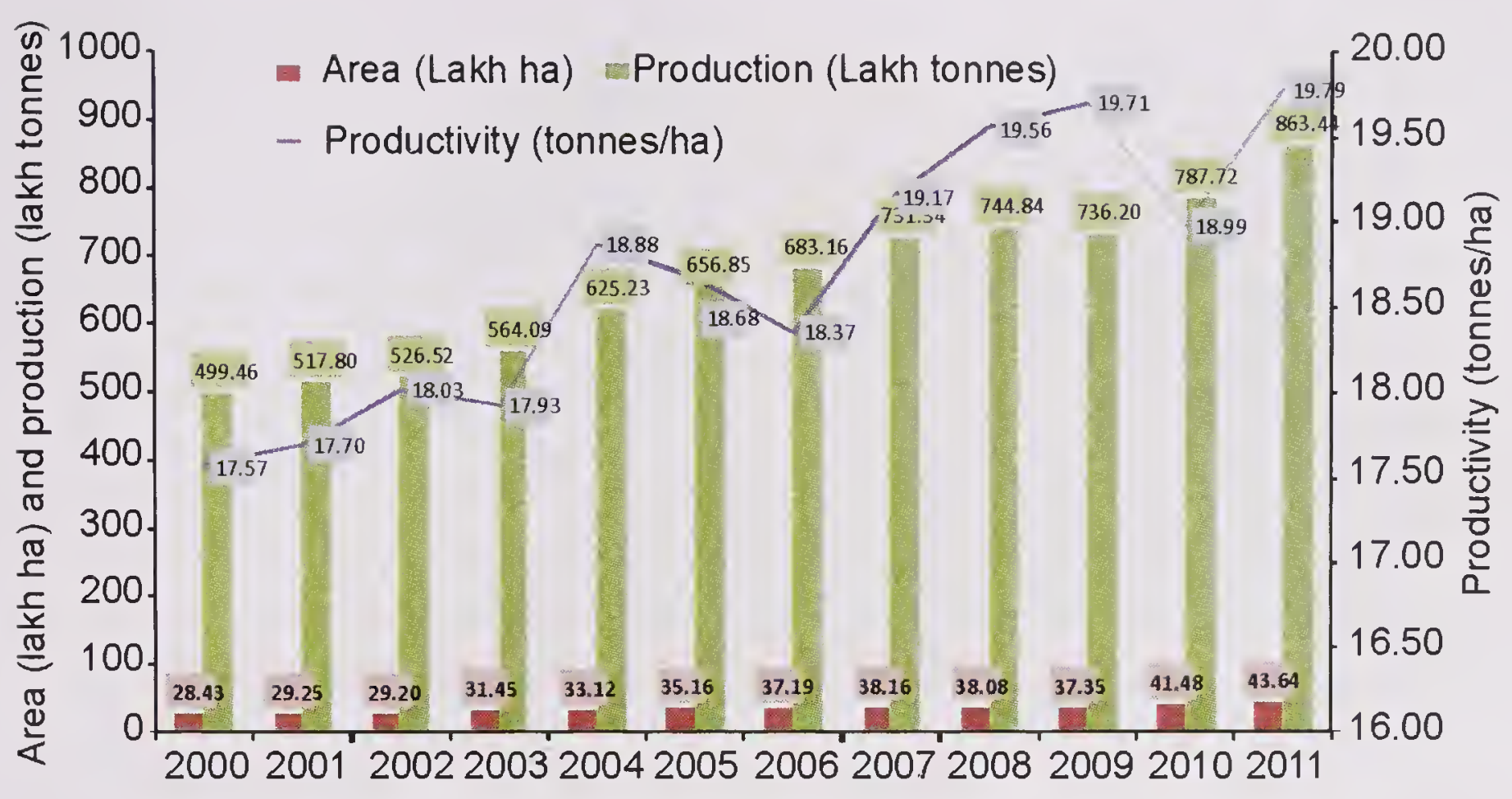

Fig.1.1 Year-wise area, production and productivity of onions in the world

The countries showing high productivity fall between $30^{\circ}$ and $50^{\circ} \mathrm{N}$ latitudes where onion is a long-day crop, requiring more than 14 hours and duration of more than 180 days. Biomass development of onion is very high due to its high yield per unit area. Onion cultivation in India, contrary to above range, is predominantly between $12^{\circ}$ and $25^{\circ} \mathrm{N}$ latitude, falling under subtropics to tropics. Here, varieties mature under short day (11-11.5 hrs) and short duration (90 to 120 days). These genotypes have inherently low yield potential, and this is the main reason for its low productivity in the country. However, management of proper production technologies has shown an increase in yield up to 40 tonnes per ha.

The world can be divided into four zones based on the adaptation of onion Very long-day conditions; Long-day conditions; Intermediate long-day conditions; and Short-day conditions-distributed on both the sides of the equator (Fig.1.3). Under the first group, major onion-growing area is under short-day and long -to intermediate long-day conditions. Under long-day, onions are biennial while under short-day, they are annual. Intermediate long-day varieties can produce bulbs in short-day conditions during the winter but they do not produce seeds under shortday; they produce seeds only under long-day and cool temperature.

\section{Trade}

Global export of onion is of the tune of 6.77 million tonnes; worth 2,856 million US dollars. India has consistently been number one exporter of onion; exporting 1.11 million tonnes worth 370.73 million US dollars. Netherlands exports onions mostly to European countries. Besides India, China (0.74 million tonnes), Egypt (0.49 million tonnes), Mexico (0.37 million tonnes), USA (0.35 million tonnes), Spain ( 0.25 million tonnes), Argentina (0.21 million tonnes), Pakistan ( 0.17 million tonnes) and Turkey ( 0.12 million tonnes) also export sizable quantity of onions (Anonymous, 2013).

China can give a tough competition in future to India in onion trade in the world. Malaysia, Russian Fed, USA, Japan, UK, Saudi Arabia, Germany, 


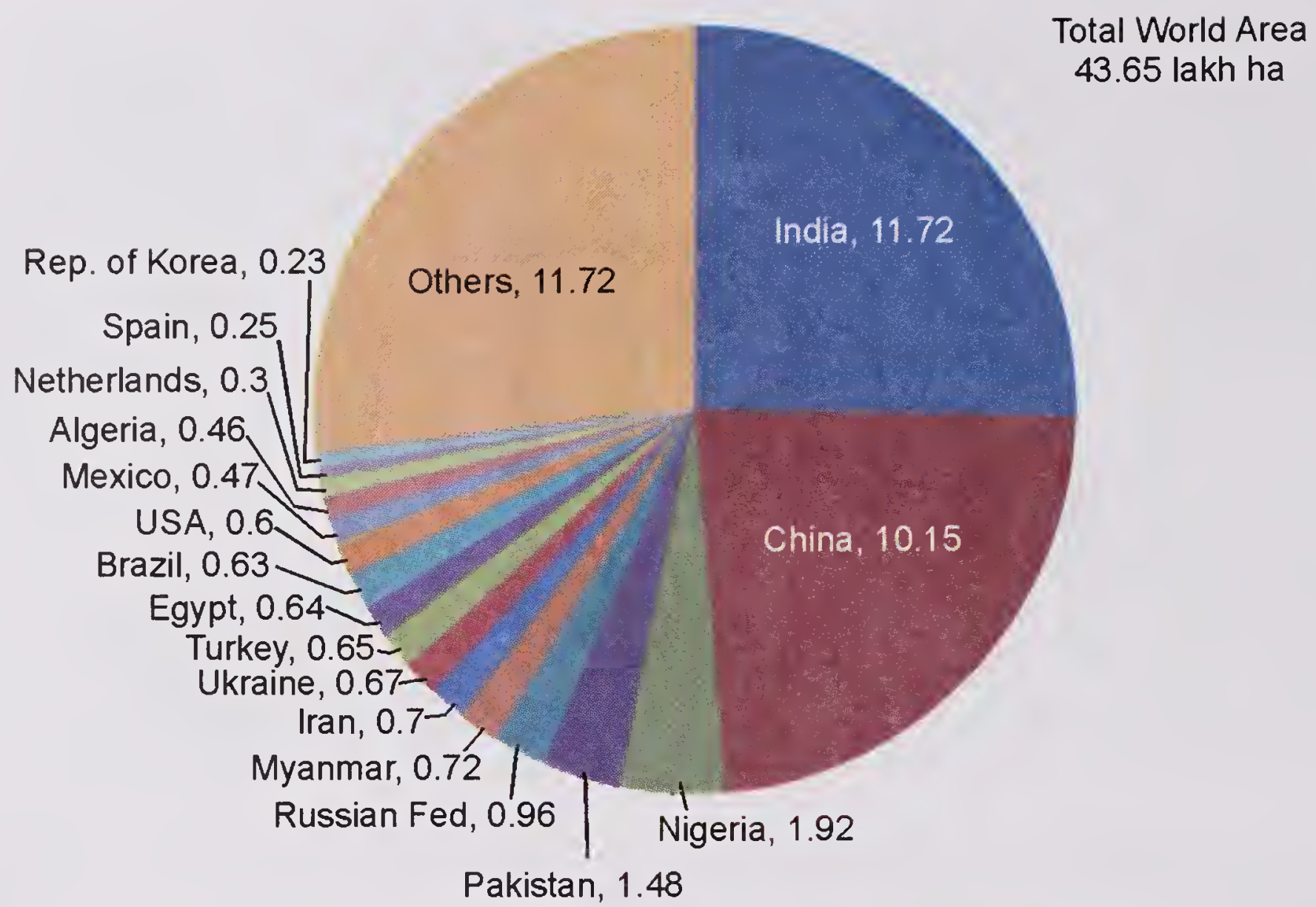

Fig.1.2a Area (lakh ha) in major onion-producing countries (2011)

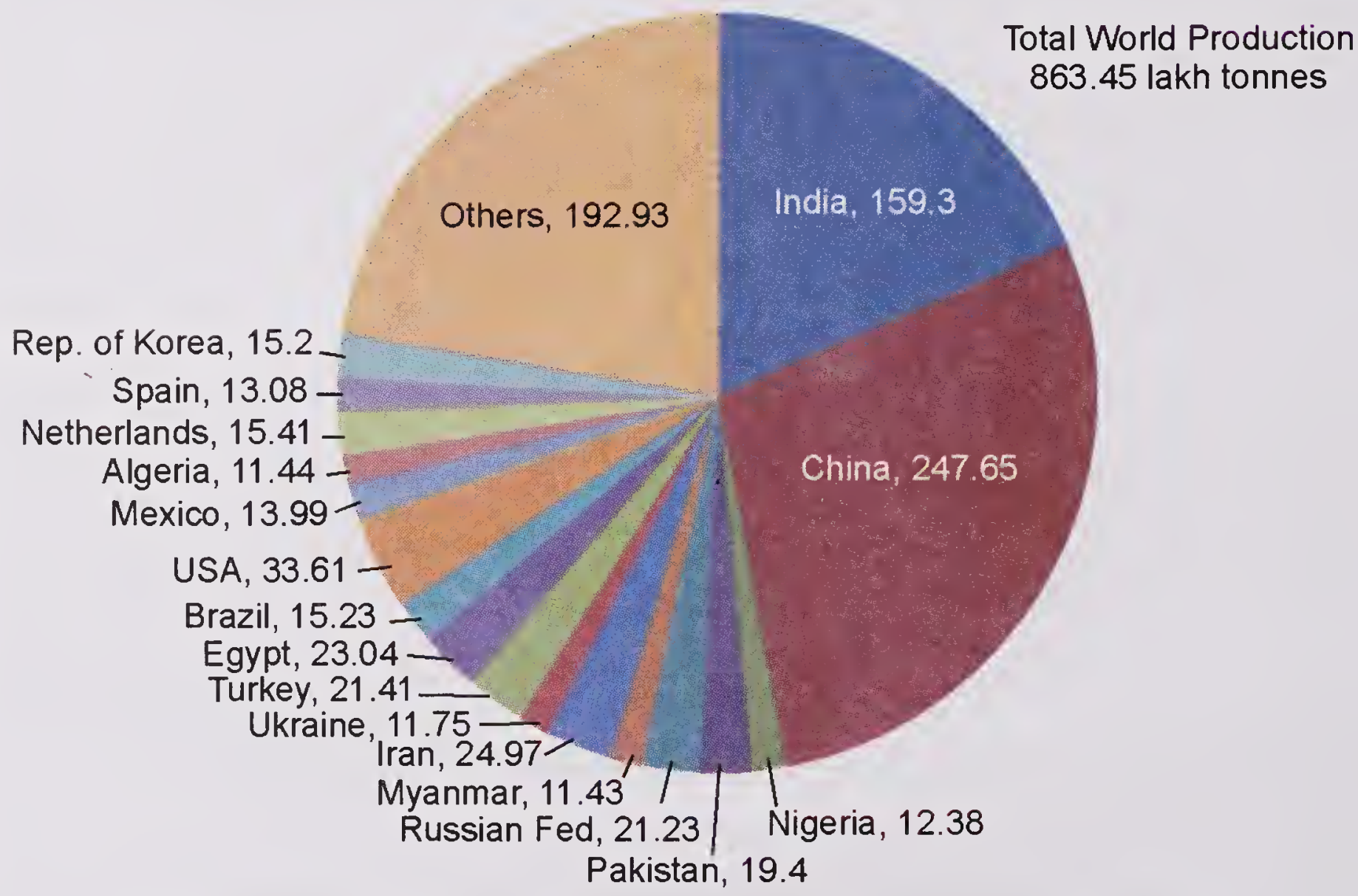

Fig.1.2b Production (lakh tonnes) in major onion-producing countries

Bangladesh, Canada, Sri Lanka, UAE, Colombia, Senegal, Belgium, France and Vietnam are the major onion-importing countries of the world. India exports 15 to 16 lakh tonnes of onion to Bangladesh, Malaysia, UAE, Sri Lanka, Indonesia, Singapore, Nepal, Oman, Kuwait, Qatar, Vietnam, Bahrain, Saudi Arabia and Mauritius. Export to European countries from India is also increasing steadily.

Pungent and tingling taste of Indian onions is famous in Middle East and South East Asian countries. Red, pink and white onions grown under short-day conditions in India are becoming popular in European countries. 


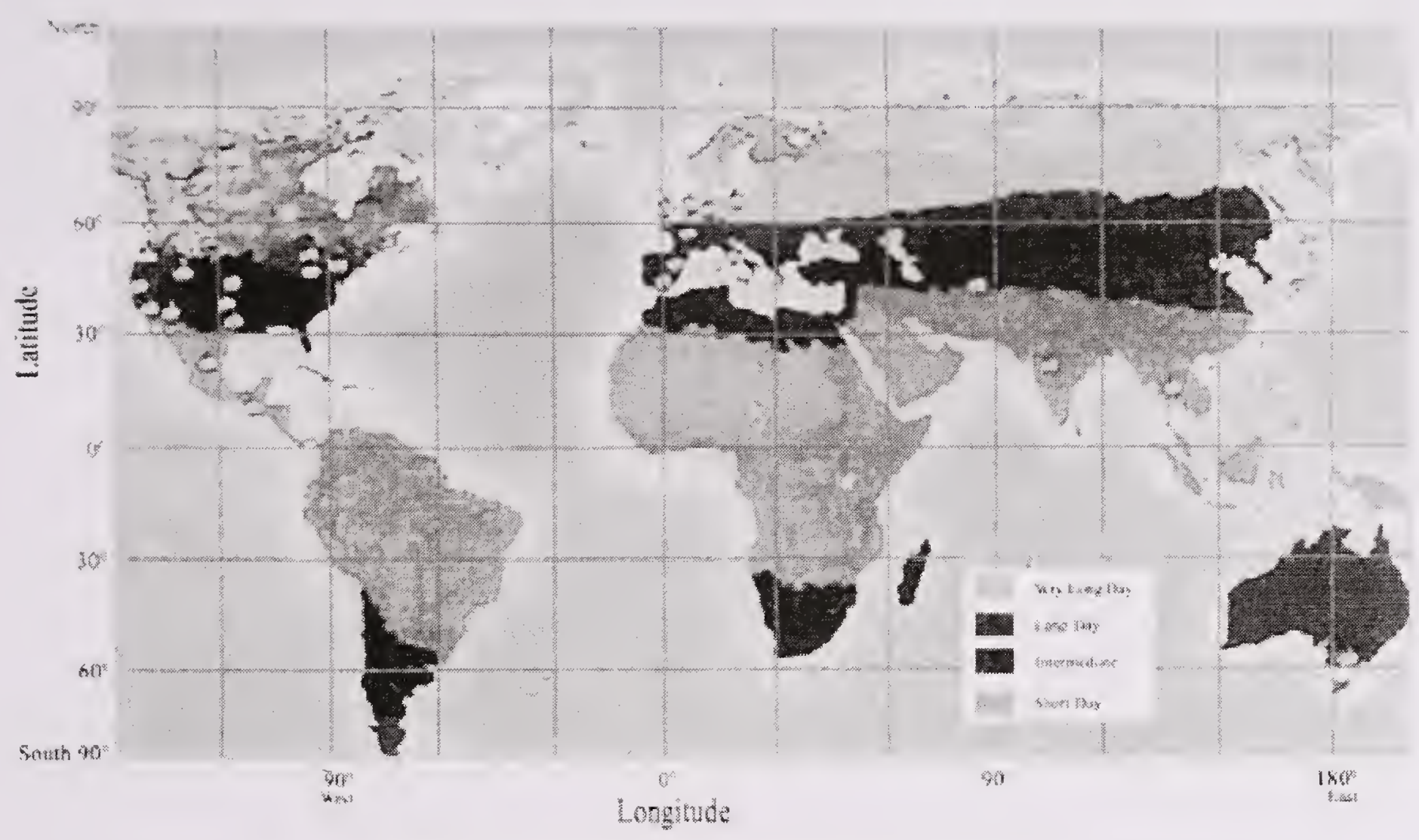

Fig.1.3 Adaption of the onion in the world

Present-day export of India can be doubled easily with systematic crop planning, infrastructure development for storage, grading, packing, transfer subsidy and strong and rigid national policy on onion export. There is a need for development of varieties exclusively for export for niche-area markets. Strengthening AgriExport Zones for onions in potential production areas would enhance overseas trade of Indian onions.

\section{References}

Anonymous. 2013. "Onion" Encyclopedia Britannica online (http: www.britannica.com/ EB checked/topic/429235/onion.

Brewster J L. 1994. Onions and other Vegetable Alliums, 236 pp. CAB INTERNATIONAL, Wallingford, United Kingdom.

Castell V R and Portas C M. 1994. Alliaceae production systems in the Iberian Peninsula: facts and figures of potential interest for a worldwide R\&D network. Acta Horticulture 358: $43-47$.

Jaramillo V J. 1994. Allium genetic resources in Latin America: Situation on perspectives. Acta Horticulture 358: 147-51.

Kotlinska T P, Havranek M, Navratill L, Gerasimova A, Pimakov and Neikov S. 1990. Collecting onion, garlic and wild species of Allium in Central Asia, USSR. Plant Genetic Resources Newsletter 83/84: 31-32.

Messiaen C M and Rouamba A. 2004. Allium ampello prasum L. Plant resources of tropical Africa (http://www.porta4u.org/search.asp).

Seshadri V S and Chatterjee S S. 1996. The history and adaptation of some introduced vegetable crops in India. Vegetable Science 23 (2): 114-40.

Shastri J L, Bhatt G P and Tagare G V. 1995. Garuda Purana Ancient Indian Traditional and Mythology. Vol.12, 30 pp. India Motilal Banarsidass Publishers Pvt. Ltd, New Delhi, India.

Swarup V. 2006. Vegetable Science and Technology in India., Kalyani Publishers, Kolkata, India. 
Vavilov N I. 1926. Origin and Geography of Cultivated Plants. ( $1^{\text {st }}$ Edn), 536. English translation by D Love 1992. Cambridge University Press, United Kingdom.

Vavilov N I and Burkinich D O. 1929. Zemeledeleheskii Afganistan. pp. 156-158. Tr. Po. Prikl. Botanike Genetike I selekcii V/R. T.Z. 


\title{
Onion R\&D in India- Status and Prospects
}

\author{
J. Gopal and A.A. Murkute
}

In India, onion is grown in three crop seasons- kharif, late kharif and rabi. Its principal crop is in rabi $(50-60 \%)$, and $20-25 \%$ each is in kharif and in late kharif. During 2011-12, total area under onion was over 9.92 lakh hectares with production of 166.54 lakh tonnes (Fig. 2.1) (Agricultural Statistics, 2013). Maharashtra, Karnataka, Gujarat, Bihar, Madhya Pradesh, Rajasthan, Andhra Pradesh and Tamil Nadu are the main onion-growing states. In general, barring north-eastern states and Kerala, all states grow onions. Country's $26 \%$ area and 29\% production comes from Maharashtra alone (Agricultural Statistics, 2013). In addition to fulfilling domestic demand constantly, India exported 18.22 lakh tonnes of onion worth ₹ 2,294 crore in 2011-12 (NAFED, 2013). About 90\% export of onion is from Maharashtra. In general, there is a critical shortage in arrival of onions in the market during November to January. From May to November stored onions are used for domestic as well as export purpose. November to December, kharif onions are available in the market and from January to March, late kharif onions from Maharashtra reach the market (Table 2.1). The productivity of late kharif and rabi crops is around 25 tonnes per hectare, and that of kharif crop is 8-10 tonnes per hectare. During kharif, cloudy weather and consistent drizzle cause diseases like anthracnose and bulb-rotting. In rabi, high thrips incidence aggravates the problems of purple-blotch and Stemphylium-blight.

\section{R\&D history of the crop}

Systematic R\&D in onions was started in 1960 at Pimpalgaon, Baswant, Nashik, and later at the Indian Agricultural Research Institute (IARI), New Delhi, and Indian Institute of Horticultural Research (IIHR), Bengaluru. The National Horticultural Research and Development Foundation (NHRDF), Nashik, was established by the National Agricultural Co-operative Marketing Federation of India Ltd (NAFED) and its Associate Shippers of onions on 3 November 1977 under the Society Registration Act 1860 at New Delhi, for carrying out research and development activities on export-oriented crops (NHRDF, 2011), to begin with was onion and garlic. Multiplier onion varieties were developed by the Tamil Nadu Agricultural University (TNAU), Coimbatore. Prior to this, research on collection and maintenance of landraces and standardization of agro-techniques was attempted by different State Agricultural Departments. With the concept of coordinated projects and Agricultural Universities, the work on the onion research was strengthened, in terms of varietal development for different seasons and standardization of production techniques in the early nineties. The R\&D on onion 

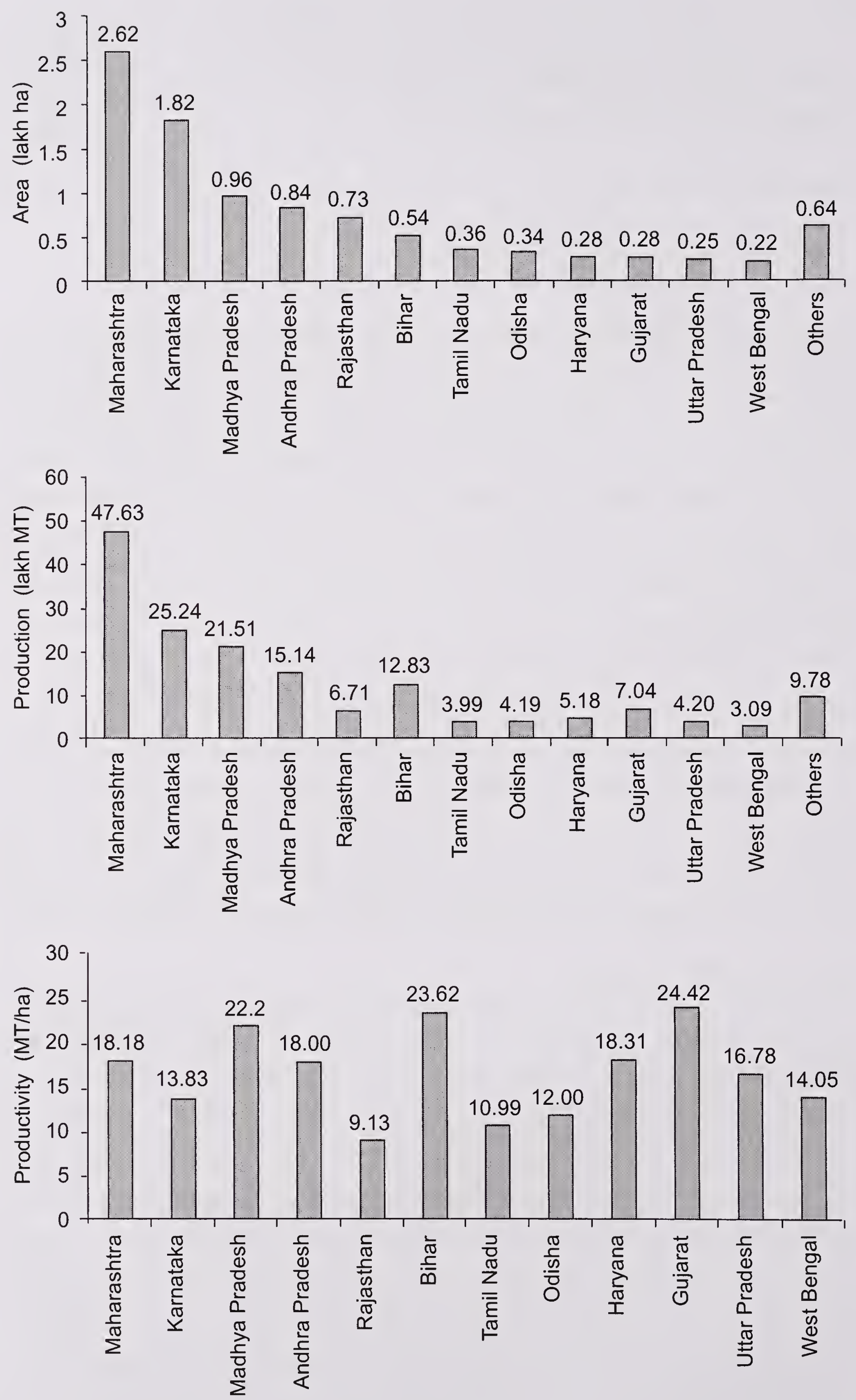

Fig. 2.1 Statewise area, production and productivity of onions in India during 2012-13 (Source: Agricultural Statistics, 2013) 


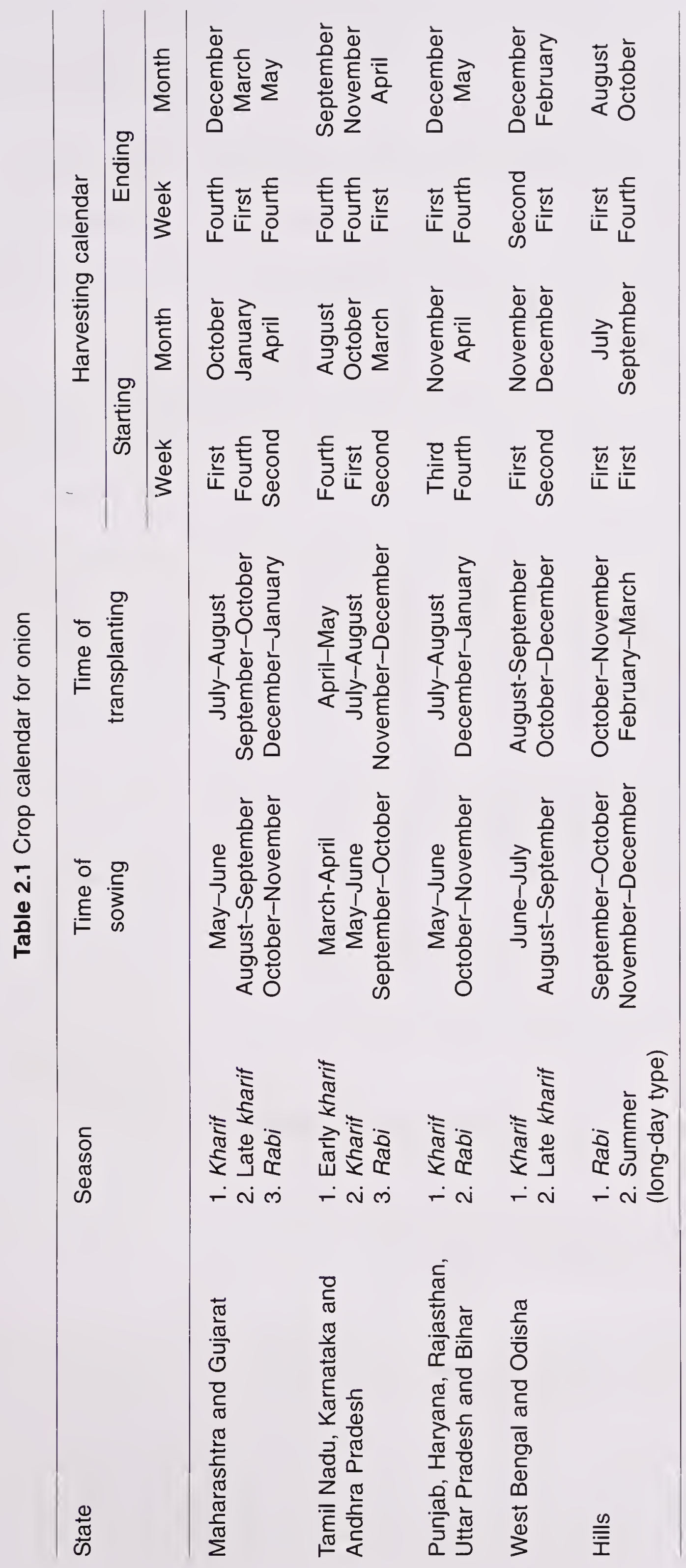


Table 2.2 Institutions working on onion in India

SI No. Institutions

Major area of work

\section{State Agricultural Universities}

1. Bidhan Chandra Krishi Viswavidyalaya, Mohanpur, Crop production West Bengal

2. Chandra Shekar Azad University of Agriculture and Crop improvement Technology, Kanpur, Uttar Pradesh

3. ChaudharyCharan Singh Haryana Agricultural Crop improvement University, Hisar, Haryana

4. Dr PanjabraoDeshmukh KrishiVidyapeeth, Akola, Crop improvement Maharashtra

5. Junagadh Agricultural University, Junagadh, Gujarat Crop improvement

6. Mahatma Phule KrishiVidyapeeth, Rahuri, Maharashtra Crop improvement

7. Maharana Pratap University of Agriculture and Crop improvement Technology, Udaipur, Rajasthan

8. Orissa University of Agriculture and Technology, Crop improvement Chiplima, Odisha

9. Punjab Agricultural University, Ludhiana, Punjab Crop improvement

10. Swami Keshwanand Rajasthan Agricultural University, Bikaner, Rajasthan

11. Tamil Nadu Agricultural University, Coimbatore, Crop improvement Tamil Nadu

12. University of Agricultural Sciences, Dharwad, Crop production Karnataka

\section{ICAR Institutes}

1. Central Institute of Temperate Horticulture, Srinagar, Jammu and Kashmir

2. Directorate of Onion and Garlic Research, Pune, Maharashtra

3. Indian Agricultural Research Institute, New Delhi

4. Indian Institute of Horticultural Research, Bengaluru, Karnataka

5. National Horticultural Research and Development Foundation, Nashik, Maharashtra

6. Vivekananda Parvatiya Krishi Anusandhan Shala, Almora, Uttrakahand

Crop improvement

Crop improvement, Crop protection, Crop production, Post-harvest management Crop improvement, Crop production Crop improvement, Crop protection, Crop production, processing Crop improvement, Crop protection, Crop production, Post-harvest management Crop improvement

\section{Private Firms}

1. BejoSheetal Seeds Pvt. Ltd, Jalna, Maharashtra

2. Jain Irrigation Systems Ltd, Jalgaon, Maharashtra

3. Jindal Crop Science, Pvt. Ltd, Jalna, Maharashtra

Crop improvement

Processing

Crop improvement

got impetus with the establishment of the National Research Centre on Onion and Garlic at Nashik in 1994. This was shifted to the present location at Rajgurunagar in 1998, and has been upgraded to the Directorate with the addition of an AllIndia Network Research Project on Onion and Garlic in 2008. Besides, 
concentrating on genetic improvement and biotechnology of onions, the institute's development work on several agro-technologies, including post-harvest management practices, has strengthened R\&D of onions, besides supplementation of work by the NHRDF and some universities. At present, different state agricultural universities, ICAR institutes across the country and private companies (Table 2.2) are working on different R\&D aspects of onions.

\section{R\&D status}

Important aspects of status and prospects of $\mathrm{R} \& \mathrm{D}$ of onions are presented as follows.

\section{Varietal improvement}

The onion cultivation in India is continuing since time immemorial. As a result, a large numbers of landraces including some wild species are also traceable in India, particularly in the north-eastern states. This variability is being maintained at the national germplasm collection of onions at the DOGR, a National Active Germplasm site for onions (Table 2.3). Many farmers in various parts of the country are growing old onion landraces. For example, Pune Fursungi, a red coloured landrace, is cultivated in Nashik and Pune areas of Maharashtra in late kharif and rabi. Junagadh, Saurashtra and Mehsana areas of Gujarat are dominated by Pili Patti, a landrace, generally grown in rabi. Bellary Red, another red onion landrace, prevalent in Karnataka and Sukhsagar, is being cultivated in West Bengal. K.P. onions dominate in Andhra Pradesh and Nirmal Local occupies larger area in Madhya Pradesh. Further, multiplier type has been a unique feature in Tamil Nadu.

The varietal improvement programme began with the improvement of local varieties. Consequently, more than 50 varieties of onions, including $2 \mathrm{~F}_{1}$ hybrids and 6 varieties of multiplier onions, have been developed and released

Table 2.3 Status of onion germplasm at NAG site (DOGR, Rajgurunagar)

\begin{tabular}{llr}
\hline SI No. & Category & No. of access \\
\hline 1 & Dark Red & 274 \\
2 & Light Red & 429 \\
3 & White & 450 \\
4 & Yellow & 50 \\
5 & Exotic onion & 237 \\
6 & Wild species & 12
\end{tabular}

(i) Allium altaicum Pall.

(ii) Allium ampeloprasum L.

iii Allium cepa $\times$ A. fistulosum

$\checkmark$ Allium cepa $\times A$. cornutum (PRAN)

$\checkmark$ Allium chinense

vi Allium flavum

vii Allium fistulosum L.

viii Allium galanthum

ix Allium guttatum

$\mathrm{x}$ Allium hookeri

xi Allium schoenoprasum var. schoenoprasum

xii Allium tuberosum 
(Table 2.4). Most of these varieties are mainly for rabi season. Development of some kharif-growing varieties was done earlier by the Mahatma Phule Krishi Vidyapeeth (MPKV), Rahuri, NHRDF, Nashik and IIHR, Bengaluru, and later by the DOGR, Rajgurunagar. In 1980s work on hybrid breeding using male sterile lines was initiated by the IIHR Bengaluru. Only two onion hybrids 'Arka Kirthiman' and 'Arka Lalima' were released from the IIHR. But these were not found better than open-pollinated varieties and hence did not pick-up. Private companies have introduced some exotic hybrids in India but they are grown on a

Table 2.4 Onion varieties developed by different organizations

\begin{tabular}{|c|c|c|c|c|}
\hline Organization & Variety & Bulb colour & Planting season & $\begin{array}{l}\text { Year of } \\
\text { release }\end{array}$ \\
\hline $\begin{array}{l}\text { Agril Dept, } \\
\text { Maharashtra }\end{array}$ & $\begin{array}{l}\mathrm{N} 53 \\
{ }^{*} \mathrm{~N} 2-4-1 \\
{ }^{*} \mathrm{~N} 257-9-1\end{array}$ & $\begin{array}{l}\text { Red } \\
\text { Red } \\
\text { White }\end{array}$ & $\begin{array}{l}\text { Kharif } \\
\text { Rabi and late kharif } \\
\text { Rabi }\end{array}$ & $\begin{array}{l}1975 \\
1985 \\
1985\end{array}$ \\
\hline MPKV, Rahuri & $\begin{array}{l}\text { Baswant } 780 \\
\text { Phule Safed } \\
\text { Phule Suvarna } \\
{ }^{*} \text { Phule Samarth (S1) }\end{array}$ & $\begin{array}{l}\text { Red } \\
\text { White } \\
\text { Yellow } \\
\text { Red }\end{array}$ & $\begin{array}{l}\text { Kharif } \\
\text { Late kharif and rabi } \\
\text { Rabi and late kharif } \\
\text { Late kharif }\end{array}$ & $\begin{array}{l}1989 \\
1994 \\
2001 \\
2006\end{array}$ \\
\hline |ARI, New Delhi & $\begin{array}{l}\text { Pusa White Flat } \\
\text { Pusa White Round } \\
\text { Early Grano } \\
\text { (Long-day type) } \\
\text { Brown Spanish } \\
\text { (Long-day) } \\
\text { "Pusa Red } \\
\text { *Pusa Ratnar } \\
\text { *Pusa Madhavi } \\
\text { (Line 120) } \\
\text { *Selection } 126\end{array}$ & $\begin{array}{l}\text { White } \\
\text { White } \\
\text { Yellow } \\
\text { Brown } \\
\text { Red } \\
\text { Red } \\
\text { Red } \\
\text { Brown }\end{array}$ & $\begin{array}{l}\text { Rabi } \\
\text { Rabi } \\
\text { Late kharif and rabi } \\
\text { Hills } \\
\text { Late kharif and rabi } \\
\text { Rabi } \\
\text { Rabi } \\
\text { Rabi }\end{array}$ & $\begin{array}{l}1975 \\
1975 \\
1975 \\
\\
1975 \\
\\
1975 \\
1975 \\
1987 \\
\\
2012\end{array}$ \\
\hline IIHR, Bengaluru & $\begin{array}{l}\text { Arka Pragati } \\
\text { *Arka Niketan } \\
{ }^{*} \text { Arka Kalyan } \\
\text { Arka Lalima } \\
\text { ( } F_{1} \text { hybrid) } \\
\text { Arka Kirtiman } \\
\text { ( } F_{1} \text { hybrid) } \\
\text { Arka Pitamber } \\
\text { Arka Bindu } \\
\text { Arka Ujjwal } \\
\text { (multiplier onion) } \\
\text { Arka Swadista } \\
\text { Arka Vishwas } \\
\text { Arka Sona } \\
\text { Arka Bheem } \\
\text { (tri-parental synthetic) } \\
\text { Arka Akshay } \\
\text { (tri-parental synthetic) }\end{array}$ & $\begin{array}{l}\text { Red } \\
\text { White } \\
\text { Dark red } \\
\text { Yellow } \\
\text { Red } \\
\text { Dark Red }\end{array}$ & $\begin{array}{l}\text { Kharif and rabi } \\
\text { Rabi and late kharif } \\
\text { Kharif } \\
\text { Rabi } \\
\text { Rabi } \\
\text { Rabi } \\
\text { Kharif, late kharif } \\
\text { and Rabi } \\
\text { Rabi } \\
\text { Rabi } \\
\text { Kharif and rabi } \\
\text { Rabi } \\
\text { Rabi }\end{array}$ & $\begin{array}{l}1984 \\
1987 \\
1987 \\
1993 \\
1993 \\
2006 \\
2006 \\
2010\end{array}$ \\
\hline
\end{tabular}


(... Table 2.4)

\begin{tabular}{|c|c|c|c|c|}
\hline Organization & Variety & Bulb colour & Planting season & $\begin{array}{l}\text { Year of } \\
\text { release }\end{array}$ \\
\hline HAU, Hisar & $\begin{array}{l}\text { Hissar } 2 \\
{ }^{*} \text { HOS1 }\end{array}$ & $\begin{array}{l}\text { Red } \\
\text { Red }\end{array}$ & $\begin{array}{l}\text { Rabi } \\
\text { Rabi }\end{array}$ & $\begin{array}{l}1976 \\
2006\end{array}$ \\
\hline NHRDF, Nashik & $\begin{array}{l}\text { Agrifound Rose } \\
\text { Agrifound Red } \\
\text { (Multiplier) } \\
\text { *Agrifound Light Red } \\
\text { Agrifound White } \\
\text { *Agrifound Dark Red } \\
\text { *NHRDF Red (L 28) } \\
\text { *NHRDF Red (L 355) }\end{array}$ & $\begin{array}{l}\text { Red } \\
\text { Red } \\
\text { Red } \\
\text { White } \\
\text { Red } \\
\text { Red } \\
\text { Red }\end{array}$ & $\begin{array}{l}\text { Rabi } \\
\text { Kharif and rabi } \\
\text { Rabi and late kharif } \\
\text { Rabi } \\
\text { Kharif } \\
\text { Rabi } \\
\text { Rabi }\end{array}$ & $\begin{array}{l}1988 \\
1994 \\
1996 \\
2006 \\
2012\end{array}$ \\
\hline VPKAS, Almora & $\begin{array}{l}\text { VL } 67 \text { (Long-day) } \\
\text { *VL } 3 \text { (Long-day) }\end{array}$ & $\begin{array}{l}\text { Red } \\
\text { Red }\end{array}$ & $\begin{array}{l}\text { Hills } \\
\text { Hills }\end{array}$ & $\begin{array}{l}1973 \\
1990\end{array}$ \\
\hline RAU, Rajasthan & $\begin{array}{l}\text { Udaipur } 101 \\
\text { Udaipur } 102 \\
\text { Udaipur } 103\end{array}$ & $\begin{array}{l}\text { Red } \\
\text { White } \\
\text { Red }\end{array}$ & $\begin{array}{l}R a b i \\
R a b i \\
R a b i\end{array}$ & \\
\hline PDKV, Akola & ${ }^{*}$ PKV White & White & $R a b i$ & 2009 \\
\hline GAU, Junagadh & $\begin{array}{l}\text { Gujarat White Onion } \\
\text { (GWO) } 1\end{array}$ & White & Rabi & 2000 \\
\hline CSAUAT, Kanpur & Kalyanpur Red Round & Red & Rabi & 1983 \\
\hline PAU, Ludhiana & $\begin{array}{l}\text { Punjab Selection } \\
{ }^{*} \text { Punjab Red Round } \\
\text { Punjab } 48 \text { (S 48) } \\
\text { Punjab White } \\
\text { *Punjab Naroya } \\
\text { (PBR 5) }\end{array}$ & $\begin{array}{l}\text { Red } \\
\text { Red } \\
\text { White } \\
\text { White } \\
\text { Red }\end{array}$ & $\begin{array}{l}R a b i \\
R a b i \\
R a b i \\
R a b i \\
R a b i\end{array}$ & $\begin{array}{l}1973 \\
1993 \\
1978 \\
1998 \\
1997\end{array}$ \\
\hline TNAU, Coimbatore & $\begin{array}{l}\text { Co } 1 \text { (Multiplier) } \\
\text { Co } 2 \\
\text { Co } 3 \\
\text { Co } 4 \\
\text { Co } 5 \\
\text { MDU }\end{array}$ & $\begin{array}{l}\text { Red } \\
\text { Red } \\
\text { Red } \\
\text { Red } \\
\text { Red }\end{array}$ & $\begin{array}{l}\text { Kharif and rabi } \\
\text { Kharif and rabi } \\
\text { Kharif and rabi } \\
\text { Kharif and rabi } \\
\text { Kharif and rabi } \\
\text { Rabi }\end{array}$ & $\begin{array}{l}1978 \\
1982 \\
1984 \\
1982\end{array}$ \\
\hline RARS, Durgapura & $\begin{array}{l}\text { Rajasthan Onion1 } \\
\text { Arpita (RO59) } \\
\text { RO } 252\end{array}$ & $\begin{array}{l}\text { Red } \\
\text { Red } \\
\text { Red }\end{array}$ & $\begin{array}{l}\text { Rabi } \\
\text { Rabi } \\
\text { Rabi }\end{array}$ & $\begin{array}{l}2004 \\
2005 \\
2010\end{array}$ \\
\hline DOGR, Rajgurunagar & 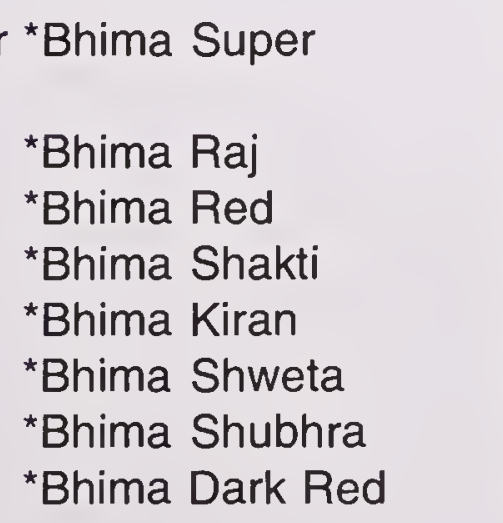 & $\begin{array}{l}\text { Red } \\
\text { Red } \\
\text { Red } \\
\text { Red } \\
\text { White } \\
\text { White } \\
\text { Red }\end{array}$ & $\begin{array}{l}\text { Kharif, late kharif and } \\
\text { rabi } \\
\text { Kharif and rabi } \\
\text { Kharif and late kharif } \\
\text { Late kharif and rabi } \\
\text { Rabi } \\
\text { Kharif and rabi } \\
\text { Kharif and late kharif } \\
\text { Kharif }\end{array}$ & $\begin{array}{l}2007 \\
2009 \\
2010 \\
2010 \\
2010 \\
2010 \\
2012\end{array}$ \\
\hline
\end{tabular}

*These varieties were released through All-India Coordinated Research Project on Vegetables or All-India Network Research Project on Onion and Garlic. Others were released by the institutes. 
very limited scale, due to high seed cost, poor storability under Indian conditions and not much advantage in terms of yield and uniformity in bulb characters. Some new hybrids, developed in the country, are under evaluation.

\section{Biotechnology}

For crop improvement, biotechnological approaches are used as contemporary tools. For onions in India, however, these approaches are still in their nascent stage. The Directorate of Onion and Garlic Research has taken lead, and has been successful in standardizing protocols for direct and indirect in-vitro regeneration of onions. A preliminary understanding of development of onion haploid through in-vitro gynogenesis has been achieved (DOGR, 2012). Molecular markers (RAPD, ISSR and SSR) have been identified to estimate genetic diversity in onion and related wild Alliums.

\section{Production technologies}

Technologies and practices have been developed for various stages of onioncrop, from sowing to harvesting. Interventions in $\mathrm{R} \& \mathrm{D}$ for production technologies are dynamic. The DOGR and other institutions have standardized cultural practices for onion cultivation. Some important practices are outlined as follows.

\section{Seed priming and nursery management}

Being a biennial crop, onion-seeds need to be stored at least for a season. The seeds are known for poor storability, which sometimes results in poor germination. Solid matrix priming and halo priming with $0.3 \% \mathrm{KNO}_{3}$ or coating with Royalflo enhanced field emergence with more than $75 \%$ germination in seeds stored for nine months (IARI, 2010). Treatment of seeds with glycine betaine $(2.5,5 \%)$ increased yield by 14-19\%; and its foliar spray by 12-18\% (IIHR, 2010). Seed treatment with vermiwash was recommended at the University of Agricultural Sciences, Dharwad, Karnataka (Jawadagi et al., 2008), as the freshly harvested onion-seeds treated with vermiwash recorded significantly higher germination (80.6\%), numerically high growth rate index (19.3), shoot length $(8.5 \mathrm{~cm})$ and seedling drymatter accumulation $(22.3 \mathrm{mg})$. Coating per $\mathrm{kg}$ of onion-seed with DAP (30 g) + Borax (0.1 g) + Carbendazim (3 g) was found suitable for $40 \%$ higher bulb yield. During kharif, karanj leaf powder (500 g/kg of seeds) gave higher seed germination (NHRDF, 2011). Gypsum in combination with cow-dung or clay or neem or vermi-compost powder $(1: 1 \mathrm{v} / \mathrm{v})$ was used for pelleting onionseeds; but germination of pelleted seeds was noticed to be at a par with nonpelleted seeds (IIHR, 2010).

During harvest and post-harvest operations, onion-seeds may be infected with storage fungi, Penicillium, Aspergillus, etc. Anthracnose, caused by Colletotrichum gleosporiodes, has also been reported to be seed-borne (DOGR, 2012). Umbels treated with systemic fungicide (Iprodione + Bavistin @ $0.2 \%$ before harvesting) yielded disease-free seeds. Their germination test showed seedling vigour more than other treatments, i.e. Mancozeb, neem oil etc. and control (DOGR, 2012). Seed treatment with Trichoderma viride @ $4 \mathrm{~g} / \mathrm{kg}$ of seeds, followed by soil application of T. viride @ 1,250 g/ha mixed with $50 \mathrm{~kg}$ FYM was useful in reducing 
damping-off disease in the nursery. Soil application of copper oxychloride @ $0.25 \%$ was adjudged as an alternative treatment to Bavistin (NHRDF, 2011).

To raise a nursery for sowing onion by transplanting in a hectare, 0.05 hectare would be sufficient. Depending on the variety, $6-8 \mathrm{~kg}$ of seeds would be sufficient to cultivate 1 ha by traditional transplanting method. Beds used for raising seedlings should be $10-15 \mathrm{~cm}$ high with $1 \mathrm{~m}$ width and length as per convenience. The distance between the two beds is kept at $30 \mathrm{~cm}$ to facilitate intercultural operations. Seeds are sown in rows manually at $10-15 \mathrm{~cm}$ distance and are irrigated preferably by drip or sprinklers. Pendimethalin 30 EC, a pre-emergence herbicide, @ $2 \mathrm{ml} /$ litre at the time of sowing seeds in the onion nursery controlled weed population effectively compared to other herbicidal sprays (DOGR, 2012).

\section{Seedling transplanting and crop geometry}

About 45-50 days old nursery becomes ready for transplanting in rabi and in 35-40 days in kharif. Uprooted seedlings are cut one-third from the top. Seedlings are dipped in a solution of Carbosulfan ( $2 \mathrm{ml} /$ litre) and Carbendazim ( $1.5 \mathrm{~g} / \mathrm{litre})$ for two hours and then gently pressed in the soil. For proper growth of the seedlings, ample nutrition is indispensable. Thus, crop geometry is vital for ensuring optimum crop density in the field. In rabi, transplanting in flat beds $(2 \mathrm{~m} \times 3 \mathrm{~m})$ at $10-\mathrm{cm}$ plant-to-plant spacing with $15-\mathrm{cm}$ row-to-row spacing is recommended. In kharif, crop geometry of 12 rows at $10 \mathrm{~cm}$ distance on broad raised beds of $15 \mathrm{~cm}$ height and $120 \mathrm{~cm}$ width is recommended (Lawande, 2011). At the University of Agricultural Sciences, Dharwad, Karnataka, maximum plant height and leaf length in cv. Bellary Red was recorded with $15 \mathrm{~cm} \times 7.5 \mathrm{~cm}$ spacing, followed by $15 \mathrm{~cm}$ $\times 10 \mathrm{~cm}$ spacing (Jawadagi et al., 2012). Bulb yield, net returns and benefit: cost ratio were maximum when crop at $15 \mathrm{~cm} \times 10 \mathrm{~cm}$ spacing was given 12.50 tonnes of FYM/ha +2 tonnes of vermi-compost/ha $+5 \mathrm{~kg}$ of biofertilizers/ha.

\section{Cropping sequence and intercropping}

Intercropping assures profit even if one crop fails due to natural vagaries, and cropping sequence maximizes utilization of soil fertility with optimum productivity. Sugarcane-based intercropping with onion has been suggested (NRCOG, 2004). Soybean in kharif, followed by onion in rabi, groundnut in summer, followed by onion in late kharif or rabi has been recommended (NRCOG, 2006). Soybean in kharif, followed by onion in rabi has been found more remunerative and cost-effective than other sequences - groundnut-onion and maize-onion (DOGR, 2012).

\section{Integrated nutrient management}

Removal of nutrients by the onion-crop depends mainly on the variety, soil condition, quantity of fertilizers applied, season and bulb yield. Integrated nutrient management is an approach for fulfilling nutrient requirements of the crop at an appropriate time in an optimum quantity with a proper mode of application. It is an integration of many practices. An onion-crop with a bulb yield of 35 tonnes/ha approximately removes $120 \mathrm{~kg}$ nitrogen, $50 \mathrm{~kg}$ phosphorus and $160 \mathrm{~kg}$ potash (Tandon, 1987). However, experiments conducted at Rajgurunagar showed that 
onion-crop removed $90-95 \mathrm{~kg} \mathrm{~N}, 30-35 \mathrm{~kg}$ of $\mathrm{P}_{2} \mathrm{O}_{5}$ and $50-55 \mathrm{~kg}$ of $\mathrm{K}_{2} \mathrm{O}$ to yield 40 tonnes of onion-bulbs/ha (DOGR, 2012). FYM @ 20 tonnes/ha + neem-cake @1 tonne/ha+S@20 kg/ha+ NPK@50:50:50 kg/ha as basal application and spray of polyfeed@1\% at 30 and 45 DAP and multi K@1\% at 60 and 70 DAP enhanced bulb yield (NHRDF, 2011). Application of $75 \%$ of the recommended fertilizer dose (RDF), FYM (5 tonnes), poultry-manure (2.5 tonnes) and vermicompost (2.5 tonnes)/ha gave marketable bulb yield with nutrient content and uptake equal to 100\% RDF (150: 50: $80: 50 \mathrm{~kg} \mathrm{NPKS/ha)} \mathrm{+} 20$ tonnes FYM/ha or $100 \%$ RDF alone (DOGR, 2012). Nitrogen $110 \mathrm{~kg} / \mathrm{ha}$ in three splits - at the time of planting and 30 and 45 DAP - with basal application of phosphorus $(40 \mathrm{~kg} /$ ha), potash (60kg/ha) and sulphur (40 kg/ha) has also been recommended (AINRPOG, 2013). Use of cytozyme @ $0.2 \%$ as a root-dip before transplanting, followed by foliar sprays $(0.2 \%)$ at 15,45 and 75 days after transplanting led to higher onion yields (NHRDF, 2011).

Supplementation of chemical fertilizers with biofertilizers proved to be beneficial for onion-crop (Yogita and Ram, 2012). Maximum plant height, number of leaves, neck thickness, bulb diameter, bulb weight, number of scales and yield and minimum number of days required for bulb formation and number of days taken to maturity were recorded with $100 \mathrm{~kg} \mathrm{~N}+50 \mathrm{~kg} \mathrm{P}+70 \mathrm{~kg} \mathrm{~K} / \mathrm{ha}+2 \mathrm{~kg} / \mathrm{ha}$ Azotobacter $+1.9 \mathrm{~kg} / \mathrm{ha}$ VAM. Biofertilizers, Azospirillum and Azotobacter, increased growth and yield compared to control (Sharma et al., 2010).

Application of plant hormones to enhance quality of onion-bulbs was evaluated at the Anand Agricultural University, Gujarat (Patel et al., 2010). GA $50 \mathrm{mg} /$ litre as root-dip, followed by foliar spray significantly increased bulb volume, equatorial and polar diameters of bulbs as well as yield. Dipping roots in NAA $100 \mathrm{mg} /$ litre was found effective to reduce physiological weight loss, spoilage loss, and finally total loss.

Subbarao et al. (2011) advocated green manuring with sesbania, cowpea, berseem, wild indigo, greengram, blackgram and dhaincha. Under organic production system, foliar application of Panchgavya (5\%) at 30, 45 and 60 days after planting improved marketable onion-bulb yield (20.2 tonnes/ha) (DOGR, $2011 b, 2012)$. This was the best among various organic growth stimulantsPanchgavya, Dashparni, Amrutparni, Vermiwash, Seeweed extract, EM Solution, Humic acid, Bio-Potash and microbial extract.

\section{Irrigation and fertigation}

Irrigation requirement of the crop depends on the season, soil type, method of irrigation and crop age. Onion being a shallow-rooted crop needs light irrigation frequently to maintain optimum soil moisture for proper growth and development. Water deficit at the crucial growth stages reduces crop productivity. Excess irrigation decreases yield, besides enhancing post-harvest losses. At the Bidhan Chandra Krishi Viswavidyalaya, Mohanpur (West Bengal), irrigation at 0.55 atmospheric tension at 6-8 day intervals to cv. Sukhsagar gave highest yield (19.90 tonnes/ha) (Deb et al., 2009). In cv. Telagi Red, bulb yield (54.91 tonnes/ha), number of leaves, leaf area, leaf area index and neck girth per plant and equatorial diameter, polar diameter and bulb weight were significantly higher when field 
was irrigated at a day's interval at $100 \%$ pan evaporation (PE) at the University of Agricultural Sciences, Dharwad (Karnataka) (Bagali et al., 2012).

Onion fields need to be irrigated $8 \mathrm{hr}$ before transplanting for proper establishment of the crop (NHRDF, 2011). With drip irrigation significantly higher marketable bulbs were produced compared to other irrigation methods. And there was around $30 \%$ saving in water with drip system than the surface system. Highest water-use efficiency $(770 \mathrm{~kg} / \mathrm{ha} \mathrm{cm})$ and minimum storage losses were recorded in drip system, followed by sprinkler $(386.5 \mathrm{~kg} / \mathrm{ha} \mathrm{cm})$, and the lowest efficiency was with surface irrigation $(252.5 \mathrm{~kg} / \mathrm{ha}-\mathrm{cm})$. B: C ratio was highest in drip irrigation (1.98), followed by surface irrigation (1.35) (Tripathi et al., 2010). To maximize fertilizer-use efficiency in onions, drip fertigation with organic manures (FYM@7 tonnes/ha, poultry-manure@3.5 tonnes/ha and vermi-compost @3.5 tonnes/ha) and $80 \%$ recommended dose of water-soluble fertilizers was recommended (DOGR, 2012).

\section{Weed management}

Frequent application of irrigation and fertilizer to the onion-crop favours severe crop-weed competition. The crop exhibits greater susceptibility to weeds in comparison to most other crops, mainly due to slow growth of the crop at the initial growth stages and also owing to its inherent characteristics such as short stature, non-branching, sparse foliage and shallow-root system. At Navsari Agricultural University, Gujarat, major weed flora was recorded in onion (Vashi et al., 2010) -Monocot weeds were Cynadon dactylon (L.) Pers., Echinochloa crusgalli L., Sorghum halpense L., Echinochloa colonum Link and Digitaria obsendens Scop, and dicot were Phyllanthus maderaspatiensis, Ephorbia hirta L. Amaranthus viridis L., Digera arvensis Fork., Trianthem aportulacastrum L., Convolvulus arvensis L. and Physalis minima L.

Chemical weed control along with cultural methods is inevitable because of labour scarcity. At the Bidhan Chandra Krishi Viswavidyalaya, West Bengal, handweeding at 40 days after transplanting along with the application of quizalofopethyl $5 \%$ EC at $2.5 \mathrm{ml} /$ litre of water at 20 DAP significantly reduced weed density (25.5) and dry weight $(55.3 \mathrm{~g})$. It also resulted in highest bulb diameter $(4.09 \mathrm{~cm})$, bulb weight $(13.42 \mathrm{~kg}$ ) and bulb yield (335.64 q/ha) in cv. Arka Kalyan (Yumnam et al., 2009).

Spray of Oxyflurofen 23.5\% EC @ 1.5ml/litre before planting of bulbs and one hand-weeding at 55 days after transplanting showed good weed-control efficiency (73.6\%), higher marketable bulb yield (36.1 tonnes/ha) and highest B: C ratio (2.54) (DOGR, 2011b). Pendimethalin @ $0.75 \mathrm{~kg} / \mathrm{ha}$ at pre-emergence stage and at 30 days after transplanting was promising for weed control (IARI, 2010). Rice-straw mulch + Pendimethalin @ 3.5 litre/ha at 3DAP was found better weed control measure and gave higher bulb yield during rabi, and alternatively, wheat-straw mulch + Oxyfluorfen @ $0.15 \mathrm{~kg}$ a.i./ha proved effective (NHRDF, 2011).

\section{Pest and disease management}

Insect-pests and diseases are biotic stresses, which are a major hurdle in reaping 
bumper onion-crop. An Integrated Pest Management (IPM) module for controlling pests and diseases has been recommended for the crop (DOGR, 2011a). It consists of seed treatment with Thiram + Carbendazim (2: 1) @ $3 \mathrm{~g} / \mathrm{kg}$ of seeds or Trichoderma @ 4-6 g/kg of seeds. Multiplying $2 \mathrm{~kg}$ of Trichoderma in one quintal of FYM and applying in one hectare is also recommended for controlling soilborne pathogens. Dipping seedlings in $0.025 \%$ Carbosulfan $+0.1 \%$ Carbendazim solution for 2 hours before transplanting in the main field is suggested to control insect-pests in the nursery. Spray of Mancozeb @ 0.25\% or Chlorthalonil @ 0.25\% or Iprodione @ 0.2\% or Propiconazole @ 0.1\% has been recommended to control purple-blotch and Stemphylium blight in the standing crop (DOGR, 2011b).

Onion thrips (Thrips tabaci L.) is a potential pest of onion, and almost $100 \%$ fields have been known to be infested with it worldwide (Krishnakumar et al., 2011). In Maharashtra, the state with the largest onion-growing area in India, yield losses were reported up to $50 \%$ in rabi if thrips were not controlled. Thrips infestation predisposes onion-crop to purple-blotch (Alternaria porri). According to a study at the DOGR, two population peaks - first one in the month of August and the other in January-February-occur in Maharashtra. Crop barriers with outer two rows of maize or an inner row of wheat with an outer row of maize (Fig.2.2) were found to block $80 \%$ infestation, as thrips are weak flier (Srinivas and Lawande, 2006). In rabi, estimated threshold level for thrips was 30 thrips/plant, and the highest $\mathrm{B}: \mathrm{C}$ ratio of chemical control was achieved when thrips were controlled between 45 and 75 days of planting (Srinivas and Lawande, 2008). Minimum thrips population $(0.28 /$

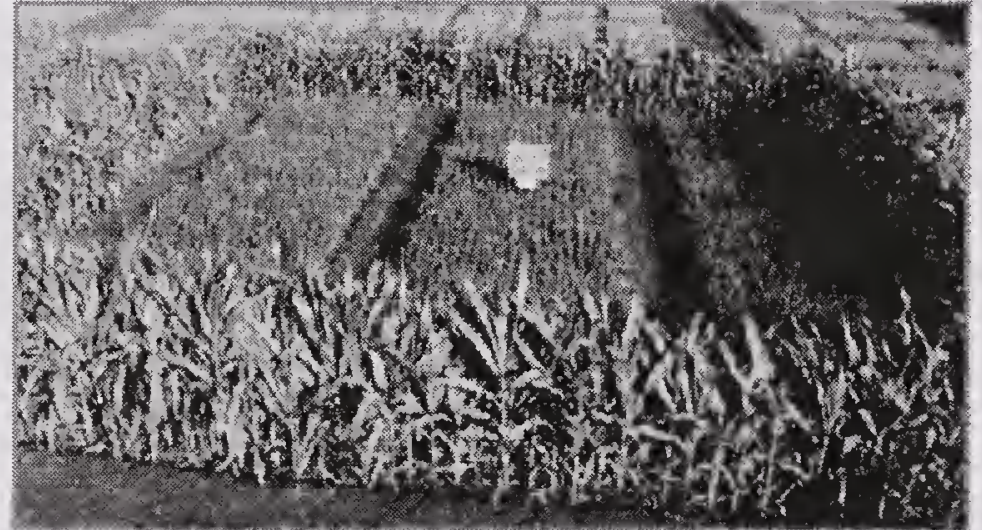

Fig. 2.2 Barrier cropping with maize plant) and almost $99 \%$ reduction in their incidence was recorded over control with foliar spray of Imidacloprid at the Rajasthan Agricultural University, Rajasthan (Bhargava, 2010). The maximum bulb yield (32.89 tonnes/ha) was recorded in treatment with foliar sprays of Imidacloprid (Confidor 200SL) at 20 $\mathrm{g}$ a.i./ha, which was at a par with seedling root-dip in Imidacloprid, followed by foliar spray of Imidacloprid (315.46 q/ha). Maximum cost: benefit (1: 39.97) ratio was in treatment with Imidacloprid. Considering Imidacloprid spray as a protective treatment (avoidable loss: 0\%), control proved non-protective with $54.08 \%$ of avoidable losses.

Six sprays of Spinosad @ 1ml/litre at a weekly interval or three sprays of Fipronil@1.5 ml/litre at 15 days interval were effective in managing thrips population and giving 25\% more marketable yield than control during rabi (NHRDF, 2011). Insecticidal spray of Dimethoate @ $0.06 \%$ or Monocrotophos @ 0.05\% or Profenofos@ 0.05\% or Carbosulfan@0.05\% or Cypermethrin@ $60 \mathrm{~g}$ a.i./ha or Methomyl @ $0.05 \%$ or Spinosad @ $56 \mathrm{~g}$ a.i./ha was recommended to control thrips. Spraying at bulbing stage (45-75 DAS) was found crucial for minimizing losses (DOGR, 2011b). 


\section{Interventions for kharif onion production}

Kharif onion productivity is very low (10 to 12 tonnes/ha) owing to high incidence of foliar as well as soil-borne diseases and weed population. A technology has been standardized for enhancing its productivity. It includes nursery-raising in summer on broad-bed furrows (BBF) with drip or sprinkler under shade-nets with seedlings ready for transplanting in the first week of June; transplanting of seedlings on the BBF; application of FYM or vermi-compost pre-mixed with Trichoderma viride before bed preparation; and application of pre-emergence weedicides. Fertigation through drip help avoid nutrient losses through leaching, which is common in high rainfall areas. This technology ensures 25 tonnes/ha without affecting quality of bulbs (DOGR, 2011a). Fortnightly schedule of Mancozeb was effective for managing foliar diseases of onion during kharif; recorded disease incidence of $35 \%$ and yield of 30 tonnes/ha as against disease incidence of $45 \%$ and yield of 16.67 tonnes/ha in control (IIHR, 2010).

\section{Sets technology}

Onion production through sets is practised in kharif when planting coincides with heavy showers and nursery-raising is difficult due to hot-and-humid weather in May. Onion-sets (small bulblets) being much larger than seeds have higher vigour than transplanted seedlings and result in early establishment, thus crop grows successfully even in less favourable conditions. Sets have a shorter growing season than plants from seeds and transplants, and therefore can be exploited when a rapid or early season production is required.

Seeds are sown in the last week of January on the raised beds @ $15 \mathrm{~g} / \mathrm{m}^{2}$ to harvest onion-sets in the third week of May. Sets are graded and stored at room temperature in a ventilated storage structure till their field planting. Different groups of sets are planted in mid-July on the raised beds. Sets of 2 to $2.5 \mathrm{~cm}$ size planted at 30-cm spacing in the last week of August on ridges gave highest yield and net returns (NHRDF, 2011). Closer distance planting $(15 \mathrm{~cm} \times 10 \mathrm{~cm})$ was found more beneficial regarding marketable bulb yield, net income, cost: benefit ratio and cost of cultivation (Singh and Singh, 2002). Planting sets on sandy-loam soil by flat system and ridge- and- furrow system resulted in an average bulb yield of 13.2 and 12.0 tonnes/ha, respectively, compared to 9.6 tonnes/ha in broad-bed system (Sharma et al., 2003). The bulb-crop from the sets during kharif recorded highest yield and better bulb development with potash@50 kg/ha as basal + foliar application of sulphate of potash @ $1 \%$ at 30 to 40 days after planting (DAP) along with nitrogen@150 kg/ha and phosphorus @ $50 \mathrm{~kg} / \mathrm{ha}$ (NHRDF, 2011).

\section{Farm mechanization}

Shortage of labour at a crucial time and also increased labour cost make farm mechanization inevitable for the crop. Mechanization is mainly required for sowing, transplanting and harvesting. Direct seed sowing during kharif as well as rabi with local machine and pneumatic seed-drill (imported by the CIAE, Bhopal, from Italy) (DOGR, 2013) was compared with manual sowing (broadcasting) and seedling transplanting methods (Fig. 2.3). Among various direct sowing 

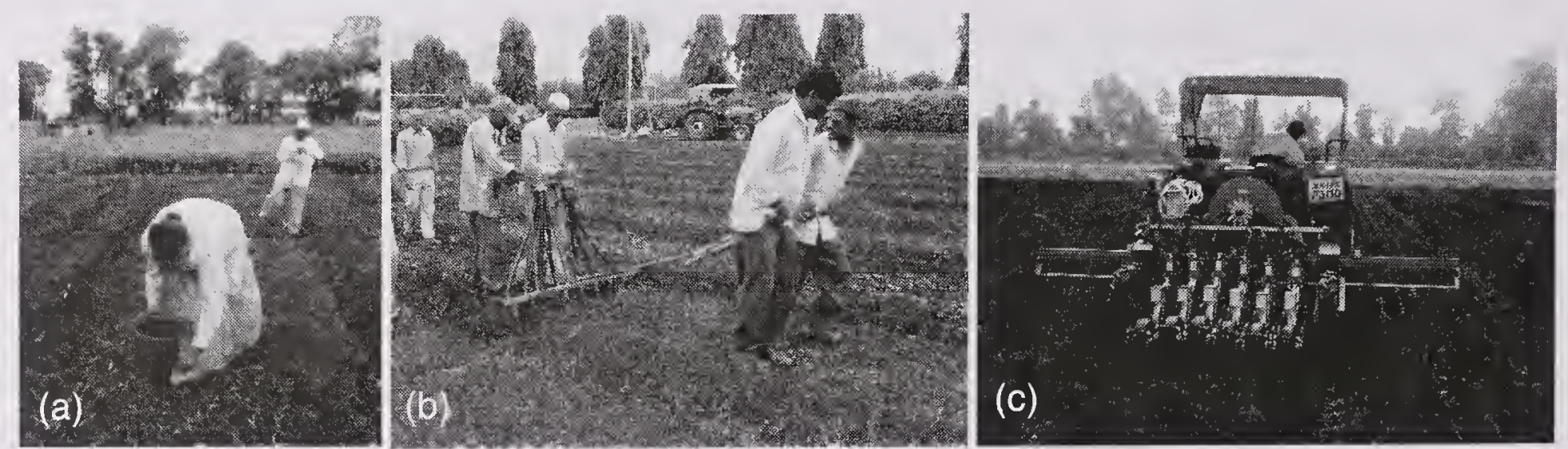

Fig. 2.3 Different sowing methods for onion

(a) Broadcasting; (b) Poona seed-drill; (c) Pneumatic seed-drill

methods, bigger bulbs, more A grade bulbs percentage and less double bulbs were observed with pneumatic seed-drill. Transplanting recorded highest marketable yield; was significantly higher over pneumatic seed-drill. Low seed rate, easy sowing, saving in time and early maturity of onions were observed with pneumatic seed-drill. The lowest marketable bulbs were observed with Poona seed-drill, followed by manual sowing (broadcasting).

A six-row tractor-operated onion transplanter for flat-bed was designed and fabricated (IIHR, 2010). The six-roller wheels pressed roots of the seedlings in the soil and shovels covered them with soil. The row spacing in the prototype was $15 \mathrm{~cm}$ and seedling spacing was $10 \mathrm{~cm}$. Its expected working speed was $1 \mathrm{~km} / \mathrm{hr}$ and field capacity was $0.8 \mathrm{ha} /$ day.

Manual onion harvesting is drudgery, and thus mechanized harvesting is of utmost importance. Prototype of onion digger, with length $1.2 \mathrm{~m}$, speed ratio 1.25: 1 and slope of elevator 15 degrees, performed with digging efficiency of $97.7 \%$ and separation index of $79.1 \%$, and showed minimal bulb damage of $3.5 \%$, and low fuel consumption of 4.1 litres/ha and draft of $10.78 \mathrm{kN}$ (Khura et al., 2011). Onion detopper was designed and developed at the Haryana Agricultural University, Hisar, to facilitate digging and top removal (Rani and Srivastava, 2012). Onion-bulbs were fed through a chute-type feeding unit to belt conveyor moving at a speed of $0.53 \mathrm{~m} / \mathrm{s}$ which ensured uniform transport of bulbs to an conveyor. The cutter was provided at the downward side of the conveyor. The speed of the cutter could be varied and output capacity was $300 \mathrm{~kg} / \mathrm{hr}$ with the detopping efficiency $79 \%$. The belt conveyor had two rollers and an endless conveyor belt.

To mechanically extract onion-seeds, experiments were conducted with spiketooth extraction mechanism in a laboratory test set-up (IARI, 2010). The mechanism gave extraction efficiency of $98.93 \%$ and cleaning efficiency of $97.07 \%$. The seed loss ranged between $2.15 \%$ and $3.08 \%$ at cylinder speeds of $3-$ $5 \mathrm{~m} / \mathrm{s}$. Seed extraction cost by mechanical seed extractor and manual/conventional method was ₹ 1,800 and $₹ 9,000$ per tonne of onion-umbel, respectively. Breakeven point for seed extractor was $78.77 \mathrm{hr}$ (31.51\% of annual utility), and it's payback period was 2.4 years.

\section{Post-harvest handling and storage}

Although, pre-harvest cultural practices such as fertilizer application, irrigation, 
etc. have profound role on storage life of bulbs, these factors cannot be managed easily. So, proper post-harvest management practices become imperative. Comprehensive studies indicated that post-harvest losses can be to the tune of $45-50 \%$ if the proper care of the harvested produce is not taken. In storage, kharif onions are more prone to losses than late kharif and rabi produce. Total losses, which include physiological loss of weight, rotting and sprouting, reached almost $70 \%$ in kharif after three months of storage (DOGR, 2013). Light red varieties have more storability than dark red and white bulb varieties (Tripathi and Lawande, 2010). Besides, varietal difference, losses in storage were also found related to bulb size, neck thickness and neck length. Curing is an important post-harvest management operation that impacts storage. Windrow method of field curing for 3-5 days, followed by shade curing for 7-10 days has been recommended. Curing bulbs under poly-tunnel in kharif and pits in rabi was effective in reducing losses. Artificial curing in curing chamber with a full load at $35^{\circ} \mathrm{C}$ temperature and airflow velocity of $3.2 \mathrm{~m} / \mathrm{s}$ cured bulbs efficiently. These bulbs were superior in storage as compared to curing under ambient conditions during kharif (NHRDF, 2011).

Grading of bulbs improves marketability of the produce; hand-grading is an expensive operation. To reduce grading cost and increase precision, two onion graders-manually operated and motorized graders (Fig. 2.4)—were designed and evaluated (Tripathi and Lawande, 2009). They increased efficiency by 5 and 20 times, respectively, over hand-grading. Grading precision achieved by graders is $98 \%$ as against $50 \%$ in hand-grading. Capacity of manual grader is 5 quintals per person per hour with $90 \%$ accuracy, and that of motorized grader is two tonnes per hour with $90 \%$ accuracy.

(a)
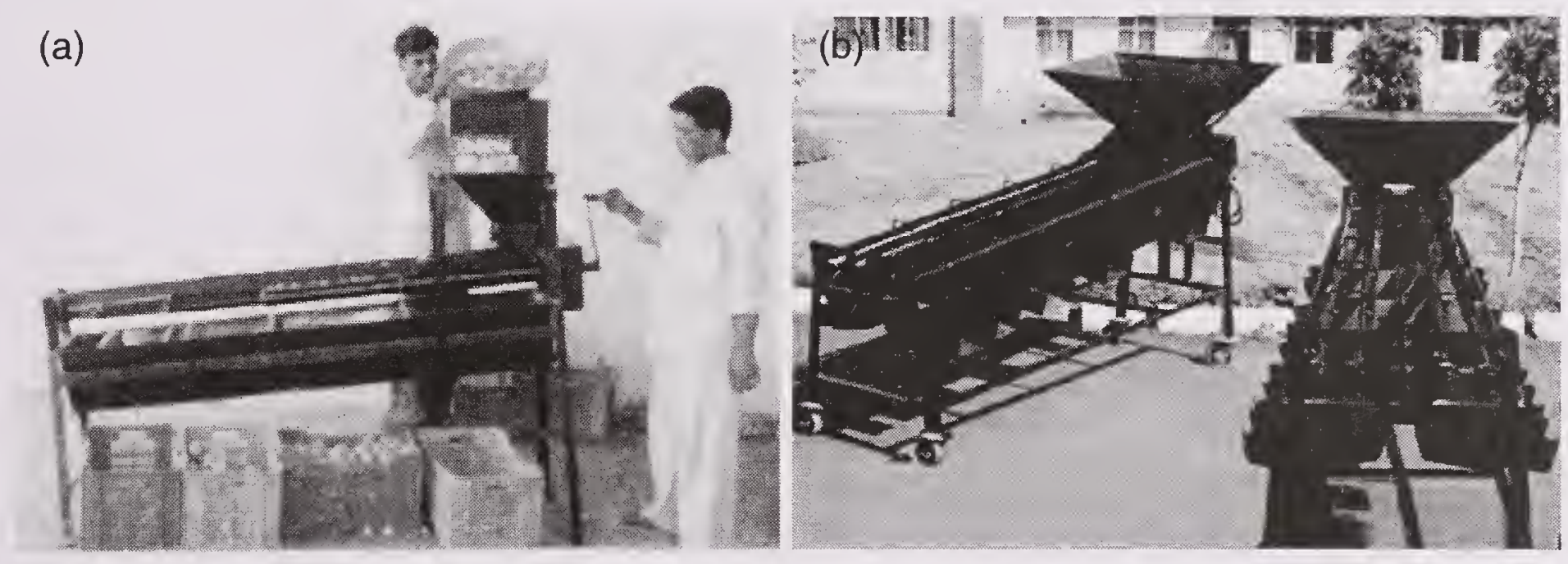

Fig. 2.4 Hand-and motor-operated grading machines developed by the DOGR (a) Hand-operated onion-grader; (b) Motorized onion-grader

A trial was conducted to assess the effect of different storage structures traditional, bottom-ventilated, mud-plastered and chain-linked structures (Fig. 2.5). And packing materials - stakes, hessain cloth bags, netlon bags and plastic crateswere compared for packaging. Mud-plastered top and bottom ventilated storage structures were superior in reduction of losses (weight loss, rotting and sprouting) over other structures irrespective of the packing materials. Among single-row structures, low-cost bottom-ventilated structure was found the best in curtailing losses and increasing net profit. Low-cost storage model of 5 to 10 tonnes capacity 

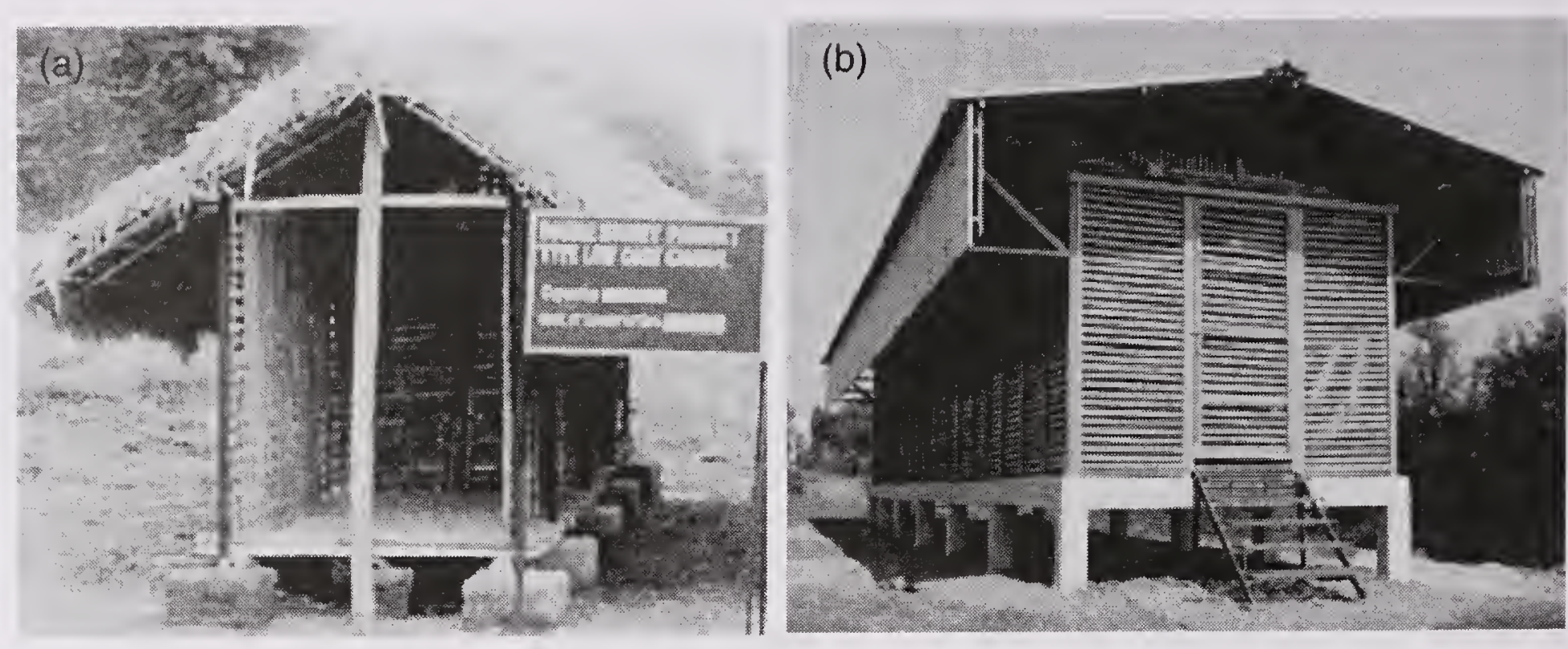

Fig. 2.5 Onion storage structures

(a) Low-volume, low-cost structure; (b) High-volume bottom and side-ventilated structure

and high cost model of 25 to 50 tonnes capacity with bottom and side ventilation recommended by the DOGR have become quite popular among farmers (Murkute and Gopal, 2013). Considering minimal storage losses, subsidy is being advanced for these models by different state governments. Cold storage is most efficient to restrict physiological weight loss, but its conduciveness for sprouting restricts its use. To restrict sprouting, use of gamma irradiation has been advocated in cold storage (Tripathi and Lawande, 2011).

\section{Processing}

Processing increases shelf-life without compromising freshness and quality of the produce. It adds value to the finished product and increases consumers' preference. Based on the recovery and quality of red and white onion flakes, cabinet-drying method has been recommended (DOGR, 2011b). White onions gave higher recovery $(11.17 \%)$ than red onions $(10.12 \%)$. While sun-drying of onions in open results in scorching and it turns them brownish in colour. Time required is maximum for sun-drying in open, followed by solar-drying in glass cabinet and is minimum in electrical cabinet-drying. Cabinet-dried onion flakes showed overall acceptability score for colour on the Hedonic scale, followed by solar-and sun-dried flakes. Cabinet-dried onion flakes are with superior shelf-life of flakes and also in rehydration ratio. Bulk trial on white onion dehydration using $50 \mathrm{~kg}$ lot indicated that dried onion yield of $9.9 \%$ on the fresh weight basis could be obtained. Sensory evaluation studies using 9-point Hedonic scale revealed that curry prepared with dehydrated onions was acceptable in colour, taste/ pungency and texture compared to fresh and rehydrated samples. Dried white onions in three different packages at the end of 6 months storage period-PET jar (100g), 150-gauge polyethylene pouch and plastic pallet - at room temperature showed that samples in PET jar and plastic pallet retained original colour, while samples packed in polythene pouch turned brown (IIHR, 2010).

Peeling of onions is essential to prepare dehydrated onions, onion powder, onion flavouring, onion salt, onion rings, and pickled and canned onions. The Central Institute of Agricultural Engineering, Bhopal, has developed a batch-type multiplier onion peeler (Naik et al., 2007). Multiplier onion needs to have ends 
cut with a sharp knife and soaked in clean water for 10 minutes to facilitate loosening of peel, followed by 1-2 minutes air-drying to remove surface water. With $92 \%$ peeling, and unpeeled and damaged percentage being $6 \%$ and $2 \%$, respectively, the capacity of the peeler has been found $50-60 \mathrm{~kg} / \mathrm{h}$.

\section{Growth and projections}

Onion production increased from 40.4 lakh tonnes in 1994-95 to 166.4 lakh tonnes in 2012-13 (Agricultural Statistics, 2013). The increase has mainly been from increased cultivated area under onion that stood at 10.6 million hectares in 2010-11. Although second in production after China at the world level, India is far behind in onion productivity in comparison to many countries. In India, average onion productivity is only 14.21 tonnes/ha, which is lower than the world average of 19.47 tonnes/ha. The highest onion productivity has been reported of 67.33 tonnes/ha from Ireland. There is a need to analyze factors responsible for lower productivity in India to come out with a workable plan to meet domestic requirement as well as for increasing export of this important crop; which India has been traditionally exporting.

To cater to the requirement of the ever-increasing population, keeping per capita consumption, export, processing and losses at existing rate (consumption, i.e. 6.7 $\mathrm{kg} /$ person/year, export 9\%, processing $6.75 \%$ and losses $30 \%$; base year 20102011), our country would require 21.12 million tonnes of onion by 2050 as against 14.82 million tonnes in $2010-11$. This demands an increase in average productivity from 14.53 to 20.7 tonnes/ha- 42.5\% higher than 2010-11. Efforts can be made to reduce losses up to $20 \%$, increase export up to $25 \%$ and processing up to $15 \%$ by 2050 . With these targets, we have to increase production from 14.82 million tonness to 28.57 million tonnes with productivity of 28.01 tonnes/ha.

\section{Reasons for low productivity}

1. Shortage of quality seed of improved varieties.

2. Low yield potential of onions under short days in India.

3. Predominance of open pollinated (OP) varieties due to non-availability of suitable $\mathrm{F}_{1}$ hybrids.

4. Non-availability of disease and pest resistant varieties.

5. Sub-optimal cultivation standards adopted by farmers.

6. Shortage of irrigation at critical stages.

7. High storage losses due to poor storage conditions.

8. Price instability leading to suboptimal use of inputs.

\section{Prospects and strategies}

Keeping in view the inherent problems of the onion-crop and changing ecological, environmental, and socio-economic scenario, technological initiatives required for meeting domestic and export market requirements are presented as follows.

Seed: Old local genotypes still predominate, and seeds are produced by the farmers without undertaking proper measures such as required isolation distance etc. There is no organized system for production and distribution of quality onion- 
seeds. Seeds produced by a few research organizations are sold to farmers in limited quantity. Need is that good quality/breeder seeds from research organizations should be procured by the state and national seed certification agencies for multiplication and distribution to farmers at the reasonable rate.

Storage: In India, storage of onions is required from May to November. For domestic supply, export as well as of bulbs, about 40 lakh tonnes of onions are to be stored. Storage of onion-bulbs for longer periods is problematic. Kharif onioncrop is rainfed, and is harvested while physiologically still immature. This cannot be stored even for a month. There is a need to develop genotypes having good storage life. Refinement of cultural practices to minimize storage losses and designing of bottom and side ventilated storage structures by which storage losses can be reduced by 10-20\% have been done. There is an urgent need for popularization of such storage structures and for providing financial assistance to onion-growers in different states.

Cold storage of onions with back-up of irradiation for suppression of sprouts would be new area for research. Cold-storage technology is now picking up, particularly with the private sector. These cold storages are ventilated types with controlled atmosphere, wherein gases, particularly carbon dioxide, product of bulb respiration, is monitored and regularly controlled. The storage losses in such stores are not more than 5\%. The technology is, however, expensive, and is not reaching small and marginal farmers. The development of technology package for pre-cooling and establishment of cool chain for overseas trans-shipment is imperative to augment exports. Innovations in design of refrigerated containers would be crucial to reduce transit losses. Development of these facilities in strategic production areas would reduce post-harvest losses. There is a need to develop and standardize technology for storing onions in controlled atmosphere cold storages, where there is scope to reduce storages losses drastically.

Onion hybrids: At present in India, only open-pollinated varieties are in cultivation. Some exotic hybrid varieties with higher seed cost are being promoted by some private seed companies, but they are not much adapted to short-duration conditions of India and thus have a little advantage over commercial openpollinated varieties. Thus development of hybrid onion varieties adapted to Indian conditions is urgently needed. Non-availability of inbred lines and durable male sterile lines are hampering hybrid production.

Disease and pest resistance: All onion varieties in cultivation in India are susceptible to various diseases and pests. Thus, breeding for disease and pest resistance is an area which needs to be prioritized. There is a need to screen all available germplasm systematically including wild Allium species for various diseases and pests. Resistant or the tolerant types so identified need to be adopted and used in breeding for developing disease and pest resistant varieties. Markerassisted selection and cloning of resistant genes can also be made use of for accelerating development of resistant varieties.

Processing and value-addition: Onion processing industries are emerging at a faster rate and would be demanding more raw material. The processing units are facing problems of year-round supply of high TSS white onion $(>18 \%)$ varieties. Varieties with low reducing sugars, high pyruvic acid and allicin content 
are required to develop value-added nutritionally rich products. However, development of onion and garlic varieties rich in medicinal and functional food value is still a challenge.

Kharif production technology: Production of successful onion-crop during kharif is still a challenge as the crop is mainly rainfed and severely attacked by many diseases and pests. Kharif production technology thus needs to be refined.

Mechanization: There is demand for the development of machines and tools for small and medium farmers to minimize labour requirement. Direct seeding can substantially reduce the labour cost involved in traditional transplanting. Available seed-drills lack precision in terms of maintanence of plant population and interspaces between plants. They need to be upgraded by using pneumatic seed-drill technology available in advanced countries, which at present is expensive, and is used in large farms only. Similarly, work on transplanters, harvesters, etc. also needs to be undertaken.

\section{Future Thrusts}

Considering natural resource degradation, climate change and associated stresses, following strategies would help carry forward technological initiatives for meeting domestic and export requirements of onions.

- Combine conventional breeding with biotechnological approaches for introgression of genes from wild species for resistance/tolerance to biotic and abiotic stresses, male sterility, high TSS, and for creation of variability.

- An organized system for production of quality seeds in sufficient quantity and their distribution at reasonable rates need to be developed by involving research organization, state and national seed certification agencies and also private sector.

- Development of low-cost cold storage technology is needed to minimize storage losses.

- Robust recommendations need to be given based on long-term multilocational trials on the Integrated Nutrient Management (INM), Integrated Pest Management (IPM) and Integrated Disease Management (IDM) for enhancing and for sustenance of productivity.

- A more flexible public private partnership (PPP) needs to be developed wherein basic and strategic research should be undertaken by research organizations, and applied aspects like variety/hybrid development, agronomic recommendations and extension activities should be undertaken through PPP mode.

- Government has to do crop planning for effective supply chain management and price control. A firm policy on promotion of exports is needed. Facilities for quick transport, provision of ventilated containers and cargo clearance through agri-export zones are to be strengthened.

\section{References}

Agricultural Statistics. 2013. Agricultural Statistics at a Glance 2013. Directorate of Economics and Statistics. Ministry of Agriculture, Government of India. http:// www.nhrdf.com/content Page.asp?sub_section_code=104. 
AINRPOG. 2013. Annual Report 2012-13, 459 pp. All-India Network Research Project on Onion and Garlic. Directorate of Onion and Garlic Research, Rajgurunagar, Pune, India.

Bagali A N, Patil H B, Guled, M B and Patil R V. 2012. Effect of scheduling of drip irrigation on growth, yield and water use efficiency of onion (Allium cepa L.). Karnataka Journal of Agricultural Sciences 25: 116-19.

Bhargava K K. 2010. Management of the onion thrips, Thrips tabaci Lindeman, through seedling root dip in insecticidal solution and sprays of conventional insecticides in the semi-arid regions of Rajasthan. Pest Management and Economic Zoology 18: 199204.

Deb M, Pandit M K, Sarkar A and Maity T K. 2009. Response of irrigation and fertilizer on growth, yield and post harvest shelf-life of onion. Environment and Ecology 27: $1025-27$.

DOGR. 2011a. DOGR Vision 2030, 32 pp. Directorate of Onion and Garlic Research, Rajgurunagar, Pune, India.

DOGR. 2011b. Annual Report 2010-11, 80 pp. Directorate of Onion and Garlic Research, Rajgurunagar, Pune, India.

DOGR. 2012. Annual Report 2011-12, 72 pp. Directorate of Onion and Garlic Research, Rajgurunagar, Pune, India.

DOGR. 2013. Annual Report 2012-13, 92 pp. Directorate of Onion and Garlic Research, Rajgurunagar, Pune, India.

IARI. 2010. Annual Report 2011-12, 200 pp. Indian Agricultural Research Institute, New Delhi, India.

IIHR. 2010. Annual Report 2009-10, 138 pp. Indian Institute of Horticultural Research, Bengaluru, Karnataka, India.

Jawadagi R S, Basavaraj N, Naik B H, Patil B N and Channappagoudar B B. 2012. Effect of planting geometry and organic sources of nutrients on growth, yield and quality of rabi onion cv. Bellary red. Karnataka Journal of Agricultural Sciences 25: 236-40.

Jawadagi R S, Deshpande V K, Pattar P S, Hunje R and Kulkarni S A. 2008. Seed invigoration in onion (Allium cepa). Journal of Ecobiology 22: 301-07.

Khura T K, Indra-Mani and Srivastava A P. 2011. Design and development of tractordrawn onion (Allium cepa) harvester. Indian Journal of Agricultural Sciences 81: 52832.

Krishna Kumar N K, Srinivas P S, Rebijit K B, Asokan R and Ranganath H R. 2011. Onion thrips, Thrips tabaci Lindman: A perspective, pp. 68-76. (in Souvenir). (In): National Symposium on Alliums: Current Scenario and Future Trends, held during 12-14 March 2011 at the Directorate of Onion and Garlic Research, Rajgurunagar, Pune, India.

Lawande K E. 2011. Onion Production (Marathi), 60 pp. Directorate of Onion and Garlic Research, Rajgurunagar, Pune, India.

Murkute A A and Gopal J. 2013. Taming the glut. Agriculture Today 16: 28-30.

NAFED. 2013. NHRDF Database. http://www.nhrdf.com/contentPage.asp?sub_ section_code $=104$

Naik R, Annamali S J K and Ambrose D C P. 2007. Development of batch type multiplier onion peeler. (In): Proceedings of the International Agricultural Engineering Conference on Cutting-edge Technologies and Innovations on Sustainable Resources for World Food Sufficiency, held during 3-6 December 2007 at Bangkok, Thailand.

NHRDF. 2011. NHRDF Research (1978-2010), pp. 61. Gupta R P, Bhonde S R, Srivastava K J, Dagade S B and Prakash H. (Eds). National Horticultural Research and Development Foundation, Nashik, India.

NRCOG. 2004. Annual Report 2003-04, 52 pp. National Research Centre on Onion and 
Garlic, Rajgurunagar, Pune, Maharashtra, India.

NRCOG. 2006. Annual Report 2005-06, 58 pp. National Research Centre on Onion and Garlic, Rajgurunagar, Pune, Maharashtra, India.

Patel M J, Patel H C and Chavda J C. 2010. Influence of plant growth regulators and their application methods on yield and quality of onion (Allium cepa L.) Asian Journal of Horticulture 5: 263-65.

Rani V and Srivastava A P. 2012. Design and development of onion detopper. AMA Agricultural Mechanization in Asia, Africa and Latin America 43: 69-73.

Sharma P K, Yadav G L and Kumar S. 2003. Effects of methods and dates of planting of onion sets on the bulb yield of kharif onion. NHRDF News Letter 23: 1-3.

Sharma R K, Singh S S, Singh K and Mishra S P. 2010. Effect of biofertilizers and nitrogen on growth and yield of onion (Allium cepa L.) Environment and Ecology 28: 1281-83.

Singh A K and Singh V. 2002. Effect of cultural practices on marketable bulb yield and economics of kharif onion (Allium cepa L.). Bioved 13: 27-31.

Srinivas P S and Lawande K E. 2006. Maize (Zea mays) barrier as a cultural method for management of thrips in onion (Allium cepa). Indian Journal of Agricultural Sciences 76: $167-71$.

Srinivas P S, Qureshi A A and Lawande K E. 2008. Growth stage susceptibility of onion (Allium серa) and its role in thrips management. Indian Journal of Agricultural Sciences 78: $98-101$.

Subbarao A, Singh A B and Ramesh K. 2011. Production of onion (Allium cepa) and garlic (Allium sativum) under organic farming, pp. 43-49. (Souvenir and Abstracts). (In): National Symposium on Alliums: Current Scenario and Future Trends, held in March 2011 at the Directorate of Onion and Garlic Research Pune, Maharashtra, India. Tandon H L S. 1987. Fertilizer Recommendation for Horticultural Crops. A Guide Book, pp. 10-14. Fertilizer Development and Consultation Organization, New Delhi.

Tripathi P C and Lawande K E. 2009. A new gadget for onion grading. AG Journal 90.

Tripathi P C and Lawande K E. 2010. Temperature related changes in respiration and $\mathrm{Q}_{10}$ coefficient in different varieties of onion. Progressive Horticulture 42: 88-90.

Trapathi P C, Sankar V and Lawande K E. 2010. Influence of micro-irrigation methods on growth, yield and storage of rabi onion. Indian Journal of Horticulture 67: 61-65.

Trapathi P C, Sankar V, Mahajan V and Lawande K E. 2011. Response of gamma irradiation on post harvest losses in some onion varieties. Indian Journal of Horticulture 68: 55660.

Vashi J M, Pandya H V and Naik R M. 2010. Study on physical and chemical methods of weed control in onion crop. International Journal of Plant Protection 2: 245-47.

Yogita and Ram R. 2012. Interaction effect of chemical and bio-fertilizers on growth and yield of onion (Allium cepa L.). Hort Flora Research Spectrum 1: 239-43.

Yumnam A, Mandal A R, Thapa U, Maity T K and Bhattacharya S P. 2009. Studies on weed management in onion (Allium cepa L.) Journal of Crop and Weed 5: 325-26. 


\section{Biosystematics, Botany and Genetic Resources}

Vijay Mahajan, K.S. Negi and A.J. Gupta

Genus Allium includes bulbous biennial or perennial herbs. A few of them like onion or garlic emit a distinctive and pungent odour when tissues are crushed; while others lack volatile compounds. Some species belonging to the genus have very long sheathing leaf-bases used for consumption and some have storage organs as rhizomes or as storage roots used for medicinal purposes.

\section{Taxonomy}

The taxonomic position of Alliums is still unclear. The genus Allium as a whole was assigned to family "Liliaceae" by some taxonomists (Polunin, 1969) on account of its superior ovary, and to Amryllidaceae by others (Traub, 1968) because of umbellate inflorescence. Because of superior ovary (characteristic of Liliaceae), scapose umbellate inflorescence (flowers borne in a bracted umbel on the top of a scape) and with membranous bracts (characteristic of Amaryllidaceae), Alliums were placed in family Alliaceae by Purseglove (1972). Others opted for a subfamily - Allioideae of Liliaceae (McCollum, 1976). Fay and Chase (1996), Friesen et al., (2000) and Chase et al., (2009) considered Allium (including Caloscordum Herb., Milula Prain and Nectaroscordum Lindl.) as the only genus in tribe Allieae. The following hierarchy regarding its classification has been adopted (Rabinowitch and Brewster, 1990).

Kingdom: Plantae

Class: Monocotyledon

Super Order: Liliflorae

Order: Asparagales

Family: Alliaceae

Tribe: Allieae

Genus: Allium

A. cepa is considered as divisible into two large cultivar groups-Common Onion Group, with a large, normally solitary bulb, reproduced from seed or from seed-grown bulblets ('sets'), and an Aggregatum Group, with smaller, several bulbs, forming an aggregated cluster, originating from a single mother-bulb. A cultivar of A. cepa will be considered as 'shallot' (belonging to Aggregatum Group) if more than 200 buds are present in one $\mathrm{kg}$ of mother-bulbs and if under the suitable climate, most of them produce new bulbs (Messiaen and Rouamba, 2004). Shinde and Sontakke (1993) described edible Alliums (Tables 3.1, 3.2). 
Table 3.1 Details of edible Alliums

\begin{tabular}{|c|c|c|}
\hline Species & Chromosome No. & Other information \\
\hline Allium cepa L. & $2 n=2 x=16$ & $\begin{array}{l}\text { Closely related to wild diploids of } \\
\text { Central Asia (A. vavilovii, } A . \\
\text { oschaninii, A. pskemense, } A . \\
\text { galanthum) }\end{array}$ \\
\hline $\begin{array}{l}\text { A.cepa var.ascalonicum } \\
\text { Backer }\end{array}$ & $2 n=2 x=16$ & $\begin{array}{l}\text { Commonly known as shallot, } \\
\text { perpetuated by bulbs, which form in } \\
\text { clusters on the soil surface }\end{array}$ \\
\hline $\begin{array}{l}\text { A.cepa var.aggregatum } \\
\text { G. Don }\end{array}$ & $2 n=2 x=16$ & $\begin{array}{l}\text { Commonly known as potato -onion/ } \\
\text { underground onion/multiplier onion/ } \\
\text { Egyptian ground onion. It grows } \\
\text { underground as closely packed } \\
\text { clusters of bulbs rather than on the } \\
\text { surface, like shallot }\end{array}$ \\
\hline $\begin{array}{l}\text { A.cepa var.viviparum(Metz) } \\
\text { Mansf. /proliferum }\end{array}$ & $2 n=2 x=16$ & $\begin{array}{l}\text { Commonly known as tree/Egyptian } \\
\text { tree onion. It is A.cepaxfistulosum } \\
\text { interspecific hybrid (Bozzini, 1964).It } \\
\text { grows as a perennial underground } \\
\text { bulb, is reported to be resistant to } \\
\text { pests and diseases }\end{array}$ \\
\hline A. sativum L. & $2 n=2 x=16$ & $\begin{array}{l}\text { Species producing bulbs consisting of } \\
\text { several cloves, is a sterile } \\
\text { diploid.Some authors consider } \\
\text { A.longicuspis to be its wild ancestor }\end{array}$ \\
\hline A. fistulosum L. & $2 n=2 x=16$ & $\begin{array}{l}\text { Commonly known as Welsh onion or } \\
\text { Japanese bunching onion.It is } \\
\text { perennial bunching type, common in } \\
\text { China and Japanese garden }\end{array}$ \\
\hline A.porrum L. & $2 n=4 x=32$ & $\begin{array}{l}\text { Commonly known as leek, considered } \\
\text { as cultivated wild of } A \text {.ampeloprasum, } \\
\text { which is common in Mediterranean } \\
\text { and South-West Asia }\end{array}$ \\
\hline A.kurrat Sfth. \& Krause & $2 n=4 x=32$ & $\begin{array}{l}\text { Commonly known as kurrat, another } \\
\text { cultivated form of A.ampeloprasum, } \\
\text { grown for green leaves, common in } \\
\text { Egypt and Near East }\end{array}$ \\
\hline A. ampeloprasum L. & $2 n=4 x=32,6 x=48$ & $\begin{array}{l}\text { Also known as great headed garlic, } \\
\text { used as substitute for garlic in } \\
\text { cooking, its bulbs are larger than } \\
\text { garlic, leaves are like leek, produces } \\
\text { inflorescence }\end{array}$ \\
\hline A.schoenoprasum L. & $2 n=2 x=3 x=4 x 2$ & $\begin{array}{l}\text { Also known as chive. It is propagated } \\
\text { by root division,is tolerant to extreme } \\
\text { cold and drought }\end{array}$ \\
\hline $\begin{array}{l}\text { A.tuberosum Rottl. } \\
\text { ex Spreng. }\end{array}$ & $2 n=4 x=32$ & $\begin{array}{l}\text { Also known as Chinese chive of } \\
\text { Eastern Asia, is grown for green } \\
\text { leaves }\end{array}$ \\
\hline A.chinense G. Don & $2 n=2 x=16,4 x=32$ & $\begin{array}{l}\text { Also known as rakkyo.It is a pickling } \\
\text { type of China, South Asia and Japan }\end{array}$ \\
\hline
\end{tabular}




\section{Morphology}

\section{Roots}

They are produced from the base plate. The new roots form an irregular ring above and around the older ones and emerge through corky outer tissue. Each successive ring has more roots than the previous one, and this continues till there is active vegetative growth.

\section{Leaf}

Each leaf consists of a hollow green photosynthetic blade and a cylindrical sheath which connects blade to the base plate of the onionplant. Each leaf arises inside encircling leaf-sheaths of the older leaves, and grows up through them, so to form a pseudostem from the concentric leaf-sheaths. The hollow, tapering leaf-blades are arranged in two rows opposite to each other. Leaves shape vary from fistular, flat, elliptic filiform to linear.

\section{Flower}

During the period of apparent external dormancy, main and usually several lateral growing points on the upper surface of the base-plate continue to grow slowly and form shoot initials consisting of bladed leaves and flower-stalk primordia (Abdalla and Mann, 1963). Individual plants may produce several scapes varying from 1 to 20 or more, depending upon the cultivar. Flower stalk may vary in height from 0.9-1.2 m. The scape is a stoutly formed green, hollow structure which becomes rather inflated at about one-third of the way up; it carries flower buds at its tip. At first buds are enclosed in a thin papery outer spathe or sheath, consisting of 2-3 bracts, which split open by pressure of the developing flowering buds, which are in a more or less spherical inflorescence known as umbel. Umbels are aggregate of cymes of 5-10 flowers each, and flowers open in definite sequence. Flowers are white to bluish in colour. Each flower has a perianth of six white tepals with a central green vein, six stamens with green or yellow anthers, and an ovary of three locules each containing two rather large ovules. The style is only 1-2 mm long when the flower opens, and reaches its full length of 4-7 mm over next 3-6 days. The stigma is simple or slightly trilobed knob which only develops when the style reaches its full length; at the time, the stigmatic surface exudes a sticky liquid to which pollen can adhere (Currah and Ockendon, 1978). The number of flowers may vary from 50 to 2,000 depending upon the species and cultivar, time of planting, size and storage conditions of mother-bulbs. The flowers are protandrous in nature and are generally cross-pollinated. The anthers of inner whorl dehisce first, and it usually occurs between $9 \mathrm{AM}$ and $5 \mathrm{pm}$. The style 
becomes receptive when it attains the length of $5 \mathrm{~mm}$. This happens in a day or two after the anthers have dehisced. An inflorescence may continue opening for two weeks or more and the plant may be in bloom for more than 30 days.

\section{Bulb}

The leafy plant eventually ceases to form leaf-blades, and instead apex begins to initiate a number of bladeless, concentric, thickened leaf-sheaths, which form bulb-scales. Together with the swollen lower leaf-sheaths of the older leaves, they make up the fleshy part of the onion-bulb.

\section{Biosystematics}

Many Allium species were found earlier in Himalayas. In the recent decades, some of them have apparently become rare, endemic or extinct. Since the work of Hooker $(1892,1947)$, who compiled for the first time information on Allium species and mentioned its 27 species in the Flora of British India, no other reports are available on this genus. At present, information in some regional floras is available, but are seemingly incomplete. From the Indian Himalaya and adjoining regions, some workers have depicted Allium species as follows- (i) Duthie (1906)-11 species; (ii) Blatter (1927-29)-12 species; (iii) Hooker revised and supplemented by Stearn (1947)-32 species; (iv) Nasir (1975)-41 species; (v) Naithani (1984)07 species; (vi) Polunin and Stainton (1984)-12 species; and (vii) Karthikeyan et al., (1989)-36 species.

The species close to cultivated Allium cepa L. are A. vavilovii Popov.\&Vved. from southern Turkmenistan and northern Iran, with which it gives $100 \%$ fertile hybrids, and A. asarense R.M. Fritsch \& Matin, from Iran. A.oschaninii O. Fedtsch. (from Uzbekistan and neighbouring countries), which was considered its ancestor, didnot produce fertile hybrids with the cultivated species. Onion species have been cultivated since long, and so their bulbs and inflorescences development must have adapted closely to varied temperature and photoperiod ranges, thus, there exists a wide range of cultivars and landraces, developed over the centuries, to fit in with the diverse climates and food preferences of the world (Brewster, 1994). Most of the 600 species of Allium are distributed in Afghanistan, Turkey, Iran and Central Asia; in Turkmen SSR, Uzbek SSR, Tadzhik SSR, Kirgiz SSR and Kazakh SSR; and in Mongolia, the Tien-Shan Mountains and the Himalayas (Kotlinska et al., 1990).

The history of infrageneric classification in Allium dates back to Linnaeus (1753), who accepted 30 species in three alliances. Later authors recognized an increasing number of infrageneric groups-six sections and 285 species (Regel, 1875, 1887); nine sections and 228 species for the former USSR (Vvedensky, 1935) alone; three subgenera, 36 sections and subsections, and about 600 species (Traub, 1968); six subgenera and 44 sections and subsections (Kamelin, 1973); three subgenera and 12 sections (Stearn, 1980); and five subgenera and 16 sections (Hanelt, 1990). Later, Hanelt et al., (1992) have revised classification that includes six subgenera, 50 sections and subsections for 600-700 species based on the 
multidisciplinary approach including morphological, anatomical, karyological, serological and numerical investigations as well as studies of life-cycle, distribution, ecology and isozyme data. A first approach to structuring the genus by molecular markers was published by Linne von Berg et al., (1996). The resulting phenogram confirms mostly with the subgeneric classification based on the integration of morphological and other methods. Friesen et al., (2006) presented a new classification of the genus consisting of 15 subgenera and 72 sections for about 780 species based on the phylogenetic study. Recently, molecular approaches using plastid DNA and nuclear ribosomal DNA (nrDNA) sequences have been applied to understand evolutionary processes and taxonomic relations within the species.

The number of the species in the genus varied from as low as thirty-one, described by Linnaeus in 1753 (Traub, 1968), to as high as 1,100 (Stearn, 1944). Traub (1968) grouped American species under 4 sections to put them on the same basis of classification as the old world species, which were later revised into subgenera, sections and subsections. About 35-40 species occur in temperate and Alpine regions of Himalaya (Hooker, 1892; Stearn; 1947; Kachroo et al., 1977; Polunin and Stainton, 1984; Karthikeyan et al., 1989) in India. Some of the species are distributed in the neighbouring regions also (Hara, 1966; Nasir, 1975; Stewart et al., 1979; Xu et al., 1990; Xu and Kamelin, 2000). Hanelt et al. (1992) and Fritsch et al. (2010) have reported that genus includes more than 700 species, which grow wildly in temperate, semi-arid and arid regions of the northern hemisphere, hence, results in a remarkable polymorphism. This is one of the largest monocotyledonous genera.

Onion adaptation in India has been carried out from a very early time; before the Christian era. Originally, native to Central Asia of temperate region with perennial/biennial habit and a long-day bulbing character, it has established well in the country under the tropical and short-day (11-11.5 h) conditions. During acclimatization of different kinds of vegetable crops and their varieties, farmers involuntarily applied selection pressure to meet market preferences. In the case of onion, ability to produce seeds indigenously has played an important role in adaptation. In the course of adaptation and diversification, out-breeding mechanisms in onion have promoted selections suitable for different environments. Among the cultivated species of Allium, onion (A. cepa L.), leek (A. porrum L.), shallot (A. ascalonicum L.) and chives (A. schoenoprasum L.) are well-known vegetable crops grown in different parts of India (Wealth of India, 1985; Pandey et al., 2005a). Several lesser-known wild species of Allium (Table 3.3) were

Table 3.3 Distribution of wild Allium species in Indian gene centres

\begin{tabular}{lll}
\hline Species & $\begin{array}{c}\text { Distribution and } \\
\text { status of occurrence }\end{array}$ & Wild/occasionally cultivated \\
\hline $\begin{array}{c}\text { Allium ampeloprasum } \\
\text { L. var. ampeloprasum L. }\end{array}$ & Western Himalaya; C & $\begin{array}{l}\text { Wild; Occasionally cultivated } \\
\text { (vegetable, pickle, condiment) }\end{array}$ \\
$\begin{array}{c}\text { Allium atropurpureum } \\
\text { Waldst.et Kit. }\end{array}$ & Western Himalaya; C & Wild
\end{tabular}


(. . Table 3.3)

Species
Allium atrosanguineum
Schrenk

Allium auriculatum Kunth*

Allium caesium Schrenk

Allium carolinianum DC. *

(A. thomsonii Baker)

Allium chinense G. Don*

Allium clarkei Hk. f. * Allium consanguineum
Kunth*

Allium fasciculatum Rendle

Allium fedschenkoanum
Regel

Allium griffithianum Boiss. *

Allium hookeri Thw. ${ }^{*}$

Allium humile Kunth*

Allium longistylum Baker

Allium loratum Baker

Allium macranthum Baker

Allium odorum L.

Allium oreoprasum Schrenk Allium platyspathum Schrenk Allium prattii Wight
Distribution and status of occurrence

Western Himalaya (Kashmir); C

Western Himalaya (Kumaon); LC

Lahaul, Himachal Pradesh; LC

Western Himalaya; C

North-eastern Himalayan region (Khasi hills); C

Uttarakhand (Kashmir) Himalaya; rare species

Western (Kashmir) and central Himalaya; C

Indian Himalaya, Tibet, Nepal; LC

Western Himalaya (Kashmir); rare species

Western Himalaya; C

North-eastern Himalaya (Khasi hills); sporadic in upper Gangetic plains; C

Western Himalaya; C; endemic species

Western Himalaya; LC

Western Himalaya,

Tibet; rare species

Bhutan and adjoining region; LC

Western Nepal, West Wild

Tibet; LC

Ladakh Himalaya; LC Wild

Western Tibet; LC Wild

West Nepal and adjoining Wild Himalaya; rare species/ sporadic in distribution

Wild

Wild

Wild

Wild

Wild

Wild

Wild

Wild

Wild

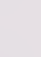

Wild/occasionally cultivated

Wild; Occasionally cultivated (condiment)

Wild; Occasionally cultivated (condiment)

Wild; Occasionally cultivated (vegetable, pickle, condiment) (high seed sterility)

Wild; Occasionally cultivated (minor cultivated species grown for vegetables and condiment in eastern Himalaya)

Wild; Occasionally cultivated (condiment)

Wild; Occasionally cultivated (condiment) 
(... Table 3.3)

\begin{tabular}{|c|c|c|}
\hline Species & $\begin{array}{l}\text { Distribution and } \\
\text { status of occurrence }\end{array}$ & Wild/occasionally cultivated \\
\hline $\begin{array}{l}\text { Allium przewalskianum } \\
\text { Regel }^{*}\end{array}$ & Western Himalaya; C & $\begin{array}{l}\text { Wild; Occasionally cultivated } \\
\text { (vegetable, condiment) }\end{array}$ \\
\hline $\begin{array}{l}\text { Allium roylei Stearn* } \\
\text { (A. lilacinum Royle) }\end{array}$ & $\begin{array}{l}\text { Western Himalaya; rare } \\
\text { species }\end{array}$ & Wild; OC (condiment) \\
\hline Allium schoenoprasum $\mathrm{L}$. & $\begin{array}{l}\text { Western Himalaya } \\
\text { (Kashmir, Drass); C }\end{array}$ & $\begin{array}{l}\text { W; Occasionally cultivated } \\
\text { (vegetable, salad, condiment) }\end{array}$ \\
\hline Allium schrenkii Regel & $\begin{array}{l}\text { Himalayan mountains to } \\
\text { Siberia; LC }\end{array}$ & Wild \\
\hline Allium semenovii Regel & $\begin{array}{l}\text { Western Himalaya, } \\
\text { Kashmir to Uttarakhand, } \\
\text { Himachal Pradesh, } \\
\text { Zanskar; C }\end{array}$ & Wild \\
\hline Allium sikkimense Baker & $\begin{array}{l}\text { Ladakh, Sikkim Himalaya, } \\
\text { Tibet; C }\end{array}$ & Wild \\
\hline Allium stracheyi Baker* & $\begin{array}{l}\text { Western Himalaya } \\
\text { (Kashmir-Kumaon); } \\
\text { narrow endemic species, } \\
\text { rare/threatened species }\end{array}$ & $\begin{array}{l}\text { Wild; Occasionally cultivated } \\
\text { (vegetable, condiment; } \\
\text { recorded in the Red Data Book } \\
\text { of Indian Plants) }\end{array}$ \\
\hline $\begin{array}{l}\text { Allium tuberosum Rottl.ex } \\
\text { Spreng. }\end{array}$ & $\begin{array}{l}\text { Widely distributed in } \\
\text { Himalaya; C }\end{array}$ & $\begin{array}{l}\text { Wild; Occasionally cultivated } \\
\text { (vegetable, condiment) }\end{array}$ \\
\hline Allium victorialis $\mathrm{L}$. & Temperate Himalaya; C & Wild \\
\hline Allium wallichii Kunth & $\begin{array}{l}\text { Eastern part of Western } \\
\text { Himalaya; C; endemic } \\
\text { species }\end{array}$ & $\begin{array}{l}\text { Wild; Occasionally cultivated } \\
\text { (vegetable, condiment) }\end{array}$ \\
\hline
\end{tabular}

${ }^{*}$ Commercially important species; C, common; LC, less common; SGB, seed genebank; FGB, field genebank; IV, in -vitro repository 2008

Sources: Gohil, 1992; Negi and Pant, 1992; Sharma et al., 1996; and Pandey et al.,

reported from the north-western Himalayan region of India (Gohil, 1992; Negi and Pant, 1992; Sharma et al., 1996).

\section{Genetic Resources}

Despite global culinary and economic significance, genetic research on onion has lagged behind to a great extent compared to other major vegetable crops (McCallum et al., 2008). Important onion temperate germplasm collections are maintained in United Kingdom, Netherlands, Hungary, United States and Japan, and tropical cultivars are maintained in India, Brazil and Colombia and at the AVRDC (Taiwan). An analysis of the data from the European collections indicated 2,800 accessions of $A$. cepa originating from 104 countries [the maximum was from the Netherlands (9\%), followed by the USA (7.4\%) and United Kingdom 
(7.4\%)]; overall, 1,394 accessions have been recorded as landraces, 2,519 as advanced cultivars and 1,555 as wild species. Specifically, 433 A. cepa landraces originated from 64 countries (14\% from Portugal, 13\% from Russian Federation, etc.). The oldest sample was collected in 1909 (A. hissaricum from Tajikistan), while $6 \%$ of the samples, for which acquisition date was known,entered in genebanks before 1960 and more than $70 \%$ were acquired after 1980 (Maggioni, 2004). About 83,A. cepa (basal) germplasm have been conserved in a small genebank at the Horticultural Research Section of the ARC at Wad Medani (eastcentral Sudan) (Mirghani and Mohammad, 1997). The largest number of national onion accessions in Africa have been kept at the Centre Régional de Recherche Agronomique (CERRA), Maradi (Niger), and the largest regional collection has been stored at the Centre Régional de Recherches Environnementales et Agricoles (CRREA) and Farako-Bâ (Burkina Faso,Africa). There are several shallot collection centres-one at Centre de Recherche Agronomique (CRA), Bareng (Guinea) and another at the Centre National de Recherche Agronomique (CNRA), Bouaké (Côte d'Ivoire). In Indonesia, shallot collection has mainly been preserved at Lembang. Kotlinska et al., (1990) collected 122 samples of 27 different Allium species from the Central Asia.

At the global level, efforts of the International Board for Plant Genetic Resources (IBPGR, now IPGRI) to conserve vegetable crops germplasm began in 1980 (Sloten, 1980). The Vegetables Network of the European Cooperative Programme for Crop Genetic Resources Networks (ECP/GR), initiated in 1980, is self-funded by the European member-countries and is coordinated by the International Plant Genetic Resources Institute (IPGRI) (Maggioni, 2004). The adoption in 1996 of the FAO/IPGRI list of Multi-crop passport descriptors for data exchange was a landmark in standardization throughout the European region (Lipman et al., 1997). At present, online vegetable databases (www.ecpgr.cgiar.org/ Databases/Databases.htm) offer mainly passport data, and additional data can be taken from the database managers.

A study on the genetic resources of Allium spp., prepared by Astley et al., (1982), traced about 9,400 accessions of cultivated and wild Allium in the major world collections. According to the online FAO-WIEWS, this figure after 20 years has almost reached three times higher. The total number of Allium accessions in European genebanks, distributed in 27 European countries, can be estimated at around 18,000; representing over $60 \%$ of the world's Allium accessions.

Cooperative Programme consists of one collection of seed-Allium species at the Genetic Resources Unit, Horticulture Research International (HRI), Wellesbourne, United Kingdom-the material conserved includes 131 advanced European leek cultivars and 124 onion landraces (mainly from Spain and Portugal) and 850 advanced onion cultivars from Europe and the rest of the world (Australia, Brazil, India, Japan, Pakistan, New Zealand, USA, etc.) (Maggioni, 2004). The second collection is at the European field of long-day Allium species, Vegetable Section, Genebank Department, Research Institute of Crop Production, Olomouc, Czech Republic - this comprises 641 garlic accessions from more than 15 countries and 119 shallot accessions, mainly from Finland and Norway (Staveliková, 2002), and the third is at the European field collection of short-day Allium species, Faculty 
of Agricultural, Food and Environmental Quality Sciences, Rehovot, Israel-this collection, supported by the Israeli Gene Bank, includes garlic, shallot, elephant garlic and $A$. tuberosum from short-day zone, and also from South-East Asia and South America (Rabinowitch, 2002).

The taxonomic Allium Reference Collection and in-vitro Allium collection are available at the Institute of Plant Genetics and Crop Plant Research (IPK), Gatersleben, Germany. Live collection of nearly 400 wild Allium species is a unique reference for taxonomic investigation of all the Allium species (Fritsch, 2002), while in-vitro collection includes 372 accessions of vegetatively propagated Allium species, including 98 virus-free garlic accessions (Keller and Senula, 2002). And the decorative Allium species collection is maintained by the Department of Floriculture, Volcani Centre, Bet Dagan, Israel. This includes about 200 entries, and is used to study floral induction and florogenesis besides understanding potential of some species as ornamental crops (Maggioni, 2004). The Centre for Genetic Resources at Wageningen (Netherlands) has $300 \mathrm{~A}$. cepa and $A$. ampeloprasum accessions (Groot and Boukema, 1986). Plant Research International, Wageningen, the Netherlands, collected Allium mainly from Greek Islands (Bothmer, 1974) and contains 73 different clones of species from the socalled ampeloprasum complex (Kik, 2002). It was found of potential value for finding male-sterility sources to be introduced in leek (Kik et al., 1997).Warwick Genetic Resources Unit (WGRU) was developed from the Vegetable Gene Bank (VGB), built in 1980, at the National Vegetable Research Station at Wellesbourne, UK. The WGRU has a unit for collection, conservation, characterization, documentation and research study of a range of vegetable crops and their wild relatives. The collection at the WGRU includes: Allium: onion, leek and wild taxa, besides current/obsolute cultivars and landraces of small-seeded outbreeding vegetables of other genus.

The Vegetable Germplasm Bank of Zaragoza (BGHZ) and the Centre for the Conservation and Breeding of the Agrodiversity (COMAV), both in Spain, have important $A$. cepa L. collections representing most of the Spanish onion variability (Castell and Díez, 2000; Carravedo and Mallor, 2007). Eighty-six Spanish onion accessions are local onion landraces, collected as seeds from farmers in the main growing regions of Spain between 1981 and 2006 (Mallor et al., 2011).

Kim et al. (2012) cryopreserved 1,158 accessions of garlic as well as some Allium species during 2005-2010 using droplet-vitrification technique with a mean regeneration of $65.95 \%$ after cryostorage at the genebank of the National Agrobiodiversity Centre, Republic of Korea.

International agencies, including Bioversity International, have recognized global centres of Allium germplasm in many countries-Czechoslovakia, Hungary, Israel, Japan, UK and USA (Astley et al., 1982; Simon, 2005). In European Allium database (EADB, 2010), at present 10,473 accessions are from 32 countries for distribution under the Standard Material Transfer Agreement (SMTA). Many other small and medium sized collections are distributed around the world, totalling to 137 collections in 66 countries (Maggioni, 2004) (Table 3.4).

According to Fan-Zhi Cheng (2004) in China, there were 151 accessions of $A$. fistulosum in the Chinese national germplasm resources bank, and breeding was 
Table 3.4 Allium species diversity conserved in the international germplasm repositories

\begin{tabular}{|c|c|c|c|c|}
\hline Allium species & $\begin{array}{l}\text { No. of } \\
\text { countries } \\
\text { holding } \\
\text { Allium } \\
\text { accessions }\end{array}$ & $\begin{array}{l}\text { European countries } \\
\text { (ISO codes) with large } \\
\text { collection (no.of accessions) }\end{array}$ & $\begin{array}{l}\text { AVRDC } \\
\text { (AVGRIS) }\end{array}$ & $\begin{array}{l}\text { NPGS } \\
\text { (USA) }\end{array}$ \\
\hline A. cepa L. & 27 & $\begin{array}{l}\text { GBR (999); RUS (944); FRA } \\
\text { (793);POL (408) }\end{array}$ & 483 & 903 \\
\hline A. sativum $\mathrm{L}$. & 18 & ESP (713); CZE (641); DEU (486) & 505 & 302 \\
\hline A. fistulosum $L$. & 9 & RUS (191); DEU (84); GBR (56) & 30 & 115 \\
\hline $\begin{array}{l}\text { A. ampeloprasum } \mathrm{L} . / \\
\text { A.porrum } \mathrm{L} \text {. }\end{array}$ & 16 & RUS (390); FRA (307); GBR (151) & 14 & 207 \\
\hline A. schoenoprasum $\mathrm{L}$. & 12 & DEU (54); BGR (16); GBR (11) & - & 31 \\
\hline A. chinense $\mathrm{G}$. Don & 1 & DEU (5) & 5 & - \\
\hline $\begin{array}{l}\text { A. tuberosum Rottl. } \\
\text { ex Spreng. }\end{array}$ & 4 & DEU (40) & 5 & 12 \\
\hline Wild species & 12 & $\begin{array}{l}\text { DEU (4300); GBR (769); ISR } \\
\text { (420); POL (240) }\end{array}$ & 87 & - \\
\hline Total Allium spp. & 27 & 17,431 & 1,129 & 1,570 \\
\hline
\end{tabular}

GBR = Great Britain; RUS = Russia; FRA = France; $\mathrm{POL}=$ Poland ESP = Spain; CZE = Czechoslovakia; DEU = Holland; BGR = Bulgaria; ISR = Israel; $A V R D C=$ Asian Vegetable Research and Development Centre ; AVGRIS = AVRDC Vegetable Genetic Resources Information System; NPGS = National Plant Germplasm System

Sources: European Allium database-versions 2001 and 1999; FAO: WIEWS 2002; Maggioni et al., 1999; Maggioni et al., 2002

mainly focused on the colony variety selection, male-sterile line selection and virus resistance selection. A total of 184 samples of Chinese chive (A. tuberosum) (native to country) and 43 samples of onion (A. cepa) are stored in the national gene bank. Among, Allium species in the USSR, A. inderiense, A. delicatulum, A. caeruleum and $A$. savranicum, require protection in Volgograd region, as $A$. regelianum in any part of the USSR. A. regelianum flowered during late June, and in the preliminary trials was successfully cultivated and produced seeds (Sagalaev, 1987). In Leningrad (USSR), Kazakova and Semenov (1985) reported about 300 wild species of Allium, which have been classified into 9 sections.

As part of the biodiversity assessment and germplasm conservation project, Adair et al., (2006), collected 55 populations of taper-tip onion $(A$. acuminatum)from throughout the Great Basin region of the USA (Idaho, Oregon, Nevada). Keller and Senula (2003) reported a large collection of Allium and its wild species maintained at Gatersleben, Germany. In addition to the field maintenance, in-vitro culture and cryopreservation are used to increase maintenance safety and plant quality. One-third of the 3,500 Allium accessions are maintained vegetatively. Allium germplasm maintained at the National Gene Bank of Ukraine consists of A. cepa, A. odorum [syn. A. ramosum], A. porrum and A. fistulosum (Shabetia et al., 2006).

\section{Germplasm resources in India}

The genetic resource of Allium in India is the potential source of genes for 
widening crop genetic base. Despite high economic value, limited number of germplasm accessions of the wild onion species have been collected and conserved mainly owing to difficulty in access to areas of occurrence. The National Bureau of Plant Genetic Resources has undertaken plant exploration activities in different regions of India has and collected wide diversity in cultivated ( $A$. cepa L.) and wild Allium species. These have been established, multiplied and conserved after characterization at different locations (Singh and Rana, 1994; Pandey et al., 2005). Search for the potential of wild species in the Indian gene centre has intensified after successful interspecific crosses between A. cepa L. and A. roylei Stearn (a wild species and an accession of Indian origin). Transfer of genes resistant to powdery mildew and leaf blight from the latter species to the former has opened new avenues in utilization of Indian species for crop improvement (Kofoet and Zinkernagel, 1990; de Vries et al., 1992). Realizing importance of germplasm in buildingup resources for future commercial exploitation, Kale et al. (1994) undertook a detailed survey of traditional and non-traditional onion-growing areas of Maharashtra, and of India in general, and collected 148 red-skin and 33 whiteskin types of onions, evaluated the tropical germplasm and identified some lines on the basis of maximum average bulb weight, high TSS and for single centreness at the Department of Horticulture, Mahatma Phule Krishi Vidyapeeth, Rahuri.

Singh and Rana (1994) reported that the National Bureau of Plant Genetic Resources had conducted extensive plant explorations in different Allium-growing states/regions in India and collected over 2,200 accessions of onion ( $A$. cepa L.) and garlic (A. sativum L.), including landraces, farmers' traditional cultivars, and wild relatives ( $A$. ampeloprasum, A. auriculatum, A. ascalonicum, A. carolinianum, A. chinensis, $A$. wallachi, $A$. tuberosum and $A$. rubellum). The Institute has also introduced over 1,100 accessions of Allium germplasm, which include improved cultivars, germplasm collections, and related species from over 40 countries. Some of them have been identified to be tolerant/resistant to diseases such as purpleblotch (Alternaria sp.), Stemphylium-blight and garlic mosaic virus (GMV). Since 1990 up to 2008, the NBPGR imported 1,316 Allium spp. (Table 3.5), comprising 47 species, excluding A. sativum (garlic), from various countries like USA, UK, Slovakia, Holland, Netherlands, Israel, Mongolia, South Africa, Taiwan, Hungary, Russia, Mexico, Germany, Denmark and Niger (Singh et al., 2006; Anitha et al., 2011).

During 1986-2006, a total of 46 accessions of wild Allium species were collected from high hills of Uttarakhand, Himachal Pradesh, Jammu and Kashmir of Western Himalaya and the north-eastern region (Chaurasia and Singh, 19962001; Negi, 2006a). Native as well as exotic wild species (37 species) have been maintained, characterized/evaluated at the field genebank (Table 3.6) at Bhowali, Uttarakhand (Negi, 2006a).

Onion germplasm diversity was also collected from three northern Telangana districts of Adilabad, Karimnagar and Nizamabad by Kamala et al., (2011). Seventy-four samples (bulbs-66; seeds-8) were collected from 33 villages and 23 mandals. The DOGR is the National Active Germplasm Site (NAGS) for onion and garlic germplasm. Its present collection exceeds 1,500 accessions of red, white and yellow Alliums from different parts of the country, including exotic 
Table 3.5 Allium species introduced from abroad by the NBPGR, New Delhi

Allium species $\quad \begin{array}{ll}\text { Number of } \\ \text { accessions }\end{array} \quad$ Allium species $\quad \begin{array}{r}\text { Number of } \\ \text { accessions }\end{array}$

A. albidum Fisch. ex M.Bieb.

A. altaicum Pall.

A. ampeloprasum $\mathrm{L}$.

A. ampeloprasum var. porrum $\mathrm{L}$.

A. angulosum Lour. nom. illeg.

A. cepa L.

A. cepa L.var. cepa

A. cernuum Rorh

A. christophii Trautv.

A. dictyoprasum C. A. Mayer Ex Kunth

A. drobovi Vved.

A. fallax Schult. \& Schult.f., nom. illegit.

A. fistulosum $\mathrm{L}$.

A. flavum $\mathrm{L}$.

A. fuscoviolaceum Fomin

A. galanthum Kar. et Kir.

A. giganteum Flickr

A. glaciale Vved.

A. guttatum Sardoum

A. ledebourianum Roem. et Schult

A. lineare $\mathrm{L}$.

A. longicuspis Rgl.

A. moly L.

A. montanum F.W. Schmidt, non Schrank
A. narcissifolium Lam.

A. obliquum $\mathrm{L}$.

A. odorum $\mathrm{L}$.

A. oreoprasum Schrenk

A. oschaninii O. Fedt.

A. porrum $\mathrm{L}$.

A. pseudoampeloprasum

Miscz. ex Grossh

A. pseudocepa Schrenk

A. pskemense B. Fedtsch.

A. pulchellum G. Don

A. pyrenaicum Costa \& Vayr.

$A$. ramosum $\mathrm{L}$.

A. ratavienee

A. roylei Stearn

A. schergianum Boiss.

A. schoenoprasum $\mathrm{L}$.

A. senescens $\mathrm{L}$.

A. thunbergii G. Don

A. tuberosum Rottl. ex Spreng.

A. ursinum $\mathrm{L}$.

A. vavilovii Popov. \& Vved.

A. vineale $\mathrm{L}$.

Other Allium spp.

Sources: Singh et al. (2006); Anitha et al. (2011)

Table 3.6 Ex-situ conservation of wild Allium species at the NBPGR, New Delhi

\section{Species maintained}

(No. of accessions)

$\begin{gathered}\text { Ex -situ } \\ \text { conservation } \\ \text { method }\end{gathered}$
FGB, IV
SGB, FGB
FGB
FGB
FGB

$S G B, F G B$

SGB, FGB, IV

\section{Species maintained}

(No. of accessions)

A. hookeri Thw. (2)

A. humile Kunth. (1)

A. roylei Stearn (4)

A. wallichii Kunth (2)

A. oreoprasum Schrenk (1)

A. auriculatum Kunth (1)

A. chinense G. Don (2)
Ex-situ

conservation method

FGB, IV

$F G B$

FGB

FGB

$S G B, F G B$ Kunth, Enum. (2)

A. stracheyi Baker (2)

A. griffithianum Boiss. (3)

$S G B, F G B$

FGB, IV

SGB, seed genebank; FGB, field genebank: IV, in-vitro repository

Source: Negi (2006a) 
introductions (Table 3.7). Underutilized and wild Allium species (A. ampeloprasum, A. tuberosum, $A$. chinense, A. ascalonicum, A. hookeri and $A$. cepa. var. aggregatum) are being multiplied and characterized for utilization in the breeding programmes (Gopal et al., 2013).

\section{Utilization of genetic resources}

Modern varieties sold by the international seed companies, particularly $F_{1}$ hybrids, which have a narrow genetic base, are replacing old varieties. Thus, there is every likelihood that old landraces with potentially valuable and adaptive genes may be lost. The risk of genetic erosion due to introduction of a single new cultivar was especially considered high by Crisp and Astley (1985) for the vegetables that are built on a narrow geneticbase. On a global level, efforts of the International Board for Plant Genetic Resources (IBPGR, now IPGRI) began in 1980 to conserve vegetable crops germplasm, including Allium and related species according to their importance for rural development and their economic value for farmers in tropics (Sloten 1980).

There is a need for collection, characterization, preservation and regeneration of seeds and clones of old varieties and landraces (Astley 1990). Besides conservation of genetic variability for future, the actual utilization of available accessions is another important goal. However, low utilization of germplasm banks is a rule worldwide (Nass and Paterniani, 2000). The main factors responsible for low utilization of plant genetic resources are lack of evaluation, documentation and adequate description of collections, lack of desired information by breeders, accessions with restricted adaptability, and insufficient number of plant breeders, particularly in developing countries (Mallor et al., 2011).

\section{For processing}

Traditional tropical African cultivars, 'Violet de Galmi', 'Blanc de Soumarana' (Niger), 'Violet de Garango' (eastern Burkina Faso), 'Bawku' (northern Ghana), 'Red Kano' (northern Nigeria), 'Violet d'Abéché' (eastern Chad), 'Malanville' (Benin), 'Rouge de Tana' (West Africa) and 'Tana' (adaptation from 'Rouge de Tana' in Madagascar); and selections like 'Yaakar', 'IRAT 19' and 'Noflaye' 
(Senegal) have bulbs with high dry matter content and they store well under natural conditions (Messiaen and Rouamba, 2004). When introduced varieties of onion were not suitable for processing in Sudan, an improved white variety (Nasi), suitable for dehydration, was selected from the local material. Three other varieties (Kamlin yellow, Hilu and Saggai improved) were developed and released for farmers of Sudan (Mirghani and Mohammad, 1997). Abd El-Hafez et al., (1976) tested 12 cultivars in Egypt-Beharry showed the highest value for total soluble solids in two growing seasons, followed by Giza 6 Mohassan, followed by American cultivar and hybrids "Texas Yellow Grano and New Mexico Early Grano". In Niger, Blanc de Galmi [Galmi White] (IRAT2) and Blanc de Soumarana [Soumarana White] (IRAT3) were intended for dehydration and had high drymatter content (Nabos, 1976).

Valdivia and Holle (1971) found Dehydrator 8 in Brazil, as the best variety for dehydration with TSS 25.11\%. Maeso and Villamil (1980) evaluated 10 long-day cultivars and reported that Dehydrator 14, Southport White Globe and Dehydrator 8 yielded up to $52.0,38.8$ and 26.0 tonnes/ha, respectively, with dry matter content of $16.3,14.0$ and $17.51 \%$, respectively, and they were recommended for processing in Southern Uruguay. Roger (1983) compared 13 cultivars for dehydration; none gave higher TSS than the standard variety Dehyso (22.3\%). Hysol and the breeding line No. 79019 were best with 18.8 and 18.3\% TSS, respectively, in NewZealand. Rogers and Henderson (1989) tested 36 cultivars of onion for dehydration. Southport White Globe, Hysol and $F_{1}$ Dehydrator 8 were found suitable for dehydration with TSS more than 15\%. In Venezuela, short-day onions, White Creoso, White Dehydrator No.3 and White Dehydrator No.2 were best for drying (Flores, 1994).

Bajaj et al., (1979) identified cv. Punjab 48 as most suitable for dehydration on account of its high TSS (14.6\%).Roopali was better suited both for storage and dehydration (Maini et al., 1984). Kalra et al., (1986) found S 74 most suitable for dehydration, followed by Punjab 48, with TSS 14.3 and 13\%, respectively. Raina et al., (1988) recorded maximum (15.8\%) TSS in Texas Yellow, followed by Punjab Selection (13.3\%), Udaipur $102(13.5 \%)$ and Punjab 48 (13.4\%). Saimbhi and Bal (1996) observed TSS ranging from 14.0 to $16.2 \%$ and cultivar PWO 1 suitable for processing. After assessing Indian varieties and landraces which did not offer TSS range more than 12\%, Jain Food Park Industries, Jalgaon, introduced White Creole, which was subjected to further selection for high TSS and developed V 12 with TSS range of 15-18\% (Mahajan, 2011). Verma et al., (1999) evaluated 5 red and 3 white onion varieties for dehydration and Punjab 48 was found superior, followed by Pusa White Flat. Since the establishment of the NRC for Onion and Garlic in 1998 at Rajgurunagar, a special programme for development of high TSS white onion variety has been launched. In 2000, about 7,199 bulbs were examined for TSS. Only $2.72 \%$ bulbs recorded TSS more than 14\%. In all, 109 bulbs with TSS from 15 to $23 \%$ were selfed, and population improvement for high TSS is in progress (Mahajan, 2011).

\section{For other characters}

Tropical African cultivars 'Noflaye' was selected for resistance to bolting. 
Mediterranean cultivars, either under their original name, 'Babosa', 'Valenciana Temprana' ('Jaune Hâtif de Valence'), from Spain, or after breeding for increased earliness and selection in South Africa, resulted in open-pollinated cultivar 'Pyramid'. The earliest of these cultivars, 'Texas Early Grano 502', could form bulbs at the latitude $0^{\circ}$, but no seed production occurred in tropical Africa. Cultivars of the Creole group of onions may have been developed in Louisiana from African onions brought to the New World at the time of the slave trade. American catalogues offer traditionally Red Creole, and more recently Yellow Creole and White Creole with relatively high dry matter content, but poor seed production in tropical conditions. Creole onions store better than Grano/Granex types, but not so well as the West African lines. Their bolting resistance is higher than onion cultivars imported from India, hence are suitable for high altitude growing areas, e.g. in Kenya. Several seed companies worldwide have undertaken breeding work to improve tropical short-day onions, including Technisem in West Africa and East West Seed Company in Zimbabwe and Asia. Improved cultivars resulting from this breeding work are commercially available. These include 'Noflaye' (Technisem-later bolting selection from 'Rouge de Châteauvieux') and 'Red Pinoy' (East West Seed Company - a long storage and late bolting red onion derived from a red polycross). The islands Réunion, Mauritius and Rodrigues, have an onion-growing tradition too e.g. 'Rouge de Châteauvieux', a red/pink onion was bred more than 100 years ago from a fortuitous cross between French 'Rouge Pâle de Niort' and an Indian cultivar. In Mauritius and Rodrigues, smaller, very pungent 'Local Red' onions are also grown and locally maintained (Messiaen and Rouamba, 2004). The storage quality of bulbs of onion cultivars, RHR White, PBR5, PW 1, Arka Niketan, IIHR Yellow and Hisar 2 under room temperature, was evaluated for 4 months. The lowest sprouting percentage was in IIHR Yellow, followed by RHR White (Batra et al., 2000). Sagalaev (1987) reported $A$. angulosum (A. tuberosum) to be tolerant to slight soil salinity. It was used locally as a food plant.

Hanelt (1985) reported that wild species located in the central Asian mountains of Turkestan had winter hardiness and high vitamin C content (A. altaicum) and heat and drought resistance (A. vavilovii, A. oschaninii and A. pskemense)

Sweet onions first became a force in the market largely due to the efforts of and the publicity generated by the Vidalia onion industry in Georgia. In the early 1930s, Mose Coleman, an onion grower in Vidalia County, Georgia, recognized that sweet onions did not have the characteristic pungent bite normally found in onions (Boyhan and Torrance, 2002). Approximately 10\% of the onions grown in New Mexico were marketed as 'sweet' (Johnson, 2005). New Mexico competes with several other growing areas, which produce their own branded sweet onions. Other brands grown in the US include 'Walla Walla' from Washington, 'Maui' from Hawaii, and 'Texas Sweets' and California's 'Sweet Imperials'. 'Nu-Mex Sweet' and 'Carzalia' are trademarks for sweet onions grown in New Mexico.

The performance of seven onion (A. cepa) genotypes 'Pusa White Flat', 'Agrifound Dark Red', 'PBR 5', 'Amrawati', 'Pusa White Round', 'Phule Safed' and 'Agrifound Light Red' was evaluated during rabi, both under alkaline $(p \mathrm{H}$ $9.20,9.45$ and 9.70 ) and salinity (EC 3.5 and $5.2 \mathrm{dS} / \mathrm{m}$ ) stresses besides a non- 
stress control. Highest mean bulb yield obtained under salinity was with 'Pusa White Flat', followed by 'Amrawati' among different tested genotypes (Sharma et al., 2000). Earlier studies in India on the influence of salinity on seed germination, growth, flavour, and yield attributes showed its adverse effect on these traits (Joshi and Sawant, 2012). A field experiment at Karnal has shown that onion and garlic can be grown in soils with salinity level up $4 \mathrm{dS} / \mathrm{m}$ (Chauhan et al., 2007).

During late kharif in Maharashtra, out of 198 germplasm, Selection Nos 175, $151,176,186$ and 168 recorded significantly minimum storage losses of 28.0, $30.0,32.0,32.0$ and $33.0 \%$, respectively, after 120 days of storage compared with other selections and Baswant 780 (35.0\%) (Ranpise et al., 2004). Out of 44 oniongermplasm lines, NRCOG 888, 910, 922, 944 and 946 from a gene pool were identified as stable genotypes with high yield and suitable for cultivation in all three seasons (kharif, late kharif and rabi); indicating their stability in unfavourable environments in western India (Prasad et al., 2006). Out of 220 white onion germplasm, W 234, W 353, W 340, W 172, W 361, W 462 and W 079 recorded less storage losses during rabi (Mahajan et al., 2005). Three hundred eighteen germplasm were evaluated for all the three seasons, 90 were found to give more than 40 tonnes/ha during rabi. Ninteen lines performed well giving higher total yield in rabi. Seventy-six lines yielded better than check PKV White, and 188 lines better than Phule Safed during late kharif. Under different environments, W 404 and W 398 were stable for marketable yield; giving higher mean values than population mean (Mahajan et al., 2005a). One hundred ninety-two white-onion germplasm were evaluated for three or more years during kharif at the DOGR. Marketable yield higher than 21 tonnes/ha was recorded in lines W160, W 082 , W 448, W 021, W 366, W 302, W 314, W 043, W 075 and W 397 (Mahajan et al., 2011a). Germplasm lines W 48, W 009, W 355, W 404, W 367, W 172, W 418, and W 056 recorded more than 25 tonnes/ha during kharif, late kharif and rabi. One hundred fifty-one red onion germplasm were evaluated during rabi season. Genotypes 670, 1044, 720 and 1015 had good storability. Thirty-three genotypes were found suitable for rabi cultivation with more than 30 tonnes marketable yield /ha with good storability and other desirable characters (Gupta et al., 2011).

\section{As food Alliums}

Field surveys and exploratory studies have confirmed utilization for edible purposes of wild Allium species in Garhwal and Kumaon regions of Himalaya (Negi and Gaur, 1991). Generally, all plant parts are edible and are consumed raw or as cooked vegetable. Young leaves of many wild species are preferred over mature as vegetable, in soups or for raw consumption. Freshly harvested leaves or bulbs are occasionally sold in village markets. Onion leaves and tuberous/ fibrous roots are rich in carbohydrates, vitamins and minerals. Bulbs/pseudostems of $A$. clarkei, A. griffithianum, A. pratii and A. victorialis are consumed raw, cooked or pickled. Cloves or bulbs of $A$. ampeloprasum and $A$. chinense are pickled. In Pithoragarh region of Uttarakhand Himalaya (India), young leaves of $A$. stracheyi are used as potherb or are cooked mixed with potato. Fleshy fibrous roots of A. hookeri are consumed as vegetable in the north-eastern hill region of India or 
in soups and pickles in the same way as A. stracheyi in the north-western Himalaya. In Bhutan, A. fasciculatum is generally used as a vegetable (leaves and scape), as salad and in soups (young inflorescence).

\section{As condiment/for flavour}

Although all Allium species have different aroma (strongly pungent to mildly aromatic) and flavour (onion- or garlic-like odour) but the selective use of the species/plant part is based on the utilization and preference by local communities. Young leaves and bulbs of $A$. humile, $A$. carolinianum and $A$. loratum have garlic flavour and are used to garnish different food preparations. Similarly, A. stracheyi, $A$. roylei and $A$. tuberosum have mild onion flavour, and are widely used as flavouring agent and for garnishing. For routine domestic use, fresh leaves and bulbs are commonly used and for off-season requirement, leaves are generally dried and processed for long-term storage. In Kumaon region of Uttarakhand (Western Himalaya), dried leaves of A. stracheyi (jumbo) are primarily used for garnishing or seasoning vegetable/curries (Negi and Gaur, 1991). Bhotia tribals collect and process (dry) and bring marketable produce for sale from areas of abundant availability of these species to lower elevations (Chaurasia and Singh, 1996-2001; Sanyal et al., 2000). Bulbs of A. consanguineum and leaves and flowers of $A$. chinense are commonly used as flavours in soups, curries, etc.

\section{For medicinal use}

Some wild Allium as A. humile, A. carolinianum and A. przewalskianum are traded for drug and trade industries in Himachal Pradesh in India (Chauhan, 1999). Dried scales of $A$. wallichii are used locally for pectoral complaints; cloves of $A$. ampeloprasum are utilized after dipping in mustard oil for paralytic limb, earpain and arthritis; bulbs of $A$. wallichii are used for anti-flatulence and digestive disorders; and leaves of $A$. griffithianum and $A$. tuberosum are used as carminative. Keusgen et al., (2006) collected information about the current medical applications of sixteen wild species, nine of which belong to different sections of Allium subgenus Melanocrommyum from Tajikistan and Uzbekistan region. These plants are used against headache, cold and stomach problems, and are mostly applied fresh or after boiling. Three wild Allium species growing in Tajikistan and Uzbekistan (A. oschaninii, A. pskemense, A. praemixtum) are closely related to common onion, and are used as spice like it, but $A$. oschaninii and $A$. pskemense are used for medicinal purpose also. Special dishes, which are much esteemed for strong tonic properties, are prepared from leaves of three following species of subgenus Melanocrommyum: A. motor, A. rosenbachianum and A. rosenorum.

\section{Commercial wild species}

Many wild species of Allium (11 species) are of commercial value for food, flavour and medicine. These exist as natural populations or are grown on a small scale in home-gardens. Processed products in the form of dried bulbs, leaves, buds and flowers of some wild species of Allium (A. auriculatum, A. carolinianum, A. griffithianum, A. humile, $A$. roylei and $A$. wallichii) are in great demand and because of that these species are occasionally grown in home-gardens. Sun dried/ 
furnaces dried leaf powder of the above mentioned species has good shelf-life for off-season consumption (Negi, 2006a, b) and for sale in the market. Market products are also available in refined forms as processed bricks/cakes or balls; sold in border areas of Himachal Pradesh, Uttarakhand and adjoining regions. Crushed foliage of A. przewalskianum prepared as balls and put in a string were reportedly sold in the market in the cold desert region of India (Baker, 1874). The dried leaves of different species are sold at the rate of ₹ 1,500-2,500 per kg (approximately 25-45 US Dollars) (Negi, 2006a). Ornamental value of wild species in India is yet to be explored for the Indian market.

\section{Future strategies}

The genetic resource is the base for any crop improvement programme. Genetic erosion is a threat owing to human intervention. Deterioriation is fast in advanced countries that disturbs natural balance. In such a situation, there is an urgent need to conserve genetic resources, and undertake their documentation and utilization. So many wild species are restricted to gene banks only, which should be evaluated in different agroecological conditions in the world for their possible utilization in terms of food, medicine, nutrition or other economic value. In Alliums so many wild resources are available and are unexploited or underexploited. Many of the species have medicinal properties and need to be analyzed properly and utilized. Foliage or roots of some of the Allium species are consumed but need systematic studies for their proper utilization, and can be used as a substitute to onion and garlic. There is a need for the systematic evaluation of available Allium species for various horticultural characters besides resistance to pests and diseases for their proper exploitation. Crossability of wild species with the cultivated one is not exploited like in other crops due to certain crossability barriers. These need to be overcome systematically among various species with biotechnological tools. Use of desirable traits in the development of hybrids and varieties according to demand of the consumers is necessary.

\section{References}

Abbey L and Fordham R. 1998. Abiotic stress affects shallot growth performance. Crop Research 16: 66-69.

Abd El-Hafez., A A, El-Safie M W, Warid W A and El-Kafory A K. 1976. Performance of some onion cultivars with respect to number of growing points, total soluble solids and number of entire rings. Agricultural Research Review 54: 107-14.

Adair R, Johnson R C, Hellier B and Kaiser W. 2006. Collecting tapertip onion (Allium acuminatum Hook.) in the Great Basin using traditional and GIS methods. Native Plants Journal 7: 141-48.

Anitha K, Venkateswaran Kamala, Chakrabarty S K, Suresh Kumar G, Sarath Babu B and Varaprasa K S. 2011. Onion genetic resources and pest resistance: the Indian scenario. Indian Journal of Plant Protection 39: 81-92.

Astley D. 1990. Conservation of genetic resources, pp. 177-98. (In): Onions and Allied Crops, Vol. 1. Rabinowitch H D, Brewster J L. (Eds). CRC Press, Boca Raton, Florida, USA.

Astley D, Innes N L and Van Der Meer Q P. 1982. Genetic resources of Allium Species- 
A Global report, pp. 41. International Board for Plant Genetic Resources, Rome, Italy.Report No: FAO-AGPG-IBPGR/81/77.

Bajaj K L, Kaur G and Singh T. 1979. Lachrymatory factor and other chemical constituents of some varieties of onion. Journal of Plant Food 3: 119-203.

Baker J G. 1874. On the Allium of India, China and Japan. Journal of Botany.

Batra V, Singh J and Singh V. 2000. Evaluation of some onion varieties for their storability. Haryana Journal of Horticultural Sciences 29(1/2): 124-25.

Bothmer R von. 1974. Studies in the Aegean flora XXI. Biosystematic studies in the ampeloprasum complex. Opera Botanica 34: 5-104.

Boyhan G E and Torrance R L. 2002. Vidalia onions-sweet onion production in southeastern Georgia. Hort-Technology 12: 196-202.

Bozzini A. 1964. On the karyotype of a viviparous onion, known as Allium cepa L. var. viviparum (Metzg.) Alf. Caryologia 17: 459-64.

Brewster J L. 1994. Onions and other Vegetable Alliums, 236 pp. CAB International, Wallingford, UK.

Carravedo M and Mallor C. 2007. Variedades Autóctonas De Cebollas Españolas, pp. 382. CITA, Zaragoza, Spain-Gobierno de Aragón.

Castell V and Díez M J. 2000. Colección de semillas de cebolla del Centro de Conservación y Mejora de la Agrodiversidad Valenciana. Monografias INIA serie: Agricola, Ministerio de Cienica y Teologia, Madrid, Spain 8: 99.

Chase M W, Reveal J L and Fay M F. 2009. A subfamilial classification for the expanded asparagalean families Amaryllidaceae, Asparagaceae and Xanthorrhoeaceae. Botanical Journal of the Linnean Society 161(2): 132-36.

Chauhan C P S, Shisodia P K, Minhas P S and Chauhan R S. 2007. Response of onion (Allium cepa) and garlic (Allium sativum) to irrigation with different salinity waters with or without mitigating salinity stress at seedling establishment stage. Indian Journal Agricultural Science 77: 483-85.

Chauhan N S. 1999. Medicinal and Aromatic Plants of Himachal Pradesh, 479 pp. Indus Publishing Co., New Delhi, India.

Chaurasia O P and Singh B. 1996-2001. Cold Desert Plants, Vol I-IV. Field Research Laboratory (FRL), Defence Research and Development Organization, Jammu and Kashmir, India.

Corgan J and Holland M. 1993. "NuMex Starlite" onion. Hort Science 28: 66-67.

Cramer C S and Corgan J N. 2007. 'NuMex Mirage' onion. Hort Science 42: 1719-20.

Cramer C S and Corgan J N. 2009. 'NuMex Radiance' onion. Hort Science 44: 820-23.

Crisp P and Astley D. 1985. Genetic resources in vegetables, pp. 281-310. (In): Progress in Plant Breeding-1. Russel GE. (Ed.) Butterworths, London.

Currah L and Maude R B. 1984. Laboratory tests for leaf resistance to Botrytis squamosa in onions. Annals of Applied Biology 105: 277-83.

Currah L and Ockendon D J. 1978. Protandry and the sequence of flower opening in the onion (Allium cepa L.) New Phytologist 81: 419-28.

Currah L and Proctor F S. 1990. Onion in Tropical Regions. Bulletin No. 35. NRI, UK.

Davies D. 1992. Alliums-The Ornamental Onions, 168 pp. Portland, Oregon, USA; Timber Press Bastford, London.

De Vries J N, Wietsma W A and de Vries T. 1992. Introgression of leaf blight resistance from A. roylei Stearn into onion (A. cepa L.). Euphytica 62: 127-33.

De Vries J N, Wietsma W A and Jongerius M C. 1992a. Introgression of leaf blight resistance from A. roylei Stearn into onion (A. cepa L.) Euphytica 62: 127-33.

Dhiman J S, Chadha M L and Sidhu A S. 1986. Studies on the reaction of onion genotypes against purple-blotch. Vegetable Science 13: 304-09.

Flores-Gutierrez A A. 1994. Evaluation of seven cultivars of onion for dehydration in 
Venezuela. Onion Newsletter for the Tropics 6: 30-31.

Emsweller S L and Jones H A. 1935. An interspecific hybrid in Allium. Hilgardia 9: 26573.

Fan-ZhiCheng, Gao-ZhaoBo and Li-JianYou. 2004. Advances on germplasm resources and breeding of bulb vegetable crops in China. China Vegetables 6: 38-41.

Fay M F and Chase M W. 1996. Resurrection of Themidaceae for the Brodiaea alliance, and recircumscription of Alliaceae, Amaryllidaceae and Agapanthoideae. Taxon 45: 441-51.

Friesen N, Fritsch R M and Blattner F R. 2006. Phylogeny and new intrageneric classification of Allium (Alliaceae) based on nuclear ribosomal DNA ITS sequences. Aliso 22: 372-95.

Friesen N, Fritsch R M, Pollner S and Blattner F R. 2000. Molecular and morphological evidence for an origin of the aberrant genus Milula within Himalayan species of Allium (Alliaceae). Molecular Phylogenetics and Evolution 17: 209-18.

Fritsch R M. 2002. Short history of the taxonomic collection of genus Allium housed at the Institute of Plant Genetics and Crop Plant Research (IPK). (In): European Collections of Vegetatively Propagated Allium. Report of a workshop held on 21-22 May 2001 at Gatersleben. Maggioni L, Keller J and Astley D. (Eds). [Germany, International Plant Genetic Resources Institute, Rome, Italy].

Galvan G A, Wietsma W A, Putrasemedja S, Permadi A H and Kik C. 1997. Screening for resistance to anthracnose (Colletotrichum gloeosporioides Penz.) in Allium cepa and wild relatives. Euphytica 95: 173-78.

Gohil R N. 1992. Himalayan representatives of Alliums, pp. 335-40. (In): The Genus Allium-Taxonomic Problems and Genetic Resources. Hanelt P, Hammer K, Knüpffer H. (Eds). Gatersleben, Germany.

Gopal J, Mahajan V, Gawande S J, Sankar V and Khar A. 2013. DOGR Vision-2050, 43 pp.

Groot E C de and Boukema I W. 1986. The Centre for Genetic Resources of the Netherlands (CGN). Zaadbelangen 40: 211-13.

Gupta A J and Mahajan V. 2013. Management of bio-diversity in onion germplasm at DOGR. (In): National Conference on Agro biodiversity Management for Sustainable Rural Development held during 14-15 October 2013, at the NAARM, Hyderabad, Telangana, India.

Gupta A J, Lawande K E, Mahajan V, Krishnaprasad V S R and Khar A. Evaluation of red onion germplasm for growth, yield and quality during rabi season. (In): National Symposium on Alliums: Current Scenario and Emerging Trends, 2011, held during 12-14 March 2011, Pune, Maharashtra, India.

Hanelt P. 1985. The taxonomy, chorology and ecology of the wild species of Allium L. sect. Cepa (Mill.) Prokh. Flora German Democratic Republic 176: 99-116.

Hanelt P. 1990. Taxonomy, evolution, and history, pp. 1-26. (In): Onions and Allied Crops. Botany, Physiology, and Genetics, Vol 1. Rabinovich H and Brewster J L. (Eds). CRC Press, Boca Raton, Florida, USA.

Hanelt P, Schultze-Motel J, Fritsch R, Kruse J, Maas H I, Ohle H and Pistrick K. 1992. Infrageneric grouping of Allium - the Gatersleben approach, pp. 107-23. (In): The Genus Allium-Taxonomic Problems and Genetic Resources. Hanelt P, Hammer K and Knupffer H. (Eds). Gatersleben, IPK, Germany.

Hara H. 1966. The Flora of Eastern Himalaya. 405 pp. University of Tokyo, Japan.

Hooker J D. 1892, rev. 1973. Liliaceae: Allium L., pp. 337-45. (In): Flora of British India, Vol VI. Bishen Singh and Mahindra Pal Singh, Dehradun, India.

Johnson J. 2005. President W.R. Johnson and Sons. Carzalia, NM. Verbal communication. Joshi N and Sawant P. 2012. Response of onion (Allium cepa L.) seed germination and 
early seedling development to salt level. International Journal of Vegetable Science 18: 3-19.

Kachroo P, Sapru B L and Dhar U. 1977. Flora of Ladakh - An Ecological and Taxonomic Appraisal. 172 pp. Bishen Singh and Mahindra Pal Singh, Dehradun, India.

Kale P N, Warade S D and Midmore D J. 1994. International symposium on alliums in the tropics, Bangkok, Thailand. Acta Horticulturae 358: 153-56.

Kalra C L, Beerh J K, Manan J K, Teotia M S and Sharma T C. 1986. Studies on influence of cultivars on the quality of dehydrated onion (Allium cepa L.) Indian Food Packer 40: $20-27$.

Kamala V, Gupta A J, Sivaraj N, Pandravada S R, Sunil N, Varaprasad K S and Lawande K E. 2011. Diversity analysis of onion germplasm collections from Northern Telangana region of Andhra Pradesh. Indian Journal of Plant Genetic Resources 24: 163-71.

Kamelin R V. 1973. Florogeneticheskij analiz estestvennoj ûory gornoj Srednej Azii. Leningrad: Nauka, 354.

Kamenetsky R and Fritsch R M. 2002. Ornamental alliums, pp. 459-90. (In): Allium Crop Science: Recent Advances. Rabinowitch HD, Currah L. (Eds). CAB International, CABI Publishing, UK.

Karthikeyan S, Jain S K, Nayar M P and Sanjappa M. 1989. Florae Indicae Enumeration Monocotyledonae. 435 pp. Botanical Survey of India, Howrah, Calcutta, West Bengal, India.

Kazakova A A and Semenov V A. 1985. The biological characteristics of growth and development of wild onion species Trudy-po-Prikladnoi-Botanike,-Genetike-i-Selektsii. pp. 24-27. 1983 rec'd; 81.

Keller E R J and Senula A. 2003. Germplasm preservation in Allium species: an integrated approach to store morphologically characterised virus-free plant material via cryopreservation. Acta-Horticulturae 623: 201-08.

Keller J and Senula A. 2002. Germplasm exchange of vegetative Alliums - minimum phytosanitary requirements. (In): European Collections of Vegetatively Propagated Allium. Maggioni L, Keller J and Astley D. (Eds). Report of a workshop, Gatersleben, Germany. International Plant Genetic Resources Institute, Rome, Italy. 21-22 May 2001.

Keusgen M, Fritsch R M and Hisoriev H. 2006. Wild Allium species (Alliaceae) used in folk medicine of Tajikistan and Uzbekistan. Journal of Ethnobiology and Ethnomedicine 2: 18 .

Khrustaleva L I and Kik C. 2000. Introgression of Allium fistulosum into A. cepa mediated by A. roylei. Theoret. Appl. Genet. 100: 17-26.

Kik C. 2002. The Allium collections at Plant Research International, with special reference to the vegetatively maintained leek (von Bothmer) collection. (In): European Collections of Vegetatively Propagated Allium. Maggioni L, Keller J and Astley D. (Eds). Report of a workshop. Gatersleben, Germany.International Plant Genetic Resources Institute, Rome, Italy. 21-22 May 2001.

Kik C, Samoylov A M, Verbeek W H J and van Raamsdonk L W D. 1997. Mitochondrial DNA variation and crossability of leek (Allium porrum) and its wild relatives from the Allium ampeloprasum complex. Theoret. Appl. Genet 94: 465-71.

Kim H H, Popova E, Shin D J, Yi J Y, Kim C H, Lee J S, Yoon M K and Engelmann F. 2012. Cryobanking of Korean allium germplasm collections: results from a 10 year experience. Cryo Letters 33: 45-57.

Kofoet A and Zinkernagel V. 1990. Resistance to downy mildew (Peronospora destructor) in Allium species. Z. Pflanzenkr. Pflanzenschutz 97: 13-23.

Kofoet A, Kik C, Wietsma W A and de Vries. 1990. Inheritance of resistance to downy mildew (Pernospora destructor (Berk.) Casp.) from Allium roylei Stearn in the back- 
cross Allium cepa L. $\times($ A. roylei $\times$ A. cepa). Plant Breeding 105: 144-49.

Kotlinska T, Havranek P, Navratill M, Gerasimova L, Pimakhov A and Neikov S. 1990. Collecting onion, garlic and wild species of Allium in Central Asia, USSR. FAO/IBPGR Plant Genetic Resources Newsletter 83184: 31-32.

Lawande K E, Mahajan V, Krishnaprasad V S R and Khar A. 2011a. Bhima Super-a new red onion variety for kharif season from DOGR. (Souvenir \& Abstract). (In): National Symposium on Alliums: Current Scenario and Emerging Trends, $160 \mathrm{pp}$.

Lawande K E, Mahajan V, Krishnaprasad V S R and Khar A. 2011b. Bhima Red and Bhima Raj a new red onion variety for different season. (Souvenir \& Abstract). (In): National Symposium on Alliums: Current Scenario and Emerging Trends, $160 \mathrm{pp}$.

Linnaeus C. 1753. Allium. pp. 294-302. (In): Species Plantarum, Vol. 1. Stockholm: Laurentiis Salvii, (ed., 1957-1959), London, Ray Society.

Linne von Berg G, Samoylov A, Klaas M and Hanelt P. 1996. Chloroplast DNA restriction analysis and the infrageneric grouping of Allium (Alliaceae). Plant Systematics and Evolution 200: 253-61.

Lipman E, Jongen M W M, Hintum van Th J L, Gass T and Maggioni L. 1997. Central Crop Databases: Tools for Plant Genetic Resources Management. International Plant Genetic Resources Institute, Rome, Italy/CGN, Wageningen, The Netherlands.

Maeso C R and V J Villamil. 1980. Evaluation of onion cultivars for dehydration in Southern Uruguay. Investigaciones-Agronomicas 1: 55-57.

Maggioni L. 2004. Conservation and use of vegetable genetic resources: A European perspective. (In): Proc. XXVI IHC-Advances in Vegetable Breeding. J D McCreight and Ryder E J. (Eds). [Acta Hort. 637: 13-30].

Maggioni L, Astley D, Rabinowitch H, Keller J and Lipman E. (compilers). 1999. Report of a Working Group on Allium, Sixth meeting. Plovdiv, Bulgaria. International Plant Genetic Resources Institute, Rome, Italy. 23-25 October 1997.

Maggioni L, Keller J and Astley D. compilers. 2002. European Collections of Vegetatively Propagated Allium. Report of a workshop held at Italy, during 21-22 May 2001. Gatersleben, Germany, International Plant Genetic Resources Institute, Rome.

Mahajan V, Krishnaprasad V S R and Lawande K E. 2005. Screening of white onion germplasm for storage. (In): National Symposium on Current Trends in Onion, Garlic, Chillies and Seed and Spices-Production, Marketing and Utilization. NRCOG, Rajgurunagar, Pune. during 25-27 Nov., 2005.

Mahajan Vijay and Lawande K E. 2011. Genetic diversity and crop improvement in onion and garlic. (Souvenir). (In): Exploiting Spices Production Potential of the Deccan Region, SYMSAC-VI, Indian Society for Spices, Dharwad, during 8-10 Dec. 2011.

Mahajan V, Lawande K E, Khar A and Krishnaprasad V S R. 2005a. Screening of white onion germplasm for year round production. (In): Proceeding of the International Conference on Sustainable Crop Production in Stress Environments: Management and Genetic Options held during 9-12 February at the JNKVV, Jabalpur. [Agrobios (International), Jodhpur, pp. 245-52].

Mahajan V, Lawande K E, Krishnaprasad V S R, Khar A and Gupta A J. 2011a. Evaluation of white onion germplasm during kharif season. (Souvenir \& Abstract). National Symposium on Alliums: Current Scenario and Emerging Trends, $165 \mathrm{pp}$.

Mahajan V, Lawande K E, Krishnaprasad V S R, Khar A and Gupta A J. 2011b. White onion germplasm lines suitable for changing climatic situations. (Souvenir \& Abstract). National Symposium on Alliums: Current Scenario and Emerging Trends, pp. 165.

Mahajan V, Lawande K E, Krishnaprasad V S R and Srinivas P S. 2011c. Bhima Shubra and Bhima Sweta a new white onion variety for different season. (Souvenir \& Abstract). National Symposium on Alliums: Current Scenario and Emerging Trends, pp.162.

Mallor C, Carravedo M, Estopañan G and Mallor F. 2011. Characterization of genetic 
resources of onion (Allium cepa L.) from the Spanish secondary centre of diversity. Spanish Journal of Agricultural Research 9(1): 144-55.

Mani V P, Chauhan V S, Joshi H C and Tandon J P. 1999. Exploiting gene effects for improving bulb yields in onion.Indian. Journal of Genetics and Plant Breeding 59: 511-14.

Maini S B, Diwan B and Anand J C. 1984. Storage behaviour and drying characteristics of commercial cultivars of onion. Journal of Food Science and Technology 21: 417-19.

Mathur K, Sharma S N and Sain R S. 2006. Onion variety RO-59 has higher yield and resistance to purple blotch and Stemphylicum blight. Journal of Mycology and Plant Pathology 36: 49-51.

McCallum J and Havey M J. 2006. Assessment of genetic diversity in bulb onion (Allium cepa L.) using simple sequence repeat markers. (abstract). Plant and Animal Genome XIV Conference, San Diego, CA. (Available on line in http://www.intl-pag.org/14/ abstracts/PAG14_P130.html) [10 March, 2010].

McCallum J, Havey M J, Shigyo M and Mcmanus M T. 2008. Molecular approaches to characterizing and improving bulb composition in onion. Acta Horticulture 770: $147-$ 51.

McCollum G D. 1976. Onion and allies, pp.186-90. (In): Evolution of Crop Plants. Simmonds N.W. (Ed.) London and New York, Longman.

McCollum G D. 1982. Experimental hybrids between Allium fistulosum and A. roylei. Botanical Gazat. 143: 238-42.

McDonald M R, Kooi K van-der, Kornatowska B and Janse S. 2002. Screening onion breeding lines for resistance to onion maggot (Delia antiqua Meigen) damage. Journal of the Entomological Society of Ontario 133: 53-62.

Messiaen C M and Rouamba A. 2004. Allium ampeloprasum L. Internet Record from PROTA4U.PROTA (Plant Resources of Tropical Africa/Ressources végétales de l'Afrique tropicale), Wageningen, Netherlands. (<http://www.prota4u.org/search.asp).

Mirghani K Ahmed and El Tahir L Mohammed. 1997. Indigenous vegetables of Sudan: production, utilization and conservation.Traditional African vegetables, pp. 117-21. (In): Proceedings of the IPGRI international Workshop on Genetic Resources of Traditional Vegetables in Africa-Conservation and Use, held on 29-31 August 1995 at ICRAF, Nairobi, Kenya.

Nabos J. 1976. Breeding onion (Allium cepa L.) in Niger. Agronomie Tropicale 31: 38797.

Nasir E. 1975. Alliaceae. (In): Flora of West Pakistan, No. 83. Stewart Herbarium, Gordon College, Rawalpindi, Pakistan.

Nass L L and Paterniani E. 2000. Pre-breeding: a link between genetic resources and maize breeding. Scientia Agricola 57: 581-87.

Negi K S. 2006a. Allium species in Himalayas and their uses with special reference to Uttaranchal. Ethnobotany 18: 53-66.

Negi K S. 2006b. Addition to the rare and economically useful plant germplasm of Allium clarkei Hk. f. of Uttaranchal. Indian Journal of Plant Genetic Resource 19: 95-98.

Negi K S and Gaur R D. 1991. Little known endemic wild Allium species in the Uttar Pradesh hills. Mountain Research and Development 11: 162-64.

Negi K S and Pant K C. 1992. Less-known wild species of Allium L. (Amaryllidaceae) from mountain region of India. Economic Botany 46: 112-14.

Netzer D, Rabinowitch H D and Weintal C H. 1985. Greenhouse technique to evaluate pink root disease caused by Pyrenochaeta terrestris. Euphytica 34: 385-91.

Pandey A, Pandey R, Negi K S and Radhamani J. 2008. Realizing value of genetic resources of Allium in India. Genetic Resources Crop Evolution 55: 985-94.

Pandey U B, Kumar A, Pandey R and Venkateswaran K. 2005a. Bulbous crops-cultivated 
Alliums, pp. 108-20. (In): Plant Genetic Resources of Vegetable Crops. Dhillon B S, Tyagi R K, Saxena S, Randhawa G J. (Eds). Narosa Publishing House Pvt Ltd, New Delhi, India.

Pandotra V R. 1965. Purple blotch disease of onion in Punjab II: Studies on the life history, viability and infectivity of the causal organism Alternaria porri. Proceedings of Indian Acadmy of Science (Section B) 61: 326-30.

Pathak C S, Singh D P, Deshpande A A and Sreedhar T S. 1986. Sources of resistance to purple blotch in onion. Vegetable Science 13: 300-03.

Pawar D B, Mote U N, Kale P N and Ajri D S. 1987. Identification of resistant sources for thrips in onion. Current Research Reporter 3: 115-17.

Polunin O. 1969. Flowers of Europe: A Field Guide. 682 pp. Oxford University Press, London.

Polunin O and Stainton A. 1984. Flowers of the Himalaya. Oxford University Press, New Delhi,India.

Prasad V S R K, Lawande K E, Mahajan V and Khar A. 2006. Assessing and prediction of environmental response of short day onion genotypes grown in three seasons of western India. Indian Journal of Horticulture 63: 270-75.

Purseglove J W. 1972. Alliaceae, pp. 37-57. (In): Tropical Crops (Monocotyledons) Book Review, Longman Group Ltd, London 334 pp.

Rabinowitch H D. 1997. Breeding alliaceous crops for pest resistance. Acta Horticulture 433: 223-46.

Rabinowitch H D. 2002. The European field collection of short-day Allium species. (In): European Collections of Vegetatively Propagated Allium. Maggioni L, Keller J and Astley D. (Eds). [Report of a workshop. Gatersleben, Germany.International Plant Genetic Resources Institute, Rome, Italy. 21-22 May 2001].

Rabinowitch H D and Brewster J L. 1990. .Onion and allied crops. (In): Botany, Physiology and Genetics, Vol. I. CRC Press, Inc. Florida, USA.

Raina B L, Teotia M S, Pruthi J S and Kalra C L. 1988. Studies on the evaluation of some new onion cultivars for their suitability for dehydration. Indian Food Packer 42: 7-14.

Ranpise S A, Patil B T, and More T A. 2004. Evaluation of rangda (late kharif) onion germplasm for morphological and storability studies. Journal of Maharashtra Agricultural Universities 29: 104-06.

Ray P and Gupta H N. 1980. "Charaka Samhita" Scientific Synopsis. Indian National Science Academy, New Delhi, India.

Regel E. 1875. Alliorum adhuc cognitorum monographia. Acta Horti Petropolitani 3: 1266.

Regel E. 1887. Allii species Asiae Centralis in Asia Media a Turcomania desertisque Araliensibus et Caspicis usque ad Mongolian crescentes. Acta Horti Petropolitani 10: 278-362.

Roger B T. 1983. Onion varieties for dehydration. New Zealand Commercial Grower 38 (3): 20.

Rogers I S and Henderson R D. 1989. Testing suitability of onion cultivars for dehydration. Acta Horticulturae 247: 157-62.

Rouamba A and Currah L. 1998. Collections of short-day onion germplasm in West Africa: a survey. Genetic Resources and Crop Evolution 45: 81-85.

Sagalaev V A. 1987. Distribution and protection of Allium species in the Volgograd region. Byulleten'Glavnogo Botanicheskogo Sada 146: 60-65.

Saimbhi M S and Bal S S. 1996. Evaluation of different varieties of onion for dehydration. Punjab Veg.Grower 31: 45-46.

Sanyal G S, Samant S S and Kumar K. 2000. Indigenous knowledge and conservation of medicinal plants used by Bhotia tribes in Kumaon Himalaya, India. International 
Journal of Sustainable Developmentand World Ecology 9: 159-66.

Shabetia V V, Shabetia O M, Vitsenia T I and Tymchuk V M. 2006. Allium collection of the gene pool of Ukraine. Vegetable Crops Research Bulletin 64: 195-200.

Sharma D C, Umesh C and Gupta R K. 1996. Allium biodiversity and its traditional prophylactic significance in Indian sub-continent. Indian Journal of Plant Genetic Resource 9: 201-18.

Sharma I M. 1997. Screening of onion varieties/lines against purple blotch caused by Alternaria porri under field conditions. Plant Disease Research 12: 60-61.

Sharma P C, Mishra B, Singh R K, Singh Y P and Tyagi N K. 2000. Adaptability of onion (Allium cepa) genotypes to alkali and salinity stresses. Indian Journal of Agricultural Sciences 70: 674-78.

Shinde N N and Sontakke M B. 1993. Bulb crops:Onion, pp. 641-85. (In): Vegetable crops, Bose T K, Som M G and Kabir J. (Eds). Naya Prokash, Calcutta,India.

Simon P W. 2005. Realizing value from central Asian Allium germplasm collection. (In): Proc.of workshop held at ASHC centennial conf., Province Rhode Island, USA, 3 October 2003. [Hort Science 40: 309-10].

Singh R V, Singh I P, Deep Chand, Vandana Tyagi, Singh A K, Singh S P and Surender Singh. 2006. Inventory of Introductions from 1990-2006. Allium Species, 42 pp. Germplasm Exchange Division, NBPGR, New Delhi, India.

Singh B P and Rana R S. 1994. Collection and conservation of Allium genetic resources: an Indian perspective. Acta Horticulture 358: 181-90.

Sintayehu A, Chemeda F, Seid A and Sakhuja P K. 2011. Evaluations of shallot genotypes for resistance against Fusarium basal rot (Fusarium oxysporum f. sp. cepae) disease. Crop Protection 30: 1210-15.

Sloten D H van. 1980. Vegetable genetic resources. Plant Genetic Resources Newsletter 44: $20-25$.

Stearn W T. 1980. Allium L. pp. 49-69. (In): Flora Europaea, Vol. 5. Tutin T G, Heywood V H and Burges N A. (Eds). Cambridge: Cambridge University Press, UK.

Stearn W T. 1947. The Alliums of British India (rev. JD Hookers list of 1892). Herbertia 12: $73-84$.

Stearn W T. 1944. Notes on the genus Allium in the Old World. Herbertia 1: 11-34.

Stewart R R, Ali S I and Nasir E. 1979. Flora of West Pakistan. pp. 76-99. Pakistan Agricultural Research Council, Pakistan.

Staveliková H. 2002. Current state of the International collection of vegetatively propagated Allium spp. maintained in the Gene Bank Olomouc, RICP Prague. (In): European Collections of Vegetatively Propagated Allium. Maggioni L, Keller J and Astley D. (Eds). Report of a workshop. Gatersleben, Germany. International Plant Genetic Resources Institute, Rome, Italy. 21-22 May 2001.

Sugha S K, Develash R K and Tyagi R D. 1992. Performance of onion genotypes against purple blotch pathogen. South Indian Horticulture 40: 297.

Traub H P. 1968. The subgenera, sections and subsections of Allium L. Plant Life 24: 147-63.

Ulloa M, Corgan J N and Dunford M. 1995. Evidence for nuclear-cytoplasmic incompatibility between Allium fistulosum and A.cepa. Theoret. Appl. Genet. 90: 74654.

Utkhede R S and Rahe J E. 1980. Screening world onion germplasm collection and commercial cultivars for resistance to smut. Canadian Journal of Plant Science 60: 157-61.

Valdivia M G and Holle M. 1971. Comparative evaluation of the dehydration characteristics of six onion cultivars. Investigaciones-Agropecuarias 2: 28-40.

Van der Meer Q P and De Vries J N. 1990. An interspecific cross between Allium roylei 
Stearn and Allium cepa L., and its backcross to A. cepa. Euphytica 47: 29-31.

Van Raamsdonk L W D, Smiech M P and Sandbrink J M. 1997. Introgression explains incongruence between nuclear and chloroplast DNA-based phylogenies in Allium section Cepa. Botanical Journal of the Linnean Society 123: 91-108.

Van Raamsdonk L W D, Wietsma W A and de Vries J N. 1992. Crossing experiments in Allium L. section Cepa. Botanical Journal of the Linnean Society 109: 293-303.

Verma L R, Pandey U B, Bhonde S R and Srivastava K J. 1999. Quality evaluation of different onion varieties for dehydration. NewsLetter National Horticultural Research and Development Foundation 19 (2/3): 1-6.

Vvedensky A I. 1935. Rod 267. Onion-Allium L., pp.112-280. (In): Flora of the USSR Leningrad. Komarov V L. (Ed.) Publishing House of the USSR Academy of Sciences, USSR.

Wealth of India. 1985. The Wealth of India-Raw Material, Vol 1. Council of Scientific and Agricultural Research, New Delhi, India.

Xu J M and Kamelin R V. 2000. Allium Linnaeus, Sp. Pl. 1: 294, 1753. Flora of China, Vol. 24, pp. 165-202. Wu Z, Raven P H.(Eds.) Science Press, Beijing, China.

Xu J M, Hanelt P and Chun-Lin L.1990. Key to the Alliums of China. Herbertia 46(2): $138-64$.

Warwick Genetic Resources Unit, http://www.warwick.ac.uk/go/gru. 


\title{
Genetics and Breeding of Open-pollinated Varieties
}

\author{
E. Sreenivasa Rao, Vijay Mahajan and C.S. Pathak
}

Onions ranging in colour from purple, red, pink, white, yellow to brown are cultivated worldwide. In India, red to pinkish-red onions with medium to strong pungency are preferred, and white onions are the next popular group. Varied choices necessitate breeding onions for a number of agronomically useful traits and market preferences. Cultivation of open-pollinated varieties predominate in India due to their easier seed-production system in comparison to hybrids.

\section{Cytology}

Allium cepa is a diploid $(2 \mathrm{n}=2 \mathrm{x}=16)$ with eight pairs of chromosomes (Stack and Coming, 1979) and is considered an excellent cytological model system because of its relatively large chromosomes which are easily observed under the microscope. Karyotype and chromosome behaviour in Alliums was described by Jones (1990). The eight basic chromosomes can be distinguished based on their lengths, ratio of two arms and staining intensity. Chromosome symmetry was observed to be highly conserved within A. cepa.

Kalkman (1984) proposed the first detailed and accurate account of onion karyotype for relative chromosome length, centromeric position and intercalary C-band pattern. These results were confirmed by several works (Peffley and Currah, 1988; de Vries and Jongerius, 1988), and have been adopted as the standard system of nomenclature for the species (Fig. 4.1).

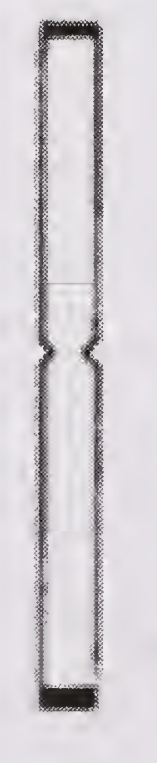

$1 \mathrm{C}$
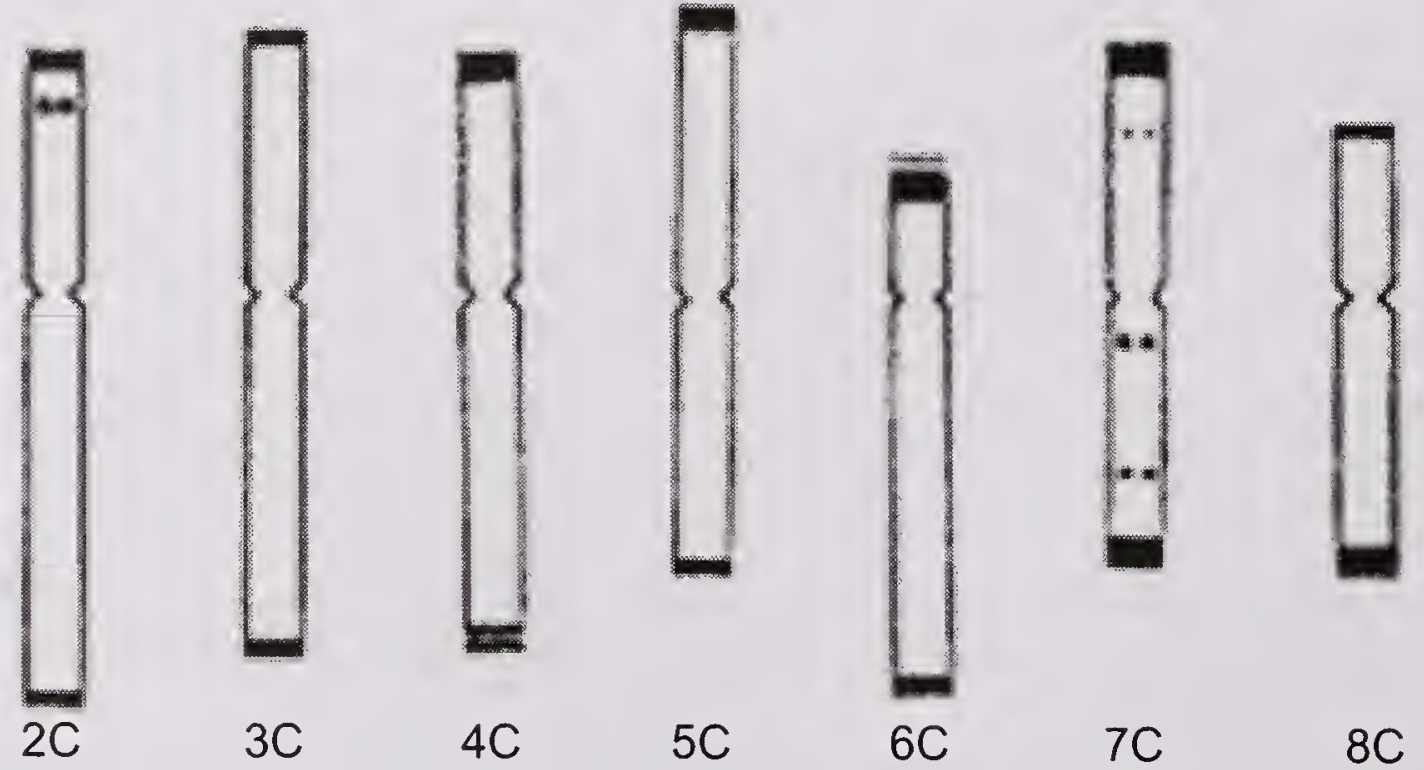

$8 \mathrm{C}$

Fig. 4.1 Idiogram of Allium cepa (adapted from de Vries 1996) 
The onion nuclear genome is notable for its great size, $15 \mathrm{Gbp}$ per $1 \mathrm{C}$ (Ricroch et al., 2005); one of the largest among cultivated plants. The $2 \mathrm{C}$ value for the species is $33.5 \mathrm{pg}$ (Jones and Rees, 1963). King et al. (1998) reasoned this extremely large diploid genome as the result of tandem duplication in the process of evolution.

\section{Genetics of Agronomic Traits}

Genetic analysis in onion is time consuming because of its biennial nature and severe inbreeding depression. Thus it is difficult to produce and maintain a large, near homozygous inbred populations for genetic linkage analysis. Therefore, compared to many other vegetable crops, only a few qualitative genes with easily visible effects have been described in onion (Table 4.1). Just 17 morphological or disease resistance genes were described (King et al., 1998), including bulb, foliage, anthers and seed coat colour, male sterility, restoration of CMS, pink-root resistance, ozone damage resistance, dwarf seed stalk and chlorophyll deficient mutants (S1 no. 1-12 in Table 4.1). Apart from these, Bacher et al. (1989) reported two partially dominant genes, Foc1 and Foc2, for basal-rot resistance and Molenaar (1984) reported $g l s 1$ and $g l s 2$ for glossy scape, epistatic to glossy foliage $(g l)$.

A number of studies reported inheritance of yield, quality and resistance traits (Havey, 1993). Highly significant general combining ability (GCA) and relatively smaller significant specific combining ability (SCA) effects for yield and maturity were also reported (Hosfield et al., 1975; Hosfield et al., 1977a, b). Additive gene effects, governing dry matter content, bulb size (Padda et al., 1973) and maturity (Pandian and Muthukrishnan, 1974), and additive and non-additive gene effects

Table 4.1 Genetics of agronomic traits in onion (Adapted from Pike 1986)

\begin{tabular}{ll}
\hline Agronomic trait & Genetic condition \\
\hline Albino seedling & $a / a$ \\
Yellow seedling linked with glossy & $y 1 / y 1$ \\
Yellow seedling not linked with glossy & $y 2 / y 2$ \\
Pale green seedling & $p g / p g$ \\
Virescent seedling & $v / v$ \\
Glossy foliage & $g / / g l$ \\
Exposed anther & $e a / e a$ \\
Yellow anther & ya/ya \\
Pink-root resistance & $p r / p r$ \\
Male-sterility nuclear gene & $m s / m s$ \\
$\quad$ (Interaction between nuclear gene & \\
and plasma gene, S) & \\
Brown seed colour & $b / b$ \\
Bulb colour & Five major genes (ICGLR) dominant white (I-), \\
& recessive white (cC), yellow (iiC-IIR-, iiC-L-rr, and \\
& $i i C-I / r r)$, and light-red to red (iiC-L-R-) L2: Another \\
Basal-rot resistance partially & locus governing red colour \\
dominant genes & Foc1, Foc2 \\
Glossy scape & gls1, gls2 \\
\hline
\end{tabular}


for bulb yield and number of leaves per plant were found to play an important role (Aghora, 1985). Available evidences suggest that bulb shape, single centre and bolting resistance during bulbing are governed by additive gene action. High heritability was reported for bulb yield, bolting percentage, bulb diameter and sprouting percentage (Patil et al., 1986); indicating better scope of improvement through selection. Traits like seed yield and 1,000 seed weight had low heritability (Dadlani and Bhagchandani, 1978). Storability has been correlated directly with soluble solids content.

Genetic analyses using molecular markers of several traits have been studied. The first public genetic linkage map was published in 1998 (King et al., 1998) and since then several mapping populations have been developed for genetic and molecular analysis of yield and quality traits in onion. A few of them include the following.

1. BYG15-23 $\times \mathrm{AC} 43$

2. B2246 $\times$ B 11159

3. W202A $\times$ Texas Grano 438

4. Interspecific A. cepa $\times$ A.roylei

5. CUD H2150 $\times$ Nasik Red

6. Doubled haploid population between DH 5225 (red, doubled-haploid onion) $\times \mathrm{OH} 1$ (yellow inbred that shows high frequency of gynogenic haploid production)

Onion mapping populations are generally based on the inbred lines that have typically been subjected to only one generation of self-pollination. In onion, high levels of residual heterozygosity have greatly complicated marker development and sequence analysis. Development of highly fecund doubled-haploid (DH) lines provides an opportunity to use homozygous, distributable reference lines for onion genetics and genomics. Notable among them and relevant to breeding programmes is the population based on Nasik Red and a homozygous doubled-haploid bulb onion line CUDH 2150 (Baldwin et al., 2012).

The details are available in "Allium Map-a comparative genomics resource for cultivated Allium vegetables" (http://alliumgenetics.org).

\section{Breeding Methods}

Onion is a highly cross-pollinated crop, and selfing beyond second generation results in inbreeding depression. The average bulb yield was only $64 \%$ in selfed generation compared to the open pollination. The mean maturity was delayed by 12 days with increase of thick-necked bulbs from 2 to $12 \%$ in the inbred populations (Dowker and Fennel, 1981). After 3 generations of selfing, survival rate was down to $50 \%$ and seed-set was only $70 \%$ (Jones and Mann, 1963). Khan et al., (2001), however, reported that degree of inbreeding depression depended on the genetic background. Therefore, breeding methods based on continuous selfing are less efficient in onion.

Onion, being cross-pollinated, has an excellent possibility for population 
Table 4.2 Onion varieties released worldwide using various population improvement methods

\begin{tabular}{|c|c|c|}
\hline Variety released & Method used & $\begin{array}{l}\text { Reference institute } \\
\text { involved and year } \\
\text { of release }\end{array}$ \\
\hline
\end{tabular}

\section{Improvement of ancient Russian variety 'Spasskii' \\ Yalova 1, Yalova 3 and Yalova 12 \\ N 53}

Punjab Selection

Pusa White Flat

Pusa White Round

\section{Co 2}

Punjab 48

Pusa Ratnar

\section{Pusa Red}

Co 3

Kalyanpur Red
Round

Arka Pragati

N 2-4-1

Arka Niketan

Agrifound Dark Red

Pusa Madhavi

Dorata di Parma resistant for Fusarium oxysporum f. sp. cepae Snyd. et Hans.

Arka Kalyan (Sel 14)

Baswant 780
Mass Selection and Intravarietal

Recurrent Hybridization

Mass Selection and Single plant selection in Thrace population

Mass Selection (Collection from Nashik, Maharashtra)

Mass Selection (Collection from Punjab)

Mass Selection

Mass Selection (Local collection 106)

Mass Selection (Collection from Tamil Nadu)

Mass Selection (Collection from Punjab)

Mass Selection (Selection from Red Granex)

Mass Selection (Local Collection)

Mass Selection (Collection from Tamil Nadu)

Mass Selection (Collection from Uttar Pradesh)

Mass Selection (Collection from Nashik, Maharashtra)

Mass Selection (Collection from Pune, Maharashtra)

Mass Selection (Mass Selection from a local collection IIHR 153)

Mass Selection (Collection from Nashik, Maharashtra)

Mass Selection (Collection from Muzaffarnagar, Uttar Pradesh)

Combination of Mass and

Recurrent Selection

Mass Selection (Mass selection from a local collection IIHR 145)

Mass Selection (Collection from Pimpalgaon, Maharashtra)
Efimochkina 1970

Akgun 1970

MPKV, Rahuri, 1975

PAU, Ludhiana, 1975

IARI, New Delhi, 1975

IARI, New Delhi, 1975

TNAU, Coimbatore, 1978

PAU, Ludhiana, 1978

IARI, New Delhi, 1978

IARI, New Delhi, 1978

TNAU, Coimbatore, 1982

CSUAT, Kanpur, 1983

IIHR, Bengaluru, 1984

MPKV, Rahuri, 1985

IIHR, Bengaluru, 1987

NHRDF, Nashik, 1987

IARI, New Delhi, 1987

Fantino and Schiavi 1987

IIHR, Bengaluru, 1987

MPKV, Rahuri, 1989 
(. . Table 4.2)

\begin{tabular}{|c|c|c|}
\hline Variety released & Method used & $\begin{array}{l}\text { Reference institute } \\
\text { involved and year } \\
\text { of release }\end{array}$ \\
\hline VL Piaz 3 & $\begin{array}{l}3 \text { cycles of Mass Selection } \\
\text { after } F_{2} \text { of cross 'In-13 x L- } 43 \text { ' }\end{array}$ & Mani et al. (1999) \\
\hline $\begin{array}{l}\text { Screening and } \\
\text { analysis of } \\
\text { components of } \\
\text { white shaft weight }\end{array}$ & $\begin{array}{l}\text { Maternal pedigree selection } \\
\text { in male-sterile plants and } \\
\text { male-fertile plants (MPSMS } \\
\text { and MPSMF) }\end{array}$ & Zhaoshui et al. (1995) \\
\hline $\begin{array}{l}\text { Composto IPA } 6 \\
\text { and Belem IPA } 9\end{array}$ & $\begin{array}{l}\text { Mass Selection for tolerance } \\
\text { to } C \text {. gloeosporioides, } T \text {. tabaci } \\
\text { and good post-harvesting } \\
\text { conservation qualities }\end{array}$ & De Franca et al. (1997) \\
\hline Cobriza INTA & $\begin{array}{l}\text { Mass Selection from } \\
\text { Valenciana type onions }\end{array}$ & Galmarini et al. (2001) \\
\hline Navideña INTA & $\begin{array}{l}\text { Mass Selection from } \\
\text { Torrentina local population }\end{array}$ & Galmarini et al. (2001) \\
\hline Antártica INTA & $\begin{array}{l}\text { Mass Selection from Valenciana } \\
\text { type onions }\end{array}$ & Galmarini et al. (2001) \\
\hline NuMex Chaco onion & Recurrent Selection & $\begin{array}{l}\text { Cramer and Corgan } \\
\text { (2001a) }\end{array}$ \\
\hline $\begin{array}{l}\text { NuMex Snowball' } \\
\text { onion }\end{array}$ & Recurrent Selection & $\begin{array}{l}\text { Cramer and Corgan } \\
(2001 \mathrm{~b})\end{array}$ \\
\hline NuMex Arthur onion & Recurrent Selection & Wall and Corgan (2002) \\
\hline Gholy & $\begin{array}{l}\text { Mass Selection (Ghesseh } \\
\text { Local Onion) }\end{array}$ & Javad et al. (2004) \\
\hline $\begin{array}{l}\text { Purifying the popular land } \\
\text { variety Abu Ferewa }\end{array}$ & $\begin{array}{l}\text { Phenotypic Recurrent Mass } \\
\text { Selection and Inbreeding } \\
\text { followed by Bulking }\end{array}$ & Bakheet (2008) \\
\hline Arka Pitambhar & $\begin{array}{l}\text { Pedigree selection from the } \\
\text { cross, U.D. } 102 \times \text { IIHR-396 }\end{array}$ & $\begin{array}{l}\text { IIHR, Bengaluru } \\
\text { http:/www.iihr.res.in } \\
\text { frmVarieties.aspx }\end{array}$ \\
\hline Bhima Super & $\begin{array}{l}\text { Rigorous Mass Selection for } \\
\text { single centeredness and } \\
\text { bulb shape }\end{array}$ & Lawande et al. (2007) \\
\hline $\begin{array}{c}\text { Bhima Red \& } \\
\text { Bhima Raj }\end{array}$ & $\begin{array}{l}\text { Single Bulb Selection up to three } \\
\text { generations, followed by Mass } \\
\text { Selection }\end{array}$ & Lawande et al. (2009) \\
\hline $\begin{array}{l}\text { Bhima Shakti and } \\
\text { Bhima Kiran }\end{array}$ & $\begin{array}{l}\text { Mass Selection for good keeping } \\
\text { quality }\end{array}$ & Lawande et al. (2010a \& b) \\
\hline Bhima Shweta & $\begin{array}{l}\text { Selection of elite lines from } \\
\text { germplasm, followed by random } \\
\text { mating and Mass Selection for } \\
\text { rabi season white onion }\end{array}$ & $\begin{array}{l}\text { Mahajan et al. } \\
(2010,2011)\end{array}$ \\
\hline Bhima Shubra & $\begin{array}{l}\text { Selection of white segregating } \\
\text { bulb from red germplasm, followed } \\
\text { by Mass Selection for kharif and } \\
\text { late kharif season }\end{array}$ & $\begin{array}{l}\text { Mahajan et al. } \\
(2010,2011)\end{array}$ \\
\hline
\end{tabular}


improvement methods, as natural variability is created constantly. Information on the nature and extent of the genetic variability and degree of transmission of traits and knowledge of correlations among various characters is of paramount importance in enhancing selection efficiency (Table 4.2).

A major contribution to onion breeding has been the development of new open-pollinated (OP) varieties through a range of population improvement methods. OP varieties are defined as genetically variable populations, which are maintained and multiplied by mass pollination in isolation. The most appropriate technique depends on how well-developed existing cultivars are, besides the expertise and resources available for breeding.

\section{Mass selection}

This has been the most preferred method for onion improvement throughout the world. In this, around 1-5\% individual plants are selected from one population based on the phenotypic performance, and seeds are composited to raise the next generation (Fig.4.2). Several cycles of mass selection are usually employed before larger-scale multiplication of new improved variety. It takes 5-6 such cycles to attain the final uniformity and superiority required in a variety for commercial cultivation. This method is effective where populations have a wide genetic-base and for the characters, which are highly heritable and governed by additive gene action. Selection intensity and population size need to be balanced to reduce any inbreeding depression due to selection of a fewer plants and for avoiding losing superior genotypes due to higher selection intensity. The main drawback in this method is that there is no control over pollen parent; and selection is purely based on the performance of the female parent. It is a simple method, and requires no specialized knowledge and is suitable where industry is just emerging.

A refinement to mass selection is the stratified mass selection, where field plots of bulbs grown for selection are subdivided equally, and the same proportion

\begin{tabular}{|c|c|c|}
\hline I Year (First selection cycle) & 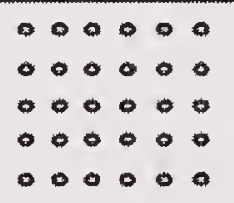 & $\begin{array}{l}\text { Select best plants based } \\
\text { on their phenotype. Open- } \\
\text { pollinated seeds from the selected } \\
\text { plants are composited }\end{array}$ \\
\hline
\end{tabular}

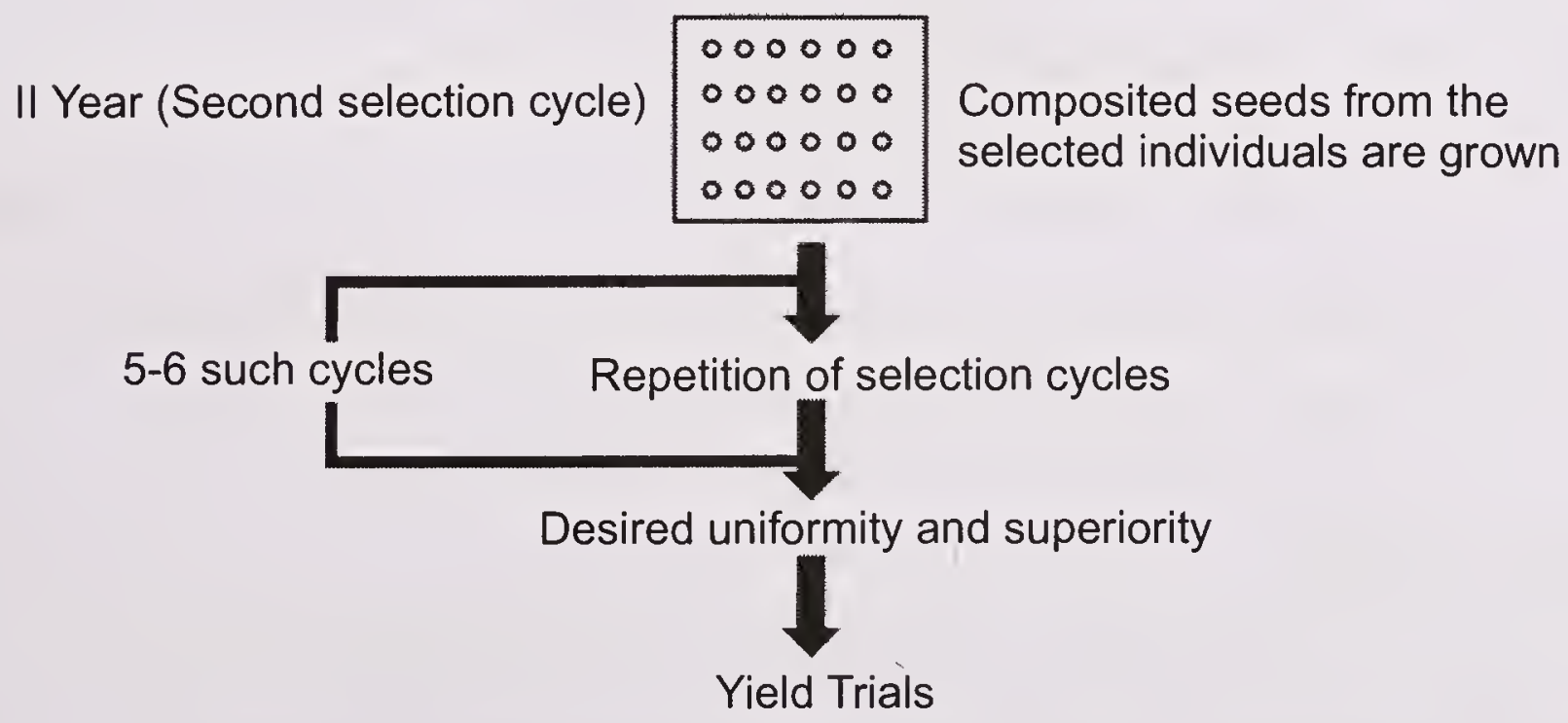

Fig. 4.2 A schematic representation of mass selection (adapted from Singh 1983) 
of selected bulbs of desired types is chosen from each area. It helps make allowance for the effect of variable growing conditions within the field plot on appearance of the mother-bulbs, and correspondingly increase chances of picking out heritable variations during the selection process (Rabinowitch and Brewster, 1990).

\section{Selfing and massing technique}

This method was suggested by Jones and Mann (1963) for onions to overcome inbreeding depression. Each breeding cycle consists of the following steps.

1. The parent population may be an open-pollinated variety or the segregating progeny of a cross between two parental lines. Selected bulbs are selfed in the first generation.

2. Selfed seed are harvested and grown separately, and poor progenies are discarded.

3. Total of $15-20$ bulbs in $5-10 \%$ of the best lines are selected and openpollinated in isolation.

4. The massed seed is harvested together.

Steps 1-4 are repeated till uniformity and superiority is attained (Fig.4.3). This breeding method is open-ended, meaning number of cycles of selection can vary and promising new lines can be brought into the sequence at any stage depending upon the requirement. Pusa Madhavi is one such variety developed through this at the IARI, New Delhi.

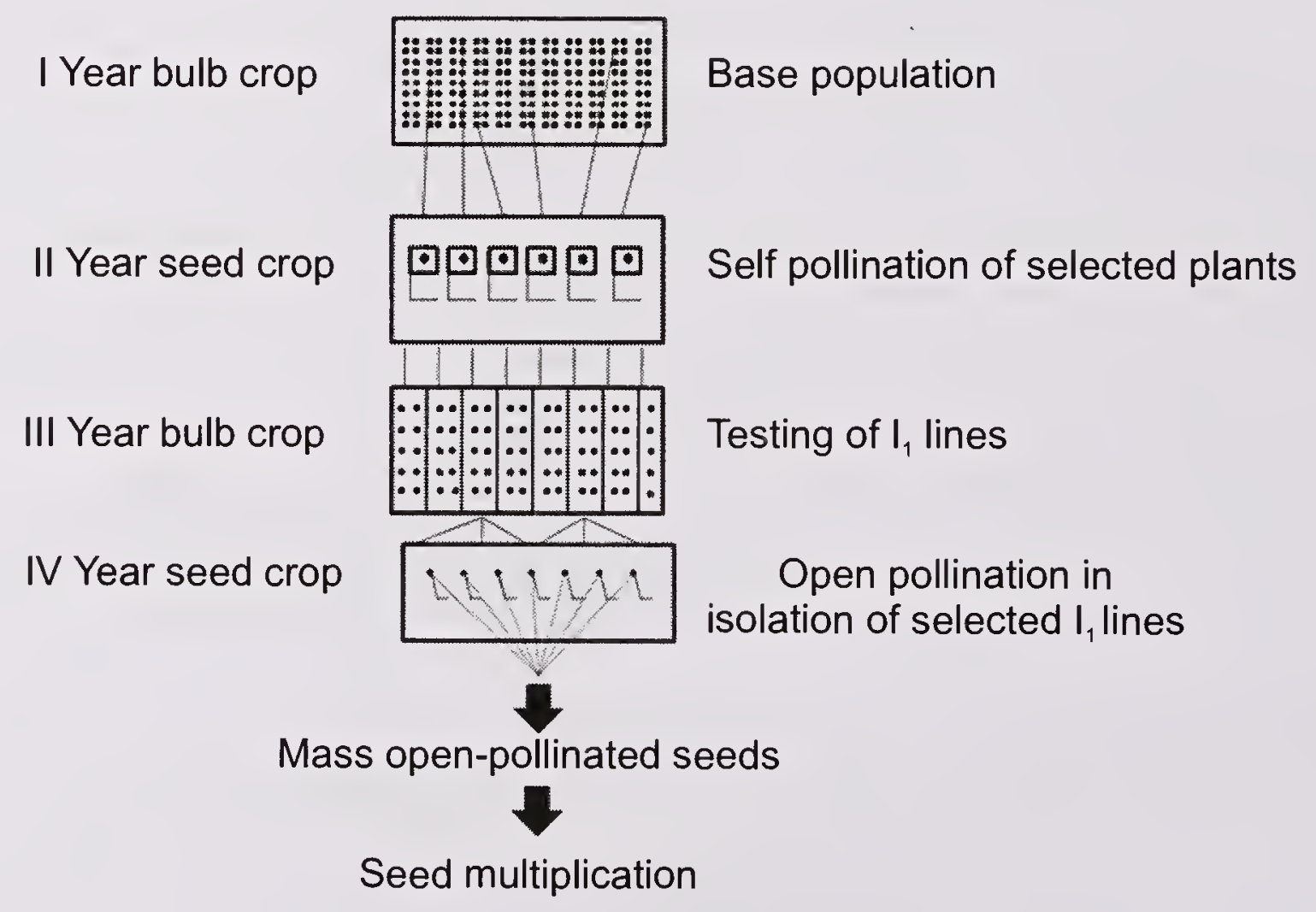

Fig. 4.3 Selfing and massing technique for genetic improvement of onion (adapted from Kalloo1988)

\section{Synthetic varieties}

This is a breeding method recommended for cross-pollinated crops like onion where floral morphology does not permit manual commercial production of $F_{1}$ hybrids. This system is valuable where commercial seed industry is not well developed to handle complex male-sterility systems for hybrid-seed production. 
General combining ability testing and selection of parental lines

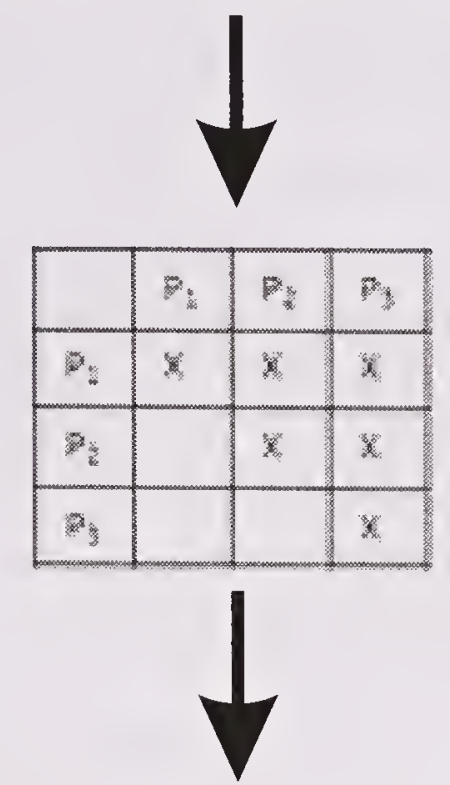

4-8 selected parental lines crossed in all possible combinations

Equal quantity of $F_{1}$ seeds of all crosses are bulked to form Syn,

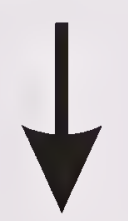

Open pollination in isolation of the bulked seed to form $\mathrm{Syn}_{2}$

Fig.4.4 Steps involved in onion synthetic variety development

In this, cost of seeds is expected to be lower than hybrid varieties, and farmers also benefit from multiplying their own seeds for the next season.

Parental lines for a synthetic variety, which can be an inbred line or a variety developed by the mass selection or recurrent selection, are chosen based on their general combining ability and hence would be exploiting additive genetic variance. Synthetic variety is produced by crossing a number of lines that combine well in all combinations with one another, and is maintained by open pollination in isolation for a limited number of generations (Fig.4.4). Hence, the variety needs to be regularly reconstructed. Arka Bheem is one such variety developed at the IIHR, Bengaluru.

Not much information is available on the prospects of synthetic varieties in onion. Hence, efforts need to be made to generate basic evidences, especially on the issues like appropriate number of parents, choice of parents, consequent level of inbreeding, and parameters for yield prediction (Rao, 2014).

\section{Family selection}

More sophisticated open-pollination breeding methods are based on the family selection. Many desirable agronomic characters are quantitative in nature with low heritability. In such circumstances, using the family mean performance, rather than the individual bulb as an unit of selection is more appropriate. Commonly, half-sib families or 1-2 generation selfed families are used. The method operates as an alternative to field evaluation of bulbs and involves controlled pollination of selected families in consecutive seasons. New promising lines may be brought 
Table 4.3 Season-wise schematic plan to breed open- pollinated onion cultivars as proposed by Pike (1986)

\begin{tabular}{|c|c|}
\hline Season & Procedure \\
\hline 1 & Grow source lines and select 100 bulbs, store bulbs \\
\hline 2 & Plant selected bulbs and self \\
\hline 3 & $\begin{array}{l}\text { Plant } S_{1} \text { seed in progeny rows, select best bulbs from best progeny rows, } \\
\text { discard poor progenies completely, store bulbs }\end{array}$ \\
\hline 4 & $\begin{array}{l}\text { Plant } S_{1} \text { bulbs and self } 5-10 \text { selected bulbs from each progeny, also make a } \\
\text { few } 3-5 \text { plant masses from same progeny rows }\end{array}$ \\
\hline 5 & $\begin{array}{l}\text { Plant } S_{2} \text { seed and three bulb mass seed obtained in the fourth year, select } \\
\text { lines that look similar, select same good 3-5 bulb masses, which look uniform, } \\
\text { store bulbs }\end{array}$ \\
\hline 6 & Plant $S_{2}$ bulbs and mass $10-15 S_{2}$ bulbs from selected progeny rows \\
\hline 7 & $\begin{array}{l}\text { Plant seed to have observation trials for early evaluation of bulbs, select } \\
\text { superior progenies and discard others }\end{array}$ \\
\hline 8 & $\begin{array}{l}\text { Mass } 100 \text { bulbs and plant in a } 9 \text { feet } \times 10 \text { feet cage for small seed increase of } \\
\text { selected lines }\end{array}$ \\
\hline 9 & $\begin{array}{l}\text { Plant seed for yield trials at multilocations, select best stock bulbs for further } \\
\text { seed increase }\end{array}$ \\
\hline 10 & $\begin{array}{l}\text { Plant bulb to make a } 12 \text { feet } \times 24 \text { feet cage for seed increase, observe seed } \\
\text { yield }\end{array}$ \\
\hline 11 & $\begin{array}{l}\text { Plant several commercial plantings to evaluate for all requirements such as } \\
\text { shipping, storage and processing which were not possible during earlier testing }\end{array}$ \\
\hline 12 & Release superior liner as a new cultivar \\
\hline
\end{tabular}

into at any stage of selection. Both the 'intermediate improved population' and 'final variety' created by the intercrossing of selected bulbs from selected families by open pollination in isolation are suitable. The final variety may be maintained by mass selection in subsequent generations. Wall et al. (1996) used half-sib family selection and proved its efficacy for improving pungency and single centeredness in onion breeding populations. Two methods of family selection were proposed in onion by Pike (1986) (Table 4.3) and Dowker (1990) (Fig.4.5).

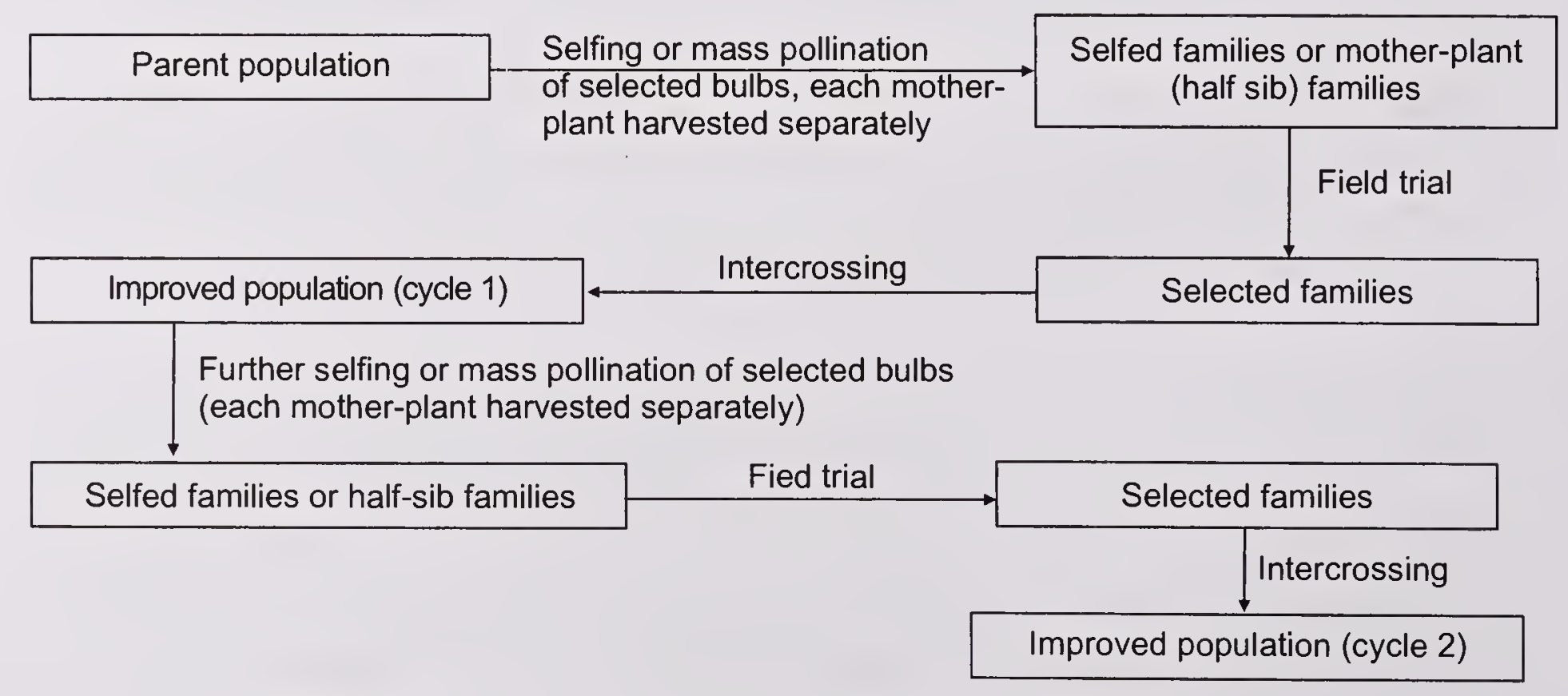

Fig. 4.5 An open- pollinated family breeding scheme in onion (adapted from Dowker 1990) 


\section{Recurrent selection}

A population having a broad genetic-base, i.e. a segregating population or a multiple hybrid or any improved population with greater genetic variability can constitute a base population. A few superior plants within the base population are selected and selfed followed by inter-mating in all possible combinations under isolation of selected selfed seeds from the previous generations to complete original selection cycle. Composited intercross seeds are planted and the repetition of the original selection cycle constitutes the first recurrent selection cycle. The cycle can be repeated until there is an increased frequency of desirable genes (Fig 4.6).

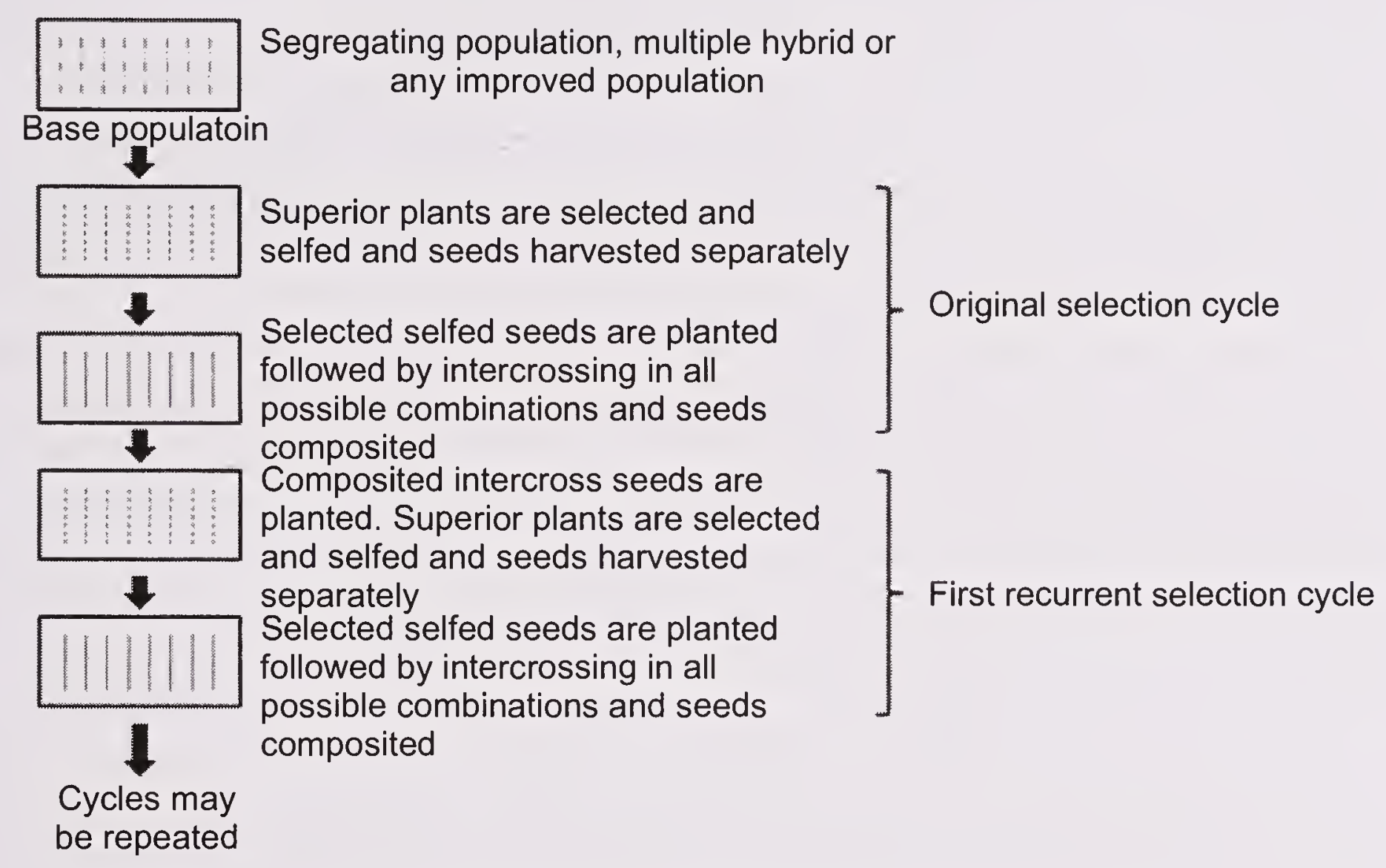

Fig. 4.6 Recurrent selection for onion population improvement (adapted from Singh 1983)

Populations based on the recurrent selections for improved yield, bulb quality and storage performance (Dowker et al., 1984) were developed. Cramer (2001a, 2001b) and Wall and Corgan (2002) developed cultivars NuMex Arthur, NuMex Chaco and NuMex Snowball using recurrent selection method. "NuMex Starlite", a yellow-onion variety developed by Corgan and Holland (1993), was obtained by 5 recurrent selections from Texas Grano 502 PRR.

\section{Pedigree selection}

Considering prevalence of inbreeding depression, pedigree selection is not a preferred method. Near inbred lines are used for hybridization, followed by selfing over generations. The Indian Institute of Horticultural Research(IIHR), Bengaluru, developed a yellow onion variety, Arka Pitambar, through pedigree selection from U.D. $102 \times$ IIHR 396. This variety produces bulbs of medium size $(5.2-6.0 \mathrm{~cm})$ in globe shape with thin neck, and it possesses mild pungency with $11 \%$ TSS and $9.81 \%$ total sugar. 


\section{Breeding Objectives}

Since preferences vary from market to market, it is not possible to characterize fully an ideal onion. Breeding goals depend on preference of the market for colour, shape and utility.

Major goals include-High yield, intact attractive skin, uniformity for bulb shape, size and maturity, thin neck, free from splits, better storage with less sprouting and rotting, high dry matter content and disease resistance.

Though it is a biennial crop, its each seed-to-seed breeding cycle in Maharashtra and Karnataka can be accomplished within a year where kharif crop is taken as compared to northern India, where it takes 2 years for each cycle.

Bulb development in onion is related to climate, and hence its breeding and selections are to be made in the region where it is to be cultivated (Brewster 2008). Usually, positive selection at a time is confined to a few major traits coupled with appropriate ways of measuring characters selected to attain breeding objectives. Many objectives for breeding like shape, colour, skin retention, splits can be assessed visually and are qualified by a simple scoring system. Maturity dates can be assessed based on $50 \%$ neck fall. Selection pressure against premature bolting may be imposed by appropriate dates of rabi sowing. TSS is an indirect measurement of dry matter content. Many special tests have been devised for pest and disease resistance to supplement gross field observations. It should be kept in mind that bulb size, shape, maturity date, percentage thickness of neck and split bulbs all are influenced by population density (Rabinowitch and Brewster, 1990).

In the absence of continuous selection, quality of open-pollinated cultivars may degenerate. Unless constant selection pressure is applied, population drifts towards flat bulbs with multiple centres and premature bolting. Hence, selection is necessary to maintain resistance for premature bolting, single centred bulbs, bulb shape and increased dry matter. The proportion of plants with any feature that tends to increase seed yield would increase with repeated seed multiplication in the absence of selection against it (Brewster, 1994).

\section{Breeding for production}

Onion has been bred to adapt to a variety of climates. Many factors affect onion development, bulb formation and maturity; environmental conditions and plant genotype are the two main components. The onion-crop that can bulb at a day length of $11.5 \mathrm{hr}$, belongs to a short-day group and that requires $14 \mathrm{hr}$ or more to bulb is a long-day type. The terms "long", "intermediate" and "short-day" are used largely by onion breeders to describe photoperiod requirements for bulb formation of different cultivars, which are misnomers (Cardoso and Cyro da Costa, 2003). "Short-day cultivars" actually from a physiological point of view are longday cultivars, since they produce bulbs with a photoperiod above a particular critical value, which is smaller only when compared to cultivars referred to as "long-day cultivars" (Jones and Mann, 1963; Brewster, 1990).

Increasing day-length enhances speed of bulb formation and decreases time between beginning of bulb formation and bulb maturation (Steer, 1980). The 
minimum photoperiodic requirement can also be reduced with increased temperature (Heath, 1943). Photoperiod and temperature relation is so important that minimum photoperiod for a cultivar should never be specified without the corresponding temperature specification (Jones and Mann, 1963). In general, higher temperature accelerates, and lower delays bulb development.

High productivity in higher latitudes is favoured by long maturity season and long-day photoperiodic condition, resulting in high TSS and very compact bulbs. In contrast, Indian onions maturing under short-day condition with short-growing season yield less. Hence, average yield in India is only 12-16 tonnes/ha against 30 tonnes/ha in countries located between 25 and $30^{\circ} \mathrm{N}$ latitude (Sheshadri and Chatterjee, 1996). Onion in India is grown commercially between 12 and $25^{\circ} \mathrm{N}$ latitude during the three major seasons (Mahajan and Lawande, 2008). In Indian plains, short-day types are planted in kharif and rabi with an intermediate rangda season. Through centuries of selection, types, which respond to warm and humid days and around 11-11.5 hr photoperiod, have been identified and maintained by farmers. Several such local types which are very well adapted to specific regions are being cultivated on a wide area. Some of them are: Patna White, Bombay Red, Patna Red, Poorna Red, Nasik Red, Bellary Red, Gujarat White, Bengaluru Rose, Krishna Puram Rose etc. From this material, superior genotypes like N 53, Agrifound Dark Red, Basawant 780, Bhima Super, Bhima Shubra and Arka Kalyan have been developed. Experience shows that long-day types developed in cooler countries, do not perform well in Indian plains.

Lee et al. (2013) studied molecular mechanism of photoperiodic influence over bulbing and flowering. They observed that different Flowering Locus T(FT) genes regulated these traits. Flowering is promoted by vernalization and it correlates with up-regulation of the gene $A c F T 2$, and bulb formation is regulated by two antagonistic $F T$-like genes. AcFT1 promotes bulb formation, while AcFT4 prevents $A c F T 1$ up-regulation and inhibits bulb formation in transgenic onions. Long-day photoperiod leads to down-regulation of AcFT4 and up-regulation of $A c F T 1$, and this promotes bulb formation. Thus interplay of these genes regulated by photoperiod decides transition from juvenile to reproductive phase. A greater understanding of this mechanism would help breeding varieties for different climates and would narrow down genetic isolation between long-day and shortday cultivars.

\section{Breeding for quality}

Important quality traits of the bulb are size, shape, colour, pungency, firmness, dormancy and amount of soluble solids. Bulbs of various shapes and colours are preferred by consumers in different parts of the world. Most bulb quality traits have a genetic basis, and can be manipulated by breeding. Nakamura (1959), McCollum (1968, 1966, 1971) and Dowker and Fennell (1974) estimated heritabilities of bulb size and shape in different onion populations. Bulb height and bulb shape index (bulb height/diameter) showed relatively larger heritabilities compared to bulb diameter and weight. Hence, breeders can expect response to selection for bulb height, but not for bulb diameter. Environment has a greater influence over bulb diameter. If bulb diameter grows in a shorter time-frame, 
bulbs will be pyriform and if more time for growth, bulb diameter will be more.

Bulb colour is an economically important trait in onion, and is conditioned by interactions of at least five major loci (Clarke et al., 1944; El-Shafie and Davis, 1967; Reiman, 1931). White bulbs result from a dominant allele at $I$ locus or recessive alleles at $C$ locus. Coloured bulbs (chartreuse, light red, red, or yellow) are due to homozygous recessive genotype at $I$ locus and a dominant allele at $C$ locus. In plants that are $i i C$-, a dominant allele at $G$ locus produces golden-yellow bulbs, and homozygous recessive genotype ( $i i C-g g$ ) results chartreuse bulbs. Lightred bulbs are produced when the plant is $i i C-G$ - and has dominant allele at both $L$ and $R$ loci; bulbs with deeper red colour are produced when both $L$ and $R$ loci are homozygous dominant (El-Shafie and Davis, 1967). If either $L$ or $R$ locus is homozygous recessive, yellow bulbs are produced. El-Shafie and Davis (1967) stated that light-red bulb colour would be produced when two yellow onions are crossed [termed complementary light-red by Jones and Peterson (1952)] of genotypes iiCCGGLLrr and iiCCGGllRR.

Among these five loci, no candidate genes were identified for $I, C$, or $G$ loci. Kim et al. (2004a, 2005b) identified a differential expression of dihydroflavonol 4-reductase (DFR) gene between yellow and red coloured bulbs, and developed functional markers for different alleles of this gene (Kim et al., 2009; Park et al., 2013). This gene was assigned to $R$ locus by Khar et al. (2008). The $L$ locus appears to be a highly variable and has been assigned to anthocyanidin synthase (ANS) gene, reported to possess several alleles. Kim et al. (2005a) and Kim et al. (2006) reported four alleles at $L$ locus [ANS- $p$ for recessive pink, ANS-l and ANS$L$ for Brazilian and North American alleles of complementary light-red system, respectively, and ANS- $h 1$ for dark red]. Khar et al. (2008) reported a new locus (L2) linked at $6.3 \mathrm{cM}$ to ANS that is for red bulb colour of onion. Additionally, $\mathrm{Kim}$ et al. (2004b) reported occurrence of a golden coloured onion owing to a natural mutation at chalcone isomerase gene; resulting in a pre-mature termination codon.

Carbohydrate (fructose) and sulphur metabolisms are important pathways contributing to quality of onions. Carbohydrate metabolism relates to stabilizing dry matter content, and the sulphur metabolism relates to pungency. Some of the long-day varieties are with high TSS, ranging from $15 \%$ to $24 \%$; TSS is a function of the genotype, cultural practices and environment. Non-structural dry matter content of onion-bulbs principally consists of fructose, glucose, sucrose and fructans. Quality trait loci(QTLs) related to carbohydrate and flavour metabolism have been identified on the basis of Alien Monosomic Addition Lines (AMALs) of Japanese bunching onion (A. fistulosum) with extra chromosomes from shallot (A. cepa) (Shigyo et al., 1996). Another SSR marker, ACM235, identified on chromosome 8 , exhibited strong linkage with bulb fructan content in $F(2: 3)$ families from 'W202A' x 'Texas Grano 438' mapping population (McCallum et al., 2006).

In Indian plains, varieties mature in high temperature, which facilitates high sulphur accumulation. Amount of s-alkyl cysteine sulphoxide precursors and enzyme allinase contribute to pungency of onion-bulbs. Candidate genes for sulphur assimilation were used to identify genomic regions affecting pungency in 
the cross 'W202A' × 'Texas Grano 438' (McCallum et al., 2007). Linkage mapping has indicated that genes encoding plastidic ferredoxin-sulfite reductase $(\operatorname{SiR})$ and plastidic ATP sulfurylase (ATPS) are closely linked (1-2 cM) on chromosome 3. QTL analysis revealed significant association between pungency and TSS with marker intervals on chromosomes 3 and 5, which were previously reported for pleiotropic effects on bulb carbohydrate composition. These markers may be used as a practical tool to break linkage between pungency and TSS.

Onion populations showed marked differences in storability (Magruder et al., 1941) and firmness (Fennell, 1978). Phenotypic correlations between large size, softness, low pungency and poor storability were recognized (Bedford, 1984; Foskett, 1949; Hosfield et al., 1976). These correlations have been countered for a firm, well storing and less pungent large size bulbs (Peterson et al., 1986). Selective genotyping in a large 'Nasik Red $\times$ CUDH2150' $\mathrm{F}_{2}$ family revealed a major QTL on chromosome 1 associated with bolting, and named it as AcBlt1 (Baldwin et al., 2014).

\section{Breeding for processing quality}

Dehydrated products such as flakes, rings, granules, powder etc., and processed products, like onion in vinegar and brine, are being prepared and marketed worldwide. Ideotype for dehydration includes pure white bulbs, with globe shape, thin neck, high pungency and high TSS (>15-18\%). In India, several attempts were made for development of white onion varieties by different research institutes (Table 4.4) (Mahajan and Lawande, 2011).

Table 4.4 Charateristics of white onion varieties developed in India (Mahajan and Lawande, 2011)

\begin{tabular}{llcc}
\hline Variety & Source & TSS (\%) & Average yield q/ha \\
\hline Pusa White Round & IARI, New Delhi & 11.13 & $300-325$ \\
Pusa White Flat & IARI, New Delhi & 10.00 & $325-350$ \\
Udaipur 102 & RAU, Udaipur & 10.06 & $300-350$ \\
Agrifound White & NHRDF, Nashik & 10.76 & $200-250$ \\
Phule Safed & MPKV, Rahuri & 10.13 & $250-300$ \\
PKV White & PDKV, Akola & 9.55 & $250-300$ \\
Gujarat White & JAU, Junagadh & - & $300-325$ \\
N 257-9-1 & Agril. Deptt, Maharashtra & 10.00 & $250-300$ \\
Punjab 48 & PAU, Ludhiana & 11.00 & $300-325$ \\
Arka Swadista & IIHR, Bengaluru & 18.00 & $160-180$ \\
V 12 & Jain Food Park & 15.00 & $350-400$ \\
Nimar Local & Land Race, Madhya Pradesh & 12.50 & $250-300$ \\
Talaja Local & Land Race Bhavnagar & 12.00 & $250-300$ \\
\hline
\end{tabular}

\section{Breeding for export}

India is the leading exporter of onions, followed by Netherlands. India's export is mostly to South-East Asia and Gulf countries; red to light-red onions with 
globe shape are mostly preferred in various sizes. Since, grading is a major requirement for export, any breeding programme for export should aim at uniformity in shape, size and colour. European markets require yellow or brown varieties with big size ( $>60 \mathrm{~mm}$ diameter) and less pungency. Three such varieties developed in India are Arka Pitambar and Arka Sona from the IIHR, Bengaluru, and Phule Swarna from the MPKV, Rahuri.

Apart from the above two segments, the other specific export segment includes rose onion, grown in Bengaluru and Kolar districts of Karnataka and Kadapa district of Andhra Pradesh. These are small (2.5-3.5-cm diameter), deep scarletred, highly pungent, flattish-round with high TSS of $21 \%$. Malaysia, Indonesia, Singapore, Sri Lanka, Brunei, Bangladesh and a few countries in West Asia such as Bahrain, Dubai constitute their main market. Premature bolting and high percentage of splits are major breeding issues for this segment. Three rose onion varieties-Arka Bindu and Arka Vishwas from the IIHR, Bengaluru, and Agrifound Rose from the NHRDF, Nashik, have been developed, which are found good for export.

\section{Breeding for resistance}

Purple-blotch, Stemphylium-blight, basal-rot and thrips are major diseases and pests of onions in India. Much of the resistance to pests and diseases has been derived by field selection under pressure of natural attack by pathogens. Availability of efficient screening technique for diseases is still a limitation. The resistance sources identified for some of the diseases and pests in India (VeereGowda, 1997) are listed in Table 4.5.

\section{Purple-blotch (Alternaria porri)}

Purple-blotch is presently the most severe disease in India, which can result in $100 \%$ losses of bulbs and seed crops in storage. Srivatsava et al. (1994) observed that the disease incidence was high in both kharif and rabi seasons when high

Table 4.5 Sources of resistance for diseases and insect- pests of onion

\begin{tabular}{|c|c|c|c|}
\hline SI No & Disease/pest & $\begin{array}{l}\text { Level of } \\
\text { resistance }\end{array}$ & Name of variety/line \\
\hline \multirow[t]{3}{*}{1} & Purple-blotch & $\mathrm{R}$ & IHR 56-1 \\
\hline & & MR & $\begin{array}{l}\text { Arka Kalyan, AFDR, IHR 25, VL 67, Red } \\
\text { Creole and Pusa Red }\end{array}$ \\
\hline & & $\mathrm{T}$ & Rampur local and Patna Red \\
\hline 2 & Stemphylium-blight & $\mathrm{T}$ & 40 accessions (NBPGR) \\
\hline 3 & $\begin{array}{l}\text { Stemphylium-blight } \\
\text { and purple-blotch } \\
\text { combined resistance }\end{array}$ & $\mathrm{R}$ & $\begin{array}{l}\text { IC } 32176 \text {, IC } 48954 \text {, IC } 48710 \text {, IC } 48724 \text {, } \\
\text { IC } 485754 \text { and IC } 49012\end{array}$ \\
\hline 4 & Basal-rot & $\mathrm{R}$ & IHR 506, IHR 141, Sel 13-1-1, Bellary Red \\
\hline \multirow[t]{2}{*}{5} & Thrips & $\mathrm{R}$ & $\begin{array}{l}\text { White Creole, N 2-4-1, Sel 171, Kalyanpur } \\
\text { Red Round }\end{array}$ \\
\hline & & $\mathrm{T}$ & Hisar 2, Panipat local, Bombay White \\
\hline
\end{tabular}

MR: Moderately resistant; R: Resistant; T: Tolerant 
humidity prevailed during 5 years of their survey (1988-93). Varieties like 'Red Creole' that have good wax covering on foliage and seed stem were found more resistant. Cuticle thickness was consistently greater in resistant varieties than susceptible ones. Resistance in such lines was markedly reduced by abrasion of leaves and by prolonged post-infection incubation at high relative humidity. Purpleblotch resistance has been found a recessive trait (Singh et al., 1992).

Sources of resistance have been reported against purple-blotch (Pathak et al., 1986; Dhiman et al., 1986). Singh et al. (1992) reported that cultivars, VL1, PBR 1, PBR 5 and Arka Niketan were most tolerant. Agrifound Light Red (Sharma, 1997), N 53-3 (Pandotra, 1965), Agrifound Dark Red, Red Globe (Sugha et al., 1992) and RO 59 (Mathur et al., 2006) were reported to be moderately resistant.

\section{Basal-rot}

Fusarium basal-rot (FBR), caused by Fusarium oxysporum f. sp. cepae, is an important soil-borne disease of onions worldwide. The causal organism infects basal stem plate of the bulb and eventually kills entire plant through degradation of basal plate. Cramer (2000) reviewed breeding and genetics of basal-rot resistance in onion. Monogenic (Tsutsui, 1991), digenic (Bacher et al., 1989) and polygenic inheritance (Villanueva-Mosqueda, 1996) of basal-rot resistance were reported. Breeding programmes have successfully used screening procedures to develop intermediate- and long-day, FBR-resistant cultivars. Cultivars showing adequate levels of resistance to FBR were developed (Gabelman, 1988). Sintayehu et al. (2011) identified some tolerant genotypes that could be used as a valuable source to enhance resistance against Fusarium basal-rot disease. High level of FBR resistance is still lacking in short-day onion cultivars.

\section{Neck-rot}

This, caused by Botrytis allii, commonly called grey mould neck-rot, is probably the most widely distributed and destructive disease of onions in storage. Owen et al. (1950) found mild flavoured cultivars in each colour group (red, yellow and white) suffering more with neck-rot than strongly pungent varieties. Difference in susceptibility among various mild pungent coloured bulb cultivars was not significant. Among the pungent ones, white suffered considerably more than coloured types. However, evidence suggests that pungency is more important than colour in giving resistance to neck-rot. Resistance has been reported in inbred lines, W420, W202 and B6693, developed at the University of Wisconsin. Other sources of onion germplasm showing resistance to Botrytis neck-rot were also reported by Van der Meer et al. (1971) and Miyaura et al. (1985).

Neck-rot resistance is a quantitative character, which shows continuous variation and is fixable in part by selection (Vik and Aastveit, 1984). Lin (1989) observed a moderate positive correlation between TSS and pyruvic acid content, a low negative correlation between pyruvic acid content and neck-rot disease index, and a medium negative correlation between TSS and neck-rot. Hence, use of simple and rapid hand refractometer method to select high TSS was effective in selecting high pungency and indirectly neck-rot resistant bulbs.

Lin et al. (1995) observed broad-sense heritability estimates, ranging from 
$42 \%$ to $63 \%$, and primary importance of additive gene action for this trait, and suggested that selection for neck-rot resistance should be effective using methods appropriate for quantitative traits. Recurrent and mass selection would be effective in a breeding programme for high pungency and high TSS cultivars with neck-rot resistance.

\section{Stemphylium-blight}

This disease is caused by Stemphylium vesicarium (Wallroth) Simmons. Singh et al. (1992) reported that this was one of the most serious diseases which can result in 100\% crop losses. The NBPGR collections IC 32176, IC 48954, IC 48710, IC 48724 and IC 49012 have been reported to be tolerant to this disease. However, no systematic breeding efforts have been made for understanding genetics and improvement of resistance to this disease.

\section{Thrips}

They are the most severe pest of onions not only in India but throughout the world. Further, it has been reported to predispose the host to purple-blotch disease. Wide angle of divergence of innermost leaves and glossy foliage (absence of wax on leaves) have been found to contribute towards resistance to this pest. Pawar $e t$ al. (1987) screened 36 diverse onion varieties and 28 local collections for resistance to Thrips tabaci from 1978-79 to 1984-85. Among varieties Kalyanpur Red Round, Udaipur 103 and N 53 were found to be most resistant. Among the local and exotic collections, Safedgol, N5 White, Mathewad 1, Shirwal 2, White Creole and Kagal 2 showed least infestation.

Jones et al. (1934) first reported resistance to thrips in cultivar White Persian. Varieties from Senegal were also reported to be resistant to thrips (Messiaen and Rouamba, 2004). The heritability of thrips resistance was found low, around 5\%, suggesting that family selection would be more effective than individual plant selection for this trait (Hamilton et al., 1999).

The basis of this resistance appears to be reduced waxiness (glossy) of the foliage. The USDA has released four glossy inbreds (B9885, B9897, B11278 and B111377) useful in the production of glossy hybrids. Molenaar (1984) studied genetics of glossiness in terms of thrips resistance with following phenotypesnonglossy foliage with nonglossy scapes (nonglossy, $\mathrm{Ng} 1$ ), glossy foliage with nonglossy scapes (single glossy, Sg1) and glossy foliage with glossy scapes (double glossy, Dg1). The gene controlling nonglossy foliage $(G l)$ was dominant to that controlling glossy foliage, and epistatic to that controlling glossy scape. Two loci were observed to control scape glossiness, and were designated as $G 1 s_{1}$ and $G 1 s_{2}$. The dominant $G l s_{1}$ allele (nonglossy) was epistatic to $G 1 s_{2}$. The 3 loci gave strong evidence of being linked, with $G 1 s_{2}$ being further from $G 1$ than $G 1 s_{1}$. Based on this genetic model, they proposed the genotypes: $\mathrm{Ng} 1, \mathrm{Gl} /-\mathrm{-l}-\mathrm{-l}-\mathrm{Sg} 1$, gl/gl Gls $\mathrm{s}_{1--/-;}$ and Dg1, gl/gl gls $/ g 1 s_{1} g 1 s_{2} / g 1 s_{2}$. On the basis of the number of thrips collected from onion umbels, glossy foliage plants were more resistant than nonglossy, and Dg1 plants were more resistant than $\mathrm{Sg} 1$ plants.

Natural variation exists in onion (A. cepa L.) for amount of epicuticular waxes on foliage; and plants with lower amounts of these waxes suffer less direct damage 
from onion thrips (T. tabaci Lindeman) (Steven, 2014). Wax crystals were clearly visible on the surface of the waxy foliage, with decreasing amounts on the semiglossy and none on the glossy leaves. Ketone hentriacontanone-16 was the most prevalent wax on the leaves of the waxy onions and was significantly less on the semi-glossy relative to waxy plants and on glossy relative to waxy and semiglossy plants. Numbers of adult and immature onion thrips were significantly reduced $(\mathrm{p}<0.05)$ on the glossy and/or the semi-glossy accessions relative to waxy in field and greenhouse cage experiments. These results indicate that semi-glossy plants possess intermediate amount of epicuticular waxes, which may protect leaves from environmental and spray damages, while still conferring resistance to onion thrips. Therefore, semi-glossy phenotype should be useful in integrated programmes managing thrips.

Genetic mapping of this trait revealed that the amount of hentriacontanone-16 was controlled only by one region on chromosome 5, and amount of several primary alcohols was controlled by a region on chromosome 2 . These results indicate that the region on chromosome 2 is likely to be associated with acyl reduction pathway of epicuticular wax biosynthesis, and the region on chromosome 5 may affect decarbonylation pathway. SNPs tagging these regions will be useful for marker-assisted selection to vary amount and type of epicuticular waxes for developing thrip-resistant onion-varieties.

\section{Pre-breeding for disease and pest resistance}

Though several reports of disease and insect resistance are available from India; none of the varieties have been found perfectly resistant, based on the trials at the DOGR. Only certain level of field tolerance was observed (Lawande et al., 2011 a, b; Mahajan et al., 2011). Further, studies on pathogen diversity, genetics of inheritance and markers for selection are lacking for short-day onions in India.

No accession of $A$. cepa screened so far in India has registered complete resistance to any of the above diseases. Interspecific hybridization with wild relatives is considered an alternative. Cultivated and wild Alliums possess many disease resistance traits, potentially useful for genetic improvement of bulb-onion. Fertile hybrids between $A$. royle $i$ and $A$. cepa were formed, and successful transfer of downy-mildew resistance was accomplished (Novak, 1986). Hybrids between A. cepa and A. fistulosum were known long ago (Emsweller and Jones, 1935) but $\mathrm{F}_{1}$ always showed extremely low fertility due to poor chromosomal pairing. The first attempt to introgress genes from A. fistulosum into A. cepa were reported by Emsweller and Jones (1935). However, these were not successful, and till lately all attempts to introgress genes from $A$. fistulosum to A. cepa failed because of sterility in backcrossed generations. Low degree of fertility exhibited by hybrids between A. cepa and other Allium spp. restricts successful introgression of disease resistance genes. Ulloa et al. (1995) suggested that such sterility was due to an imbalance between nuclear and cytoplasmic genomes. Van der Meer and De Vries (1990) and McCollum (1982) showed that A. roylei $(2 \mathrm{n}=2 \mathrm{x}=16)$ crossed readily with A. cepa and A. fistulosum, respectively. Hence, $A$. roylei can be used as a bridging species between $A$. fistulosum and A. cepa. By means of this bridgecross not only genes from $A$. fistulosum can be introgressed into $A$. cepa but 
simultaneously also genes from $A$. roylei. In A. fistulosum, resistance genes are present against Botrytis squamosa (Currah and Maude, 1984), Pyrenochaeta terrestris (Netzer et al., 1985), Colletotrichum gloeosporioides (Galvan et al., 1997), Urocystis cepulea and OYDV (Rabinowitch, 1997), and in A. roylei resistance is available against Peronospora destructor (Kofoet et al., 1990) and Botrytis squamosa (De Vries et al., 1992). Hence, via bridge-cross approach unique populations can be developed in which these resistant genes can be pooled. Introgression of $A$. fistulosum into the genome of $A$. cepa using $A$. royle $i$ as a bridging species by means of genomic in-situ hybridization was reported by Khrustaleva and Kik (2000), and is the first such successful effort.

\section{References}

Aghora T S. 1985. 'The heterosis and combining ability studies in onion (Allium cepa) using line $\times$ tester analysis'. M.Sc Thesis, University of Agricultural Sciences, Bengaluru, Karnataka, India.

Akgun H. 1970. Selection in native onion populations as a means of producing whitefleshed, yellow-skinned keeping varieties of onion suitable for export. Yalova Bahce Kulturleri Arastirma ve Egitim Merkezi Dergisi 3: 20-32.

Bacher J W, Pan S and Ewart L. 1989. Inheritance of resistance to Fusarium oxysporum f.sp. cepae in cultivated onions., pp. 85-91. (In): Proc. Natl. Onion Res. Conf. Jensen L. (Ed.) Boise, Idaho, held on 7-8 $8^{\text {th }}$ December 1989.

Bakheet K A. 2008 'Assessing relative efficiency of two breeding methods for the improvement of yield and quality of the local sudanese onion variety (Allium cepa $\mathrm{L}$.) abu ferewa'. Thesis (M.Sc. in Horticulture), Sudan Academy of Sciences, Khartoum, Sudan.

Baldwin S, Revanna R, Pither-Joyce M, Shaw M, Wright K, Thomson S, Moya L, Lee R, Macknight R and McCallum J. 2014. Genetic analyses of bolting in bulb onion (Allium cepa L.) Theoret. Appl. Genet. 127 (3): 535-47.

Baldwin S, Revanna R, Thompson S, Pither-Joyce M, Wright K, Crowhurst R, Fiers M, Chen L, Mucknight R. and McCallum J A. 2012. A toolkit for bulk PCR-based marker design from next generation sequence data: application for development of a framework linkage map in bulb onion (A. cepa L.) BMC Genomics 13: 637-45.

Bedford L. 1984. Dry matter and pungency tests on British grown onions. J. Natl. Inst. Agric. Bot. (UK) 16: 58.

Brewster J L. 1990. Physiology of crop growth and bulbing, pp. 53-88. (In): Onions and Allied Crops: Botany, Physiology and Genetics, Vol. 3. Rabinowitch H D and Brewster J L. (Eds). CRC Press, Boca Raton, Florida, USA.

Brewster J L. 1994. The genetics and plant breeding of Allium crops, pp. 41-62. (In): Onions and other Vegetable Alliums. CABI Publishers, UK.

Brewster J L. 2008. The genetics and plant breeding of Allium crops, pp. 51-84. (In): Onions and other Vegetable Alliums. CABI Publishers, UK.

Brewster J L. and Rabinowitch H D. 1990. Onions and Allied Crops, Vol I. CRC Inc. Boca Raton, Florida, USA.

Cardoso A I I and Cyro P da Costa. 2003. Selection for bulb maturity in onion. Sci. Agric 60 (1) (http://dx.doi.org/10.1590/S0103-90162003000100009).

Clarke A E, Jones H A and Little T M. 1944. Inheritance of bulb colour in the onion. Genetics 29: 569-75.

Corgan J and Holland M. 1993. "NuMex Starlite" onion. HortScience 28: 66-67. 
Cramer C S and Corgan J N. 2001a. 'NuMex Chaco' onion. HortScience 36: 1337-38.

Cramer C S and Corgan J N. 2001b. 'NuMex Snowball' onion. HortScience 36: 1339-40.

Cramer C S. 2000. Breeding and genetics of Fusarium basal rot resistance in onion. Euphytica 115: 159-66.

Currah L and Maude R B. 1984. Laboratory tests for leaf resistance to Botrytis squamosa in onions. Annals of Applied Biology 105: 277-83.

Dadlani N K and Bhagchandani P M. 1978. Variability and correlation studies in onion. Ind J Hort 35: 118-22.

De Franca J G E, Candeia J A, de Menzes J T, Maranhao E A, A de, Menzes D and Wanderlay L J de G. 1997. Development of short-day yellow onion for tropical environment of the Brazilian northeast. I International Symposium on Edible Alliaceae. Acta Horticulturae 433: 285-89.

De Vries J N. 1990. Onion chromosome nomenclature and homeology relationshipsworkshop report. Euphytica 49: 1-3.

De Vries J N and Jongerius M C. 1988. Interstitial C-bands on the chromosomes of Allium species from the section cepa, pp. 71-78. (In): Proc. 4th Eucarpia Allium Symp., Institute of Horticultural Research, Wellesbourne, UK.

De Vries J N, Wietsma W A and Jongerius M C. 1992. Introgression of leaf blight resistance from A. roylei Stearn into onion (A. cepa L.) Euphytica 62: 127-33.

Dhiman J S, Chadha M L and Sidhu A S. 1986. Studies on the reaction of onion genotypes against purple blotch. Vegetable Science 13: 304-09.

Dowker B and Fennell J. 1974. Heritability of bulb shape in some north European onion varieties. Ann. Appl. Biol. 77: 61.

Dowker B D. 1990. Onion breeding, pp. 215-232. (In): Onions and Allied Crops: Vol. I Botany, Physiology and Genetics, Rabinowitch H D and Brewster J L. (Eds). CRC Press Inc. Boca Raton, Floida, USA.

Dowker B D and Fennel J F M. 1981. The relative performance of inbreds and open pollinated populations of spring sown bulb onions. Journal of Agricultural Sciences 97: 25-30.

Dowker B D, Horobin J F, Crowther T C and Fennell J F M. 1984. Breeding of improved open-pollinated populations of spring-sown onions. Journal Agriculture Science 102: 615-23.

Efimochkina O N. 1970. The Spasskii onion. Tr. po selektsii i semenovodstvu ovoshch. kul'tur. Gribov. ovoshch. selekts. st. 1: 68-78.

El-Shafie M W and Davis G N. 1967. Inheritance of bulb color in the onion (Allium cepa L.) Hilgardia 9: 607-22.

Emsweller S L and Jones H A. 1935. An interspecific hybrid in Allium. Hilgardia 9: 26573.

Fantino M G and Schiavi M. 1987. Onion breeding for tolerance to Fusarium oxysporum f. sp. cepae, in Italy. Phytopathologia Mediterranea 26: 108-12.

Fennell J. 1978. Use of a durometer to assess onion bulb hardness. Expl. Agric 14: 269.

Foskett R. 1949. 'Relation of dry matter content to storage quality in some onion varieties and hybrids'. M. S. Thesis. Iowa State College. Ames, IA.

Gabelman W. 1988. Breeding for disease and pest resistance in onions. (In): Proc. 4th Eucarpia Allium Symp., Wellesbourne, UK.

Galmarini C R, Della G P and Fuligna H. 2001. New argentine onion cultivars. II International Sÿmposium on Edible Alliaceae. Acta Horticulturae 555 (http:// www.actahort.org/books/555/555_39.htm)

Galvan G A, Wietsma W A, Putrasemedja S, Permadi A H and Kik C. 1997. Screening for resistance to anthracnose (Colletotrichum gloeosporioides Penz.) in Allium cepa and wild relatives. Euphytica 95: 173-78. 
Gupta P N, Mathur R A, Umesh C, Kochhar S, Singh B, Kamala V and Pratibha B. 1993. Building up of genetic resource of vegetable crops, their charaterization, evaluation and maintenance. Annual meeting AICVIP, Jabalpur, during 16-18 Dec. 1993.

Hamilton B K, Pike L M, Sparks A N, Bender D A, Jones R W, Candeia J and de Franca G. 1999. Heritability of thrips resistance in the 'IPA-3' onion cultivar in South Texas. Euphytica 109: 117-22.

Havey M J. 1993. Onion (Allium cepa L.), pp. 35-49. (In): Genetic Improvement of Vegetable Crops. Kalloo G. (Ed.) Pergamon Press, Oxford, UK.

Heath O V S. 1943. Studies in the physiology of the onion plant. I. An investigation of factors concerned in the flowering ('bolting') of onions grown from sets and its prevention. Part II. Effects of day length and temperature on onions grown from sets, and general discussion. Annals of Applied Biology 30: 308-19.

Hosfield G L, Vest G and Peterson C E. 1975. Usefulness of the diallel cross to evaluate combining ability and inbred line performance in hybrid onion breeding programme. HortScience 10: 313.

Hosfield G L, Vest G and Peterson C E. 1976. A ten parent diallel cross to evaluate inbred line performance and combining ability in onions. Journal of American Society of Horticulture Science 101: 324.

Hosfield G L, Vest G and Peterson C E. 1977a. A seven parent diallel cross in onions to evaluate general and specific combining ability and their interaction with years and locations. Journal of American Society of Horticulture Science. 102: 56-61.

Hosfield G L, Vest G and Peterson C E. 1977b. Heterosis and combining ability in diallel cross of onions. J. Am. Soc. Hortic. Sci. 102: 355-60.

Javad L H, Behrouz M and Hamid S M. 2004. Investigation and mass selection on GholyGhesseh Local onion. Agricultural and Natural Resources Research Center of Zanjan province, Zanjan (Iran), pp. 31

Jones H A. 1994. Problems and progress in onion breeding. Herbertia 11: 175.

Jones H A and Mann L K. 1963. Onion and their Allies, Botany Cultivation and Utilization. Leonard Hill, London,UK.

Jones H A and Peterson C E. 1952. Complementary factors for light-red bulb color in onions. Proc. Amer. Soc. Hort. Sci. 59: 457.

Jones H A and Rees H. 1963. Nuclear DNA variation in Allium. Heridity 23: 591.

Jones H A, Bailey S F and Emsweller S L. 1934. Thrips resistance in onion. Hilgardia 8: 215.

Jones R N. 1990. Cytogentics. pp. 199-204. (In): Onions and Allied Crops, Vol I. Rabinowitch H D and Brewster J L (Eds), CRC Press, Boca Raton, Florida, USA.

Kalkman E R. 1984. Analysis of the C-banded karyotype of Allium cepa L. Standard system of nomenclature and polymorphism. Genetica 65: 141-48.

Kalloo, G. 1988. Breeding methods in vegetable crops, pp. 75-104. (In): Vegetable Breeding, Vol 1. Boca Raton: CRC Press, Florida, USA.

Khan S A, Amjad M and Khan A A. 2001. Onion (Allium cepa L.). International J. Agril and Biology 4: 498-500.

Khar A, Jakse J and Havey M J. 2008. Segregations for onion bulb colors reveal that red is controlled by at least three loci. J. Am. Soc. Hortic. Sci. 133: 42-47.

Khrustaleva L I and Kik C. 2000. Introgression of Allium fistulosum into A. cepa mediated by A. roylei. Theoret. Appl. Genet. 100: 17-26.

Kim S, Baek D, Cho D Y and Yoon M. 2009. Identification of two novel inactive DFR-A alleles responsible for failure to produce anthocyanin and development of a simple PCR-based molecular marker for bulb color selection in onion (Allium cepa L.) Theoret. Appl. Genet. 118: 1391-99.

Kim S, Bang H, Yoo K S and Pike L M. 2006. Identification of the fourth allele of ANS 
(anthocyanidin synthase) gene and its effect on red color intensity in onions (Allium cepa). Euphytica 149: 45-51.

Kim S, Binzel M L, Park S, Yoo K S and Pike L M. 2004a. Inactivation of DFR (dihydroflavonol 4-reductase) gene transcription results in blockage of anthocyanin production in yellow onions (Allium cepa). Mol. Breeding 14: 253-63.

Kim S, Jones R, Yoo K and Pike L M. 2004b. Gold colour in onions (Allium cepa): A natural mutation of the chalcone isomerase gene resulting in a pre-mature termination codon. Mol. Genet Genomics 272: 411-49.

Kim S, Jones R, Yoo K S and Pike L M. 2005a. The $L$ locus, one of complementary genes required for anthocyanin production in onions (Allium cepa), encodes anthocyanidin synthase. Theoret. Appl. Genet. 111: 120-27.

Kim S, Yoo K S and Pike L M. 2005b. Development of a PCR-based marker utilizing a deletion mutation in the dihydroflavonol 4-reductase $(D F R)$ gene responsible for the lack of anthocyanin production in yellow onions (Allium cepa). Theoret. Appl. Genet. 110: $588-95$.

King J J, Bradeen J M, Bark O, McCallum J A and Harvey M J. 1998. A low density genetic map of onion reveals a role for tandem duplication in the evolution of an extremely large diploid genome. Theoret Appl. Genet. 96: 52-62.

Kofoet A, Kik C, Wietsma W A and de Vries. 1990. Inheritance of resistance to downy mildew (Pernospora destructor (Berk.) Casp.) from Allium roylei Stearn in the backcross Allium cepa L. $\times($ A. roylei $\times$ A. cepa). Plant Breeding 105: 144-49.

Lawande K E, Khar A, Mahajan V, Krishna Prasad V S R, Devi A and Srinivas P S. 2010a.

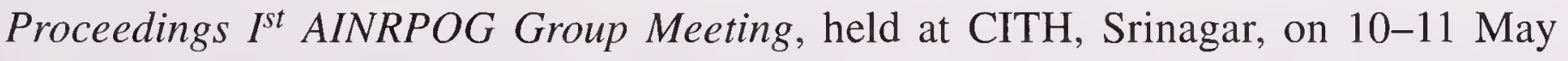
2010.

Lawande K E, Krishna Prasad V S R, Mahajan V and Srinivas P S. 2010b. Proceedings of IRC, DOGR, DOGR and ICAR News.

Lawande K E, Mahajan V, Krishna Prasad V S R and Khar A. 2007. Proceedings of IRC, DOGR, ICAR News Proceedings of XXV AICRP(VC) Group meeting.

Lawande K E, Mahajan V, Krishna Prasad V S R and Khar A. 2009. Proceedings of XXVII AICRP (VC) Group Meeting.

Lawande K E, Mahajan V, Krishna Prasad V S R and Khar A. 2011a. Bhima Super-a new red onion variety for kharif season from DOGR, pp. 160. (Souvenir). (In): National Symposium on Alliums: Current Scenario and Emerging Trends, held on 12-14 March 2011 at Pune, Maharashtra, India.

Lawande K E, Mahajan V, Krishna Prasad V S R and Khar A. 2011b. Bhima Red and Bhima Raj a new red onion variety for different season, pp.161. (Souvenir \& Abstract). National Symposium on Alliums Current Scenario and Emerging Trends, held on 1214 March 2011 at Pune, Maharashtra, India.

Lee R, Baldwin S, Kenel F, McCallum J and Macknight R. 2013. Flowering locus T genes control onion bulb formation and flowering. Nature doi:10.1038/ncomms 3884 .

Lin M W, James F W and Baggett J R. 1995. Inheritance of resistance to neck-rot disease incited by Botrytis allii in bulb onions. J. Amer. Soc. Hort. Sci. 120 (2): 297-99.

Lin M W. 1989. 'The genetic analyses of neck-rot (Botrytis allii) resistance, pungency and soluble solids content of onion (Allium cepa)'. Ph D Thesis, Oregon State University, USA.

Magruder R, Webster R, Jones H, Randall T, Snyder G, Brown H and Hawthorn L. 1941. Storage quality of the principal American varieties of onions, USDA Circular No. 618. Washington, USA.

Mahajan V and Lawande K E. 2008. Recent advances, problems and prospects of onion cultivation in India, pp. 91-101. (Souvenir). (In): Recent Trends in Research on Spices 
and Aromatic Plants, on $10^{\text {th }}-12^{\text {th }}$ September 2008 held at CCS HAU, Hisar, India. Mahajan V and Lawande K E. 2011. Genetic diversity and crop improvement in onion and garlic, pp. 19-40. (Souvenir). (In): Exploiting Spices Production Potential of the Deccan Region, SYMSAC-VI, Indian Society for Spices held on $8^{\text {th }}-10^{\text {th }}$ December 2011 at Dharwad, Karnataka, India.

Mahajan V, Lawande K E, Krishna Prasad V S R and Srinivas P S. 2010. New onion varieties released, DOGR News 14 (1): 2-3.

Mahajan V, Lawande K E, Krishna Prasad V S R and Srinivas P S. 2011. Bhima Shubra and Bhima Sweta a new white onion variety for different season, pp.162 (Souvenir \& Abstract). (In): National Symposium on Alliums: Current Scenario and Emerging Trends, held on 12-14 March 2011 at Pune, Maharashtra, India.

Mani V P, Chauhan V S, Joshi H C and Tandon J P. 1999. Exploiting gene effects for improving bulb yields in onion. Indian Journal of Genetics and Plant Breeding 59: 511-14.

Mathur K, Sharma S N and Sain R S. 2006. Onion variety RO-59 has higher yield and resistance to purple blotch and Stemphylium blight. Journal of Mycology and Plant Pathology 36: 49-51.

McCallum J, Clarke A, Joyce M P, Shaw M, Butler R, Brash D, Scheffer J, Sims I, van Heusden S, Shigyo M and Havey M J. 2006. Genetic mapping of a major gene affecting onion bulb fructan content. Theoret. Appl. Genet. 112 (5): 958-67.

McCallum J, Joyce M P, Shaw M, Kenel F, Davis S, Butler R, ScheVer J, Jakse J and Havey M J. 2007. Genetic mapping of sulfur assimilation genes reveals a QTL for onion bulb pungency. Theoret. Appl. Genet. 114: 815-22.

McCollum G D. 1966. Heritability and genetic correlations of some onion bulb traits, $J$. Hered. 57: 105.

McCollum G D. 1968. Heritability and genetic correlations of soluble solids, bulb size and shape in white sweet Spanish onion. Can. J. Genet. Cytol. 10: 508.

McCollum G D. 1971. Heritability of onion bulb shape size: estimates from half-sib families. J. Hered. 62: 101.

McCollum G D. 1982. Experimental hybrids between Allium fistulosum and A. roylei. Botanical Gazat. 143: 238-42.

Messiaen C M and Rouamba A. 2004. Allium ampeloprasum L. Internet Record from PROTA4U.PROTA (Plant Resources of Tropical Africa/Resources végétales de l'Afrique tropicale), Wageningen, Netherlands. (<http://www.prota4u.org/search. asp).

Miyaura K, Shinanda Y and Gabelman W H. 1985. Selection for resistance of onions to Botrytis allii by scale inoculation method. HortScience 20: 760.

Molenaar N D. 1984. 'Genetics, thrips resistance, and epicuticular wax characteristics on nonglossy and glossy onions'. Ph.D. Thesis. University of Wisconsin, Madison,USA.

Nakamura N. 1959. Studies on the breeding of Allium cepa L., I. Estimating heritability, Jpn. J. Hered. 8: 255.

Netzer D, Rabinowitch H D and Weintal C H. 1985. Greenhouse technique to evaluate pink root disease caused by Pyrenochaeta terrestris. Euphytica 34: 385-91.

NHB database, 2012 http://nhb.gov.in/area-pro/database-2011.pdf

Novak F J, Havel L and Dolezel J. 1986. Allium, p. 419. (In): Handbook of Plant Cell Culture, Techniques and Applications, Vol 4. Evans D, Sharp W and Ammirato P. (Eds). MacMillan, New York, USA.

Owen J H, Walker J C and Stahmann M A. 1950. Pungency, colour and moisture supply in relation to disease resistance in the onion. Phytopathology 40: 292.

Padda D S, Singh G and Saimbhi M S. 1973. Genetic variability and correlation studies in onion. Indian J Hort 30: 391-93. 
Pandian I R S and Muthukrishnan C R. 1979. Heterosis and combining ability in onion (Allium cepa L.) Madras Agric. J. 66: 707-18.

Pandotra V R. 1965. Purple blotch disease of onion in Punjab II: Studies on the life history, viability and infectivity of the causal organism Alternaria porri. Proceedings of Indian Academy of Science, Section B. 61: 326-30.

Park J, Cho D Y, Moon J S, Yoon M K and Kim S. 2013. Development of functional markers for detection of inactive DFR-A alleles responsible for failure of anthocyanin production in onions (Allium cepa L.) Kor. J. Hort. Sci. Technol. 31 (1): 72-79.

Pathak C S, Singh D P, Deshpande A A and Sreedhar T S. 1986. Sources of resistance to purple blotch in onion. Vegetable Science 13: 300-03.

Patil J D, Desale G Y and Kale P N. 1986. Genetic variability studies in onion. $J$. Maharashtra Agri. Univ. 11: 281.

Pawar D B, Mote U N, Kale P N and Ajri D S. 1987. Identification of resistant sources for thrips in onion. Current Research Reporter 3: 115-17.

Peffley E B and Currah L. 1988. The chromosomal locations of enzyme-coding genes Adh-1 and Pgm-1 in Allium fistulosum L. Theoret. Appl. Genet. 75: 945-49.

Peterson C P, Simon P W and Ellerbrock L. 1986. 'Sweet Sandwich' onion. HortScience 21: 1466.

Pike L M. 1986. Onion breeding, pp. 357-413. (In): Breeding Vegetable Crops. Bassett M J. (Ed.) The AVI Publishing Company. Inc., Westport, Conn., USA.

Rabinowitch H D. 1997. Breeding alliaceous crops for pest resistance. Acta Horticulture 433: $223-46$.

Rabinowitch H D and Brewster J L. 1990. Onions and Allied Crops, Vol. I. CRC Inc. Boca Raton, Florida, USA.

Rao E S. 2014. Prospects and considerations for development of synthetic varieties in onion, pp. 13-28. (In): Proceedings of Brain Storming Session on Crop Improvement and Seed Production of Onion, held on 15 March 2014 at Nashik, India.

Reiman G H. 1931. Genetic factors for pigmentation in the onion and their relationship to disease resistance. J. Agr. Res. 42: 251-78.

Ricroch A, Yockteng R, Brown S C and Nadot S. 2005. Evolution of genome size across some cultivated Allium species. Genome 48: 511-20.

Sharma I M. 1997. Screening of onion varieties/lines against purple blotch caused by Alternaria porri under field conditions. Plant Disease Research 12: 60-61.

Sheshadri V S and Chaterjee S S. 1996. The history and adaptability of some introduced vegetable crops in India. Vegetable Science 23: 114-40.

Shigyo M, Tashiro Y, Isshiki S and Miyazaki S. 1996. Establishment of a series of alien monosomic addition lines of Japanese bunching onion (A. fistulosum L.) with extra chromosome from shallot (A. cepa L. Aggregatum group). Genes Genet. Syst 71: 36371.

Singh B D. 1983. Plant Breeding: Population Improvement. 1 Edn. Kalyani Publishers, Ludhiana, India.

Singh D, Dhiman J S, Sidhu A S and Singh H. 1992. Current status of onions in India: Strategies for disease resistance breeding for sustained production. Onion Newslett. Tropics 4: 43-44.

Sintayehu A, Chemeda F, Seid A and Sakhuja P K. 2011. Evaluations of shallot genotypes for resistance against fusarium basal rot (Fusarium oxysporum f. sp. cepae) disease. Crop Protection 30: 1210-15.

Srivastava P K, Bhardwaj B S and Gupta R P. 1994. Status of field diseases and insectpests of onion in India. News Letter National Horticultural Research and Development Foundation. 14: 11-14.

Stack S and Coming D. 1979. The chromosomes and DNA of Allium cepa. Chromosoma 
70: 161 .

Steer B T. 1980. The bulbing response to day length and temperature of some Australian cultivars of onion (Allium cepa L.) Australian Journal of Agricultural Research 31: 511-18.

Steven J D. 2014. 'Phenotypic and genetic variation for amounts and types of epicuticular waxes on onion foliage and association with onion thrips resistance'. Ph.D. Thesis. University of Wisconsin, Madison, USA.

Sugha S K, Develash R K and Tyagi R D. 1992. Performance of onion genotypes against purple blotch pathogen. South Indian Horticulture 40: 297.

Thomas T A, Kalala V, Debas B S and Bisht I S. 1990. Genetic resources of onion and garlic, their evaluation and maintenance. (In): National Symposium on Onion and Garlic-Production, Marketing and Export, held on 2-3 June 1990 at Dr. Y.S. Parmar University of Horticulture and Forestry, Solan, Himachal Pradesh, India.

Tsutsui K. 1991. 'Inheritance of resistance to Fusarium oxysporum in onion'. M.S. thesis. University of Wisconsin, USA.

Ulloa M, Corgan J N and Dunford M. 1995. Evidence for nuclear-cytoplasmic incompatibility between Allium fistulosum and A. cepa. Theoret. Appl. Genet. 90: 74654.

Steer B T. 1980. The bulbing response to day length and temperature of some Australian cultivars of onion (Allium cepa L.) Australian Journal of Agricultural Research 31: 511-18.

Steven J D. 2014. 'Phenotypic and genetic variation for amounts and types of epicuticular waxes on onion foliage and association with onion thrips resistance'. Ph.D. Thesis. University of Wisconsin, Madison, USA.

Sugha S K, Develash R K and Tyagi R D. 1992. Performance of onion genotypes against purple blotch pathogen. South Indian Horticulture 40: 297.

Thomas T A, Kalala V, Debas B S and Bisht I S. 1990. Genetic resources of onion and garlic, their evaluation and maintenance. (In): National Symposium on Onion and Garlic-Production, Marketing and Export, held on 2-3 June 1990 at Dr. Y.S. Parmar University of Horticulture and Forestry, Solan, Himachal Pradesh, India.

Tsutsui K. 1991. 'Inheritance of resistance to Fusarium oxysporum in onion'. M.S. thesis. University of Wisconsin, USA.

Ulloa M, Corgan J N and Dunford M. 1995. Evidence for nuclear-cytoplasmic incompatibility between Allium fistulosum and A. cepa. Theoret. Appl. Genet. 90: 74654.

Van der Meer Q P, Van Bennekom J L and Van der Giessem A C. 1971. Testing onions and other Allium species for resistance to Botrytis allii. Euphytica 19: 152.

Van der Meer, Q P and De Vries J N. 1990. An interspecific cross between Allium roylei Stearn and Allium cepa L. and its backcross to A. cepa. Euphytica 47: 29-31.

VeereGowda. 1997. Crop improvement in bulb and root crops. (In): Indo-Russia Collaborative Protocol on Vegetable Improvement and Seed Production, held on 1718 March 1997 at IIHR, Bengaluru, Karnataka, India.

Vik J and Aastveit K. 1984. Breeding for resistance to neck rot (Botrytis allii) in onions (Allium cepa). Euphytica 33 (1): 257.

Villanueva-Mosqueda E. 1996. 'Onion heritability for pink root resistance, Fusarium basal rot resistance and bolting traits'. MS Thesis. New Mexico State Univ., Las Cruces, USA.

Wall M M and Corgan J N. 2002. 'NuMex Arthur' onion. HortScience 37: 707-08.

Wall M M, Mohammad A and Corgan J N. 1996. Heritability estimates and response to selection for the pungency and single center traits in onion. Euphytica 87: 133-39. 
Zhaoshui L, Qipei Z and Dehang C. 1995. Effect of two methods of maternal pedigree selection on components of white shaft weight in green onion (Allium fistulosum var. giganteum makino.) ISHS Acta Horticulturae 402. 


\section{Breeding for Hybrid Technology}

Amar Jeet Gupta, R VeereGowda and Vijay Mahajan

The commonly practised breeding methods in onion are mass selection, recurrent selection, selfing and massing, hybridization, followed by different population improvement methods and heterosis breeding (Pike, 1986). Heterosis breeding is an opportunity for improvement in productivity, earliness, and uniformity in yieldattributing characters. Even though most of the area under onion in India is covered by open-pollinated varieties, cultivation of hybrids is rapidly increasing; most of the hybrids are produced by private seed companies using cytoplasmic malesterile lines.

\section{Use of male sterility}

The most important qualitative genes in onion are those causing male sterility. Pollen fail to develop in male-sterile plants, and thus there is no self-pollination; and seed production, therefore, would be through cross-pollination. This property has been utilized to produce $F_{1}$ hybrid cultivars, which show hybrid vigour, hence these genes are vital for hybrid breeding. In the absence of male sterility, controlled cross-pollination without any self-pollination can be achieved by manually removing ripened anthers from a flower-head before pollen are shed, and by transferring desired pollen to stigmas. This is labour-intensive and is practically useful only in breeding or in experimental work (Brewster, 1994).

Male sterility in onion was first exploited by Jones and Clarke, using a malesterile genetic stock of cultivar 'Italian Red', found in breeding plots at Davis, California, in 1925 (Jones and Emsweller, 1936). When this plant was not allowed to cross-pollinate, bulbils were produced on the flower-head, and it could be propagated. Jones and Clarke (1943) published this classical work describing genetics of male sterility, and indicated how to use sterility to produce hybrid cultivars. On the basis of this technique, developed originally in onions, male sterility has since been exploited in hybrid breeding in more than 150 crop species (Kale and Munjal, 2005).

Male sterility in onion is expressed due to combined effects of a nuclear (i.e. chromosomal) gene and a cytoplasmic factor. The nuclear gene has two formsthe dominant $M s$ form, which when present, results always in fertile pollen and recessive $m s$ form, which, if homozygous, may result in sterile pollen. Homozygous $m s$ genotypes are male sterile only if they are combined with cytoplasmic sterility factor $S$. The cytoplasm of the egg cell can carry factor $S$, allowing $m s m s$ genotypes for expression of sterility, or it can carry factor $N$, which results in a plant with fertile pollen, irrespective of $m s$ and $M s$ alleles of its nuclear genes. Three following 
genotypes for male-sterility gene can exist in a diploid onion-MsMs, Msms and msms. Each genotype can occur in cytoplasm carrying either $N$ or $S$ factor. The only combination that results in male sterility is Smsms. The cytoplasmic factor $(S)$ is transmitted only via female (pistillate) parent in a cross, not by pollen parent. If a male-sterile mother-plant is pollinated by various possible fertile pollen donor genotypes, there will be varied results (Table 5.1). Only the third combination in Table 5.1, would result all male-sterile offspring (Brewster, 1994).

Table 5.1 Male-sterile plants pollinated by various fertile pollen donor genotypes

\begin{tabular}{lll}
$\begin{array}{l}\text { Mother plant } \\
\text { (male sterile) }\end{array}$ & $\begin{array}{l}\text { Pollen donor } \\
\text { (male fertile) }\end{array}$ & $F_{1}$ offspring \\
\hline Smsms & NMsMs & All SMsms - male fertile \\
Smsms & NMsms & SMsms - male fertile and Smsms - male sterile \\
Smsms & Nmsms & All Smsms - male sterile \\
$S m s m s$ & $S M s M s$ & AllSMsms - male fertile \\
Smsms & SMsms & SMsms - male fertile and Smsms - male sterile
\end{tabular}

A: Smsms; B: Nmsms; C/R: SMsms or NMsMs; $F_{1}=\mathrm{A} \times \mathrm{R}$ Hybrid production; $\mathrm{A}=\mathrm{A} \times \mathrm{B}$ Maintaining $A$ line

The male-sterility gene has been found widespread in several genotypes, collected from many parts of the world (Little et al., 1946; Davis 1957). The male-sterile plants have translucent, green anthers in contrast to normal, darkgreen anthers. Their pollen mother cell (PMC) meiosis is normal and degeneration of microspores starts after tetrad stage, which leads to complete pollen sterility. Li et al. (2006) suggested that microspore abortion in male-sterile anthers can be attributed to premature degeneration of middle layer and tapetum. The $N$ cytoplasmic onion populations often possess relatively high frequency of $M s$ allele, which has no obvious function (Gokce and Havey, 2006). Computer simulation was done to estimate changes in allelic frequencies at $M s$ for onion populations possessing $S$-cytoplasm or a mixture of $N$ - and $S$-cytoplasms and to determine if frequencies of $M s$ allele stay constant or change due to failure of male gamete production from male-sterile ( $\mathrm{Smsms}$ ) plants. The models revealed selection against recessive $m s$ allele over generations in onion populations possessing $S$-cytoplasm, and varying amounts of self-pollination may lead to inbreeding depression. These models were consistent with field and molecular analyses documentation that $N$ cytoplasm and dominant $M s$ allele predominate in open-pollinated onion populations.

Cytoplasmic-genic male-sterility system (CGMS) is presently used widely in onions for commercial exploitation of heterosis (Kaul, 1988). The second source of CMS ( $T$-cytoplasm) in onion was discovered in French cultivar 'Jaunepaille des Venus'. This CMS (cytoplasmic male sterile) line was found different from 'Italian Red 13-53', as three independent segregating restorer loci were identified in this line, which were responsible for its complex inheritance. It has common occurrence of restorers, which makes this $T$-cytoplasm more difficult to use. Later, male sterility was observed in several other onion populations, mainly in longday cultivars-Pukekohe Long Keeper, Red Wethersfield, Scott County Globe, 
Stuttgarter Riesen and Zittauer Glebe. In India, male sterility was identified in a local cultivar Nasik White Globe at the IIHR, Bengaluru (Pathak et al., 1980). Investigations on the causes of cytoplasmic male sterility in onion indicated that tapetal abnormalities and histochemical changes were responsible for male sterility in onions; there was no role of meiotic abnormalities (Saraswathi and VeereGowda, 2006).

Maintainer lines used to seed propagate male-sterile lines possess normal $(N)$ male-fertile cytoplasm and homozygous recessive at $\mathrm{Ms}$ locus, $\mathrm{Nmsms}$ (Jones and Emsweller, 1936; Jones and Clarke, 1943). To identify maintainer lines, malesterile plants were initially crossed with about 50 indigenous accessions and all $\mathrm{F}_{1}$ hybrids produced were male sterile, indicating widespread distribution of $m s$ genes in the population (Pathak, 1997). Transfer of cytoplasms from related species into cultivated populations may produce new sources of CMS. A. galanthum was backcrossed for 7 generations to bulb-onion populations to diversify cytoplasm conditioning male sterility. Flowers of galanthum-cytoplasmic (GC) populations possess upwardly curved perianth and filaments with no anthers, making identification of male-sterile plants easier than for either $S$ - or $T$-cytoplasmic malesterile onion-plants. Mean seed yield per bulb of GC populations was measured in cages using blue-bottle flies [Calliphora erythrocephala (C. vicina)] as pollinators, and this was not significantly different from one of the two $S$ cytoplasmic male-sterile $\mathrm{F}_{1}$ lines, a $T$-cytoplasmic male-sterile inbred line or $\mathrm{N}$ cytoplasmic male-fertile lines. Male-sterile lines possessing either $S$ or galanthum cytoplasm were crossed with populations known to be homozygous dominant and recessive at the nuclear locus conditioning male-fertility restoration of $S$ cytoplasm, and progenies were scored for male-fertility restoration. Nuclear restorers of male fertility for $S$-cytoplasm did not condition male fertility for GC populations. It is intended that these GC onion populations may be used as an alternative male-sterile cytoplasm for diversification of hybrid onion-seed production (Havey, 1999). Yamashita and Tashiro (2004) also developed malesterile lines of Japanese bunching onion (A. fistulosum), possessing cytoplasm of A. galanthum by backcrossing. Fertility-restoring gene $(R f)$ for cytoplasmic male sterility (CMS) in A. fistulosum from segregation of pollen fertility of backcross generation of $A$. galanthum has been confirmed to be located on the $5 \mathrm{~F}$ chromosome of male-fertile plants (Yamashita et al., 2005).

Identification of $S$-cytoplasm of a single plant takes 4 to 8 years, and is complicated by segregation of a nuclear gene that restores fertility. Although CMS in onion may be due to incompatibility between mitochondrial and nuclear genomes, southern analyses of DNA from individual plants from crosses of $S$ and $N$-cytoplasmic plants supported maternal inheritance of chloroplast and mitochondrial DNA. Therefore, polymorphisms in chloroplast DNA may be used to classify cytoplasm. Amplification by polymerase chain reaction of a fragment that carries an automorphic 100-bp insertion in the chloroplast DNA of $\mathrm{N}$ cytoplasm offers a significantly quicker and cheaper alternative to crossing or southern analysis. Molecular characterization of $N$ - and $S$-cytoplasms and frequencies of nuclear non-restoring allele allow onion breeders to determine proportion of plants in the open-pollinated populations that maintain CMS, and 
can significantly reduce investment required to identify individual maintainer plants (Havey, 1995). Various aspects of A, B and C/R lines, their identification, maintenance and uses in hybrid production have been discussed by Kalloo (1988).

\section{Chemicals for producing male-sterile lines}

Male sterility of a cytoplasmic genic nature has been utilized in producing commercial onion hybrids for a number of years. This requires time-consuming technique of introduction of male-sterility controlling factors into inbred lines before testing and added cost of maintainer lines for production of male-sterile inbreds. Chemical induction of male-sterility would circumvent both these requirements, as there is no breeding for $\mathrm{A}$ line and $\mathrm{B}$ line; only maintenance is needed in the case of chemically induced male sterility.

Chemically-induced male sterility has been reported in many crop species. In onions too influence of the same potential gametocides was studied (Chopra et al., 1960; Cohan and Weigle, 1966; Kaul and Singh, 1976). Meer and Bennekom (1976) showed gametocidal effect of $\mathrm{GA}_{4 / 7}$ on onions. Frequent spraying during bolting period with relatively high concentrations $(0.1$ and $0.3 \%)$ resulted a very high number of completely male-sterile plants in the beginning of the flowering period. Gametocidal effect was accompanied by a considerable reduction in seed production. Gibberellic acid use for production of hybrid seeds does not seem to be very attractive, mainly because of reduced seed-set and high price of $\mathrm{GA}_{3}$ and $\mathrm{GA}_{4 / 7}$. Most likely, phenomenon can be used as a substitute for emasculation when making interspecific crosses, inter-varietal crosses and recurrent crosses, because in these cases only moderate quantities of seeds are sufficient.

\section{Molecular markers for identification of male sterility}

Davis (1966) suggested a new method for producing hybrid seeds. He developed a brown-seeded line in which brown seed-coat colour was linked with male sterility. Brown seeds are smaller, rounder and smooth. This seed-coat colour is governed by a single recessive gene (b), while black seed-coat is due to dominant gene (B). A homozygous brown-seeded male-sterile line, B 2246B, was developed from variety 'Brigham Yellow Globe', and the black-seeded line, B 12115C, was derived from variety 'Yellow Sweet Spanish'. Brown-seeded male-sterile line and blackseeded pollen-parent line can be used for producing hybrid seeds. Hybrid seeds harvested from male-sterile line were black. This improved method would be useful in rouging off-types occurring in both the parents.

Identification of nuclear markers tightly linked to $M s$ locus would allow for molecular-facilitated selection of maintainer lines. Restriction enzyme analysis of chloroplast DNA (ctDNA) revealed five polymorphisms between $S$ and normal $(N)$ fertile cytoplasms. S-cytoplasm was different from Allium species closely related to bulb-onion, and cladistic estimates of phylogenies supported introduction from an unknown species (Havey, 1995). Both RFLP and PCR approaches gave some proof of existence of mitochondrial heteroplasmy in onion, using probes for mitochondrial genes: atpA, atp6, atp9, cob, coxl nad3, nad4 and nad6 (Szklarczyk et al., 2002). Gokce et al. (2002) evaluated test cross progenies from a segregating family for nuclear restoration of male fertility over at least three 
environments. Although segregations in $\mathrm{F}_{2}$ family fit expected $1: 2: 1$ ratio $(\mathrm{P}=0.973)$, proportion of male-sterile test cross progenies showed significant $(\mathrm{p}<$ 0.01 ) year effects, and it is, therefore, imperative to score male-fertility restoration over environments. Too many male-sterile test cross progenies were often observed, indicating that dominant allele conditioning male-fertility restoration for $S$-cytoplasm may not show complete penetrance. Segregations of amplified fragment length polymorphisms and restriction fragment length polymorphisms (RFLPs) revealed RFLPs flanking $M s$ locus at 0.9 and $8.6 \mathrm{cM}$ distance. An onion cDNA, showing highly significant homology to an aldehyde dehydrogenase, conditioned by the $r f 2$ locus of maize, was identified and mapped to linkage group $\mathrm{I}$, independent of $M s$ locus. A sample of commercial onion germplasm was evaluated for putative allelic diversity at the RFLP loci linked to $M s$. Genomic region corresponding to $c$ DNA (AOB272) revealing closest RFLP to $M s$ was sequenced to reveal numerous single nucleotide polymorphisms. Single-stranded conformational polymorphisms and single nucleotide extensions that revealed genomic variations at AOB272-EcoRI were developed (Gokce et al., 2002). Cho et al. (2006) demonstrated usefulness of SNP detected in psbA gene for highthroughput discrimination of CMS factors using real-time PCR and a TaqMan probe assay. Cho et al. (2005) selected maintainer line with $N$-cytoplasm plants, using sequence characterized amplified region (SCAR) marker linked to cytoplasmic male-sterile factor.

Limited molecular analysis was done on onion male sterility. Molecular analysis of genetic diversity in onion genotypes and hybrids was conducted (Narayan et al., 2006). Genetic relatedness analysis of male sterile and their maintainer lines was done by using RAPD primers (Dhanya et al., 2012). In-silico identification and validation of micro satellite markers from onion EST sequences was conducted (Radhika et al., 2013). Review published on the molecular markers in the improvement of Allium crops detailed the information on male-sterility system and its utilization in $\mathrm{F}_{1}$ hybrids (Reddy et al., 2013). Among different types of molecular markers available for identification of A and B lines, PCR-based markers have gained attention because of ease of use and being comparatively less timeand-labour consuming.

\section{Haploidy}

In-vitro haploid production through gynogenesis has been routinely used for one-step inbred production. Induction of haploids was done through in-vitro gynogenesis using unpollinated ovule culture and ovary and whole flower culture of long-day cultivars (Campion et al., 1992). Doubled haploids from gynogenic lines of onion, through spontaneous and induced chromosome doubling in $A$. cepa, using unfertilized ovary and flower culture, were obtained (Campion et al., 1995).

Genotype effect on gynogenesis was studied with different explants like flowerbuds, ovary and ovules (Ionescu and Popandron, 1995). Gemesne and Martinovich (1995) studied effect of immature flower-buds and ovary on four Hungarian genotypes on BDS medium. Ovary culture gave best results with $80 \%$ regenerants being haploid and $20 \%$ dihaploid. The effect of flower-buds of thirty Polish onion 
genotypes on gynogenesis was reported by Michalik et al. (2000). It was established that $3.5-4.5 \mathrm{~mm}$ long flower-buds were most responsive to gynogenesis. Cultivars differed with regard to their demands for media composition and yield of resultant embryos depended strongly on the genotype. Different mitotic poisons like colchicines, oryzlin and APM were evaluated; oryzalin and APM are being routinely used for chromosome doubling (Jakse et al., 2003).

Bohanec et al. (1995) were successful in inducing gynogenesis in four onion cultivars using ovule and ovary. Esterase isozyme analysis showed that $59 \%$ of the regenerants were homozygous. RAPD showed that high genetic stability of onion homozygous lines passed through two cycles of gynogenesis (Javornik et al.,1998).

Attempts to produce haploid plants via androgenesis failed as reviewed by Keller and Korzun (1996). Campion et al. (1985) were successful in having anthers with 1-3 nuclei microspores; microspores did not survive due to degeneration of tapetum.

\section{Maintenance breeding of male sterile, maintainer and pollen lines}

Seeds of A, B and C/R lines during initial stages are produced in the insectproof cages, followed by an increase in the open-isolated fields. Seeds of A and B lines can be maintained/increased in the same cage, while C/R line is maintained/ increased in a separate cage. A plastic, nylon or wire-net cage of 20'20 or 24'24 mesh, measuring 6-m long, 3-m wide and 2-m high with a small door at one corner for entrance, is suitable and accommodates 4 rows of bulbs at $60-\mathrm{cm}$ spacing. Seeds to the tune of 1.0 to $2.5 \mathrm{~kg}$ can be produced from this nylon cage. The cage covers over plants before flowering, and necessary care should be taken that umbels do not touch the net, otherwise protruded stigma will get contaminated with foreign pollen, carried by insect-vectors. The scape (seed-stalk) should be kept straight by staking. In each cage, a medium-sized bee colony with a queen inside is kept and bees are fed with $10 \%$ sugar solution. Honeybees colony before placing under the cages should be fed on sugar solution for 3-4 days in isolation to ensure them to be free from foreign pollen. Roughing of off-types should be done every morning before anther dehiscence. At the same time, pollen-bearing plants (shedders) from A line and male-sterile line from B line, if any, should be rouged out. Later, initially multiplied seeds are further maintained/increased in the open-planting under isolation.

\section{Hybrid Breeding}

Male-sterile line is crossed with a pollen donor to produce $F_{1}$ hybrid with desirable traits. Jones and Clarke maintained their male-sterile lines vegetatively using bulbils produced on the flower-head. However, bulbils are difficult to store, and viruses tend to accumulate in plants. Male-sterile lines are also maintained by male-fertile 'maintainer lines' with the genetic constitution Nmsms. Such a line will produce pollen which can fertilize male-sterile line, but its offspring has the constitution Smsms, and is therefore male sterile (Table 5.1). Using these two lines, it is possible to propagate male-sterile line from seeds. 
Once a maintainer line has been identified in a locally adapted inbred population, male-sterile line must be developed so that it is near-identical genetically to it, apart from presence of $S$ cytoplasmic factor. This is done by repeatedly backcrossing male-sterile offspring with original Nmsms adapted maintainer line. With each generation of such a cross, genetic contribution from the original sterile Smsms parent gets diluted by a factor of two; and after four generations, $96.87 \%$ of the genes in the resultant Smsms line are derived from the original Nmsms line, and is near isogenic, similar to use as a male-sterile line in test crosses to

Table 5.2 Development of $A$ and $B$ lines

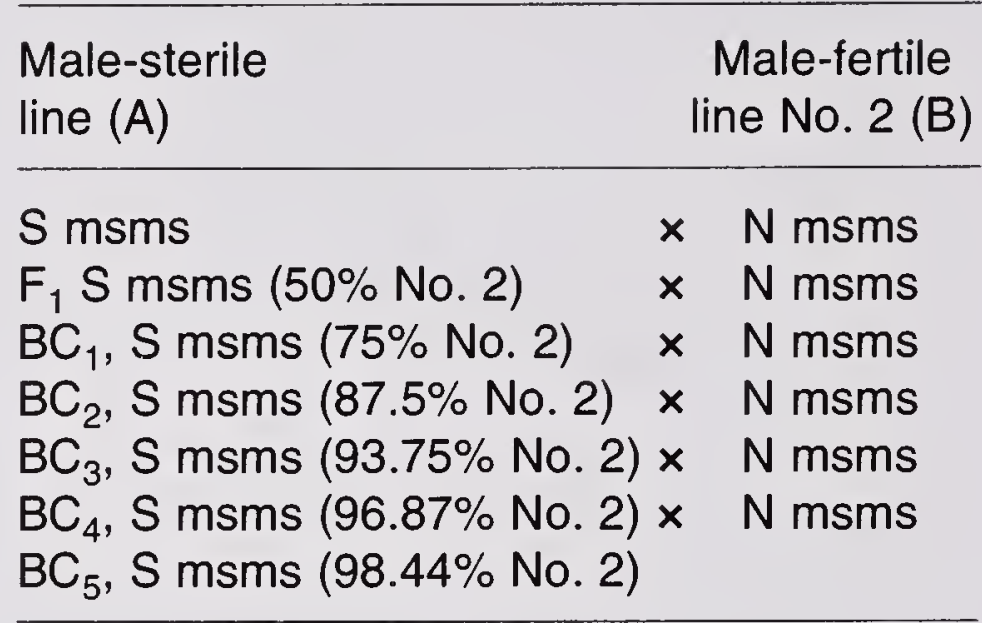
identify vigorous hybrids. The procedure of developing A and B lines by backcrossing has been outlined in Table 5.2.

A schematic plan for breeding improved onion hybrids, as outlined by Pike (1986), is given as follows.

\section{Year Procedure}

1 Grow and select 100 bulbs, store, and plant, also grow supply of malesterile bulbs for use in test crosses

2 Self selected bulbs and at the same time test cross with the known malesterile line

3 Grow-out bulbs from self and $\mathrm{F}_{1}$ test crosses, select, discard poor progeny rows and their $F_{1}$ pairs, store

4 Plant bulbs for seed production, observe sterility characters in $F_{1}$ lines, if $100 \%$ sterile, self selections and make backcross to $F_{1}$, discard pairs with fertile $\mathrm{F}_{1}$ lines

5 Grow out A and B lines as pairs, continue to select in B line side, save best bulbs from A line for the next backcross

6 Self B line of selected progenies and make backcross to the sterile side of pair

7 Grow bulbs and make final selection on the basis of B line side

8 Mass B line using 10-20 bulbs in cage while backcrossing to the sterile side of pair

9-12 At this point, begin seed-to-seed and continue through the fifth backcross, using the same procedure as in the 8th year; several A and B lines should have been developed, begin making hybrid combinations for testing

When large numbers of test crosses are made, only certain crosses result in desirable $\mathrm{F}_{1} \mathrm{~s}$. Therefore, a number of adapted male-sterile and maintainer lines need to be used in the development of $F_{1}$ hybrids. The breeder must make many crosses on to male-sterile lines, and grow and evaluate progeny that gives desirable 
hybrids. By accumulating data from such test crosses one can build-up information that would help predict crosses giving good hybrids. As with the maintainer lines, pollen-donor lines used to produce hybrids have normally been inbred for a few generations to eliminate deleterious recessive and off-type alleles from the genepool. Many practicalities of breeding onion hybrids of improved short-day onion hybrids for Texas were described by Pike (1986). Development of hybrids in onions was also described by Gupta (2014). Development of new hybrid onions involves a 15-20 year time-scale as most seed-to-seed cycles in onion breeding involve two years. Seeds are sown and bulbs are selected, harvested and stored in year one. In the second year, selected bulbs are grown for flowering and seed production (Fig.5.1; Dowker, 1990).

Development of selected male-sterile line Development of pollinator line

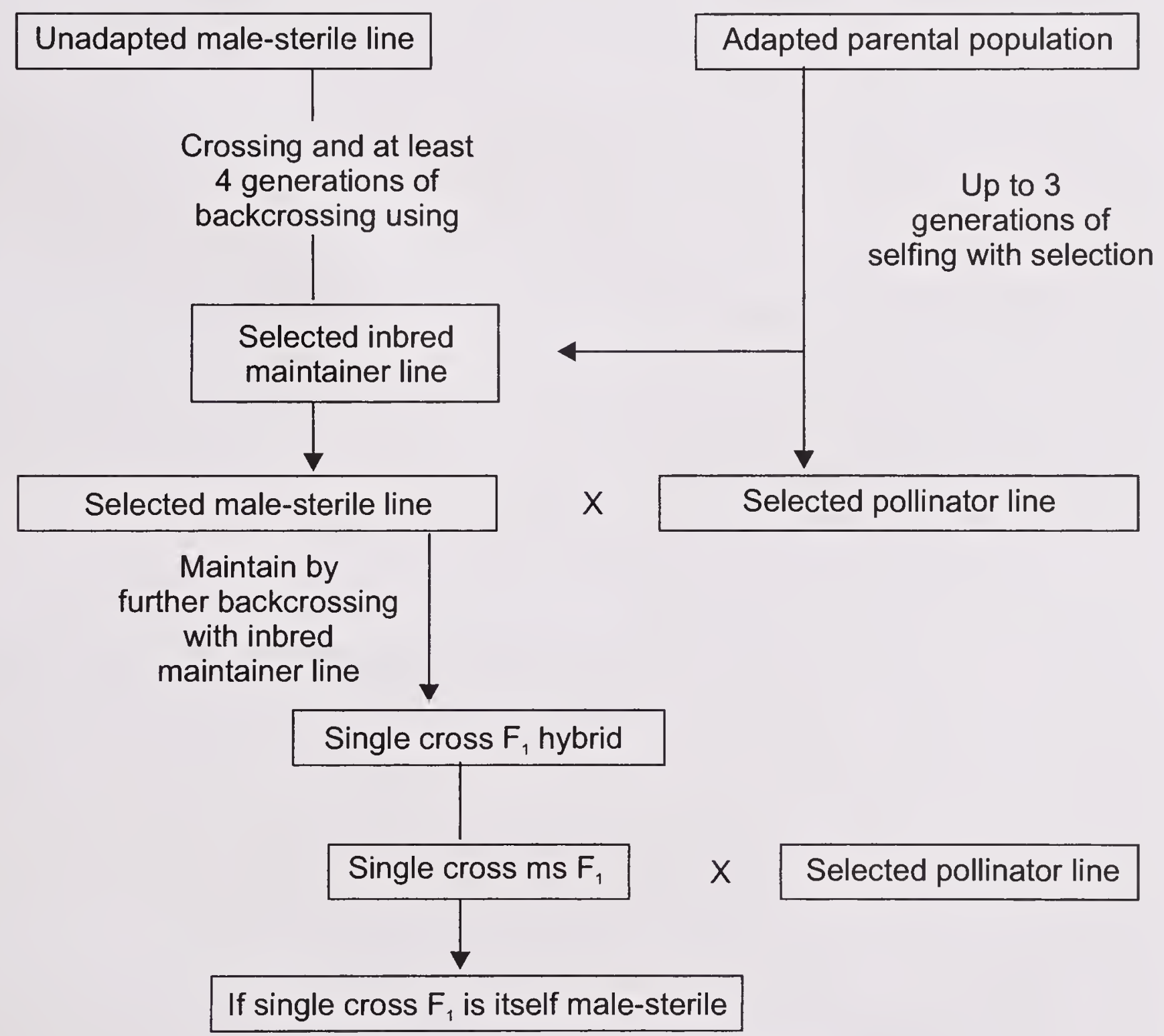

Fig. 5.1 $F_{1}$ hybrid scheme for onion breeding

Studies conducted at the IIHR, Bengaluru, indicated strong cytoplasmic factor for male sterility in Indian short-day onions (Pathak et al., 1986). The cytoplasmic factors operating in Indian short-day onions were further confirmed by malesterile lines developed at the IIHR (Rao et al., 2005). Male sterility could be successfully transferred to several breeding lines of different genetic backgrounds by backcross method, and two $\mathrm{F}_{1}$ hybrids (hybrid 1 and hybrid 5) were identified with significant increase in bulb yield of $40.89 \%$ and $25.82 \%$ over check variety 
(Pathak and Gowda, 1994). The adaptation of hybrids by farmers was slow due to inherent problems associated with traditional onion-production system (VeereGowda et al., 2002).

The weak parental inbred line may give a low seed yield. Adequate seed production is essential if a hybrid has to be commercially viable. The parent lines of a hybrid must also flower simultaneously so that they cross-pollinate. If a cross is made between a male-sterile line and a related maintainer line, resulting hybrid will itself be male sterile. Being a hybrid it may well be more vigorous than parental lines, and consequently it may have greater potential for seed production. This male-sterile hybrid may itself be crossed with another malefertile line to produce what is termed a 'three-way hybrid'. The extra vigour of male-sterile parent in a three-way hybrid makes seed production easier, but some genetic uniformity of a $\mathrm{F}_{1}$ between two inbreds is lost. As with two-way hybrids, various three-way hybrid combinations must be made and tested.

\section{Single-cross/three-way hybrids}

Most of the commercial onion hybrids are single crosses. Hybrid seed is produced on the plants, usually weakened by inbreeding, which generally causes a rapid vigour loss. Comparison between $F_{1}$ hybrids and inbreds showed that $F_{1}$ hybrids produced $91 \%$ more seeds than inbreds. The seeds were also of better quality (Erickson and Gableman, 1964). The uniformity of the bulb-crop need not be sacrificed, provided parental material is selected and combined in such a way as to minimize segregation of unlike inbreds. Where inbreds chosen are phenotypically alike and perform similarly in 3-way crosses, uniformity of a 3way hybrid is equal to that of a 2-way hybrid (Davis, 1966).

\section{Heterosis and combining ability}

Onion is one of the pioneer crops in which since about six decades heterosis has been commercially exploited. Although India is one of the leading onion producers, not much emphasis was given to heterosis breeding in the past. One of the main components for exploiting heterosis in onion is the availability of stable male sterility. In India, development of suitable male sterile and fertile inbred lines has remained very slow. Sen and Srivastava (1957) attempted to develop $\mathrm{F}_{1}$ hybrids in onion as early as in 1948 using exotic male sterile lines and Indian local male stocks. The exotic male sterile lines were found unsuitable in photoperiodically different environments in India. Later, very few workers attempted to test different hybrid combinations for heterosis and combining ability studies using male-sterile lines (Pathak et al., 1987). Male sterility was isolated from indigenous germplasm by several workers in India [Patil et al. (1973) in cv. 'Niphad 2-4-1'; Pathak et al. (1980) in cv. 'Nasik White Globe']. Further studies indicated strong cytoplasmic factor responsible for male sterility in cv. 'Bombay White Globe' (Pathak et al., 1986). This male-sterility factor has been transferred to several breeding lines by backcross breeding method.

Bulb weight is an important character directly related to bulb yield. Joshi and Tandon (1976) noted heterosis to an extent of $72 \%$ over the mid-parent value and up to $37 \%$ over the better parent in onion hybrids. Hosfield et al. (1977) observed 
significant heterosis for bulb weight based on the mid-parent. However, heterosis over better parent was significant but comparatively low. Vadivel et al. (1982) evaluated 30 hybrids and their parents. The results showed both positive and negative heterosis for bulb weight; one cross recorded significant heterosis for yield and most yield components. Aghora (1985) observed that seven crosses of onion were with significant heterosis over better parent and 13 crosses over midparent. VeereGowda (1988) also observed significant positive heterosis for onion bulb weight in seven crosses out of 55 crosses over better parent. Doruchowsk (1986) crossed eight male-sterile lines with eight pollen parents and heterosis was observed only for bulb weight. In a study involving $10 \times 10$ half diallel, out of 45 crosses, 8 had significant positive heterosis over mid-parent for bulb weight, 30 over better parent and 15 were found significant over standard check (Divakar, 2001).

In hybrids of 3 male-sterile lines and 20 inbreds, various economic traits were studied by Pathak et al. (1987). Positive heterosis was observed in 9 hybrids over better parent for total bulb yield, and it ranged from 47.9 to $89.5 \%$, while heterosis over best parent for marketable bulb yield was over 35\% in three hybrids-MS1 $\times$ NER1, MS1 $\times$ IIHR21-1and MS8 $\times$ IIHR 52-1. Popandron (1998) obtained three $F_{1}$ hybrids by crossing a male-sterile line of onion with inbred lines in $S_{2}$ studied for 3 years. Biometrical measurements of plant height, leaf breadth, number of leaves per plant and yield were made for both $\mathrm{F}_{1}$ hybrids and their parents. Heterosis was clearly evident for plant height and yield, less for leaf breadth, and was completely absent for number of leaves per plant. According to Janik et al. (1999), crop uniformity is considered a desirable character in modern agriculture because product uniformity is essential in marketing; uniformity in maturity permits crop scheduling, and uniformity in plant structure and maturation permits efficient mechanical harvest.

Line $\times$ tester cross of 3 lines (male-sterile parents) and 23 testers (fertile-male parents), thus making a total of 26 inbred parents, and their $69 \mathrm{~F}_{1}$ 's along with 6 controls; quite a good number of $\mathrm{F}_{1} \mathrm{~s}$, showed desirable heterosis over top parent for all characters except a few for maturity and neck thickness (Netrapal and Singh,1999). All the characters revealed superiority of $F_{1}$ s over standard controls. Mostly the better performing $\mathrm{F}_{1} \mathrm{~s}$ also expressed higher heterosis over better parent, top parent and standard control. Mani et al. (1999) crossed 5 red-skinned openpollinated populations as males to 4 exotic yellow-skinned cytoplasmic malesterile inbred lines. The resulting $20 \mathrm{~F}_{1}$ hybrids and their 9 parents were evaluated at 2 locations in the Uttar Pradesh hills. The results indicated positive and significant heterosis over better parent for bulb yield in a cross inbred $13 \times \mathrm{L} 43$. In this, $F_{1}$ between inbred $13 \times \mathrm{L} 43$ was used as a base material, advanced to $F_{2}$, and was subjected to 3 cycles of mass selection for bulb yield, skin colour, shape and size. An improved, high-yielding onion strain was thus developed and designated as VL Piaz 3.

Crosses PBR $139 \times$ AN 184 and PBR $140 \times$ AN 187 recorded high heterosis of 45.31 and $32.83 \%$ over the better parent and 27.40 and $31.01 \%$ over the standard check (Arka Kalyan), respectively, for marketable bulb yield, and were identified as the best hybrid combinations (Shashikanth et al., 2007). According to Abubakar 
and Adu (2008), crosses Red Creole $\times$ Kaharda and Kaharda $\times$ Red Creeole recorded highly significant $(P<0.01)$ positive high parent heterosis for disease incidence. Red Creole $\times$ Kaharda and Kaharda $\times$ Red Creeole also recorded highly significant $(P<0.01)$ positive high parent heterosis for fresh bulb yield. Cross Kaharda $\times$ Ori recorded highly significant $(P<0.01)$ positive high parent heterosis for bulb weight. Gupta et al. (2011a) evaluated different $F_{1}$ hybrids developed through male-sterile lines, and six $\mathrm{F}_{1}$ hybrids-DOGR Hy 7, DOGR Hy 29, DOGR Hy 1, DOGR Hy 41, DOGR Hy 27 and DOGR Hy 17 were found superior over the standard check.

Analyses of combining ability among onion inbreds have demonstrated consistent heterosis over the best inbred parent and occasionally over the leading commercial OP population. Large general combining abilities (GCA) and specific combining abilities (SCA) were reported for bulb maturity, yield and its components (rings per bulb, ring thickness), firmness and storability (Dowker and Gordon, 1983; Hosfield et al., 1976, 1977b; Joshi and Tandon, 1976). Diallel crosses of onion inbreds were generated, and consistently greater GCA over SCA for bulb yield and weight, earliness, rings per bulb, ring thickness, number of centers and storage loss was observed (Hosfield et al., 1976, 1977b). The SCA effects were about $10 \%$ of the GCA, but significant for 19 out of 24 comparisons. Dowker and Gordon (1983) observed that most reports of heterosis in onion compared hybrid with inbred parents and not with the best commercial cultivar. Significant heterosis over widely grown OP populations was reported by Jones and Davis (1944) and Joshi and Tandon (1976). Most publicly released onion inbreds were developed by selfing individual plants from OP cultivars or recombining previously developed inbreds. The large GCA effects indicate that superior inbreds are more likely to be selected from populations improved by recurrent selection or synthesized by recycling inbreds with good combining ability. However, it is important that inbreds should be evaluated over years and locations before recycling into new populations (Hosfield et al., 1977a).

\section{Performance of $\mathbf{F}_{\mathbf{1}}$ hybrids}

In USA and Japan, $\mathrm{F}_{1}$ hybrids occupy large-growing areas, while in European countries like Netherlands, UK, and many others, open-pollinated varieties are more commonly grown. Heterosis for yield, earliness, uniformity, storability and dry-matter content has been reported by many workers. In 1959, onion hybrids in New York surpassed open-pollinated varieties by $30 \%$ in yield and increase in storage life up to $40 \%$, which stimulated growing of $\mathrm{F}_{1}$ hybrids in the northern United States and Canada. Variety protection is the second strong stimulus for popularity of $\mathrm{F}_{1}$ hybrids in onion.

Commercially available $\mathrm{F}_{1}$ hybrids suitable for tropical regions are mainly of yellow skin, and they are generally of poor storability. In the USA, almost $100 \%$ area of onion is under hybrids. Some of the male-sterile lines have been developed in India but in most cases sterility is not stable and even inbred lines developed are not pure due to inbreeding depression, long breeding cycle, less storability of seeds and difficult seed production processes for inbreds and male-sterile lines. Very few seeds are produced through manual crossing, and for commercial scale 
production, this is not practical. First attempt for the development of hybrid in India of onion was made as early as 1948 using exotic male-sterile lines. But these lines were found unsuitable for short-day conditions of our country. Despite reports of high percentage of heterosis, the hybrids in onion did not made much headway in India due to non-availability of stable male-sterile lines along with maintainers for short-day onions. The work got momentum in eighties at the IIHR (Bengaluru), IARI (New Delhi) and MPKV (Rahuri). At the IARI, male sterility was isolated in a commercial variety 'Pusa Red'. Only two onion hybrids 'Arka Kirthiman' and 'Arka Lalima' have been released from the IIHR. Some new hybrids are being developed and are under evaluation. Some of the exotic hybrids are performing well during late kharif in Indian conditions, and their yields are almost double than Indian varieties at the DOGR, but they have less TSS, less storability and are of yellow colour, which lacks consumer preference in India. They can be exploited to trap European and Japanese market where there is great demand of these onions, but it can be only through cool chain export.

Unfortunately in India, absence of male-sterile lines along with maintainer for short-day onions remained a bottleneck in heterosis breeding programme. Private seed companies lately have started selling $\mathrm{F}_{1}$ hybrids, however, rigorous testing is required in different agroclimatic zones for different purposes. Knowing the importance of $F_{1}$ hybrids, the DOGR has started research on $F_{1}$ hybrids. Trials conducted on exotic $F_{1}$ hybrids of yellow type exhibited very good performance in late kharif and rabi (Table 5.3).

Table 5.3 Performance of exotic hybrids/varieties under Indian plain conditions (2000-2008)

\begin{tabular}{lcccc}
\hline $\begin{array}{l}\text { Exotic } \\
\text { hybrids/varieties }\end{array}$ & $\begin{array}{c}\text { Late kharif } \\
\text { (yield: tonnes/ha) }\end{array}$ & $\begin{array}{c}\text { \% increase over } \\
\text { Bhima Super }\end{array}$ & $\begin{array}{c}\text { Rabi } \\
\text { (yield: tonnes/ha) }\end{array}$ & $\begin{array}{c}\text { \% increase } \\
\text { over N 2-4-1 }\end{array}$ \\
\hline HN 9539 & 54.03 & 22.34 & - & - \\
HN 9733 & 31.13 & -29.52 & 65.90 & 52.55 \\
HN 9935 & 36.09 & -18.29 & 68.00 & 57.41 \\
Hy 3404 & 57.36 & 29.89 & 56.45 & 30.67 \\
DPS 2023 & 60.87 & 37.84 & 59.80 & 38.43 \\
Early Supreme White & 54.65 & 23.75 & 41.50 & -3.94 \\
Cougar & 56.50 & 27.95 & 67.84 & 57.04 \\
DPS 1008 & 31.80 & -27.99 & 52.50 & 21.53 \\
DPS 1009 & 31.12 & -29.54 & 64.45 & 49.19 \\
DPS 1024 & 38.62 & -12.55 & 66.05 & 52.89 \\
DPS 1031 & 5.10 & -88.45 & 54.30 & 25.69 \\
DPS 1034 & 59.66 & 35.10 & 58.60 & 35.65 \\
DPS 1043 & - & - & 61.45 & 42.25 \\
Linda Vista & 50.58 & 14.53 & 59.59 & 37.93 \\
Mercedes & 47.93 & 8.53 & 63.27 & 46.46 \\
Lexus & 59.66 & 35.10 & 63.83 & 47.75 \\
Reforma & 37.67 & -14.70 & 66.53 & 53.99 \\
Gobi & 42.22 & -4.39 & 52.67 & 21.92 \\
Kalarahi & 53.10 & 20.23 & 38.04 & -11.94 \\
Rio-Tinto & 54.37 & 23.11 & 34.52 & -20.09 \\
Serengeti & 55.87 & 26.52 & 50.85 & 17.71 \\
Bhima Super (C) & 44.16 & - & - & - \\
N 2-4-1 (C) & - & - & 43.20 & - \\
\hline
\end{tabular}


Table 5.4 Heterosis and percentage superiority over better parent and check varieties of $F_{1}$ hybrids with MS65A

\begin{tabular}{lcccc}
\hline Entries & $\begin{array}{c}\text { Marketable yield } \\
\text { of parents } \\
\text { (tonnes/ha) }\end{array}$ & $\begin{array}{c}\text { Marketable yield } \\
\text { of } F_{1} \text { hybrids with MS65A } \\
\text { (tonnes/ha) }\end{array}$ & \multicolumn{2}{c}{$\begin{array}{c}\text { \% Superiority of the } \\
F_{1} \text { hybrids over }\end{array}$} \\
\cline { 4 - 5 } & & & N 2-4-1 & ALR \\
\hline MS65A & 33.50 & - & - & - \\
444 & 40.00 & 73.34 & 43.80 & 35.81 \\
$14-2 W$ & 54.33 & 78.28 & 53.48 & 44.95 \\
465 & 38.00 & 71.65 & 40.49 & 32.69 \\
153 & 55.66 & 81.30 & 59.41 & 50.56 \\
133 & 48.66 & 67.95 & 33.24 & 25.83 \\
$169-2$ & 41.33 & 71.35 & 39.90 & 32.13 \\
131 & 35.00 & 63.35 & 24.22 & 17.31 \\
208 & 45.00 & 79.15 & 55.20 & 46.57 \\
A. Niketan & 48.33 & 70.25 & 37.75 & 30.09 \\
179 & 39.67 & 69.90 & 37.06 & 29.44 \\
147 & 11.67 & 59.95 & 17.55 & 11.02 \\
\hline
\end{tabular}

Out of 90 exotic lines tested during 2000 to 2008, 10 lines had more than $20 \%$ higher yield than Bhima Super during late kharif and 16 during rabi over 'N 2-4-1' in Maharashtra. Further, $F_{1}$ hybrids developed under hybrid network programme at the DOGR by using two CMS lines indicated very high percentage of heterosis over standard checks (Table 5.4), which ranged from 17 to $59 \%$ over 'N2-4-1' and 11 to $50 \%$ over 'ALR' (Lawande, 2004). Out of $60 \quad F_{1}$ hybrids evaluated during rabi,
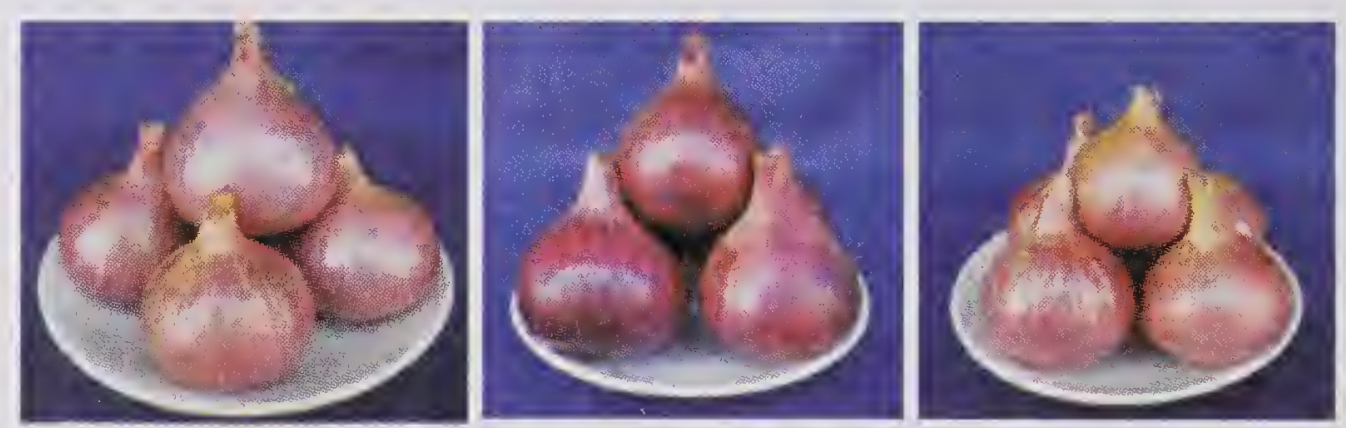

Fig. 5.2 Promising $F_{1}$ hybrids along with Arka Lalima

five $F_{1}$ hybrids, viz. DOGR Hy 50, DOGR Hy 2, DOGR Hy 5 , DOGR Hy 7 and DOGR Hy 8 showed more than $30 \%$ heterosis in marketable yield over standard check Bhima Kiran (25.3 tonnes/ha) whereas $10 \mathrm{~F}_{1}$ hybrids showed more than $20 \%$ heterosis in marketable yield over standard check Arka Lalima (20.6 tonnes/ ha) (Fig. 5.2) during kharif (DOGR, 2013). Commercially released $F_{1}$ hybrids of onion from different organizations have been listed in Table 5.5. Progress and future of onion hybrids has been discussed by VeereGowda and Gupta (2014).

Table 5.5 $F_{1}$ hybrids developed through male-sterile lines

\begin{tabular}{lll}
\hline & Remarks & Reference \\
\hline Tamara & $12 \%$ dry matter content in bulbs & $\begin{array}{l}\text { Skofand Ugrinovic } \\
(2004)\end{array}$ \\
Donglingbai & $244 \mathrm{~A} \times 244 \mathrm{~B}$, higher vigour & Tong et al. (2005) \\
Early Globe & W202A $\times$ S87-707, less foliage, poor in storage & Muro et al. (2006)
\end{tabular}

(Contd...) 


\begin{tabular}{|c|c|c|}
\hline & Remarks & Reference \\
\hline Liaocong No.6 & $\begin{array}{l}2000 \text { Y } 24-3 S 98 \times 244-152 \mathrm{~A} \text {, resist wind, stalk } \\
\text { single, edible rate } 60.63 \% \text {, yield } 69.0 \text { tonnes/ha }\end{array}$ & Cui et al. (2007) \\
\hline $\begin{array}{l}\text { Safrane } \\
\text { Hypark } \\
\text { Alonso }\end{array}$ & $\begin{array}{l}\text { Severity of downy mildew achieved is } 1.6 \% \\
3.1 \% \text { (Hypark) and } 4.5 \% \text { (Safrane) }\end{array}$ & $\begin{array}{l}\text { Bimsteine et al. } \\
(2009)\end{array}$ \\
\hline $\begin{array}{l}\text { Musica } \\
\text { Vaquero } \\
\text { Manas } \\
\text { Sedona }\end{array}$ & $\begin{array}{l}\text { High yield, Musica ( } 82 \text { tonnes/ha), Vaquero } \\
\text { ( } 77.4 \text { tonnes/ha), Manas ( } 78.6 \text { tonnes/ha), } \\
\text { Sedona ( } 78.3 \text { tonnes/ha) }\end{array}$ & $\begin{array}{l}\text { Popandron et al. } \\
\text { (2009) }\end{array}$ \\
\hline Jinqiu & $\begin{array}{l}\text { B } 2354 \mathrm{~A} \times 3104 \text {, bulb growth period about } \\
120 \text { days, yellowish bulb colour, bulb weight } 203 \mathrm{~g} \text {, } \\
\text { yield } 67.5 \text { tonnes/ha }\end{array}$ & Cui et al. (2009) \\
\hline Jinxing & $\begin{array}{l}\text { Round bulb, golden-brown, bulb weight } \\
370-430 \mathrm{~g} \text {, sweet pungency }\end{array}$ & Yan et al. (2009) \\
\hline Yeongpunghwang & $\begin{array}{l}\text { MOS } 8 \times \text { Mokpo } 11 \text {, broad ovate bulb, } \\
\text { lodging date May } 26\end{array}$ & Lee et al. (2009) \\
\hline Jintianxing & $\begin{array}{l}\mathrm{HGO2} \mathrm{A} \times \mathrm{K} 400 \mathrm{C} \text {, long day, round bulb, } \\
\text { yellowish, bulb weighs } 216 \mathrm{~g}\end{array}$ & Ma et al. (2009) \\
\hline Wonye 30002 & $402 \mathrm{AC} 203 \times \mathrm{M} 1$, circular bulb, bulb weight $283 \mathrm{~g}$ & Kim et al. (2010b) \\
\hline Wonye 30001 & $\begin{array}{l}\text { Ginque } \times \text { YG1 }-1 \text {, circular bulb, bulb weight } \\
260 \mathrm{~g} \text {, mid-late maturing type }\end{array}$ & Kim et al. (2010a) \\
\hline Quer-rich & NOR1A $\times$ SRG12, $20 \%$ higher quercetin content & Muro et al. (2010) \\
\hline Baifeng & Good for dehydration, higher dry matter & Zeng et al. (2011) \\
\hline DOGR Hy 7 & $\begin{array}{l}\text { High yield, significantly superior over N 2-4-1, } \\
\text { red bulb, suitable for rabi }\end{array}$ & $\begin{array}{l}\text { Gupta et al. } \\
\text { (2011a) }\end{array}$ \\
\hline $\begin{array}{l}\text { Hybrid Nun } 3001 \\
\text { Hybrid Orient }\end{array}$ & High yield, poor in storage & $\begin{array}{l}\text { Gupta et al. } \\
\text { (2011b) }\end{array}$ \\
\hline Sojiro & $\begin{array}{l}\text { Extremely early maturity, attractive dark brown } \\
\text { coloured skin, strong resistance to Fusarium } \\
\text { basal-rot }\end{array}$ & $\begin{array}{l}\text { Maekawa et al. } \\
(2012)\end{array}$ \\
\hline $2572,2573,2578$ & High yield, earliness & Faria et al. (2012) \\
\hline Hybrid Optima & $\begin{array}{l}\text { Good commercial bulb yield and average mass } \\
\text { of commercial bulbs }\end{array}$ & Boas et al. (2012) \\
\hline Daekwanhwang & $\begin{array}{l}\text { Manchuhwang } \times \text { NIHA5001, yellowish brown } \\
\text { bulb, is good storer }\end{array}$ & Kwon et al. (2013) \\
\hline $\begin{array}{l}\text { Arka Kirthiman* } \\
\text { Arka Lalima* }\end{array}$ & $\begin{array}{l}\text { Released from IIHR Bangalore for high bulb yield } \\
\text { and quality }\end{array}$ & $\begin{array}{l}\text { VeereGowda et al. } \\
\text { (1998) }\end{array}$ \\
\hline $\begin{array}{l}\text { Hybrid } 63^{\star} \\
\text { Hybrid } 35^{\star}\end{array}$ & $\begin{array}{l}\text { Released from the IARI, New Delhi, for high } \\
\text { bulb yield and quality }\end{array}$ & Dhall $(2010)$ \\
\hline DOGR Hy $1^{*}$ & $\begin{array}{l}\text { Light red, flat-globe, } 41.30 \text { tonnes/ha marketable } \\
\text { yield is } 42.84 \% \text { higher than check Bhima Kiran }\end{array}$ & DOGR (2013) \\
\hline DOGR Hy $2^{\star}$ & $\begin{array}{l}\text { Dark red, globe, } 34.96 \text { tonnes/ha, marketable } \\
\text { yield is } 20.91 \% \text { higher than check Bhima Kiran }\end{array}$ & DOGR (2013) \\
\hline
\end{tabular}

*Short-day $F_{1}$ hybrids 


\section{Hybrid seed production}

Investigations conducted on seed-set and seed-yielding abilities of male-sterile and male-fertile lines and their $F_{1}$ hybrids of onion (VeereGowda and Saraswathi, 2002) have indicated that number of seeds per flower is influenced by fertilization and availability of pollen and abortion of embryo. Recovery of seeds per umbel and seed-set percentage may depend on number of flowers per umbel, number of flower stalks per plant and pollen germination. Higher seed weight was observed in crosses than selfed parents. This may be due to contribution of genes from parenting combination. Parental synchronization and efficiency of $F_{1}$ hybrid-seed production were investigated in two $\mathrm{F}_{1}$ hybrids Arka Kirthiman and Arka Lalima (Padmini et al., 2008).

Hybrid seeds are produced in open isolated fields where pollination is carried out mainly by bees. The bulbs of male-sterile line (A line) and pollen parent (C/R line) are planted alternatively in $4: 1$ or $8: 2$ ratio. Hybrid seed yield can be improved by taking the following steps.

- Flowering time of $\mathrm{A}$ and $\mathrm{C} / \mathrm{R}$ line must synchronize, which can be accomplished by adjusting either storage temperature of parental bulbs (9$14^{\circ} \mathrm{C}$ ) or planting dates.

- Keeping 3-5 fully developed bee-colonies per acre to ensure large population of bees for effective pollination.

- A single application of $50 \mathrm{ppm} \mathrm{GA}_{3}$, at the time of first seed-stalk emergence, reduces time of $80 \%$ flower-stalk emergence by half besides ensuring uniformity in length of flower stalk.

Daily roughing of pollen-bearing plants and other off-types in A line (pollen shedders) in the morning before anther dehiscence is essential. Seed stalks of A and $C$ lines should be harvested separately with great care to avoid intermixing. It is always better to harvest seeds of $\mathrm{C}$ lines first to avoid mixing with $\mathrm{A}$ line. The seeds collected from $A$ lines are $F_{1}$ hybrid seeds. Harvesting of seeds should be done when seeds are with 60-70\% dry matter content while still in capsule attached to stalk. Spraying of anti-shattering chemical like polyvinyl acetate may be done to avoid shattering of seeds. The harvested umbels from $\mathrm{A}$ and $\mathrm{C}$ lines are heaped separately for a few days before threshing to ensure proper curing of seeds, drying and for threshing. Yield of hybrid seeds ranges from 400 to $600 \mathrm{~kg}$ per hectare, depending upon the ratio of $\mathrm{A}$ and $\mathrm{C}$ lines, climatic conditions, cultivation practices and honey-bee colonies.

\section{Reverse Breeding}

It is a novel plant-breeding technique that involves suppression of meiotic recombination to recreate homozygous parental lines that, once hybridized, reconstitute composition of an elite heterozygous plant without backcrossing or selection. Reverse breeding enables breeder to go backwards from such an individual to directly recreate homozygous parental lines that created it - essentially allowing mass production through seed of an elite heterozygous genotype. Reverse breeding process begins with the production of gametes (haploid microspores) from heterozygous starting plant in which meiotic recombination has been suppressed. 


\section{Convergence Breeding}

It is a breeding method which involves reciprocal addition to each of the two inbred lines with the dominant favourable genes, which are lacking in one line and are present in the other. In this, backcrossing and selection are simultaneously performed, with each of the original lines, which serve as a recurrent parent in one series. Thus, it is a special case of backcross; a single cross is backcrossed separately to two parental inbreds. Selection is made on the basis of the phenotype during backcrossing. It is hoped that two parental inbreds, e.g., A and B, would be improved by retention of some of the favourable genes contributed by the other inbred. Thus $\mathrm{A}$ is expected to improve by genes from $\mathrm{B}$, and $\mathrm{B}$ by genes from $\mathrm{A}$. There is some evidence that this method improves, to some extent, performance of inbreds as well as that of hybrids produced by them. Promotion of $F_{1}$ hybrids in onions is top priority and can be achieved with reverse breeding/convergence breeding, as most of the private seed companies have followed these methods for achieving desirable $\mathrm{F}_{1}$ hybrids.

\section{Future Strategies}

$\mathrm{F}_{1}$ hybrids will play an increasingly important role in future breeding because of the advantages to breeder of exclusive ownership of the parental lines. The full exploitation of the potential of $F_{1}$ hybrids is hampered by difficulties of commercial seed production from relatively weak parent inbreds. Further biometrical work is needed to predict vigour of recombinant inbreds, derivable from appropriate crosses; in parallel, more rapid ways of getting homozygous inbred lines, e.g., by anther culture, are required. There are obvious dangers in relying on a malesterility system based on a single sterile cytoplasm type, especially one which shows some evidence of instability. Work is needed at the molecular level to determine biochemical basis for male sterility and hence possible ways of manipulating and controlling.

Male-sterile lines developed at various institutes need to be tested at different locations for stability and transferred into the background of best selected varieties and genotypes with diverse nature along with the development of maintainer lines. Constant upgradation and improvement of parental lines by reciprocal recurrent selection and introgression of genes from long-day types would elevate genetic potential of parental lines. Development of 100\% homozygous lines through haploidy by anther culture and deploidization would be the best option for developing quality inbred lines. Training of the elite farmers for seed production and making available quality seeds of $F_{1}$ hybrids at reasonable rate are the need of the hour. Besides, potential of $F_{1}$ hybrids needs to be demonstrated through frontline demonstrations vis-à-vis farmers own material and released openpollinated varieties. This will definitely lead to successful commercialization of $\mathrm{F}_{1}$ hybrids. 


\section{References}

Abubakar L and Adu S G. 2008. Heterosis of purple blotch (Alternaria porri (Ellis) Cif.) resistance, yield and earliness in tropical onions (Allium cepa L.). Euphytica 164: 6374.

Aghora T S. 1985. 'The heterosis and combining ability studies in onion (Allium cepa L.) using $\times$ tester analysis'. M. Sc. (Agri.) Thesis, University of Agricultural Sciences, Dharwad, Karnataka, India.

Bimsteine G, Lepse L and Bankina B. 2009. Possibilities of integrated management of onion downy mildew. Sodininkysteir Darzininkyste 28: 11-17.

Boas R C V, Pereira G M, Souza R J, Geisenhoff L O and Lima J A. 2012. Development and production of two onion cultivars irrigated by drip system. Revista Brasileira de Engenharia Agricola e Ambieental 16: 706-13.

Bohanec B, Jakse M, Ihan A and Javornik B. 1995. Studies of gynogenesis in onion (Allium cepa L.): Induction procedures and genetic analysis of regenerants. Plant Science (Limerick) 104: 215-24.

Brewster J L. 1994. Onion and Other Vegetable Alliums, 236. pp. CAB International, Wallingford, UK.

Campion B, Azzimonti M T, Vicini E, Schiavi M and Falavigna A. 1992. Advances in haploid plant induction in onion (Allium cepa L.) through in vitro gynogenesis. Plant Science (Limerick) 86 (1): 97-104.

Campion B, Bohanec B and Javornik B. 1995. Gynogenic lines of onion (Allium cepa L.): evidence of their homozygosity. Theor. Appl. Genet. 91: 598-602

Campion B, Falavigna A, Soressi G P and Schiavi M. 1985. Efforts for in vitro androgenesis in onion (Allium cepa L.). Genetica Agraria 39: 315.

Cho K S, Hong S Y, Kwon Y S, Woo J G, Moon J Y, Ryu S Y and Park H G. 2005. Selection of maintainer line in open-pollinated onion (Allium cepa L.cv. Manchuhwang) using SCAR marker linked to cytoplasmic male sterile factor. Korean Journal of Breeding 37: 133-37.

Cho K S, Yang T J, Hong S Y, Kwon Y S, Woo J G and Park H G. 2006. Determination of cytoplasmic male sterile factors in onion plants (Allium cepa L.) using PCR-RFLP and SNP markers. Molecules and Cells 21: 411-17.

Chopra V L, Jain S K and Swaminathan M S. 1960. Studies on the chemical induction of pollen sterility in some crop plants. Indian Journal of Genetics and Plant Breeding 20: 188-99.

Cohan S S and Weigle J L. 1966. Chemically induced male sterility in onions (Allium cepa). Horticulture Science 1: 16.

Cui C R, Jia T J, Ma Y H and Xu Q J. 2009. A new long-day onion $\mathrm{F}_{1}$ hybrid 'Jinqiu'. China Vegetables 22: 80-81.

Cui L W, Tong C F and Du XJ. 2007. A new welsh onion variey-'Liaocong No.6'. China Vegetables 10: $39-40$

Davis E. 1966. An improved method of producing hybrid onion seed. Journal of Heredity 57: $55-57$.

Davis G H. 1957. The distribution of male sterility gene in onion. Proceedings of American Society for Horticultural Science 70: 316-18.

Dhall R K. 2010. Status of male sterility in vegetables for hybrid development-A review. Advances in Horticultural Science 24 (4): 263-79.

Dhanya S, Reddy D C L, VeereGowda R, Sreedhara S A and Aswathi C. 2012. The genetic relatedness analysis of male sterile and their maintainer lines of onion (Allium cepa L.) by using RAPD Primers. Journal of Crop Sci. and Biotech. 14 (3): 85-95. 
Divakar D S. 2001. 'Heterosis and combining ability studies for bulb yield, its components and quality parameters in onion.' M.Sc. (Agri.) Thesis, University of Agricultural Sciences, Dharwad, Karnataka, India.

DOGR. 2013. DOGR Annual Report 2012-2013, pp. 10-12. Directorate of Onion and Garlic Research, Rajgurunagar, Pune, Maharashtra, India.

Doruchowsk R W. 1986. Variability, heterosis, inheritance, heritability and inter-dependence of some economic characters in the parental forms of $F_{1}$ and $F_{2}$ generations in onion (Allium cepa L.). Plant Breeding Abstract 156: 9135.

Dowker B D. 1990. Onion breeding, pp. 215-32. (In): Onion and Allied Crops. Vol. I. Botany, Physiology and Genetics. H.D. Rabinowitch and J.L. Brewster (Eds). CRC press Inc. Boca Raton, Florida, USA.

Dowker B D and Gordon G. 1983. Heterosis and hybrid cultivars in onion, 220 pp. (In): Heterosis, Frankel, R. (Ed.) Springer Verlag, Berlin, Germany.

Erickson H T and Gabelman W H. 1964. Potential value of inbred and $F_{1}$ hybrid onions for seed production. Proc. American Society of Horticultural Science 64: 393-98.

Faria M V, Morales R G F, Resende J T V de, Zani D S, Menezes C B de and Kobori R F. 2012. Agronomic performance and heterosis of onion genotypes. Horticultura Brasileira 30: $220-25$.

Gemesne J A and Martinovich L. 1995. In vitro gynogenesis induction in Hungarian lines of onion (Allium cepa L.). ZKI Bulletin, Kecskemet. 27: 37-43.

Gokce A F and Havey M J. 2006. Selection at the Ms locus in open pollinated onion (Allium cepa L.) populations possessing S-cytoplasm or mixtures of $\mathrm{N}$ - and $\mathrm{S}$ cytoplasms. Genetic Resources and Crop Evolution 53: 1495-99.

Gokce A F, McCallum J, Sato Y and Havey M J. 2002. Molecular tagging of the Ms locus in onion. Journal of the American Society for Horticultural Science 127: 576-82.

Gupta A J. 2014. Development of hybrids in onion, pp. 27-41. (In): Compendium of Model Training Course on 'Production Technology in Onion and Garlic' organized during 1017 Feb 2014 by DOGR, Rajgurunagar, Pune, Maharashtra, India.

Gupta A J, Mahajan V and Lawande K E. 2011a. Evaluation of different onion $\mathrm{F}_{1}$ hybrids developed through male sterile lines, pp. 151. (In): National Symposium on Alliums: Current Scenario and Emerging Trends, held on 12-14 March 2011 at DOGR, Pune, Maharashtra, India.

Gupta A J, Mahajan V and Lawande K E. 2011b. Performance of exotic red onion hybrids under short day conditions, pp. 151-52. (In): National Symposium on Alliums: Current Scenario and Emerging Trends, held on 12-14 March 2011 at DOGR, Pune, Maharashtra, India.

Havey M J. 1995. Identification of cytoplasms using the polymerase chain reaction to aid in the extraction of maintainer lines from open-pollinated populations of onion. Theor Appl. Genet. 90: 263-68.

Havey M J. 1999. Seed yield, floral morphology and lack of male-fertility restoration of male sterile onion (Allium cepa) populations possessing the cytoplasm of Allium galanthum. Journal of the American Society for Horticultural Science 124: 626-29.

Hosfield G L, Vest G and Peterson C E. 1976. A ten parent diallel cross to evaluate inbred line performance and combining ability in onions. Journal of American Society for Horticultural Science 101: 324-29.

Hosfield G L, Vest G and Peterson C E. 1977a. A seven parent diallel cross in onions to evaluate general and specific combining ability and their interaction with years and locations. Journal of American Society for Horticultural Science 102: 56-61.

Hosfield G L, Vest G and Peterson C E. 1977b. Heterosis and combining ability in diallel cross of onions. Journal of American Society for Horticultural Science 102: 355-60.

Ionescu A and Popandron N. 1995. Research on the in vitro culture of ovules, ovaries and 
flower buds of some Allium genotypes. Anale Institutul de Cercetari Pentru Legumicultura Si Floricultura Vidra 13: 17-22.

Jakse M, Havey M J and Bohanec B. 2003. Chromosome doubling procedures of onion (Allium cepa L.) gynogenic embryos. Plant Cell Reporter 21: 905-10.

Janik J. 1999. Exploitation of Heterosis: Uniformity and stability, pp. 319-33. (In): The Genetics and Exploitation of Heterosis in Crops. Coors J G and Pandey S. (Eds). American Society of Agronomy, Inc., Crop Science Society of America, Inc., Madison, WI. USA.

Javornik B, Bohanec B and Campion B. 1998. Second cycle gynogenesis in onion, Allium cepa L. and genetic analysis of the plants. Plant Breeding 117: 275-78.

Jones H A and Clarke A E. 1943. Inheritance of male sterility in the onion and the production of hybrid seed. Proceedings of the American Society for Horticultural Science 43: 189-94.

Jones H A and Davis G N. 1944. Inbreeding and Heterosis and their Relation to the Development of New Varieties of Onions. United States Department of Agricultural Technology Bulletin, p. 874.

Jones H A and Emsweller S L. 1936. A male sterile onion. Proceedings of the American Society for Horticultural Science 34: 582-85.

Joshi H C and Tandon J P. 1976. Heterosis for yield and its genetic basis in onion. Indian Journal of Agricultural Science 46: 88-92.

Kale A A and Munjal S V. 2005. Molecular analysis of mitochondrial DNA of lines representing a specific CMS-fertility-restorer system of pearl millet [Pennisetum glaucum (L.) R.Br.] by RAPD markers. Indian Journal of Genetics 65: 1-4.

Kalloo G. 1988. Heterosis in vegetable crops, pp. 105-35. (In): Vegetable Breeding. CRC Press, Florida, USA.

Kaul, C L and Singh S P. 1976. Staminal and functional male sterility induced by chemical treatment in papilionaceous plants. Indian Journal Agriculture Science 37: 264-69.

Kaul M L H. 1988. Male sterility in higher plants, pp. 775-97. (In): Monographs. Volume 10. R. Frankel, M. Grossman, P. Maliga P (Eds). Berlin, Heidelberg, New York: Springer.

Keller E R J and Korzun L. 1996. Haploidy in onion (Allium cepa L.) and other Allium species, pp. 51-75. (In): In-vitro Haploid Production in Higher Plants. S.M. Jain, S.K. Sopory, R.E. Veilleux. (Eds). Kluwer Academic Publishers, Dordrecht, Boston, London, UK.

Kim C W, Lee E T, Choi I, Jang Y S and Suh S J. 2010a. Mid-late maturing male sterile line of onion (Allium cepa L.) 'Wonye 30001'. Korean Journal of Breeding Science 42: 294-97.

Kwon Y S, Cho K S, Lee E H, Jang S W, Suh J T, Kim J S, Kim W B, Im J S and Lee J N. 2013. High-quality and long-storability of $F_{1}$ hybrid long-day onion. 'Daekwanhwang'. Korean Journal of Breeding Science 45: 61-65.

Lawande K E. 2004. Heterosis in onion: prospects and challenges, pp. 119-20. (Souvenir). (In): National Symposium on Harnessing Heterosis in Crop Plants, held on 13-15 March 2004 at IIVR, Varanasi, Uttar Pradesh, India.

Lee E T, Kim C W, Choi I H, Jang Y S, Bang J K, Bae S G. Hyun D Y, Jung J M, Ha I J and Kim S B. 2009. New mid-late maturing $\mathrm{F}_{1}$ hybrid onion cultivar, Yeongpunghwang, Korean Journal of Breeding Science 41: 587-90.

Li Y Y, Yang Q, Yan J Y and Chen M. 2006. Cytoplasmic male-sterility of onion (Allium cepa L.) $63 \mathrm{~A}$ is associated with premature degeneration of the tapetum. Acta Agronomica Sinica 32: 369-72.

Little J M, Jones H A and Clarke A E. 1946. The distribution of male sterile gene in varieties of onion. Hereditas 111: 310-12. 
Ma Y H, Liu W and Cui C R. 2009. A new onion cultivar 'Jintianxing'. Acta Horticulturae Sinica 36: 1401

Maekawa K, Tanaka S, Yanagida D, Koyano S, Noda T, Akiba M., Majima T, Kondo K, Hagihara T and Mori N. 2012. 'Sojiro' extremely early maturity spring-sowing onion hybrid with resistance to Fusarium basal rot. Acta Horticulturae 969: 103-06.

Mani V P, Chauhan V S, Joshi H C and Tandon J P. 1999. Exploiting gene effects for improving bulb yield in onion. Indian Journal of Genetics and Plant Breeding 59: 511-14.

Meer Q P V and Bennekom J L V. 1976. Gibberellic acid as a gametocide for the common onion (Allium cepa L.). Euphytica 25: 293-96.

Michalik B, Adamus A and Nowak E. 2000. Gynogenesis in Polish onion cultivars. Journal of Plant Physiology 156: 211-16.

Muro T, Ito K, Sato Y, Abe H, Turui H, Asari H, Minagawa Y and Harada H. 2006. Breeding of early-maturing hybrid onion variety 'Early Globe' and its characteristics. Research Bulletin of the National Agricultural Research Center for Hokkaido Region 184: 4555.

Muro T, Noguchi Y, Morishita M, Ito K, Sugiyama K, Kondo T, Kurenuma Y and Ono T. 2010. Quer-rich a new variety of hybrid red onion with high quercetin content. Research Bulletin of the National Agricultural Research Center for Hokkaido Region 192: 2532.

Narayanan T V A., Ravi B A and VeereGowda R. 2006. Molecular analysis of genetic diversity in onion genotypes and hybrids, pp. 73-96. (In): Recent Advances in Allium Research. Singh U P, Singh D P and Sarma B K. (Eds). Association of Allium workers in India, Varanasi, Uttar Pradesh, India.

Netrapal and Singh N. 1999. Heterosis for yield and storage parameters in onion (Allium cepa). Indian Journal of Agricultural Sciences 69: 826-29.

Padmini K, VeereGowda R and Naik L B. 2008. Studies on parental synchronization in flowering for hybrid seed production in onion (Allium cepa L.) Journal of Horticultural. Sciences 2: 47-49.

Pathak C S. 1997. A possible new source of male sterility in onion. Acta Horticulturae 433: $313-16$.

Pathak C S and VeereGowda R. 1994. Breeding for the development of onion hybrids in India: Problems and Prospects. Acta Horticulturae 358: 239-42.

Pathak C S, Aghora T S, Singh D P and Deshpande A A. 1987. Exploitation of heterosis in onion by using indigenous source of male sterility, pp. 53. (In): National Symposium on Heterosis Exploitation: Accomplishment and Prospects, held at Marathwada Agricultural University, Parbhani, India.

Pathak C S, Singh D P and Deshpande A A. 1980. Annual Report, pp. 34-36. Indian Institute of Horticultural Research, Bengaluru, Karnataka, India.

Pathak C S, Singh D P and Deshpande A A. 1986. A new type of cytoplasmic male sterility in onion (Allium cepa L.), pp.13. (Abstract). (In): First All India Conference of Cytology and Genetics, Bangalore University, held in December 1986, Bengaluru, Karnataka, India.

Pathak C S, Singh D P, Deshpande A A and Sreedhar T S. 1986. Sources of resistance to purple blotch in onion. Vegetable Science 31: 300-03.

Patil J A, Jadhav A S and Rane M S. 1973. Male sterility in Maharashtra onion. Research Journal of Mahatma Phule Agriculture University 4: 29-31.

Pike L M. 1986. Onion breeding, pp. 357-94. (In): Breeding Vegetable Crops. Basset M J. (Ed.) AVI Publishing Co. Inc., Westport, Connecticut, USA.

Popandron N. 1998. Revealing heterosis phenomenon in some $F_{1}$ onion hybrids obtained at the Institutul de Cercetaripentru Legumiculturasi Floriculture, Vidra. AnaleInstitutul 
de Cercetaripentru Legumiculturasi Floriculture, Vidra 15: 45-50.

Popandron N, Basturea M and Tudora M. 2009. Researches regarding the behaviour of some onion cultivars in the vegetable agro-system in southern Romania. Lucrari Stiintifice, Universitatea de Stiinte Agricole Si Medicina Veterinara "Ion Ionescu de la Brad" Iasi, Seria Horticultura 52: 477-80.

Radhika V, Reddy D C L, VeereGowda R and Aswathi C. 2013. In silico identification and validation of micro satellite markers from onion EST sequences. Journal of Horticultural Sciences and Biotechnology 88: 664-70.

Rao E S, VeereGowda R, Ganeshan G and Manjanna E R. 2005. Influence of male sterility cytoplasm on $\mathrm{F}_{1}$ hybrids in Indian onion genotypes. Journal of Genetics and Breeding 59: $153-56$.

Reddy L, Chinnappareddy D, Khandagale K, Chennareddy A and VeereGowda R. 2013. Review on molecular markers in the improvement of Allium crops, Czech J. Genet. Plant Breeding 49: 131-39.

Saraswathi K M and VeereGowda R. 2006. Studies on causes of male sterility in short day onion (Allium cepa, L), pp. 107-27. (In): Recent Advances in Allium Research. Singh U P, Singh D P and Sharma B K. (Eds). Published by Association of Allium workers in India, Varanasi, Uttar Pradesh, India.

Sen B and Srivastava S N. 1957. Utilization of cytoplasmic male sterility. (In): Production of Hybrid Onion Seeds. [Proceeding of 44th Indian Congress, Part 2, 225 pp, held at Kolkata, India].

Shashikanth E, Gowda V R, Gangappa E and Manohar R K. 2007. Heterosis for yield, yield components and quality traits in onion (Allium cepa L.). Karnataka Journal of Agriculture Science 20: 813-15.

Skof M and Ugrinovic K. 2004. Storage capability of different onion cultivars. Novi izziviv-poljedelstvu 2004 Zborniksimpozija, Ljubljana, Slovenia, pp. 269-75. 13-14 December 2004.

Szklarczyk M, Simlat M, Jagosz B and Ba G. 2002. The use of cytoplasmic markers in onion hybrid breeding. Cellular and Molecular Boilogy Letters 7: 625-34.

Tong C F, Tang C Y, Cui L W, Wang G Z and Du D J. 2005. Selection and utilization of the male-sterile line "244A" in Welsh onion. Acta Horticulturae 688: 151-57.

Vadivel B, Muthurkishana C R and Irulappal I. 1982. Line $\times$ tester analysis in aggregatum onion. I. Heterosis in seed to bulb generations. South Indian Horticulture 29: 191-98.

VeereGowda R. 1988. 'Studies on the genetics of yield and quality characters in bulb and seed crop of onion (Allium cepa L.).' Ph.D. Thesis. University of Agricultural Sciences, Bengaluru, Karnataka, India.

VeereGowda R and Gupta A J. 2014. Progress and future of onion hybrids, pp. 29-53. (In): Souvenir of Brain Storming Session on Crop Improvement and Seed Production of Onion, organized by DOGR and NHRDF on 15 March 2014 at Nashik, Maharashtra, India.

VeereGowda R and Saraswathi K M. 2002. Investigating on seed set and seed yielding abilities of male sterile and male fertile lines of onion (Allium cepa L.), pp. 513-16. (In): Proceedings of International Conference on Vegetables, held on 11-14 Novmber 2002 at Bengaluru, India.

VeereGowda R, Pathak C S, Singh D P and Deshpande A A. 1998. Onion hybrids: Arka Kirthiman and Arka Lalima. Indian Horticulture 43: 20.

VeereGowda R, Rao E S, Pathak C S and Singh TH. 2002. Development and commercialization of $F_{1}$ hybrids in short day onion: Indian Perspective, pp. 560-62. (In): Proceedings of International Conference on Vegetables, held on 11-14 November 2002 at Bengaluru, India.

Yamashita K and Tashiro Y. 2004. Seed productivity test of CMS lines of Japanese bunching 
onion (Allium fistulosum L.) possessing the cytoplasm of a wild species, A. galanthum Kar. et Kir. Euphytica 136: 327-31.

Yamashita K, Takatori Y and Tashiro Y. 2005. Chromosomal location of a pollen fertilityrestoring gene, Rf, for CMS in Japanese bunching onion (Allium fistulosum L.) possessing the cytoplasm of $A$. galanthum Kar. etKir. revealed by genomic in situ hybridization. Theor. Appl. Genet. 111: 15-22.

Yan J Y, Xu H L, Zhuang Y, Gao B, Hong J Z and Li B. 2009. A new onion $\mathrm{F}_{1}$ hybrid'Jinxing'. China Vegetables 16: 71-73.

Zeng A S, Yan J Y, Yun J S, Song L X and Gao B. 2011. A new onion $F_{1}$ hybrid for dehydration-'Baifeng'. China Vegetables 12: 103-05. 


\title{
Aggregatum Onion and Shallots
}

\author{
P. Paramaguru, M. Velmurugan and L. Pugalendhi
}

Two types of onion are commercially grown in India; one is common onion Allium cepa var. cepa, which is most important in commercial trade. Common onion bulbs are large, normally single, and its plants are propagated through seeds. The second type is multiplier onion A. cepa var. aggregatum, which produces small size bulbs, many in number, to form an aggregated cluster. Multiplier onion is also known as country onion or potato onion or Egyptian ground onion, and is being grown since ancient times in India. It has got a Sanskrit equivalent 'Palandu', mentioned in Apastamba Dharma Sutra I (dated 800 BC to 300 BC), which confirms its early introduction into India. In Tamil Nadu, aggregatum onion is grown in 26,491 hectares with a production of 2.56 lakh tonnes.

\section{Varieties}

\section{Aggregatum Onion}

Cuddalore, Podusu, Dindigul Red, Mutlore Natu and Palluvengayam are local cultivars in Tamil Nadu. The Tamil Nadu Agricultural University, Coimbatore, is the only institute in India working on breeding multiplier onions (Table 6.1).

\section{Cultivation}

The aggregatum onion is gaining momentum among progressive onion-growers of Tamil Nadu. Certain types of aggregatum onions, grown particularly near seashores of east coast of Tamil Nadu (Thengaithittu and Gnanamedu, near Cuddalore; and Puducherry and Mutlur, near Chidambaram), exhibit seed-setting ability.

Twelve seed-setting onion types were collected from different regions of Tamil Nadu and evaluated with Co (On) 5 (check) to study per se performance (Kumaravelu, 2009). Cultivars Aca 12, Aca 3 and Aca 7 were found performing better for yield and quality compared to the check (Table 6.2). Aca 12, a collection from Puttarsal (near Palladam,) was superior with respect to bulb yield, growth parameters, bulb characters and quality characters, mainly ascorbic acid content. Moderate estimates of genotypic coefficient of variation (GCV) and phenotypic coefficient of variation (PCV) for number of leaves per plant, leaf girth, shoot girth, bulblet weight, number of bulblets per bulb and bulb weight were recorded. High heritability estimates in conjunction with high genetic advance were observed for number of leaves per plant, leaf girth, shoot girth, bulblet weight, number of bulblets per bulb and bulb weight (Kumaravelu, 2009).

The major expenditure in aggregatum onion cultivation is that large quantities 
Table 6.1 Varieties of aggregatum onion

\begin{tabular}{ll}
\hline Variety & Characters \\
\hline CO 1 & It is a clonal selection from a germplasm type CS 450 , introduced from \\
Manachanallur. The crop duration is 90 days and its yields 10 tonnest/ha. Bulbs \\
are medium in size, red in colour. The bulb weight per plant is 55 to $60 \mathrm{~g}$ with \\
an average of 8 bulbs per plant. The plant is medium in height $(30 \mathrm{~cm})$ with \\
green leaves. It is fairly pungent with a medium TSS content $\left(8-9^{\circ} \mathrm{brix}\right)$. \\
It is a selection from a germplasm type CS 911 . The crop yields 12 tonnes/ha \\
in 65 days. The bulbs are crimson and moderately bigger in size. The bulb \\
weight per plant ranges from 60 to $65 \mathrm{~g}$, with an average of 9 bulbs per plant. \\
The leaves are green with cylindrical shape. The plant height is $30 \mathrm{~cm}$. The \\
number of shoots per plant ranges from 7 to 9 . The weight loss during storage \\
is lesser than CO 1 . This variety is pungent with high TSS content (12 brix). \\
It is a clonal selection from open-pollinated progenies of CS 450 . The crop \\
duration is 65 days and its yields 15.8 tonnes/ha. The bulbs are pink and bolder \\
in size. The bulb length and girth are $3.5 \mathrm{~cm}$ and $8.3 \mathrm{~cm}$, respectively. The \\
mean bulb weight per plant is $75 \mathrm{~g}$. Number of bulbs per plant range from 8 to \\
10. The plant has light-green erect cylindrical leaves. Its height is $40 \mathrm{~cm}$. The \\
number of shoots ranges from 6 to 8 . Its bulbs are bigger than CO 2 with good \\
consumer appeal. Plants are moderately resistant to thrips. The bulbs store \\
well for 120 days, devoid of sprouting in well ventilated store-rooms. The variety \\
contains $17.5 \%$ dry matter with $0.53 \%$ sulphur and $13.0 \%$ TSS.
\end{tabular}

MDU1 It is a selection from Sempatti local. It has uniform big size bulbs of bright red colour and with better keeping quality without any weight loss. Its yield potential is $13,000 \mathrm{~kg} / \mathrm{ha}$.

$\mathrm{CO} 4$ It is a hybrid derivative of the cross AC $863 \times \mathrm{CO} 3$. The crop duration is 65 days and its yields 19.0 tonnes/ha. Its leaves are light-green, erect and cylindrical. The number of bulbs per plant varies from 8 to 13 with an average weight of $90 \mathrm{~g}$ per clump. Bulbs are attractive, light-pink, bold with good consumer appeal. They store well over 150 days.

$\mathrm{CO}(\mathrm{On}) 5$ It is a high-yielding variety, developed by mass pedigree method. It has the ability of free flowering and seed-set throughout Tamil Nadu. It possess high bulb yield 18.9 tonnes/ha ( $18.8 \%$ higher than $\mathrm{CO} 4)$ in a crop duration of 90 days. It is free-flowering type with seed-setting ability of $250-300 \mathrm{~kg} / \mathrm{ha}$ and thus is propagated through seeds. March-July is for bulb production and November-January is for seed production. It possesses attractive pink-coloured bold bulbs. Its total soluble solids content is $13 \%$. Its pungency principle measured as pyruvic acid is $2.37 \mu \mathrm{m} / \mathrm{g}$ of fresh weight.

of seed bulbs are needed for planting, 1,000 kg bulbs/ha; and thus the cost of the planting material is high. Alternative way to reduce cost of production is to propagate through seeds.

\section{Seedling raising and planting}

Among aggregatum onions, Co (On) 5 is a free-flowering and seed-setting type, and can be propagated both by seeds and by bulbs. In plains, seeds are sown during October-November for a rabi crop, and in hills, seeds are sown from March to June. Sowing is first done in well-prepared nursery beds of $90-120 \mathrm{~cm}$ width, 7.5-10.0 cm height and of convenient length.

Area ratio between nursery and main field is $1: 20$, and seed rate varies from 
Table 6.2 Performance of seed-setting aggregatum onion types

\begin{tabular}{llccc}
\hline Cultivar & Source & $\begin{array}{c}\text { Weight of Bulb/plant } \\
(\mathrm{g})\end{array}$ & $\begin{array}{c}\text { TSS } \\
\left({ }^{\circ} \text { Brix }\right)\end{array}$ & $\begin{array}{c}\text { Pyruvic acid } \\
(\mu \mathrm{mol} / \mathrm{g})\end{array}$ \\
\hline Aca 1 & Coimbatore & 64.63 & 14.42 & 2.45 \\
Aca 2 & Ottanchatram & 60.69 & 13.80 & 2.64 \\
Aca 3 & Dindigul & 68.50 & 13.18 & 3.12 \\
Aca 4 & Dindigul & 51.64 & 12.92 & 2.22 \\
Aca 5 & Rasipuram & 49.64 & 12.67 & 2.28 \\
Aca 6 & Salem & 55.52 & 13.10 & 2.70 \\
Aca 7 & Gnanamedu & 69.68 & 13.68 & 2.95 \\
Aca 8 & Gnanamedu & 61.58 & 12.88 & 2.33 \\
Aca 9 & Gnanamedu & 66.19 & 13.15 & 2.77 \\
Aca 10 & Gnanamedu & 55.18 & 12.75 & 2.54 \\
Aca 11 & Palladam & 54.17 & 13.32 & 2.26 \\
Aca 12 & Palladam & 73.70 & 13.92 & 2.84 \\
Co (On) 5 & Coimbatore (Check) & 65.22 & 13.40 & 2.60 \\
& Mean & 61.26 & 13.32 & 2.59 \\
& CD (P=0.05) & 4.64 & 1.01 & 0.20 \\
\hline
\end{tabular}

Source: Kumaravelu (2009)

8 to $10 \mathrm{~kg} / \mathrm{ha}$. Seedlings of $15 \mathrm{~cm}$ height and $0.8 \mathrm{~cm}$ neck diameter are ideal for transplanting, and they are ready in eight weeks (period varies from 6-10 weeks depending on soil, climate and rains). At the time of transplanting, practice of topping of seedlings is done if seedlings have over-grown. To avoid seedling mortality owing to damping-off, drench beds with copper fungicides at 2.5-3.0 g or Carbendazim at $2 \mathrm{~g}$ per litre of water. Bulbs are planted at a spacing of $10 \mathrm{~cm}$ between plants on the both sides of the ridges. Onion seedlings are transplanted at a distance of $15 \mathrm{~cm} \times 10 \mathrm{~cm}$.

Soaking of onion-seeds in water or sodium phosphate solution for 2-6 hours, followed by drying was found beneficial for vigour and viability (Basu et al., 1975). Highest yield was obtained with planting of eight week-old seedlings (Rathore and Yadav, 1971). Partial pruning of seedlings at the time of transplanting augmented crop stand and increased bulb size (Maiti and Sen, 1968); similar results were reported by Rathore and Kumar (1974). Top pruning may add to convenience in transplanting, and no adverse effects of it are seen on bulb yield.

\section{Manuring and fertilization}

Onion-crop yielding $300 \mathrm{q} / \mathrm{ha}$ removed $73 \mathrm{~kg}$ of nitrogen, $36 \mathrm{~kg}$ of phosphorus and $68 \mathrm{~kg}$ of potash (Yawalkar et al., 1962). Zink (1966) reported uptake of onioncrop from the soil to the tune of $66 \mathrm{~kg}$ nitrogen, $11 \mathrm{~kg}$ phosphorus and $52 \mathrm{~kg}$ potash and $40 \mathrm{~kg}$ calcium per hectare. Use of slow-release $\mathrm{N}$ fertilizer, sulphurcoated urea as pre-plant application in direct-sown crops with furrow irrigation was beneficial for onions (Brown et al., 1988).

Higher amounts of nitrogen reduced development of premature seed-stalk formation (Singh and Kumar, 1972). N higher dose reduced bolting percentage also (Verma et al., 1972; Hassan and Ayoub, 1978). Onion-bulbs are often stored for varied time periods depending on the necessity. Hence, NPK dose should be 
optimum so that bulb quality does not deteriorate, and spoilage is not much. Application of sulphur is found to improve quality and pungency of onion bulbs; higher doses of sulphur reduced bolting.

In Tamil Nadu, application of FYM 25 tonnes/ha, Azospirillum $2 \mathrm{~kg}$ and Phosphobacteria $2 \mathrm{~kg} / \mathrm{ha}, \mathrm{N} 30 \mathrm{~kg}, \mathrm{P} 60 \mathrm{~kg}$ and $\mathrm{K} 30 \mathrm{~kg} / \mathrm{ha}$ as basal and $30 \mathrm{~kg} \mathrm{~N} /$ ha on 30th day of sowing gave maximum bulb yield (HC\&RI,2013). Whereas under fertigation systems, $75 \%$ of the total recommended dose of superphosphate ( $285 \mathrm{~kg} / \mathrm{ha}$ ) as basal dose and Azospirillum and Phosphobacteria each @ $2 \mathrm{~kg} / \mathrm{ha}$ along with FYM $50 \mathrm{~kg}$ and neem cake @ $100 \mathrm{~kg}$ are applied before the last ploughing. Raised beds of $120 \mathrm{~cm}$ are formed at an interval of $30 \mathrm{~cm}$, and laterals are placed at the centre of each bed.

\section{Fertigation}

Fertigation, a hi-tech agro-technique combining water and fertilizer application through drip irrigation, is one of the most effective and convenient methods of supplying nutrients and water at the root zone specific to crop requirement to maintain optimum soil fertility and for getting better quality produce (Shirgure et al., 2000).

Fertigation allows application of nutrients exactly and uniformly only to root volume, where active roots are concentrated. This refined technology remarkably increases efficiency of applied fertilizers, thus economizing on fertilizer quantity, water and cost of labour and energy, and thus also reduces cost of cultivation. Normally, for fertigation high-cost water soluble fertilizers are used. If there is a possibility of using easily available water-soluble straight fertilizers through drip, a drastic reduction in cost of cultivation can be achieved.

Taking these aspects into consideration, studies were undertaken to standardize fertigation for $\mathrm{Co}(\mathrm{On})$ 5. Superphosphate was given as a basal dressing and $\mathrm{N}$ and $\mathrm{K}$ were applied through drip fertigation. In Co (On) 5, fertigation with $75 \%$ of the recommended fertilizer dose (i.e., $45: 45: 22.5 \mathrm{~kg}$ of NPK/ha) registered higher bulb yield ( 8.34 and 11.05 tonnes/ha) compared to soil application of fertilizers. The higher yield was due to increased plant height, number of leaves and root length, leaf area index, total chlorophyll content and dry matter content. Quality parameters like TSS, pyruvic acid, ascorbic acid, protein and total sugar content were also high. Its benefit; cost ratio was 3.72 .

Application of micronutrients improved quality of bulbs. Zinc at 1, 2 and 3 ppm significantly increased yield and quality of bulbs by increasing TSS, sugars and ascorbic acid (Mayura and Lal,1975). Rao and Deshpande (1971) reported appreciable increase in bulb yield with copper and boron at 13.4 and $1.8 \mathrm{~kg}$ per hectare, respectively.

Abrol and Dixit (1972) recorded significant increase in yield and water-use efficiency in drip irrigation than conventional methods of check-basin. The field should be irrigated immediately after planting and again on the third day. Afterwards field needs to be irrigated once in 7 or 10 days, depending on the soil moisture (Veeraragavathatham, 1998). In general, irrigation should be given as and when required based on the soil moisture and prevailing weather. 


\section{Weed management}

Onion, being a short-duration crop, is affected by weed competition severely at bulb initiation and development stage. As the crop is closely planted and possesses shallow roots, hand-weeding is difficult, and may damage the crop. Manual weeding is expensive also. Therefore, it is suggested to use safer herbicides along with one or two hand-weedings based on the field condition, especially at the critical stages of growth.

Patel et al. (1988) suggested that for overall weed control efficiency, Fluchloralin at $0.9 \mathrm{~kg} / \mathrm{ha}$ before planting should be applied along with weeding at 40 days after sowing (92.1\%). Pre-emergence application of Fluchloralin at 1.0 $\mathrm{kg} / \mathrm{ha}$ with two hand-weedings at 30 and 60 days after transplanting recorded least weed count and dry matter production, favouring highest yield of bulbs (72.4 tonnes/ha) (Warade et al., 2007; Warade et al., 2008).

\section{Harvesting}

Harvesting of the bulbs at the appropriate maturity stage is very important in deciding its storage life. The bulbs reach maturity when plants cease to produce new leaves and roots. In onions, neck fall is the indication of maturity. Bhonde et al. (1983) reported that onions could be safely harvested a week after $50 \%$ of the crop was with neck fall; three days field curing was desirable to improve storability. All plants in the field do not mature at the same time. Harvesting should start when $25-50 \%$ of the top falls.

Harvesting time depends on the planting, season, variety, market price and condition of the crop. If immature bulbs are harvested, longer time is required for their drying, and keeping quality is also affected adversely. Late harvesting results in sunburn and poor storability. The bulbs are harvested by pulling if soil is light textured. They are also harvested by hand implements or modified potato-digger. Kharif onion is harvested when leaves are still green; the tops and roots are removed and bulbs are ready for market.

On an average, crop yield is 12-16 tonnes/ha in 70 to 90 days. However, Co (On) 5 yields 18 tonnes/ha in 90 days.

\section{Post-harvest technology}

Out of the total annual production of over 45 lakh tonnes, 25-30\% is lost during handling in storage and transportation. Major loss is noticed during storage. It is very well established that pre-harvest factors, such as variety, nitrogen application, irrigation, plant protection and harvesting affect bulb quality. Postharvest factors like field curing, grading, packing and transportation are also responsible for the quality. Respiration, growth and development, transpiration and natural water loss, physical damage and pathological breakdown are biological factors involved in deterioration of onion-bulbs (Pandey et al., 1999).

In India, about $35-40 \%$ of onion yield is estimated to be lost as post-harvest losses. In general, losses are owing to reduction in weight (20-25\%), sprouting (4-5\%) and rotting (decay) (10-12\%).

In aggregatum onion var. Co (On) 5 experiments were conducted to reduce 
post-harvest losses. Pre-harvest spraying and standardization of curing methods and packing and storing were done by Anbukkarasi (2010).

In pre-harvest spraying, foliar spraying of maleic hydrazide @ 2,000 ppm + Carbendazim @1,000 ppm at 30 days before harvest recorded relatively low percentage of weight loss in storage (Table 6.3). Maleic hydrazide was found to reduce physiological loss in weight and Carbendizim was protective against pathogenic infections (Rao and Chundawat, 1990). Maleic hydrazide has, however, been banned.

Table 6.3 Effect of curing on aggregatum onion, var.Co (On) 5

\begin{tabular}{lccccc}
\hline Treatment & $\begin{array}{c}\text { Physiological } \\
\text { loss i } \\
\text { weight }(\%)\end{array}$ & $\begin{array}{c}\text { Sprouting } \\
(\%)\end{array}$ & $\begin{array}{c}\text { Moisture } \\
\text { content }\end{array}$ & $\begin{array}{c}\text { TSS } \\
\text { content } \\
\left({ }^{\circ} \text { Brix }\right)\end{array}$ & $\begin{array}{c}\text { Pyruvic } \\
\text { acid } \\
(\mu \mathrm{mol} / \mathrm{g})\end{array}$ \\
\hline $\begin{array}{l}\text { Bulbs with } 2 \mathrm{~cm} \text { neck length + } \\
\text { Maleic hydrazide @ 2,000 ppm + } \\
\begin{array}{l}\text { Carbendazim @ 1,000 ppm as } \\
\text { pre-harvest spray }\end{array}\end{array}$ & 1.28 & 0.02 & 94.63 & 13.97 & 2.71 \\
\begin{tabular}{l} 
Bulbs with tops removed \\
\hline
\end{tabular} & 3.23 & 0.15 & 93.98 & 13.57 & 2.60 \\
\hline
\end{tabular}

Source: Anbukkarasi (2010)

\section{Drying and curing}

Drying is for removing excess moisture from outer skin and neck to reduce infestation by disease-causing organisms and with the minimal shrinkage.

Curing is a process that aids in the development of skin colour and also for removing field heat before storage of bulbs. The length of curing time depends largely on the weather, and in winter season in north, thorough curing requires 2 3 weeks as temperature is low at the harvesting time.

Curing in shade improves bulb colour and reduces losses significantly during storage. This curing system may be practised for multiplier onions also to minimize losses in handling and storage. As period of field curing depends on the type of onion and temperature prevailing, drying of foliage is considered completion of field curing.

Different curing methods with bulb tops removed, bulbs with 2-cm neck length and 4-cm neck length such as sulphur fumigation $\left(50 \mathrm{~g} / \mathrm{m}^{3}\right)$ for three hours, bulbs treated with gamma rays @ $2 \mathrm{kr}$ and $4 \mathrm{kr}$ were studied. In aggregatum onion Co (On) 5, harvested bulbs are to be pre-cured in fields for three days and in shade for two days before curing. Retaining 2-cm neck length of the top leads to reduction in physiological weight loss, sprouting, loss in moisture content and improved quality characters, TSS and pyruvic acid content.

\section{Packaging}

Cured bulbs stored under low-cost bottom ventilated storage structure improved quality parameters, enzyme activities and shelf-life of onion bulbs (Table 6.4).

Onions are packed in jute (hessian) bags for transporting to yards or brought as loose material. For safe handling, 40-kg open-mesh jute bags of 200-300 g 
weight should be used for domestic market. For export, common big onions are packed in 5-25-kg size open-mesh jute bags. Bangalore Rose and multiplier onions are packed for export in 14-15 kg wooden baskets. Plastic-netted bags are attractive and also better in strength, but these are not being used commercially either in domestic market or for export markets. In foreign countries, plastic-netted bags for onion packing are common.

\section{Storage}

Onion is a delicate and perishable commodity and it cannot be stored for a longer duration at room temperature due to high moisture content and other associated factors. In temperate countries, climatic conditions are more favourable for onion storage, since bulbs are harvested in autumn and stored during low temperature.

But in tropical and subtropical countries, like India, the crop is harvested in summer and stored for 4-6 months in ambient conditions of high temperature and high humidity. During this period, the bulbs sprout easily, besides rotting due to fungal and bacterial diseases. In these countries, proper storage of bulbs is necessary both for 으 consumption and also for seed production purposes.

The post-harvest period of onion-bulbs has been separated into two well defined stages like the rest period, when bulbs would not $\$$ sprout even under conditions favourable for growth, and a dormant period, when sprouting 
occur under high humidity and suitable temperature. Sprout activation is controlled by a complex natural inhibitor-promoter interaction, and sprout extension is controlled by natural gibberellins (Thomas and Isenberg, 1972). Thus, a growth inhibitor may be a prime factor involved in dormancy process. Kato (1966) suggested that inhibitor was produced in leaves during bulbing and translocated into bulbs during senescence. Defoliated onions sprouted much earlier in storage than those in which senescence occurred naturally in the field. It indicated that the growth inhibitor was present in the bulbs after harvesting but it decreased gradually until the onset of sprouting while both auxin and gibberllins increased around the beginning of the sprouting period.

In India, different storage methods are adopted by farmers. Onions are bulk stored in special houses or structures with thatched-roof and sides covered by bamboo-sticks with a provision of good air circulation. In north India, the sides are also covered with gunny cloth. The bulbs are stored in these sheds by spreading them on dry and damp-proof floor or racks. Periodical turning of bulbs or removal of rotten, damaged and sprouted bulbs needs to be done. Well-ventilated room with racks or tiers having two or three layers of bulbs would be desirable for proper storage.

Onion-bulbs packed in gunny bags and stored in modified storage structure for three months showed minimum storage losses (34.65\%). Adamicki (1998) reported that 17 onion cultivars stored in an ambient ventilated store at $0^{\circ} \mathrm{C}$ for 6 months suppressed sprouting to a great extent, and had no effect on root development.

Benkeblia et al. (2004) noted an increase of fructans, particularly DP 5-8, in onion-bulbs after six months at 10 and $20^{\circ} \mathrm{C}$. High dry matter onion cv. Sherpa when stored in controlled atmosphere $\left(1 \%\right.$ or $0.5 \% \mathrm{O}_{2}$ with less than $0.3 \% \mathrm{CO}_{2}$ at $2{ }^{\circ} \mathrm{C}$ ) had an improved shelf-life (when tested for 3 weeks at $18^{\circ} \mathrm{C}$ after 9,27 and 36 weeks storage) compared with those stored in refrigerated condition (Praeger et al., 2003). Pyruvate concentration in onion-bulbs cv. Hysam decreased 9 weeks after storage at $0.5^{\circ} \mathrm{C}$ in the $\mathrm{CA}$ conditions $\left(2 \% \mathrm{O}_{2}, 2 \% \mathrm{CO}_{2}, 2 \% \mathrm{O}_{2}\right.$ and $\left.8 \% \mathrm{CO}_{2}\right)$ and increased in ambient atmospheric storage (Uddin and Mactavish, 2003).

\section{Processing}

Pickles: Pickled onions are very popular in UK and other European countries. The pickles can be made by the following methods.

Without fermentation: Select fully dried onions which are free from adhering soil and grade them according to the size. Remove outer layer of brown skin, tops and tails with a stainless steel knife. For pickling without fermentation, pack onions fairly tight in a cask and fill the cask with brine of 850 salometer. After 48 hours, run-off the brine and replace it with saturated brine. Fifty five grams of potassium metabisulphite for a 200 to 225 -litre cask may be added to bleach onions.

With fermentation: For adopting fermentation process, soak onions in water for 2-3 days then place them for a further period of 4-5 days in 5\% brine. This will leach out strong taste and give a whiter product. Drain brine and replace it with fresh brine of 600 salometer and increase this to 800 for longer storage. 
Drain brine from onions and leach out salt by soaking in hot water for about 12 hours. Run the water-off and pour $4 \%$ acetic acid solution over the onions. Allow mass to stand for 24 hours. Then remove onions from the cask. Fill them into wide mouthed bottles, covered with $5 \%$ acetic acid or white vinegar and seal bottles airtight. A few fresh red chillies and a small quantity of white mustard seeds may be added for better appearance. Suitable spice may also be added.

\section{Dehydration}

Preserving vegetables by drying them is one of the traditional methods. Sundrying, is however, good and housewives dry vegetables for off-season by this method. Onion slices, rings or shreds could be dried and packed in moisture proof containers like high-density polythene bags having gauge 750 or above, sealed tins or jars. The leaves are removed and onions are cut into $2.5-\mathrm{mm}$ thick slices. These slices are immersed in 5\% solution of common-salt for about 10 minutes and then drained. They are dried at $60-65^{\circ} \mathrm{C}$ for $11-13$ hours. However, it is better to keep temperature below $57^{\circ} \mathrm{C}$. The drying ratio depends on the varieties and varies from 1: 7 to $1: 9$.

Vijayalakshmi et al. (2005) studied dehydration of different forms of onions to suit varied needs of consumers and stated that moisture content of dehydrated onion products declined rapidly during the first month of storage and declined gradually during the second and third month. The vacuum packed samples had better quality and retained pungency than the control. There was a reduction in ascorbic acid content throughout the storage and only minimal increase in reducing and total sugars was noticed during storage. Browning of samples was observed during third month of storage, which made products less acceptable.

\section{Transportation}

Onion stocks are transported in tractor-trolleys and trucks. Railway wagons are used for longer distance transport within the country. Besides, onions are transported in ventilated ships as well as sailing vessels/motorboats for export to Gulf and South-East Asian countries. They are also shipped in 20-ft containers or 40-ft containers through ships.

For safe transportation of onions, sorting and grading must be practised thoroughly. Also suitable packages of jute having $9 \times 10$ mesh per inch ${ }^{2}$ should be used. It is desirable to have cushioning material below bags to avoid damage from jerks due to poor roads. Overloading should be avoided. Hooks should not be used while loading or unloading bags. Though losses on account of rotting are lower in trucks than wagons, transport by trucks is costlier than railway wagons. Further to save onions from damage due to high heat, modified ventilated wagons by providing ventilators should be used. For transportation of onions to foreign markets, particularly yellow onions, ventilated container vessels should be arranged to minimize losses. It is also better to load bags on pallets for easy handling at the destinations in importing country. Disinfection of containers and other transport means should also be practised. 


\section{Marketing}

About $10-15 \%$ of total production is exported and used for processing, and remaining produce is consumed internally or used as seed material.

Lasalgaon and Pimpalgaon in Nashik district in Maharashtra are the leading onion markets in India. About $40 \%$ of onion production arrives in these markets; totalling 4.5-5 lakh tonnes annually. Peak period of arrival in this market is December to June when $60 \%$ of the total arrivals are received. Chakan (Pune), Lonand (Satara), Gultekdi (Pune), Nashik, Dhule, Malegaon, Yeola, Niphad, Saikheda, Chandwad, Marunad, Dindori and Sinnar in Maharashtra are other major assembly markets for onion. Major markets for aggregatum onion are as follows.

Crop-growing districts in : Perambalur, Trichy, Dindigul, Namakkal,

Tamil Nadu

Major markets in Tamil Nadu Coimbatore, Erode, Tirunelveli

: Dindigul, Palani, Palladam, Madurai, Trichy, Ottanchathiram, Coimbatore and Chennai

Preferred variety

Grade specification

Various methods for sales followed in different assembling and distributing markets are: (1) open auction system, (2) tender system and (3) open agreement system.

Onions are also moved for exports to ports like Mumbai, Chennai and Tuticorin. All big city markets like Kolkata, Mumbai, Delhi, Guwahati, Bengaluru, Hyderabad and Kanpur are major consuming centres of onions.

\section{Seed production}

Production of quality seed is an important factor for successful onion cultivation (Tomar, 2005) with the growing consciousness about the high-yielding varieties among farmers. Onion is grown as a rabi crop in northern plains, while it is grown both as kharif and rabi crops in southern plains (Gupta et al., 1979). The time of planting is the most important factor in seed set (Mishra and Mishra, 1991). Delayed or early planting adversely affects seed yield (Sumanaratne, 2000).

Onion growth for seed production requires vernalization for flowering and cold stimulation for bolting (Rabinowitch, 1990). Mostly, bulb to seed method is used for seed production, since it permits selection of true-to-type and healthy bulbs with comparatively high seed yield.

The major constraint in the cultivation of aggregatum onion is the requirement of large quantity of seed-bulbs for planting and cost of planting material. For production of seeds, genotypes, which exhibit good seed-setting ability like Co (On) 5, Puttarasal type and Santhaipadugai local can be used. These genotypes showed both high bulb yield and better seed-setting ability. Growing of such seed-setting aggregatum onions commercially need standardized cultural practices.

Seed-setting season for aggregatum onion was studied with three genotypesCo (On) 5, Puttarasal type and Santhaipadugai local. The bulbs were planted in September, October, November and December. Among different genotypes, Puttarasal recorded better flowering and seed characters. Among different seasons, planting of bulbs during September recorded more flowering, seed yield and 
seedling vigour characters. It is recommended to plant aggregatum onion-bulbs during September for better seed yield and vigorous seedlings.

\section{Shallot (Allium cepa var. ascalonicum)}

All cultivated shallots, onions and leeks are hybrids-some are natural, some are not, but all of them are of obscure parentage. Shallots flower rarely, if ever, and multiplier onions, and in particular white ones, flower annually or at irregular interval. This clearly emphathetically indicates the necessity of vegetative propagation for production of traditional shallots.

Differences between shallots and multiplier onions are: shallots flower rarely and they on an average have two eyes per asymmetrical bulb while multiplier or potato onions, regardless of their size, usually have only one eye. There are some varieties that are intermediate between the two, as all $A$. серa are believed to be hybrids of various wild Allium species (Table 6.5).

Table 6.5 Allium species used as vegetables

\begin{tabular}{llcl}
\hline Botanical name & $\begin{array}{l}\text { Common } \\
\text { name }\end{array}$ & $\begin{array}{c}\text { Chromosome } \\
\text { number }\end{array}$ & Character \\
\hline Allium cepa var. cepa & Common onion $2 n=16$ & $\begin{array}{l}\text { Large bulbs, born singly, and } \\
\text { propagated through seeds. It is } \\
\text { mainly used as salad or in } \\
\text { curries }\end{array}$ \\
A.cepa var. ascalonicum & Shallot & $\begin{array}{l}\text { Produces bulbs in clusters on } \\
\text { the surface of the soil. This } \\
\text { perennial onion rarely } \\
\text { produces seeds and is } \\
\text { propagated through bulbs } \\
\text { Produces small bulbs borne in } \\
\text { clusters and is generally } \\
\text { propagated through small } \\
\text { bulbs. Mainly used for } \\
\text { seasoning curries }\end{array}$ \\
\hline
\end{tabular}

Source: Vishnu Swarup (2006)

\section{True shallots}

True shallots (A. cepa var. aggregatum) are grown primarily for their bulbs, although green tops may also be consumed. Each compound bulb consists of several sets/cloves ideally 30 to $40 \mathrm{~mm}$ in diameter, with brown skin and purplish tinge inside the bulb. These shallots are used in place of onions as they have a delicate, yet distinctive, flavour that persists even after cooking.

Medicinal properties: Shallot-bulbs have mild pungent taste and distinct smell as compared to onion and garlic. Shallots add flavour to dishes and is a popular ingredient used by chefs around the world. They are used as a condiment in various Asian cuisines in a finely sliced or deep-fried form, and are popularly used in cuisines like Malaysian and Thai. 


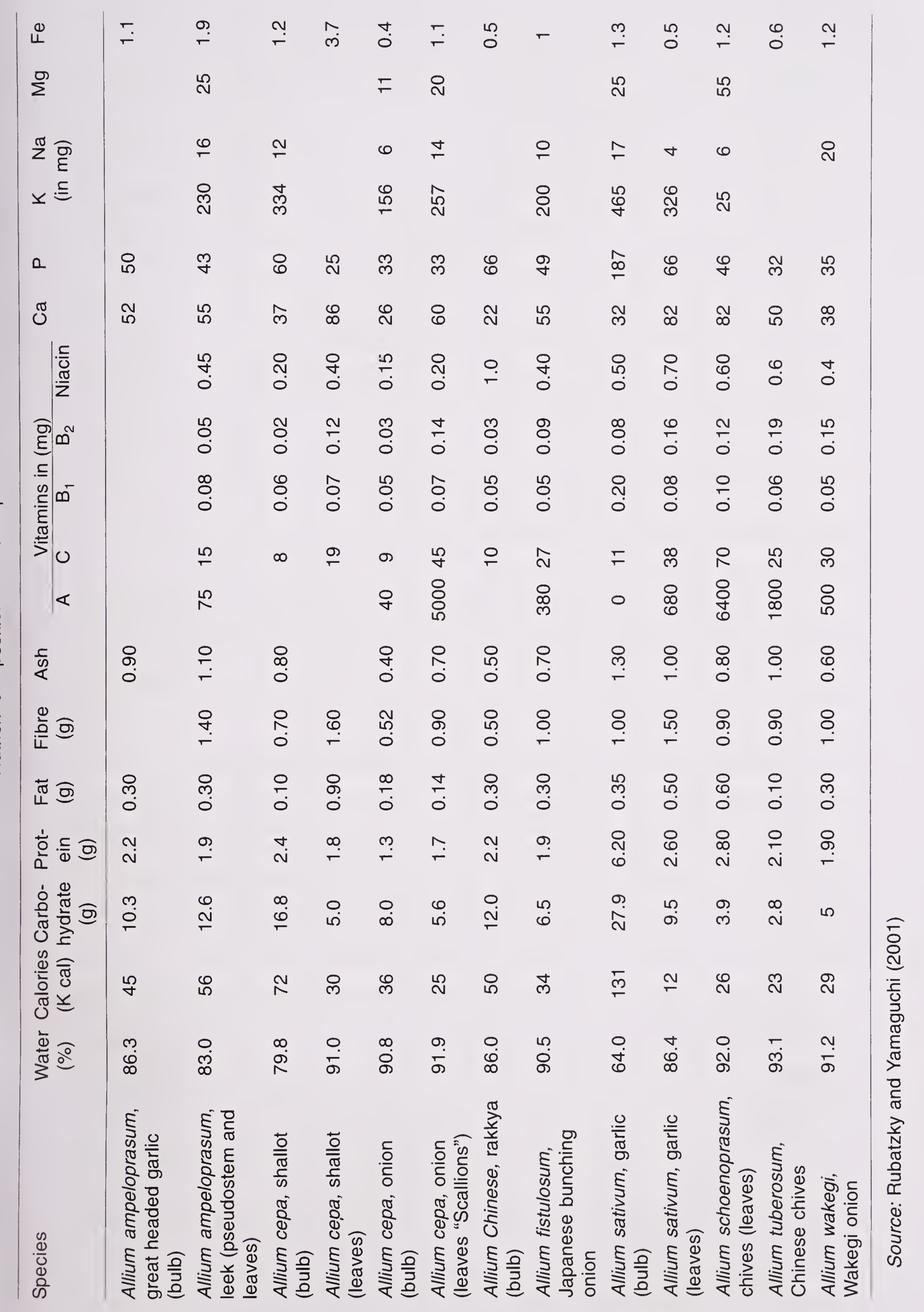


Shallots have various health benefits and have high nutrient content. Their bulbs contain antihelmintic, anti-inflammatory, antiseptic, antispasmodic, carminative, diuretic, expectorant, febrifuge, hypoglycaemic, hypotensive and lithontripic properties (Sheela et al., 1995; Augusti, 1996). Shallots contain very less amount of calories and loads of nutrients. Their calories depend on cooking procedure. Shallots are more nutritious than onions (Tables 6.6, 6.7). They have more minerals, vitamins, flavonoid, antioxidants like quercetin and kemferfol. Shallots contain iron, required for proper functioning of red blood cells and help in proper digestion also. Due to dietary fibre content, water is absorbed and stomach appears to be full after a meal. Shallots release sugar slowly in the bloodstream and helps soften stool and is a preventive for constipation. They are useful in reducing blood cholesterol level and are curative against many heart diseases. One cup of shallots yields $5.1 \mathrm{~g}$ of dietary fibres ( $20 \%$ of the daily required fibre for women and 13\% for men), and gives 534 milligrams of potassium ( $11 \%$ of daily required intake).

Shallots contain phyto-chemicals, allicin and allyl disulphide, which have antidiabetic properties: lower blood sugar level in diabetics. They are the richest source of vitamin A (an antioxidant), which protects eyes from harmful free radical damage, and promotes healthy immune system, and proper growth and development. Shallots are the oldest and the most efficient home remedies for hair growth. They are rich in sulphur that helps in production of collagen tissues.

\section{Varieties}

Red Sun: French-type with golden-red skin and reddish interior rings. Days to maturity 80.

Gray Shallots: 20 to 28 bulbs per pound.

Prisma: Hybrid, red-to-the-core bulb with strong onion flavour with highgloss finish, and long-day type. Days to maturity 100.

Bonilla: Hybrid, round, straw-coloured, thick-skinned, very pungent, whitefleshed, 2-inch bulbs. Produce 4 or 5 separate bulbs by mid-summer. Store well in spring and early summer. Days to maturity 100-105.

Olympus: Hybrid, produce 11/2 inch, white-skinned, white-fleshed bulbs. Stores well. Days to maturity 90.

Armador: Dia. 3 inch with deep-red colour. Produce only one bulb.

Ambition: Hybrid, large, French-style half-long teardrop-shaped bulbs with 
reddish-copper skin and creamy-white flesh. Suitable for long-term storage through spring. Best grown in northern climate. Days to maturity 100.

Holland Red: Short, plump, flat bulbs with reddish skin and white-flesh tinged with purple. Store well.

Matador: Dia.2 inch, round, reddish-brown, thick-skinned bulbs with white flesh. Days to maturity 90.

French Red: Single bulbs multiply into 10 to 15 reddish-purple shallots in just one season. Easy to peel. Days to maturity 100.

Mirage: Large, French, half-long style shallots with reddish-copper skin and white flesh. Very firm and can store through spring. Adaptability: $35-65^{\circ}$ latitude. Days to maturity 92.

French Gray: Plants produce pear-shaped, purple-fleshed bulbs with tough, thick, grey-blue, wrinkled skins. Days to maturity 100.

Picador: Large, French, half-long style hybrid. Plants produce single, reddishbrown bulbs with white flesh. Store well. Adapted for $35-65^{\circ}$ latitude. Similar to 'Ambition'. Days to maturity 105.

Pikant: Large, French style. Plants produce mahogany bulbs with reddish flesh. Store well. Adapted to $35-65^{\circ}$ latitude. Days to maturity 80 .

Saffron: Hybrid, produce bright copper-skinned bulbs with pale-yellow flesh. Store well. Adapted for 35-65 latitude. Days to maturity 100.

Conservor: Hybrid, produce single, reddish-brown bulbs. Similar to 'Ambition'. Store well. Adapted to $35-65^{\circ}$ latitude. Days to maturity 110.

Ed's Red: Plants produce 1- to 2-inch, red-skinned, red-fleshed bulbs. Days to maturity 100 .

\section{Cultivation}

Shallots are adapted to grow in cool mild to mild tropical climates. Seeds germinate at a temperature range of 10 to $30^{\circ} \mathrm{C}$, with an optimal germination temperature between 18 and $24^{\circ} \mathrm{C}$. The ideal growing temperature is in the range of 13 to $24^{\circ} \mathrm{C}$. Plantings should be timely to avoid periods when daytime temperature exceeds $27^{\circ} \mathrm{C}$. In most regions of Queensland, shallot production is restricted to winter and it stops before hot summer months. Only in areas where summers are very mild (e.g. Stanthorpe) they can be grown over summer months. Shallots can be grown over a wider climatic range than common onion as they do not have specific day-length or temperature requirement.

The best soil for growing shallots is deep, well-drained clay-loams of $p \mathrm{H} 6.5$ to 7.5 with high levels of organic matter. However, they have grown successfully on a wide range of soils, from relatively shallow, low- $p \mathrm{H}$ sandy soils to alkaline alluvial soils.

Land preparation reduces weeds to minimum. Ground should be worked to provide a fine tilth at planting. This may include ploughing, several discings and either one or two passes with a rotary hoe or a power harrow. A bed former is used to create beds (about 1.2-m wide) into which seed or seedlings will be planted.

Shallots are usually grown on beds of four to six rows; they may be planted as single rows $20-\mathrm{cm}$ apart or as three or four double rows on each bed. This is best achieved by using a precision planter, although it is not as critical for shallots as 
for other Allium species, as relatively high plant density is required. The seeding rate is around $8 \mathrm{~kg} / \mathrm{ha}$ to $10 \mathrm{~kg} / \mathrm{ha}$, at a depth of $1 \mathrm{~cm}$ to $2 \mathrm{~cm}$.

Direct-seeded shallots are planted dry, then are given a light irrigation. Frequent light irrigations of about $12 \mathrm{~mm}$ are required until plants emerge and develop a good root system. The top soil should not be allowed to dry until plants are well established.

Shallots have nutritional requirements similar to other alliums, removing about $130 \mathrm{~kg}$ of nitrogen $(\mathrm{N}), 30 \mathrm{~kg}$ of phosphorus $(\mathrm{P})$ and $60 \mathrm{~kg}$ of potassium $(\mathrm{K})$ per hectare, as well as other nutrients in smaller quantities.

They are ready for harvest in about 10 to 12 weeks after planting, but some hybrid varieties may mature a little earlier. Their stem should ideally be more than $25-\mathrm{cm}$ long and $8 \mathrm{~mm}$ to $10 \mathrm{~mm}$ in thickness. They are hand-pulled, washed and bunched with trimmed roots. Any damaged or diseased leaves should be removed, and then they should be packed in bunches of 10 to 12, depending on the size with a rubber-band or wrapped in plastic.

\section{References}

Abrol I P and Dixit S P. 1972. Studies of the drip method of irrigation. Journal of Experimental Agriculure 8: 171-75.

Adamicki F. 1998. Comparison of quality and storage ability in some onion cultivars. Biuletyn Wazzywniczy 48: 89-100.

Anbukkarasi V. 2010. 'Studies on pre and post-harvest treatments for extending shelf life in onion (Allium cepa. var aggregatum don.) cv. Co On 5'. Ph.D. Thesis, Department of Vegetable Crops, HC \& RI, TNAU, Coimbatore, Tamil Nadu, India.

Augusti K. 1996. Therapeutic values of onion and garlic. Indian Journal of Experimental Agriculure 34: 634-40.

Basu R N, Bose T K, Chattopadhyay K, Gupta N D, Dhar N, Kundu C, Mitra R, Lal P and Pathak G. 1975. Physio-chemical control of seed deterioration. Indian Journal of Agriculture 19: 91-96.

Benkeblia N, Onodera S and Shiomi N. 2004. Effect of gamma irradiation and temperature on fructans (fructo-oligosaccharides) of stored onion bulbs (Allium cepa L.). Journal of Food Chemistry 87: 377-82.

Benkeblia N, Varoquaux P, Shiomi N and Sakai H. 2002. Storage technology of onion bulbs cv. Rouge Amposta: Effects of irradiation, maleic hydrazide and carbamate isopropyl, n-phenyl (CIP) on respiration rate and carbohydrates. International Journal of Food Science and Technology 37: 169-75.

Bhonde S R, Srivastava K J, Qadri S M H and Bhagachandani P M. 1983. Studies on onion storage structures and reducing losses in onion storage, pp. 41-57. (In): Proceedings of National Workshop on Onion, held during December 1983 at Nashik, Maharashtra, India.

Brown B D, Hornbacher A J and Naylor D V. 1988. Sulphur-coated urea as a slow-release nitrogen source for onions. Journal of American Society of Horticulture Science 113: 864-69.

Gupta R P, Pandey U B, Singh L and Srivastava P H. 1979. Important onion disease and their control. Seeds and Farms 5: 17-19.

Hassan M S and Ayoub A T. 1978. Effects of N, P and K on yield of onion. Sudan Gezira Exp. Agric 14: 29-32. 
HC\&RI. 2013. Small onion, pp. 147-49. (In): Crop Production Techniques of Horticultural Crops. Horticultural College and Research Institute, TNAU, Coimbatore, India.

Kato T. 1966. Physiological studies on the bulbing and dormancy of onion plant. VIII. Relations between dormancy and organic constituents of bulbs. Journal of Japanese Society of Hortiulture Science 35: 142-52.

Kumaravelu K V. 2009. 'Evaluation of seed propagated cultivars of multiplier onion (Allium cepa L. var. aggregatum Don.).' M.Sc (Hort). Thesis, Dept of Vegetable Crops, HC \& RI, TNAU, Coimbatore, Tamil Nadu, India.

Maiti S C and Sen P R. 1968. Onion, pp. 622-41. (In): Vegetable Crops in India. 2nd Edn. Naya Prakash, Bidan Sarani, Kolkata, India.

Mayura A N and Lal S. 1975. Effect of zinc on yield of bulbs crops. Punjab Horticultural Science Journal 15: 61-66.

Mishra H P and Mishra B. 1991. Effects of planting dates and bulb size on the yield components of onion seed crops. Indian Journal of Agricultural Research 25: 107-12.

Pandey U B, Bhonde S R and Singh D K. 1999. Effect of maleic hydrazide and in combination with fungicides, on post-harvest losses in storage of rainy-season onion. Acta Horticulturae 358: 285-88.

Patel J D, Dasale G Y and Kale P N. 1988. Storage studies in onion. Journal of Maharashtra Agricultural University 13: 91-93.

Praeger U, Ernst M K and Weichmann J. 2003. Effect of ultra low oxygen storage on post harvest quality of onion bulbs (Allium cepa L. var. cepa). European Journal of Horticultural Science 68: 14-19.

Rao D V R and Chundwat B S. 1990. Effect of certain ripening retardants on post harvest behaviour of banana at non-refrigerated temperature, pp. 34-47. (In): Advances in Horticulture and Forestry, Vol. 1. Scientific publishers, Jodhpur, Rajasthan, India.

Rao V J M and Deshpande R. 1971. Effect of micronutrients copper and boron on the growth and yield of onion (Allium cepa. L.). Indian Journal of Agricultural Research 5: $257-60$.

Rathore S V S and Yadav B S. 1971. Performance of bulb crop of onion as affected by sowing dates and age of transplants. Progressive Horticulture 3: 29-33.

Rathore S V S and Kumar R. 1974. Alliums, pp. 105-11. (In): Vegetable Crops in India. Naya prakash, Bidhan Sarani, Kolkata, India.

Robinowitch H D. 1990. Physiology of flowering, pp. 113-34. (In): Onions and Allied Crops. Vol. 1. Robinowitch and Brewster (Eds). CRC Press, Inc., Boca Raton, USA.

Rubatzky and Yamaguchi. 2001. World Vegetables, Principles, Production and Nutritive Values. Dept of Vegetable Crops, University of California, Davis, USA.

Shanmugavelu K G. 1989. Production Technology of Vegetable Crops. Oxford \& IBH Publishing Co., Pvt. Ltd, New Delhi, India.

Sheela C, Kumud K and Augusti K. 1995. Anti-diabetic effects of onion and garlic sulfoxide amino acids in rats. Planta Medica 61: 356-57.

Shirgure P S, Srivastava A K and Singh S. 2000. Fertilization and drip irrigation in Nagpur Mandarin (Citrus reticulata Blanco). South Indian Horticulture 49: 95-97.

Singh K and Kumar S. 1972. Effect of nitrogen and phosphorus fertilization on the growth and yield of onion (Allium cepa L.). Journal of Research, Ludhiana 6: 764-68.

Sumanaratne J P. 2000. True seed production, Red onion. Chapter 3, pp. 20. (In): Other Field Crops. Department of Agriculture at the turn of century, DOA, Peradeniya.

Thomas T H. and Isenberg F M. 1972. Hormone physiology of onion bulbs during dormancy. Experimental Horticulture 23: 48-51.

Tomar B S. 2005. Quality Seed Production of Onion. Seed production unit. Indian Agricultural Research Institute, ICAR, New Delhi, India. 
Uddin M and Mactavish H S. 2003. Controlled atmosphere and regular storage induced changes in S-alk (en) yl-L-cysteine sulfoxides and allinase activity in onion bulbs (Allium cepa L. cv. Hysam). Post harvest Biology Technology 28: 239-45.

Veeraragavathatham D, Jawaharlal M and Seemanthini Ramadas. 1998. A Guide on Vegetable Culture, pp. 216-18. Suri associates. Coimbatore, Tamil Nadu, India.

Verma, J P, Rathore, S V S and Ram, V. 1972. Effect of level of nitrogen and spacing on the performance of the bulb crop of onion (Allium cepa. L.) Horticulture Abstracts 44: 5739 .

Vijayalakshmi R, Arun Kumar R and Malathi D. 2005. Studies on dehydration of onion products. South Indian Horticulture 53: 142-49.

Vishnu, S. 2006. Vegetable Science and Technology in India. Kalyani publishers, New Delhi, India.

Warade A D, Gonge V S, Bharad S G, Ingole P G and Nandre D R. 2008. Influence of integrated weed management on growth and yield of onion (Allium cepa L.) Plant Achieves 8: $325-28$.

Warade A D, Gonge V S, Jogdande N D, Ingole P G and Karunakar, P. 2007. Integrated weed management in onion. Asian Journal of Horticulture 2: 205-08.

Yawalkar, K S, Jakate P N and Srivastava, M M P. 1962. Commercial Fertilizers in India. Agri-Horticultural Publishing House, Nagpur, Maharashtra, India.

Zink, F W. 1966. Studies on the growth rate and nutrient absorption of onion. Hilgardia 37: 203-18.

http://www.goodhousekeeping.com/recipes/cooking-tips/shallots-onions.2008.

http://www.the-gardeners-calendar.co.uk/Plant_Database/plants.asp?p=3.2014.

http://www.nutrition-and-you.com/shallots.html.2009-14.

http://www.ncbi.nlm.nih.gov/pubmed/8979497.2014.

http://www.webmd.com/vitamins-supplements/ingredientmono-643-onion.aspx? Active ingred ientid $=643 \&$ activeingredientname $=$ onion $.2005-14$.

http://www.onions-usa.org/img/site_specific/uploads/phytochemical_brochure.pdf.2013 http://www.lifesciencesite.com/lsj/life0902/115_9105life0902_775_780.pdf.2012. 


\section{Biotechnology}

D.C. Lakshmana Reddy, S. Anandhan and C. Aswath

Biotechnological tools for onions namely - tissue culture for production of doubled-haploids, somatic embryogenesis, transgenic development; use of molecular markers for diversity analysis, varietal identification, colour and quality improvement, male-sterility analysis; and the latest efforts for genome sequencing in Alliums-have been detailed in the following paragraphs.

\section{In-vitro Techniques}

In-vitro culture is a technology that includes broad areas of cell, tissue and organ culture, and has played an important role in breeding, production and improvement of crops. Non-conventional techniques for breeding such as gynogenesis, gene transfer through wide-hybridization and genetic transformation have been used extensively for onion improvement. Parthasarathy and Nagaraju (2001) have presented a detailed review on the biotechnology of onions, including various invitro techniques.

\section{Plant regeneration-Organogenesis and somatic embryogenesis}

Kahane et al. (1992) succeeded in cultivating onion-plants in-vitro with a high potential of shoot regeneration from the basal plate, where apex may have been destroyed or injured for multiplication of axillary buds. A procedure for bulb formation from onion, garlic, and shallot using cut-stem bases as explants was described by Mohamed et al. (1995). Adventitious shoots were induced on twin scales cut from small bulbs and on split in-vitro shoots as secondary explants (Hussey and Falavigna, 1980). A novel method of direct organogenesis in onion resulting in formation of multiple shoot structures induced on mature flowerbuds or ovaries in a two-step culture procedure was described by Luthar and Bohanec (1999). Shoots were produced on explants from flower-head receptacles in A. porrum (Novak and Havel, 1981). Different organogenic responses like induction of multiple shoots from shoot tip (Khar et al., 2002a), seeds, flowerbud (Asha Devi and Khar, 2000) and root tip (Khar et al., 2002b) were studied in a few short-day Indian onions. Somatic embryogenesis was observed in callus cultures of $A$. cepa, A. fistulosum and of $\mathrm{F}_{1}$ hybrids between $A$. cepa and $A$. fistulosum. Seedling shoot meristem-tip explants were successfully used by Phillips and Luteyn (1983) for having high frequency somatic embryogenesis from two onion lines, 'Yellow Grano' and 'Yellow Sweet Spanish'. Somatic embryogenesis for having true-to-type and more number of plants was reported from mature 
zygotic embryos of A. cepa, A. fistulosum, their interspecific hybrids, and from mature seeds, flower-buds, immature zygotic embryos and mature flower-buds or ovaries of $A$. porrum.

\section{Doubled-haploids production}

Doubled-haploids (produced after doubling of haploid chromosomes) gained importance for generating homozygous and homogenous populations for varietal improvement in self-pollinated crops, inbred development in cross-pollinated crops and for experiments involving use of plants with uniform genetic background. Though chromosome doubling is daunting task in many crop species, haploid induction is an attractive area for plant breeding and has become important used technique for generation of homozygous populations.

Attempts to produce haploid plants via androgenesis failed; as reviewed by Keller and Korzun (1996). The first report on successful haploid induction via gynogenesis by using unpollinated ovaries was by Muren (1989), which was followed by other researchers. Several attempts to improve haploid induction procedure using different cultural conditions or altering media components were tested later. Effects of media additives for increased haploid induction were also studied. Effects of flower part, cultivar and megaspore development stage on the plant and haploid regeneration frequency from in-vitro culture were investigated, and some researchers reported unpollinated flower-buds and ovaries as better explants for haploid induction, while others opined that ovary or flower culture showed similar induction frequency.

Haploid induction was reported from in-vitro gynogenesis from isolated flowerbud culture (Campion et al., 1992; Bohanec and Jakše, 1999). In-situ induction of maternal haploids was also achieved by pollination with irradiated pollen (Dore and Marie, 1993) and with sterile pollen from triploid donor in the case of shallot onion (multiplier type) (Endang-Sulistyaningsih et al., 1997). To induce regeneration through androgenesis was not successful (Keller, 1990a). There are only a few reports on the isolated flower-bud culture (Campion et al., 1992; Bohanec and Jakše, 1999); may be due to comparatively low rate of haploid induction in other methods than in-vitro gynogenesis.

Genetic factors: Gynogenic induction is a routine method for haploid regeneration in onions (Muren, 1989; Campion and Alloni, 1990; Keller, 1990). The gynogenic response has been reported to vary in genotypes originated from different regions of the world. Many American long-day onion genotypes (Bohenac and Jakse, 1999) showed highest gynogenic potential $\left(51.5 \%\right.$ in Rocket $\mathrm{F}_{1}$ ). Shallot-type onions are reported to possess the highest $(55.2 \%)$ regeneration efficiency (Cohat, 1994). In bulb-onion, gynogenic efficiency varied even over seasons as was reported by Geoffriau et al. (1997), however, Bohenac and Jakse (1999) reported a few genotypes which were stable in gynogenic efficiency over seasons.

Possible variation in the regeneration efficiency in individual plant population may be due to genetic structure of the population. Inbreds and synthetics performed better than open-pollinated populations (Geoffriau et al., 1997) which might be due to recessive genes in the population affecting embryo development efficiency. 
There could be possibly two levels of genetic effects on the genotype of the donor and genetic structure of the population. The genotypes also vary in response on the days taken for regeneration; only a few reports are available on the duration required for regeneration. Further, even the time requirement also varied with season. Systematic study on the genetic the effects of gynogenesis revealed that gynogenic potential was controlled by recessive factors and it displayed nonadditive action (Bohenac et al., 2003).

Explant selection: Ovule, ovary and unpollinated flower-bud are used as explants for gynogenic studies. In unpollinated flower-bud culture, stage of the flower plays an important role in determining its gynogenic efficiency. In general, large size buds yield higher number of gynogenic plants (Campion and Alloni, 1990), which can be correlated with embryo-sac maturity. Flower-buds, which were to open in 3-5 days, responded better than small buds (Smith et al., 1991). In an intercross $\mathrm{BC}_{1} \mathrm{~F}_{1}$ population of $A$. cepa $\times A$. roylei, only small buds responded for gynogenic induction (Alan et al., 2003). Diversity among the Allium species indicates possible strategy needed while dealing with the interspecific hybrids, which are targeted to transfer desirable traits.

Ovary culture is generally used for in-vitro seed development and haploid production. It is also being used for recovery of interspecific hybrids among many Allium species. About nineteen species belonging to different subgenera of Allium were crossed to onion-seed parent, and from 18 crosses, hybrids were successfully obtained through ovary culture (Keller et al., 1996). Ovule culture (Ohsumi et al., 1993), embryo culture (Dubouzet et al., 1998; Dubouzet et al., 1998) or combination of both (Peterka et al., 1997; Gonzalez and Ford-Lloyd, 1987), were also employed for production of interspecific hybrids. Usually flowers are pollinated in the field and ovaries are excised after pollination. The excision of the ovaries vary with crosses as it depends on the stage of the embryo degeneration in-vivo. But early excision, i.e. immediately after style senescence, was successful for crossing many species (Keller et al., 1996).

Pre-treatment: As the floral explant is derived from the stock-plant, the environment in which it grows may also affect gynogenesis potential. A ten-fold increase in embryogenesis was observed when flower-buds were cultured from stock-plants maintained at $15^{\circ} \mathrm{C}$ compared to $10^{\circ} \mathrm{C}$ or at ambient temperature of a glasshouse (Puddephat et al., 1999). Temperature improved gynogenesis efficiency than time required to embryo germination. The effect could possibly be due to elimination of variations in the external factors. Exposure of cut-umbels for 4-23 days to water at $10^{\circ} \mathrm{C}$ had efficiency comparable with fresh buds (Alan et al., 2004). A part from environmental factors, pre-conditioning with a spray of CCC and an injection of putrescine (Ponce et al., 2006) at lower concentrations was observed improving gynogenic efficiency.

Culture medium: Apart from genotypic factors, medium composition was found to affect to some extent gynogenesis efficiency. High sucrose concentration (10\%) (Muren, 1989) and high level of growth regulators (2, 4-D and BAP each at $2 \mathrm{mg} / \mathrm{litre}$ ) (Campion et al., 1992;Bohanec and Jakše, 1999) in the medium promoted gynogenesis in onion. Other growth supplements like polyamines were reported to be essential for growth and development of living tissues (Geoffriau 
et al., 2006). Putrescine and spermidine induced onset of embryogenesis and increased number of gynogenic embryos and plantlets of onions (Martínez et al., 2000). The gelling agent is another factor that may contribute to success of the technique. Jakše et al. (1996) reported that gellan gum (Gelrite) doubled number of regenerated embryos, compared to agar-solidified medium.

Chromosome doubling: Although several groups have shown that gynogenesis can be achieved in a wide range of onion materials; reports of successful application of the system to onion improvement are rather limited. Barriers include variations in donor response to induce gynogenesis (genotype specificity), low frequency of diploid regenerants and lack of efficient chromosome doubling procedure. Spontaneous chromosome doubling is rare in the gynogenic onion-plants; usually induced chromosome doubling is required to re-establish diploidy and fecundity. There are a few published procedures for obtaining DH gynogenic onion-plants, and they are limited to in-vitro plants (Alan et al., 2004; Geoffriau et al.,1997; Campion et al., 1995) and emerging plantlets (Jakse et al., 2003; Grzebelus et al., 2004). Based on the explants used in chromosome doubling treatment, procedure can be categorized as split basal (Geoffriau et al., 1997; Campion et al., 1995), intact plantlet (Jakse et al., 2003; Grzebelus and Adamus, 2004), and whole basal (Alan et al., 2004). In protocols for split basal explants, lower portions of the young in-vitro gynogenic plants are longitudinally sliced into halves or quarters to allow exposure of damaged apices to anti-mitotic chemicals and then they are cultured in regeneration medium with or without growth regulators. Campion et al. (1995) suggested treatment of split basal halves with $25 \mathrm{mM}$ colchicine for 72 $\mathrm{hr}$ in solid medium that resulted $46 \%$ diploid regenerants; as determined by chromosome counts in shoot apices. According to Geoffriau et al. (1997), the best doubling efficiencies were achieved by treatment of split basal quarters with $2.5 \mathrm{mM}$ colchicine or $50 \mathrm{mM}$ oryzalin for $24 \mathrm{hr}$, yielding 65.7 and $57 \%$ diploid regenerants, respectively. However, the split basal explant method did not perform well owing to losses of treated explants up to $85 \%$ (Alan et al., 2004). According to Jakse et al. (2003) and Grzebelus and Adamus (2004), a strategy based on the treatment of intact plantlets with antimitotic chemicals for $24-72 \mathrm{hr}$ in liquid or solid medium can help re-establish diploid state in about one-third of the surviving gynogenic plants. This approach has many drawbacks-high mortality of treated explants, inability to determine whether diploid plants are of spontaneous or induced origin, and loss of spontaneous diploid plants due to cytotoxicity or polyploidization. An alternative is to induce spontaneous doubling in plants from flower-bud culture (Alan et al., 2007). Sixty per cent regenerants obtained from flower-buds of haploid plants were diplodized.

Origin of gynogenic embryo: In-vitro gynogenesis in A. cepa revealed that there was no callus formation before regeneration of gynogenic plants (Muren, 1989; Campion and Alloni, 1990). A low percentage of callusing ovaries was observed only by Keller (1990). Musial et al (2001) confirmed that gynogenic embryos were produced directly from a reduced cell of female gametophyte and embryo developed from egg cell (parthenogenesis). In in-vitro cultures of A. cepa, endosperm develops autonomously without fertilization (Musial et al.,1999, 2000). Induction of multicellular endosperm is common in in-vitro cultures, and 
endosperm can also develop from unfused polar nuclei of embryo-sac (Musial et al., 2001).

Application of DH inbreds: DH plants are a valuable resource in a number of crop species, both for rapid generation of inbred lines for hybrid production and for creation of recombinant inbred lines (RILs), useful for developing molecular markers, mapping genes of interest, and detecting QTLs affecting quantitative traits. When working with a trait that is difficult to screen on a single plant basis, generation and evaluation of lines with fixed loci is of considerable value.

\section{Protoplast fusion}

Somatic hybridization is used to create variability in nuclear and cytoplasmic genomes; but there are a few reports for its use in Alliums. Polyethylene glycol (PEG)-based fusion of protopiast was reported between $A$. ampeloprasum and $A$. cepa (Buiteveld et al., 1998) and A. sativum and A. monanthum (Kim et al., 1986). Chromosomal elimination was observed in somatic hybrids (Buiteveld et al., 1998). Though there were many reports of use of interspecific gene transfer, the hybrids displayed either sterility or reduced fertility (Peterka et al., 1997). This could be possibly due to variations in ploidy (Yanagino et al., 2003; Peterka et al., 1997) or aberrations in meiotic pairing of chromosomes (Kielkowska, 2012).

\section{Genetic transformation in Allium}

Introduction of genes into crops through biotechnological approaches acts as a complement to field-breeding programme. An efficient in-vitro regeneration system is a prerequisite for genetic transformation in any crop. It provides opportunity to introduce genes across barriers of reproduction. Also the recent developments, like silencing targeted genes specifically using RNAi technology, provide opportunity to develop resistance or tolerance to biotic stresses where source is not available within crossable germplasm.

Explants and regeneration system for Alliums: Regeneration has been achieved through somatic embryogenesis, direct regeneration and callus induction in onion (Eady et al., 2000; Aswath et al., 2006) and shallots (Zheng et al., 2000). For genetic transformation in A. cepa, callus from immature embryo has been preferred. Callus from other explants like root and root-tip (Zheng et al., 2004), stem disc (Xu and Cui, 2007), immature leaf tissue (Kenel et al., 2010) has also been proven useful for transformation. When the callus is used for regeneration, efficiency decreases with age, and aged callus (more than 3 months) are not preferred. Root explants are preferred over embryo explants as roots can be obtained from aseptic cultures, and thus contamination can be avoided.

Transformation: As monocotyledons, Allium species are predisposed to be recalcitrant to transformation. By mid-nineties, both particle bombardment and Agrobacterium-mediated DNA delivery systems were successfully used for transformation with uid a ( $\beta$-glucuronidase) reporter gene. Microprojectile bombardment for transformation was employed on onion (Xu and Cui, 2007). Degradation of naked DNA in the tissue affects transformation efficiency, and treating tissues with nuclease inhibitor [aurintricarboxylic acid $(2 \mathrm{mM})$ ] improved 
transformation efficacy (Barandiaran et al., 1998). But Agrobacterium-mediated transformation was frequently used, and it was established to be valuable for different species of Allium. This could possibly be because of the ease of use even in small lab and availability of chemicals like acetosyringone, which proved effective for infecting Agrobacterium in monocots. Variations in efficiency could be due to the methods or inherent variations among genotypes for competency to transformation.

Agrobacterium-mediated transformation was successfully carried out using immature embryos as explants (Eady et al., 2000). Recently, Zheng et al. (2001) developed a reproducible Agrobacterium tumefaciens-mediated transformation system for onion and shallot with young callus, derived from mature embryos with two different Agrobacterium strains. In India, Khar et al. (2002b) reported, callus to be the best explant in onion for genetic transformation, followed by shoot-tip and root-tip. A common feature among transformation studies in onion was the use of immature embryos as target explants due to their excellent morphogenetic competence (Eady et al., 1996, 2000). However, contamination rate in these explants ranged from 40 to $100 \%$; probably from infected embryos. Zheng et al. (2001) used mature embryos, which were tedious to remove, and required stereomicroscope to identify shoot-apex portion. Klein et al. (1987) and Scott et al. (1999) used epidermal tissues with high velocity microprojectiles resulting in transient expression of chloromphenicol acetyl transferase and green fluorescent protein genes, respectively. Contamination rate was also high in epidermis. Seedling radicle, which is in no way inferior to other explants, has an added advantage of ease in extraction with zero contamination.

Selectable markers: The most common selective protocols for plant transformation are the use of kanamycin, hygromycin and phosphinothricin. In onion, Eady and Lister (1998) demonstrated kanamycin ineffective up to $200 \mathrm{mg}$ / litre and they used 50-100 mg/litre geneticin. Kanamycin is not recommended for spray, as it is expensive (Altmann et al., 1992); Though hygromycin is moderately expensive and works well both in medium and soil, it is not recommended because of its high toxicity to humans (Altmann et al., 1992); even 20-50 mg/litre hygromycin in onion resulted in a few escapes (Eady and Lister, 1998). Phosphinothricin is an excellent marker for soil-grown plants. Selection on culture medium-plates requires purified and expensive phosphinothricin. Additionally, a large number of escapes were noticed during selection on a medium containing 10-30 mg phosphinothricin/litre (Eady et al., 2000). Unlike most selectable markers, pmi confers a positive advantage to plants grown in tissue culture using mannose, which is a carbon source. In addition it does not lead to necrotic cells, which may release toxic compounds, and thus is non-toxic to humans. Mannose selection of resistant plants works equally well in soil and in medium-plates, and is very cheap, perhaps the least expensive among all the agents (Todd and Tague, 2001).

As there is growing concern for use of antibiotic markers for transgenic selection, the efficiency of selection using bacterial pmi gene (phosphomannose isomerase) was demonstrated in onion by Aswath et al. (2006). The pmi gene helps cells utilize mannose as carbon source, thus providing positive selection for 
transformed cells. The selection system used Escherichia coli gene that encodes phosphomannose isomerase (pmi). Transgenic plants carrying mannose gene that codes pmi can detoxify mannose-6-phosphate by conversion to fructose-6-phosphate, an intermediate of glycolysis via pmi activity. Six-week-old embryogenic callus initiated from seedling-radicle was used for transformation. Transgenic plants were produced using Agrobacterium and biolistic system, with transformation rate of 27 and $23 \%$, respectively. Untransformed shoots were eliminated by a stepwise increase from $10 \mathrm{~g}$ sucrose/ litre with $10 \mathrm{~g}$ mannose/litre in the first selection to only $10 \mathrm{~g}$ mannose/litre in the second selection. Integrative transformation was confirmed by PCR, RT-PCR and southern hybridization.

Traits: Resistance against beet armyworm (Spodoptera exigua Hubner) in shallots was the targeted trait to be developed through cry genes (Zheng et al., 2005). OSISAP1 gene was used to impart salt tolerance in onion, and transgenic plants showed survival up to $400 \mathrm{mM}$ of $\mathrm{NaCl}$, and control plants showed mortality at $200 \mathrm{mM}$ of $\mathrm{NaCl}$ (Xu and Cui, 2007). Imai et al. (2002) have discovered an enzyme, which catalyzes specifically lachrymatory factor, named as lachrymatory factor synthase (lfs). This has led to the development of genetically modified onions that do not bring tears while chopping, and hence can be aptly named as "tearless onions". Eady et al. (2008) used RNAi to develop tearless onions by silencing lachrymatory factor synthase gene. Silencing of lfs also induced metabolic changes.

There are many traits of economic importance which need to be further explored, like purple blotch and a few for viral resistance in vegetative Alliums.

\section{Molecular Breeding}

Research on physiological, biochemical and genetic traits of Alliums is gaining momentum. With the advent of molecular techniques, it has been possible to study evolutionary details and differentiate cultivars for germplasm management, patent protection and detection of major genes of economic importance. In onion-crop, these techniques are being used in a moderate way. Markers are of two typesisozymes and DNA markers. The latter are preferred because of their polymorphic nature, co-dominance, selective neutral behaviour, easy and fast assay, high reproducibility and easy exchange of data between laboratories (Joshi et al., 1999). There are different marker systems available for crop-plants such as restriction fragment length polymorphism (RFLP), random amplified polymorphic DNA (RAPD), inter simple sequence repeat (ISSR), microsatellite or simple sequence repeat (SSR), amplified fragment length polymorphism (AFLP), sequence characterized amplified region (SCAR), cleaved amplified polymorphic sequences (CAPS) and single nucleotide polymorphism (SNP) etc. (Semagn et al., 2006).

In spite of advances in sequencing technologies, sequencing of onion ( $A$. серa) remains a huge challenge because of its 16.4 giga base genome size. It has one of the largest nuclear genome (Arumuganathan and Earle, 1991). The use of genetic markers in Alliums has increased several-fold with the development of different marker systems. 


\section{Development of genomic resources in Alliums}

With the development of different easy tools and protocols, SSR development has been initiated in Alliums. Tsukazaki et al. (2006) isolated more than hundred simple sequence repeats (SSRs) of clones from size-fractionated genomic DNA libraries of Japanese bunching onion. The clones were highly polymorphic and cross applicable to related species such as bulb onion. They have showed that bunching onion SSRs are very rich source of highly informative genetic markers; by isolating 1,796 SSR clones by large-scale sequencing of SSR-enriched genomic DNA libraries (Tsukazaki et al., 2007). Of these, $74.1 \%$ contained (GT) ${ }_{n}$ repeats $(\mathrm{n}>5)$, while $17.5 \%(\mathrm{GA})_{\mathrm{n}}$-contained clones. The average number of SSR repeats was 10.5 and 10.4 in the $(\mathrm{GT})_{\mathrm{n}}$ and $(\mathrm{GA})_{\mathrm{n}}$-containing clones, respectively. The MISA (Microtellite identification tool) programme has revealed 336 dinucleotide to hexa-nucleotide SSRs among 313 unique onion ESTs; representing a frequency of $1 \mathrm{SSR} / 25 \mathrm{~kb}$, similar to $1 \mathrm{SSR} / 27.2 \mathrm{~kb}$ in the survey of higher plants (Cardle et al., 2000). Joseph et al. (2004) generated 11,008 unique ESTs from a normalized cDNA library of the onion to assess genomic differences between Asparagales and Poales; sequence analyses of these ESTs revealed microsatellite markers, single riucleotide polymorphisms and homologs of transposable elements.

Molecular markers development in Allium have been restricted due to giga base genome size and costs of sequencing. Expressed sequence tags (ESTs) from the onion, that showed significant similarities (70-80\%) to single positions in rice genome, revealed scant co-linearity, demonstrating grasses are not appropriate genomic models for Asparagales; this indicated necessity to develop genomic resources for these important plants (Martin et al., 2005). Tsukazaki et al. (2009) developed a SSR tagged breeding scheme for bunching onion (A. fistulosum). Samantha et al. (2010) reported application of Roche 454 technology to develop sequence resources for population analyses and genetic mapping. So far, 170 genomic SSRs, 9 EST-SSRs, 31 Indels and 156 CAPS markers have been developed and tested (Table 7.1).

Table 7.1 Development of SSRs in Alliums

\begin{tabular}{|c|c|c|}
\hline Method & Marker developed & Reference \\
\hline MISA programme & Revealed 336 SSRs, 1 SSR/25kb & Cardle et al., 2000 \\
\hline $\begin{array}{l}\text { Normalized CDNA } \\
\text { library of onion }\end{array}$ & 11,008 unique ESTs generated & Joseph et al., 2004 \\
\hline $\begin{array}{l}\text { Size fractionated } \\
\text { genomic library }\end{array}$ & $\begin{array}{l}\text { Thirty-two SSR and } 18 \text { bulb onion } \\
\text { expressed sequence tag (EST) }\end{array}$ & Tsukazaki et al., 2006 \\
\hline $\begin{array}{l}\text { Large-scale sequencing } \\
\text { of SSR-enriched } \\
\text { genomic DNA libraries }\end{array}$ & 1,796 SSRs isolated & Tsukazaki et al., 2007 \\
\hline Roche 454 technology & $\begin{array}{l}170 \text { genomic SSR, } 9 \text { EST SSR, } \\
31 \text { InDels and } 156 \text { CAPS markers } \\
\text { developed }\end{array}$ & Samantha et al., 2010 \\
\hline
\end{tabular}




\section{Molecular markers in diversity analysis and varietal identification}

RAPD, AFLP, ISSR markers are widely used by onion-breeders due to their low cost, simplicity and absence of prior sequence information in Alliums diversity (Table 7.2). Knowledge on molecular genetic diversity perhaps helps in efficient management of germplasm pool, drawing of mini-pool, and selection of parents in crossing progeny for various commercial traits. Diversity analysis of seven cultivars of $A$. cepa and single cultivar of Japanese bunching onion, chive, leek and a wild relative of onion (A. roylei) with RAPD showed $A$. roylei as the closest relative of $A$. cepa, putting a question at the current classification of $A$. cepa in section Rhizideum (Susan et al., 1993). Mes et al. (1998) included 29 species of Allium and seven species of related genera in a phylogenetic study using RFLP data from PCR amplified cpDNA for differentiating between subgenera Rhizirideum and Allium. Their study confirmed artificial nature of subgenera Rhizirideum, Bromatorrhiza and Allium. Phylogenetic relationships between Allium and Milula spicata, a rare Central Himalayan-south-eastern Tibetan endemic species, closely related to genus Allium, were analyzed using molecular markers, which unambiguously placed the former within Allium subgenus Rhizirideum. These studies help in addressing crop evolution and the interrelationships of cultivars and varieties. The determination of genetic diversity of crop accessions is of direct use in a gene bank, both to access value of a collection and to direct future collection missions. Sangeeta et al. (2006) used 90 RAPD primers and grouped 24 onion cultivars into northern and southern region of India. Ten varieties of onion (A. cepa) were analysed by Maniruzzaman et al. (2010), and they found, Bermis and India-2, most dissimilar, while Faridpuri and Bhati were most similar genetically.

Table 7.2 Diversity analysis and fingerprinting of Alliums using molecular markers

\begin{tabular}{lll}
\hline Marker & Population & Reference \\
\hline RAPD & Cultivars of onion, chives, bunching onion and leek & Susan et al., 1993 \\
RAPD & 24 cultivars of short-day onions & Sangeeta et al., 2006 \\
ISSR & 32 onion cultivars & Qijiang et al., 2007 \\
SSR & Fourteen short-day and two long-day onion cultivars & Mahajan et al., 2009 \\
EST SSR & Tropical Indian onion & Khar et al 2010 \\
ISSR & In-vitro regenerated clones for fidelity test & Gantait et al., 2010 \\
RAPD & 10 varieties & Maniruzzaman et al., 2010 \\
AFLP & Argentinean collection & Lampasona et al., 2012 \\
\hline
\end{tabular}

Abdoli et al. (2009) found paradox in genetic diversity detected by RAPD technique with reference to geographical origins of onion. This may be due to limited genome coverage and poor reproducibility of RAPDs; it indicated the need of alternative more efficient marker systems.

ISSRs exhibit high specificity like microsatellite markers, but can be used on genome with no sequence information for primer synthesis, enjoying advantage of random markers (Joshi et al., 2000). Thirty-two onion germplasm resources analysed using ISSRs, divided them into five groups-first group consists of 
Yellow sweet Spanish system; second with Bejo Dyatona cultivar; third Yellow Globe system; fourth Yellow Globe Danvers system; and fifth group with Yellow Danvers system (Qijiang et al., 2007). The exotic cultivars Alisa Craig and Brigham Yellow Globe were different compared to Indian cultivars, and Nashik Red and Poona Red were indistinguishable and similarly N 53 and Bombay Red were quite close (Mahajan et al., 2009). The genetic fidelity of in-vitro regenerated clones of $A$. ampeloprasum and A. sativum, using 10 ISSR primers, revealed significance of shoot-tip explants in maintaining their regeneration frequency with morphogenetic competence even after prolonged in-vitro culture (Gantait et al., 2010). Jakse et al. (2005) identified 398 SNP, indels and SSRs, which in turn distinguished 35 elite onion populations. The diversity assessment of tropical Indian onion and cross amplification of genomic and EST-SSR markers in distantly related native wild species were estimated. Clustering revealed five groups, and indigenous short-day onions formed separate cluster from exotic short-day and long-day onions (Khar et al., 2010).

The AFLP is one of the powerful techniques used for diversity analysis. It combines RFLP and PCR; therefore, it is more specific, gives large number of bands and allows more genome coverage.

\section{In-silico mining of markers}

Microsatellites or simple sequence repeats (SSRs) play an important role in plant genetics and breeding. The development of microsatellites is a timeconsuming and expensive process. In-silico mining of microsatellites from expressed sequence tags (ESTs), which are available in electronic molecular databases, is a cheaper alternative. Radhika et al. (2013) used a computational approach for mining SSRs from 20,159 ESTs in A. cepa. These onion ESTs, representing a total length of $13.2 \mathrm{Mb}$, were downloaded from dbEST database of the National Centre for Biotechnology Information (NCBI) and were subjected to various pre-processing steps. The pre-processed ESTs were clustered, resulting in non-redundant unigenes. These unigenes were analysed for their SSR content and distribution.

In all, 1,464 SSRs consisting of di-, tri-, tetra-, penta- and hexa-nucleotide repeats were mined from non-redundant ESTs (contigs and singletons). Trinucleotide SSRs were most abundant, followed by tetra-, di-, hexa- and pentanucleotide SSRs. Among the tri-coding repeats, leucine and serine codons were more abundant. The SSR-containing sequences were annotated and grouped into their respective functional categories. The predominant functional group among the annotated unigenes was "metabolism", followed by "transcription factors" and "transporter proteins". Primer pairs could be designed for 1,092 SSRcontaining sequences. Of these, 51 primer pairs were validated in the laboratory. A database has been developed to store unigenes, primer pairs, putative annotations, and BLAST results. After validation, EST-derived microsatellite (SSR) markers can be used in studies related to marker-assisted selection, detection of polymorphism, DNA fingerprinting and diversity analysis in onion. 


\section{Molecular marker-assisted selection}

Colour improvement: Bulb colour is one of the important traits in onion $(A$. cepa). Three major colours white, yellow, red, and a variety of other bulb colours, such as chartreuse and golden, exist in onion germplasm. The colour is due to flavonoid compounds, and 54 types of flavonoids were reported in onion (Slimestad et al., 2007). Flavonoids are involved in UV protection, fertility and pigmentation in plants (Shirley, 1996) and act as antioxidants when consumed by humans (Lotito and Frei, 2006). Bulb colour is inherited in a complex manner and involves epistatic interaction, and loci might code for enzymes involved in the anthocyanin synthesis (El-Shafie and Davis, 1967; Koops et al., 1991).

Unusual gold-coloured onions showed reduced amount of quercetin, the most abundant flavonoid in onions. Kim et al. (2004) identified critical mutations in chalcone isomerase ( $\mathrm{CHI}$ ) gene resulting in golden onions. The colour difference between yellow and red onions revealed involvement of two complementary genes in anthocyanin production (Kim et al., 2005a). Inactivation of dihydroflavonol 4reductase (DFR) in anthocyanin synthesis pathway was responsible for the colour differences between yellow and red onions, and two recessive alleles of anthocyanidin synthase (ANS) gene were responsible for a pink bulb (Kim et al., $2005 \mathrm{~b}$ ). Based on the mutations in the recessive alleles of these two genes, Kim et al. (2007) developed PCR-based markers for identification of polymorphism between pink and red alleles of the ANS gene. Most pink onions are homozygous recessive for $A N S$ gene. The two pink onions, heterozygous for ANS gene, were also heterozygous for $D F R$ gene, indicating pink colour formation by incomplete dominance of a red colour gene over yellow colour. Kim et al. (2006) identified allele of ANS, $A N S-h 1$, in a dark red doubled haploid line. $\mathrm{F}_{2}$ populations originating from crosses between wild-type $(A N S-L)$ allele containing red and pink $(A N S-p)$ allele containing white or yellow parents show a discrete segregation ratio of 3 red to 1 light pink; suggesting that the wild-type allele is completely dominant over pink allele.

Two novel inactive alleles of $D F R$ - $A$ in yellow onion cultivars and breeding lines from Korea and Japan were identified (Kim et al., 2009). Deletion of $20 \mathrm{bp}$ of a simple sequence repeat in the promoter region of the DFR-APS allele was used to develop a simple PCR-based molecular marker for selection of DFR-APS allele. Furthermore, RT-PCR results showed that no DFR-A transcript was detected in any yellow $\mathrm{F}_{2}$ individuals. Further, Park et al. (2013) developed functional CAPS markers for two inactive DFR-A alleles, DFR-A ${ }^{P S}$ and DFR-A ${ }^{\mathrm{DEL}}$, for detection of inactive DFR-A alleles responsible for failure of anthocyanin production in onions. Of these, two alleles, DFR-A ${ }^{P S}$ exists predominantly in yellow onion cultivars.

Quality traits: Onion and other Alliums have been valued since antiquity for their pungent flavour and aroma. Modern science has confirmed the traditional beliefs that organosulphur compounds that impart flavour have significant human health benefits. Flavour precursors of onion are 1-propenyl, propyl and methyl cysteine sulfoxides (Randle and Lancaster, 2002). Galmarini et al. (2001) derived a genetic map to identify and estimate effects of QTLs on the phenotypic correlations among soluble solids content (SSC), total dry matter, pungency and 
onion-induced in-vitro anti-platelet activity. McCallum et al. (2006) found polymorphic SSR marker, which exhibited strong disequilibrium with bulb fructan content, and it was mapped to chromosome 8 in interspecific population of $A$. cepa $\times$ A. roylei. QTL analysis of total bulb fructan content in intraspecific mapping population, using a complete molecular marker map, revealed only one significant QTL, which may account for major difference in bulb carbohydrate content between storage and sweet onion varieties. Candidate genes for sulphur assimilation were used to identify genomic regions affecting pungency. Linkage mapping has revealed that genes encoding ferredoxin-sulfite reductase and ATP sulfurylase (ATPS) are closely linked (1-2 cM) on chromosome 3. QTL analysis has revealed significant associations of both pungency and bulb soluble solids content with marker intervals on chromosomes 3 and 5 (McCallum et al.,2007). Non-structural dry-matter content of onion-bulbs principally consists of fructose, glucose, sucrose and fructans. A cDNA subtraction library has been constructed to differentiate high and low fructan accumulating background (Raines et al., 2007).

Identification of sex-linked markers and hybrids: Interspecific hybridization is known in many Allium groups as a mode of speciation through evolution of the genus. Usually interspecific hybrids are recognized from intermediate morphological features and chromosomal variability. Lately, molecular techniques have been assigned to identify hybrid nature of many cultivated crops. Hybrid nature (A. fistulosum $\times A$. cepa) of $A$. wakegi, a sexually sterile species, was initially proven by Genome In-Situ Hybridisation (GISH) (Hizume 1994). Additional evidence for the nature was gathered by localization of 5S RNA loci at chromosomal positions corresponding to A. cepa and A. fistulosum. A. fistulosum was identified as the maternal parent by the RFLP on purified plastid DNA that was hybridized to an A. fistulosum cpDNA probe (Tashiro et al., 1995). Other examples of use of different markers for identification of hybrids in Allium includes, top onions and viviparous onions, of suspected $A$. fistulosum $\times$ A. cepa origin, with the RFLP probes (Havey, 1991b), using isozyme assays (Maa, 1997a) and GISH (Friesen and Klaas, 1998). The ambiguous parentage of 'Pran', a cultivated species in Kashmir, was also analyzed (isozyme analysis, Maa, 1997b; RAPD analysis, Friesen and Klaas, 1998; cp DNA pattern, Havey, 1991a) and the data suggested that 'Pran' originated from a cross between a so far unknown seed parent and A. cepa. Further, identification of the diploid grey shallot, a distinct form of shallot, long cultivated in France and Italy, was done using the RAPD (Le Thierry D'Ennequin et al., 1996), where affiliation was shown with other normal shallots, belonging to A. cepa. However, GISH and RAPD data of Friesen and Klaas (1998) showed that most of the chromosomes of grey shallot belong to $A$. oschaninii, with only one-and-a-half chromosome arms derived from either cepa or vavilovii. Although there is a need to address these contradictions; in general, application of molecular markers has become more of a routine in Allium research due to their ease of use and standardization of new and effective techniques and procedures.

Identification of cytoplasmic male sterility (cms): Cytoplasmic male sterility is a maternally inherited trait. CMS observed in many of the flowering plants is 
mainly due to chimeric mitochondrial open reading frames (ORFs) originated through recombination. In most of the CMS forms, transcripts originating from these altered ORFs are translated into unique proteins that appear to interfere with mitochondrial function and pollen development. Nuclear restorer ( $R f$ or $F r$ ) genes function to suppress deleterious effects of CMS-associated mitochondrial abnormalities. In onion, CMS condition exists widely in most natural populations of welsh and bulb onions ( $A$. fistulosum, A cepa), which makes it possible to breed male-sterile lines for heterosis utilization. Unfortunately, the breeding of CMS in onion has made little progress owing to limitation of its biological characteristic and traditional selection approach. Identification of male sterile lines and their maintainers is a major hurdle in exploitation of male sterility in onion hybrid-seed production.

A low-density genetic map of onion (A. cepa) using RFLP was developed to distinguish fertile $(\mathrm{N})$ and sterile $(\mathrm{S})$ cytoplasms. A correlation was observed between expected and observed numbers of plants maintaining cytoplasmic-genic male sterility (Havey et al., 2001). The RFLP approach was applied to identify CMS genotypes using probes for the following mitochondrial genes: atpA, atp6, atp9, cob, cox1, nad3, nad4 and nad6 (Szklarczyk et al., 2002), and these markers are located in a chloroplast psbA gene amplicon, which distinguishes male-fertile (N) and male-sterile (S) cytoplasms (Cho et al., 2006). Genomic and mitochondrial genome diversity was evaluated by RAPD, SSR and RFLP markers (Chaurasia et al., 2010). Specific cytoplasm types of all tested cultivars were identified. At least three restorer genes are involved in restoration of fertility in CMS-T malesterile, while fertility restoration in CMS-S is controlled by only a single gene, rendering it suitable for establishment of molecular breeding systems (Kim et al., 2009). One SCAR marker and one RAPD marker were identified, which could distinguish between $\mathrm{N}$ and $\mathrm{S}$ cytoplasms in several welsh onion cultivars, confirmed by Southern Blotting (Gai et al., 2010). Park et al. (2013) developed a high resolution linkage map of $M s$ locus, which was involved in restoration of fertility. Tightly linked RAPD and CAPS markers were used to construct this fine map using $\mathrm{F}_{2}$ populations. Such closely linked markers could be utilized in markerassisted selection of $M s$ locus and map-based cloning. Further, origin and dynamics of genome rearrangements between normal and male-sterile onions were studied (Kim et al.,2013). Very recently, Havey (2013) studied linkage disequilibrium in male-fertility restoration $(M s)$ locus in open-pollinated and inbred populations using single nucleotide polymorphism (SNP). Three SNPs were identified which were tightly linked to $M s$ locus on chromosome 2; these SNPs can be helpful in the development of maintainer lines for hybrid onion development (Table 7.3). RAPD markers analysis was performed by Dhanya et al. (2013) to investigate genetic relatedness among nine sterile (A), maintainer lines $(\mathrm{B})$, and male parents (C). Initially, 180 arbitrary decamer primers were screened; of these 20 primers were selected, which yielded 812 bands, $45.34 \%$ of which were found polymorphic. Squared-Euclidean Distance matrix revealed a minimum genetic distance between genotypes MS 48A and MF 65C and a maximum genetic distance between genotypes MLT 84C and MF 65B. Cluster analysis grouped nine onion genotypes into two major clusters - the first cluster consisted of two male sterile groups, i.e. 
Table 7.3 Molecular markers for cytoplasmic male-sterility analysis in Alliums

\begin{tabular}{|c|c|c|}
\hline Marker & Application & Reference \\
\hline RFLP & Identify cytoplasmic genotypes & Szklarczyk et al., 2002 \\
\hline PCR-RFLP & $\begin{array}{l}\text { Distinguish male-fertile }(\mathrm{N}) \text { and } \\
\text { male-sterile }(\mathrm{S}) \text { cytoplasm }\end{array}$ & Cho et al., 2006 \\
\hline RFLP & $\begin{array}{l}\text { CMS-T and CMS-S cytoplasm type } \\
\text { identification }\end{array}$ & Kim et al., 2009 \\
\hline RAPD, SSR, RFLP & $\begin{array}{l}\text { Genomic and mitochondrial genome } \\
\text { diversity }\end{array}$ & Chaurasia et al., 2010 \\
\hline SCAR and RAPD & $\begin{array}{l}\text { Distinguish between } \mathrm{N} \text { and } \mathrm{S} \text { cytoplasm } \\
\text { in welsh onion }\end{array}$ & $\begin{array}{l}\text { Gai Shu-peng et al., } \\
2010\end{array}$ \\
\hline RAPD and CAPS & $\begin{array}{l}\text { High-resolution linkage map of the } \\
\text { Ms locus }\end{array}$ & Park et al., 2013 \\
\hline $\begin{array}{l}\text { Chloroplast and } \\
\text { Mitochondrial } \\
\text { markers }\end{array}$ & $\begin{array}{l}\text { Study of mitochondrial genome } \\
\text { rearrangements }\end{array}$ & Kim et al., 2013 \\
\hline SNP & $\begin{array}{l}\text { Linkage disequilibrium study in the male- } \\
\text { fertility restoration (Ms) locus }\end{array}$ & Havey, 2013 \\
\hline
\end{tabular}

MS 65 (Arka Lalima) and MS 48 (Arka Kirthiman) of single bulb onions; and the second consisted of MLT (Multiplier) group. PCA re-confirmed results of the dendrogram, revealing the precision in estimation of genetic relatedness among the tested genotypes. None of the primers produced unique banding patterns to distinguish all nine genotypes. This information about genetic relatedness among the nine genotypes would be better utilized in onion breeding programmes in future.

\section{Linkage and QTL mapping studies}

In onion breeding, traits such as size, shape, colour, pungency, soluble solids and disease resistance are important objectives. Quantitative trait loci (QTL) analysis based on a genetic linkage map would be effective for revealing mode of inheritance of these traits. Large genome size, clonal propagation and lack of flowering in some clones are some problems with mapping population development, however, with the availability of self pollinating and male-sterile lines, mapping has been initiated.

The first genetic linkage map of Japanese bunching onion, based primarily on AFLP markers by using reciprocally backcrossed progenies, has been constructed (Takayoshi et al. 2005). A $P_{1}$ linkage map comprising 149 AFLPs, 2 CAPSs, and 12 SSRs from Japanese bunching onion, and 1 SSR from bulb onion (A. cepa) on 15 linkage groups covering $947 \mathrm{cM}$ has been built by Tsukazaki et al. (2008). The $\mathrm{P}_{2}$ linkage map composed of 105 AFLPs, 1 CAPS, and 13 SSRs has been developed from Japanese bunching onion and 1 SSR from bulb onion on 14 linkage groups, covering $775 \mathrm{cM}$.

Two partial bacterial artificial chromosome (BAC) libraries of the A. sativum were constructed and sequence compositions of these $\mathrm{BAC}$ clones have been 
characterized by southern hybridization, and BAC clones have been localized by FISH (Hye-Ran et al., 2003).

\section{Future Trends}

There are almost no known stable sources of disease and pest resistance within the species, A. cepa, and source of resistance for salinity and drought are yet to be identified. However, there are known sources of resistance in wild Allium species. But the problem encountered is of cross incompatibility between many of the species, which could be either pre- or post-fertilization barriers. Where crossfertilization occurs, embryo survives seldomly; herein the technique of embryorescue would be of help. The studies need to be intensified on these aspects. Besides the molecular markers and linkage mapping, sequencing of genome of onion has been initiated with the development of high throughput methods but collaborative international efforts are crucial for sequencing of large genome of onion. Initially, McCallum et al. (2001) and Kuhl et al. (2004) did Sanger sequencing of random cDNAs from non-normalized and normalized libraries of onion. Then Jakse et al. (2008) undertook pilot sequencing project of onion genomic DNA to estimate gene densities and investigate nature and distribution of repetitive DNAs. Complete sequences from two onion Bacterial Artificial Chromosome (BACs) were AT rich $(64.8 \%)$ and revealed long tracts of degenerated retroviral elements and transposons, similar to other larger plant genomes. Samantha et al. (2010) reported application of Roche 454 technology to develop sequence resources for population analyses and genetic mapping to develop SSRs and ESTs. Bhasi et al. (2010) developed 'RoBuST' (http://robust.genome.com), an integrated genomic resource, for families, Apiaceae and Alliaceae, which can be used for sequence annotations, access to traits, biosynthetic pathways, genetic linkage maps and comparative analysis of plant splicing patterns. McCallum et al. (2012) developed a comparative genomics resource 'Allium Map' for cultivated Allium vegetables, which is first online resource providing genetic map and marker data from multiple Allium species and populations. In future, we need to exploit high throughput SNP genotyping, functional genomics using RNAi or other mutagenic methods and transcriptome mapping to know function of each gene in Allium genome. Genomic resources and databases thus developed will be very useful for onion improvement.

\section{References}

Abdoli M, Habibi-Khaniani B, Baghalian K, Shahnazi S and Rassouli H. 2009. Classification of Iranian garlic (A. sativum L.) ecotypes using RAPD marker. Journal of Medicinal Plants 8: 45-51.

Alan A R, Brants A, Cobb E, Goldschmied P A, Mutschler M A and Earle E D. 2004. Fecund gynogenic lines from onion (Allium cepa L.) breeding materials. Plant Science 167: $1055-66$.

Alan A R, Lim W, Mutschler M A and Earle E D. 2007. Complementary strategies for ploidy manipulations in gynogenic onion (Allium cepa L.) Plant Science 173: 25-31. 
Alan A R, Mutschler M A, Brants A, Cobb E, Earle E D. 2003. Production of gynogenic plants from hybrids of Allium cepa L. and A. roylei Stearn. Plant Science 165: 120111.

Altmann T, Damm B, Halfter U, Willmitzer L and Morric P C. 1992. Protoplast transformation and methods to create specific mutants in Arabidopsis thaliana, pp. 310-30. (In): Methods in Arabidopsis Research. Koncz C, Chua N-H and Schell J. (Eds). World Scientific Publishing Co., River Edge, New Jersey, USA.

Al-Zahim M A, Ford-Lloyd B V and Newbury H J. 2005. Detection of somaclonal variation in garlic (A. sativum L.) using RAPD and cytological analysis. Plant Cell Reports 18: 473-77.

Arumuganathan K and Earle E. 1991. Nuclear DNA content of some important plant species. Plant Molecular Biology Reports 9: 208-18.

Asha Devi A and Khar A. 2000. Preliminary studies on in vitro regeneration from flower bud explants of onion (Allium cepa L.) (In): Proceedings of National Symposium on Onion-Garlic Production and Post Harvest Management Challenges and Strategies, Maharashtra, India.

Aswath C R, Mo S Y, Kim D H and Park S W. 2006. Agrobacterium and biolistic transformation of onion using non-antibiotic selection marker phosphomannose isomerase. Plant Cell Reporter 25: 92-99.

Barandiaran X, Di Pietro A, Martín J. 1998. Biolistic transfer and expression of a uidA reporter gene in different tissues of Allium sativum L. Plant Cell Reports 17: 737-41.

Basak R. 1987. The Hindu concept of the natural world, pp. 111-112. (In): The Religion of the Hindus. Morgan K. (Ed.) Motilal Banarsidass, Delhi, India.

Bhasi A, Doug S, Philipp W S, Brajendra K, Vinu M, Philge P and Periannan S. 2010. RoBuST: an integrated genomics resource for the root and bulb crop families Apiaceae and Alliaceae. BMC Plant Biology 10: 161-66.

Bino R J, Janssen M G, Franken J and de Vries J N. 1989. Enhanced seed development in the interspecific cross Allium cepa $\times$ A. sphaerocephalon through ovary culture. Plant Cell, Tissue and Organ Culture 16: 135-42.

Bohanec B and Jakse M. 1999. Variations in gynogenic response among long-day onion (Allium cepa L.) accessions. Plant Cell Reporter 18: 737-42.

Bohanec B, Jakse M, Ihan A and Javornik B. 1995. Studies of gynogenesis in onion (Allium cepa $\mathrm{L}$.): induction procedures and genetic analysis of regenerants. Plant Science 104: 215-24.

Bradeen J M and Havey M J. 1995. Randomly amplified polymorphic DNA in bulb onion and its use to assess inbred integrity. Journal of American Society of Horticultural Science 120: 752-58.

Buiteveld J, Suo Y, van Lookeren Campagne M M and Creemers-Molenaar J. 1998. Production and characterization of somatic hybrid plants between leek (Allium ampeloprasum L.) and onion (Allium cepa L.) Theoret. Appl. Genet. 96: 765-75.

Campion B Alloni C. 1990. Induction of haploid plants in onion (Allium cepa L.) by in vitro culture of unpollinated ovules. Plant Cell Tissue Organ Culture 20: 1-6.

Campion B, Azzimonti M T, Vicini E, Schiavi M and Falavigna A. 1992. Advances in haploid plant induction in onion (Allium cepa L.) through in vitro gynogenesis. Plant Science 86: 97-104.

Campion B, Bohanec B and Javornik B. 1995. Gynogenic lines of onion (Allium cepa L.): evidence of their homozygosity. Theoret Appl. Genet. 91: 598-602.

Campion B, Falavigna A, Soressi G P and Schiavi M. 1985. Efforts for in vitro androgenesis in onion (Allium cepa L.) Genetica Agraria 39: 315.

Campion B, Perri E, Azzimonti M T, Vicini E and Schiavi M. 1995. Spontaneous and induced chromosome doubling in gynogenic lines of onion (Allium cepa L.). Plant 
Breeding 114: 243-46.

Cardle L, Ramsay L, Milbourne D, Macaulay M, Marshall D and Waugh R. 2000 Computational and experimental characterization of physically clustered simple sequence repeats in plants. Genetics 156: 847-54.

Chaurasia A K, Adsul G G, Nair D, Subramaniam V R, Krishna B and Sane P V. 2010. Diversity in Indian and some exotic onion cultivars as revealed by genomic and mitochondrial DNA. ISHS Acta Horticulturae 859 [International Symposium on Molecular Markers in Horticulture].

Cho K S, Yang T J, Hong S Y, Kwon Y S, Woo J G and Park H G. 2006. Determination of cytoplasmic male sterile factors in onion plants (A. cepa L.) using PCR-RFLP and SNP markers. Molecular Cells 21 (3): 411-17.

Cohat J. 1994. Obtention chez l'echalote (Allium cepa L. var. aggregatum) de plantes haploides gynogénétiques par culture in vitro de boutons floraux. Agronomie 14: 299304.

Dhanya S, Lakshmana Reddy D C, VeereGowda, Sreedhara S A and Aswath C. 2013. The genetic relatedness analysis of male sterile and their maintainer lines of onion (Allium cepa L.) by using RAPD primers. Journal of Crop Science Biotechlogy 16 (1): 29-33.

Dodds J H. (Ed.) 1991. Conservation of plant genetic resources-the need for tissue culture, pp. 1-9. (In): In-vitro Methods for Conservation of Plant Genetic Resources. Chapman and Hall, London, UK.

Doré C and Marie F. 1993. Production of gynogenetic plants of onion (Allium cepa L.) after crossing with irradiated pollen. Plant Breeding 111: 142-47.

Dubouzet J G, Shinoda K and Murata N. 1998. Interspecific hybridization of Allium giganteum Regel: production and early verification of putative hybrids. Theoret. Appl. Genet. 96: 385-88.

Dunstan D I and Short K C. 1979. Shoot production from the flower head of Allium cepa L. Scientia Horticulturae 10: 345-56.

Eady C C and Lister C E. 1998. A comparison of four selective agents for use with Allium Cepa L. immature embryos and immature embryo-derived cultures. Plant Cell Reporter 18: $117-21$.

Eady C, Davis S, Catanach A, Kenel F and Hunger S. 2005. Agrobacterium tumefaciensmediated transformation of leek (Allium porrum) and garlic (Allium sativum). Plant Cell Reporter 24: 209-15.

Eady C C, Kamoi T, Kato M, Porter NG, Davis S, Shaw M, Kamoi A and Imai S. 2008. Silencing onion lachrymatory factor synthase causes a significant change in the sulfur secondary metabolite profile. Plant Physiology 147: 2096-106.

Eady C C, Weld R J and Lister C E. 2000. Agrobacterium tumefaciens-mediated transformation and transgenic-plant regeneration of onion (Allium cepa L.) Plant Cell Reporter 19: 376-81.

El-Shafie M W and Davis G N. 1967. Inheritance of bulb colour in the onion (A. cepa L.) Hilgardia 38: 607-22.

Endang-Sulistyaningsih, Tashiro Y, Shigyo M and Isshiki S. 1997. Morphological and cytological characteristics of haploid shallot (Allium cepa L. Aggregatum group). Bull Fac Agr Saga Univ. 82: 7-15.

Endang-Sulistyaningsih, Yamashita K and X Tashiro Y. 2002. Haploid induction from $\mathrm{F}_{1}$ hybrids between CMS shallot with Allium galanthum cytoplasm and common onion by unpollinated flower culture. Euphytica 125: 139-44.

Friesen N and Klaas M. 1998. Origin of some minor vegetatively propagated Allium crops studied with RAPD and GISH. Genetic Resources and Crop Evolution 45: 511-23.

Gai S and Meng X. 2010. Application of molecular markers linking to cytoplasmic male sterile loci to assist maintainer line selection and their selection efficiency in Welsh 
onion (A. fistulosum L.) Agricultural Sciences in China 9 (11): 1571-76.

Galmarini C R, Goldman I L and Havey M J. 2001. Genetic analyses of correlated solids, flavor, and health-enhancing traits in onion (A. cepa L.) Molecular Genetics and Genomics 265: 543-51.

Gantait S, Mandal N, Bhattacharyya S and Das P K. 2010. Determination of genetic integrity in long-term micropropagated plantlets of $A$. ampeloprasum L. using ISSR markers. Biotechnology 9: 218-23.

Geoffriau E, Kahane R and Rancillac M. 1997. Variation of gynogenesis ability in onion (Allium eepa L.) Euphytica 94 (1): 37-44.

Geoffriau E, Kahane R and Martin-Tanguy J. 2006. Polyamines are involved in the gynogenesis process in onion. Physiologia Plantarum 127 (1): 119-29.

Gonzalez L G and Ford-Lloyd B V. 1987. Facilitation of widecrossing through embryo rescue and pollen storage in interspecific hybridization of cultivated Allium species. Plant Breeding 98: 318-22.

Grzebelus E and Adamus A. 2004. Effect of anti-mitotic agents on development and genome doubling of gynogenic onion (Allium cepa L.) embryos. Plant Science 167: 569-74.

Havey M J. 1991a. Phylogenetic relationships among cultivated Allium species from restriction enzyme analysis of the chloroplast genome. Theoret. Appl Genet. 81: 75257.

Havey M J. 1991b. Molecular characterization of the interspecific origin of viviparous onion. Journal of Heredity 82: 501-08.

Havey M J. 2013. Single nucleotide polymorphisms in linkage disequilibrium with the male-fertility restoration $(M s)$ locus in open-pollinated and inbred populations of onion. Journal of the American Society for Horticultural Science 138 (4): 306-09.

Havey M, King J J, Bradeen J M, Bark O, Sato Y and Gökçe A F. 2001. A low-density genetic map of onion (A. cepa L.) and its use for marker-facilitated selection of maintainer lines. ISHS Acta Horticulturae. 555. [II International Symposium on Edible Alliaceae].

Hizume M. 1994. Allodiploid nature of Allium wakegi Araki revealed by genomic in situ hybridization and localization of $5 \mathrm{~S}$ and $18 \mathrm{~S}$ rDNAs. Japanese Journal of Genetics 69: 407-15.

Hussey G. 1978. In vitro propagation of the onion Allium cepa by axillary and adventitious shoot proliferation. Scientia Horticulturae 9: 227-36.

Hussey $\mathrm{G}$ and Falavigna A. 1980. Origin and production of in vitro adventitious shoots in the onion, Allium cepa L. Journal of Experimental Botany 31: 1675-86.

Hye-Ran L, Eun-Mi E, Yong-Pyo L, Jae-Wook B and Dong-Hee L. 2003. Construction of a garlic BAC library and chromosomal assignment of BAC clones using the FISH technique. Genome 46: 514-20.

Imai S, Tsuge N, Tomotake M, Sawada H, Nagata T and Kumagai H. 2002. Plant biochemistry: An onion enzyme that makes the eyes water. Nature 419: 685 .

Ipek M, Ipek A, Almquist S G and Simon P W. 2005. Demonstration of linkage and development of the first low-density genetic map of garlic, based on AFLP markers. Theoret. Appl. Genet. 110 (2): 228-36.

Jabbes N, Clerc V, Dridi B and Hannechi C. 2011. Inter simple sequence repeat fingerprints to assess genetic diversity of Tunisian garlic populations. Journal of Agricultural Science 3 (4): $77-85$.

Jakse M, Bohanec H and Ihan A. 1996. The effect of media components on the gynogenic regeneration of onion (Allium cepa L.) cultivars and analysis of regenerants. Plant Cell Reporter 15: 934-38.

Jakse M, Havey M J and Bohanec B. 2003. Chromosome doubling procedures of onion (Allium cepa L.) gynogenic embryos. Plant Cell Reporter 21: 905-10. 
Jakse J, Jenelle D F, Suzuki G, Mccallum J, Foo C, Christopher D and Havey J M. 2008. Pilot sequencing of onion genomic DNA reveals fragments of transposable elements, low gene densities, and significant gene enrichment after methyl filtration. Molecular Genetics Genomics 280: 287-92.

Jakse J, Martin W, Mccallum J and Havey J M. 2005. Single nucleotide polymorphism, Indels, simple sequence repeats for onion cultivar identification. Journal of American Society for Horticultural Science 130 (6): 912-17.

Javornik B, Bohanec B and Campion B. 1998. Second cycle gynogenesis in onion, Allium cepa L., and genetic analysis of the plants. Plant Breeding 117 (3): 275-78.

Jme M, Bohanec B and Ihan A. 1996. Effect of media components on the gynogenic regeneration of onion (Allium cepa L.) cultivars and analysis of regenerants. Plant Cell Reporter 15: 934-38.

Joseph C, Foo C, Qiaoping Y, William M, Yayeh Z, Mccallum J, Andrew C, Paul R, Kenneth C, Maria J, James P P, Christopher D T and Havey J M. 2004. A unique set of 11,008 onion expressed sequence tags reveals expressed sequence and genomic differences between the monocot orders Asparagales and Poales. The Plant Cell 16: 114-25.

Joshi S P, Gupta V S, Aggarwal R K, Ranjekar P K and Brar D S. 2000. Genetic diversity and phylogenetic relationship as revealed by inter simple sequence repeat (ISSR) polymorphism in the genus Oryza. Theoret. Appl. Genet. 100: 1311-20.

Joshi S P, Ranjekar P K and Vidya S G. 1999. Molecular markers in plant genome analysis. Current Science 77: 230-40.

Kahane R, Teyssendier de la Serve, B and Rancillac M. 1992. Bulbing in long day onion (Allium cepa L.) cultured in vitro: comparison between sugar feeding and light induction. Annals of Botany 69: 551-55.

Keller J. 1990. Culture of unpollinated ovules, ovaries and flower buds in some species of the genus Allium and haploid induction via gynogenesis in onion (Allium cepa L.) Euphytica 47: 241-47.

Keller J. 1990a. Results of anther and ovule culture in some species and hybrids in the genus Allium L. Arch Zuchtungsforsh 20: 189-97.

Keller E R J, Schubert L and Fuchs J. 1996. Interspecific crosses of onion with distant Allium species and characterization of the presumed hybrids by means of flow cytometry, karyotype analysis and genomic in situ hybridization. Theoret. Appl. Genet. 92: 41724.

Kenel F, Eady C and Brinch S. 2010. Efficient Agrobacterium tumefaciens-mediated transformation and regeneration of garlic (Allium sativum) immature leaf tissue. Plant Cell Reports 29: 223-30.

Khar A, Bhutani R D, Chowdhury V K, Lawande K E and Asha Devi A. 2002b. Effects of genotype and media on direct and indirect organogenesis in onion (Allium cepa L.). (In): Proceedings of International Conference on Vegetables, Bengaluru, Karnataka, India.

Khar A, Lawande K E and Negi K S. 2010. Microsatellite marker based analysis of genetic diversity in short day tropical Indian onion and cross amplification in related Allium spp. Genetic Resources and Crop Evolution 58 (5): 741-52.

Khar A, Yadav N R, Bhutani R D, Chowdhury V K and Sindhu A. 2002a. Regeneration studies in onion (Allium cepa L.) and garlic (Allium sativum L.) (In): National Symposium on New Opportunities and Challenges for Improving Crop Productivity through Biotechnology, Hisar, Haryana, India.

Kielkowska A. 2012. Meiotic irregularities in interspecific crosses within edible alliums, pp. 351-66. (In): Meiosis -Molecular Mechanisms and Cytogenetic Diversity. Andrew Swan (Ed.) DOI: 10.5772/30029. 
Kim H I, Kim Y H, Chung T Y and Ryu I S. 1986. Studies on protoplast fusion of Allium sativum with Allium monanthum, 1; effects of polyethylene glycol, high $\mathrm{pH} / \mathrm{Ca}++$ solution and temperature treatments. Korean Journal of Plant Tissue Culture 13: 3744.

Kim S, Doohyun B, Dong Y C, Eul-Tai L and Moo-Kyoung Y. 2009. Identification of two novel inactive $D F R-A$ alleles responsible for failure to produce anthocyanin and development of a simple PCR-based molecular marker for bulb color selection in onion (A. cepa L.). Theoret. Appl. Genet. 118: 1391-99.

Kim S, Haejeen B, Kil-Sun Y and Leonard M P. 2006. Identification of the fourth allele of the ANS (anthocyanidin synthase) gene and its effect on red colour intensity in onions (A. cepa L.) Euphytica 149: 45-51.

Kim S, Haejeen B, Kil-Sun Y and Leonard M P. 2007. Marker-assisted genotype analysis of bulb colors in segregating populations of onions (A. cepa L.) Molecular Cell 23 (2): 192-97.

Kim S, Jones R, Yoo K and Pike L M. 2004. Gold colour in onions (A. cepa): a natural mutation of the chalcone isomerase gene resulting in a pre-mature termination codon. Molecular Genetics Genomics 272: 411-19.

Kim S, Kil-Sun Y and Leonard M P. 2005b. Development of a co-dominant, PCR-based marker for allelic selection of the pink trait in onions (A. cepa L.), based on the insertion mutation in the promoter of the anthocyanidin synthase gene. Theoret. Appl. Genet. 110: $628-33$.

Kim S, Lee E T, Kim C W and Yoon M K. 2009. Distribution of three cytoplasm types in onion (A. cepa L.) cultivars bred in Korea and Japan. Korean Journal of Horticultural Science and Technology 27 (2): 275-79.

Kim S, Rick J, Kil-Sun Y and Leonard M P. 2004. Gold colour in onions (A. cepa L.): a natural mutation of the chalcone isomerase gene resulting in a premature stop codon. Molecular Genetics Genomics 272: 411-19.

Kim S, Rick J, Kil-Sun Y and Leonard M P. 2005a. The $L$ locus, one of complementary genes required for anthocyanin production in onions (A. cepa L.), encodes anthocyanidin synthase. Theoret Appl. Genet. 111: 120-27.

Klein T M, Wolf E D, Wu R and Sanford J C. 1987. High-velocity microprojectiles for delivering nucleic-acids into living cells. Nature 327: 70-73.

Kondo T, Hasegawa H and Suzuki M. 2000. Transformation and regeneration of garlic (Allium sativum L.) by Agrobacterium mediated gene transfer. Plant Cell Reports 19: 989-93.

Koops A J, Hall R D and Kik C. 1991. Bolkleurvorming bij de ui: een biochemisch genetisch model. Prophyta 6: 20-22.

Kuhl J C, Cheung F, Yuan Q, Martin W, Zewdie Y, Mccallum J, Catanach A, Rutherford P, Sink K C, Jenderek M, Prince J P, Town C D and Havey M J. 2004. A unique set of 11,008 onion (A. cepa L.) ESTs reveal expressed sequence and genomic differences between monocot orders Asparagales and Poales. Plant Cell 16: 114-25.

Kyung-Ho M, Jae-Gyun K, Weiguo Z, Anupam D, Gi-An L, Haeng-Hoon K, Ill-Min C and Nam-Soo K. 2009. Isolation and characteristics of eight novel polymorphic microsatellite loci from the genome of garlic (A. sativum L.) Scientia Horticulturae 122 (3): 355-61.

Le Thierry D'Ennequin M, Panaud O, Robert T and Ricroch A. 1996. Assignment of genetic relationships among sexual and asexual forms of Allium cepa using morphological traits and RAPD markers. Heredity 78: 403-09.

Lotito S B and Frei B. 2006. Consumption of flavonoid-rich foods and increased plasma antioxidant capacity in humans: cause, consequence, or epiphenomenon? Free Radical Biology Medicine 41: 1727-17. 
Luthar Z and Bohanec B. 1999. Induction of direct somatic organogenesis in onion (Allium cepa L.) using a two step flower or ovary culture. Plant Cell Reports 18: 797-802.

Maa H I. 1997a. Genetic diversity in the top onion, Allium xproliferum, analysed by isozymes. Plant Systematics and Evolution 208: 35-44.

Maa H I. 1997b. Studies on triploid viviparous onions and their origin. Genetic Resources and Crop Evolution 44: 95-99.

Mahajan V, Jakse J, Havey M J and Lawande K E. 2009. Genetic fingerprinting of onion cultivars using SSR markers. Indian Journal of Horticulture 66 (1): 62-68.

Maniruzzaman M E, Haque M M and Haque M A. 2010. Molecular characterization of onion (A. cepa L.) using RAPD markers. Bangladesh Journal of Agricultural Research 35 (2): 313-22.

Martin W J, Mccallum J, Shigyo M, Jakse J, Kuhl J C, Yamane N, Pither-Joyce M, Gokce A F, Sink K C, Town C D and Havey M J. 2005. Genetic mapping of expressed sequences in onion and in silico comparisons with rice show scant colinearity. Molecular Genetics Genomics 3: 197-204.

Martinez L E, Aguero C B, Lopez M E and Galmarini C R. 2000. Improvement of in vitro gynogenesis induction in onion (Allium cepa L.) using polyamines. Plant Science 156: 221-26.

Mccallum J, Andrew C, Meeghan P J, Martin S, Ruth B, John S, Ian S, Masayoshi S and Havey M J. 2006. Genetic mapping of a major gene affecting onion bulb fructan content. Theoret. Appl. Genet. 112: 958-96.

Mccallum J, Leite D, Pither-Joyce M and Havey M J. 2001. Expressed sequence markers for genetic analysis of bulb onion (A. cepa L.). Theoret. Appl. Genet. 103: 979-91.

Mccallum J, Meeghan P J, Martin S, Fernand K, Sheree D, Ruth B, John S, Jakse J and Havey M J. 2007. Genetic mapping of sulfur assimilation genes reveals a QTL for onion bulb pungency. Theoret. Appl. Genet. 114: 815-22.

Mccallum J, Samantha B, Masayoshi S, Yanbo D, Sjaakvan H, Meeghan P and Fernand K. 2012. Allium map-A comparative genomics resource for cultivated Allium vegetables. BMC Genomics 13: 168-73.

Mes T H M, Friesen N, Fritsch R M, Klaas M and Bachmann K. 1998. Criteria for sampling in Allium (Alliaceae) based on chloroplast DNA PCR-RFLPs. Systematic Botany 22: 701-12.

Mohamed Yasseen Y, Barringer S A and Splittstoesser W E. 1995. In vitro bulb production from Allium spp. In vitro Cell Developmental Biology 31: 51-52.

Muren R C. 1989. Haploid plant induction from unpollinated ovaries in onion. HortScience 24 (5): 833-34.

Musial K, Bohanec B and Przywara L. 1999. Embryological analysis of in vitro cultured ovules of Allium cepa L. (Abstracts). (In): IX International Conference of Plant Embryologists, during 20-22 September 1999, Cracow, Poland. [Acta Biol Cracov Ser Bot [Suppl. 1] 41: 51].

Musial K, Bohanec B and Przywara L. 2000. Gynogenesis in onion (Allium cepa L.) embryological study. (Abstracts). (In): XXIV Conference on Embryology: Plants, Animals, Humans during 24-26 May 2000, Podlesice, Poland. [Acta Biol Cracov Ser Bot [Suppl. 1] 42: 25].

Musial K, Bohanec B and Przywara L. 2001. Embryological study on gynogenesis in onion (Allium cepa L.) Sex Plant Reproduction 13: 335-41.

Nomura Y, Saito M and Komori H. 2005. Breeding of autumn-flowering interspecific Hybrids of Allium, pp.141-47. (In): Proc. IX Intl. Symp. on Flower Bulbs. Okubo H, Miller W B and Chastagner G A. (Eds). [Acta Hort. 673, ISHS 2005].

Novak F J and Havel L. 1981. Shoot production from in vitro cultured flower heads of Allium porrum L. Biologia Plantarum 23: 266-69. 
Ohsumi C, Kojima IA, Hinata K, Etoh T and Hayashi T. 1993. Interspecific hybrid between Allium cepa and Allium sativum. Theoret. Appl. Genet. 85: 969-75.

Park J, Bang H, Cho D Y, Yoon M, Patil B S and Kim S. 2013. Construction of highresolution linkage map of the $M s$ locus, a restorer-of-fertility gene in onion (Allium cepa L.) Euphytica 192: 267-78.

Park J, Cho D Y, Moon J S, Yoon M K and Kim S. 2013. Development of functional markers for detection of inactive $D F R-A$ alleles responsible for failure of anthocyanin production in onions (Allium cepa L.) Korean Journal of Horticultural Science and Technology 31 (1): 72-79.

Park M Y, Yi N R, Lee H Y, Kim S T, Kim M, Park J H, Kim J K, Lee J S, Cheong J J, and Choi Y D. 2002. Generation of chlorsulfuron-resistant transgenic garlic plants (Allium sativum L.) by particle bombardment. Molecular Breeding 9: 171-81.

Parthasarathy V A and Nagaraju V. 2001. Onion. Biotechnology of Horticultrual Crops. Vol. 2, pp. 375-396. Parthasarathy V A, Bose T K and Deka P C. (Eds). Naya Prokash, Kolkata, India.

Peterka H, Budahn H and Schrader O. 1997. Interspecific hybrids between onion (Allium cepa L.) with S-cytoplasm and leek (Allium ampeloprasum L.). Theoret. Appl. Genet. 94: 383-89.

Phillips G C and Luteyn K J. 1983. Effects of picloram and other auxins on onion tissue cultures. Journal of American Society of Horticultural Science 108 (6): 948-53.

Ponce M, Martínez L and Galmarini C. 2006. Influence of CCC, putrescine and gellam gum concentration on gynogenic embryo induction in Allium cepa. Biological Plant 50: 425-28.

Puddephat I J, Robinson H T, Smith B M and Lynn J. 1999. Influence of stock plant pretreatment on gynogenic embryo induction from flower buds of onion. Plant Cell Tissue Organ Culture 57: 145-48.

Qijiang C C and Jia T. 2007. Genetic diversity analysis of onion (A. cepa L.) germplasm by ISSR markers. Chinese Agricultural Science Bulletin CNKI: SUN: ZNTB.0.200706-027.

Radhika V, Reddy D C L, VeereGowda R and Aswath C. 2013. In silico identification and validation of microsatellite markers from onion EST sequences. Journal of Horticultural Science and Biotechnology 88 (5): 664-70.

Raines S, Havey, M J and Henson C A. 2007. Candidate genes affecting fructan accumulation in onion. (In): Plant and Animal Genome Conference. [Available: http:/ /www.intl-pag.org/15/abstracts/PAG15_P05a_223.html].

Randle W M and Lancaster J E. 2002. Sulphur compounds in Allium in relation to flavour quality, pp. 1-62. (In): Allium Crop Science-Recent Advances. Rabinowitch H and Currah L. (Eds). CABI Publishing, Oxford, UK.

Samantha J B, Meeghan P J, Roopashree R, Mark F, Ross C, Richard M and Mccallum J. 2010. Application of $454^{\mathrm{TM}}$ sequencing for marker development in onion. (In): Plant and Animal Genomes XVIII Conference, held on 9-13 January 2010 at San Diego, USA.

Sangeeta K M, Gowda R V and Lalitha A. 2006. Analysis of genetic diversity among Indian short-day onion (A. cepa L.) cultivars using RAPD markers. Journal of Horticultural Science and Biotechnology 81 (4): 774-77.

Scott A, Wyatt S, Tsou P L, Robertson D and Allen N S. 1999. Model system for plant cell biology: GFP imaging in living onion epidermal cells. Biotechniques 26 (6): 1125, 1128-32.

Semagn K, Bjørnstad A and Ndjiondjop M N. 2006. An overview of molecular marker methods for plants. African Journal of Biotechnology 5 (25): 2540-68.

Shirley B W. 1996. Flavonoid biosynthesis: 'new' functions for an 'old' pathway. Trends 
Plant Sciences 1: 377-82.

Slimestad R, Fossen T and Vågen I M. 2007. Onions: a source of unique dietary flavonoids. Journal of Agricultural Food Chemistry 55: 10067-80.

Smith B M, Godwin R M, Harvey E and Werner C P. 1991. Gynogenesis from whole flower buds in bulb onions (Allium cepa L.) and leeks (Allium porrum L.) Journal of Genetics Breeding 45: 353-58.

Susan E W, Peter G I and Robert J S. 1993. Random amplified polymorphic DNA (RAPD) markers for genetic analysis in Allium. Theoret. Appl. Genet. 86 (4): 497-504.

Szklarczyk M, Simlat M, Jagosz B and Ba G. 2002. The use of cytoplasmic markers in onion hybrid breeding. Cell Molecular Biology Letters 7 (2B): 625-34.

Takayoshi S, Yeon-Sang T, Hikaru W, Tadayuki N and Tsukasa K. 2005. Genetic mapping of AFLP markers in Japanese bunching onion (A. fistulosum). Euphytica 144 (3): 25563.

Tashiro Y, Oyama T, Iwamoto Y, Noda R and Miyazaki S. 1995. Identification of maternal and paternal plants of Allium wakegi Araki by RFLP analysis of chloroplast DNA. Journal of Japanese Society for Horticultural Science 63: 819-24.

Todd R and Ttague B W. 2001. Phosphomannose isomerase: a versatile selectable marker for Arabidopsis thaliana germ-line transformation. Plant Molecular Biology Reports 19: 307-19.

Tsukazaki H, Ken-Ichiro Y, Akio K and Tadayuki W. 2009. SSR-tagged breeding scheme for allogamous crops: a trial in bunching onion (A. fistulosum). Euphytica 169: 327 34.

Tsukazaki H, Ken-Ichiro Y, Shigenori Y, Shinichi M, Hiroyuki F, Junichi Y, Hiroyuki $\mathrm{K}$, Izumi K and Masayoshi S. 2008. Construction of SSR-based chromosome map in bunching onion (A. fistulosum). Theoret. Appl. Genet. 117 (8): 1213-23.

Tsukazaki H, Nunome T, Fukuoka H, Kanamori H, Kono I, Ohara T, Song Y S, Yamashita K, Wako T and Kojima A. 2006. Applications of DNA marker technology in Japanese bunching onion breeding. ISHS Acta Horticulturae 770. [XXVII International Horticultural Congress- IHC: International Symposium on Cultivation and Utilization of Asian, Sub-tropical, and Underutilized Horticultural Crops].

Tsukazaki H, Nunome T, Fukuoka H, Kanamori H, Kono I, Yamashita K, Wako T and Kojima A. 2007. Isolation of 1,796 SSR clones from SSR-enriched DNA libraries of bunching onion (A. fistulosum). Euphytica 157: 83-94.

Umehara M, Sueyoshi T, Shimomura K and Nakahara T. 2006. Production of interspecific hybrids between Allium fistulosum L. and A. macrostemon Bunge through ovary culture. Plant Cell Tissue Organ Culture 87: 297-304.

Umehara M, Sueyoshi T, Shimomura K, IwaiM, Shigyo M, Hirashima K and Nakahara T.2006. Interspecific hybrids between Allium fistulosum and Allium schoenoprasum reveal carotene-rich phenotype. Euphytica 148: 295-301. [UNFAO, Statistics, 2012, faostat.fao.org/site].

van der Valk P, de Vries S E, Everink J T, Verstappen F and de Vries J N. 1991. Pre- and post-fertilization barriers to backcrossing the interspecific Hybrid between Allium fistulosum L. and A. cepa L. with A. cepa. Euphytica 53: 201-09.

Vvan der Meer Q P. 1997. Old and new crops within edible alliums. Acta Horticulturae 433: $17-31$.

Xu Q J and Cui C R. 2007. Genetic transformation of OSISAP1 gene to onion (Allium cepa L.) mediated by a microprojectile bombardment. Zhi Wu Sheng Li Yu Fen Zi Sheng Wu Xue Xue Bao. 33: 188-96.

Yanagino T, Sugawara E, Watanabe M and Takahata Y. 2003. Production and characterization of an interspecific hybrid between leek and garlic. Theoret. Appl. Genet. 107: $1-5$. 
Zheng S J. 2000. 'Towards onions and shallots (Allium cepa L.) resistant to beet armyworm (Spodoptera exigua Hübner) by transgenesis and conventional breeding'. Thesis. 146 pp. Wageningen University, The Netherlands.

Zheng S J, Henken B, Ahn Y K, Krens F A and Kik C. 2004. The development of a reproducible Agrobacterium tumefaciens transformation system for garlic (Allium sativum L.) and the production of transgenic resistant to beet armyworm (Spodoptera exigua Hübner). Molecular Breeding 14: 293-307.

Zheng S J, Henken B, de Maagd R A, Purwito A, Krens F A and Kik C. 2005. Two different Bacillus thuringiensis toxin genes confer resistance to beet armyworm (Spodoptera exigua Hubner) in transgenic Bt-shallots (Allium cepa L.) Transgenic Research 14: 261-72.

Zheng S J, Khrustaleva L, Henken B, Sofiari E, Jacobsen E, Kik C. and Krens F A. 2001. Agrobacterium tumefaciens mediated transformation of Allium cepa $\mathrm{L} .:$ The production of transgenic onions and shallots. Molecular Breeding 7: 101-15. 


\section{Production Technology}

V. Sankar, P.C. Tripathi, K.E. Lawande and A.N. Ganeshamurthi

Onion is an environment-sensitive crop; it is relatively a cold-tolerant species. For proper development of onion-plant, environmental factors should be considered carefully in the production areas. In India, both short-day and longday onions are grown. Almost all short-day onions are grown in the plains and require 10-12 hours day-length, whereas long-day type onion varieties are grown in hills, requiring 13-14 hours day-length. Day-length requirement may differ for different onion varieties. It has been observed that long-day varieties, if planted under short-day conditions, do not form bulbs, however, short-day varieties form bulbs even under long-day conditions.

Onion is adaptable to a wide range of temperature. It is frost-tolerant also. Its leaf, root and bulb develop in cool temperature between $12.5^{\circ}$ and $24^{\circ} \mathrm{C}$. Optimal growth of onion leaf takes place at $20^{\circ}$ to $25^{\circ} \mathrm{C}$. Once bulbing begins, onion-plant tolerates even temperature higher than $25^{\circ} \mathrm{C}$. The plant occasionally tolerates quite well to extremely low temperature also. Seedling can withstand $2^{\circ} \mathrm{C}$ in soil (in this case germination can last up to 1 month, which affects yield). The optimum temperature for germination is above $10^{\circ} \mathrm{C}$. Three important factors of temperature change effect development of the plant. Low temperature combined with shorter daylight period (11-13 hours) induces foliage and root development. Therefore, proper timing of the sowing should be carefully considered. Late sowing considerably reduces time for plant development, which results in lesser yield at the end of the season as foliage biomass and roots are vital for good bulb development. It is obvious that opposite temperature and light conditions (high temperature + longer daylight) induce bulb formation during summer-time. However, extremely high temperature for a longer period may cause stress, which may shorten crop cycle, weaken foliage development and lead to early bulbing (especially, in late sowing it can happen often), resulting in much lower yields at harvest.

Relative humidity at $70 \%$ is found good for onion growth. The plant grows well in places where average annual rainfall during monsoon is $650-750 \mathrm{~mm}$ with good distribution. It does not thrive well in places where average rainfall exceeds 750-1,000 mm during monsoon. There it can be grown only as a summer crop (Rao and Purewal, 1957; Chandrasekaran et al., 2010).

\section{Soil}

Onion grows in all types of soils with $p \mathrm{H}$ varying from 5.5 to 8.0 - sandyloam, clay-loam, silt-loam and heavy soils. The best soils for onion cultivation 
are deep, friable loam and alluvial soils with good drainage, moisture-holding capacity and sufficient organic matter. Soils with high organic matter, enough drainage and no persistent weeds favour bulb production (Yawalkar, 1969; Kandil et al., 2013). High marketable bulbs are obtained on heavy soils such as clay, provided adequate quantity of organic matter is supplied to loosen soil. In lightsandy soils, bulbs mature early but yields are low (Dhesi et al., 1965; Ortola 2013). In light-textured soils, bulbs are often softer with less dry matter content, and in heavy clay soils frequently infested with soil-borne pathogens, like Fusarium (Ozer et al., 2009). Types of tillage also affect production considerably. Onion roots are mainly in the upper $30-\mathrm{cm}$ soil layer, and desirable soil structure in this layer is essential for uniform bulbs (Enciso et al., 2007). Proper water supply is also needed to attain higher yields.

The crop is very sensitive to highly acidic soil, alkaline soil and also waterlogging. The optimum $p \mathrm{H}$, regardless of soil type, is $6.0-7.5$, but onion can grow in mild alkaline soils also. Onion may not grow in soils with $p H$ below 6.0, as these soils may have trace element deficiencies or occasionally toxicity of $\mathrm{Al}$ or Mn. Threshold electrical conductivity of a saturation extract (ECe) for onioncrop is $4.0 \mathrm{dS} / \mathrm{m}$. When ECe level exceeds this, crop yields decline. Marketable bulb yields of onion were reduced by $50 \%$ when ECe was $4.1 \mathrm{dS} / \mathrm{m}$ (Russel, 1974). Vegetative growth of most of the onion cultivars was inhibited when salt concentration was above $4.0 \mathrm{dS} / \mathrm{m}$ (Shannon and Grieve, 1999).

\section{Season}

The optimum season for onion planting is important as it affects its marketable bulb yield and its post-harvest shelf-life. Sowing, transplanting and harvesting timing of onion varies from region to region (see Table 2.1, Chapter 2). Kharif onion in many parts of the country is grown during rainy season through transplanting. In Nashik (Maharashtra), kharif onion can be transplanted during May to June. Early rabi or late kharif crop can be sown during the first week of September and transplanted during November first week in western Maharashtra (Bhonde et al., 1987; Sankar et al., 2002). Rabi season crop is sown in October and November, and seedlings are transplanted in December to January (Sankar et al., 2003).

\section{Growth and developmental stages}

Apart from germination stage, onion cycle has 9 developmental stages-from planting to bulb

Table 8.1 Growth stages of onion-crop

\begin{tabular}{|c|c|c|}
\hline Short & $\begin{array}{l}\text { Long } \\
\text { duration }\end{array}$ & $\begin{array}{l}\text { Growth stage } \\
\text { duration }\end{array}$ \\
\hline $8-25$ & $10-30$ & $\begin{array}{l}\text { Radicle and flag leaf } \\
\text { emergence }\end{array}$ \\
\hline $25-40$ & $30-50$ & $1-2$ true leaves \\
\hline $40-55$ & $50-70$ & 3-4 leaves; 4 leaves \\
\hline $55-70$ & $70-90$ & $5-7$ leaves \\
\hline $70-85$ & $90-110$ & $\begin{array}{l}8-12 \text { leaves, bulb } \\
\text { initiation }\end{array}$ \\
\hline $85-100$ & $110-130$ & $\begin{array}{l}\text { bulb diameter of } 1-1.5 \\
\text { inches }\end{array}$ \\
\hline $100-120$ & $130-150$ & $\begin{array}{l}\text { bulb diameter of } 1.5-3.0 \\
\text { inches }\end{array}$ \\
\hline $120-135$ & $150-170$ & $\begin{array}{l}\text { bulb enlargement } \\
\text { complete, } 50 \%+\text { topped }\end{array}$ \\
\hline $135+$ & $170+$ & $\begin{array}{l}\text { dry down from pre- } \\
\text { harvest to harvest }\end{array}$ \\
\hline
\end{tabular}



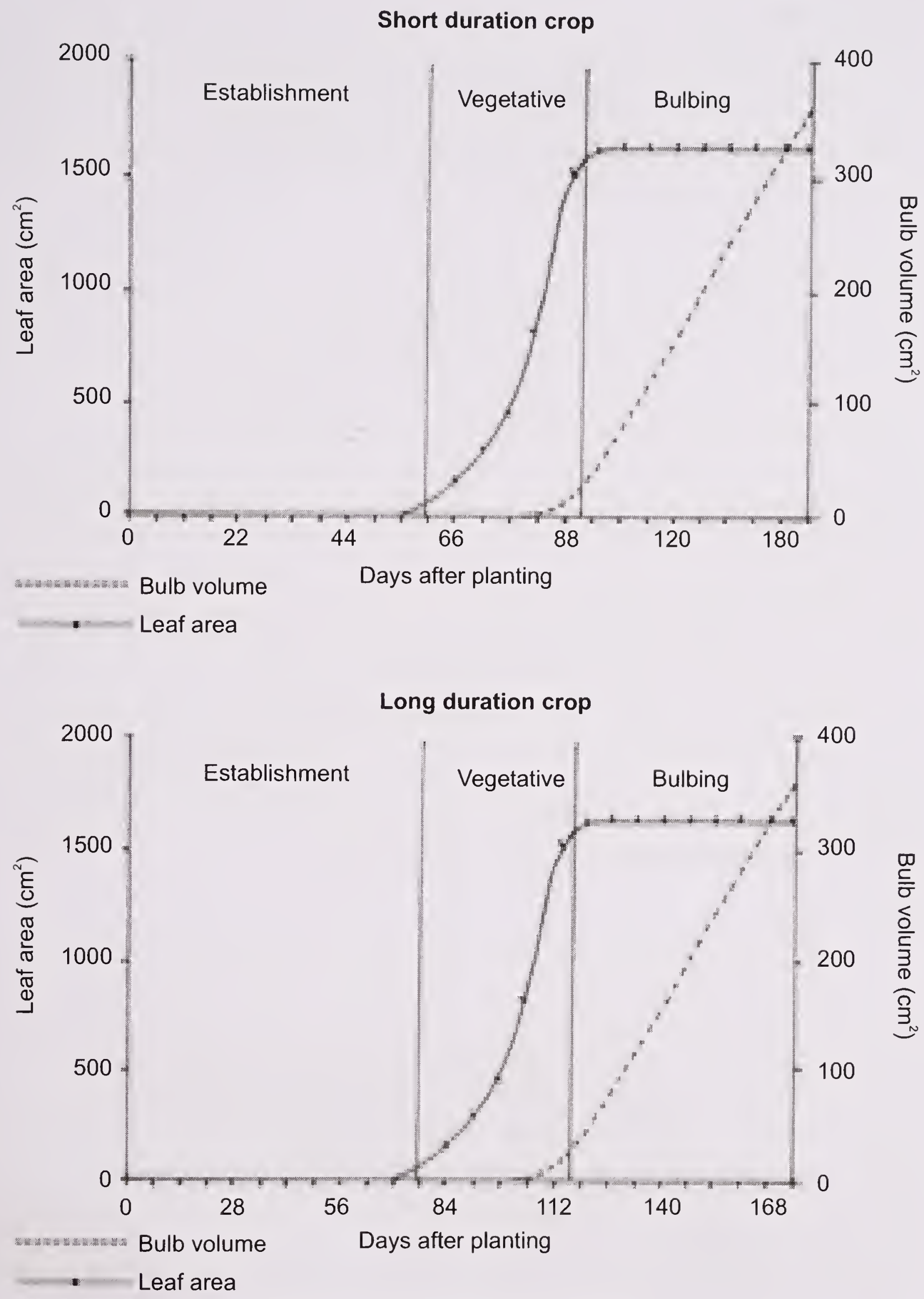

Fig. 8.1 Onion developmental stages

maturity. To recognize each stage is imperative for implementing an efficient crop-management programme (Table 8.1; Fig. 8.1). Environmental factors influence growth, development and biological yield of plants primarily by affecting physiology. Plant responses and myriad possible interactions are very extensive and also complex to be predictable. Analysis of this set of factors would contribute in understanding the system and may offer valuable insights and may enable efficient management. 


\section{Raising onion-crop}

Onion can be grown from seeds, sets or transplants. Precision seeding leads to easier controlled plant spacing and also improves seed survival rate. Since most varieties in India are of short duration, growers usually raise onion from direct seeding. The seed requirement and nursery management for raising a successful onion crop are covered in Chapter 2.

\section{Land preparation}

Before land preparation, primary weed control is a must. This can be done manually or by non-selective herbicides, e.g. Glyphosate (2-4 litres/ha). Apply herbicides when weeds are growing actively, prior to 10-14 days before land preparation. Plough the land to a depth of $15 \mathrm{~cm}$. Bed width and length are decided according to the irrigation facility. Normal recommendation for bed is $1 \mathrm{~m} \times 3 \mathrm{~m}$ $\times 15 \mathrm{~cm}$. In some regions of Tamil Nadu and Karnataka, ridges and furrows are formed at a distance of $30 \mathrm{~cm} \times 30 \mathrm{~cm}$ or $30 \mathrm{~cm} \times 45 \mathrm{~cm}$ or raised beds of convenient length and width for both kharif and rabi onion production. To avoid waterlogging during kharif or rainy season, flat beds should not be formed. And before planting, apply any type of well-decomposed organic manure at least at the rate of 10 metric tonnes/ha. Planking should be done for proper soil levelling.

In case of microirrigation (drip and sprinkler irrigations), 1 to $1.5 \mathrm{~m}$ wide and 50 to $60 \mathrm{~m}$ long raised beds or BBF (Broad based furrows) can be prepared. BBF is the best method for kharif onion production, as excess water drains off through furrows. This method also improves aeration and helps in reducing anthracnose incidence. BBF of $15 \mathrm{~cm}$ height and $120 \mathrm{~cm}$ top width with $45 \mathrm{~cm}$ furrow are formed for optimum spacing and population density.

\section{Direct seeding}

Sowing density should be adopted according to the final product specification of the market. A good example is the processing onion market, where most important grade portion is the bulb size of more than $7 \mathrm{~cm}$, herein sowing density optimum should be around 750,000 seeds, approximately $3.0 \mathrm{~kg} / \mathrm{ha}$. Plant density is also adjusted to seed quality and variety type. Open-pollinated varieties are sown at $5-6 \mathrm{~kg} / \mathrm{ha}$, while hybrids are sown at 4 to $5.5 \mathrm{~kg} / \mathrm{ha}$, as hybrids are more uniform in vigour, growth habit and germination. Precise sowing method would also help optimize amount of seeds and would reduce cost, if we consider cost of hybrid seeds. Several types of onion planters are available for direct seeding, proper accuracy can be reached with different instrumental variations of machines.

\section{Transplanting}

Onion seedling transplanting is more commonly practised in most part of the country for an irrigated crop, and this results in high yield combined with largesized bulbs. Seedlings are ready for transplanting in 35-40 days after sowing for kharif and 45-50 days after sowing for late kharif and rabi seasons. Proper care should be taken while selecting seedlings for transplanting. Seedlings of $0.8-0.9$ $\mathrm{cm}$ in diameter and about $20-35 \mathrm{~cm}$ in height are optimum for transplanting. Plant population needs to be optimized to get higher marketable bulb yield per 
unit area. Optimum use of spacing or plant population results in no competition among plants for growth factors - water, nutrient and light - and enables efficient use of available crop-land without wastage (Geremew et al., 2010). For achieving high productivity, optimum plant density is 65 to 70 plants per $\mathrm{m}^{2}$; higher plant density may reduce bulb size while lower plant density may result in bulb splitting (double bulbs). It has been reported that total bulb yield increases significantly as population density increases and number of marketable bulbs increases significantly with higher planting density (Kantona et al., 2003). Intra-spacing of $7.5 \mathrm{~cm}$ recorded good yield, bigger bulbs combined with better quality bulbs for market and storage (Kahsay et al., 2013). Spacing of $15 \mathrm{~cm}$ between rows and 8 to $10 \mathrm{~cm}$ between plants has been found conducive for high marketable bulb yield in the most parts of the country. In case of ridges and furrow method, plant-toplant distance has been reduced to $6-7 \mathrm{~cm}$ to accommodate optimum number of plants. Irrigate fields soon after transplanting. Seedlings should be transplanting either in early hours or late in the evening to avoid their drying. Care must be taken to cull-out seedlings with damaged roots or diseases. At the time of transplanting, one-third of the seedling top should be cut to have good establishment. It has been reported that larger seedlings yield higher, but they should be topped to facilitate transplanting. There are reports that yield and bulb weight decline when seedling tops were removed 25,50 or $70 \%$ before planting as compared to whole seedlings. Simulated damage of up to $75 \%$ at the early stage of crop growth (15 days after transplanting) had no adverse effect on onionbulb size and weight. Artificial defoliation slightly delayed maturity of bulbs, except when simulated damage was done at the early stage of crop growth. Partial trimming of onion seedlings at the time of transplanting augmented crop stand and increased bulb size. Similar results were also obtained by Rathore and Kumar (1974). Onion seedlings should be transplanted after dipping roots in Carbendazim solution $(0.1 \%)$ to contain incidences of fungal diseases.

\section{Sets planting}

Sets are small-sized onion produced by allowing seedlings to mature in nurserybeds as such, instead of transplanting. These bulbs are used as sets and planted in the next season to ensure early crop. In some parts of Gujarat, Maharashtra and Rajasthan, onion is grown in kharif by sets (Pandey and Singh, 1993). Mahuwa and Talaza areas in Gujarat are the major areas where quality onion sets are raised for local use and also for supply to other states. Seed sowing is done by the end of January or February, and small bulbs are harvested in April-May. The plants form small sets due to close spacing. It has been reported that seed sowing in January with $50 \mathrm{~g}$ seed per $\mathrm{m}^{2}$ gave maximum quality sets. The topped and graded sets are stored in hessian-cloth bags or in shallow baskets or in racks in layers, not more than $8-\mathrm{cm}$ deep. One tonne of sets of 1.5 to $2.0 \mathrm{~cm}$ diameter are enough for one hectare. But higher yield and net returns could be obtained with 2.0-2.5 cm size sets (Pandey et al., 1990). For good marketable bulb yield, sets are planted $10-\mathrm{cm}$ apart in rows on both sides of the ridges. The distance between two ridges should be $30-45 \mathrm{~cm}$. A light irrigation should be given immediately after sowing. The subsequent irrigations are to be given after every 10 days. 


\section{Fertilization}

Onion is highly nutrient-responsive crop. Conventional methods of fertilization have undoubtedly helped improving bulb yield and quality. But lately, routine management practices in India are apparently not sufficient in maintaining yields over long-term. Steady depletion of native soil fertility and multiple nutrient deficiencies in onion fields have indicated nutrient management as the key factor limiting sustainable onion production (Sharma et al., 2003). Integrated nutrient management (INM) offers an effective strategy (Santhi et al., 2005). Fertilizer prediction equations for onion for targeted yields are available in different regions of the country. These equations can be used for efficient management of plant nutrients for targeted yields (Sonar and Kadam, 2002; Santhi et al., 2005).

\section{General effects' of major nutrients}

Nitrogen: It strongly supports plant development resulting in foliage growth during the day, and bulb growth in night. Overdosed $\mathrm{N}$ can increase yield, however, a negative impact on late maturity and less storability can also occur. Even severe thrips infestation may also occur. Continuous application of $\mathrm{N}$ during the growth period can deteriorate bulb skin quality.

Phosphorus: It supports development of roots and skin-leaves. Addition of $\mathrm{P}$ in the last phase of bulb development helps grow thick and strong skin.

Potassium: It is an essential element for the proper dry matter content, especially for flesh firmness and good storability. This can improve effectiveness of water uptake and also help utilize applied N. Ideal K supply reduces disease susceptibility owing to stronger epidermis. Plants supplied with adequate $\mathrm{K}$ are more tolerant to low temperature and drought.

\section{General recommendations of fertilization}

Fertilization should be based on soil analysis. For example food-legumes, vegetables or sunflower as prior crop results in considerable organic matter in the soil that may cause problems in bulb quality, skin retention and earliness. Application of chloride-based fertilizers like muriate of potash before sowing should be avoided. Onion-plant is sensitive to chloride at any stage. $\mathrm{KCl}$ affects even germination negatively when applied as a basal dose.

\section{Nutrient application guidelines}

Nitrogen: Total applied $\mathrm{N}$ should be around $200 \mathrm{~kg} / \mathrm{ha}, 50 \%$ of this is to be applied as the basal application and the remaining at the vegetative stage as well as bulb formation stage in equal splits. The amount of $\mathrm{N}$ can be added based on soil test values.

Phosphorus: It should be around $100-160 \mathrm{~kg} / \mathrm{ha}$, depending upon the soil type and soil-test values. Traditionally, $100 \%$ of it is given during planting. But if this can be split into $75 \%$ at planting and $25 \%$ at bulb formation, it would be beneficial. This allows more phosphorus in the soil during bulb-skin development.

Potassium: The total amount to be applied is $120-200 \mathrm{~kg} / \mathrm{ha}$, depending upon the soil type and soil-test values. Traditionally, it is applied as $100 \%$ basal 
application. But $50 \%$ of the $\mathrm{K}$ at planting and $50 \%$ during growth season would improve yield and also bulb quality.

Sulphur: Onion-crop requires sulphur at higher levels even more than phosphorus for enhancement in yield and bulb quality. Indian soils are generally low in available sulphur (Ganeshamurthy and Saha, 1997). But a general recommendation for sulphur application is lacking. However, based on the general status of available sulphur in soils, $20 \mathrm{~kg}$ S/ha benefits crop.

Micronutrients: They have an important role in obtaining potential yield, improving quality and improvement in storability and skin quality. It is recommended to apply $10 \mathrm{~kg} \mathrm{Zn} / \mathrm{ha}$ and $1 \mathrm{~kg}$ boron/ha after every 2 nd or $3 \mathrm{rd}$ year.

Foliar nutrients can also be applied with fertilizers, containing more of $\mathrm{N}$ and $\mathrm{K}$ and less of $\mathrm{P}$. For example, during vegetative growth, foliar application of 19 $\mathrm{N}, 11 \mathrm{P}$ and $24 \mathrm{~K}$ is beneficial and at the bulbing stage, foliar spray of NPK at 10-5-26 ratio would benefit the crop.

\section{Water requirement}

Water requirement of any crop depends upon the nature of crop, soil, evapotranspiration rate of that particular area and plant growth stage. Onion has very shallow roots and frequent irrigation is necessary for better growth and bulb development. Irrigation schedule depends upon the plant cycle and planting system. Crop at the initial growth period requires less water, which also depends on crop growth, soil type and planting season. In case of direct-seeded crop, the first stage when proper and accurate irrigation is necessary is the pre-emergent stage. This is vital to realise proper germination and uniform vigour of the crop. The amount varies between 8 and $14 \mathrm{~mm}$ with a low intensity of 5 to $7 \mathrm{~mm} / \mathrm{hr}$.

The second irrigation is given at the bulb initiation and development stage to obtain marketable size and quality and for hybrids to realise their yield potential. The crop is very sensitive to moisture stress during this stage. The crop root system is normally restricted to top $5 \mathrm{~cm}$, and roots seldom penetrate deeper than $15 \mathrm{~cm}$. Farmers need to ensure proper growth of the plant by regular watering and keeping water availability in the profile up to 15 to $20 \mathrm{~cm}$.

Onion requires less water immediately after the crop establishment but the consumption increases with advancing season. Extensive research work has been done in scheduling irrigation water and total water requirement of onion in India (Table 8.2). The most common method of applying water is basin or border-strip flooding or furrow irrigation. Onion needs to be irrigated at transplanting, three days after transplanting, and the subsequent irrigation at 7-10 days interval depending upon the soil type and moisture content. In general, kharif crop needs 5-8 irrigations, late kharif 10-12 and rabi crop 12-15 irrigations. Transplanted seedlings should be irrigated as soon as possible after being set, if the soil is dry. Well-hardened seedlings will survive for 12 or more days, but delayed irrigation results in lowering of yield. For irrigated crop, just before transplanting or at the time of transplanting, field is irrigated, and life irrigation is given on the third day after planting. Frequent irrigations are given during the early crop growth, and more frequent are essential during bulb development. Do not irrigate the crop when it matures (10-15 days before harvest) and when its top starts falling; this 
Table 8.2 Onion water requirement

\begin{tabular}{|c|c|c|c|c|}
\hline $\begin{array}{l}\text { Optimum } \\
\text { soil moisture }\end{array}$ & $\begin{array}{l}\text { No. of } \\
\text { irrigations }\end{array}$ & $\begin{array}{l}\text { Depth of } \\
\text { irrigation } \\
(\mathrm{cm})\end{array}$ & $\begin{array}{l}\text { Total water } \\
\text { requirement } \\
\quad(\mathrm{mm})\end{array}$ & $\begin{array}{l}\text { Consumptive } \\
\text { use of water } \\
(\mathrm{mm})\end{array}$ \\
\hline Based on soil type & $\begin{array}{l}16 \text { (sandy-loam soil) } \\
12 \text { (clay-loam soil) }\end{array}$ & - & - & - \\
\hline Based on season & $\begin{array}{l}5-6 \text { (kharif) } \\
10-12 \text { (late kharif) } \\
12-15 \text { (rabi) } \\
15-20 \text { (summer) }\end{array}$ & - & - & - \\
\hline Based on soil-water potential & $16-18$ & $7.5-8.0$ & $640-720$ & $450-630$ \\
\hline
\end{tabular}

controls rotting during storage. Excessive irrigation is always harmful, and dry spell followed by irrigation would result in splitting of outer scales and also formation of bolters. Irrigation at 10-12 days interval during November December, 10 days interval during January and 7 days interval during February has been optimum for successful rabi onion production in Maharashtra, particularly Pune area. In clay soils of Andhra Pradesh, irrigation at 5 days interval gave higher yields in December-May crop, and an average total of 12-15 irrigations were essential to complete life-cycle of onion, grown during rabi.

At Bengaluru, maintaining soil-water potential at -0.85 bar or less, either during pre-bulb development (20-60 days after transplanting) or at bulb development stages (60-110 days after transplanting), reduced bulb yield significantly; bulb development stage was found more sensitive to moisture stress than pre-bulb development stage (Hegde, 1986). According to Saha et al. (1997), for optimum yield potential of Taherpuri onion, irrigation at 10 to $20 \%$ depletion of field capacity moisture maximize efficiency of irrigation. Consumptive use of water increased with increased available soil moisture (Koriem et al.,1999). Water-use efficiency was the highest when irrigation was withheld, followed by irrigation after depletion of $30 \%$ of available soil moisture. Bulb yield increased as IW/CPE values increased (Ramamoorthy et al., 2000). Water-use efficiency was higher at IW/CPE of 1.2.

Bulbs grown at low moisture can dry out earlier, and lose more weight during storage than those grown with adequate moisture. Over irrigation as well as under irrigation may result into lowering of yields. Onion foliage becomes yellowishgreen in colour with excessive irrigation. Heavy irrigation at harvest time or 1-2 weeks prior to harvest may cause immature thick-skinned bulbs. Frequent irrigation delays maturity of onion-bulbs. When plants begin maturing, irrigation should be discontinued, and soil should be allowed to dry out, which facilitates quick maturing of bulbs, otherwise secondary growth may start, which is difficult to be stopped and would complicate the process of proper onion curing. Irrigation after leaf withering pre-disposes bulbs to infection with Fusarium. Frequent irrigations reduce total soluble solids of bulbs. Moisture stress increases $\mathrm{No}_{3}-\mathrm{N}$ content of the bulbs.

\section{Microirrigation}

The most advanced method is drip irrigation. It is expensive but is most appropriate for water usage and precision irrigation as fertigation can be done with 
it. In drip irrigation, seedbeds should be laid with dripping tapes between $1 \mathrm{st}-2 \mathrm{nd}$ and $3 \mathrm{rd}-4$ th rows. Onion seedlings need to be planted at a spacing of $10 \mathrm{~cm} \times 15 \mathrm{~cm}$ in a broad-based furrow (BBF); 15-cm high, 120-cm top width and with $45-\mathrm{cm}$ furrow. Each BBF should have two drip laterals (16- $\mathrm{mm}$ size) at $60-\mathrm{cm}$ distance with in-built emitters. The system requires $30-50-\mathrm{cm}$ distance between two inbuilt emitters and the discharge flow rate of 4 litres/hr. Its only serious bottleneck is high investment cost of the main pipe network and tape set-up. It means considerable investment, but at the same time, water-use efficiency of the properly designed and well-managed microirrigation system may go up to $90 \%$. It can also be compensated by an improvement the marketable bulb yield apart from enhanced yield of 40-60 tonnes/ha compared to 25-30 tonnes/ha with regular irrigation. It is a matter of decision and situation (Bhonde et al., 2003; Sankar et al., 2008).

In the case of micro-sprinklers, the distance between two laterals $(20 \mathrm{~mm})$ should be $6 \mathrm{~m}$ with a discharge rate of 135 litres/hr. Very high yield $(441.76 \mathrm{q} / \mathrm{ha})$ and higher water-use efficiency were obtained with drip irrigation (Gorantiwar et $a l ., 1991$ ) in comparison with flood, furrow and sprinkler irrigations. Irrigation at $100 \%$ CPE gave highest bulb yield on medium black soils, and water-use efficiency was higher with all rates of drip irrigation than with surface irrigation. Drip irrigation at $100 \%$ pan evaporation recorded higher marketable bulb yield, high percentage of A grade bulbs and improved post-harvest storage-life, followed by micro-sprinkler irrigation at $100 \%$ pan evaporation. Drip irrigation could save irrigation water up to $37.8 \%$ and sprinkler irrigation system by $32.5 \%$ as compared to surface irrigation (Sankar et al., 2008). In white onion on medium black soils during summer season, an overall 53-69\% water saving was achieved (Patil et al., 2000). Higher water-use efficiency was also achieved on raised-bed planting with micro-sprinkler irrigation (Gethe et al., 2006).

\section{Weed management}

\section{Types of weeds}

The common monocot, dicot and broad-leaf weed species found in oniongrowing areas are: Cyperus rotundus, Cynodon dactylon, Chenopodium album, Amaranthus retroflexus, Convolvulus arvensis, Echinochloa colonum, Argimone maxicana, Avena sativa, Portulaca sp., Echino chloacrus-galli, Brachiaria ramosa, Phalaris minor, Oxalis latifolia, Poa annua, Ageratum conyzoides, Chenopodium murale, Coronopus didymus, Melilotus parviflora, Avena fatua, Euphorbia pilulifera, Amaranthus viridis, Trianthem aportulacastrum, Euphorbia sp., Leucas aspera, Eclipta alba and Digitaria sp. More than 30 weed species are recorded in onion fields at various places but Cyperus rotundus and Cynodon dactylon were the most prominent weeds that limited bulb production in onions (Sinha, 1999; Kalhapure and Shete, 2012).

\section{Crop-weed competition}

Onion-crop is usually infested by a wide spectrum of broad-leaf and grassy weeds. Due to its slow initial growth and inherent characteristics of crop such as short stature, non-branching habit, sparse foliage, shallow root systems coupled with frequent irrigations and fertilizer applications at high doses, the crop exhibits 
greater susceptibility to weed competition than most other crops. Without weed control, onion-bulb yields reduced drastically; losses due to weed infestation were recorded to the tune of 40 to $80 \%$ (Channapagoudar and Biradar, 2007). Proper and timely weed control measures are essential for good bulb development. The critical period of crop-weed competition in onions is from 15 to 45 days after transplanting (Shuaib, 2001). Delay in weeding operations results in lanky growth, yellowing of leaves and poor bulb development, besides impairing keeping quality of bulbs. The crop is more sensitive to duration of weed competition than to weed load. Bulb size and marketable yield were affected by weed competition (Sukhadia et al., 2002; Chopra and Chopra, 2007; Channapagoudar and Biradar, 2007). Onion-crop kept weed-free up to 45 days gave significantly higher bulb yield. Weed competition during the whole crop-cycle reduced bulb yield by $86 \%$, and weed competition during the first 15 days had no adverse effect. It indicates that proper and timely weeding is crucial for good quality bulbs. The critical period of crop-weed competition in onion is from 45 to 90 days after transplanting (Sankar et al., 2011). Monocotyledons weed population was found to increase up to 60 days after transplanting. Dicotyledonous weeds dominate with advanced crop age (Singh and Singh, 1994).

\section{Weed control}

Manual, mechanical and chemical methods of weed control are practised in India in onion. But very close spacing and shallow root system of onion make the mechanical method of weed control tedious, expensive and time-consuming. Moreover non-availability of sufficient labour at the critical period of crop competition and sometimes field conditions do not permit manual weeding in time, which ultimately results in poor bulb development and yield. Under such situations, chemical weed control becomes effective and economical. Successful pre-emergent herbicide application is crucial. The most common practice is to use Pendimethalin. A list of pre- and post-emergence herbicides used in onion and the dosages used is given in Table 8.3. These herbicides are applied with recommended dose at the time of seedling transplanting or before transplanting

Table 8.3 Pre- and post-emergence herbicides use in onion

\begin{tabular}{lclc}
\hline Pre-emergence herbicide & $\begin{array}{c}\text { Dose } \\
\text { (kg/ha) }\end{array}$ & $\begin{array}{l}\text { Pre-emergence herbicide } \\
\text { and post date of planting } \\
\text { application }\end{array}$ & $\begin{array}{c}\text { Dose } \\
\text { (kg/ha) }\end{array}$ \\
\hline Metribuzin (SencorLexone) & 0.35 & Loxynil (Toxynil) & 0.5 \\
Propachlor (Ramrod) & 4.5 & Pendimethalin (Stomp) & $2.5-3.5$ \\
Oxyfluorfen (Goal) & $0.15-0.25$ & Butralin (Tamex, Sector) & $\begin{array}{c}3.5 \\
\text { Fluchloralin (Basalin) }\end{array}$ \\
Pendimethalin (Stomp) & 1.5 or 2.0 & Oxyfluorfen (Goal) & 0.15 or 0.25 \\
Oxadiazon (Ronstar) & $2.5-3.5$ & Fluchloralin (Basalin) & 1.5 or 2.0 \\
Methabenzthiazuron (Tribunil) & 1.25 & Oxadiazon (Ronstar) & 1.25 \\
Nitrofen (Tok) & 1.4 & Alachlor (Lasso) & 2.0 \\
Linuron (Lorox) & 2.0 & Trifluralin (Treflan) & 1.0 \\
Trifluralin (Treflan) & 0.94 & Oxydiargyl (Raft) & 0.25 \\
Oxydiargyl (Raft) & 1.0 & & \\
\hline
\end{tabular}


or after transplanting followed by irrigation. For effectiveness of the herbicide, it should be supported by irrigation to facilitate its movement to the roots of young weed plants.

After successful pre-emergent herbicide application, next herbicide treatment should be applied at 4-6 leaves stage. Commonly used chemicals include totrli, maloran and goal. These herbicides can temporarily stop plant development (sometimes for 2 weeks); therefore the proper application period is when the plants are getting stronger-bigger (6 leaves stage). Mechanical weeding is also necessary during the season. This also acts as interculturing of the soil for water management. Machine cultivation 2 to 3 times, and, if needed, 1-2 times manual weeding, often before harvest, to pull out the large weeds (not to block the harvest machines) are generally required.

\section{Integrated weed management}

It is a science-based decision-making process that coordinates use of environmental information, weed biology and ecology, and all the available technologies to control weeds by most economical means, while posing least risks to people and environment (Sanyal, 2008). By using different appropriate management practices against weeds, farmers have more options for controlling weeds, thereby reducing possibility of escapes and weed adaptation to any single weed management tactic. Because of the diversity and plasticity of weed communities, weed management needs to be viewed as a continuous process. Major thrust on the integrated weed management (IWM) in India is given on herbicide-based IWM. Almost no work is reported on ecological based IWM. In onion, integrated weed management practices are very essential for good quality bulbs. A combination of pre-emergence herbicide Pendimethalin @ 2.5 litres and one hand-weeding helped in maximum number of seedling establishment and minimum fresh weight of weeds (Pandey et al., 1991). Combined application of Fluchloralin@1.25-2.50 kg/ha incorporated in soil 4 days before transplanting, followed by Pendimethalin @1.25-2.50 kg/ha applied 1 day after transplanting in addition to one hoeing gave effective control of weeds, besides higher bulb yield in sandy soils (Singh et al., 1991). In Vertisols of Karnataka, pre-emergence application of Pendimethalin $(1.0 \mathrm{~kg} / \mathrm{ha})+$ hand-weeding at 45 days after sowing proved better for weed control (93.5\%), bulb yield (13.16 tonnes/ha), for benefit: cost ratio (4.87) and also in lowering weed index (11.8\%) (Nadagouda, 1996). Mulching is an effective way to suppress weeds. Mulching at 30 days after transplanting gave maximum onion-bulb yield ( $263.34 \mathrm{q} / \mathrm{ha}$ ), followed by 3 handweedings at 30,60 and 90 days after transplanting. Well prepared and pre-irrigated onion-seedbed plots covered with $50 \mu \mathrm{m}$-thick transparent polyethylene mulch for 6 weeks prior to onion planting showed higher seedling emergence (Abdallah, 1998). Work related to non-chemical based IWM is the need of the hour. Effect of crop rotation, tillage, crop competitiveness, solarization and others needs attention to economize production and to reduce environmental damage.

\section{Cropping systems}

The success of any cropping system depends upon the appropriate management 
of resources including balanced use of manures and fertilizers. Integrated use of fertilizers, organic manure and recyclable crop residues along with residual fertility plays an important role in maintaining soil-health as well as raising productivity of the system. Onion is suitable to be adopted for various cropping patterns including intercropping and sequential cropping systems depending upon the location, nature of the soil and climate, as it is a short-duration and shallowrooted crop. Onion is most commonly grown as an intercrop with chilli and cotton in Karnataka, Andhra Pradesh, Maharashtra and other parts (Elangovan et al., 1985; Dodamani et al., 1993). In Tamil Nadu, it is grown as an intercrop in turmeric and sugarcane field. In high potential but low productive eastern Indo-Gangetic plains, rice-Potato-Onion has been found as one of the most profitable system (Khurana and Bhatia, 1991; Kumar and Lal, 2004). Maize-potato-onion was found most ecologically sound and economically potential rotation in north-western part of Indo-Gangetic plain (Walia et al., 2010). Sugarcane: onion (1:1) planting in Punjab was found better in terms of yield and soil-health (Singh and Vashist, 2004). Net profit too followed the same trend. Both cane yield and net profit decreased significantly when the number of onion rows planted in-between sugarcane rows increased to either two or three in comparison to one. Paired-row planted sugarcane with drip irrigation system was the most suitable system than potato, garlic and cabbage under western Maharashtra (Tripathi and Lawande, 2008). In Gujarat, groundnut-onion/garlic was better in terms of soil-health and profitability (Ibrahim et al., 2005).

Crop rotation and cropping sequences varies depending upon the agro-climatic condition of a particular location. Normally food legumes (mung, urd, lentil, rajma, peas, cowpea), vegetables (cauliflower, tomato, potato), aster, bajra, wheat and groundnut are good preceding crops for onion as they require much organic matter in the soil. In western Maharashtra, aster-onion, marigold-onion, groundnutonion, bajra-onion, onion-wheat, potato-onion and cucumber-onion sequences are popularly followed by farmers.

Crop rotation of brinjal as preceding crop, followed by onion as succeeding crop recorded maximum number of micro-organisms in the onion rhizosphere; minimum numbers of bacteria, actinomycetes and other microorganisms were noticed in monoculture (Rankev and Surlekov, 1976).

Crop rotation reduces incidence and magnitude of infested onion debris and pathogens harbouring it during non-host cycles. Small grains, especially barley, are highly recommended to improve organic matter content and reduce problems of pink root and Fusarium basal-rot in onion (Schwartz, 2014). Highest onion yields were obtained after preceding crop of celery or lettuce, less after onion and least after carrot (Hamilton and Bernier, 1976). The nematode species occurring in largest numbers after continuous growing of carrot, onion, celery and lettuce were Meloidogyne hapla, Pratylenchus matu and Pratylenchus penetrans, respectively. Crop rotation of onion with sugarbeet, maize and spring wheat increased marketable yield of onions and decreased basal-rot (Higashida et al., 1982). In Maharashtra and Madhya Pradesh, onion cultivation is more profitable when okra and radish are one of the component vegetables. Aubergine-Chinese cabbage-onion and okra-radish-onion are also promising. The same crop sequence 
also produced the highest net returns and benefit: cost ratio at Himachal Pradesh. Groundnut-potato-onion cropping system was the best crop sequence with higher yield, more remunerative, and with land-use efficiency of $90 \%$ in Punjab (Roy et al., 1999). In Tamil Nadu, populations of Rotylenchulus reniformis and Pratylenchus delattrei increased in onion-maize-onion cropping sequence, and in onion-tomato-okra cropping sequence, populations of Heterodora dihystera, H. seinhorsti and $M$. incognita increased (Vetrivelkalai and Subramanian, 2006). On Vertisols of central India, soybean in kharif, followed by onion in rabi performed better in terms of yield, soil-health and cost : benefit ratio. Significant improvement in physical and chemical properties of soil can be obtained from legume-based cropping sequences, particularly soybean, followed by rabi onion and groundnut, followed by late kharif onion (Sankar et al., 2011). Intercropping of onion with some of the vegetables like tomato decreased thrips infestation and increased marketable yield (Afifi and Haydar, 1990; Dilip Singh, 1996; Mishra et al., 2014).

\section{Precision technology}

The success of precision agriculture depends on accurate assessment of variability, its management and evaluation in space-time continuum in crop production. The agronomic feasibility of precision agriculture has been intuitive, depending largely on the traditional recommendations at finer scales. The success has been quite convincing in crops like sugarbeet, sugarcane, tea and coffee. The potential for economic, environmental and social benefits of precision agriculture is largely unrealized as space-time continuum of crop production has not been adequately addressed. In India, onion has not received attention for precision agriculture, as it is traditionally grown by small and marginal farmers under intensive cropping system; and very little mechanization is practised for the onion. Some distinct features of this crop such as uniform maturity, one time harvesting and limited crop height offer good scope for partial mechanization and also other sensor-based technologies. The operations like bed-making, precision seeddrilling, spraying of herbicides and pesticides, harvesting, topping, grading can be performed mechanically. Bullock-drawn implements are usually used for field preparation; and use of tractor-drawn implements has increased since a decade. Sowing and transplanting of onion is manually done, and lay out for planting either as flat beds or ridged and furrows is also manual. The development of suitable and cost-effective equipment for these operations may help reduce cost of production. Several prototypes have been developed in the recent years, like bed maker and rotary drum roller, size graders of the DOGR and onion seeddrills. They increased efficiency by 5 and 20 times, respectively, over the normal operations.

\section{Future Strategies}

There is a need to develop appropriate eco-friendly agro-techniques specific to various agroclimates for maximum productivity of onion under available natural and other resources vis-à-vis distribution of quality planting material of promising 
varieties. Moreover, standardization of year-round production technology for onion under changing global climate is the need of the hour. Sensor-based input management practices are very essential for enhancement of onion production and productivity. Development of Good Agricultural Practices (GAP) for export of onion to other countries is very important. Emerging labour problem is becoming a big hindrance for small- and medium-scale farmers. Power supply is another challenge for successful cultivation. Mechanization in onion is becoming critical for increasing production. Short-duration, uniform maturing varieties suitable for mechanical harvesting would be the requirement in future.

\section{References}

Abdallah. 1998. Improving vegetable transplants using soil solarization. II. Onion "Allium cepa". Annals of Agricultural Science (Special Issue) 3: 831-43. (Proceedings of Seventh Conference of Agricultural Development Research, Cairo, Egypt).

Afifi F M L and Haydar M F. 1990. Effect of different intercropping systems on onion and garlic infestation with the 'cotton and onion thrips', Thrips tabaci Lind. Bulletin of Faculty of Agriculture, University of Cairo 41: 3, 639- 48.

Bhonde S R, Singh N B and Singh D K. 2003. Studies on the effect of drip irrigation in onion bulb crop. NHRDF Newsletter 23: 1-3.

Bhonde B R, Srivasstava K J and Singh K N. 1987. Effect of different ages of seedlings and dates of transplanting on the yield and quality of onion during kharif at Nasik. Annual Report, p.3, NHRDF, Nashik, Maharashtra, India.

Chandrasekaran B, Annadurai K and Somasundaram E. 2010. A Textbook of Agronomy. New Age International (p) Limited, New Delhi India.

Channapagoudar B B and Biradar N R. 2007. Physiological studies on weed control efficiency in direct sown onion. Karnataka Journal of Agricultural Science 20: 37576.

Chopra N and Chopra N K. 2007. Production of weed free mother bulb of onion (Allium cepa) through integration of herbicides and weeding. Indian Journal of Agronomy 52: $80-82$.

Dhesi N S, Nandpuri K S and Kumar J C. 1965. Onion cultivation in Punjab. Agricultural Information News, Punjab Agricultural University, Ludhiana, Punjab, India.

Dilip Singh. 1996. Comparative study of autumn v/s spring sugarcane crop in different cropping systems. Indian Sugar 46: 9, 727-29.

Dodamani B M, Hosmani M M and Hunshal C S. 1993. Management of chilli + cotton + onion intercropping systems for higher returns. Farming Systems 9: 52-55.

Elangovan M, Suthanthirapandian I R and Sayed S. 1996. Intercropping of onion in chilli. Annals of Agricultural Science 34: 3, 839-57.

Enciso, J, Jifon, J and Wiedenfeld B. 2007. Subsurface drip irrigation of onions, effects of drip tape emitter spacing on yield and quality. Agriculture Water Management 92: 126-30.

Ganeshamurthy A N and Saha J K. 1997. Sulphur status in soils of agro-ecological regions of India. Fertiliser news $\mathbf{4 4}$ (5).

Geremew A, Teshome A, Kasaye T and Amenti C. 2010. Effect of intra spacing on yield of three onion varieties at mid rift valley of Ethiopia. Journal of Horticulture Forestry 2: 7-11.

Gethe R M, Pawar V S, Sonawane D A and Kadlag A D. 2006. Influence of planting, layouts, irrigation regimes and fertilizer levels on growth and yield of onion under microsprinkler. Journal of Maharashtra Agricultural University 31: 272-74. 
Gorantiwar S D, Papattiwar P S, Legad S M and Borude D M. 1991. Evaluation of sprinkler and border methods of irrigation for onion. Maharastra Journal of Agriculture 5: 8892.

Hamilton A and Bernier J. 1976. Carrot, onion, celery and lettuce crop succession studies on an organic soil. Canadian Journal of Pant Science 56: 881-84.

Hegde M. 1986. Effect of irrigation regimes on drymatter production, yield, nutrient uptake and water use of onion. Indian Journal of Agronomy 31: 343-48.

Higashida S, Ohsaki I and Narita Y. 1982. Effects of crop rotation on onion yields and its microbial factors. Bulletin of Hokkaido Prefectural Agricultural Experiment Stations 48: 1-9.

Ibrahim S T, Khalil H E and Kamel A S. 2005. Growth and productivity of sugarbeet, onion and garlic grown alone and in associations under different inter and intraspacing. Annals of Agricultural Science 43: 497-516.

Kahsay Y, Abay F and Belew A. 2013. Intra row spacing effect on shelf life of onion varieties (Allium cepa L.) at Aksum, Northern Ethiopia. Journal of Plant Breeding and Crop Science 5: 127-36.

Kalhapure A H and Shete B T. 2012. Integrated weed management in onion. Indian Journal of Weed Science 44 (2): 88-91.

Kandil A A, Sharief A E and Fathalla A H. 2013. Effect of organic and mineral fertilizers on vegetative growth, bulb yield and quality of onion cultivars. Journal Crop Production 2: $91-100$.

Kantona RAL L, Abbeyb R G, Hillac M A and Tabil N D. 2003. Planting densities effect on yield and yield components of onion (Allium cepa). Journal of Agricultural Research 47: 397-404.

Khurana S C and Bhatia A K.1991. Intercropping of onion and fennel with potato. Indian Journal of Weed Science 23: 64-66.

Koriem S O, Koliey M M and E 1 Sheekh H M. 1999. Effect of drought conditions on yield, quality and some water relationships of onion. Journal of Agricultural Sciences 30: $75-84$.

Kumar D and Lal S S. 2004. Evaluation of potato based cropping systems in Bihar plains. Potato Journal 31: 49-53.

Mishra R K, Jaiswal R K, Kumar D, Saabale P R and Singh A. 2014. Management of major diseases and insect pests of onion and garlic. Journal of Plant Breeding and Crop Science 6: 160-70.

Nadagouda B T, Kurdikeri C B, Salakinkop S R, Hunshal C S and Patil S L. 1996. Integrated weed management in drill sown onion (Allium cepa L.). Farming Systems 12: 22-27.

Ortola M P. 2013. 'Modelling the impacts of in-field soil and irrigation variability on onion yield.' M.Phil Thesis. School of Applied Science. Cranfield University, UK.

Özer N, Koç M and Der B. 2009. The sensitivity of Aspergillus niger and Fusarium oxysporum $\mathrm{f}$. sp. cepae to fungistasis in onion-growing soils. Journal of Plant Pathology 91: 401-10

Pandey U B and Singh J. 1993. Agro techniques for onion and garlic, pp. 440-41. (In): Advances in Horticulture, Volume 5. Chadha K L and Kalloo G. (Eds). Malhotra Publishing House, New Delhi, India.

Pandey U B, Singh Lallam and Singh V K. 1990. Effect of size of onion sets and planting distance on growth, yield and quality of kharif onion. (In): National Symposium on Onion and Garlic at Dr. Y S Parmar University of Horticulture, Solan, Himachal Pradesh, India.

Pandey U B, Singh D K, Singh J B, Pandey J P N and Chauhan K P S. 1991. Studies on weed control in onion. Newsletter Associated Agricultural Development Foundation 11: $2-3$. 
Patil S L, More N N, Firke, Desale S B and More T A. 2000. Effect of micro-irrigation system and nitrogen fertigation levels on yield and quality of white onion.cv. PhuleSafed during summer season, pp. 9-10. (In): National Symposium on Onion and Garlic Production and Post-harvest Management-Challenges and Strategies, held at Nashik, Maharashtra, India.

Ramamoorthy K, Selvaraj K V and Velayutham A. 2000. Effect of irrigation and nitrogen levels on bulb yield of small onion (Allium cepa L.) Madras Agricultural Journal 86: $140-41$.

Rankev and Surlekov. 1976. The effect of monoculture on the micro flora in the rhizosphere of onions. Pohvoznanie-I-agrokhimiya 11: 85-91.

Rao H and Purewal S S. 1957. Onion and garlic cultivation in India. Farm Bulletin No.3, pp. 18-22, ICAR, New Delhi, India.

Rathore S V S and Kumar R. 1974. Performance of bulb-crop of onion Allium cepa L. as affected by top pruning. Progressive Horticulture 6 (2/3): 105-11.

Roy S K, Sharma R C and Sud K C. 1999. Production potential, profitability and soil fertility as affected by potato based crop sequences in N.W. plains of Punjab. Journal of Indian Potato Association 26: 33-38.

Russel E W. 1974. Soil Conditions and Plant Growth.10th Edition, Longman Publishing Group and Co Limited, London, UK.

Saha U K, Khan M S I, Haider J and Saha R R. 1997. Yield and water use of onion under different irrigation schedules in Bangladesh. Japanese Journal of Tropical Agriculture 41: $268-74$.

Sankar V, Anil Khar, Asha Devi and Lawande K E. 2002. Evaluation of onion varieties during rabi season under different dates of planting. Annual Report, pp. 14. National Research Centre for Onion and Garlic, ICAR, Rajgurunagar, Pune, Maharashtra, India.

Sankar V, Anil Khar, Asha Devi and Lawande K E. 2003. Evaluation of onion varieties during late kharif season under different dates of planting. Allium Improvement Newsletter 11.

Sankar V, Lawande K E and Tripathi P C. 2008. Effect of micro-irrigation practices on growth and yield of onion. Indian Journal of Agricultural Sciences 78: 584-88.

Sankar V, Thangasamy A and Lawande K E. 2011. Weed management studies in rabi onion under western Maharashtra conditions. (In): National Symposium on Alliums: Current Scenario and Emerging Trends, held during12-14 March 2011 at the VAMNICOM, Pune, Maharashtra, India.

Santhi R, Natesan, R and Selvakumari G. 2005. Soil test based fertilizer recommendation of nitrogen, phosphorus and sulphur in wheat (Triticum aestivum L.) in an alluvial soil. Indian Journal of Agriculture Research 39 (3): 213-16.

Sanyal Debanjan. 2008. Introduction to the integrated weed management revisited symposium. Weed Science 56 (1): 140.

Schwartz H F. 2014. Soil-borne Diseases of Onion. Fact Sheet 2.940. Colorado State University, USA.

Shannon M C and Grieve C M. 1999. Tolerance of vegetable crops to salinity. Scientia Horticulturae 78: 5-38.

Sharma R P, Datt N and Pritam Sharma. 2003. Indian Journal of Agriculture Science 73 (4): 225-27.

Shuaib O S B. 2001. Critical period for weed competition in onions (Allium cepa L.) University of Aden Journal of Natural and Applied Sciences 5: 355-60.

Singh A and Vashist K K. 2004. Rabi onion-intercropping in autumn planted sugarcane. Sugar Tech. 6: 101-02.

Singh J, Chadha M L and Sandhu K S. 1991. Evaluation of different herbicides for weed control in kharif onion. Journal of Research, PAU 28: 199-202. 
Singh M P and Singh K P. 1994. Weed behaviour in rainy season onion (Allium cepa L.) as influenced by various weed-free and weedy treatments. Indian Journal of Agricultural Sciences 64: 686-90.

Sinha M, Mandal N, Rekha Kumari, Gupta U D and Kumari R.1999. Weed flora of direct sown onion (Allium cepa L.) field. Journal of Applied Biology 9: 45-46.

Sonar K and Kadam B. 2002. Targeted yield approach for fertilizer requirement of onion in Vertisols. Symposium No. 30 Paper 156, 17 th World Congress of Soil Science, Bangkok, Thailand.

Sukhadia N M, Ramani B B and Dudhantra M G. 2002. Response of onion (Allium cepa L.) to methods of sowing and weed management practices. Indian Journal of Weed Science 34: 76-79.

Tripathi P C and Lawande K E. 2008. Intercropping in sugarcane (Saccharum officinarum) with onion (Allium cepa) and other vegetables under different planting and irrigation systems. Indian Journal of Agricultural Sciences 78: 78-81.

Vetrivelkalai P and Subramanian S. 2006. Plant parasitic nematode populations as influenced by onion based cropping sequences. Indian Journal of Nematology 36: 1014.

Walia S S, Ghill M S and Dhaliwal S S. 2010. Production potential and economics of different cropping systems and their impact on soil health. Indian Journal of Ecology. 37: 23-26.

Yawalkar K S. 1969. Bulb vegetables, pp. 7-8. (In): Vegetables Crops of India. Agricultural Horticultural Publication House, Nagpur, Maharashtra, India. 


\title{
Nutrient Management
}

\author{
R. Palaniappan and A. Thangasamy
}

To achieve maximum yield potential from any crop, balanced application of required nutrients is imperative. Current fertilizer recommendations for onion are based on the empirical methods. Most of the farmers apply all fertilizer nutrients at the time of transplanting as a basal application without consideration of crop nutrient removal. Further, secondary and micronutrients are rarely applied. Replenishment of nutrients removed by crop-plants through supply of chemical fertilizers and organic manures is essential for sustainable production. Application of plant nutrients through inorganic fertilizers in a balanced manner would increase crop productivity while maintaining soil-health. Organic manures benefit by adding plant nutrients directly on mineralization and indirectly through improved soilhealth for plant growth and development. The quantity of plant nutrients supplied through organic manures may not be sufficient to fulfill requisite nutrient requirement. Hence, integrated use of both inorganic fertilizers and organic manures as per the requirement at the right time and quantity would be the ideal option to sustain onion production by increasing fertilizer-use efficiency. In this chapter, nutrient requirements and integrated plant nutrient system for onion have been discussed in details. Organic cultivation of onion has also been discussed, although limited information is available on this aspect.

\section{Nutrient budgeting}

The use of nutrient audits and nutrient balances to assess changes in soil-nutrient status and prospects for future generations is incessantly becoming important (Sheldrick et al., 2003). The relevance of soil nutrient balances for agricultural potential of the land has been emphasized. Soil nutrient flow is the amount of plant nutrients that flow in and out of the system (Nkonya et al., 2004). Difference between nutrient inflow (sum of nutrient inputs) and outflow (sum of nutrient outputs) is nutrient balance. Nutrient inputs include application of mineral fertilizers, organic manures, crop residues, biological nitrogen fixation, atmospheric deposition, sedimentation by irrigation and flooding, and nutrient outflow comprises removal of economic crop products, crop residues, gaseous losses, runoff and leaching losses. A situation where inputs exceed outputs is termed as nutrient accumulation, and when output exceeds inputs, it is nutrient depletion. Negative nutrient balance indicates that the system is losing nutrients. On the contrary, excess nutrient accumulation may lead to extended losses as a result of toxicities. Balanced or equilibrium nutrient levels occur when inputs equals outputs. A summary of the nutrient inputs and outputs from a defined 
system over a definite time is nutrient budget for that spatio-temporal unit (Onenema et al., 2003). Nutrient management practices must underline nutrient balances in the soil for sustaining its health. Soil testing and plant analysis are important tools for determining plant-nutrient requirement.

\section{Soil testing and plant analysis}

Soil testing evaluates soil fertility, provides an index of the nutrient availability in a given soil, and is also a basis for fertilizer recommendation. The main objective of sustainable nutrient management is to reduce production cost, conserve natural resource and minimize possible negative environmental impact, while maintaining an initial soil-fertility level without build-up or depletion over years. Plant analysis, on the other hand, is used as a monitoring tool to determine sufficiency or deficiency of plant nutrients and ability of soils to supply nutrients for good growth and development of plants. Plant tissue testing also helps in achieving high degree of precision in fertilizer management. Onion-plants exhibit deficiency symptoms characteristic for each element, which are useful for diagnostic purposes. However, in many cases, the symptoms may be masked by other nutritional disorder symptoms or by those caused by unfavourable environments or stresses caused by plant pests. In such situations, plant-tissue analysis provides useful information to complement and confirm visual diagnosis. Nutritional disorders in vegetables rarely occur in well-managed crops. If a nutrient deficiency is identified during the growth period, it can be corrected by side dressing or through foliar feeding. If the deficiency appears during the late growth period, a considerable yield reduction may occur. Application of fertilizer nutrients would help reduce percentage yield losses and may guide to modify fertilization programme for the next year's crop.

\section{Management of nutrients}

In India, research conducted at different locations have shown that onion-crop required $2.10-2.16 \mathrm{~kg} \mathrm{~N}, 0.70-0.80 \mathrm{~kg} \mathrm{P}_{2} \mathrm{O}_{5}, 2.00-2.25 \mathrm{~kg} \mathrm{~K}_{2} \mathrm{O}$ and $0.25-0.30$ $\mathrm{kg} \mathrm{S}$ for yielding a tonne of onion (AINRPOG, 2011). Similar studies by Dogliotti (2003) reported that onion-crop removed $1.92 \mathrm{~kg} \mathrm{~N}, 0.30 \mathrm{~kg} \mathrm{P}$ and $1.30 \mathrm{~kg} \mathrm{~K}$, and Zhao et al., (2011) found that the crop needed 2.93, 1.16 and $2.69 \mathrm{~kg}$ of N, $\mathrm{P}_{2} \mathrm{O}_{5}$ and $\mathrm{K}_{2}$, respectively. All these studies indicated that to produce a tonne of onionbulbs, nutrient requirements were more or less similar at varied locations and also for different varieties or ecotypes, like long-day or short-day. Dry matter accumulation was very slow at the initial establishment stage, up to 20 days after transplanting (DAT), and at a faster rate after 20 DAT. Daily dry matter accumulation rate reached a maximum after 55-60 DAT. And nutrient uptake was higher from 15 to 60 DAT, followed by a sharp decrease after 60 DAT (Thangasamy, 2014). Application of plant nutrients through external sources is a must to maintain soil nutrient equilibrium, and it should match with crop nutrient demand for higher nutrient-use efficiency.

Addition of $\mathrm{N}, \mathrm{P}, \mathrm{K}$ and $\mathrm{S}$ through mineral fertilizers plays a major role in plant nutrition. In India, fertilizer application is mainly restricted to $\mathrm{N}, \mathrm{P}$ and $\mathrm{K}$; and thus fertilizer consumption is unbalanced, tilted more towards $\mathrm{N}$, followed 
by $\mathrm{P}$ and $\mathrm{K}$, which is the root cause of low yield and declining soil fertility in many areas (Subbarao and Sammi Reddy, 2006). Unbalanced use of chemical fertilizers for seven years caused depletion of N, P and K from the initial NPK levels (Sinha and Prasad, 1980, 1981). Addition of excess of NPK and S resulted in build-up of applied nutrients in the soil, and their deficiency reduced crop yields and further depleted plant nutrients from the soil. Balanced use of NPKS increases crop yield and contributes to carbon sequestration by favouring crop growth and crop-derived carbon inputs in the soil (Gong et al., 2012).

\section{Nitrogen}

Onion has medium to high requirement for nitrogen. Mature healthy onionleaves at pre-bulbing stage (20-45 DAT) have $3-4 \% \mathrm{~N}$, and it reduced to $2 \%$ at the bulb initiation and development stages (45-75 DAT). Plants with less than $1 \% \mathrm{~N}$ are usually regarded as deficient (Fig. 9.1). Nitrogen is absorbed in the form of $\mathrm{NH}_{4}{ }^{+}$and $\mathrm{NO}_{3}{ }^{-1}$. Normally, almost all Indian soils are deficient in nitrogen. Nitrogen deficiency usually occurs in soils with poor organic matter, and continuous depletion of soil-nitrogen owing to intensive agriculture, and $\mathrm{N}$ nonreplenishment aggravates its deficiency. The deficiency is also caused by repeated cropping with non-leguminous crops, and due to microbial immobilization of applied and soil-nitrogen when high $\mathrm{C}: \mathrm{N}$ ratio organic matter is used. Thus, there is a need to apply nitrogen through external sources. Onion yields increased with $\mathrm{N}$ application from 0 to $150 \mathrm{~kg} / \mathrm{ha}$, and reached plateau beyond $150 \mathrm{~kg} / \mathrm{ha}$, and after crop harvest, soil- $\mathrm{N}$ balance increased with additional $\mathrm{N}$ application (Brewster 2008). Application of locally available organic manures, such as FYM, poultry-manure or vermi-compost, equivalent to $75 \mathrm{~kg} \mathrm{~N}$ through broadcasting at the field preparation, is recommended for onion-crop; along with addition of 110 $\mathrm{kg} \mathrm{N} / \mathrm{ha}$ for late kharif and rabi onion and $75 \mathrm{~kg} \mathrm{~N} / \mathrm{ha}$ for kharif season are also recommended. Nitrogen-management practices for achieving higher $\mathrm{N}$-use efficiency include split application of $\mathrm{N}$ fertilizers; its proper incorporation into
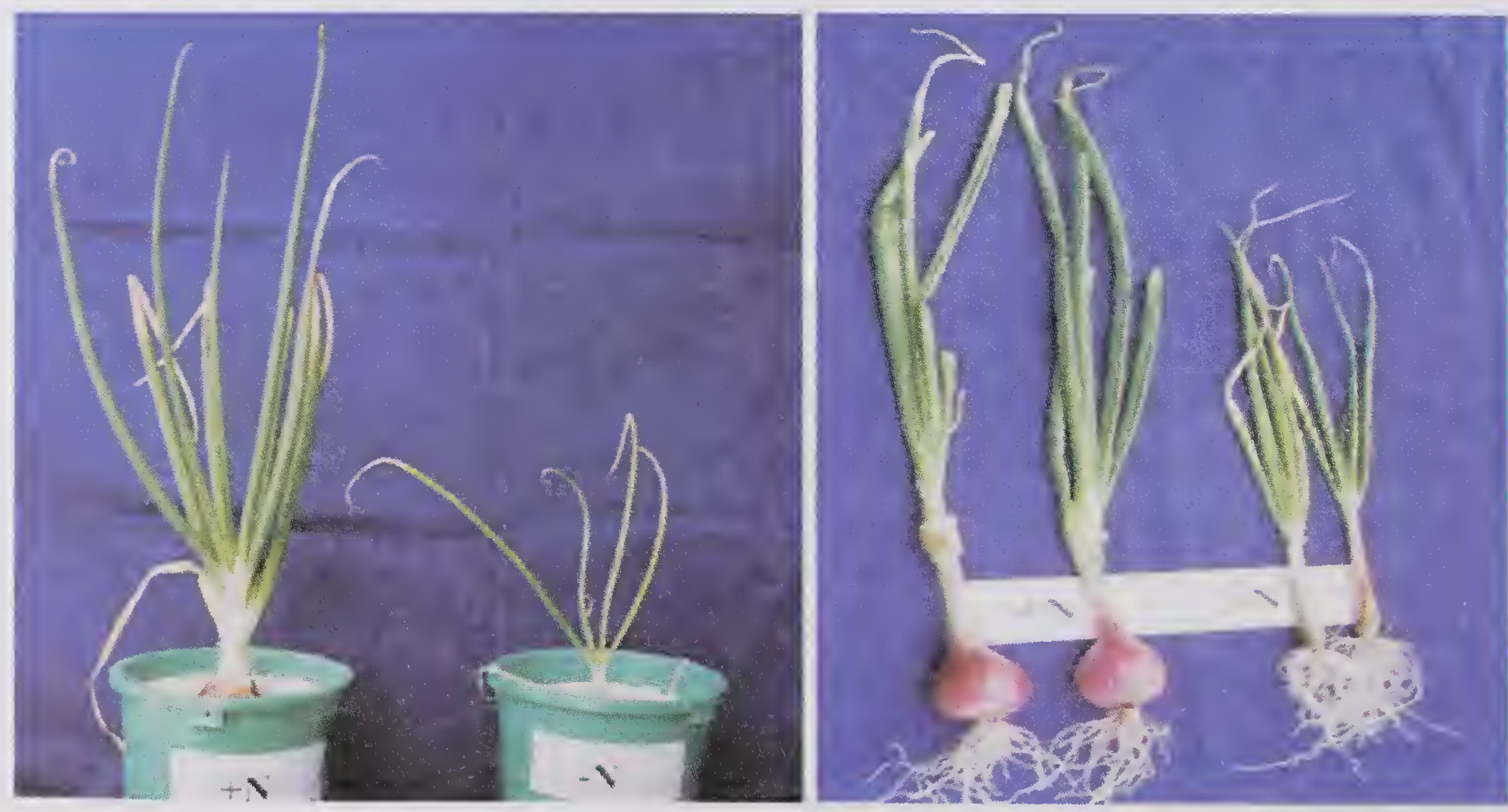

Fig.9.1 Nitrogen deficiency 
the soil to avoid volatilization losses; use of modified forms of urea fertilizers, like urea supergranules; and integrated use of organic and inorganic sources including green manures and biofertilizers. Calcium nitrate or calcium anmmonium nitrate has a positive effect on $\mathrm{N}$ nutrition of onion in red and light soils. Excess $\mathrm{N}$ in onion-plants cause thick stem (Fig. 9.2) and neck thickness (Fig. 9.3), and aggravates incidence of purple-blotch disease and attack of sucking pests. Excess $\mathrm{N}$ in the soil can be lost through gaseous volatilization and emission, denitrification, runoff and leaching (Raun and Johnson, 1999; Raun et al., 2002), and would pollute environment and contaminate groundwater.

\section{Phosphorus}

Onion-crop removes $15-20 \%$ of the total $\mathrm{P}$ from transplanting to 20 DAT, i.e. crop-establishment stage, and 70-75\% during 20-60 DAT. Only about $5-6 \%$ of the total $P$ was removed

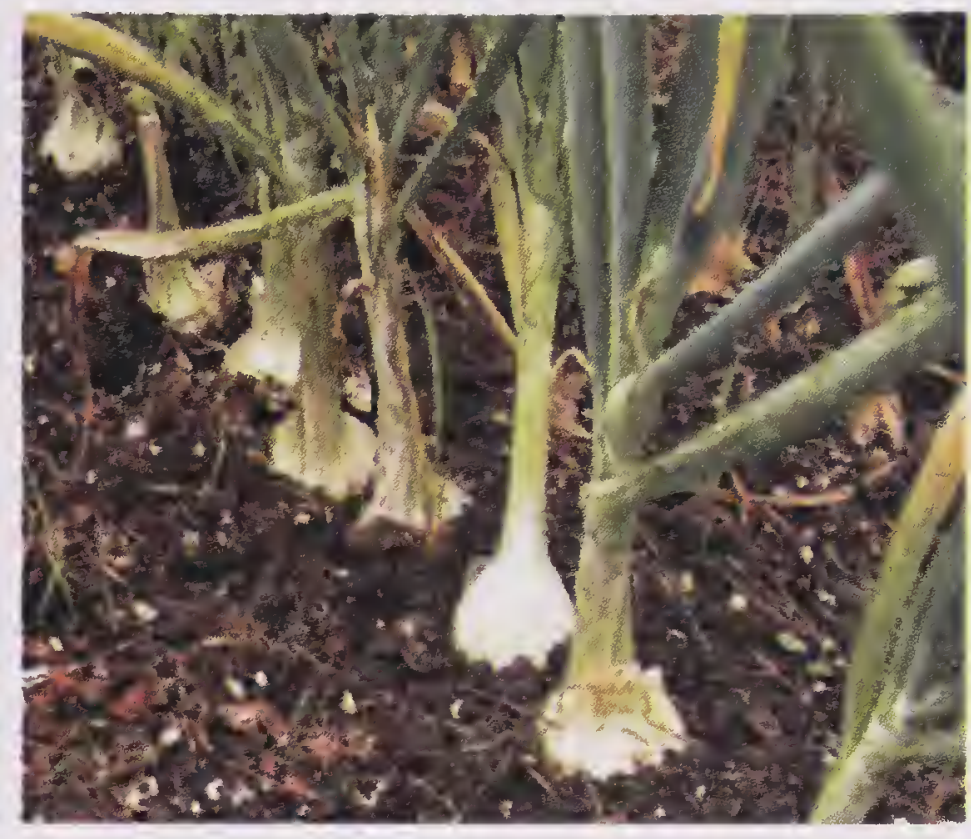

Fig. 9.2 Excess $\mathrm{N}$ leads to thick stem

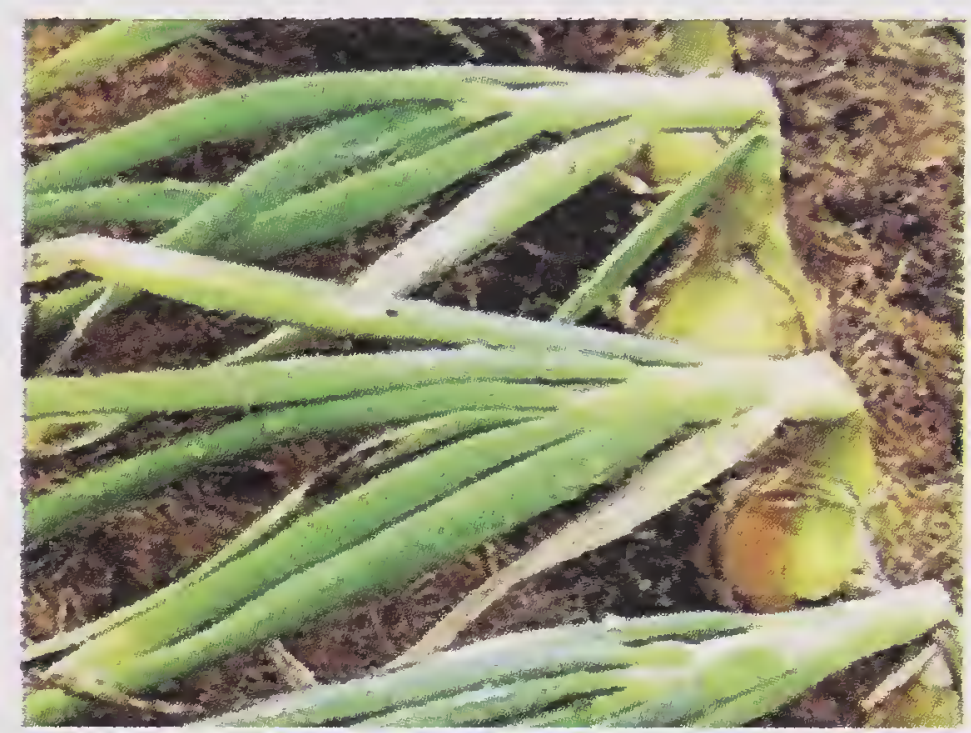

Fig. 9.3 Late application of $\mathrm{N}$ leads to thick neck, and the encrusted soil results in bent neck after 60 DAT (DOGR, 2013). Phosphorus is absorbed by the plants as $\mathrm{H}_{2} \mathrm{PO}_{4}{ }^{-}$by an active process. In normal plants, $\mathrm{P}$ content varies from 0.3 to $0.4 \%$ during active vegetative growth stage (20-45 DAT) and from $0.1-0.3 \%$ during bulb initiation to developmental stages. Plants having less than 0.2 and $0.1 \% \mathrm{P}$ during active vegetative growth stage (20-45 DAT) and bulb initiation to developmental stages (45-75 DAT), respectively, are designated as P-deficient (Fig. 9.4).

Phosphorus at $40 \mathrm{~kg} / \mathrm{ha}$ is recommended for onion-crop, and full dose is applied as basal at the time of transplanting. Phosphorus applied through external sources enriches soil-available $\mathrm{P}$ and with time, the applied $\mathrm{P}$ gets fixed in soil complexes. Soil-available phosphorus remains in equilibrium with fixed phosphorus in the soil. When soil-available $\mathrm{P}$ is removed by plants, fixed-P would be released into the soil solution to maintain equilibrium. Available $\mathrm{P}$ in the soil is highly $p \mathrm{H}$ sensitive, and gets affected both in acidic as well as alkaline range. Root development is seriously hampered whenever P level in the soil is less than 10 ppm. Hence, its full recommended dose is applied at the time of transplanting. Soil application of phosphorus-solubilizing bacteria (phospho-bacteria) at $5 \mathrm{~kg}$ / ha is also recommended to enhance P-use efficiency. Organic manures and phosphobacteria application increased phosphorus uptake over inorganic fertilizers (DOGR, 2013). Organic manures supply plant $P$ directly and also releases indirectly 

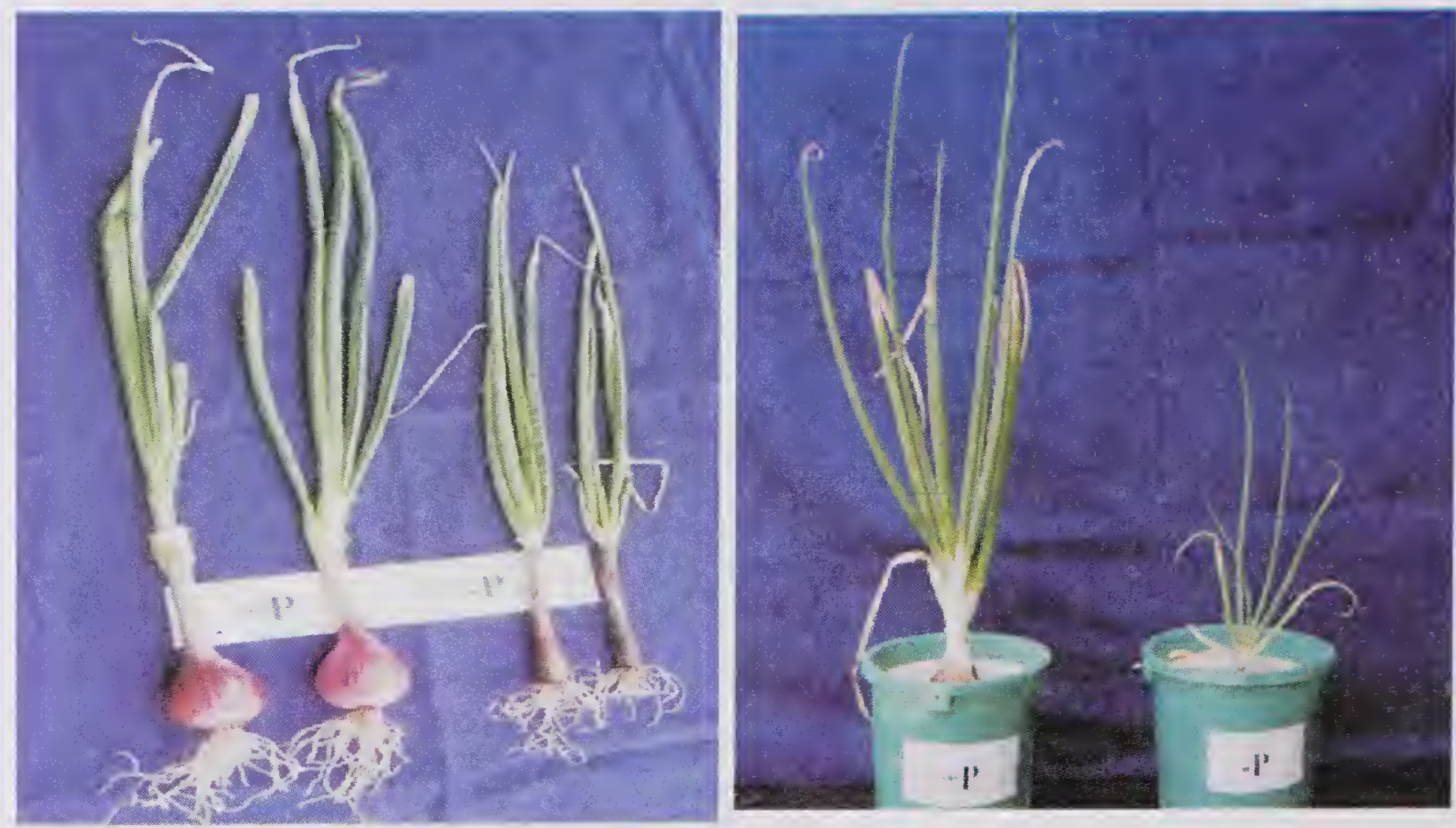

Fig. 9.4 Phosphorus deficiency

fixed-P through chelation. Organic acids released during mineralization of organic manures form complexes with fixed-P and thus releases fixed-P. Phospho-bacteria solubilizes fixed-P and enhances efficiency of applied-P. Hence application of PSB (phosphorus-solublizing bacteria) along with organic manure is recommended in package of practices for onion-crop to increase P-efficiency. For instance, dipping seedlings in $2 \% \mathrm{P}$ solution or slurry has been found useful in meeting $\mathrm{P}$ requirement in the initial establishment stages. In Karnataka, excessive use of DAP and single superphosphate in onions results in $\mathrm{P}$ accumulation. This situation warrants more zinc application.

\section{Potassium}

Its concentration in healthy plants varies from 3.5 to $5.5 \%$ and $2.0-4.0 \%$ during active vegetative growth stage (20-45 DAT) and bulb initiation to developmental stages (45-75 DAT), respectively. Plant tissues having level lesser than $1.0 \% \mathrm{~K}$, develop potassium deficiency symptoms (Fig. 9.5). Potassium requirement is more or less equal to that of $\mathrm{N} . \mathrm{N}: \mathrm{K}$ ratio of $1: 1.2$ is found to give resistance to various diseases like purple-blotch. Like $\mathrm{N}$ and $\mathrm{P}, \mathrm{K}$ is also highly mobile and is transported rapidly to younger tissues. Hence spray of sulphate of potash $(0.5 \%)$ at later stages improves yield and increases disease resistance. Potassium balance in soil remains consistently negative and $\mathrm{K}$ supply through external sources is

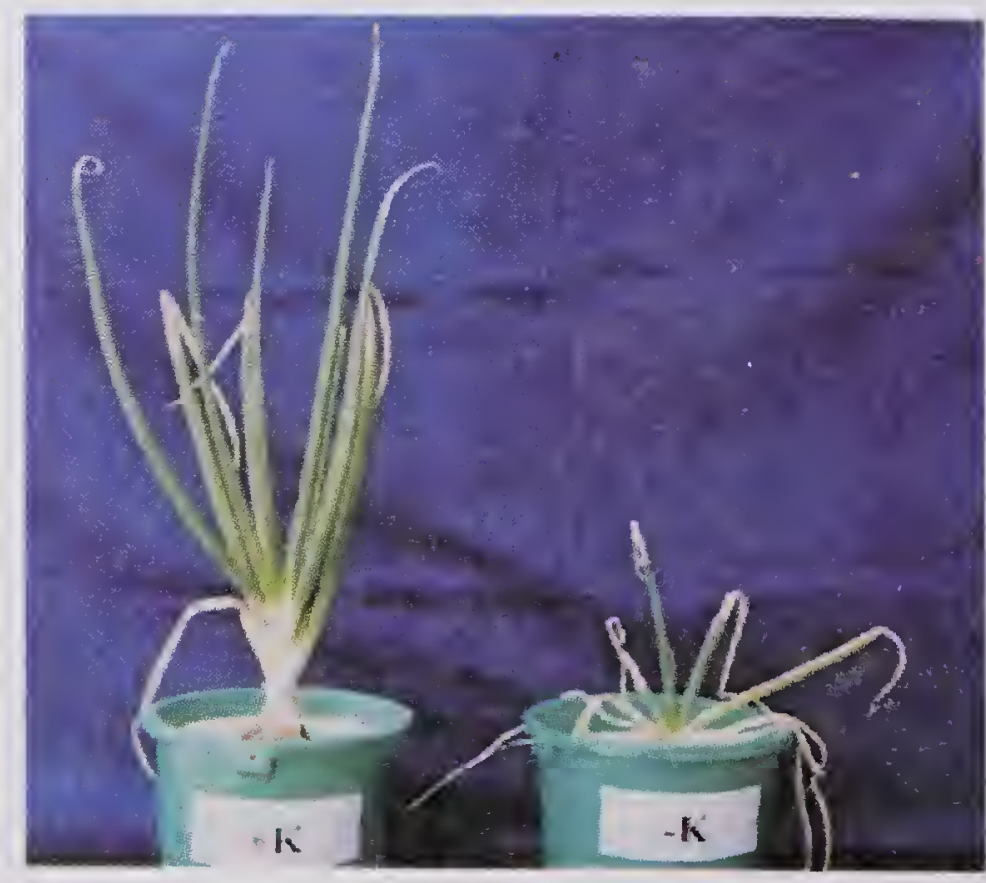

Fig. 9.5 Potassium deficiency 
comparatively lesser than the removal by the crop in many places in the country. Soils subjected to high cropping intensity and high $\mathrm{K}$ removal suffer considerable reduction in non-exchangeable content compared to soils with a low cropping intensity (Mingfang et al., 1999). This negative balance results in serious soil-K depletion, which ultimately affects crop yield (World Bank Report, 2007). By balanced $\mathrm{K}$ application, $\mathrm{N}$ and $\mathrm{P}$ use efficiency and crop production can be enhanced. Potassium at $40 \mathrm{~kg} / \mathrm{ha}$ is required at the time of planting for kharif onion-crop. Potassium uptake and yield of the late kharif and rabi onion is higher over kharif crop. Therefore, potassium at $60 \mathrm{~kg} / \mathrm{ha}$ is recommended for late kharif and rabi crops. Potassium chloride (Muriate of potash) is often used as a potassium source. Most of the onion-growing areas fall in the range of medium to high category of available-K. Though soil-potassium level is high in onion-growing areas, the crop also responds well to external addition of potassium fertilizers. This indicates that replenishment of potassium removed by the crop is inevitable to maintain soil quality and sustain crop productivity. Intensive cropping without $\mathrm{K}$ addition in soils having high $\mathrm{K}$ content could lead to depletion of native soil- $\mathrm{K}$. Excess $\mathrm{K}$ application may result in build-up in the soil, and may cause imbalance in the soil, and affect uptake of other nutrients also.

\section{Sulphur}

In addition to NPK, sulphur is an essential plant nutrient for onion-crop for improving yield and pungency of bulbs. Sulphur is absorbed as sulphate ions $\left(\mathrm{SO}_{4}{ }^{2-}\right)$. Leaf-tissue sulphur level of 0.3 to $0.5 \%$ is required during active vegetative growth stage (20-45 DAT) and $0.2-0.3 \%$ during bulb initiation to developmental stages (45-75 DAT). Sulphur content below sufficiency level is deficient and above this level interferes with $\mathrm{P}$ uptake. Response to sulphur is more conspicuous in soils where $p \mathrm{H}$ is more than 7.8. Several studies were carried out on the effect of sulphur application on yield, pungency, sulphur uptake and soil-sulphur, and results indicated that potassium sulphate application gave better results over potassium chloride due to the presence of sulphur in the former. Qureshi and Lawande (2006) revealed onion yield increased with increasing sulphur nutrition up to $75 \mathrm{~kg} / \mathrm{ha}$ in soils with low sulphur $(<10 \mathrm{ppm})$, while in soils with sulphur level of $14 \mathrm{ppm}$, bulb yield increased significantly up to $20 \mathrm{~kg} \mathrm{~S} / \mathrm{ha}$, and increase beyond this did not improve yield. Soil application of sulphur beyond $20 \mathrm{~kg} / \mathrm{ha}$ to onion successively for two years increased soil-available sulphur, slightly over the initial sulphur level (Thangasamy et al., 2013). No yield increase was recorded in soils with high sulphur (Yoo et al., 2006). This indicates $15 \mathrm{~kg}$ sulphur/ha is sufficient for growing onion-crop in soils having sulphur level above $25 \mathrm{~kg} / \mathrm{ha}$, while $30 \mathrm{~kg}$ sulphur/ha is needed for soils with sulphur below $25 \mathrm{~kg} / \mathrm{ha}$ for the optimum onion production. Sulphur levels low enough to reduce onion yield and pungency range between 5 and $10 \mathrm{ppm}$ (Yoo et al., 2006). From the earlier studies it has been found that critical limit for soil available sulphur is $100 \mathrm{ppm}$, and soils with sulphur below 10 ppm are considered deficient (Parischa and Sarkar, 2002).

\section{Micronutrients}

Deficiency of micronutrients drastically affects growth, metabolism and 
reproductive phase in plants, animal and human-beings. Widespread deficiencies of micronutrients have been found in Indian soils. Intensive cropping with straight chemical fertilizers without micronutrients aggravates micronutrient deficiencies. World-over micronutrients are gaining much importance not only for their role in sustaining higher crop yields, but also as their increased deficiency in soil, seed/or feed, affects more animal and human health.
Table 9.1 Available micronutrients content and their critical limit in Indian soils

\begin{tabular}{lcc}
\hline Element & $\begin{array}{c}\text { Available } \\
\text { nutrient content } \\
(\mathrm{mg} / \mathrm{kg})\end{array}$ & $\begin{array}{c}\text { Critical } \\
\text { limit } \\
(\mathrm{mg} / \mathrm{kg})\end{array}$ \\
\hline Zinc & $0.1-24.6$ & 0.6 \\
Boron & $0.08-2.6$ & 0.5 \\
Iron & $0.36-174$ & 4.5 \\
Manganese & $0.6-164$ & 2.5 \\
Copper & $0.1-32$ & 0.2 \\
\hline
\end{tabular}

Sources: Takkar (1982), Singh (1999), Singh (2009)

Deficiencies of $\mathrm{Zn}, \mathrm{Fe}, \mathrm{Cu}, \mathrm{Mn}, \mathrm{B}$ and Mo have been noticed at 48, 12, 4, 5, 33 and 13\%, respectively, in soils of India (Singh, 2009; Table 9.1). Among micronutrients, deficiency of available $\mathrm{Zn}$ in Indian soil is high, followed by $\mathrm{B}$ (Singh, 1991, 2009). Micronutrients can be applied either through soil or foliar application. When micronutrients are applied to soil, applied micronutrients are fixed in the soil and unavailable to plant growth. The availability of the micronutrients is governed by soil $p \mathrm{H}$, calcium carbonate, soil-organic matter, sodium, calcium and magnesium. Micronutrients are so termed because their small, or micro amounts are required for crop nutrtion. Such micro amounts can be supplied adequately through foliar applications to correct temporary deficiency. Boron is highly immobile in the plant, and to correct boron deficiencies, small amounts of boron must be applied frequently to young tissues or buds. Application of recommended doses of inorganic fertilizers $(110: 40: 60: 30 \mathrm{NPKS} / \mathrm{ha})$, organic manures equivalent to $75 \mathrm{~kg} \mathrm{~N}$ and foliar application of micronutrient mixture increased marketable bulb yield by 5-7\% (DOGR, 2014). Regular application of farmyard manure (FYM) at 10-15 tonnes/ha helps mitigating deficiencies of all micronutrients in the long run (Singh, 2004).

Micronutrients should be applied to soil only when a specific deficiency has been clearly diagnosed (Table 9.2). There is a fine line between adequate and toxic amounts of these nutrients. Indiscriminate application of micronutrients may reduce plant growth and restrict yields because of toxicity. Francois et al. (1991) reported that relative yield of onions was reduced by $1.9 \%$ with each unit $(\mathrm{mg} /$ litre) increase in soil-solution $B$ above $8.9 \mathrm{mg} \mathrm{B} /$ litre, which indicate that an important part of any micronutrient programme involvès careful calculation of all micronutrients applied from all sources. In general, if the leaf nutrient content during active vegetative growth and bulb initiation stage is less than the lower limit, deficiency symptoms may appear. When the contents exceed

Table 9.2 The critical limit of micronutrients in onion leaves

\begin{tabular}{lc}
\hline Elements & $\begin{array}{c}\text { Sufficiency ranges } \\
(\mathrm{mg} / \mathrm{kg})\end{array}$ \\
\hline Zinc & $15-25$ \\
Boron & $30-40$ \\
Iron & $400-600$ \\
Manganese & $60-90$ \\
Copper & $5-8$ \\
\hline
\end{tabular}

Source: Unpublished data 
upper value, toxicity symptoms may be visible. Both micronutrient deficiency and toxicity affect bulb yield and quality (Figs 9.6, 9.7). It should be noted that soil and environmental factors such as temperature and rainfall may also influence plant nutrient level and sometimes make the interpretation of results difficult. Hence, both plant tissue analysis and soil-test values should be used for diagnosis and interpretation of micronutrients' deficiency and management.

\section{Methods and time of fertilizer application}

Nutrient requirement varies with the crop growth stages. Farmers are generally applying higher $\mathrm{N}$ fertilizers at the time of planting to get maximum bulb yield. As discussed earlier, onion has a shallow and sparse root system, concentrated mainly on the surface soil

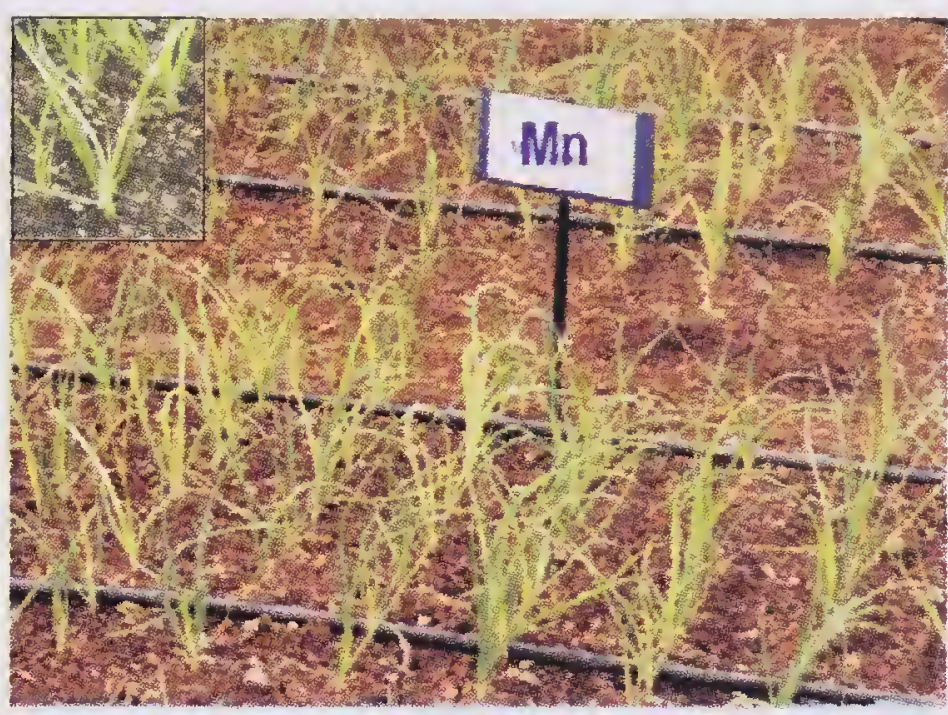

Fig. 9.6 Manganese deficiency in onion-crop

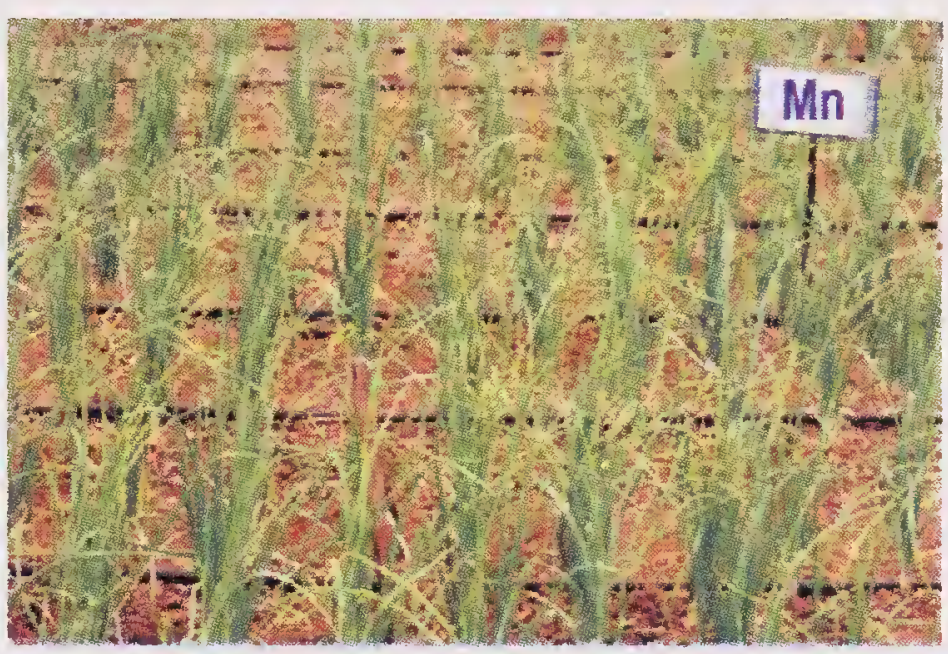

Fig. 9.7 Recovered manganese deficiency plot after foliar application $(0-30 \mathrm{~cm})$. Application of fertilizers as basal at the time of planting may be moved to subsurface along with the irrigation water through leaching and may pollute groundwater. Sammis (1997) reported the need for high rates of $\mathrm{N}$ to onion for optimizing onion yield in New Mexico but expressed concern about leaching of $\mathrm{NO}_{3}-\mathrm{N}$ from the root zone and low $\mathrm{N}$ fertilizer-use efficiency (30\%) of onion.

Field experiment carried out to determine the growth and $\mathrm{N}$ uptake pattern of onion grown on a silty clay-loam soils showed that the greatest demand for $\mathrm{N}$ by onion was during bulb development, and fertilizer- $\mathrm{N}$ recovery by onion was about $15 \%$. Much of the fertilizer $\mathrm{N}$ that remained in the upper $60-\mathrm{cm}$ soil profile at the harvest leached to subsurface (Halvorson et al., 2002). Application of starter $\mathrm{N}$ fertilizer in combination with reduced rates of supplementary $\mathrm{N}$ improved crop growth during initial growth stages and gave yields comparable with higher rates of basal $\mathrm{N}$ in onion-crop and showed that the starter fertilizer helped reducing $\mathrm{N}$ inputs, while maintaining yield and quality of onion (Stone, 2000). Drost and Koenig (2002) observed that application of $\mathrm{N}$ through polymer-coated urea to the crop reduced $\mathrm{N}$ losses and improved $\mathrm{N}$-use efficiency compared to single or multiple applications of water soluble $\mathrm{N}$ sources in direct-seeded onions. Controlled release of $\mathrm{N}$ fertilizers is often used to reduce leaching losses from the soils (Wang and Alva, 1996) and to extend $\mathrm{N}$ availability throughout the growing season (Weidenfeld, 1986). In Netherlands, slow-release fertilizer $\mathrm{N}$ applied to onion-crop improved crop growth, bulb yield and $\mathrm{N}$ concentration over soluble fertilizers (Amans and Slangen, 1994). Addition of chemical fertilizers stimulates 
plant growth, crop yield, increases organic matter input to soil, and effect of organic fertilizers is double as this also adds organic matter to the soil (Heitkamp et al., 2009). The organic manure application improves soil-organic carbon content and also supplies secondary nutrients and micronutrients.

\section{Organic farming}

Soil organic matter is a key component in maintaining soil quality (Doran and Parkin, 1994). It affects crop growth and yield either directly by supplying plant nutrients or indirectly by modifying soil physical environment that can improve root environment and stimulate plant growth (Darwish et al., 1995). Application of organic manures over the years continuously enhanced soil organic matter and soil physical properties such as hydraulic conductivity, porosity and aggregate stability, lowered bulk density and increased soil biological activity than soils receiving only inorganic fertilizers (Edmeades, 2003;Diacono and Montemurro, 2010). Use of organic fertilizer with low $\mathrm{N}$ and high carbon as an alternative fertilizer in organic farming produced lower yields than chemical fertilizers due to slow rate of mineralization (Blatt, 1991). Although organic production provides better quality food and a balanced environment, but almost $25-40 \%$ lesser yield in the initial years. Bulb yield increased in the succeeding years. However, the yield level recorded in organic farming was comparatively less over inorganic farming (Lawande et al., 2009). The production cost of organic onion was also higher than conventionally produced onion-crop. This indicates that application of organic manure improves soil-health but is not sufficient to sustain onion production. To increase production and to sustain soil-health, both chemical fertilizers and organic manures need to be applied together in a balance as per the crop requirement. The major challenge is to increase productivity through integrated use of organic manures, microbial inoculants and inorganic fertilizers as per the crop requirement at the right time.

\section{Integrated plant nutrient system}

Integrated application of 75\% NPK, 10 tonnes FYM/ha and Azotobacter to onion-crop produced bulbs at par with $100 \% \mathrm{RDF}$, which was significantly higher over control without fertilizer application in sandy-loam soils of Bichpuri, Uttar Pradesh (Singh and Pandey, 2006). Similarly, combined application of $75 \%$ NPK, organic manures equivalent to $75 \mathrm{~kg} \mathrm{~N}$ and Azospirillum produced yield at par with 100\% RDF (150:50:80:50 kg NPKS/ha) + 20 tonnes FYM/ha at Rajgurunagar, Srinagar, Udaipur, Dharwad, Samastipur, Hisar and Jabalpur (AINRPOG Annual Report, 2011). Jayathilake et al. (2002) found that integration of organic amendments (farmyard manure or vermi-compost) and biofertilizers with inorganic fertilizers resulted in higher yields and greater growth than inorganic fertilizers alone. Similarly, Selvakumari et al. (2001) found that inclusion of organic manures and biofertilizers reduced required amounts of inorganic $\mathrm{N}$, $\mathrm{P}$, and $\mathrm{K}$. However, current integrated nutrient management practices involve just inorganic fertilizers and organic sources such as FYM or compost, which need an improvement by including all possible local sources of plant nutrients. 


\section{Inclusion of legume as a proceeding crop}

Due to increased fertilizer prices and consideration for ecological sustainability, interest is focused on the intensive cropping system, especially with legume crops in a sustainable crop sequence as a supplement to chemical fertilizers. Inclusion of legume as a proceeding crop enriches soil- $\mathrm{N}$ and also has a synergistic effect on the succeeding crop. The potential of $\mathrm{N}$ fixation by legume crops varies from 26 to $300 \mathrm{~kg}$, depending on the crop species. Inclusion of soybean as a proceeding crop in onion-cropping sequence, improved bulb yield and soil-health over bajra, followed by onion sequence (NRCOG, 2007). Substitution of nitrogen through farmyard manure, addition of bioinoculant (Rhizobium + phosphate-solubilizing bacteria) and in-situ incorporation of soybean-straw along with $75 \%$ RDF produced comparable bulb yield with $100 \% \mathrm{RDF}$, indicating a saving of recommended fertilizers to the extent of $25 \%$ in onion-crop in the soybean-onion cropping sequence (Tumbare and Pawar,2003). Legume-based cropping system effect was evaluated on the succeeding rice-crop at Thanjavur, Tamil Nadu. Besides, more rice yield, soil-organic carbon and available nitrogen status also improved (Porpavai et al., 2011). Studies conducted at Rajgurunagar, Pune, revealed that inclusion of legume as a proceeding crop in kharif, followed by onion or garlic in rabi is ideal cropping sequence under western Maharashtra in terms of yield, soil-health and cost: benefit ratio (Sankar et al., 2005).

\section{Crop residues and green manure}

Crop residues are also one of the sources of organic material and supply of carbon and nutrients to agricultural systems. Continuous incorporation of organic residues increases soil-organic matter, and also improves delivery potential of nutrient elements (Kolahchi and Jalali, 2011). About 80.12 million tonnes of crop residues are available for recycling with the total nutrient potential of 1.61 million tonnes, which can replace $0.80 \mathrm{Mt}$ chemical fertilizers in India (Gill et al., 2008). Recovering nutrients by reincorporating organic residues into the farming systems is a sustainable alternative that can contribute to restoring natural environmental equilibrium and also protecting environment from pollution. Incorporation of green manure crop with tender twigs planted during late summer or leaves from outside into the soil would provide plant nutrition and also improve soil architecture for achieving a good seedbed and fast emergence and early vigour of onions; each of these contribute to good crop establishment. Growing green manure crops during late summer and incorporating them into soil reduce weed menace also. The rooting depth of the onion-crop is about $0.3 \mathrm{~m}$, and the crop is unable to use nitrogen of the deeper layers. However, $\mathrm{N}$ uptake of onion increased when green manure was grown as a proceeding crop, which was due to dual effect of green manure crop -biological $\mathrm{N}$ fixation and ability to concentrate available- $\mathrm{N}$ in the upper soil (Thorup-Kristensen, 2006).

\section{Biofertilizers}

Microbes harbouring rhizosphere benefit crops through increased nutrient availability by way of atmospheric $\mathrm{N}$-fixation and/or through solubilizing fixed mineral forms of nutrients. The symbiotic and non-symbiotic $\mathrm{N}$ fixation is a well 
known phenomenon involving leguminous and non-leguminous crops. $\mathrm{N}$ fixing and $\mathrm{P}$ solubilizing bacteria help increase crop yield and nutrient-use efficiency (Hegde et al., 2007). Integrated use of Azotobacter with $120 \mathrm{~kg}$ N/ha recorded highest marketable onion-bulb yield, followed by Azospirillum $+120 \mathrm{~kg} \mathrm{~N} / \mathrm{ha}$ at Kanpur, India (Dubey and Singh, 2008). Combined application of poultry-manure and Azotobacter gave 64\% higher bulb yield over control. Such a response of poultry-manure owing to relatively high nutrient concentration and microbial population helped mobilizing unavailable pool of nutrients in the soil, thereby triggering acquisition of optimum nutrient supply across the critical crop growth stages (Yeptho et al., 2012). However, the response to microbial inoculation depends on different factors including inoculation, chances for survival, adsorption by soil particles and competition with indigenous population and soil fertility. Some soil microorganisms like Azospirillum sp., Enterobacter sp., Azotobacter sp. and Pseudomonas sp. have shown to encourage plant growth by promoting growth of secondary roots, acting as protectors against pathogenic microorganisms by release of plant hormones and siderophores (Awad et al.,2011).

\section{Future Thrusts}

- Fertilizer scheduling based on the nutrient uptake pattern to enhance nutrientuse efficiency.

- Quantification of nutrient losses by different means in different nutrient management options.

- Quantification of availability of nutrients in different fractions in soils to monitor build-up and/or depletion of nutrients in soils through different management practices.

- Improving productivity and nutrient-use efficiency through microbial inoculation such as vesicular arbuscular mycorrhiza.

- Enhancing productivity and nutritional and storage quality through micronutrient management.

- Screening of germplasm for higher nutrient-use efficiency through traditional breeding methods or by using biotechnological tools.

\section{References}

AINRPOG. 2011. Annual Report2011. All-India Network Research Project on Onion and Garlic. Directorate of Onion and Garlic Research, Rajgurunagar. Pune, Maharashtra, India.

Amans E B and Slangen J H G. 1994. The effect of controlled released fertilizer "Osmocote" on growth, yield and composition of onion plants. Fertilizer Research 37: 79-84.

Awad M, Abd El-Kader A A, Attia M and Alva A K. 2011. Effects of nitrogen fertilization and soil inoculation of sulfur oxidizing or nitrogen fixing bacteria on onion plant growth and yield. International Journal of Agronomy doi: 10.1155/2011/316856. 2011: 1-6.

Blatt C R. 1991. Comparison of several organic amendments with a chemical fertilizer for vegetable production. Scientia Horticulturae 47: 177-91.

Brewster J L. 2008. Agronomy and crop production, pp. 251-93. (In): Onion and other Vegetable Alliums. Second Edition. CABI Publishing, Wallingford, UK. 
Darwish O H, Persaud N and Martens D C. 1995. Effect of long-term application of animal manure on physical properties of three soils. Plant and Soil 176: 289-95.

Diacono M and Montemurro F. 2010. Long-term effects of organic amendments on soil fertility. A review. Agronomy of Sustainable Development 30: 401-22.

Dogliotti, S. 2003. 'Exploring options for sustainable development of vegetable farms in South Uruguay ' Ph. D. Thesis, Wageningen University, Wageningen, The Netherlands.

DOGR. 2013. Annual Report 2013. Directorate of Onion and Garlic Research Directorate of Onion and Garlic Research, Rajgurunagar, Pune, Maharashtra, India.

DOGR. 2014. Annual Report 2014. Directorate of Onion and Garlic Research, Rajgurunagar, Pune, Maharashtra, India.

Doran J W and Parkin T B. 1994. Defining and assessing soil quality, pp. 3-21. (In): Defining Soil Quality for a Sustainable Environment. Doran J W, Coleman D C, Bezdick D F and Stewart B A. (Eds). Soil Science Society of America, Special Publication No. 35. American Society of Agronomy INC and Soil Science Society of America INC. Madison, Wisconsin, USA.

Drost D and Koenig R. 2002. Improving productivity and N use efficiency with a polymer coated nitrogen source. HortScience 37: 338-42.

Dupey A K and Singh S K. 2008. Effect of biofertilizers with nitrogen on growth and yield of onion (Allium cepa L.) Journal of Farming Systems Research and Development 14: $109-10$.

Edmeades D C. 2003. The long-term effects of manures and fertilizers on soil productivity and quality: a review. Nutrient Cycling Agroecosystem 66: 165-80.

Gill M S, Pal S S and Ahlawat I P S. 2008. Approaches for sustainability of rice (Oryza sativa)-wheat (Triticum aestivum) cropping system in Indo-Gangetic plains of Indiareview. Indian Journal of Agronomy 53: 81-96.

Gong W, Xiaoyuan Y and Jingyan W. 2012. The effect of chemical fertilizer application on carbon input and export in soil-A pot experiment with wheat using natural $13 \mathrm{C}$ abundance method. Geoderma, pp. 189-90, 170-75.

Halvorson A D, Bartolo M E, Reule C A and Berrada A. 2008. Nitrogen effects on onion yield under drip and furrow irrigation. Agronomy Journal 100: 1062-69.

Hegde D M, Sudhakarababu S N, Qureshi A A and Murthy I Y L N. 2008. Enhancing nutrient efficiency in crop production: A review. Indian Journal of Agronomy 52: 26174.

Heitkamp F, Raupp J and Ludwig B. 2009. Impact of fertilizer type and rate on carbon and nitrogen pools in a sandy Cambisol. Plant and Soil 319: 259-75.

Jayathilake P K S, Reddy I P, Srihari D, Neeraja G and Ravinder R. 2002. Effect of nutrient management on growth, yield and yield attributes of rabi onion (Allium cepa L.). Vegetable Science 29: 184-85.

Kolahchi Z and Jalali M. 2011. Kinetics of nutrient release from different organic residues using a laboratory system. Archives of Agronomy and Soil Science 58: 1013-31.

Lawande K E, Khar Anil, Mahajan V, Srinivas P S, Sankar V and Singh R P. 2009. Onion and garlic research in India. Journal of Horticultural Sciences 4: 91-119.

Mingfang C, Jin Jiyun and Huang Shaowen. 1999. Release of native and nonexchangeable soil potassium and adsorption in selected soils of North China. Better Crops International 13: 3-5.

Nkonya E, Pender J, Jagger P, Sserunkuuma D, Kaizzi C and Ssali H. 2004. Strategies for sustainable land management and poverty reduction in Uganda. International Food Policy Research (IFPRI) Report 133, Washington, DC.

NRCOG. 2007. Annual Report 2007. National Research Centre for Onion and Garlic, Rajgurunagar, Pune, Maharashtra, India.

Oenema O, Kros H and De Vries W. 2003. Approaches and uncertainties in nutrient budgets: 
implications for nutrient management and environmental policies. 20. European Journal of Agronomy 20: 3-16.

Pasricha N S and Sarkar A K. 2002. Secondary nutrients, pp. 384 (In): Fundamentals of Soil Science. Sekhon G S, Chhonkar P K, Das D K, Goswami N N, Poonia S R, Rattan R K and Seghal J. (Eds). Indian Society of Soil Science. New Delhi, India.

Porpavai S, Devasenapathy P, Siddeswaran K and Jayaraj T. 2011. Impact of various ricebased cropping systems on soil fertility. Journal of Cereals and Oilseeds 2: 43-46.

Qureshi A A and Lawande K E. 2006. Response of onion (Allium cepa) to sulphur application for yield, quality and its storability in S-deficient soils. Indian Journal of Agricultural Sciences 76: 535-37.

Raun W R and Johnson G V. 1999. Improving nitrogen use efficiency for cereal production. Agronomy Journal 91: 357-63.

Raun W R, Solie J B, Johnson G V, Stone M L, Mullen R W, Freeman K W, Thomason W $E$ and Lukina $E$ V. 2002. Improving nitrogen use efficiency in cereal grain production with optical sensing and variable rate application. Agronomy Journal 94: 815-20.

Sammis T. 1997. Nutrient management of onions: A New Mexico perspective, pp. 49-53. (In): Proceeding of Western Nutrient Management Conference, Volume 2, Tindall $\mathrm{T}$ and Westermann D (Eds). Salt Lake City, UT. Univercity of Idaho, Moscow, Russia.

Sankar V, Qureshi A A, Tripathi P C and Lawande K E. 2005. Production potential and economics of onion based cropping systems under western Maharashtra Region, pp. 79. (In): Proceeding of National Symposium on Current Trends in Onion, Garlic, Chillies and Seed Spices- Production, Marketing and Utilization (SYMSAC-II), held during 25-27 November 2005 at NRCOG, Rajgurunagar, Pune, Maharashtra, India.

Selvakumari G, Santhi R, Natesan R and Sathiyabama K. 2001. Soil test and vegetable crop response under integrated plant nutrition system for optimization of fertilizer doses. South Indian Horticulture 49: 130-36.

Sheldrick W, Syres K and Lingard J. 2003. Contribution of livestock excreta to nutrient balances. Nutrient Cycling in Agroecosystems 66: 119 31.

Singh M V. 1991. Proceedings of Workshop on Rice-Wheat Cropping System, pp. 13344. Project Directorate of Cropping System Research, Modipuram Uttar Pradesh, India.

Singh M V. 2004. Micronutrient deficiencies in Indian soils and field usable practices for their correction. (In): IFA International Conference on Micronutrient, held during 2324 February 2004. New Delhi, India.

Singh M V. 2009. Micronutrient nutritional problems in soils of India and improvement for human and animal health. Indian Journal of Fertilizer 5: 11-26.

Singh V and Pandey M. 2006. Effect of integrated nutrient management on yield and nutrient uptake by onion and on soil fertility. Journal of the Indian Society of Soil Science 54: 365-67.

Sinha N P and Prasad B. 1981. Balance sheet of soil phosphorus and potassium as influenced by intensive cropping and fertilizer use. Plant and Soil 60: 187-93.

Sinha N P and Prasad B. 1980. Influence of different fertilizers on net gain or loss of soil nitrogen in long-term manure and fertilizer applications. Plant and Soil 57: 159-65.

Stone D A. 2000. The effects of starter fertilizers on the growth and nitrogen use efficiency of onion and lettuce. Soil Use and Management 16: 42-48.

Subbarao A and Sammi Reddy K. 2006. Integrated nutrient management vis-à-vis crop production/productivity, nutrient balance, farmer livelihood and environment: India, pp. 26. (In): Improving Plant Nutrient Management for Better Farmer Livelihoods, Food Security and Environmental Sustainability. RAP Publication. Proceedings of a Regional Workshop Beijing, China.

Thangasamy A. 2014. Quantification of dry matter accumulation and nutrient uptake pattern of short day onion, pp. 330. (In): Book of abstracts (Poster papers), $6^{\text {th }}$ Indian 
Horticulture Congress-An International event on Horticulture for Inclusive Growth, Chadha K L, Singh S K, Srivastava, Manish and Behera T K. (Eds), held during 6-9 November, 2014. Tamil Nadu Agricultural University, Coimbatore, Tamil Nadu, India.

Thangasamy A, Sankar V and Lawande K E. 2013. Effect of sulphur nutrition on pungency and storage life of short-day onion (Allium cepa). Indian Journal of Agricultural Sciences 83: 1086-89.

Thorup-Kristensen K. 2006. Root growth and nitrogen uptake of carrot, early cabbage, onion and lettuce following a range of green manures. Soil Use and Management 22: 29-38.

Tumbare A D and Pawar V S. 2003. Effect of integrated nutrient management system in soybean (Glycine max)-onion (Allium cepa) cropping sequence on yield and keeping quality of winter onion. Indian Journal Agricultural Sciences 73: 373-75.

Wang F L and Alva A K. 1996. Leaching of nitrogen from slow-release urea sources in sandy soils. Soil Science Society of America Journal 60: 1454-58.

Wiedenfeld R P. 1986. Rate, timing and slow-release nitrogen fertilizers on bell peppers and muskmelon. HortScience 21: 233-35.

World Bank Report. 1997. China, Long-term Food Security Report No. 16469-CHA. Rural and Social Development Operations Division, China and Mongolia Department, East Asia and Pacific Regional Office, pp. 193.

Yeptho A K, Singh A K, Kanaujia S P and Singh V B. 2012. Quality production of kharif onion (Allium серa) in response to biofertilizers inoculated organic manures. Indian Journal of Agricultural Sciences 82: 236-40.

Yoo K S, Pike L, Crosby K, Jones R and Leskovar D. 2006. Differences in onion pungency due to cultivars, growth environment and bulb sizes. Scientia Horticulturae 110: 144 149.

Zhao K, Xu K, Xu N and Wang Y G. 2011. Absorption and distribution of nitrogen, phosphorus and potassium in onion. Plant Nutrition and Fertilizer Science 15: 24146. 


\title{
Seed Production
}

\author{
R.P. Gupta and H.P. Sharma
}

Onions are normally produced from seeds, except multiplier onions, which multiply through vegetative means from bulblets. The importance of quality seed and improved varieties is well established in cereals. Quality seeds and $F_{1}$ hybrids of vegetables (tomato, cabbage, cauliflower) and some other crops have brought considerable improvement in their yields. It is high time to have an organized production and distribution of quality seeds of improved onion varieties to increase crop production for meeting domestic and export requirements.

Onion-seed production is a difficult process, as it is produced in two phases. In the first phase, bulbs are to be produced, and in the second phase, onion-seeds are produced from bulbs. It takes longer to produce quality onion-seeds compared to other annual vegetables. Further, extra precautions are to be taken from seed sowing to seed production. Details for onion-seed production such as good cultural practices for bulb production and purity of variety, seed cleaning, packing and storage need to be defined well with the latest production technologies.

\section{Improved onion varieties and their seed production}

Though there are more than 45 improved varieties of onion developed in different universities and institutes; all varieties are not popular among farmers, mainly as their seeds are not available on a commercial scale. The seeds of Pusa Red, N2-4-1, N53, Baswant 780, Agrifound Dark Red, Agrifound Light Red, NHRDF Red, NHRDF Red2, Arka Kalyan, Arka Niketan, Punjab Selection, Hissar 2, Bhima Red, Bhima Super, Bhima Kiran and Bhima Shakti in common bigonion group of red types, Agrifound Rose in common small-onion group of red types, Phule Safed, Punjab 48, Agrifound White and Bhima Shweta in white types, $\mathrm{CO} 4$ and Agrifound Red in multiplier types are being produced either by universities and institutes in small quantities or by the NSC, Mahabeej, NHRDF, DOGR and some other state seed corporations and private seed companies on a commercial scale in India.

Seeds of Early Grano in short-day yellow types and Spanish Brown in intermediate day-length types are also produced and distributed locally by farmers or institutes. Bejo Sheetal and Nunhems are also producing seeds of a few $F_{1}$ hybrids and distributing them. There are many other varieties like Pusa Madhavi, Punjab Red Round, Arka Pitamber, Phule Suvarna, Pusa White Round and Pusa White Flat; seeds of them are not yet produced or distributed. 


\section{Seed Production Technology}

\section{Seed-to-seed}

This method is also called "in-situ" method. In this, bulbs are as such left in the field and allowed for bolting and flowering in the same field. Seeds are sown in the nursery from June to August. Bolting starts in January-February and seeds are ready by mid-May. Seeds of Agrifound Dark Red, Baswant 780, Arka Kalyan, Bhima Raj and other kharif varieties are produced by this method. It has following merits: low-cost of seed production, early maturity and no need to store bulbs. And demerits are: it is not possible to select true-to-type bulbs and thus high quality seed production is not possible and seed yield is low. Thus, this system may be avoided.

\section{Bulb-to-seed}

In this, bulbs are lifted from the field, and after proper selection, they are replanted in the field. Following two methods are used for seed production.

\section{Annual method}

Seeds are sown in June-July and seedlings are transplanted in AugustSeptember. Bulbs are ready by November-December. Selected bulbs are replanted in another field after 10-15 days; from mid-November to mid-December. Bolting starts in January-February and seeds are ready by May. Since the method takes a year, it is called the annual method. Seeds of Agrifound Dark Red, N 53, Baswant 780, Arka Kalyan, Phule Safed, Bhima Dark Red, Bhima Raj, Bhima Super and Bhima Shubra are produced by this method. Its advantage is less cost of production as bulbs are not to be stored. The rabi onion varieties do not form proper bulbs, therefore this method is not being used for rabi onion varieties.

\section{Biennial method}

Seeds are sown in October-November, and seedlings are transplanted in December-January. Bulbs are ready by April-end to mid-May. Selected bulbs are stored up to mid-October and planted in well-prepared fields. Since this takes about one-and-a-half-year, it is called a biennial method and seeds of Agrifound Light Red, NHRDF Red, NHRDF Red 2, Pusa Red, N-2-4-1, Bhima Red, Bhima Kiran, Bhima Shakti and other rabi onion varieties are produced with this method, which are true-to-type. But it takes more time, losses of onion-bulbs during storage are high and thus cost of seed production is high. This is a better method for pure and quality seed production.

\section{Storage of mother-bulbs}

In the case of annual method, selected bulbs are planted in well-prepared beds after curing for 10-15 days, but under biennial method, bulbs are stored from June to October in well-ventilated godowns for planting during OctoberNovember. Onions are stored in especially designed storage structures with proper and adequate ventilation. Disinfection of storage premises for handling and storage of onions is a must to reduce post-harvest losses, particularly decay. 


\section{Cultural practices for onion seed production}

Temperature and day-length set the broad limits to the areas, which are suitable for seed production. When seeds are produced from the bulbs that have been raised during the preceding year, the day-length of the growing season required for the crop is relatively short. Long days, early in the season, which are characteristic of high latitude, favour rapid bulbing rather than flowering. A fairly cool temperature over considerable time while bulbs are in storage or over wintering in the field, conditions plant for flower-stalk formation; $4.5-14^{\circ} \mathrm{C}$ is favourable for the conditioning, which results more flower-stalks and more flowers in each umbel. The best seed-producing areas are the ones with low humidity. Long rainy season or heavy dew and fog favour development of Stemphyliumblight and purple-blotch. During flowering of onions, clear and bright days are necessary to ensure insect activity for pollination. Equally important is hot and dry weather during harvesting, curing and threshing of seeds.

\section{Selection of bulbs}

Medium-sized bulbs $(4.5-6.0 \mathrm{~cm}$ for big onions and $2.5-3.0 \mathrm{~cm}$ for small onions), especially single centred, should be selected for planting to get maximum yield. Though big-sized bulbs have more number of sprouts and thus give higher seed yield, they are not economical as cost increases. Medium-sized bulbs are better and economical for seed production.

\section{Land preparation}

Onion seed-crop can be grown on a wide range of soils but very light sandy soils are to be avoided. Moderately heavier soils should be preferred as they are cooler, have a high water-holding capacity and are more productive. The field is ploughed with tractor-drawn implements or desi plough to a fine tilth by giving four ploughings with sufficient interval between two ploughings. The planking should be done for proper levelling. The field is then divided into beds and channels. Field should be levelled to avoid waterlogging.

\section{Time of bulb planting}

Last week of October to first fortnight of November is the best time for bulb planting of rabi onion varieties. Kharif onion bulbs are available during midOctober and early November. They should be planted by 15 November from the same crop, and this way seed production can be within a year. Maharashtra, Madhya Pradesh, Karnataka, Gujarat and Rajasthan are considered better for onion-seed production. The highest seed yield is obtained from Rajkot area of Gujarat as it has dry weather during flowering and seed-setting (Pandey et al., 1994a). If planting is done early, crop is damaged by rains in March/April. If late planting is done, there would be lesser vegetative growth and that would lead to lesser number of bolters and seeds.

\section{Method of planting, spacing and bulb requirements}

Planting of uncut onion-bulbs of large size with higher dose of nitrogen up to $160 \mathrm{~kg} / \mathrm{ha}$ increases onion-seed yield (Sharma et al., 2008). Selected bulbs of 
4.5-6.0 cm are planted in a well-prepared field of normal loam to clay-loam soil at a distance of $45 \mathrm{~cm} \times 30 \mathrm{~cm}$ (Pandey et al., 1990a). If spacing is lesser, it results in lesser ventilation, and thus drying of the field is slower after irrigation, favouring diseases. In sandy soils, spacing may, however, be reduced to even 30 $\mathrm{cm} \times 30 \mathrm{~cm}$. The depth should be at $5-7.5 \mathrm{~cm}$. Irrigation is given immediately after planting. The spacing can be reduced if seed production is under drip system. About 25-30 quintal bulbs for big and 15-18 quintal for small onions are enough to plant a hectare.

\section{Manures and fertilizers}

About 20-25 tonnes of farmyard manure per hectare is required at the time of field preparation. Nutrient requirement usually depends on the soil type, growing region, varieties and amount of major nutrients removed. Generally $80 \mathrm{~kg}$ of nitrogen, $60 \mathrm{~kg}$ of $\mathrm{P}_{2} \mathrm{O}_{5}$ and $50 \mathrm{~kg}$ of $\mathrm{K}_{2} \mathrm{O} /$ ha are recommended for better seed yield (Bhonde et al., 1996). If the soil is low in nitrogen, $120 \mathrm{~kg} \mathrm{~N} / \mathrm{ha}$ should be applied. Whole quantity of phosphorus, potash and half of nitrogen should be mixed in the soil before planting. The rest of nitrogen should be given as topdressing in two equal split doses, first 30 days after planting and the second 45 days after planting. Application of $150: 75: 75 \mathrm{~kg} / \mathrm{ha}, \mathrm{N}, \mathrm{P}_{2} \mathrm{O}_{5}$ and $\mathrm{K}_{2} \mathrm{O}$ along with FYM @ 20 tonnes/ha and biofertilizers was promising for higher seed yield (Adagale et al., 2010). Foliar spray of water soluble fertilizer NPK+6 trace elements (19: 19: 19+6TE) @1\% at 60 and 75 days, and NPK (13:0: 45) @ 1\% at 105 and 120 days after bulb-planting should be done for higher seed yield.

\section{Irrigation and aftercare}

Irrigation in onion is given at an interval of 10 days (Bhonde et al., 1996), depending on the soil type and season. Earthing-up is done after two months of planting to avoid lodging. Weeding and hoeing are done as per the requirement. Specific precautions should be taken while irrigating the crop more frequently during flowering and seed-setting. Saturating soil surface and keeping it wet should be avoided as it may cause neck-rot and other diseases, which may lead to premature dying of seed-stalks. Drip irrigation and mulching with wheat or paddystraw is recommended for higher seed yield (Gupta et al., 2005). Drip irrigation at every 3 days interval with 75\% Cumulative Pan Evaporation (CPEU) is most effective for growth, yield and for production of good quality onion-seeds (Dingre et al., 2012).

\section{Weed management}

The problem of weeds is inevitable, and is a serious and widespread constraint, and is one of the major causes for low productivity. Apart from the depletion of nutrients and moisture from the soil by weeds, they may also harbour insect, pests and diseases, and thus provide an ideal ecological condition to shelter them and for their proliferation. Spraying of Pendimethalin @ 3.50 litres per hectare + one hand-weeding at 60 days after planting are recommended for effective weed control and higher seed yield. 


\section{Diseases and insect-pests management}

Onion-seed crop is affected by a number of diseases and insect-pests in the field. Each disease and insect-pest requires a specific management practice. The details of the most commonly occurring diseases and insect-pests, which may cause economical losses to farmers/seed producers, are given in the subsequent chapters.

\section{Rouging}

Diseased and off-type plants as follows are rouged out before flowering for quality seed production - weed plants; any other crops' plant; other varieties of onion; and diseased plants.

\section{Mode of pollination}

Onion is highly cross-pollinated crop, and bees are the main pollinating agent. So, it is necessary to have a good number of bees for proper pollination and seedsetting. Following points should be taken care of for improving pollination.

- Bee-colonies are kept in the field.

- Irrigation should be given more frequently at the time of flowering and seed-setting.

- Only safe insecticides should be sprayed during flowering. The spray should be done in evening or early morning, when there is no bee activity.

Benefits of pollination by bees

\begin{tabular}{lc}
\hline Product & $\%$ Increase \\
\hline Seed & 277 \\
Seed germination & $38-40$ \\
1,000 seed weight & $8-10$ \\
\hline
\end{tabular}

\section{Certification standards for seed production}

\section{Land requirement}

The land to be used for onion-seed production shall be free from volunteer plants.

\section{Field inspection}

Mother-bulb production stage

- First inspection should be done after seedling transplanting to determine isolation, volunteer plants, off-types, including bolters and other relevant factors.

- The second inspection should be after the bulbs have been lifted to verify their true characteristics.

Seed production stage

- The first inspection should be done before flowering to determine isolation and off-types. 
- The second and third inspection should be during flowering to check isolation and off-types and other relevant factors.

- The fourth inspection should be at maturity to verify true nature of the plant and other relevant factors.

\section{Field standards}

General requirements

Isolation : Following table gives the isolation distance.

\begin{tabular}{lccccc}
\hline Contaminant & \multicolumn{4}{c}{ Isolation distance $(\mathrm{m})$} \\
\cline { 2 - 3 } & $\begin{array}{c}\text { Foundation } \\
\text { seed }\end{array}$ & $\begin{array}{c}\text { Certified } \\
\text { seed }\end{array}$ & & $\begin{array}{c}\text { Foundation } \\
\text { seed }\end{array}$ & $\begin{array}{c}\text { Certified } \\
\text { seed }\end{array}$ \\
\hline $\begin{array}{l}\text { Field of other variety } \\
\text { Field of the same variety, not }\end{array}$ & 5 & 5 & & 1,000 & 500 \\
$\begin{array}{l}\text { conforming to varietal purity } \\
\text { requirement for certification }\end{array}$ & 5 & 5 & & 1,000 & 500 \\
\hline
\end{tabular}

For breeder seed production isolation distance should be $1,500 \mathrm{~m}$

\section{Specific requirements}

\begin{tabular}{lcc}
\hline \multirow{2}{*}{ Factor } & \multicolumn{2}{c}{ Maximum permitted limit } \\
\cline { 2 - 3 } & Foundation & Certified \\
\hline * Bulbs not confirming to the varietal \\
$\begin{array}{l}\text { characteristics } \\
* \text { Off-types }\end{array}$ & $0.10 \%$ (by number) & $0.20 \%$ (by number) \\
\hline
\end{tabular}

* Maximum permitted at the second inspection at mother- bulb production stage

** Maximum permitted at and after flowering at seed- production stage

\section{Seed standards}

\begin{tabular}{lcc}
\hline Factor & \multicolumn{2}{c}{ Maximum permitted limit } \\
\cline { 2 - 3 } & Foundation seed & Certified seed \\
\hline Pure seed (minimum) & $98 \%$ & $98 \%$ \\
Genetic purity (minimum) & $98 \%$ & $98 \%$ \\
Inert matter (maximum) & $2 \%$ & $2 \%$ \\
Other crop seed (maximum number) & $5 / \mathrm{kg}$ & $10 / \mathrm{kg}$ \\
Weed seeds (maximum number) & $5 / \mathrm{kg}$ & $10 / \mathrm{kg}$ \\
Germination (minimum) & $70 \%$ & $70 \%$ \\
Moisture (maximum) & $8 \%$ & $8 \%$ \\
For vapour-proof containers (maximum) & $6 \%$ & $6 \%$ \\
\hline
\end{tabular}




\section{Minimum seed certification standards for onion hybrids}

The general certification standards are basic, and together with the following specific standards constitute the standards for certification of hybrid onion-seed. The general standards are amplified as follows to apply specifically to hybrid onion-seeds.

\section{Eligibility requirement for certification}

- An inbred line to be eligible for certification shall be from such a source that its identity may be assured and approved by the certification agency.

- Hybrid seed to be eligible for certification shall be the progeny of two approved inbred lines, one of which shall be male sterile.

\section{Classes and sources of seed}

- An inbred line shall be relatively true breeding strain resulting from selfpollination with selection.

- The foundation class seed shall consist of an approved male-sterile line to be used as a female parent and an approved inbred line to be used as a male parent for production of hybrid seed.

- A male sterile line shall be a strain A (Smsms), carrying cytoplasmic genetic male sterility, which sheds no viable pollen, and is maintained by the normal sister strain B (Nmsms), which is used as a pollinator. For maintaining sterile line, crossing of A and B line is necessary. R line (S MS MS) crosses with A line to produce hybrid seed.

- The certified class seed shall be the hybrid seed to be planted for any use, except seed production.

\section{Field inspection}

\section{Mother-bulb production stage}

Minimum of two inspections shall be done as follows.

- The first inspection shall be made after seedling transplanting to determine isolation, volunteer plants and off-types, including bolter and other relevant factors.

- The second inspection shall be made after bulbs have been lifted to verify their true characteristics.

\section{Seed-production stage}

Minimum of four inspections shall be made as follows.

- The first inspection shall be made before flowering to determine isolation, volunteer plants, outcrosses, planting ratio, errors in planting and other relevant factors.

- The second and third inspections shall be made during flowering to check isolation, pollen-shedding umbels, off-types and other relevant factors.

- The fourth inspection shall be made at maturity to verify true nature of umbels and other relevant factors. 


\section{Field standards}

General requirements

Isolation: Following table gives the details.

\begin{tabular}{|c|c|c|c|c|}
\hline \multirow[t]{3}{*}{ Crop } & \multicolumn{4}{|c|}{ Isolation distance (m) } \\
\hline & \multicolumn{2}{|c|}{ Mother- bulb production } & \multicolumn{2}{|c|}{ Seed production } \\
\hline & $\begin{array}{c}\text { Foundation } \\
\text { seed }\end{array}$ & $\frac{\text { Certified }}{\text { seed }}$ & $\frac{\text { Foundation }}{\text { seed }}$ & $\begin{array}{c}\text { Certified } \\
\text { seed }\end{array}$ \\
\hline $\begin{array}{l}\text { Field of other variety, including } \\
\text { commercial hybrids of the same variety }\end{array}$ & 5 & 5 & 1,200 & 600 \\
\hline $\begin{array}{l}\text { Field of the same hybrids (code } \\
\text { designation), not conforming to varietal } \\
\text { purity requirements for certification }\end{array}$ & 1 & 5 & 1,200 & 600 \\
\hline $\begin{array}{l}\text { Fields of others varieties of different } \\
\text { skin colour }\end{array}$ & 5 & 5 & 1,500 & 750 \\
\hline
\end{tabular}

\section{Problems in certification}

Seed-producing agencies are facing many problems while processing for certification. Mother-bulbs are produced in one state, and certified seed production programme is in another state; leading to problems in documentation and verification. This problem needs to be addressed so that certified seed of onion is produced trouble-free.

Certified seeds of kharif onion varieties are produced by annual method and bulbs after harvesting need to be verified immediately so that planting of bulbs for seed production is done timely, but this is generally delayed by certification agencies. Therefore, preference needs to be given for kharif onion bulb certification by certification agencies. Seed germination testing, especially of kharif varieties, is not given priority by the agencies so to distribute seeds on time to farmers.

\section{Harvesting and curing}

In onions, all seed heads do not mature at the same time, therefore, harvesting cannot be done simultaneously. When the seed inside the capsule becomes black and 10-20\% black seeds are exposed, the umbel should be cut with $10-15 \mathrm{~cm}$ stem attached. The umbels are spread on to ground or canvas to avoid attack of mould during drying (Pandey et al., 1991).

\section{Threshing, cleaning and seed extraction}

After proper drying, umbels are threshed either by rubbing manually with hands or seed umbels are treading under bullock or tractor.

- Seeds are threshed when capsules are brittle and can break readily. Threshing is done by flairing. Cleaning is done by air-screen machine by using $1 / 14 \times$ 112 as grading screen.

- Thresher with low fan speed is also used for threshing large quantities of umbels.

- Seeds are cleaned by using hand-winnowers and fans. 
- Use of seed cleaners, graders and gravity separator with appropriate sequence would help obtain clean and graded seeds.

- For proper cleaning, seeds are dipped in water before putting them on airscreen cleaner. The heavier seeds at the bottom are taken out, and are spread on to the bottom trays for immediate drying.

- Dipping of seeds in water for cleaning should not be done for more than 23 minutes, as germination would be affected adversely. Upgrading is further done on gravity separator.

\section{Drying, packing and storage}

For safe storage, seeds are dried to a level of $6 \%$ moisture, and then packed in aluminium foil or tin, which are moisture-proof (Pandey et al., 1990b). Seeds are then stored in air-conditioned and dehumidified stores at $16-20^{\circ} \mathrm{C}$ and relative humidity of $30-40 \%$. Onion-seed coated with polymer@ $12 \mathrm{ml} / \mathrm{kg}+$ Thiram @ $2 \mathrm{~g} / \mathrm{kg}$ seeds and stored in aluminium pouch resulted in good germination (Basavaraj et al., 2008). In hot-and-humid climate, viability of onion-seed is lost within a year. Onion-seeds dried up to 5 days and packed in polythene or aluminium foil could be maintained at germination standard up to 24 months (Pandey et al., 1994b). If onion-seeds are dried to 6.0\% moisture level and stored in sealed containers, their life can be prolonged for 3-4 years, without loss in germination.

\section{Production of $\mathbf{F}_{\mathbf{1}}$ hybrid onion-seeds}

The usual ratio of male: female rows are ơ: o (1:4) or ơ: o (1: 8). The pattern and the ratio depend upon the mechanization and amount of pollen-grains produced by the male parent. Male: female parent ratio of $2: 4$ is also ideal. Remove offtype male-fertile flower plants from male-sterile female parent. Seeds from ơ sterile or o lines are harvested. Seeds produced on the male parent are harvested first to avoid mixing. The other practice of raising mother-bulbs and further multiplication are the same as for seed production of open-pollinated varieties.

\section{Seed production of multiplier onion}

Since this onion type is mainly propagated vegetatively, well-grown, uniform bulbs of a particular variety should be selected. The planting details including cultural practices followed for production of planting material are the same as those for production of bulbs for consumption. The seeds of multiplier type are also produced in a way similar to that of common big onion.

\section{Cost of Seed Production}

The normal seed yield is 6-8 $\mathrm{q} / \mathrm{ha}$. When weather is favourable, $12-15$ quintal seeds, especially in Gujarat, can be obtained from a hectare. Seed production cost has been estimated as ₹ 190-236/kg for Agrifound Dark Red, ₹ 163-239/kg for Agrifound Light Red and ₹ 117-140/kg for NHRDF-Red in different areas. Cost of seed production also varies due to high/low cost of mother-bulbs at the time of planting. 


\section{Seed requirement}

Though no authenticated data on demand of seeds is available, NHRDF has worked out some estimates on the season-wise requirement and also based on the types of onions grown in the country. The seed requirement on the basis of the calculation is $8 \mathrm{~kg}$ seeds for a hectare. The details are as follows.

\section{Certified/truthfully-labelled seeds}

\begin{tabular}{lc} 
Season/type & $\begin{array}{c}\text { Certified or truthfully labelled } \\
\text { seed requirement (tonnes) }\end{array}$ \\
\hline Kharif, including late kharif (big) & 2,918 \\
Rabi (big) & 4,752 \\
Small rose onion & 667 \\
Multiplier onion (bulblets) & 100,000 \\
\hline
\end{tabular}

Foundation or $2^{\text {nd }}$ stage and breeder seed

\begin{tabular}{lcc}
\hline Season/type & Foundation/Stock seed $(\mathrm{q})$ & Breeder seed $(\mathrm{kg})$ \\
\hline Kharif and late kharif (big) & 60.78 & 12.66 \\
Rabi (big) & 96.97 & 19.79 \\
Small rose onion & 25.01 & 9.38 \\
Multiplier onion (bulblets) & 200,000 & $4,000,000$ \\
\hline
\end{tabular}

Note: Multiplication ratio in the case of multiplier onion is $1: 5$

\section{Present Position of Seed Availability}

Seed production sector of onion is still not well organized. The NHRDF, NSC and MSSC are major agencies producing quality seed/certified seed in an organized manner. The total production of onion-seed by these agencies ranges between 700 and 750 tonnes, which is about $8-9 \%$ of the total requirement. The private seed companies also arrange some seed production, the quantity of which ranges between 800 and 1,000 tonnes. The DOGR is producing high quality seed to the tune of about 30 quintals per year of its own varieties.

By assessing the availability position of onion-seeds in public and private sectors, it is clear that around $80 \%$ seeds are produced by farmers and private traders without observing any standard for isolation or varietal purity, etc.

Adequate quantities of breeder and foundation seeds are available only for Agrifound Dark Red and Agrifound Light Red, NHRDF Red and NHRDF Red 2; varieties developed by the NHRDF. The breeder seeds of Bhima Red, Bhima Super, Bhima Raj, Bhima Kiran, Bhima Shakti, Bhima Shweta, B 780 and Arka Kalyan and Arka Niketan are also available with the DOGR and IIHR. However for the other varieties in demand, the basic seed material is not available. Weather vagaries also adversely affect seed-crop. Many times, it is also observed that indenters do not lift the seeds. All these factors affect seed availability. 
The details of the estimated onion-seeds produced by different agencies are as follows.

\begin{tabular}{lc}
\hline Agency & $\begin{array}{c}\text { Qty of truthfully labelled/ } \\
\text { certified seed (MT) }\end{array}$ \\
\hline NHRDF & 400 \\
NSC & 260 \\
MSSC & 100 \\
DOGRand SAUs & 10 \\
Private Seed Companies & 900 \\
Private Traders & 1,300 \\
Farmers & 5,500 \\
Total: & 8,470 \\
\hline
\end{tabular}

Private seed companies also distribute hybrid onion-seeds, but in a very little quantity, by producing themselves and also by importing. Though bulbs produced are uniform from hybrid seeds but they are poor in storage, and need immediate disposal. Private traders are also managing seed production through farmers in Maharashtra and Gujarat but mainly for dark red varieties where kharif onion bulbs are not required to be stored.

Following are the reasons for low production of onion-seeds in the organized sector.

- Rabi onion-seed production in India is mostly done by biennial method. Seed-producing agencies produce mother-bulbs and store them and then use them for seed production. Therefore, mother-bulbs production becomes a costly affair.

- Because of huge losses in storage of mother-bulbs, seed production becomes uneconomical.

- Price fluctuation: Onion seed price varies from year to year. The NSC and even private seed companies are not sure if onion-seed production would be remunerative.

- Short viability of onion-seed: Onion-seed is having shortest viability period, normally less than a year. Unless seeds are dried up to $6 \%$ moisture level and packed in moisture-proof containers and stored in controlled conditions, storage-life cannot be increased. Most of the agencies do not have these facilities.

\section{Quality Seed Production- Constraints}

\section{Non-availability of statistics on variety-wise area and seed demand}

As mentioned earlier, authentic data on variety-wise area are not available. In view of this, it is not possible to plan seed production programme for breeder, foundation and certified seeds; resulting in surplus in one and deficit in other.

\section{Marketing of seed collected from premature bolters}

There are many farmers who collect seeds from premature bolters and use 
themselves or supply the same to traders or other farmers at a very low price. Since seed produced in an organized way is costlier, it is not possible to compete with traders, and quality seed is carried over to the next year, which does not allow public sector agencies to continue seed production at the same level every year.

\section{Isolation distance}

It is experienced that seed companies are taking up seed production in areas where bulbs production is going on simultaneously. In such a situation, no care is taken in maintaining required isolation distance in the seed-production plot from premature bolters of the bulb-production plot. Further, seed companies are also taking up seed production of white, dark red and light red in the same pocket without maintaining the required isolation distance. The seeds so produced are thus of poor quality.

\section{Lack of awareness regarding suitable seed-production pockets}

Seed companies and even farmers are not aware about the suitable pockets for taking up seed production. The climatic conditions suitable for good seed production are not available in all pockets. Onion-bulbs conditioning is required to produce flower-stocks. It varies from variety to variety. Temperature of $4.5^{\circ} \mathrm{C}$ to $14^{\circ} \mathrm{C}$ is favourable for conditioning. Longer this conditioning prevails, more flower stems will each plant produce and more flowers will be in each umbel. High humid areas with long rainy period or heavy dew/fog or hailstorm favour development of downy mildew in hills and Stemphylium-blight in northern plains. Suitable areas for seed production of onion are Saurashtra in Gujarat; Nashik, Pune, Ahmednagar, Satara and Marathwada in Maharashtra; Khargaon, Indore and Dhar in Madhya Pradesh; Jaipur, Chittorgarh, Udaipur and Sriganganagar in Rajasthan; northern Karnataka; and Kurnool in Andhra Pradesh. The areas with good honeybee activity also yield good onion-seed.

\section{Slow spread of improved varieties}

Improved varieties are not being popularized by extension agencies at a faster rate. Seed producing agencies are also not cautious in selecting varieties for seed production according to demand and recommendation.

\section{Inadequate bulb storage facility}

Neither seed-producing agencies nor farmers have adequate bulb handling and storage facilities. This is one of the major hurdles in taking up seed production of light red varieties by seed-producing agencies.

\section{Sub-optimal standards of seed production}

Location-specific technologies are lacking for seed production of different varieties. Further, extension education on suitable seed processing including drying methods, packaging and storage conditions are also lacking.

\section{Inadequate facility for seed storage}

Onion seed looses viability very fast under ambient storage conditions. Adequate 
facility for grading and drying up to $6 \%$ moisture is not available. Similarly, controlled condition storage facilities are not available with many agencies, although facilities have been created by the NHRDF in Maharashtra, Gujarat, Madhya Pradesh, Delhi and Haryana.

\section{Future Strategies}

It is true that quality seed of improved varieties of onions in adequate quantities is not available. It is also true that there is no organized production of onion-seed, and non-availability of quality seed of improved varieties is one of the major hurdles in increasing productivity and production. There is sufficient scope for improvement in production and productivity if a critical assessment is made to all aspects and seed production is taken up in a well-planned strategic manner. The following strategies are suggested for improving seed production.

\section{Demand projection and advance planning}

More than $80 \%$ onion-seed is produced by farmers and traders without observing any standards for isolation or varietal purity. At present, there is no advance planning for assessing demand of quality seed; the programme is taken in an adhoc manner. There is, therefore, a need to assess seed demand based on the demand of onion for domestic and export markets for the next 10-20 years. There is also need to replace seeds of local old varieties with new improved varieties. Assuming that during the next 10 years it would be possible to replace old varieties with new varieties to the extent of $50 \%$, the seed requirement should be assessed and production of all classes of seeds need to be managed accordingly, mainly by organized sector.

State Governments should give indents of seed requirement in advance so that risk in production of quality onion-seed is minimized and sufficient quantity of seed is produced.

\section{Production of breeder, foundation and certified seed/truthfully-labelled seed}

After varieties are tested, specific responsibilities for production of breeder seed will have to be given to respective universities and institutes for developing varieties or to NHRDF and DOGR. Further, NHRDF, NSC, State Seed Corporations and SFCI may be made responsible for production of foundation seed of improved varieties. For certified or truthfully-labelled seeds also NHRDF, NSC and SSC (s) and also private reputed seed companies may be made responsible by the Govt of India.

\section{Identification of suitable seed-production pockets}

The areas suitable for seed production have been described above. There is, however, a need to identify more suitable pockets for sustainable production and makeing available adequate quantity of onion-seed.

\section{Infrastructural facilities}

Before seed production is taken up on a large scale, there is a need to create 
necessary infrastructural facilities-bulb storage godown, seeds-processing plant with gravity separator in addition to air-screen cleaner, dehumidifier drier, airconditioned and dehumidified packing and store-rooms. Presently, such facilities are not adequate. The assistance is although provided for this as well as for seedvillage concept by the Ministry of Agriculture under its National Horticulture Programme, this needs to be revised and increased for creating facilities in different areas.

\section{Quality control}

At present mostly truthfully-labelled seeds are being sold in the market. Many traders are selling seeds without even labelling them. Quality is thus not maintained. It is necessary to take up certified seed production through adequately trained staff with certification agencies. There is a need to devise certain quality control measures by which sale of seed without labelling can be checked. Adequate training on quality control is also essential for seed production of onion.

\section{Research and development work}

Disease- and insect- pest-resistant onion varieties need to be developed. Highyielding hybrids with good storage quality also need to be developed. Locationspecific technologies for production of seeds need to be developed. Also farmers need to be educated and trained with latest production and post-harvest management practices in onion. The NHRDF and DOGR should intensify their work on research and development for enhancing seed viability and seed storage. The trials on drip irrigation and mulching in onion-seed production have given very encouraging results. This technology needs to be popularized for increasing production and reducing unit cost of seed production. There is also a need to decide package of practices for different varieties of onion.

\section{References}

Adagale S V, Masalkar S D and Pandure B S. 2010. Response of onion seed production to integrated nutrient management. Asian Journal of Horticulture 5: 165-67.

Basavaraj B O, Patil N K B, Vyakarnahal B S, Basavaraj N, Channappagoudar B B and Ravihunje. 2008. Effect of fungicide and polymer film coating on storability of onion seeds. Karnataka Journal of Agricultural Science 21: 212-18.

Bhonde S R, MishraV K and Chougule A B. 1996. Effect of frequency of irrigation and nitrogen levels on yield and quality of onion seed variety Agrifound Light Red. NHRDF News Letter 16: 4-7.

Dingre S K, Pawar D D and Kadam K G. 2012. Productivity, water use and quality of onion (Allium cepa) seed production under different irrigation scheduling through drip. Indian journal of Agronomy 57: 186-90.

Gupta R P, Bhonde S R, Srivastava K J and Singh D K. 2005. Efficacy of different mulching materials and drip irrigation system on onion-seed crop, India, pp. 257. (Abstract). (In): International Conference on Plasticulture and Precision Farming, held during 17-21 Nov 2005. New Delhi.

Pandey U B, Gupta R P and Srivastava P K. 1994b. Onion seed viability and vigour as influenced by time of drying and packing. Seed Tech News 24: 108-09. [Abst. No. 201]. 
Pandey U B, Singh Lallan and Bhonde S R. 1991. Influence of stage of harvesting on germination and vigour of onion seed. pp. 25. (In): Proc of $79^{\text {lh }}$ Session of Indian Science Congress (Section Agriculture Sciences), held at Baroda. Part-III (Advance abstract).

Pandey U B, Singh Lallan, Chauhan K P S and Singh S P. 1990a. Effect of bulb size, spacing and date of planting on growth, yield and quality of onion seed. (In): International Conference on Seed Science and Technology held on 21-25 February, 1990 at IARI, New Delhi, India. [Abst. No-1: 42: pp. 22].

Pandey U B, Singh Lallan and Chougule A B. 1994a. Studies on onion seed production potentialities in different parts of India. NHRDF News Letter 14: 5-10.

Pandey U B, Singh Lallan, Gupta R P, Bhonde S R and Qadri S M H. 1990b. Viability of onion seed as influenced by different methods of cleaning and packing. (In): International Conference on Seed Science and Technology, held on 21-25 February 1990. New Delhi, India. [Abst. No.28: pp. 36].

Sharma P K, Kumar S, Yadav G L and Verma R. 2008. Effect of bulb size, cut and uncut bulbs under various levels of nitrogen on growth and seed yield of onion (Allium cepa). Research on Crop 9: 103-05. 


\title{
Onion Seed Industry and Trade
}

\author{
Suresh O. Agrawal
}

Seed is a basic and important input in any crop-production system. In addition to climate, nutrition and production technologies, quality seed contributes $30 \%$ to yield component. Yield of the vegetable crops almost doubled due to the development of high-yielding good quality varieties and hybrids and by making available their quality seeds on time. Seed sector in crop-plants has assumed immense importance since the Green Revolution. Sustainable Green Revolution would not have been possible without quality seed developed through hard-core Research and Development. Indian seed industry handles seed worth 2 billion US\$. Vegetable seeds belong to "low volume and high value" category. The National Seed Corporation, State Seeds Corporations and about 50 private sector partners' deal with the business of vegetables seeds production. Among different vegetables, onion is an important component of the seed industry.

\section{Seed requirement scenario}

Exact data on onion-seed production and requirement are not available in India. However, based on the area planted, some estimates can be gauged considering that $6-8 \mathrm{~kg}$ seeds are required for a hectare. Assuming that 1.0 million hectares is covered under onion every year, about $6,000-8,000$ tonnes of seeds would be required for net planting. And about $20 \%$ additional seeds would be required for covering storage losses, bufferstock and poor germination. Total seed requirement, thus would be about 8,000 tonnes. Kharif and late kharif occupy $40 \%$ of the area. Approximately 3,000/3,500 tonnes of seeds would be required during June to September, and for rabi season, about 4,000/4,500 tonnes would be required during November to December. For multiplier onion, assuming $1,000 \mathrm{~kg}$ seed-bulblets would be required per hectare, around 100,000 tonnes of bulbs would be needed.

As against the requirement, supply scenario of quality seed is very dismal. The public sectors, NSC, State Seed Corporations, NHRDF, DOGR and some SAUs are producing seeds of the recommended varieties to the tune of 700-800 tonnes, which is $10 \%$ of the total requirement. The private seed companies produce around 800 to 1,000 tonnes of seed of open-pollinated varieties. Bejo Sheetal Seeds Pvt. Ltd has started producing for the first time hybrid onion-seeds in the country. In 2013-14, Bejo Sheetal produced and sold 180 tonnes of hybrid onionseeds. This clearly indicates that $75-80 \%$ of the seeds are produced by farmers and private traders, which are actually out of scientific seed-production chain. In fact, this is a major constraint in stagnation in productivity of Indian onion. Onion production from such seed-stocks suffers from the following drawbacks-(i) 
variation in colour, shape, size, and maturity, (ii) high percentage of bolting and spilt bulbs or non-bulbing, (iii) less storability due to high percentage of sprouting and low TSS and dry matter and (iv) susceptibility for many diseases and pests.

There is a need to organize seed production of improved varieties, developed by research organizations, on a large scale in a scientific manner. Seed replacement ratio must be enhanced vis-à-vis other vegetables through front-line demonstrations.

\section{Improved varieties availability}

Research on onion had started in the country as early as in 1950 in Maharashtra. Department of Agriculture released cv. N 53 for kharif (wet) season and N 2-4-1 for rabi (dry) season by the selection of onion landraces from Nashik. And these very varieties are still popular by trade names: Nashik Red, Bombay Red, Poona Red and Fursungi. Later systematic onion-breeding programme had started at the MPKV, Rahuri; IARI, New Delhi; NHRDF, Nashik; IIHR, Bengaluru and DOGR, Pune. PAU, Ludhiana, TNAU, Coimbatore and HAU, Hisar, also contributed in this.

The private sectors such as Bejo Sheetal, Mahyco, Seminis (currently Monsanto) and East West Seed also started R\&D in onion. The IIHR and IARI have also started developing hybrid onion (Table

Table 11.1 Hybrid onion developed and marketed by private and public organizations

\begin{tabular}{|c|c|}
\hline Organization & Hybrids \\
\hline $\begin{array}{l}\text { Bejo Sheetal Seeds } \\
\text { Pvt. Ltd, Jalna }\end{array}$ & $\begin{array}{l}\text { Lucifer, Orient, Flair, } \\
\text { BSS } 441 \text {, White, and } \\
\text { Grano } 858\end{array}$ \\
\hline $\begin{array}{l}\text { Indian Institute of } \\
\text { Horticultural Resea } \\
\text { Bengaluru }\end{array}$ & $\begin{array}{l}\text { Arka Kirtiman and } \\
\text { Arka Lalima }\end{array}$ \\
\hline
\end{tabular}
11.1). In India, only short-duration onions are grown. Internationally, onion varieties are classified in 4 categories (Table 11.2). Bejo Zaden, Nunhems, the Netherlands and Takii Seeds, Japan, are the big partners and deal mostly with long-day onion hybrids.

Table 11.2 Classification of onions according to day-length

\begin{tabular}{|c|c|c|}
\hline Type & Duration & Varieties \\
\hline Very long-day & $160-180$ days & Rignburger \\
\hline $\begin{array}{l}\text { American long-day } \\
\text { (good for storage) }\end{array}$ & $\begin{array}{l}160 \text { days } \\
\text { (popular in the USA and Cana }\end{array}$ & $\begin{array}{l}\text { T 400, Tamera (Bejo) } \\
\text { da) }\end{array}$ \\
\hline Intermediate & 150 days (good for storage) & Spanish Brown, Legend Brown, Leony \\
\hline Short-day & $140-150$ days & Grano, Indian Bombay, Cruel \\
\hline
\end{tabular}

\section{Seed quality}

Onion-seeds are smaller in size with irregular shape and black seed-coat. Seed viability and vigour is retained up to one year, and afterwards it reduces drastically. Seed-coat is very thin and endosperm is too little. During storage, if not packed properly, seed-coat absorbs moisture and seed germinates and thus looses viability. Seeds when not dried properly to appropriate moisture level (6-8\%), fail to germinate. The quality standards for onion-seed are given in Chapter 10 . 


\section{Constraints in seed production Isolation distance}

Onion is $100 \%$ cross-pollinated crop, being protandrous in nature. It requires more than 800 metres isolation distance for truthful seeds and more than 1,500 metres for breeder seed production. Maintaining such an isolation distance in the main seed-production area is a problem. In known and potential seed-production areas, many agencies organize seed-production programmes with more than 3 or 4 varieties of different colours and seasonal suitability. Thus, maintenance of purity is a big challenge. Any good variety if multiplied under such a situation is likely to get $100 \%$ contaminated.

\section{Suitable seed-production areas}

For onion-seed production, moderate sunny days with $4-14^{\circ} \mathrm{C}$ night and $18-25^{\circ} \mathrm{C}$ day temperature are required during flowering and seed-setting. After seed-set, seed maturity and seed drying requires higher day temperature. Pollination is mostly by honey-bees alone, which are active at 18 to $30^{\circ} \mathrm{C}$. Therefore, all-over India, onion-seed production is restricted to winter only. Highly humid and warm areas are also not suitable for onion-seed production. Further areas likely to suffer from hailstorms and rains during March-April are also not suitable. These regions pose problem of Stemphyllium-blight and downy mildew. Best suited areas for onion-seed production are: Saurashtra in Gujarat; Nashik, Pune, Ahmednagar, Satara and Marathwada in Maharashtra; Khargone, Indore, Dhar in Madhya Pradesh; Jaipur, Chittargadh, Udaipur and Sriganganagar in Rajasthan; northern Karnataka; and Kurnool in Andhra Pradesh. These areas are cool and dry with good honey-bees activity, and seed yields are comparatively high.

\section{Inadequate storage facilities}

Onion-seeds loose viability quickly under ordinary packing and storage. But, neither seed-producing agencies nor farmers have adequate and suitable bulb handling and storage facilities. Seeds remain in good conditions up to 3-4 years in cold storage. However, cold storage facilities in strategic seed-production areas are not available. Seed drying at very low moisture (6-8\%) and storage at low temperature with $\mathrm{CO}_{2}$ and good quality packing improves storage of onion-seeds. Studies indicated that cold storage at $15^{\circ} \mathrm{C}$ and $45 \%$ humidity enhanced storage life of seeds up to three years. Packing in 400-gauge polythene bags and cold storage are recommended for long-term storage. Onion-seed production is always affected by hailstorms and untimely rains in major production areas. So, there is a need to have bufferstock at least with public sector undertakings. This will keep spurious seeds away from production chain.

\section{Lack of awareness about seed-production technologies}

Farmers produce seed on their own without following proper isolation distance. Seed-production practices followed are also sub-standard, which result in poor quality seed production. Identification of new seed-production areas and a whole package of practices for seed production are required. 


\section{Reduction in bee activities}

Honeybees are the main pollinators of onion. Due to pollution, over use of pesticides, and sudden change in temperature, their activity is reducing day by day. This reduces seed yield by almost $50 \%$, despite good agronomy practices and production technologies.

\section{Poor seed replacement rate}

Country's $80 \%$ seed is being produced by farmers and small traders, who organize their seed-production programme with farmers' help. Farmers and traders produce seed of their own genetic-stock maintained without scientific upgradation and improvement. Many times small traders purchase seed bulbs from the market and supply to farmers for seed production. These bulbs are available at cheaper rate than breeder or certified bulbs, produced by research organization. Seed production at a lower cost of local genotypes is the main reason for slow replacement. Further, onion-bulbs are planted for seed production in November and December, when price of onions is very high in the market. And farmers opt out for selling their best bulbs at higher premium, and thus small and rejected bulbs are used for seed production. There is high cost involved in storage of bulbs from April to December, especially of rabi varieties. Any seed company or a public sector, who is involved in seed production over thousands of acres, needs to store huge bulb-stock nearly for six months. This would definitely increase overheads and thus cause an impediment in faster seed replacement of new varieties.

Research organizations do not have infrastructure to produce enough breeder seed of released varieties; besides strict regulations delay proposals for notification by central as well as state governments. There is a time lag of 5 to 10 years between identification for release and notification of varieties. Research institutes lose their interest and the release of a variety ends up only an academic record. Private seed dealers many times purchase breeder seed and change variety nomenclature; this affects realization of the impact of the varieties released by research organizations. In short, seed-production chain is not being monitored in a holistic manner by all stakeholders, resulting into slow rate of replacement of varieties. The notification for registration under the Protection of Plant Varieties and Farmers' Rights Authority (PPV\&FRA) for the onion would solve this problem.

\section{Hybrid onion, far from reality}

Heterosis for onion was reported much earlier than many other vegetables. Yet its exploitation in onion is lagging behind tomato, cole-crops, melon and many other vegetables. Onion research workers are divided on this issue. Many researchers think that hybrids do not excel in yield and other characters than open-pollinated varieties. However, the supporters are of the opinion that there is good amount of heterosis in onion for yield, uniformity in colour, shape, size and maturity. Private sector is promoting hybrids; whereas public sector is still with open-pollinated varieties. For quality seed supply chain management, hybrids can play a significant and an important role, and therefore hybrids should be 
promoted. Non-availability of male sterility in different backgrounds of colour and maturity groups and their maintainers is the main impediment for production of hybrid onions. Maintenance of three parental stocks and slightly higher technique involved in hybrid onion-seed production is also an important reason for non-spread of hybrids. However, there is much scope for promotion of this technology to produce potential hybrids for increasing yield, quality and earliness.

\section{Export of onion-seed}

Many countries in the world, especially South-East Asian and African countries, grow onions on a commercial scale, but they are not able to produce quality seed owing to climatic unsuitability. India is at advantage in this regard. India exports about 500-700 tonnes of onion-seed annually. There is increasing demand for onion-seed but in the absence of definite policy, spurious seed and unfair trade are increasing. In fact, we can take up the customized seed production of varieties and hybrids for many international seed companies; where Indian farmers show no interest.

\section{Policy issues}

Central Government becomes sensitive about onions only when their prices shoot up in the domestic market. Under, such a situation only and easiest way appears to ban export, whether effective exports are happening or not. Following issues need to be addressed with proper perspective.

1. There should be a regular national policy on production plan, storage and export of onion-bulbs and seed. There is a need to assess demand of seeds based on the demand of onions for domestic as well as export market. There is a need to set-up policy for phasing out old varieties and their replacement with new varieties by $50 \%$ during next 10 years. Advance planning for breeder, foundation and truthful seed production should be done as is done for cereal crops.

2. There is a need for creation of cold storage facilities for seed bulbs as well as onion-seed in strategic production areas. Seed processing and packing units are also important.

3. Ministry of Agriculture, research organizations and seed production companies should join hands for identifying variety specific seed production areas to do away with the burning problem of isolation distance vis-à-vis quality seed production.

4. Seed-village concept needs to be developed and implemented under the NHM programme. One village one variety will help in quality seed production.

5. Activating and enforcing quality control mechanism from every State Government is highly essential in production and supply of quality seed. Many traders sell seed without labelling. All district seed officers and quality control officers need rigorous training in this regard.

6. There should be a regular mechanism for training farmers and seedproduction agency personnel for quality seed production.

7. Bee-keeping and maintenance of beehives during the seed production must 
be an integral part of onion-seed production. There should be a subsidy component in the seed-production programme.

8. Export of onion-seed should be well thought of, and an official channel should be opened by the Government to cut down supply of sub-standard and spurious seed. Otherwise this will cut-down export of seed in the long run. The licensing policy should encourage quality seed production for domestic as well as export markets.

\section{Future Strategies}

Availability of onion-seeds with good genetic and physical qualities is a big problem, which is resulting in yield reduction and unavailability of quality onionbulbs in India. Government has to solve these problems and needs to formulate strategies to improve availability of good quality seeds. In general, onion prices are highly fluctuating, sometimes very high and sometimes very low. Role of Government becomes very important to balance onion prices with good strategy and policies for stable pricing round-the-year. This can be achieved by establishing good onion-bulb storage facilities in onion-growing areas. Ban on export needs to be minimized, and if possible removed. 


\title{
Fungal Diseases
}

\author{
S.J. Gawande
}

Onion (Allium cepa L.) is known to be affected by 66 diseases that include 14 bacterial, 40 fungal, 6 nematode, 3 viral, 1 phytoplasmal disease and 1 parasitic plant, and 7 miscellaneous diseases and disorders (Schwartz and Mohan, 2008). From India, 29 fungal, 3 viral and 4 bacterial pathogens were recorded on the onion-crop (Gupta et al., 1994). These diseases cause production and storage losses up to $50 \%$ annually depending upon the location, environment, host cultivar and pathogen involved (Srinivas et al., 2007). Apart from the direct production losses, these pathogens reduce marketable quality significantly. Anthracnose, purple-blotch and Stemphylium-blight cause extensive crop losses, and are important throughout the onion-producing areas. Fungal diseases such as purpleblotch cause yield reduction up to $50 \%$ in seed-crop of onion (Anonymous 1986). There are a few diseases of local importance such as downy mildew in temperate zones, Jammu and Kashmir and Uttarakhand in India. Pink-root and Fusarium basal-rot have significant impact on reducing onion yield in the country.

Economic losses due to diseases vary significantly across three seasons. Kharif onion suffers heavily, and losses reach as high as $50-60 \%$, followed by $20-30 \%$ in rabi and losses are least in late kharif. Although, kharif onion share in the total onion production is lesser (up to 20\%) still this has significant impact on market stabilization as it fills the gap during October to December when supply from rabi stored onions depletes. Thus disease management in kharif onion is very important to ensure continuous supply of onions in the market. Disease management during late kharif and rabi seasons is important to maximize yield potential. Precise knowledge about pathogens infecting the crop is the key to devise effective management strategies. No stable source of host resistance in Indian short-day onions against major diseases has been recorded or reported. It compels to resort only to chemical methods of disease control. However, disease management through chemicals is not only costly but also it is hazardous besides polluting environment.

\section{Purple-blotch (Alternaria porri (Ellis) Cif.)}

It is a pandemic disease, known to cause up to $80 \%$ yield losses in India (Yadav et al., 2013). The disease has been observed throughout the world, but is most serious in hot-humid climates. Apart from onion, the pathogen attacks other members of Allium family including Egyptian onion (A. proliferum), Welsh onion (A. fistulosum) and leek (A. ampeloprasum var. porrum) (Shref and MacNab, 1986). The name 'Purple-blotch' was proposed by Nolla (1927), who named its 
causal fungus as Alternaria allii sp. nov., which was later changed to Alternaria porri (Ellis) Cif. In India, it was first reported by Ajrekar (1921) from Bombay (now Mumbai) as Macrosporium sp. In the following years, he further studied the disease, and reported causal organism as Alternaria sp., which was later confirmed to be Alternaria porri (Pandotra, 1964).

Symptoms: They are prominently seen on leaves, scape and pseudostem as small, white, oval sunken spots/lesions with well-defined margins between the infected tissue and healthy part of the leaf/scape (Fig.12.1b). The lesions expand to become zonate and turn brown to purple surrounded by a broad chlorotic spot that extends upwards and downwards for some distance. The lesion margins have often shade of purple to reddish brown colour (Fig.12.1a, c). Under humid condition's, surface of the lesion gets covered with brown to dark grey fungal sporulation. In advanced stage, lesions may coalesce to form larger spots, leading to girdling of leaf/scape, which results in necrosis or death of plant. There is a significant reduction in yield and quality of produce in the infected plants. Severe disease symptoms on the older leaves were attributed to their low sugar content (Horsefall and Diamond, 1957).
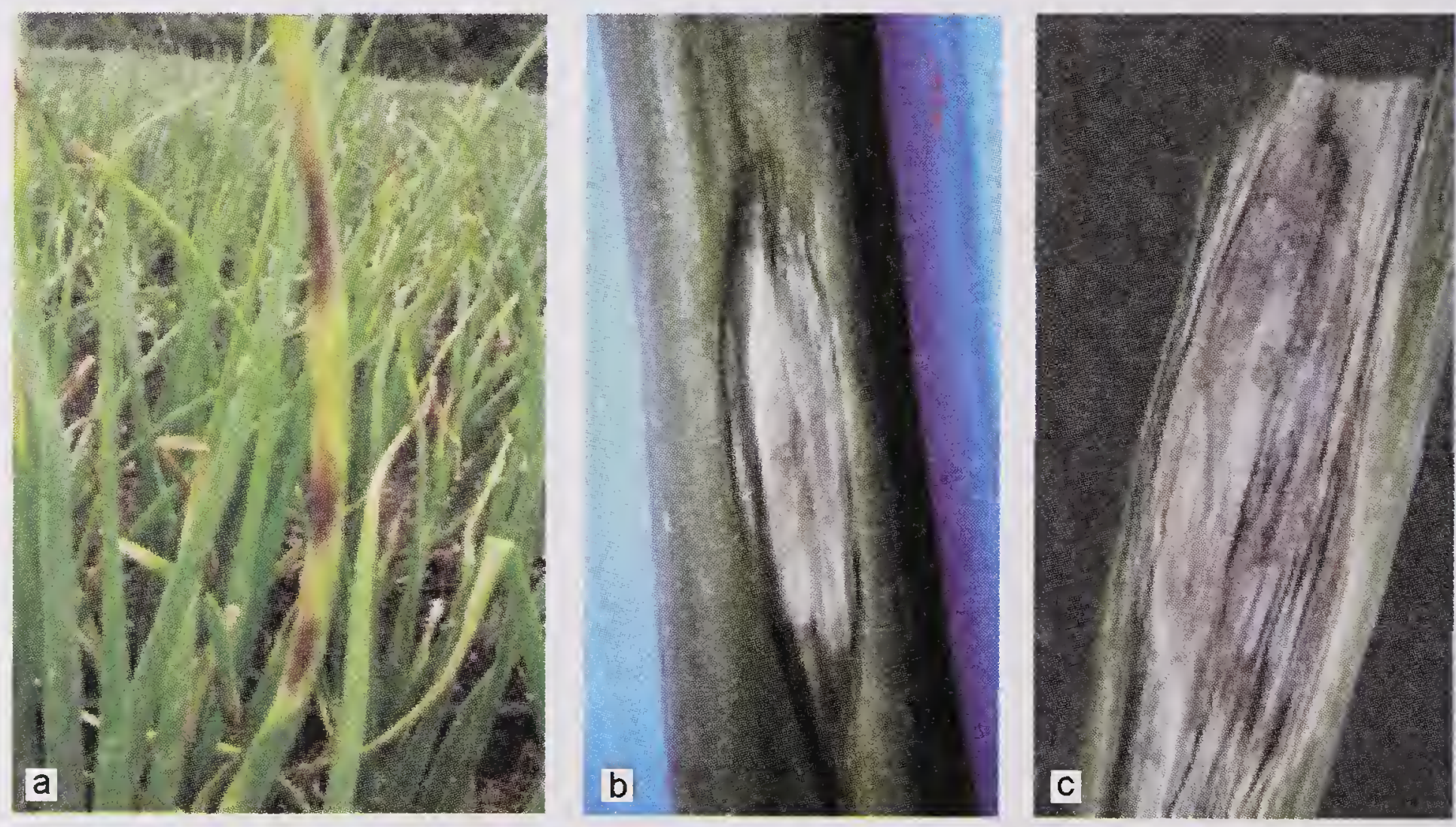

Fig.12.1 (a) Symptoms of purple-blotch. (b) Initial white oval sunken spot with welldefined margins. (c) Purple-blotch in later stage when lesions turn purple

In most of the cases, fungus invades through neck, but sometimes it may enter into bulbs through wounds on fleshy scales. Purple-blotch on bulbs are characterized by semi-watery rotting of bulb-neck, which later turns yellow to red. The fungus secretes pigments profusely through scales in the advanced stages. Because of it, bulb tissues become desiccated and eventually dry and become papery.

Causal organism and pathogen biology: Alternaria porri (Ellis) Cif. is a dematiaceous fungus, of class Hypomycetes. Its conidiophores arise singly or in group and are straight or flexuous, sometimes geniculate, septate and pale to medium brown (Aveling et al., 1994), $120 \mu \mathrm{m}$ long and 5-10 $\mu \mathrm{m}$ thick with one 
or several well-defined conidial scars. Conidium borne singly is straight or curved, obclavate (the body of the conidium may be ellipsoidal), and it tapers to a beak that is commonly about the same length as or slightly larger than the body of the conidium. Conidia are pale to golden-brown, are smooth or minutely varicose, overall length measures about $100-300 \mu \mathrm{m}$, and thickness in the centre is $15-20$ $\mu \mathrm{m}$. Conidia contain 8-12 transverse and zero to several longitudinal or oblique septae, and a pale, tapering beak of $2-4 \mu \mathrm{m}$ thick. Till date no sexual stage is known. Conidiophores are borne singly or in groups on lesions. Dark olivaceous, long, multicellular conidia are produced at conidiophore tips. Conidia may repeatedly form on lesions with alternating cycles of low and high relative humidity. The fungus can grow at a temperature range of $6-34^{\circ} \mathrm{C}$. But, the optimum temperature for growth is $25^{\circ} \mathrm{C}$, and the growth is slower below $13^{\circ} \mathrm{C}$. For sporulation, relative humidity of $90 \%$ or higher is required. Conidial initials are formed after $9 \mathrm{hr}$, septa develop after $12 \mathrm{hr}$, and fully mature conidia appear after $15 \mathrm{~h}$ of dew (Ellis, 1971). Conidia formed during dew period of $12 \mathrm{hr}$ or less cause flecks and typical lesions are formed when dew duration is $16 \mathrm{hr}$ or more.

Normally, sporulation takes place during night under high relative humidity. Since during day, humidity decreases, hygroscopic movement in the conidial apparatus causes detachment of mature conidia. Secondary spread of disease is through rain, sprinkler irrigation, spraying, or wind, which increase the release and spread of conidia.

When conidia land on susceptible onion tissues and germinate, germ tubes can invade tissues through wounds or stomata or can directly penetrate epidermis (Skiles, 1953). Susceptibility of onion-leaves to infection by A. porri is influenced by plant age, season, foliage architecture, and injuries caused through thrips and mites. Other factors that aggravate purple-blotch are moisture stress and excess moisture in the soil. Disease incidence and severity varies with year and season. At Pune, India, the peak incidence of purple-blotch was observed during October to January.

Management strategy: Follow clean cultivation and long crop rotation with non-host crops to break disease cycle. Preferably use raised bed for growing onion for proper drainage. Avoid sprinkler irrigation as it may help spore dispersal. Reduce plant density by using $15 \mathrm{~cm} \times 10 \mathrm{~cm}$ spacing, which helps reduce infection. Hot-water soaking of onion-seed $\left(50^{\circ} \mathrm{C}\right.$ for $\left.20 \mathrm{~min}\right)$ is also advised. High rates of calcium, phosphorus and potassium fertilizers reduce possibility of infection but increased nitrogen fertilizers enhance disease infestation. Application of Trichoderma viride (1,000 spores/ml) helps manage the disease. Onion-leaves are increasingly susceptible to $A$. porri as they age, and emerging leaves at the bulb maturity stage are more susceptible. Purple-blotch is increasingly difficult to be managed as bulb approaches maturity. Foliar sprays of Mancozeb @ 0.25\%, Tricyclazole @ 0.1\% and Hexaconazole @ 0.1\% at 30,45 and 60 days, respectively, after transplanting help checking disease incidence/spread. Varieties such as Red Creole and Kaharda were reported resistant to purple-blotch in Nigeria (Abubaker and Ado, 2013). In India, onion line PBR 287 was reported to be resistant and genotypes, Arka Kalyan 704 and MS 65-268 from the IIHR, Bengaluru, were moderately resistant to purple-blotch. 


\section{Stemphylium leaf-blight}

This disease has come to prominence throughout the world since the last 20 years. Its outbreak caused significant losses in Texas and New York in North America (Miller et al., 1978; Lorbeer 1993). The disease was also recorded from Europe, Africa, North and South America (Ellis, 1971). It is a major disease of onion in South-east Asia and India. It was first reported in India from Varanasi by Rao and Pavagi (1973) and later has been reported all-over India (AINRPOG Report, 2013). It occurs frequently at the same time and on the same plants as $A$. porri, the cause of purple-blotch, forming disease complex.

Symptoms: Small, light yellow to brown to purple, water-soaked lesions appear. These lesions elongate, become spindle-shaped to ovate-elongate, and turn into diffusive spots, often extending to leaf tips. The spots frequently coalesce into patches blighting leaves. As conidiophores and conidia develop on the lesions, they turn light brown to tan purple at the centre, and later to dark olive-brown to black (Miller et al., 1978). Similar symptoms may also occur on the scape of onion (Fig. 12.2a,b). Perithecia may appear in blighted areas of leaves and scape as small, black, pinhead like raised bodies.
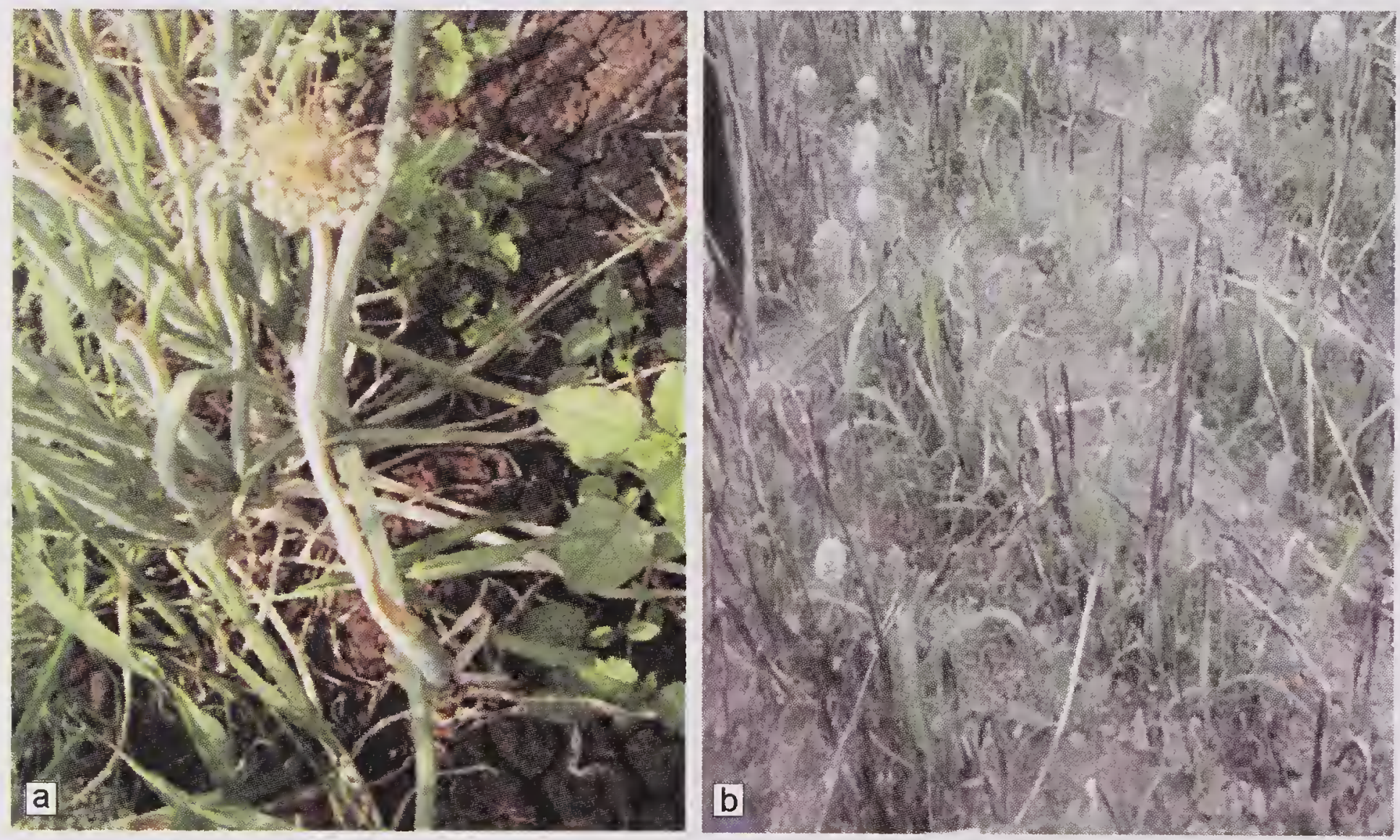

Fig.12.2 (a) Symptoms of Stemphylium-blight on scape of onion. (b) Severely affected onion-seed production plot by the blight

Besides, above symptoms, the pathogen also forms yellow mottle lesions (Misawa, 2008a), characterized by bright yellow mosaic-like symptoms, ranging from 0.5 to $4 \mathrm{~cm}$ in diameter on the inner leaves (Misawa, 2008). These symptoms are distinct, and there are no intergrades between them.

Perithecial stage appears in isolated locations, and is more prominent on the onion scape. The pathogen enters normally through dead or dying tissue like leaf tips, purple-blotch lesions and insect injuries, causing minimal foliage damage. Under wet conditions for about more than $24 \mathrm{hr}$, conidial inocula multiply and cause minute lesions, which later coalesce and may cover entire leaf. 
Causal organism and disease biology: Stemphylium vesicarium (Wallr.) Simmons causes Stemphylium leaf-blight in onion. The perfect stage of fungus is Pleospora allii (Rab.) Ces and de Not. Its conidia are oblong or broadly oval and sometimes are equilateral. Conidium has 1-6 transverse septa, measures about $12-22 \times 25-42 \mu \mathrm{m}$ and is light or medium golden brown to olive brown. It has conspicuous basal scar-like zone up to $7 \mu \mathrm{m}$ in diameter surrounding small spore. Its external walls are conspicuous and densely verrucose at all ages.

Conidiophores measure $5-8 \times 33-47 \mu \mathrm{m}$; are straight to variously curved; are simple and occasionally branched; are cylindrical but enlarging apically to the site of conidia production; are light yellow-brown or olive-brown, dark to medium golden-brown at the swollen apex; and are smooth throughout, except sparsely punctuate roughened on the apical cell. They have one to four septa, and their apical cells are swollen or distinctly flared to 7-9 $\mu \mathrm{m}$ in diameter (Fig.12.3). Apical sporiferous cells have a single pore $(4-7 \mu \mathrm{m}$ in diameter) and as many as five apical proliferations (Ellis, 1971).

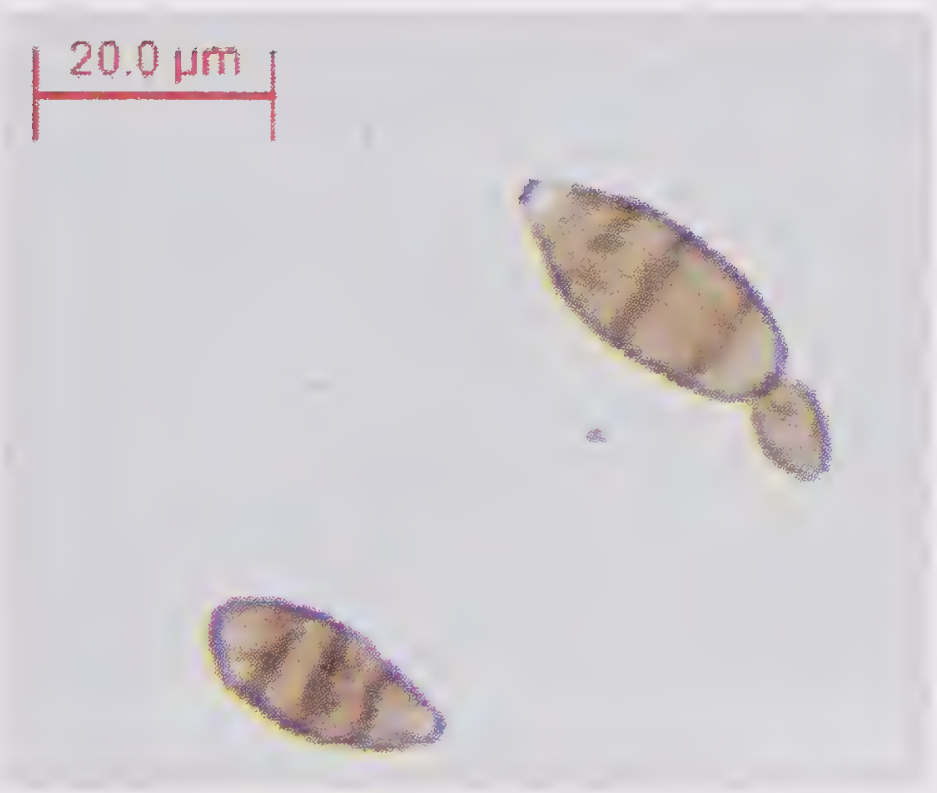

Fig.12.3 Conidia of Stemphylium vesicarium

Perithecia of $S$. vesicarium mature in 3-6 months. Mature asci are 25-170 $\mu \mathrm{m}$, narrowly cylindrical to clavate, tapering to knob-like base. Ascospores are ellipsoidal initially with upper part tapering narrowly. They become distinctly constricted at the three transverse septa by the time longitudinal septa are produced. The base of the ascospore becomes broadly rounded and remains so in maturity; the apex of the spore develops an obtusely pointed appearance that is maintained in maturity. Mature ascopore measures $18 \mu \mathrm{m} \times 38 \mu \mathrm{m}$, and has seven transverse septa. Its wall colour deepens from an initial pale-yellow to a final translucent yellow-brown.

Infection usually remains confined to leaves and does not extend down to scales of the bulbs. Lesions generally occur on the side of the leaf facing the prevailing wind. The pathogen is necrotrophic in nature, and normally invades dead and dying onion tissues-necrotic leaf tips, purple-blotch and downy-mildew lesions, injured tissues and senescent tissues. The fungus can be isolated from necrotic leaf tissues at most growth stages; however, serious leaf damage is apparent only after long, warm periods of leaf wetness. If rains continue for more than $24 \mathrm{hr}$, population on leaf surface may reach 200 conidia per square centimetre, and the minute lesion caused by each conidium coalesces to form larger lesion, ranging from $1 \mathrm{~cm}$ in diameter to that covering entire leaf (Maude, 1990).

Management strategy: The disease can be effectively minimized by following practices.

- Follow crop rotation with the non-host crops such as cabbage, cauliflower and mustard. 
- Clean the cultivation by destroying plant debris of the previous season.

- Provide good field drainage by using raised beds, and reduce plant density, as stress triggered oxidative process attracts Stemphylium-blight incidence.

- Drip irrigation should be used over conventional irrigation to avoid spore dispersal and resultant disease outbreak.

- Hot-water soaking of onion-seed $\left(50^{\circ} \mathrm{C}\right.$ for $20 \mathrm{~min}$ ) is recommended (Aveling et al., 1993).

- Welsh onion lines, TA104, TA108, TA198, AF468 and TA204, are moderately resistant to Stemphylium leaf-blight (Pathak et al., 2001).

- Bioagents such as Bacillus subtilis at $10^{8} \mathrm{cfu} / \mathrm{ml}$ and Saccharomyces cerevisiae at $4 \times 10^{4} \mathrm{cfu} / \mathrm{ml}$ could effectively control Stemphylium blight to 53.49 and $51.23 \%$, respectively, as compared to chemical fungicide Ridomil, which had $69.87 \%$ efficacy (Hussein et al., 2007).

- Application of salicylic acid (5mM) reduced disease up to $40 \%$ under controlled conditions (Kamal Abo-Elyousr et al., 2009).

- Foliar sprays of Mancozeb@0.25\%,Tricyclazole@0.1\% and Hexaconazole @ 0.1\% at 30,45 and 60 days after transplanting effectively managed disease.

\section{Anthracnose/Twister (Colletotrichum gloeosporioides (Penz.) Penz.\& Sacc.)}

The disease was first recorded during 1924-1925 in the eastern and northern part of Puerto Rico (Nolla, 1926). It has been reported from Africa, Brazil and Asian countries. Aquino and Wanderley (1966) reported anthracnose as "Seven Curls", a serious disease in Brazil. Due to this disease, 50-100\% losses in yield were reported (Ebenebe, 1980).

In India, it is predominantly observed in kharif onion-crop. It was recorded for the first time in 1981 from Lonand area of Satara district in Maharashtra. It was observed during 1982 and 1983 on crops grown in Nashik and Pune districts, and was reported from Karnataka in 1987 (Qadri and Shrivastava, 1985; Quadri, 1988).

In the past, there was controversy regarding etiology of twister disease symptoms. Asif et al. (1976) and Viets (1967) reported that symptoms were due to zinc deficiency or virus/mycoplasma infection. Robbs et al. (1972) reported Fusarim oxysporum f. cepae as the causal organism for these symptoms. Finally, Ebenebe (1980) conclusively proved Colletotrichum gloeosporioides as the causal organism of twister disease.

Symptoms: Initially white sunken-oval lesions appear, which turn into paleyellow water soaked spots in the later stages. Spots expand to cover whole leaf as the disease progresses. Besides lesions on the leaves; abnormal elongation and twisting of the pseudostem, i.e. neck of bulb is noticed (Fig.12.4 a, b) (Chawda and Rajasab, 1996). In the advanced stages of disease, plant bends from the pseudostem.

Water-soaked spots extend up to bulb as disease advances. On these spots, numerous black coloured raised structures of acervuli are produced in concentric rings-characteristic morphological symptoms (Fig.12.4 d,e) (Nolla, 1926). Tiny oval whitish spots grow on the leaves and extend to bulb scales.

The symptoms appear initially in patches in the field where water stagnates- 
low laying area in the field, near field trenches, near drip and sprinkler irrigation points. These patches grow, and finally cover the whole field. The progress of the disease depends upon the frequency and intensity of rainfall; the intensity is higher in heavy soils than light soils.

There is a secondary infection of saprophytes in bulbs of affected crop, which gives rise to rotting and substantial reduction in quality of bulbs. In the severely affected crop, there is no bulb formation (Fig. 12.4c). In India, since seed production is carried out during rabi season (Nov-Mar), anthracnose symptoms are not recorded on the onion-seed crop. But, incidence on the seed crop was observed in many other countries (Ebenebe, 1980; Chawda, 1992).
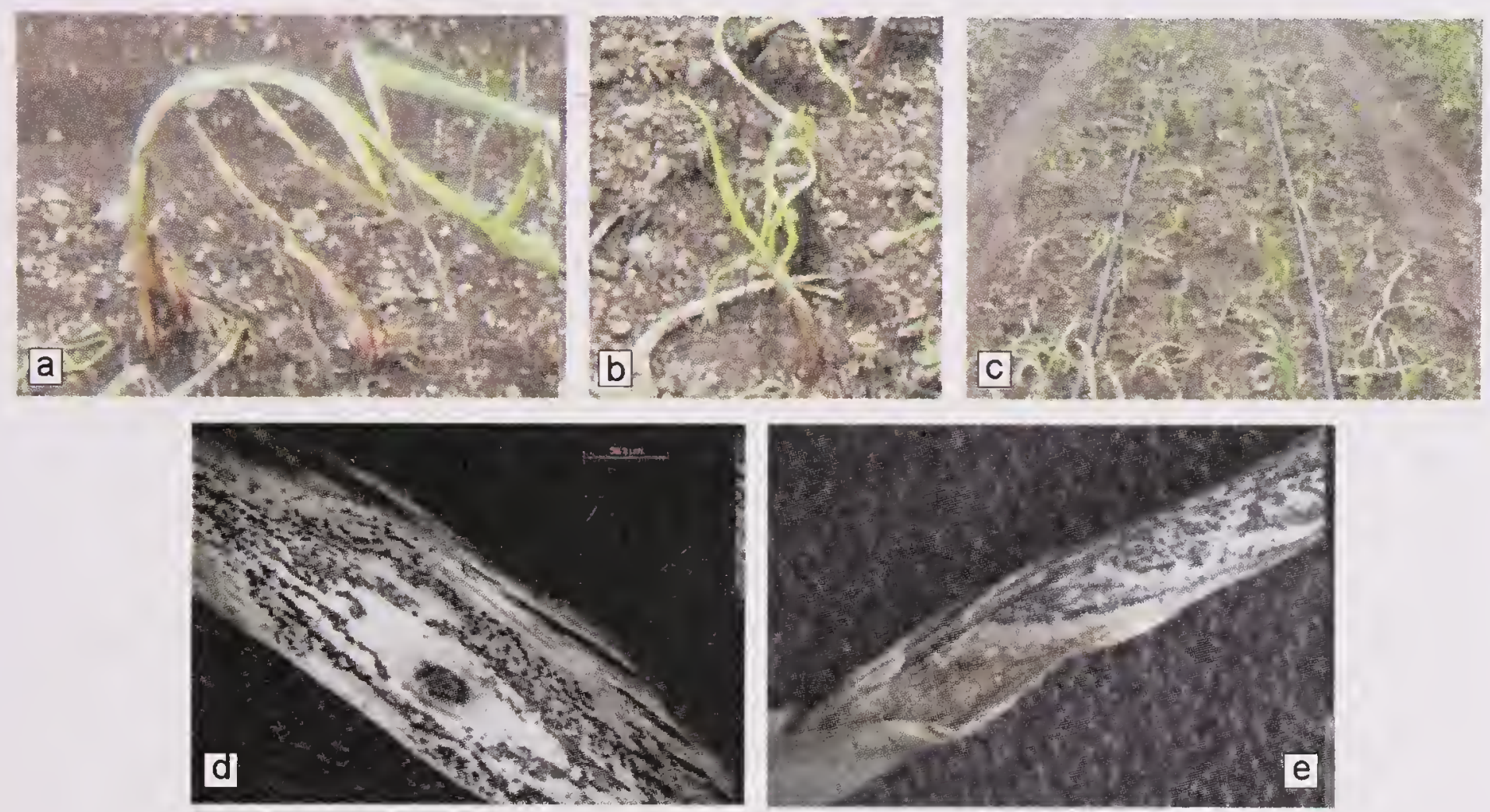

Fig.12.4 (a,b) Long neck and twisting symptoms of anthracnose. (c) Severely affected onion plot by anthracnose/twister. $(d, e)$ Concentric rings formed by acervuli of Colletotrichum gloeosporioides

Causal organism and pathogen biology: Colletotrichum gloeosporioides (Penz.) Penz.\& Sacc. (Teleomorph: Glomeralla cingulata (Stonem) Spauld. \& Von Schrenk) causes anthracnose in onion. The fungus survives in plant debris and spreads through seedlings and onion-bulbs. However, seed-borne nature of the pathogen has also been reported (Boff et al., 1995). The progress of the disease depends upon the intensity, quantity and frequency of rainfall. Dispersal of conidia occurs from soil to lower leaves to the neck of the onion-bulb by rain splashes (Rajasab and Chawda, 1994). The pathogen normally infects plant from the inoculum in the soil. Conidia germinate and infect onion tissues under high humidity and temperature of 23 to $30^{\circ} \mathrm{C}$.

The secondary spread of inoculum is through rains and wind, which results in a more uniform distribution of infected plants in the field. The fungus may persist on seeds, debris and alternative host. Insects and irrigation water can also spread the pathogen. In the perfect state, dark brown to black perithecia $(85-300 \mu \mathrm{m}$ in diameter) bear eight spored asci $(8-14 \mu \mathrm{m} \times 35-80 \mu \mathrm{m})$. Ascospores are hyaline oval to cylindrical, unicellular and sometimes slightly curved (Fig. 12.5). They may become faintly brown and unisepted prior to germination. In imperfect state 
or telomorphic stage, acervuli may form on the necrotic areas of the host. The hyaline conidia $(3-6 \mu \mathrm{m} \times 9-24 \mu \mathrm{m})$ are cylindrical with obtuse ends, aseptate and uninucleate. Conidia are formed on the unicellular, hyaline or faintly brown, cylindrical, phialidic conidiophores. Grayish white to dark gray colonies develop on potato dextrose agar. Perithecia may form in culture.

The peak incidence of anthracnose at Rajgurunagar (Pune, India) was

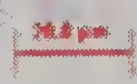

Fig. 12.5 Ascospores of Colletotrichum gloeosporioides observed during August-September, when humidity is around $75-90 \%$ and rainfall averages $36 \mathrm{~mm} /$ week (Fig. 12.6).

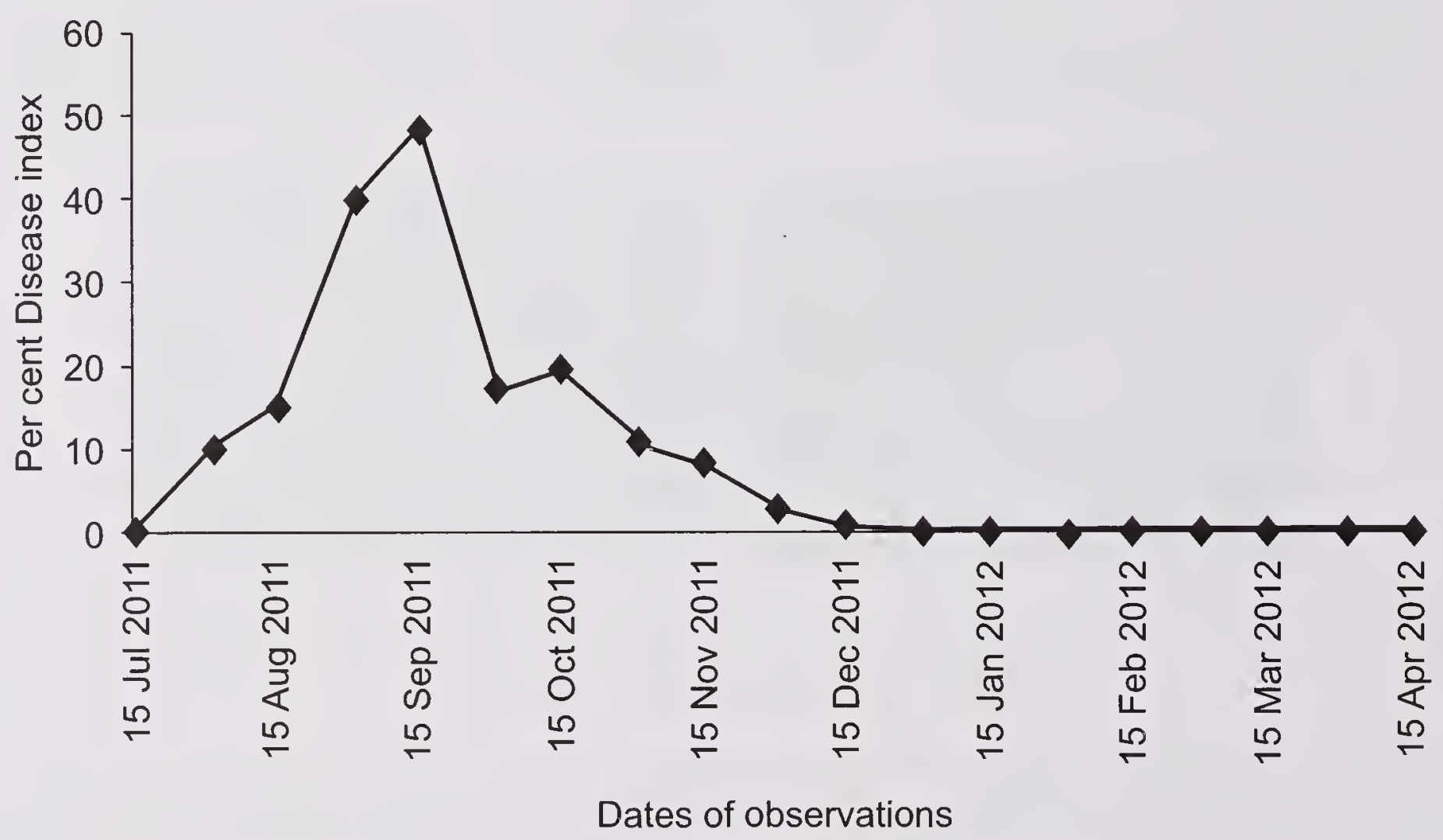

Fig. 12.6 Severity of anthracnose on onion at different dates in 2011-12

Management strategy: The control measures usually adopted are as follows.

- Clean cultivation, removal of debris from the previous crop, and 3-4 years crop rotations to minimize inoculum load in the soil.

- Growing of onion on the raised beds drains out excess water in the field and thereby avoids water stagnation, which ultimately results in checking disease incidence.

- Cultivation of disease-tolerant cultivars like Bhima Raj and Red Creole is recommended.

- Biological control agents such as Trichoderma viride @ 1,000 spores/ml can be effective to some extent.

- Application of Benomyl at $0.2 \%$ as soil treatment is recommended.

- Seed treatment with Bavistin @ 0.1\% is recommended. 
- Foliar sprays of Mancozeb@0.25\%,Tricyclazole@0.1\% and Hexaconazole @ $0.1 \%$ at 30, 45 and 60 days, respectively, after transplanting checks disease incidence/spread.

\section{Downy mildew (Perenospora destructor (Berk.) Casp.)}

This disease is widely distributed on all continents, particularly temperate areas of the world. The pathogen was first described by Berkeley in the later half of the $19^{\text {th }}$ century from the UK. Downy mildew is reported from most onion-producing regions of America, Africa, China, Europe, and Japan. In cool and humid weather, the disease can be highly destructive, causing losses in both yield and quality. This disease affects many wild and cultivated species of Allium, including onion, chive and shallot. In India, downy mildew was first reported by Mir (1977), and it is still limited to Jammu and Kashmir and Uttarakhand, where considerable losses were recorded.

Symptoms: The disease commonly starts in patches in the field, and spreads to the surrounding areas. Symptoms are found most readily by examining older leaves in the morning, while dew is still present. Elongate patches (3-30-cm long) may appear on leaves, which are slightly paler than the rest of the leaf area or which have turned light tan to brown, and may be confused with initial lesions of purple-blotch. A grayish-violet, furry growth may be visible on the surface of the leaf or seed-stem during moist periods.

Affected leaves gradually become pale-green, and later yellow, and diseased parts, such as leaf tip, folds over and collapse. Sporulation on these lesions produces thick grey to purple belt of conidiophores. Under unfavourable climate, lesions are restricted to non-sporulating white-spots on the foliage. Lesions on the seed stems are circular or elongate, often affecting only one side of the stalk. They weaken stalk and it breaks over with the weight of the seed-umbel, thereby resulting in shrivelled seeds. The pathogen also may infect flower parts and may be carried with seeds. After a period of storage, infected bulbs become soft and shrivelled, and their outer fleshy scales become partly or wholly amber in colour, wrinkled and watery. Other infected bulbs may remain firm and sprout prematurely. Plants developing from such bulbs can be detected by their light-green foliage.

Pathogen and disease biology: Downy mildew is caused by Perenospora destructor (Berk.) Casp. The fungus is a phycomycete with aseptate mycelium and asexual monopodially branched sporangiophores, which bear fusiform to pyriform sporangia. Sporangia germinate by one or two germ tubes. Sporangia are pyriform to fusiform, attached to sterigmata by their pointed end and measure 40 to $72 \mu \mathrm{m} \times 18$ to $20 \mu \mathrm{m}$. The sporangiophores are aseptate, 122 to $820 \mu \mathrm{m}$ in length; swollen at the base to a diameter of 7 to $8 \mu \mathrm{m}$. Branching is dichotomous. Sterigmata are sub-acute or acute. The coenocytic mycelium is intercellular with filamentous haustoria. Oogonia are formed in intercellular spaces.

The main infection source for seed-production crop is systemically affected onion-bulbs. Leaves of overwintering plants also carry the disease, on which sporangia are produced, and these spread to infect spring-sown onions. The fungus may also over-winter as oospores, and decaying onion tissues may release oospores into the soil thereby increasing inoculum potential. It is reported that mycelium 
may invade onion-seeds. However, seed does not seem to be a significant source of pathogen.

The pathogen overwinters in volunteer onion-plants as oospores and also persists from one year to another as mycelium in infected bulbs (in storage) and seeds. The oomycetes possess both asexual (lemon-shaped sporangia) and sexual stage (think-walled oospores), both of which can infect growing plants by being blown or splashed from the soil, respectively.

Pathogen requires cool conditions (less than $22^{\circ} \mathrm{C}$ ) to infect along with water film on the leaf surface or relative humidity greater than $95 \%$. A few hours of dry, sunny weather can dramatically impede disease progress. The infection cycle is characterized by long latent periods of 9-16 days and 1 to 2 days of sporulation, dispersal and infection. Spores are produced at night and dispersed during the day responding to varying environment conditions. Dispersed spores survive on the host leaves for 1-3 days. Duration of spore survival depends on the temperature, relative humidity and absence of intense radiations. The fungus may destroy the onion-foliage in the field almost completely within four infection cycles.

Management strategy: Mildew contaminated onion-sets should not be planted. Rotation schedules that exclude Allium crops for more than 3-4 years should be followed. Well-drained land should be used. Rows should be planted in the same direction as the prevailing wind. Dense population of plants and wind-breaks or other protection should be avoided. Surface and drip irrigation rather than sprinkler irrigation are to be preferred. Various disease forecasts systems of sporulation and infection period are available internationally, and include DOWNCAST, ONIMIL, and MILIONCAST (De Visser, 1998; Battilani et al., 1996; Gilles et al., 2004). Infected crop debris should be destroyed after harvest to eliminate inocula, and refuse heaps of onions culled from storage should be removed. $A$. roylei possesses resistance for downy mildew (Kofoet and Zinkernagel 1990). Onion lines, IC 48045, IC 32149, IC 49371 and DOP 2 have been reported to be resistant to downy mildew. For eradication of mycelium in bulb destined for seed production, direct heat treatment for $4 \mathrm{hr}$ at $41^{\circ} \mathrm{C}$ was proposed (Yarwood, 1943).

Foliar application of diathiocarbamate fungicides, Zineb, Mancozeb and Maneb/ Zineb mixtures control onion downy mildew (Newhall and Rawlin, 1952). Spraying Mancozeb @ $0.25 \%$ and Ziram @ $0.1 \%$ at $10-12$ days interval is recommended. Bulb and seedling dip in Ridomil MZ @ $0.25 \%$ for 12 h, followed by 2 foliar sprays of the same gives effective disease control.

\section{Other Diseases of Minor Importance}

\section{Damping-off}

This is a serious disease in nurseries and in areas of intensive production of direct-seeded onions.

Symptoms: This disease results in seed-rotting, pre-emergence damping-off and post-emergence damping-off. In pre-emergence damping-off, younger seedlings are killed before their emergence from the soil. They may, in fact, be killed even before hypocotyl has come out of the seed-coat. Radicle and plumule, when come out of the seed, completely rot. Post-emergence damping-off is 
characterized by toppling over of the infected seedlings any time after their emergence. It usually occurs at or below the ground level, and infected tissues appear soft and water-soaked. As the disease advances, stem becomes constricted at the base and plant collapses. The disease may appear in the field in roughly circular areas in which plants are killed. Later stunting and root-rot may occur.

Causal organism and disease biology: Many fungi are known to cause damping-off. Pythium species, Fusarium spp. and Rhizoctonia solani are pathogenic to onion seedlings. F. oxysporum and F. oxysporum f.sp. cepae cause delayed seedling emergence and damping-off (Davis and Reddy, 1932). Colletotrichum circinans causes damping-off in warm humid conditions (Shref and MacNab, 1986).

This disease is seed and soil borne. The pathogens persist in the soil in areas which are constantly under production of transplants. It is most severe under high soil moisture and temperature.

Management strategy: Soil solarization of nursery-beds with transparent polyethylene sheet for 30 days before sowing provides a good control (Srivastava and Tiwari, 2000). Agricultural practices that minimize periods of excessive soil moisture (crop rotation and land leveling, installing drains, sowing of clean and healthy seed on raised beds) are used to reduce infection. Overcrowding of plants or dense sowing of onion-seeds should be avoided. Well-decomposed farmyard manure should be used in the nursery.

Seed treatment with Trichoderma viride @ $4 \mathrm{~g} / \mathrm{kg}$ of seeds, followed by soil application of $T$. viride mixed with farmyard manure at $500 \mathrm{~g}$ in $50 \mathrm{~kg}$ of the FYM/ha provides good control of damping-off (Srivastava and Tiwari 2000).

Damping-off disease can be effectively controlled by using protectant fungicides such as Thiram or Captan @ $0.35 \%$ as seed-dressing before sowing. Drenching of the nursery-beds should be done with Benomyl @ $0.25 \%$ in the standing crop.

\section{Fusarium basal-rot (Fusarium oxysporum f.sp. cepae)}

The disease is prevalent in almost all parts of the world. This also causes damping-off and wilting at seedling stage and bulb-rot in mature crop, accounting for $30-40 \%$ losses in storage.

Symptoms: Initially, there is progressive yellowing and dying back from tips of the leaves; aerial part may die in 1-2 weeks or decay may extend over much longer period. When disease appears above the ground level, decay has already taken place at the base. The roots may turn pink and gradually decay until the entire root system disappears. A semi-watery decay affecting fleshy scales starts from the base and progresses upwards with early infection and may be almost complete by the harvest time. White mycelium appears on the stem plate, and the later may show a brown discolouration.

Causal organism and disease biology: The basal-rot is caused by Fusarium oxysporum f.sp. cepae. The pathogen is commonly found in the soil, and its longterm survival is by means of chlamydospores. Incidence of disease appears to increase with injury of roots, stem plate or bulb by onion maggot (Delia antique) or other insects. Stress due to high temperature and drought leading to tissue damage, also increases disease incidence. 
Management strategy: Crop rotation with non-host crops has been found effective in eliminating disease. Mixed cropping with tobacco and sorghum was effective in reducing the disease (Srivastava and Pandey, 1995). Good drainage, deep ploughing in hot summer and avoiding injury during cultural practices reduce disease incidence. Satisfactory control of basal-rot can be achieved by flooding soil in fallow season (Tanaka et al., 1996).

Hybrid onion Spanish and Mustang showed resistance to bulb rotting after harvest. Girija et al. (1998) found three lines (IIHR 141, IIHR 506 and Sel 13-11) consistently resistant to $F$. oxysporum in field in different growing seasons. Stadnik and Dhingra (1997) reported Bola Precoce, Roxa de Barreiro, Crioula, Texas Grano 502, Roxa IPA3, Monte Alegre and Pera IPA1 as resistant.

Trichoderma spp., Pseudomonas fluroscence and Bacillus subtilis have been found effective against $F$. oxysporum under in-vitro conditions (Rajendran and Ranganathan, 1996). Combined seed treatment of $T$. viride $+P$. fluroscence reduced onion basal-rot in pot and field conditions.

Dipping onion-sets in Benomyl, Carbendazim, Thiram and Dofolatan@0.2\% controls pink root, basal-rot and neck-rot of onion. Spraying Carbendazim @ $0.1 \%$ at 30,20 and 10 days before harvest gave lowest yield loss owing to decay after 5 months of storage (Srivastava and Tiwari, 1997).

\section{Pink root [Phoma (Pyrenochaeta) terrestris]}

It is mainly a field disease, affecting mainly growing plant but losses occur during transport and storage. Pink root often occurs in association with Fusarium basal-rot.

Symptoms: The affected roots turn yellow, shrivel and die, meanwhile taking on distinct pink colour. The new roots, which grow from the infected plants, are infected and become functionless. The disease is confined to roots only. The affected plants are generally not killed but bulb growth is retarded.

Causal organism and disease biology: The fungus Phoma (Pyrenochaeta) terrestris causes pink root. $F$. solani has also been reported to be associated with pink root rot (Mathur et al., 2005). The pathogen persists in the soil and is distributed on onion seedlings, sets and garlic cloves. Dissemination also results from movement of spores, infected soil and plant residue by agricultural tools, wind and surface irrigation or through drainage water.

Management strategy: Some garlic lines and A. fistulosum are resistant to pink root. Cultivars reported to be pink-root resistant may not be resistant in all situations. Soil solarization reduces pink-root incidence. It has been observed that early sowing resulted in higher disease incidence than late sowing (Robinowitch et al., 1981). Long rotations with non-host crops should be followed.

Many workers have reported soil fumigation and use of fungicides but it is uneconomical at the field level. After chemical control in field conditions, pathogen population gets reduced early in the season but reappears.

\section{References}

Abubakar L and Ado S G. 2013. Variability pattern for resistance to purple blotch (Alternaria porri) disease of onions (Allium cepa L.) in North Western Nigeria. Nigerian Journal 
of Basic and Applied Sciences 21(2): 109-15.

AINRPOG Annual Report. 2013. Survey and major diseases of onion and garlic, pp. 36775. (In): IVth AINRPOG Group Meeting, held at the BCKV, Kalyani (West Bengal) India.

Ajrekar S L. 1921. Annual Report, pp.102-04. Bombay Deparment of Agriculture (192021).

Anonymous. 1986. Pest Control in Tropical Onions, pp.109. Overseas Development Administration. Tropical Development and Research Institute, London.

Aquino M L N and Wanderley J L da G. 1966. O "mal das setevoltas" noscebais de Sao Francisco. Instituto Agronomico de Pernambuco, BoletimTecnico 16: 44.

Asif M I, Khan A A and Ajakaiye M N. 1976. Zinc nutrition of onions as influenced by phosphorus. Journal of Agricultural Science, Cambridge 87: 277-79.

Aveling T A S, Snyman H G and Naude S P. 1993. Evaluation of seed treatments for reducing Alternaria porri and Stemphylium vesicarium on onion seed. Plant Disease 77: 1009-11.

Aveling T A S, Snyman H G and Rijkenberg F H J. 1994. Morphology of infection of onion leaves by Alternaria porri .Canadian Journal of Botany 72: 1164-70.

Aattilani P, Rossi V, Racca P and Giosue S. 1996. ONIMAIL, a forecaster for primary infection of downy mildew of onion. Bull. OEPP/EPPO 26, pp.567-76.

Boff P, Stadnik M J, Ferrari R and Da Silva, T D. 1995. Assessment of health status of onion seed commercialized in the state of Santa Catarina. Revista Brasileira de Sementes, 17: 165-70. Brekely M J. 1884. Vegetable Pathology, Gardeners. Chronicles 22: 689.

Chawda H T. 1992. 'Epidemiological investigations on purple blotch and anthracnose of onion (Allium cepa L.)'. Ph.D. Thesis, Gulberga University, India.

Chawda H T and Rajasab A H. 1996. Onion anthracnose disease symptoms: a review. Onion Newsletter for the Tropics 7: 82-84.

Davis G M and Reddy C S. 1932. A seedling blight stage of onion bulb rot. Phytopathology 22: 8 .

De Visser C L M. 1998. Development of downy mildew advisory model based on DOWNCAST. European Journal of Plant Pathology 104: 933-43.

Ebenebe A C. 1980. Onion twister disease caused by Glomerella cingulata in northern Nigeria. Plant Disease 64: 1030-32.

Ellis M B. 1971. Dematiaceous Hyphomycetes, CMI, Kew, Surrey, 608.

Ganeshan Girija, Pathak C S, Gowda R V and Ganeshan G. 1998. Reaction of onion lines to basal rot disease caused by Fusarium oxysporum f. spp. cepae. PKV Research Journal 22: $53-54$.

Gilles T, Phelps K, Clarkson J P and Kennedy R. 2004. Development of MILIONCAST, an improved model for predicting downy mildew sporulation on onions. Plant Disease 88: 695-702.

Gupta R P, Srivastava K J and Pandey U B. 1994. Diseases and insect pests of onion in India. Acta Horticultureae 358: 365-69.

Horsefall T G and Dimond A F. 1957. Pflantebaup Flan Ensclurtz 64: 415. var. ascalonicum in Sri Lanka. Plant Disease 83: 695.

Hussein M A M, Hassan M H A, Allam A D A and Abo-Elyousr K A M. 2007. Management of Stemphylium blight of onion by using biological agents and resistance inducers. Egyptian Journal of Phytopathology 35: 49.

Kamal Abo-Elyousr A M, Hussein M A M, Allam A D A and Hassan M H. 2009. Salicylic acid induced systemic resistance on onion plants against Stemphylium vesicarium. Archives of Phytopathology and Plant Protection 42 (11): 1042-50.

Kofoet, A and Zinkernagel V. 1990. Resistance to downy mildew (Perenospora destructor) 
in Allium spp. Z. Pflanzenkr. Pflanzenschutz 97: 13-23.

Lorbeer J W. 1993. A serious outbreak of Stemphylium leaf blight of onion in New York, pp. 32-37. (In): Proceedings of the 1993 National Onion Research Conference. Department of Fruit and Vegetable Science, Cornell University, Ithaca, NY, USA.

Mathur K, Gupta R B S and Sharma S N. 2005. Management of pink root rot disease of onion induced by Fusarium solani. (In): National Symposium on Current Trends in Onion, Garlic, Chillies and Seed Spices Production, Marketing and Utilization. NRCOG, Rajgurunagar, Pune, Maharashtra, India.

Maude R B. 1990. Leaf diseases of onion, pp. 173-89. (In): Onion and Allied Crops, Vol. II: Agronomy, Biotic Interaction, Pathology and Crop Protection. Rabinowitch H D and Brewster J L. (Eds). CRC Press Boca Raton, Florida, USA.

Miller M E, Taber R A and Amador J M. 1978. Stemphylium blight of onion in South Texas. Plant Disease 62: 851.

Mir N M. 1977. Peronospora destructor (Berk.) Casp., a new record from India. Current Science 46: 206.

Misawa T. 2008. Optimum conditions of lesion formation of brown oval symptom and yellow mottle symptom of leaf blight of Welsh onion caused by Stemphylium vesicarium (in Japanese). Annual Report of Plant Protection, North Japan 59: 46-49.

Misawa T. 2008a. Yellow mottle symptom of Welsh onion caused by Stemphylium vesicarium (Abstract in Japanese). Ann Phytopathol Soc Japan 74: 82.

Newhall A G and Rawlins W A. 1952. Control of onion blast and mildew with carbamates. Phytopathology 42: 212.

Nolla J A B. 1926. Onion leaf anthracnose. Journal of Department of Agricuture, Puerto Rico 10: 245-56.

Nolla J A B. 1927. A new Alternaria disease of onion (Allium cepa L.) Phytopathology 17: 115 .

Pandotra V R. 1964. Purple blotch disease of onion in Punjab. I. Its occurrence, pathogenicity and host range. Proceedings of Indian academic Science, Sec. B. 60: 336-40.

Pathak C S, Black L L, Cherng S J, Wang T C, Ko S S and Armstrong G. 2001. Breeding onions for Stemphylium life blight resistance. (In): Proceeding of the Second International Symposium on Edible Alliaceae, during 10-13 November 1997 at Adelaide, Australia. [Acta Horticultureae 555: 77-81].

Quadri S M H. 1988. Two onion diseases new to Andhra Pradesh and Karnataka. Indian Phytopathology 47: 165-312.

Quadri S M H and Srivastava K J. 1985. Leaf blight of onion (Allium cepa L.) caused by Colletotrichum gloeosporioides (Penz) Penz \& Sacc. Hitherto unrecorded in India. (In): Proc. $72^{\text {nd }}$ Indian Science Congress, Pt III, Section X, Agricultural Sciences Abstract No. 129.

Rabiowitch H D, Kattan J and Rotem I. 1981. The response of onion to solar heating agricultural practices and pink diseases. Scientia Horticulturae 15: 331-34.

Rajasab A H and Chawda H T. 1994. Dispersal of conidia of Colletotrichum gloeosporioides by rain and the development of anthracnose on onion. Grana 33: 162-65.

Rajendra K and Ranganathan K. 1996. Biological control of onion basal rot (Fusarium oxysporum $f$. spp. sepae) by combine application of fungal and bacterial antagonists. Journal of biological control 10: 97-102.

Rao N N R and Pavagi N S. 1973. Pleospora alli on onion from Varanasi. Current Science 42: 734 .

Robbs C F, Ribeiro R de L D, Akiba F and Kimura O. 1972. Novosestudossobre o "mal das setevoltas" da cebola (Allium cepa L.) no vale de Sao Francisco. Arquivos da Universidad Federal Rural do Rio de Janeiro 2: 21-27. 
Schwartz H F and Mohan S K. 2008. Compendium of Onion and Garlic Diseases and Pests. II ${ }^{\text {nd }}$ Ed.APS Press. St. Paul. MN. USA.

Shref A F and MacNab A A. 1986. Onion, garlic, leek and shallots. (In): Vegetable Disease and their Control. John Wiley and Sons, New York,USA.

Srinivas P S, Singh R P and Lawande K E. 2007. Integrated Pest Management in Onion and Garlic. Technical Bulletin No. 17, Directorate of Onion and Garlic Research, Rajgurunagar, Maharashtra, India.

Shrivastava P K and Pandey U B. 1995. Compendium of Onion Disease, pp. 36. Technical bulletin. No.7, NHRDF Nashik, Maharashtra, India.

Shrivastava P K and Tiwari B K. 1997. Effect of pre-harvest fungicidal spray on control of storage disease of onion. NHRDF Newsletter 17: 4-6.

Shrivastava P K and Tiwari B K. 2000. Nursery disease management in onion with biocontrol and plant product, pp.21. (In): National Symposium on Onion and Garlic Production and Post-Harvest Management: Challenges and Strategies. Nashik, Maharashtra, India.

Simmons E G. 1969. Perfect states of Stemphylium. Mycologia 61: 1-26.

Skiles R L. 1953. Purple and brown blotch of onions. Phytopathology 43: 409.

Stadnik M J and Dhingra O D. 1997. Root infection by Fusarium oxysporum f. sp. cepae at different growth stages and its relation to the development of onion basal rot. Phytopathologica Meditarranea 36: 8-11.

Tanaka K, Terao H, Kubota E, Teramota S and Motomura T. 1996. Effect of flooding on the survival and pathogenecity of Fusarium oxysporium f. sp. cepae in paddy field. Marine and Highlad Bioscience Centre Report 3: 39-43.

Viets J F G. 1967. Zinc Deficiency of Field and Vegetable Crops in the West, pp. 7. Soil and Water Conservation Research Division, Agriculture Research, Washington DC. Leaflet No. 495.

Yadav P M, Rakholiya, K B and Pawar D M. 2013. Evaluation of bioagents for management of the onion purple blotch and bulb yield loss assessment under field conditions. The Bioscan 8(4): 1295-98.

Yarwood C E. 1943. Onion downy mildew. Hillgardia 14: 595. 


\section{Viral Diseases}

K. S. Ravi, Muktha Raghuram and Mahesh Shekar

Viruses are one of the major constraints in onion production. A number of viruses, Iris yellow spot virus, Groundnut bud necrosis virus, Tobacco streak virus, Onion yellow dwarf virus, Allexivirus and Rymovirus, have been reported and among them, Iris yellow spot virus and Onion yellow dwarf virus are the common and the prevalent ones in major onion-growing regions across the world.

\section{Iris yellow spot virus}

The Iris yellow spot virus (IYSV) is an emerging onion disease, which was first reported from Treasure Valley, Idaho, USA, in 1989 (Hall et al., 1993). Since then, it has also been reported from the Netherlands, Australia, Brazil, Chile, India, Israel, Japan, Peru, Spain and eastern and western parts of the USA. The widespread incidence of IYSV in seed and bulb production areas of the USA might have been by the natural infection of the wild relatives of the cultivated onion (Pappu et al., 2006). In India, IYSV-infected onions were first reported in Jalna and Nashik regions of Maharashtra by Ravi et al. (2005).

Distribution: IYSV is widely prevalent in most of the onion-growing regions of the country-Maharashtra, Punjab, Haryana and others. High incidence of the virus was found in Maharashtra; it was up to 100\% in Aurangabad, 90 to 100\% in Chinchipur, Sangamner districts. In Tamil Nadu, its incidence was $80-100 \%$ in Dindigul and 12-20\% in Viralapatti districts (Sivamani 2009 - Unpublished).

Causal organism: Iris yellow spot virus

Virus morphology: Genus: Tospovirus; Family: Bunyaviridae.It consists of enveloped quasi spherical particle, measuring approximately $80-120 \mathrm{~nm}$ in diameter.

Symptomatology: The disease has the following characteristics.

- Spindle/diamond-shaped chlorotic lesions on the leaves and the scapes (Fig. 13.1a).

- In advanced stage, chlorotic lesions coalesce and result in withering of leaves and scapes (Fig. 13.1b).

- Twisting or bending of flower-bearing stalks (Fig. 13.1c).

- Bulbs are affected with hay-coloured spots in advanced stage.

Symptoms on different host-plants: Kumar and Dhawan (2013) described its symptoms as follows.

- The IYSV produced local chlorotic ringspots; 3-6 days post-inoculation in Nicotiana tabaccum L. and $N$. clevelandii A. Gray.

- The chlorotic local lesions were produced on the inoculated leaves of 

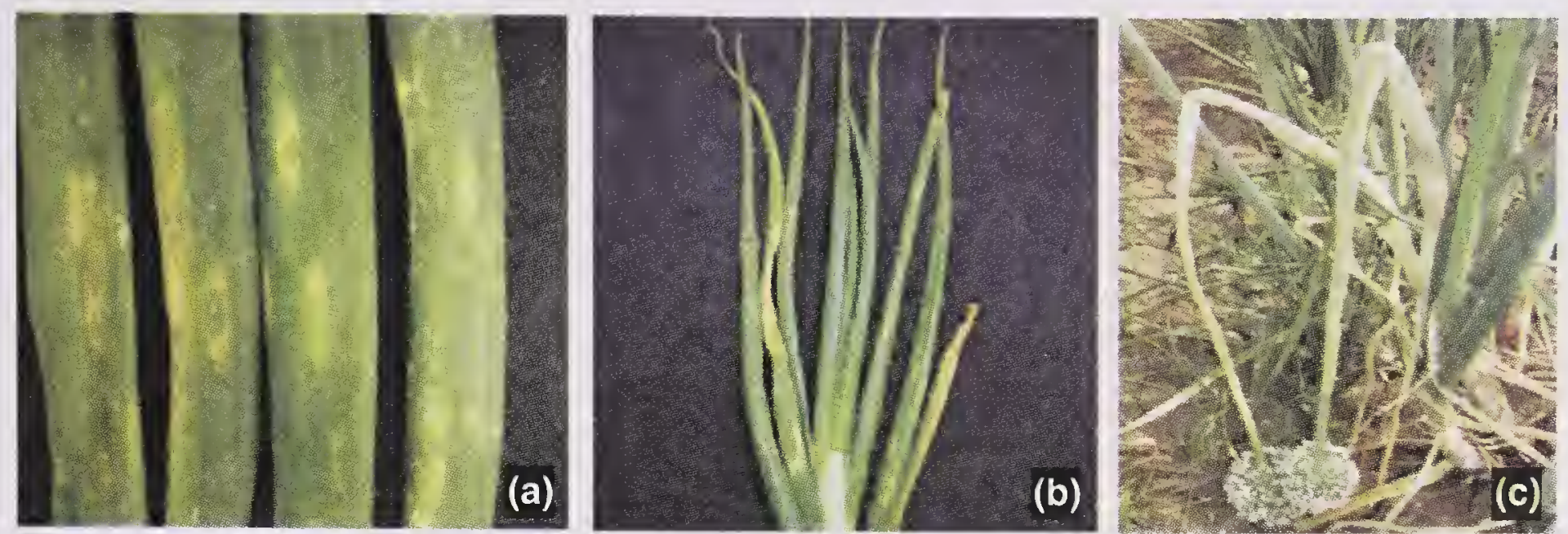

Fig.13.1 Symptoms of IYSV on onion. (a) Diamond/spindle shaped chlorotic lesions on leaves. (b) Withering of leaves and scapes. (c) Bending/twisting of flower-bearing stalks

Amaranthus retroflexus L., Chenopodium album L., C. amaranticolor L., C. muralae L., Nicotiana benthamiana Domin., Physalis floridana Rydb. Zinnia elegans Jacq. and Iris hollandica L.

- The necrotic local lesions developed in Vigna unguiculata 3-4 days postinoculation

Transmission: The virus is transmitted as follows.

- The virus is transmitted by mechanical sap inoculation under greenhouse conditions and produce typical symptoms.

- Nymphs of onion thrips (Thrips tabaci L.) are known to transmit the virus under laboratory conditions, and percentage infliction was up to $54.17 \%$ (Kumar and Rawal, 1999). Thrips tabaci L. is involved in virus spread under field conditions.

- The presence of virus in bulbs was detected and diagnosed by many workers, and its transmission across generations is yet to be confirmed.

Virus diagnosis: Following are the means of diagnosis of the disease.

(a) The disease can be characterized by spindle or diamond-shaped spots on the scapes and on the flower-bearing stalks. The symptoms are more prominent on flower-bearing stalks.

(b) The virus can be detected by serological and PCR-based techniques. Tissue Immuno Blot Assay was used to detect the virus from infected plants and bulbs, using polyclonal antibody prepared against recombinant nucleocapsid protein (NP) of IYSV (Sivamani et al., 2012) (Fig.13.2).

(c) Double Antibody Sandwich Enzyme Linked Immunosorbent Assay (DASELISA) was also used to detect the virus from infected plants. The ELISA kit (Loewe Biochemica GmbH Company, Germany) of IYSV was used for

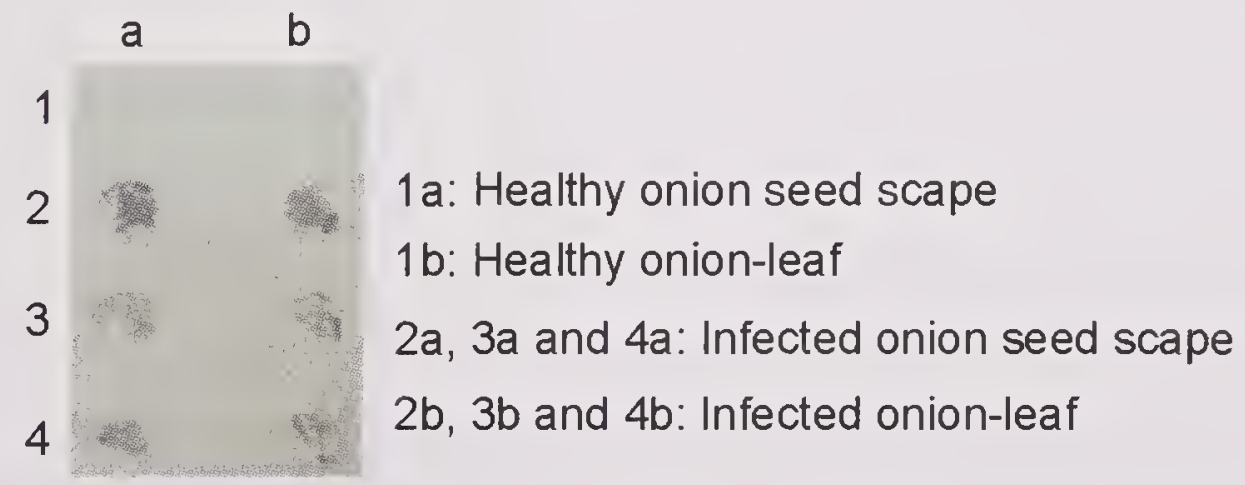

Fig. 13.2 Tissue Immuno Blot Assay to detect IYSV from the infected onion 
detection, diagnosis and confirmation of the virus causing the disease (Kumar and Dhawan, 2013).

(d) The virus was detected from infected onion plants and bulbs by Reverse Transcriptase Polymerase Chain Reaction (RT-PCR) using primer specific for Nucleocapsid gene of IYSV (Ravi et al., 2005).

Host range: The virus is known to infect different plant species-Chenopodium amaranticolor L., Chenopodium quinoa L., Datura stramonium L., Gomphrena globosa L., Portulaca oleracea L., Nicotiana benthamiana L. and Nicotiana rustica $\mathrm{L}$.

Some of the weed-hosts which harbour the virus are-Redroot lettuce (Lactuca serriola L.), Common lamb squarters (Chenopodium album L.), Redroot pigweed (Amáranthus retroflexus L.), Spiny sowthistle (Sonchus asper L.), Green foxtail (Setaria viridis L.) and Two-scale salt brush (Atriplex micrantha L.) (Kumar and Dhawan, 2013).

Dissemination: The disease spreads by onion thrips (Thrips tabaci L.) under field conditions (Kumar and Rawal, 1999).

Management: The disease management is as follows.

(a) Use healthy and virus-free bulbs for planting.

(b) Removal of virus-infected plants at the early stage of crop growth to reduce source of inoculum.

(c) Vector control: (i) Management of thrips by spraying systemic insecticides: Confidor (Imidacloprid) at $0.2 \mathrm{ml} / \mathrm{litre}$, Regent (Fipronil) at $1-2 \mathrm{ml} / \mathrm{litre}$, Tracer (Spinosad) at $0.1 \mathrm{ml} /$ litre, Pride (Acetamiprid) at $0.2 \mathrm{~g} /$ litre for three times at 20 days interval; (ii) Spray crop with neem oil (3.5 litres/ha) for managing onion thrips; (iii) Apply Trumpet (Dimethyl phosphate) three times at 5 days interval, followed by two sprays of Orthene (Acephate) at $1.5 \mathrm{~g} /$ litre or Decis (Deltamethrin) at $1.5 \mathrm{ml} /$ litre at 10 to 14 days interval.

\section{Groundnut bud necrosis virus}

The first report of natural occurrence of this disease (Serogroup IV of Tospovirus) in onion-crop was given by Sujitha et al. (2012) from Andhra Pradesh.

Distribution: The disease is widely prevalent in the commercial onion fields of Kadapa district of Andhra Pradesh.

Causal organism: Groundnut bud necrosis virus (GBNV)

Virus morphology: Genus: Tospovirus; Family: Bunyaviridae .It consists of enveloped quasi spherical particle, approximately $80-120 \mathrm{~nm}$ in diameter.

Symptomatology: The host-plant shows the following symptoms.

- Straw coloured, mosaic and necrotic lesions are observed on the young leaves (Fig.13.3a).

- The necrosis starts with apical portion of young leaves and finally

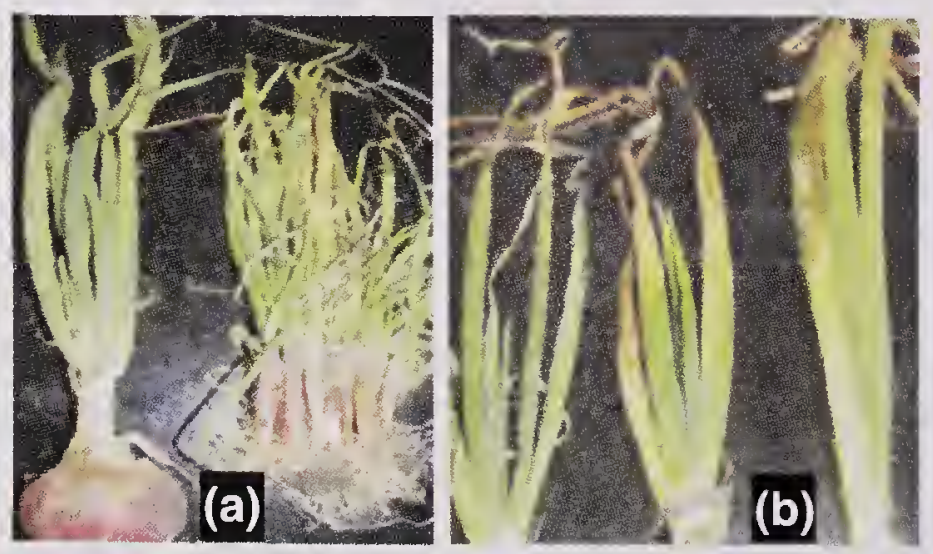

Fig.13.3 Symptoms of GBNV on onion. (a) Chlorosis and mosaic mottling symptoms on leaves. (b) Necrosis and tip dying symptoms 
die-back of plants (Fig.13.3b).

- In severe stage, necrosis on flower-stalks is observed and eventually the flower aborts.

Transmission: The virus is transmitted through onion thrips (Thrips tabaci L.) and Scritothrips dorsalis Hood. (Meena et al., 2005).

Virus diagnosis: To detect the virus, the following methods are used.

(a) Direct Antigen Coating Enzyme Linked Immunosorbent Assay (DAC-ELISA) using GBNV polyclonal antibodies to detect virus from leaves (Sujitha et al., 2012) (Fig. 13.4).

(b) Reverse Transcriptase Polymerase Chain Reaction of leaf tissue from onion-plants using specific primer against Nucleocapsid gene of GBNV (Sujitha et al., 2012).

Host range: GBNV is known to have a wide host range. It infects legumes, oilseeds, vegetables, ornamentals, weeds and other hosts (Reddy, 1991).

Dissemination: The virus is known to spread in fields by onion thrips-Thrips tabaci L. and Scritothrips dorsalis Hood.

Management: This disease is managed as follows.

(a) Use healthy and virus-free bulbs for planting.

(b) Removal of infected plants at an early stage to reduce source of inoculum.

(c) Vector control: (i) Management of thrips by spraying systemic insecticides: Confidor (Imidacloprid) at $0.2 \mathrm{ml} / \mathrm{litre}$, Regent (Fipronil) at $1-2 \mathrm{ml} / \mathrm{litre}$, Tracer (Spinosad) at $1 \mathrm{ml} /$ litre, Pride (Acetamiprid) at $0.2 \mathrm{~g} /$ litre for three times at 20 days interval; (ii) Spray the crop with neem oil (3.5 litres/ha) for managing onion thrips; (iii) Apply Trumpet (Dimethyl phosphate) three times at 5 days interval, followed by two sprays of Orthene (Acephate) at $1.5 \mathrm{~g} /$ litre/Decis (Deltamethrin) at $1.5 \mathrm{ml} /$ litre at 10 to 14 days interval.

\section{Tobacco streak virus}

This virus in onion was first reported by Sivaprasad and co-workers during 2010 from Kurnool district of Andhra Pradesh.

Distribution: Kurnool district of Andhra Pradesh.

Causal organism: Tobacco streak virus (TSV).

Virus morphology: Genus: Ilarvirus; Family: Bromoviridae. It consists of non-enveloped, quasi-isometric particle, approximately $25-28 \mathrm{~nm}$ in diameter with tripartite positive sense single stranded RNA (RNA1, RNA2 and RNA3).

Symptomatology: Host-plants show the following symptoms.

- Irregular straw-coloured necrotic lesions on the leaves (Fig.13.5a). 

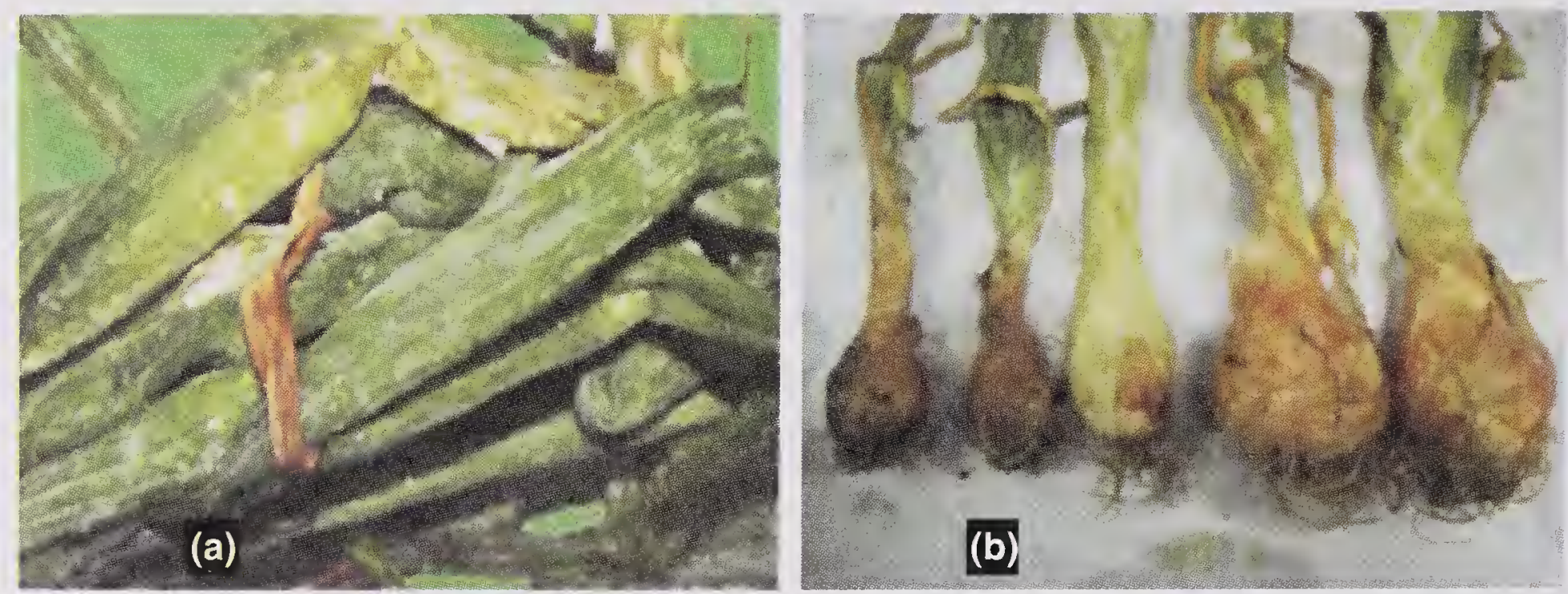

Fig.13.5 Symptoms of TSV on onion. (a) Infected onion-plants showing necrotic lesions on leaves. (b) Virus infected bulbs with various abnormalities

- Early infection aborts flowers.

- Reduction in bulb size and necrosis of bulbs (Fig.13.5b).

- Wilting and necrosis of plants, leading to yield reduction.

Transmission: The virus is transmitted as follows.

- Through mechanical sap inoculation under laboratory conditions.

- This virus spreads through pollen-assisted transmission by thripsMegalurothrips usitatus (Bagnall), Frankiniella schultzei (Trybom) and Scritothrips dorsalis Hood. (Prasad Rao et al., 2003).

Virus diagnosis: Its presence is diagnosed as follows.

(a) Detection of the virus from leaves is by DAC-ELISA using TSV polyclonal antibodies (Sivaprasad et al., 2010).

(b) RT-PCR checks the virus from leaf tissue of diseased onion-plants using specific primers for the Coat Protein gene of tobacco streak virus (Sivaprasad et al., 2010) (Fig.13.6).

Host range: The virus is known to infect a large number of host-plants, and some commonly infected plants are groundnut, sunflower, cotton,

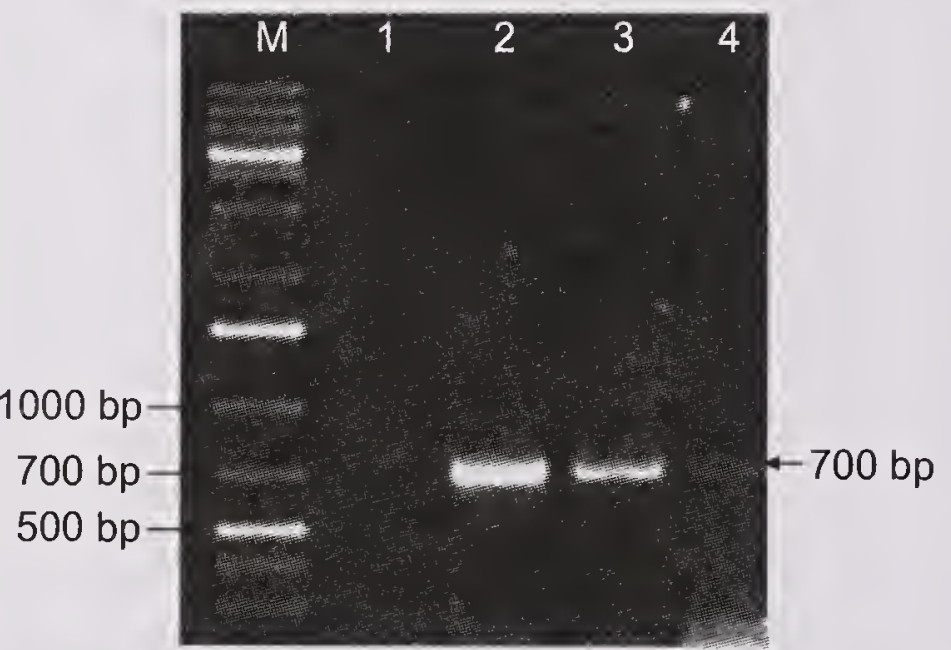

Fig.13.6 Detection of virus by amplification of $\sim 700 \mathrm{bp}$ fragment of TSV-Coat Protein gene by RT-PCR. [Lane M: $1 \mathrm{~kb}$ DNA ladder; Lane 1: Uninfected onion leaf; Lanes 2-4: Infected onion leaves] mungbean, soybean, sunnhemp, okra, cucumber, gherkin, safflower, chilli the as well as several weeds and ornamentals (Kumar et al., 2006).

Dissemination: The virus spreads in the fields through thrips-Megalurothrips usitatus (Bagnall), Frankiniella schultzei (Trybom) and Scritothrips dorsalis Hood. (Prasad Rao et al., 2003).

Management: This disease is controlled as follows.

(a) Removal of infected plants at an early stage to reduce source of inoculum.

(b) Intercropping of onion with groundnut, chilli and other vegetable crops to stop virus spread. 
(c) Vector control: (i) Management of thrips by spraying systemic insecticides, Confidor (Imidacloprid) at $0.2 \mathrm{ml} /$ litre, Regent (Fipronil) at 1-2 $\mathrm{ml} /$ litre, Tracer (Spinosad) at $1 \mathrm{ml} /$ litre, Pride (Acetamiprid) at $0.2 \mathrm{~g} / \mathrm{litre}$, three times at 20 days interval; (ii) Spray crop with neem oil (3.5 litres/ha) for managing onion thrips; (iii) Apply Trumpet (Dimethyl phosphate) three times at 5 days interval, followed by two sprays of Orthene (Acephate) at $1.5 \mathrm{~g} / \mathrm{litre} /$ Decis (Deltamethrin) at $1.5 \mathrm{ml} /$ litre at 10 to 14 days interval.

\section{Onion yellow dwarf}

This is the most common virus in onion. Bulb and seed yield can be drastically reduced in virus infected onion-plants. OYDV occurs in epiphytotic proportion and has been implicated in reduced onion-seed production. It was first reported from onion in Iowa, USA (Melhus et al., 1929), and occurs worldwide; its incidence was recorded up to 52\% in Europe and 86\% in Asian countries (Van Dijk, 1993). Since then, it has also been reported in Egypt, India, Serbia and Sudan. In India, it was first reported by Dhingra and Nariani in 1963 from the Indian Agricultural Research Institute (IARI), New Delhi.

Distribution: The disease was recorded from commercial fields in Haryana, Delhi, Rajasthan and Maharashtra. In 1995-1997, the disease similar to onion yellow dwarf was recorded in seed-crop at the IARI, New Delhi. Subsequently, its epiphytotic form was recorded in and around Delhi in onion-seeds (Ahlawat and Varma, 1997). Incidence of this disease up to 90\% was recorded in 1998-99 on seed crop of commercial varieties at the IARI farm.

Causal organism: Onion yellow dwarf virus (OYDV)

Virus morphology: The virus belongs to Family: Potyvirus. It is nonenveloped, rod-shaped/flexuous virus particle, ranging from 650 to $900 \mathrm{~nm}$.

Symptomatology: The disease is recognized by following.

- Short chlorotic streaks are on the leaves, which eventually become yellow throughout.

- Infected onion-plants show irregular yellow stripes on leaves (Fig13.7a).

- In severe cases, yellowing of the entire plant is observed.

- The leaves become crinkled and somewhat flat.

- Infected plants become highly stunted and distorted (Fig.13.7b).

- In severe infections, older

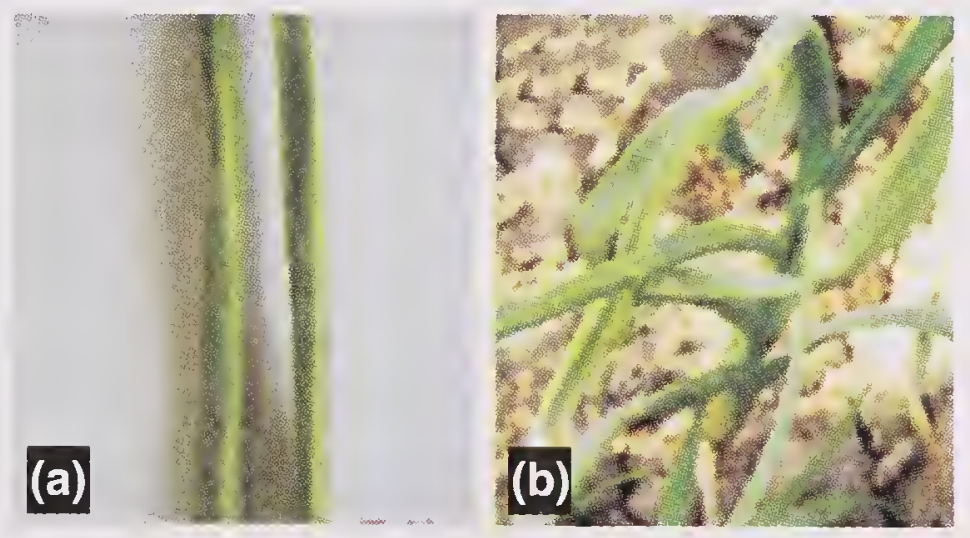

Fig.13.7 Symptoms of OYDV. (a) Infected leaves showing discontinued yellow stripes on leaves. (b) Severely infected plants showing stunting and leaf distortion leaves fall, and plants appear abnormal.

- Flower-stalks of infected plants show yellow streaks extending upward from the base. The streaks coalesce, stalks become dwarf, yellow and twisted in a characteristic manner and bear a fewer flowers.

- Bulbs produced from the infected onion-plants are underdeveloped, deformed and of little commercial value. 
- Immature sprouting results in infected bulbs under storage.

- OYDV develops local lesions in Chenopodium murale L. and C. quinoa L. Transmission: The virus transmission is by following means.

(a) The virus is transmitted onto onion by mechanical inoculation on leaves and bulb injections under the laboratory condition.

(b) In fields, virus is known to spread by 50 aphid species (Tate, 1940) such as Aphis craccivora Koch, A. gossypi Glover and Myzus persicae Sulzer. The maximum transmission of virus up to $20 \%$ was by A. gossypi Glover (Hoa et al., 2003).

Virus diagnosis: This virus can be detected by the following methods.

(a) Virus detection is by DAC-ELISA using OYDV specific polyclonal antibodies from the infected plants (Hoa et al., 2003).

(b) Immunosorbent electron microscopy was used to detect virus presence in infected leaf tissues (Hoa et al., 2003).

(c) The virus was also detected in onion-plants by RT-PCR, which is 10-100 times more sensitive than ELISA, using specific primer designed for the conserved region of RNA dependant RNA polymerase gene and 3' UTR regions (Meenakshi et al., 2006) (Fig.13.8).

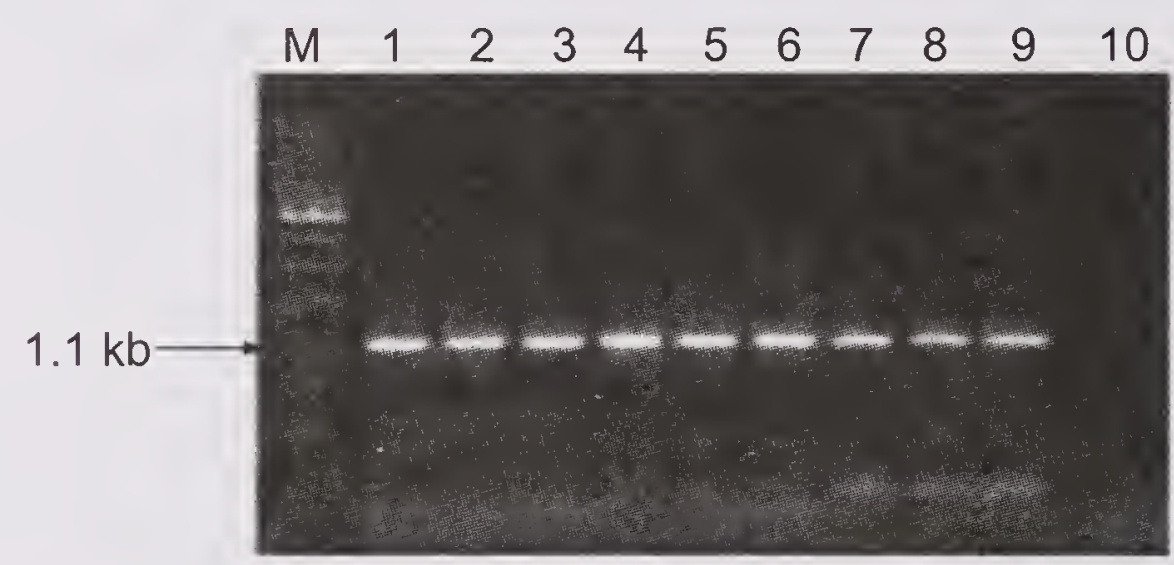

Fig.13.8 Detection of virus by amplification of 1.1kb RNA dependent RNA polymerase gene fragment of OYDV using RT-PCR. [Lane M: 1 kb DNA marker; Lanes 1-4: Garlic leaf samples; Lanes 5-8: Garlic bulb samples; Lane 9: Onion leaf sample; Lane 10: Negative control]

(d) The primer used was OYDVVKBF- 5'-ATAGCAGAAACAGCTCTTA-3' (forward) OYDVVKBR- 5'-GTCTCYGTAATTCACGC-3' (Reverse), which produced an amplicon of $1.1 \mathrm{~kb}$ indicating OYDV presence.

The techniques mentioned above developed for viral diagnosis would be useful for developing healthy planting material of onion-seed crops, and thus, primary spread of virus from seed-crop to main crop would be avoided.

Host range: The virus is known to infect $A$. cepa $\mathrm{L}$. and $A$. satium $\mathrm{L}$.

Dissemination: Under field conditions, the virus spreads by different species of aphids-Aphis craccivora Koch, A. gossypi Glover and Myzus persicae Sulzer.

Management: To save plants, following methods are applied.

(a) Use virus-free bulbs for planting.

(b) Corn is recommended as the barrier crop to stop influx of insect-vectors (aphids), and spray the crop with systemic insecticide, like Confidor (Imidacloprid) $(0.2 \mathrm{ml} /$ litre). 
(c) Apply Furadon @ of $1 \mathrm{~kg}$ a.i./ha at the time of transplanting seedlings, followed by 3-4 foliar sprays of Monocrotophos $(0.05 \%)$ or Dimecron $(0.05 \%)$ at 10 days interval.

(d) Control aphid vector by spraying systemic insecticides: Carbosulfan (Marshal) $1.5 \mathrm{ml} /$ litre, Asataf (Acephate) (1.5 g/litre) for 4-5 times at 10 days interval.

\section{Mixed Infections in Onions}

\section{Mixed infection of onion yellow dwarf virus and allexivirus}

This was reported from Delhi and its adjoining regions. Ahlawat and Varma (1997) reported presence of OYDV mixed infection in garlic and onion.

Distribution: Onion yellow dwarf virus and allexivirus are common flexuous virus particles, which infect onion in Delhi region. Allexivirus is known to cause significant yield losses in garlic and also affect onion-crop in mixed infection with onion yellow dwarf virus.

Causal organism: Onion Yellow Dwarf Virus and Allexivirus

Virus morphology: Onion yellow dwarf virus belongs to Family: Potyvirus.It is non-enveloped, rod-shaped/flexuous virus particle, ranging from 650 to 900 $\mathrm{nm}$.Allexivirus is also non-enveloped, flexuous, filamentous, $800 \mathrm{~nm}$ long and $12 \mathrm{~nm}$ in diameter.

Symptomatology: The symptoms for infection are as follows.

- Yellow stripes on the leaves are with diffused chlorotic spots.

- Twisting of leaves and distortions are noticed.

Transmission: Onion yellow dwarf virus is transmitted in fields by different aphid species-Aphis craccivora Koch, A. gossypi Glover and Myzus persicae Sulzer, and Allexivirus transmission is by mites.

Virus diagnosis: Detection of this mixed infection is done as follows.

(a) Onion yellow dwarf virus and Allexivirus were detected by Duplex RTPCR using specific primers having conserved regions of nuclear inclusion protein (NIB), coat protein (CP) and 3' untranslated region (Fig. 13.9). The primer set details used for the Duplex RT-PCR for OYDV and Allexivirus are detailed in Table 13.1 (Sandeep et al., 2010).

(b) OYDV could be detected by Primer set 3 in leaves and bulbs of five cultivars of rabi onion- Pusa Red, Pusa Madhavi, Early Grannow, Pusa White Flat and Pusa White Round (Fig. 13.10). Similarly, allexivirus was detected both in bulb and leaf tissues but was more in bulb tissues (Fig. 13.11).

Table 13.1 Primer-sets for the duplex RT-PCR for OYDV and Allexivirus

\begin{tabular}{llcc}
\hline Primers & Base pairs & Virus \\
\hline 1. & Primer- set 3:OYDV.VKB3F-5' ATAGCAGAAACAGCTCTTA 3' & $\sim 500 \mathrm{bp}$ & OYDV \\
& OYDV.VKB3R-5' TCCATCATAGTCCAATTTCC 3' & & \\
2. Primer -set 4: & & \\
$\quad$ Allexi1F-5' CYGCTAAGCTATATGCTGAARGG 3' & Allexi \\
& Allexi2R-5' TGTTRCAARGTAAGTTTAGYAATATCAACA 3' & & \\
\hline
\end{tabular}



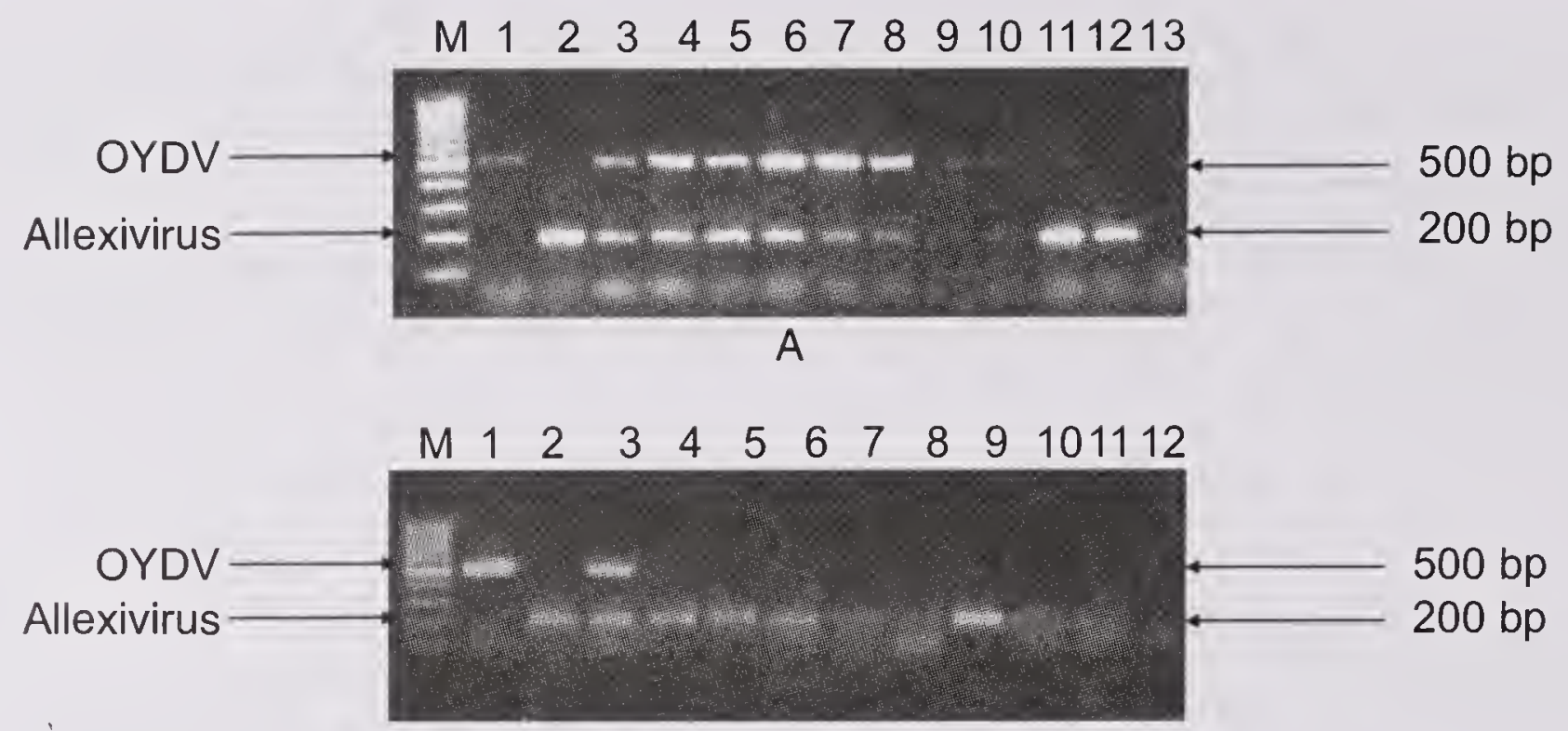

B

Fig.13.9 Amplification of OYDV and Allexivirus by Duplex RT-PCR. [Lane M: 100 bp marker; Lane 1: OYDV by RT-PCR; Lane 2: Allexivirus by RT-PCR; Lanes 3-12: Amplification of OYDV and Allexivirus by Duplex RT-PCR; Lane 13: Healthy control]

(A) Detection of OYDV and Allexivirus in rabionion. (B) Detection of OYDV and Allexivirus in kharif onion.

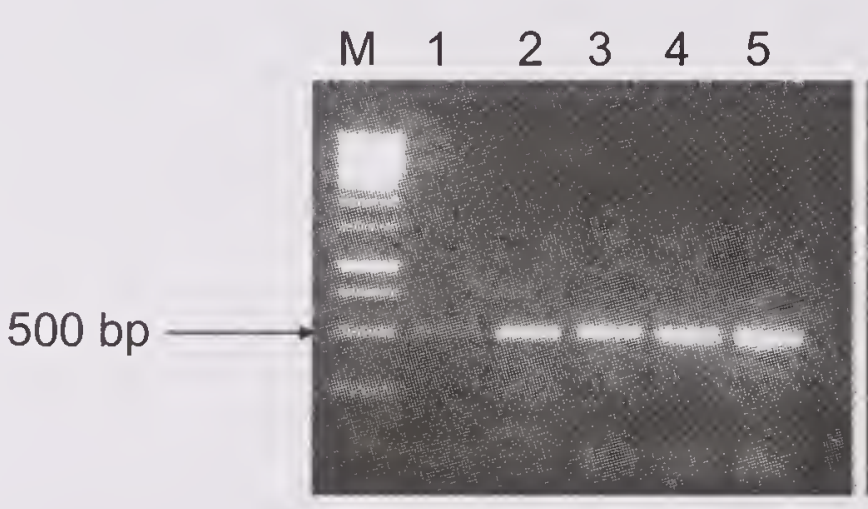

A

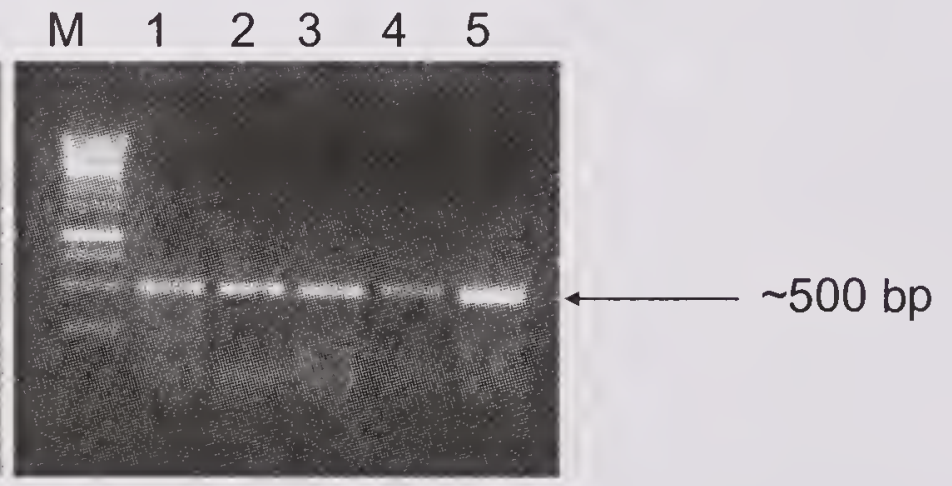

B

Fig. 13.10 Detection of OYDV using primer set 3 producing amplicons of $\sim 500 \mathrm{bp}$. (A) in leaves. (B) in bulbs. Lane M 100 bp ladder; Lanes 1-5 PR, PM, EG, PWF and PWR accessions]

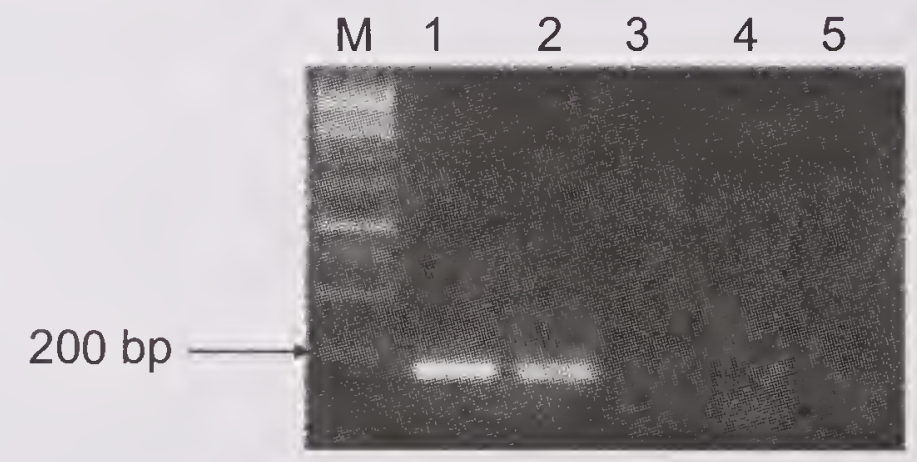

A

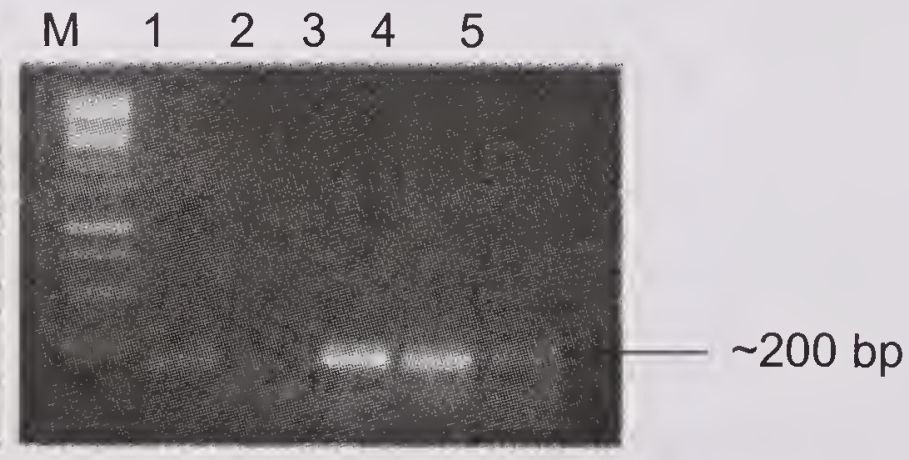

B

Fig.13.11 Detection of an Allexivirus: $(A)$ in leaves. $(B)$ in bulbs [Lane M: 100 bp ladder; Lanes 1-5: PR, PM, EF, PWF, PWR accessions]

(c) Immunosorbent electron microscopy was used to detect presence of virus in leaf tissue (Hoa et al., 2003).

Management: Following care needs to done.

(a) Seed-crop should be grown away from the main crop to avoid infection of main crop by aphid and mite vectors.

(b) Select seeds/bulbs from healthy explants. 
(c) Roguing of infected plants from the seed-crop is a must to prevent source of virus inoculum, and further spread of virus by insect-vectors.

(d) Manage aphid vectors by spraying systemic insecticides: Carbosulfan (Marshal) at $1.5 \mathrm{ml} /$ litre Asataf (Acephate) at $1.5 \mathrm{~g} /$ litre for 4-5 times at 10 days interval.

(f) Mites can be managed by spraying Acaricides: Kelthane (Dicofol) $2 \mathrm{ml} /$ litre, Omite (Propargite) $2 \mathrm{ml} /$ litre and Karathane (Dinocap) $1 \mathrm{ml} /$ litre once in 5-7 days interval.

\section{Mixed infection of onion yellow dwarf virus and rymovirus}

In 1997, Ahlawat and Anupam first reported the presence of onion yellow dwarf virus (OYDV) and mite transmitted Rymovirus at the Indian Agricultural Research Institute, New Delhi.

Distribution: The mixed infection of OYDV and Rymovirus was observed in onion-seed crop in villages around Delhi and at Nazafgarh in Haryana.

Causal organism: Onion yellow dwarf virus (OYDV) and mite transmitted rymovirus

Virus morphology: Onion yellow dwarf virus belongs to Family Potyvirus. It is non-enveloped, rod-shaped/flexuous virus particle, ranging from 650 to 900 $\mathrm{nm}$. Rymovirus is also non-enveloped, flexuous/filamentous, approximately 690$700 \mathrm{~nm}$ long and $12-15 \mathrm{~nm}$ in diameter.

Symptomatology: The infection leads to following symptoms.

- The leaves and flower-stalks showed mosaic mottling, short chlorotic streaks, yellowing and stunted growth of infected plants.

- Crinkling and drooping of older leaves was observed.

- Severely infected plants did not develop flower-buds, resulting in severe losses in seed production.

Transmission: Onion yellow dwarf virus is transmitted in fields byAphis craccivora Koch, A. gossypi Glover and Myzus persicae Sulzer, and Rymovirus transmission is by mites.

Virus diagnosis: Presence of viruses is detected as follows.

(a) Electron microscopic investigations were conducted to determine the cause of the disease.

(b) Immunosorbent electron microscopy was used for presence of virus in leaf tissue. Leaf-dip preparations were made and stained with uranyl acetate.

Management: The mixed infection is controlled as follows.

(a) Seed-crop should be grown away from the main crop to avoid infection of the main crop by aphid and mite vectors.

(b) Mother-bulb for seed crop should be harvested from healthy plants.

(c) Indexing for the presence of viruses in the mother-bulb should be done.

(d) Roguing infected-plants from seed-crop to reduce source of virus inoculum and to prevent further spread of virus.

(e) Control aphid vector by spraying systemic insecticides like Carbosulfan (Marshal) $1.5 \mathrm{ml} / \mathrm{litre}$, Asataf (Acephate) (1.5 g/litre) for 4-5 times at 10 days interval. 
(f) Mite vector can be managed by spraying Acaricides like Kelthane (Dicofol) $2 \mathrm{ml} /$ litre, Omite (Propargite) $2 \mathrm{ml} / \mathrm{litre}$ and Karathane (Dinocap) $1 \mathrm{ml} / \mathrm{litre}$ once in 5-7 days interval.

\section{References}

Ahlawat Y S and VarmaA. 1997. Serological detection of mixed viral infection in onion seed crop and possible measure for its management. Indian Phytopathology 50: 137-40.

Dhingra K L and Nariani T K. 1963. A virus disease of onion. Indian Phytopathology 16: 311-12.

Hall J M, Mohan K, Knott E A and Moyer J W. 1993. Tospoviruses associated with scape blight of onion (Allium cepa) seed crops in Idaho. Plant Disease 77: 952.

Hoa N V, Ahlawat Y S and Pant R P. 2003. Partial characterization of OYDV from onion in India. Indian Phytopathology 56: 276-82.

Kumar A N, Lakshmi-Narasu M, Zehr U B and Ravi K S. 2006 Natural occurrence and distribution of Tobacco streak virus in South India. Indian Journal of Plant Protection 34: 54-58.

Kumar N K K and Rawal R D. 1999. Onion thrips, Thrips tabaci, a vector of onion tospovirus. Insect Environment 5: 52.

Meena R L, Ramasubramanian T, Venkatesan S and Mohankumar S. 2005. Molecular characterization of Tospovirus transmitting thrips population from India. American Journal of Biochemistry and Biotechnology 1: 167-72.

Meenakshi Arya, Baranwal V K, Ahlawat Y S and Lokendra Singh. 2006. RT-PCR detection and molecular characterization of onion yellow dwarf virus associated with garlic and onion. Current Science 91: 1230-34.

Melhus I E, Reddy C S, Henderson W J and Vestal E. 1929. A new virus disease epidemic on onion. Phytopathology 19: 73-77.

Pappu H R, Hellier B C and Dugan F M. 2006. Wild Allium spp. as natural hosts of iris yellow spot virus. Plant Disease 90: 378.

Pawan Kumar and Dhawan Poonam. 2013. Biological and serological diagnosis of iris yellow spot virus in onion from Northern India. Annal of Agri-Bio Research 18: 48-54.

Rao Prasada J, Reddy D V R, Chander RaoAS, Thirumala Devi K, Kumar M V, Subramaniam K, Yellamanda Reddy T, Nigam S N and Reddy D V R. 2003. The host range of tobacco streak virus in India and transmission by thrips. Annals of Applied Biology 142: 365-68.

Ravi K S, Kitkaru AS and Winter S. 2006. Iris yellow spot virus in onions: A new tospovirus record from India. Plant Pathology 55: 288.

Reddy D V R. 1991. Groundnut viruses and virus diseases; distribution, identification and control. Review Plant Pathology 70: 665-78.

Sandeep Kumar, Baranwal V K, Joshi Subodh, Meenakshi Arya and Majumder S. 2010. Simultaneous detection of mixed infection of onion yellow dwarf virus and an Allexivirus in RT-PCR for ensuring virus free onion bulbs. Indian Journal of Virology 21: 64-68.

Sivaprasad Y, Bhaskara Reddy B V, Rekha Rani K, Raja Reddy K and Sai Gopal D VR. 2010. First report of tobacco streak Ilarvirus infecting onion (Allium cepa). New Disease Reports 22: 17.

Sujitha A, Bhaskara Reddy B V, Sivaprasad Y, Usha R and Sai Gopal D V R. 2012. First report of groundnut bud necrosis virus infecting onion (Allium cepa). Australasian Plant Disease Notes 7: 183-87.

Tate. 1940. Iowa St. Coll. Journal of Science 14: 267.

Van Dijk P. 1993. Survey and characterization of potyviruses and their strains of Allium species. Netherlands Journal of Plant Pathology 99: 1-48. 


\title{
Insect and Nematode Pests
}

\author{
P. S. Srinivas and N. K. Krishna Kumar
}

Several insect-pests cause serious damage to onion leaves, bulbs, flowers and developing seeds. In addition, mites and nematodes are also known to cause considerable damage and yield loss to the onion. Around 10 to $25 \%$ of world's onion production loss is due to pests (Soni and Ellis, 1990). Pests, like onion thrips, are cosmopolitan and distributed worldwide. Onion-fly is more of a specialized type of pest; and other lepidopteran pests invade onion-crop sporadically and feed on the leaves. Nematodes are soil-borne and slow moving; they have been reported to have reduced onion-bulb yield significantly in many countries. In this chapter, major insect- and non-insect pests that infest onioncrop and their management have been discussed (Table 14.1; Figs 14.1, 14.2).

Table 14.1 Pests of onion-crop in India and other parts of the world

\begin{tabular}{|c|c|c|}
\hline Pest & Scientific name & Taxonomy \\
\hline \multicolumn{3}{|c|}{ Leaf-feeding insect-pests } \\
\hline Thrips & $\begin{array}{l}\text { Thrips tabaci } \\
\text { Frankliniella occidentalis }\end{array}$ & Thysanoptera: Thripidae \\
\hline Leaf miner & $\begin{array}{l}\text { Liriomyza trifoli } \\
\text { L.sativae } \\
\text { L. nietzkei }\end{array}$ & Agromyzidae: Diptera \\
\hline Aster leafhopper & Macrosteles quadrilineatus & Hemiptera: Cicadellidae \\
\hline Psyllid & Bactericera tremblayi & Psyllidae: Hemiptera \\
\hline Beet army worm & Spodoptera exigua & Noctuidae: Lepidoptera \\
\hline Cut worm & Agrotis ipsilon & Noctuidae: Lepidoptera \\
\hline Gram borer & Helicoverpa armigera Hubner & Noctuidae: Lepidoptera \\
\hline Red spidermite & Tetranychus urticae & Acari: Tetranychidae \\
\hline \multicolumn{3}{|c|}{ Insect-pests infesting bulb } \\
\hline Onion maggot & $\begin{array}{l}\text { Delia antique } \\
\text { D.platura }\end{array}$ & Anthomyiidae: Diptera \\
\hline Bulb mite & $\begin{array}{l}\text { Rhizoglyphus robini } \\
\text { R. setosus } \\
\text { Tyrophagus sp. }\end{array}$ & Acaridae: Acari \\
\hline \multicolumn{3}{|l|}{ Nematode pests } \\
\hline Stem and bulb nematode & Ditylenchus dipsaci & Tylenchida: Anguinidae \\
\hline Root knot nematode & $\begin{array}{l}\text { Meloidogye incognita } \\
\text { M. hapla }\end{array}$ & Tylenchida: Heteroderidae \\
\hline Needle nematode & Longidorus elongatus & Dorylaimidae: Longidoridae \\
\hline Root lesion nematode & Pratylenchus penetrans & Tylenchida: Pratylenchidae \\
\hline Stubby root nematode & $\begin{array}{l}\text { Paratrichodorus allius } \\
\text { P. minor }\end{array}$ & Triplonchida: Trichodoridae \\
\hline
\end{tabular}




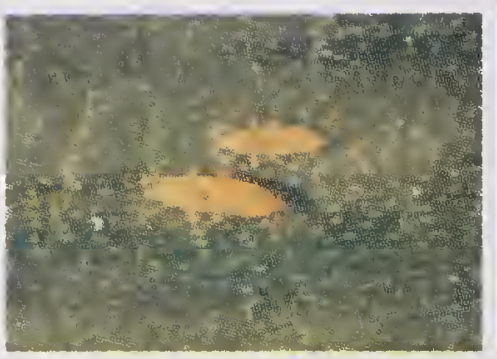

Early instars of Thrips tabaci

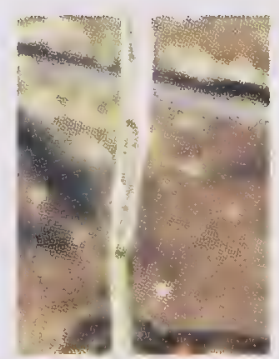

Helicoverpa armigera feeding inside a flower-stalk

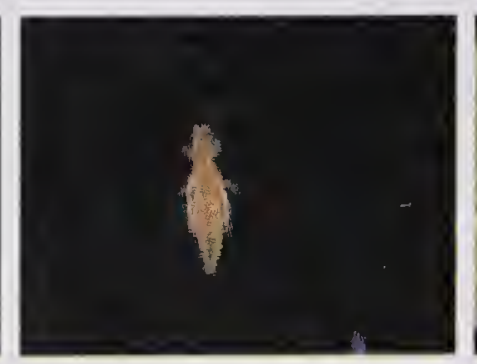

Pupa of T. tabaci

Pre-pupa of T. tabaci

Fig. 14.1 Onion pests

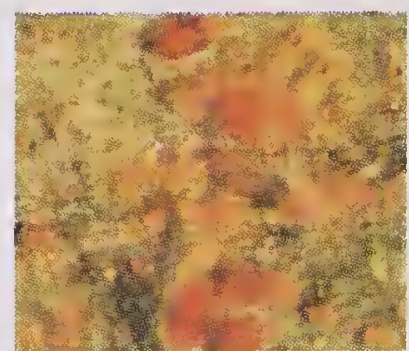

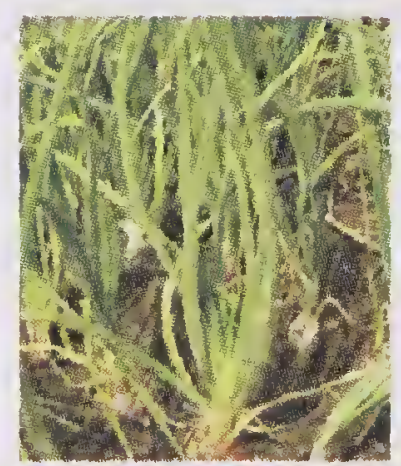

Thrips damage on the plant

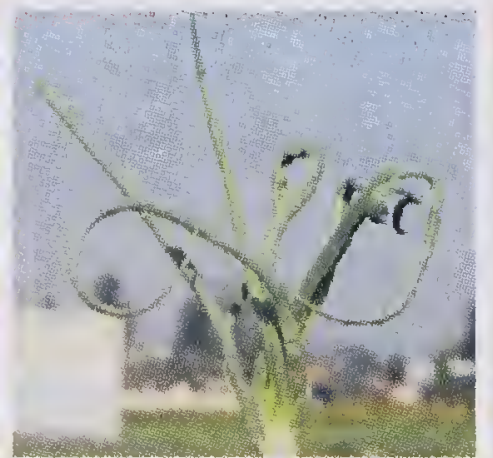

Curling and twisting of onion-leaves due to thrips attack

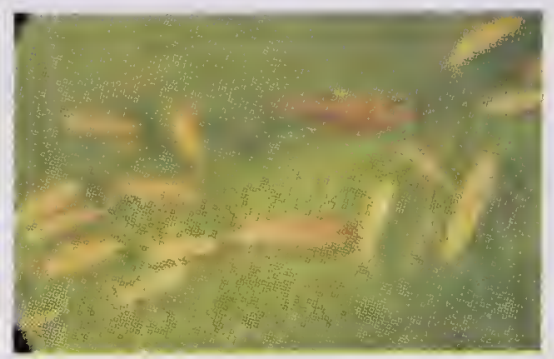

T. tabaci-nymphs and adults
Red spidermite colony on onion

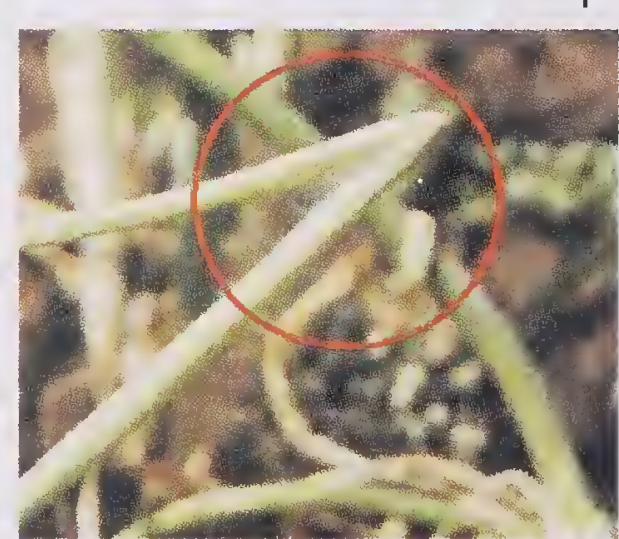

Webbing white specs on onion-leaves by red spidermite

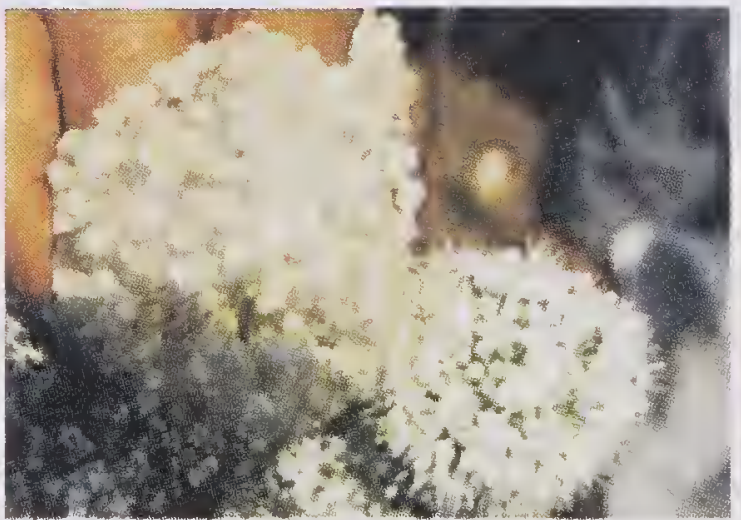

Webbing of umbel by red spidermite

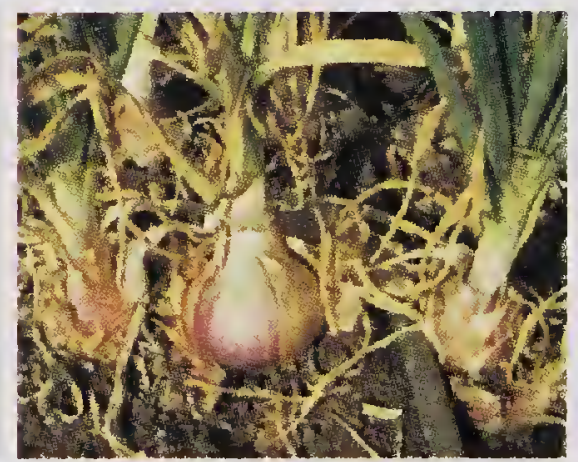

Thrips damage on bulbs in the field

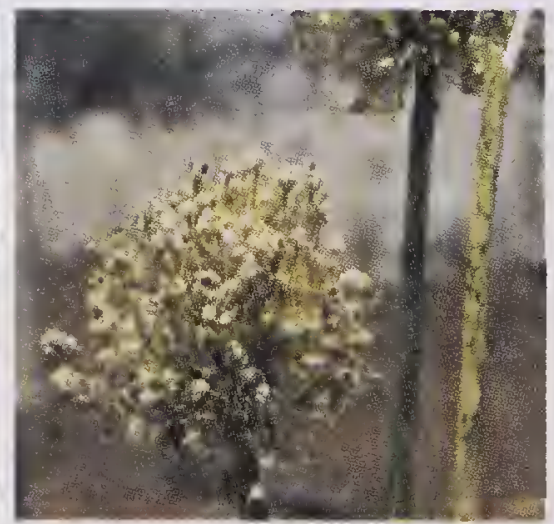

Helicoverpa damage to umbles and flower-stalk

Fig. 14.2 Symptoms of different pests

\section{Thrips}

Thrips are minute, soft-bodied insects with fringed wings belonging to order Thysanoptera. A total of 5,500 thrips species identified, so far, are distributed in 8 families belonging to 2 suborders. Many pests of Thysanoptera are members of family Thripidae, a group of 1,700 species worldwide. Thrips cause damage with their piercing and sucking mouth parts through direct feeding or by many indirect means as vectors.

\section{Onion thrips}

Only $1 \%$ of the total thrip species act as crop pests. Onion thrips, Thrips tabaci, is an important pest found in different parts of the world. Thrips feed on leaves and flowers and cause quantitative damage, while on bulbs damage is mostly qualitative 
in nature. This most diversified group of insect-pest differs greatly between crops and geographical areas. Apart from T. tabaci, another species, Frankliniella occidentalis, has also been reported on onion-crop in many countries. In India, only T. tabaci is predominant in all onion-growing areas (Srinivas et al., 2011c).

Thrips damage plants through not only feeding and by oviposition, but they have a great ability to act as vectors, particularly tospoviruses. Of more than 5,500 species of thrips, it is a interesting fact to note that only 10 species act as a vector. Recent studies have proved $T$. tabaci a non-vector of tomato spotted wilt virus (TSWV); it was earlier considered its vector. It transmits effectively other viruses; the most recent one is onion Iris yellow spot virus, which is spreading worldwide on the crop. Transmission is successful only when first or early second instar larva of thrips acquire virus; adults cannot acquire and transmit tospoviruses.

Apart from acting as a virus vector, thrips are known to be associated with the spread of fungal diseases. Population of onion thrips, T. tabaci, is positively correlated with purple-blotch disease, caused by Alterneria porri (Thind and Jhooty, 1982; Bhangale and Joi, 1983). In general, A. porri infection is more on the older leaves but shifts to younger leaves in the presence of thrips injury. $A$. porri enters leaf tissue through stomata or directly through epidermal cell layer. Leaf tissue turns more necrotic when thrips and purple-blotch occur simultaneously. A. porri uses thrips damaged tissues as alternative penetration sites and the disease aggravates (Mc Kenzie et al., 1993). Thrips also increase Botrytis allii infection in storage (Mayer et al., 1987).

Damage and symptoms: It was earlier believed that thrips feed by rasping and sucking mouth parts but lately this has been proved wrong. Recent studies have suggested their mouth parts of piercing and sucking type. Adults and larvae puncture food substrate (leaves, flowers and bulbs) and suck the sap. Some of the common symptoms caused by thrips are curling, twisting, silvering of leaves, drying of flowers and scarring of bulbs. Onion thrips congregate at the innermost leaves. As the leaf grows, silver blotches are more visible and shine in the sun light. Under severe infestation, whole plant turns white. A highly infected onionplant harbours more than 600 thrips. High infestation sometimes kills the seedlings. Bulb yield losses can be as high as $50 \%$ during rabi season.

T. tabaci is a polyphagous pest and survives on many vegetable crops and flower-plants but its most preferred crops are onion, garlic, leek and cabbage. It overwinters as the adult and lays eggs when suitable temperature is reached (Lewis, 1973). Volunteer plants, weeds like Amaranthus hybridis and Chenopodium album, and soil are important overwintering sites for thrips (Larentzaki et al., 2007). In India, off-season survival of thrips was observed on cotton, brinjal, bottlegourd, bhindi and sunhemp (Lall and Singh, 1960).

Thrips also cause damage to onion-bulbs; the damage starts in the field itself, and they are carried to storage with bulbs. They continue feeding but do not multiply in bulbs. They penetrate into inner scales but not beyond $3^{\text {rd }}$ scale. The damage affects bulb quality in storage. Though the damage is cosmetic, it may reduce onion export especially in countries like New Zealand.

Biology and life-cycle: Thrips measure about 1-2 $\mathrm{mm}$ in length, and are with dorso-ventrally flattened bodies, which help them hide under small-and-tight 
spaces. The colour of the adult may be pale or black, depending on the temperature; high temperature results in darker colour. Thrips complete their life-cycle by passing through egg, two larval, prepupa, pupa and adult stages. Their different stages occupy different niches - an adult female lays 50 to 80 eggs inside the leaf tissue, which are not visible; nymphs and adults are seen on the plants and pupal stage occurs in soil or plant debris. Their life-cycle completes in 13-24 days, depending on the temperature, the shortest was at around $30^{\circ} \mathrm{C}$ (Lall and Singh, 1960). Males are rare; and females lay eggs parthenogenetically. In onion thrip, thelytoky (female produced from unfertilized egg) is the predominant mode of reproduction, and the other two are, arrhenotoky (male produced from unfertilized egg and female produced from fertilized egg) and deuterotoky (female and male produced from unfertilized egg).

Weather and thrips: Knowledge about pest-host-plant relationship and their interaction with other biotic and abiotic factors would help in understanding pest abundance as well as population dynamics to decide strategies for effective management programmes. Generally, it is considered that thrips population increase during hot and dry climates. Many workers across the world studied relationship between weather factors like maximum and minimum temperature, mean temperature, morning $\mathrm{RH}$, evening $\mathrm{RH}$, rainfall, evaporation rate, sunshine hours and wind velocity with thrips populations on onions and other host-crops (Panickar and Patel, 2001; Duraimurugan and Jagadish, 2002; Gahukar, 2003; Chhatrola et al., 2003). Dry weather $(30.3 \mathrm{~mm}$ rainfall) with moderately high temperature $\left(15.6-28.2^{\circ} \mathrm{C}\right)$ increased number of thrips, while wet season (391$\mathrm{mm}$ rainfall) with moderately high relative humidity was negatively correlated with thrips number (Waiganjo et al., 2008).

Temperature, rainfall, relative humidity and wind have been reported as important factors affecting number of thrips (Kirk, 1997). Maximum temperature showed positive (Hamdy and Salem, 1994), negative or no (El-Gendi 1998) correlation with thrips populations. Heavy rains proved to be detrimental as thrips were washed off the plants. Relative humidity and rainfall were negatively related to thrips population (Waiganjo et al., 2007). Thrips multiplication was high during hot and dry years as more generations were produced, and there was decrease in mortality rate due to no rains. In Maharashtra, two population peaks occurred (Fig.14.3) - a smaller one in kharif during August and the large one in rabi during January-February (Srinivas and Lawande, 2004). Hot and relatively dry climate that prevails during January-February conditions are ideal for thrips to reach to harmful proportions in a short span of time (Table 14.2). Due to these factors, geographical variations were evident in population fluctuations, abundance and time of population peaks (Hayder and Sheriff, 1990; Torres et al., 1994; Gonclaves, 1997; El-Gendi, 1998).

In T. tabaci, $63 \%$ of the total variation in flight capture of adults was explained by degree-days, number of rainy days and total precipitation. A commonly used model for predicting effects of weather factors on thrips is degree-day model. This model was developed to predict development in the field (Edelson, 1988). During low and fluctuating temperatures, development took 228.2 day-degrees against 191.1 day-degrees at high temperatures. 


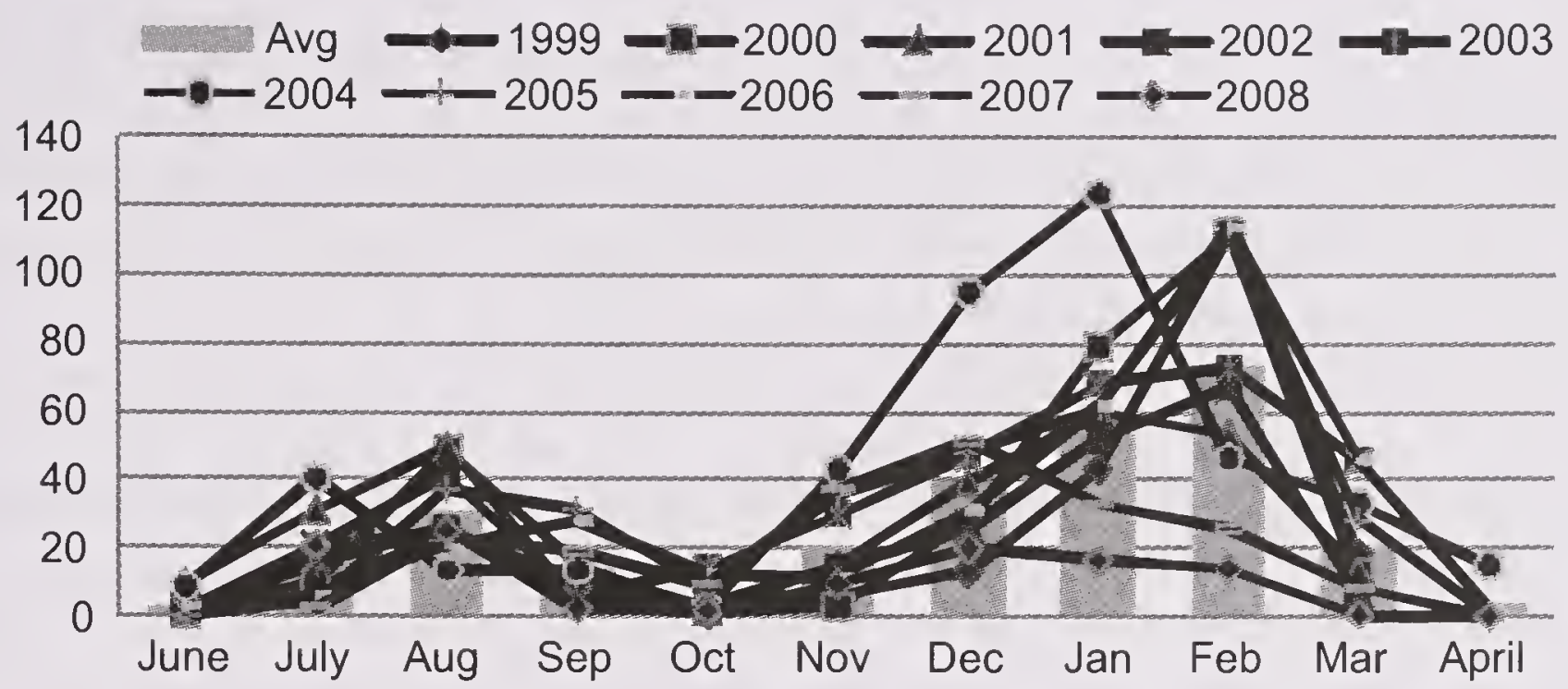

Fig. 14.3 Seasonal incidence of onion thrips at Rajgurunagar, Maharashtra

In India, prediction models were developed using regression analysis. The results varied, and were mostly derived from a very few years' data. A forewarning system for $T$. tabaci based mainly on the temperature sums was developed in Belgium that claims to be reliable in leek. Mathematics models may help understand host-pest relation and may be used as prediction tools in decision support system. Using these models, thrips population prediction was attempted in glasshouse chrysanthemum. A GIS-based modelling developed in the Netherlands suggested that population dynamics of $T$. tabaci was dependent on the interplay of different sources at small or large scale but not totally on weather and susceptibility of the crop (Anonymous, 1978). In Cuba, a logarithmic model, which was based on phenology and climatic variables, estimated efficiently population densities of thrips in garlic (Cortinus Abrahantes et al., 2003). In India,

Table 14.2 Thrips abundance and impact of planting dates in different parts of India

\begin{tabular}{|c|c|c|c|c|}
\hline Location & $\begin{array}{c}\text { Occurrence } \\
\text { of thrips } \\
\text { (Standard weeks) }\end{array}$ & $\begin{array}{c}\text { Peak } \\
\text { occurrence } \\
\text { (Standard weeks) }\end{array}$ & $\begin{array}{c}\text { Planting date } \\
\text { with higher } \\
\text { infestation } \\
\text { of thrips }\end{array}$ & $\begin{array}{l}\text { Thrips number/ } \\
\text { plant under } \\
\text { different dates } \\
\text { of planting }\end{array}$ \\
\hline \multicolumn{5}{|l|}{ North } \\
\hline Srinagar & $15-30$ & $24-25$ & 15-Dec & $11.1-18.7$ \\
\hline Durgapura & - & - & 01-Jan & $4.2-24.3$ \\
\hline Kanpur & $46-19$ & 10 & 15-Jan & $8.5-27.3$ \\
\hline \multicolumn{5}{|l|}{ East } \\
\hline Samastipur & - & - & 15-Dec & $21.1-32.6$ \\
\hline Imphal & $40-13$ & 6 & Nov & $16.2-21.2$ \\
\hline Chiplima & $37-15$ & 11 & 01-Dec & $3.4-40.0$ \\
\hline \multicolumn{5}{|l|}{ Central } \\
\hline $\begin{array}{l}\text { Jabalpur } \\
\text { West }\end{array}$ & $28-05$ & Dec & $150 \mathrm{ct} / 1 \mathrm{Nov}$ & $2.6-34.0$ \\
\hline Junagarh & $40-06$ & 3 & 01-Nov & $7.2-25.5$ \\
\hline Rajgurunagar & $33-14$ & 7 & 15Nov/1 Dec & $3.2-64.2$ \\
\hline \multicolumn{5}{|l|}{ South } \\
\hline Coimbatore & $25-04$ & 44 & 01-Dec & $4.6-28.1$ \\
\hline Dharwad & $25-14$ & 32,12 & Nov-Dec & $25.5-54.2$ \\
\hline
\end{tabular}


statistical models based on weather indices and through artificial neural networks forecasting models, developed by the Directorate of Onion and Garlic Research (DOGR), Pune, and the Indian Agricultural Statistics Research Institute (IASRI), New Delhi, are used for forecasting first appearance of thrips, time (crop age) of peak population and maximum population of thrips.

Climate change and impact: Significant predictable changes are projected for temperature and $\mathrm{CO}_{2}$. Insects being cold blooded in nature, temperature would have a direct and maximum impact on their development, survival and number of generations. Developmental dynamics of onion thrips depends strongly on temperature thresholds, which are usually represented in the models as degreedays. Potential climatic change would affect temperature, and thus the development of onion thrips. Through simple degree-day models, it has been demonstrated that expected increases in temperature would result in faster development of thrips, and there would be more number of generations in a year (Bergant et al., 2003).

In countries like Slovenia, it is expected to have larger increase in degreedays, and thus more number of generations with warmer climate. As a result, damage would probably be more in areas that are exposed more to thrips (Klemen Bergant et al., 2005). There is a chance of change in sex ratio between the male and the female. At the same time, changes that are taking place in host-plant and nutritional quality may also indirectly affect the pest. Climate change is a longterm process, and therefore, adaptations in both plants and in thrips need to be considered.

Integrated management: Monitoring and scouting of thrips is of prime importance to initiate programmes. Sticky traps with various colours and hues have been reported to be effective in attracting thrips of great geographical and species variations. The most commonly and widely used traps are yellow and bright blue in open as well as in greenhouse (Fernandez and Lucena, 1990; Diraviam and Uthamasamy, 1992; Cho et al., 1995). Even regular scouting is a must to identify invasions of new thrips species into a new locality. In recent times, some semio-chemicals are commercially available abroad with the trade names such as Thripline ${ }_{\text {ams }}{ }^{\mathrm{TM}}$ and Lurem-TR. These are not attracting T. tabaci but are effective in trapping to other thrips species (Broughton and Harrison, 2012). Lures with ethyl isonicotinate, methyl isonicotinate and ethyl nicotinate captured a number of thrips in white-water traps in an onion-crop in New Zealand (Davidson et al., 2009; Wogin et al., 2010).

In some countries, cumulative thrips days (CTD) are used to monitor abundance and damage of thrips in onion. Presence of thrips on an onion-plant is difficult to detect. Even damage caused by them becomes visible only with plant growth due to plant's cryptic habit and small size. The better way to detect them is to check randomly 20-25 plants, particularly at the inner most whorl of the leaves.

Cultural methods: Commonly practised cultural methods include time of planting, crop rotation, irrigation, fertilization, intercropping, clean management etc. In general, crop rotation is useful for thrips species surviving in the soil but it needs to be practised on larger areas. Peak flights of thrips in the cabbage fields were recorded during maturations and senescence (North and Shelton, 1986). Therefore, in onion-growing areas, care should be taken to avoid cabbage, cotton, 
garlic, celery, leek, beans and tomato crops in the vicinity. Thrips from the adjacent fields and old plantings of onion can migrate to new plantings. By planting new crop in upwind direction to old ones may slow down thrips migrations to a great extent. Crop rotation as such has little impact as migrations and infestations are from external sources. Deep ploughing destroys soil-dwelling stages, like pupae and overwintering adults. Top 2-cm soil bears more thrips, and they are negligible at 8-10 cm (Deligeorgidis and Ipsilandis, 2004).

Planting date can also have a significant effect on thrips damage. Dramatic impact on thrips densities and amount of damage thrips cause was noticed with the planting date (Stoner and Shelten, 1988). In onion, plantings in the month of September and October were less prone to thrips, whereas November plantings were more prone to thrips (Srinivas and Lawande, 2004). Well established crops can withstand thrips density and damage; so early plantings are desirable (Table 14.2).

Thrips survive on many weeds as they have a wide host range, which act as a green bridge between seasons. Many of the weeds harbour viruses also, and $T$. tabaci is a potential virus vector for diseases like Iris yellow spot.

Intercropping helps reduce thrips abundance on many vegetable crops compared to monocropping. In Kenya, coriander, maize and marigold as intercrops reduced thrips population on Frenchbean (Kasina et al., 2006). In Egypt, intercropping onion and garlic with tomato reduced infestation of T. tabaci by $80 \%$ but with declined yields (Afifi and Hayder, 1990). Infestation of T. tabaci on onion was reduced to half in England when it was grown with carrots (Uvah and Coaker, 1984). This was attributed to masking of onion by carrot foliage. Thrips were low on onions with companion crops, like Rasmarinus and Ocimum sanctum (Cabrera Asencio and Velez, 2006).

Wind plays a major role in spread of adult thrips from one location to other. Therefore, live-barriers around onion fields may block thrips. Maize and wheat as a live-barrier in two rows effectively blocked adult thrips by $80 \%$ and decreased nymphal population, besides reducing pesticide use to half on the onion-crop (Srinivas and Lawande, 2006). Care should be taken to avoid long maize varieties, as this would impose shading effect and reduce onion bulb yield.

In onions, reflective silver mulch repelled adult thrips but only during early stages of the crop growth. Shadow caused by fully grown plants reduced effect of reflection later in the season. In seed-crop, bulb rotting occurs when plastic mulches are used. Aluminium painted (Scott et al., 1989) reflective mulch repelled 33$68 \%$ of thrips, and was found very effective at the seedling stage than at the mature plant stage (Lu, 1990), but was not effective in New Zealand (Toor et al., 2004). Spreading of mulches is labour-intensive, and their disposal after use is of environmental concern. Organic mulches were also found effective in reducing thrips and increasing predatory ground beetles (Jenson, 2003; Larentzaki et al., 2008b). In India, application of FYM, vermi-compost and oil-cakes was effective in reducing thrips population in onions (Ali et al., 2002).

In onion, flood irrigation has been a common practice. At present, microirrigation systems, like drip and sprinklers, are gaining popularity. Overhead sprinkler irrigation systems simulate rains and wash-off thrips from onion-plants. 
While using drip system, soil should be kept moist for longer period; this would help reduce thrips damage. In addition, moist soil may be detrimental to pupal stages of thrips dwelling in the soil.

Host resistance: This plays a vital role in suppressing thrips to a safer level (Table 14.3). However, so far no variety with stable resistance exists in India. Among the released varieties Baswant 780 is found moderately resistant. Many sweet Spanish onion varieties were found resistant to T. tabaci (Davis et al., 1995). Resistant genotypes were also reported from Brazil (Loges et al., 2004), Iran (Alimousavi et al., 2007; Yousefi et al., 2011) and Pakistan (Muhammad Shakeel et al., 2006). Many germplasm sources were also reported as resistant to thrips in India (Anitha et al., 2011). Some of the wild species, A. gallanthum, A. ampeloprasum, and some accessions of $A$. fistulosum showed resistance to thrips (Srinivas et al., 2007). But bottlenecks in breeding with cultivated A. cepa are discouraging their use. Crosses with wild species often gave sterile plants. However, advanced breeding and molecular techniques may help removing these hurdles. Understanding resistance mechanism of thrips would also give proper direction for selection of physical or biochemical property associated with the resistance. Genotypes with wide angled leaves and open types are less prone to thrips. Genotypes with glossy foliage were resistant to thrips, while non-glossy ones were susceptible (Alimousavi et al., 2007; Molenaar, 1984). It is also believed that white onions are relatively resistant than red, while yellow are intermittent, yet with no clear-cut evidence.

Table 14.3 Some of the resistant sources identified for thrips in onion

Meshkat, Sefid-e-Kurdistan, Sefid-e-Qom, Eghlid.

Giza 6, Giza 20

Valeouro, IPA11, Roxa IPA3, Belem IPA9, Texas

Grano 502, Brownville, Daquesa

Chiltan89, Phulkara, Sariab red, Swal1

544, Kalyanpur Red round, Udaipur 103, N 53

N 2-4-1, Sello 04Ratnar, Sel 71, Hissar brown, Sel 202

Pusa Red, N 53

Sefid-e-Kashan, Sefid-e-Qom, Sefid-e- Khomein
Alimousava et al., 2007

El Khayat et al., 1997

Loges et al., 2004

Muhammad Shakeel et al., 2006

Pawar et al., 1987

Darshan Singh et al., 1986

Sinha et al., 1993

Youseffi et al., 2011

Protease inhibitors have shown significant effects on oviposition rate restricting build-up of thrips population. Therefore, the concept of enhancing cystein protease inhibition activity may be utilized through suitable approaches in species like $F$. occidentalis, where cystein proteases are more prodominent.

Biological control: This was successful against T. tabaci under greenhouse conditions. In fields, not much control was observed, even though, 90 predators, parasites and pathogen, have been listed worldwide (Waterhouse and Norris, 1989). Most commonly reported predators in greenhouses belong to mirid bug, Orius sp., and predatory mite Amblyseius; and entomopathogens, fungi, Verticillium, Metarrhizium and Beauveria; nematodes, Steinernema feltiae Thripinema and Heterorhabditis.

In many cases, predators were found active in protected cultivation. They consumed 23.2-96 thrips per day (Saxena, 1981). However, in the open fields, 


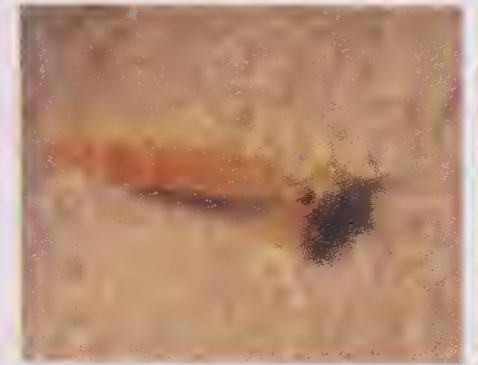

Predatory thrips, Aeolothrips sp

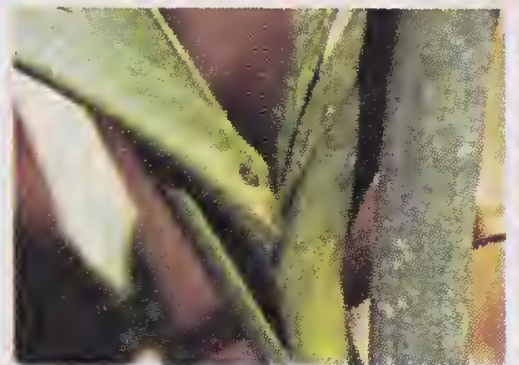

Mirid bug, Orius tantillus

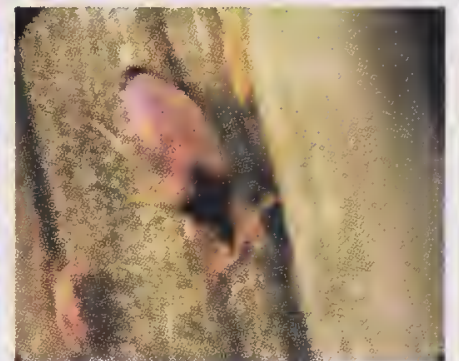

Mirid bug, Orius tantillus predating T. tabaci

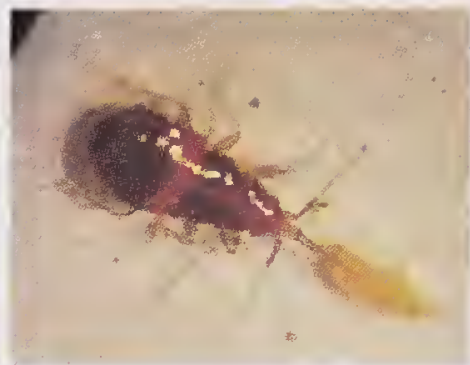

Orius nymph predating $T$. tabaci

Fig.14.4 Predators of onion thrips

their incidence was very low. The main parasitoid on T. tabaci was endoparasitoid wasp (Loomans, 1995). One such parasite recorded in India, Ceranisus menes Walker, showed very low incidence in fields but was effective in Japan with 34\% parasitism (Sakimura, 1937; cited by Kirk, 1997). Thrips escape from natural enemies by hiding in the inner whorl leaves. Predatory mite, Amblyseius, controlled thrips in the greenhouses but not in open fields. In India, Orius tantillus occurs naturally on onion thrips. It is a good predator on thrips (Fig. 14.4). But because of its poor reproductive potential, field releases on a large scale may not be possible with this bug. It is commonly noticed feeding on sunflower-heads. Therefore, raising sunflower plants near onion fields helps augmenting these predators in the onion ecosystem. In Maharashtra, Orius population increased only in February and March, and by that time thrips number declined. Another mirid bug, Blaptostethus, also proved effective under laboratory and caged released conditions, but could not be established in fields. Maize pollen also supports Blaptostethus. A predatory thrips, Aelothrips mongolicus Pelikan was recorded on T. tabaci in onion fields in Maharashtra (Satya Srinivas et al., 2011c).

Under laboratory conditions, mortality of $T$. tabaci was more with entomopathogens, like Metarrhizium anisopliae, Paecilomyces fumosoroseus and Verticillium lecani (Bradley et al., 1998; Kubota, 1999). M. anisopliae was reported to be effective in fields also (Ganga Visalakshi and Krishna Moorthy, 2012). Beauveria bassiana caused highest mortality at $26^{\circ} \mathrm{C}$ and $75 \% \mathrm{RH}$ (Murphy et al., 1998). However, such high level of humidity seldom occur in fields for a longer period during rabi; hence cannot be employed as a stand-alone method. $V$. lecani and $B$. bassiana reduced thrips up to $35 \%$ in fields.

Entomopathogens in combination with entomopathogenic nematode, Steinernema feltia, was evaluated against onion thrips (Elad et al., 2004). For entomopathogenic nematode, T. tabaci was also a suitable host with equal reproduction rate for Thripinema nicklewoodi Siddiqi, which is an obligate parasite of F. occidentalis Pergande, (Un Taek Lim and Van Driesche, 2005). Soil application of Heterorhabditis indicus caused $70 \%$ mortality in T. tabaci (AlSiyabi et al., 2006).

In fields, bringing in plant diversity by using cover crops like buckwheat and sunflower that bloom most of the growing season would support large number of predators and enhance their population; as was done in California vineyards. Use of biological control for thrips is still far from reality where potential viruses are associated with the crop. 
Alternative to insecticides: Most widely used alternatives for insecticides are botanicals that are considered safer to environment, and result in pesticide-residuefree produce. Among them, neem has gained much popularity in many IPM programmes.

Even though some studies have shown that neem stops development of early instars of thrips (Klein et al., 1993), many of the Azadirachtin-based formulations could not suppress T. tabaci populations to the desired level in onion fields. Neem, Karanj and Annona proved inferior to insecticides in reducing thrips (Gupta and Sharma, 1998; Altaf Hussain et al., 1999; Srinivas and Lawande, 2000a). Plant extracts of eucalyptus and other in-situ growth regulators did not prove effective against thrips and were not economically viable (Sujay Pandey et al., 2012). Sole application of mineral oil sprays @ 2.0\% reduced thrips population up to 48\% only. But their efficacy improved when mixed with insecticides like Profenofos and Carbosulfan even at half the dose. A non-chemical, kaolin-particle film reduced oviposition of thrips and increased their mortality in laboratory (Larentzaki et al., 2008a).

Chemical control: Use of chemical insecticides still remains the sole and dependable method of thrips control, particularly in warm regions. Different insecticides belonging to organophosphate, carbamate and pyrethroid groups are widely used for pest control.

In India, onions are planted in a staggered manner till the month of January. Therefore, late planting in rabi (winter) season, results in poor establishment of the crop owing to high attack of thrips. Seedling root-dip with Carbosulfan $(0.025 \%)$ or Imidacloprid $(0.04 \%)$ solution for $2 \mathrm{~h}$ before planting protects young plants up to 30 days (Srinivas and Lawande, 2007). Economic threshold levels (ETLs) in many locations ranged as low as 1 to 35 thrips/plant (Shelton et al., 1987; Fournier et al., 1995; Srinivas and Lawande, 2000b; Rueda et al., 2007). It depends largely on location, season, input costs and market price of bulbs; hence, it is not possible to have one prescribed ETL across all situations. Thrips control is critical during bulb initiation stage, beginning with the seventh week after planting. Farmers had highest benefit : cost ratio when insecticides were sprayed on 45-75 days old crop (Srinivas et al., 2008).

Many of conventional insecticides vary in their efficacy due to long-term and indiscriminate use. With reduced effectiveness of insecticides, growers often are forced to increase spray frequency. Farmers in Indonesia, spray insecticides up to 16 times to control thrips on chilli, onion and potato throughout the growing season (Sastrosiswojo, 1991). Same is the case in the Philippines with Carbamate compounds (Bernardo, 1991). Insecticides like Lambda Cyhalothrin, Imidacloprid, Abamectin, Spinosad, Thiamethoxam, Fipronil, Clothianidin are found promising in minimizing thrips population (Gupta et al., 2002;Zezlina and Blazic, 2003; Sule et al.; 2008). As on today, in India, only two insecticides, Dimethoate and Lambda Cyhalothrin are registered for use against onion thrips. In most of the western countries, Lambda Cyhalothrin and Methomyl are extensively used (Shelton et al., 2003; Allen et al., 2005). Others like Spinosad and Acetamiprid are also used on a large scale. Use of Spinosad and Acibenzolar-S-Methyl was suggested in Italy (Mautino et al., 2012). 
Thrips insert eggs into plant tissues while prepupal and pupal stages occur in soil or plant debris; only nymph and adults are visible on plants. Whenever foliar sprays are given, larvae and adults are exposed and killed, but other stages escape. This results in re-infestation of thrips soon from freshly hatched eggs or newly emerged adults. High volume sprays with good pressure would reach the base of the leaves where majority of the thrips feed. Addition of a spreader to spray fluid is useful for retention and spread on erect leaves of onions. Onion-plants are more vulnerable to thrips at bulb initiation and development stage, foliar application at this stage gives better yields (Srinivas et al., 2008). Thrips management in seed-crop is more challenging. Foliar sprays even wash out pollen and prove fatal to bees.

Over reliance and frequent usage of pesticides cause intense selection pressure, and encourages development of resistant populations. Thrips resistance is reported for Deltamethrin in England and New Zealand (Stephen et al., 2010). Differential resistance of thrips against some insecticides under field conditions has also been reported (Davis et al., 1995; Gangloff, 1999). Lambda cyhalothrin had shown large temporal spatial variations in the susceptibility of thrips. No resistance was developed in thrips with Acetamaprid and Spinosad (Shelton et al., 2006). In Maharashtra, susceptibility of thrips was reduced to $40 \%$ against Cypermethrin in areas where its usage was more (Satya Srinivas et al., 2011a). It is always advisable to use insecticides belonging to different groups to reduce chances of development of resistance.

Pesticide residues and scope for organic farming: Onions are widely used as salad, besides being used for culinary preparations. Therefore, pesticide residues are a threat to consumers and farmers as well. Bulbs should be free from harmful pesticides. Pyrethroids like Cypermethrin, Permethrin, Fenvalerate and organo phosphorus compounds, Fenitrothion, Methyl Demeton and Dimethoate left no residues on onion-bulbs (Sinha et al., 1992). Monocrotophos residues on onionleaves and bulbs reached undetectable levels in 15-20 days after application. A minimum waiting period of 14-20 days for onion-tops and 6-13 days for bulbs has been suggested (Srinivasan and Lingappa, 1986). Insecticide residues were found in onion-bulbs collected from different markets of Maharashtra, Gujarat, Andhra Pradesh and Tamil Nadu (Satya Srinivas et al., 2011b). Application of insecticides at the recommended doses up to 75 days after planting did not leave any residues on bulbs at harvest. Onion-tops are used as a vegetable in many parts of the country, and only Spinosad has been found safest to be sprayed 2 days pre-harvest (Satya Srinivas et al., 2012).

Organic farming is gaining importance in many crops, particularly those with export potential. With increased awareness of non-insecticide-based cultivation, the demand for such products is increasing, particularly among the urban population. Growing onions in an organic way is a big challenge in warm countries, including India. Biological and cultural controls as well as sprays of Spinosad are acceptable for use on organically certified crops. In India, thrips were managed on a special type of onion called rose onion that is grown organically with manures and neem seed kernel extract (Krishna Kumar et al., 2008). Still some more 
alternatives should be available to growers to manage pests like thrips to take up onion cultivation organically.

\section{Onion fly (maggot)}

There are three important species-Delia antiqua, D. platura (seed-corn maggot or bean-seed fly) and D. allaria-in different parts of the world. Onion maggots infest onion-crop in cooler coastal climates, and heavy organic soils are ideal for them. In India, their incidence is not widespread and it is restricted to only a very few areas. Adults are small grey flies with hunch back. Onion fly completes several generations in a year. Female lays eggs in groups on the soil surface nearer to plants. Maggots are creamy-white. Seed-corn maggots are present during early stages of the crop growth and feed on the developing seedlings, and onion maggot infests at the later stage of crop, and feed on the developing bulbs. Pupation occurs in the soil.

It can cause losses up to $90 \%$ in the plant stand (Eckenrode et al., 1994). This is not a major pest in India. But, in Kargil district of Jammu and Kashmir, infestation up to 17.0-37.5\% was observed (Pandey and Namgayal, 2010).

D. antiqua lays 4-8 times more eggs on older plants. Temperature of $15^{\circ} \mathrm{C}$ and $\mathrm{RH}$ of $90 \%$ are ideal for egg-laying. Soil temperature of $20^{\circ} \mathrm{C}$ is more congenial for survival and development of eggs. Plant chemical, n-dipropyl disulphide, present in the onion attracts both mated and gravid females than males (Romeis and Ebbinghaus, 2003). D. antiqua prefers internal sections of the onion-bulbs for faster development and survival (Schneider et al., 1985).

Management: This pest can be monitored by erecting yellow sticky traps. Delayed onion planting reduces its damage by 35-95\%. Delaying planting up to mid-May reduced $D$. antiqua damage without affecting crop period (Nault et al., 2011).

Organic and animal manure applied to soil is allowed to be decomposed completely before crop sowing. Egg-laying of the fly increases with seedling density (Chiang and Perron, 1980). Integration of plant resistance and insecticide application was better alternative in situations where crop rotation is difficult (Walters and Eckenrode, 1996). Allium fistulosum was reported to be resistant to onion fly (Ellis et al., 1979). Resistant cultivars produce alkyl thio compounds while it is not so in susceptible cultivars (Ikeshoji et al., 1981). Plants with basal diameter of 1-4 mm and height of 100-350 $\mathrm{mm}$ had significantly lesser oviposition (Harris et al., 1987).

Seven insect species were confirmed as parasites on onion fly. Only Aphaereta pallipes (Family: Braconidae) and Aleochara bilineata (Family: Staphylinidae) caused mortality of onion fly (Tomlin et al., 1985) but performance was poor in the field. Grassy refuge stripes in onion-crop enhance ground beetle population which reduces maggot population. Adults were more prone to entomopathogens than maggots. Entomophthora muscae (Tu and Harris, 1988) and Metarrhizium anisopliae (Davidson and Chandler, 2005) were found effective in managing the pest. Entomopathogenic nematodes, Steinernema feltiae and Heterorhabditis, could cause 50-100\% mortality of D. antiqua (Choo et al., 1988; Ellis and Scatcherd, 2007). No biological agent has been found promising at the field level. 
Insecticide application in the soil or on the seed at the time of planting was very effective. Commonly registered insecticides in the USA for onion fly are Diazinon and chlorpyriphos. In-furrow application of granular formulations of Dichlorofenthion, Ethion, Carbofuran and Chlorfenvinfos or Chlorpyriphos or Pirimiphos Methyl or Deltamethrin (Ritcey and Mc Ewen 1984, Finch et al., 1986, Paulauskyte 1999) was used conventionally for its control. But susceptibility to these insecticides decreased by $45 \%$. Seed treatment is widely practised. New chemicals like Fipronil $80 \mathrm{WG}$ (25 g a.i./kg) and Cyromazine (50 g a.i./kg), an insect growth regulator, or Spinosad (25 g a.i./kg) and Clothianidin (50 g a.i. $/ \mathrm{kg}$ ) or Tefluthrin (Hoepting et al., 2000; Nault et al., 2006; Ellis and Scatcherd, 2007) are recommended as seed treatment. Film coating or pelleting of Cyromazine was very effective in reducing crop stand damage (Taylor et al., 2001). A strategy known as Stimulo-deterrent-diversion (SDD), where attractants and deterrents are used simultaneously, has been suggested along with soil insecticides that might reverse selection for physiological resistance of $D$. antiqua to insecticides (Miller and Cowles, 1991).

\section{Lepidopteran pests}

Beet armyworm, Spodoptera exigua and common armyworm, S. litura, are reported in Taiwan and India. In Guntur district of Andhra Pradesh, they were found active during November-February with peak activity in December and January (Rao and Subbaratnam, 1999). Leaves are eaten away, and sometimes larvae bore into cylindrical leaf. Sex pheromones are used for monitoring and disruption of mating in these pests by placing pheromone trap at 125 -cm height. Resistant varieties are not known, and research in this area is being carried out at the AVRDC, Taiwan, and elsewhere. Insecticides like Cypermethrin, Methomyl, Quinolphos, Acephate etc., are commonly used for their management.

Helicoverpa armigera occurs sporadically and infests the seed-crop. Larvae feed inside the flower-stalk and move on upwards, and feed on the developing seed at later stages. This results in complete drying of flowers and thus seed losses. Although no resistant varieties are available; Arka Niketan was least attacked in India (Brar et al., 1993). Sex pheromones can be used for monitoring. Ha NPV and Bacillus thuringiensis formulations can be used for killing larvae on the seed-crop.

Cutworm, Agrotis sp., is a localized pest in areas where sugarcane, potato and other related crops are grown. Eggs are laid on leaves. After hatching, larvae settle in soil. Cutworms attack seedlings in nursery and in the transplanted fields as well. Larvae hide in the soil and damage onion-plant at night. They feed on the plant at the ground level, and as a result plant gets cut-off at the ground level. A single larva can damage more plants. Early instars are yellowish-grey, which turn brown later on, greasy to touch, and larvae coil if disturbed. Incorporation of Carbofuran (1 kg a.i./ha) granules or Chlorpyriphos into the soil at the time of planting is recommended.

\section{Bulb mite}

Bulb mites (Rhizoglyphus robini Claparede, Tyrophagus sp.) attack bulbs of 
Allium sp. These tiny mites are shiny, creamy-white, $0.5-$ to $1-\mathrm{mm}$ long and are visible to naked eye. They occur in clusters under the root plate of onion bulb. Therefore, onion bulbs sown for seed purpose should be properly monitored. Mites are carried to storage also, and easily penetrate bulbs that are infected by Fusarium and multiply rapidly. They are attracted to alcohol released from fungus, $F$. oxysporum (Okabe and Amano 1990). Root plate of the infested plant detaches, leading to death of the plant.

$R$. setosus, has been reported in Taiwan. The mite enters the bulb through the neck and later penetrates to outer scales. Neck of the damaged bulb shows brown rotting and leaves appear abnormal. Damaged tissue hosts thousands of mites and eggs. Infected plants have a few roots and plant becomes stunted. Sometimes, mites aggregate on roots, causing collapse of the plant (Chen et al., 2002).

Management: Onion, garlic, species of Lilium and Gladiolus should not be grown in succession. Decaying cauliflower is a good source for bulb-mite multiplication. Use clean cloves for sowing. Drenching soil with dicofol at $2 \mathrm{ml} /$ litre is a better method of control. Even soil application of powdered sulphur is effective for 3-4 weeks (Kassab and Hafez, 1990). For stored bulbs, fumigation with methyl bromide @ $16 \mathrm{~g} / \mathrm{m}^{3}$ for $3 \mathrm{~h}$ or $10 \mathrm{~g} / \mathrm{m}^{3}$ for $6 \mathrm{~h}$ is recommended, and this practice did not affect germination (Perez et al., 1989). Use of methyl bromide is put under 'restricted use' for fumigation, so other options need to be explored.

\section{Red spidermite}

Tetranychid mite [Tetranychus cinnabarinus (urticae)] is found throughout the world on major food crops, like beans, okra, cucumber, amaranth, cassava, tomato, potato, chillies; fruits, like papaya and some flower-plants, like rose, chrysanthemum, gerbera, etc. This mite prefers garlic than onion but at maturity stage only. Mites develop colonies under webbing. Because of continuous feeding, small white specs develop on the leaves. Infestation can occur on both old and new leaves. In case of onion, along with foliage, flower-stalks are also infested. Fine silk webbing is spun around the umbel (Srinivas and Lawande, 2004a). Their population was found more in plots where synthetic pyrethroid, Cypermethrin was repeatedly applied.

Management: Miticides like Dicofol and Ethion are commonly applied to control this pest. Many insecticides or miticides were found effective against this pest on various crops, but have not been evaluated on onion. But reinfestation by it is faster as larval stages and eggs survive owing to protection by silk webs produced by mites. Even a thorough water spray during the initial stages of infestation washes off mites from the plant.

\section{Nematodes}

Nematodes are microscopic creatures that dwell in the soil and infest cropplants. They move very slowly and may move a few centimetres in a year. The most commonly found plant-parasitic nematodes in onion fields in many parts of the world are: Stem and bulb nematode, (Ditylenchus dipsaci), root-knot nematode (Meloidogyne sp.) and root lesion nematode (Pratylenchus penetrans). The most common symptoms associated with nematode infections are stunted plant growth, 
poor plant stand, yellowing of leaves, stem swelling and deformation of bulbs.

Stem and bulb nematode: This nematode is not reported from India but occurs in many parts of the world. Due to its infection, seedlings become stunted and turn pale. Yellowish-brown spots develop on leaves, and stems are swollen. Gradually neck and scales become soft and gray. Bulbs are malformed and lose weight. Infected bulbs emit characteristic foul smell due to fungal and bacterial invasion. The nematode is seed borne in nature and spread through onion sets; migrate through infected soil, water and farm machinery. A chemical attractant from onion root exudates with a molecular mass $<700 \mathrm{kDa}$ that was stable to heat and proteolytic enzymes was identified (Spiegel et al., 2003). Soil temperature around $20^{\circ} \mathrm{C}$ is favourable for nematode spread and development of symptoms.

Regulatory methods are the best to prevent this in newer areas. Soil and seed stock should be thoroughly inspected for its presence. Once the field is infected, it is better to go for long rotations and avoid growing host and related crops. Soil fumigation with methyl bromide is recommended. Hot-water treatment of onionbulbs at $43.5^{\circ} \mathrm{C}$ for $2 \mathrm{hr}$ is also suggested for its management. However, proper care should be taken, otherwise it may affect germination. Crop rotation with non-hosts like carrots, beet, crucifers, spinach etc. has proved effective.

Root-knot nematode: It infects many of the vegetable crops. Characteristic small galls can be found on the roots of the infected plants. The shape and size of galls vary with the species. Egg mass is many a time visible on the infected roots. Infected onion fields show poor crop stand, with stunted yellow plants. Three Meloidogyne spp.-M. incognita, $M$. javanica and $M$. arenari-are the most common species infecting onions. In direct-seeded onion-crop, $M$. incognita considerably reduced yields and economic returns. Transplanted onions did not suffer economic losses. This disease was found widespread in all onion-growing areas of Allahabad with an average incidence at $82.04 \%$ (Anamika et al., 2010). Temperature at $10-35^{\circ} \mathrm{C}$ is congenial for infection. This nematode spreads through infected bulbs, and in fields through irrigation water and farm implements.

Management: It is a soil-borne pest with a wide host range. Once infected, this pest cannot be easily controlled. Cultural method like crop rotation with non-host crops like wheat, maize and other grain crops offers a better control. In India, it was reported lately, hence strict measures like restricting soil movement through farm equipment and irrigation may prove promising. Seed material and soil needs to be tested for infection of this nematode before growing onioncrop, particularly in areas where it has been reported. Cover crops like Sudan grass and marigolds are used in some countries which showed negative effects on nematodes. Soil fumigation and nematicides like Oxamyl are recommended in many countries.

Lesion nematode: This results in stunting of plants and poor root development. Small, round to elongated yellow lesions develop on roots. The yellow lesions may turn dark brown as disease develops. Depending on the disease severity, infected plants will grow poorly, produce low yield and will show symptoms of water and nutrient deficiencies. Moderate soil moisture and temperatures (20$30^{\circ} \mathrm{C}$ ) favour growth and development. Crop rotation and field sanitation are better management practices to contain this pest. 


\section{Future Prospects}

IPM is an evolutionary process and already many effective thrips management practices have been developed in different crops. Biocontrol methods, which were not effective in the fields, were successful in greenhouses, particularly for cucumbers, sweet-peppers and chrysanthemums in temperate conditions. In India, no such success has been reported. Only promise in thrips control is through mirid bugs. Efforts shall be made to improve reproductive potential and rearing methods. Conservation of natural enemies in open fields and their enhancement by growing plants to which they attack or through habitat manipulations may help their establishment in the fields for a long term. More emphasis needs to be given on taxonomy and biosystematics of thrips in India. Molecular tools can be standardized to make species identification easier and error-free.

Development and incorporation of resistant cultivars in the IPM programmes for thrips control is still in its infancy; resistant varieties will play a vital role. In the absence of highly resistant sources, accessions with tolerance can be identified and developed so that frequency of insecticides use can be considerably reduced. Overcoming breeding hurdles in crossing with wild species will open a great source of resistance incorporation. Resistant varieties also gain significance in reducing tospoviruses. Search for sources of resistance should be increased with more focus on wild species where resistance is not found in existing germplasm.

Climate change is another area of concern. Implications of global warming are more visible now. Anticipated increase in global temperature favours thrips and other similar insects. Besides thrips, threat from mites may be expected with more economic damage to onions in future. Looking into the current status, it is evident that cultural control methods are more effective. Undisputedly use of chemicals is inevitable. Insecticide resistance is being reported in India against Cypermethrin. There is a need to rationalize its use and awareness should be created among growers. As onion is an export-oriented commodity, pesticide residues should be within the prescribed limits.

Other insect-pests and their management practices should be compatible with those of thrips. Pheromones can be integrated into the existing thrips management to make it more holistic. Mite problems are on the rise not only in onion but in many other crops. Management tactics need to be formulated for mites. Increasing temperatures may be a reason for such outbreaks. Nematode is not a major problem in India, however, changing climate may influence their importance. Free trade and movement of onions through imports may pose a threat of introducing nematodes in India. Regulatory measures should be implemented strictly to avoid any entry of these nematodes. Consolidation of available individual components of thrips management practices is necessary. A multi-faceted approach that effectively exploits weak links in the life-cycle of the thrips would strengthen IPM programmes.

\section{References}

Afifi F M L and Haydar M F. 1990. Effect of different intercropping systems on onion and garlic infestation with the 'cotton and onion thrips', Thrips tabaci Lind. Bull. Fac. 
Agric. Univ. Cairo 41: 639-48.

Ajay Kumar Pandey and Dorjay Namgayal. 2010. Quantification of damage and evaluation of different insecticides against onion maggot, Delia antiqua (Meigen) (Diptera:Anthomyiidae) in Kargil District of Ladakh Region. Journal of Hill Agriculture 1: $62-65$.

Ali M A A, Chandrasekar S S, Vardarasan S, Gopakumar B, Paramaguru P, Ponnusamy V and Muthusamy M. 2002. Impact of organic cultivation of chilli (Capsicum annum Linn.) on pests and diseases, pp.451-56. (In): Proceedings of the 15 th Plantation Crops Symposium placrosym-XV, during10-13 December 2002 at Mysore, Karnataka, India.

Alimousavi S A, Hassandokht M R and Moharramipour S. 2007. Evaluation of Iranian onion germplasm for resistance to thrips. International Journal of Agriculture and Biology 9: 455-58.

Allen J K M, Scott-Dupree C D, Tolman J H and Harris C R. 2005. Resistance of Thrips tabaci to pyrethroid and organophosphorus insecticides in Ontario, Canada. Pest Management Science 61: 809-15.

Al-Siyabi A A, Kinawy M M, Al-Ansri M, Mahar A N, Gowen S R and Hague N G. 2006. The susceptibility of onion thrips, Thrips tabaci to Heterorhabditis indicus. Communications in Agricultural and Applied Biological Sciences 71: 239-43.

Altaf Hussain Hazara, Muhammad Shakeel, Khan Juma, Iqbal Muhammad and Khan Saifulla. 1999. Effects of non chemical methods and botanical insecticides on onion thrips, Thrips tabaci Lind. (Thysanoptera: Thripidae) in onion crop in Balochistan. Sarhad Journal of Agriculture 15: 619-24.

Anamika, Sobita Simon and Saily Dass. 2010. Record of root knot nematode (Meloidogyne incognita) infection in green onion in Allahabad district. Indian Journal of Nematology 40: $229-30$.

Anitha K, Venkateswaran Kamala, Chakrabarty S K, Kumar G S, Babu B Sarath, Varaprasad K S. 2011. Onion genetic resources and pest resistance: The Indian scenario. Indian Journal of Plant Protection 39: 81-92.

Anonymous. 1978. Citrus, p.106. (In): Annual Report, Cyprus Agricultural Research Institute.

Anonymous. 2000. Annual Report. National Research Centre for Onion and Garlic, p. 71.

Bergant K, Trdan S and Znidarcic D. 2003. The potential impact of climate change on the harmfulness of onion thrips (Thrips tabaci L., Thysanoptera, Thripidae). Zbornik Predavanj in referatov 6 Slovenskega Posvetovanje O Varstvu Rastlin Zrece Slovenije 46: 346-54.

Bernardo E N.1991. Thrips on vegetable crops in the Philippines. AVRDC Publication No. 91-342, pp.5-11.

Bhangale G T and Joi M B.1983. Role of thrips in development of purple-blotch of onion. Journal of Maharashtra Agricultural Universities 8: 299-300.

Bradley C A, Lord J C, Jaronski S T, Gill S A, Dreves A J and Murphy B C. 1998. Pests and Diseases-1998, Volume 1, pp. 177-82. [Proceedings of Crop Protection Conference during November 1998. Brighton, UK].

Brar K S, Sidhu A S and Chadha M L. 1993. Screening onion varieties for resistance to Thrips tabaci Lind. and Helicoverpa armigera (Hubner). Journal of Insect Science 6: $123-24$.

Broughton S and Harrison J. 2012. Evaluation of monitoring methods for thrips and the effect of trap colour and semiochemicals on sticky trap capture of thrips (Thysanoptera) and beneficial insects (Syrphidae, Hemerobiidae) in deciduous fruit trees in Western Australia. Crop Protection 42: 156-63.

Cabrera Asencio I and Velez A L. 2006. Companion crops and insecticides to control populations of Thrips tabaci L. and Liriomyza trifolii B. in onion. Journal of Agriculture 
of the University of Puerto Rico 90: 115-23.

Chen W H, Liu Y C, Ho C C and Chang T Y. 2002. A newly recorded mite pest, Rhizoglyphus setosus Manson (Acari: Acaridae), of onion in Taiwan. Plant Protection Bulletin (Taipei) 44: 249-53.

Chhatrola D P, Vyas H J and Baraiya K P. 2003. Influence of abiotic factors on population build-up of thrips, Thrips tabaci Lindeman in garlic. Indian Journal of Plant Protection 31: $98-100$.

Chiang M S and Perron J P. 1980. Effects of seedling density and soil moisture on attractiveness of egg laying by the onion maggot. Phyto Protection 61: 9-12.

Cho K, Eckel C S, Walgenbach J F and Kennedy G G. 1995. Comparison of colored sticky traps for monitoring thrips populations (Thysanoptera: Thripidae) in stacked tomato fields. Journal of Entomological Science 30: 176-90.

Choo H Y, Kaya H K and Reed D K. 1988. Biological control of onion maggot and tobacco cutworm with insect parasitic nematodes, Steinernema feltiae and Heterorhabditis heliothidis. Korean Journal of Applied Entomology 27: 185-89.

Cortinus Abrahantes J, Jimenez-Jimenez S F and Reyes-Tornes S. 2003. Descriptive and predictive models of Thrips tabaci populations in garlic plantation in Cuba. Manejo Integrado de Plagas y Agroecologia 67: 30-34.

Darshan Singh, Sidhu A S, Thakur J C and Singh D. 1986. Relative resistance of onion and garlic cultivars to Thrips tabaci Lind. Journal of Research Punjab Agricultural Universities 23: 424-27.

Davidson $G$ and Chandler D. 2005. Laboratory evaluation of entomopathogenic fungi against larvae and adults of onion maggot (Diptera: Anthomyiidae). Journal of Economic Entomology 98: 1848-55.

Davidson M M, Butler, R C and Teulon D A J. 2009. Pyridine compounds increase thrips (Thysanoptera: Thripidae) trap capture in an onion crop. Journal of Economic Entomology 102: 1468-71.

Davis M, Grafius E, Crenshaw W and Royer T. 1995. Onions, pp. 136-46. (In): Vegetable Insect Management with Emphasis on the Midwest. Foster R and Floo B. (Eds). Meister Publication Company, Willoughby, Ohio, USA.

Deligeorgidis P N and Ipsilandis C G. 2004. Determination of soil depth inhabited by Frankliniella occidentalis (Pergande) and Thrips tabaci Lindeman (Thysan., Thripidae) under greenhouse cultivation. Journal of Applied Entomology 128: 108-11.

Diraviam J and Uthamasamy S. 1992. A new sampling technique involving yellow sticky traps for monitoring thrips infesting different crops. Journal of Entomological Research 16: $78-81$.

Duraimurugan P and Jagadish A. 2002. Seasonal incidence and effect of weather parameters on the population dynamics of chilli thrips, Scirtothrips dorsalis Hood (Thysanoptera: Thripidae) on rose, pp.180-83. (In): Proceedings of Resources Management in Plant Protection During Twenty First Century, held during November 2002 at Hyderabad, Andhra Pradesh, India.

Eckenrode C J, Walters T W, Burba and Galmarini C.R. 1997. The onion maggot in New York state: evaluation of host plant resistance, pp. 639-43. (In): Proceedings of the First International Symposium on Edible Alliaceae, held during March 1994 at Mendoza, Argentina.

Edelson J V and Magaro J J. 1988. Development of onion thrips Thrips tabaci Lindeman, as a function of temperature. Southern Entomologist 13: 171-76.

El Gendi S M. 1998. Population fluctuation of Thrips tabaci Lind. on onion plants under Fayoum environmental conditions. Arab Universities Journal of Agricultural Sciences 6: 267-76.

Elad Y, Pertot I and Enkegaard A. 2004. Combined use of insect pathogenic fungi and 
nematodes against onion thrips, Thrips tabaci, in the field. Bull. OILB/SROP 27: 14143.

Ellis P R, Eckenrode, C J and Harman G E.1979. Influence of onion cultivars and their microbial colonizers on resistance to onion maggot. Journal of Economic Entomology 72: $512-15$.

Ellis S A and Scatcherd J E. 2007. Bean seed fly (Delia platura, Delia florilega) and onion fly (Delia antiqua) incidence in England and an evaluation of chemical and biological control options. Annals of Applied Biology 15: 259-67.

El Khayat E F, Shalaby F F, Lotfy F M and Ibrahim A R. 1997. Thrips infestation to onion plants in relation to onion varieties, planting there and nitrogen fertilization. Annals of Agricultural Science 35: 1761-77.

Fernandez S A and Lucena C. 1990. Evaluation of the effect of different coloured sticky traps in attracting Thrips tabaci Lindeman (Thysanoptera: Thripidae). Agronomia Tropical Maracay 40: 4-6.

Finch S, Eckenrode C J and Cadoux M E. 1986. Behaviour of onion maggot (Diptera; Anthomyiidae)in commercial onion fields treated regularly with parathion sprays. Journal of Economic Entomology 79: 107-13.

Fournier F, Boivin G and Stewart R. 1995. Effect of Thrips tabaci (Thysanoptera: Thripidae) on yellow onion yields and economic thresholds for its management. Entomological Society of America 88: 1401-07.

Gahukar R T. 2003. Factors influencing thrips abundance and distribution on rose flowers in Central India. Journal of Entomological Research 27: 271-79.

Ganga Visalakshy P N and Krishnamoorthy A. 2012. Comparative field efficacy of various entomopathogenic fungi against Thrips tabaci: prospects for organic production of onion in India. Acta Horticulturae (ISHS) 933: 433-37.

Gangloff J L. 1999. 'Population dynamics and insecticide resistance of onion thrips, Thrips tabaci Lindeman (Thysanoptera: Thripidae) in onion'. Ph.D. Dissertation. Cornell University, Ithaca, NY, USA.

Gonclaves P A S. 1997. Seasonal fluctuation of thrips, Thrips tabaci Lind., on onion in Ituporanga, Santa Catarina. Anais da Sociedade Entomologica do Brasil 26: 365-69.

Gupta R P and Sharma R C. 1998. Effect of new insecticide/biopesticides on control of onion thrips. News Letter, National Horticultural Research Foundation. 18: 5-7.

Gupta R P, Srivastava K J, Tiwari B K, Pandey J G and Sharma R C. 2002. Effect of different neem based insecticides against onion thrips. News Letter National Horticultural Research and Development Foundation 22: 5-8.

Hamdy M K and Salem M. 1994. The effect of plantation dates of onion temperature and relative humidity on the population density of the onion thrips, Thrips tabaci Lind., in Egypt. Annals of Agricultural Science, Cairo 39: 417-24.

Harris M O, Miller J R and de Ponti O M B. 1987. Mechanisms of resistance to onion fly egg-laying. Entomologia Experimentalis et Applicata 43: 279-86.

Hayder M F and Sheriff L S. 1990. Ecological aspects development method onion pest control. Bulletin of Entomological Society of Egypt, Economic series 16: 119-26.

Hoepting C A, Scott Dupree C D, Harria C R and Ritcey G. 2000. Evaluation of insecticide and fungicide combinations for the control of onion maggot (Delia antiqua) and onion smut (Urocystis cepulae) in Ontario, pp. 279-84. (In): Proceedings of BCPC Conference, during November 2000 at Brighton, UK.

Ikeshoji T, Ishikawa Y and Matsumoto Y. 1981. Ecological and chemical interactions between onion and onion maggot. Review of Plant Protection Research 14: 141-49.

Jensen L, Simko B, Shock C and Saunders L. 2003. Alternative methods for controlling onion thrips, pp. 895-900. (In): Proceedings of The BCPC International Congress: Crop Science and Technology November 2003 at Glasgow, Scotland, UK. 
Kasina J, Nderitu J, Nyamasyo G, Olubayo F, Waturu C, Obudho E and Yobera D. 2006. Evaluation of companion crops for thrips Thysanoptera: Thripidae) management on Frenchbean Phaseolus vulgaris (Fabaceae). International Journal of Tropical Insect Science 26: 121-25.

Kassab A S and Hafez S M. 1990. Use of powdered sulfur against the bulb mite, Rhizoglyphus robini, and its effect on nematodes in garlic field soil. Annals of Agricultural Science Cairo 35: 533-41.

Kirk W D J. 1997. Distribution, abundance and population dynamics, pp. 217-57. (In): Thrips as Crop Pests. Lewis T. (Ed.) CAB International. NewYork, USA.

Klemen Bergant, Stanislav Trdan, Dragan Znidaricic, Zalika Crepinsek and Luka KajfezBogata. 2005. Impact of climate change on developmental dynamics of Thrips tabaci (Thysanoptera: Thripidae): Can it be quantified? Environmental Entomology 34: 755-66.

Klein M, Meisner J, Ben-Moshe N E, Nemny Capsy I and Ascher K R C. 1993. Formulations of neem (Azadirachta indica) seed extracts inhibit growth of nymphs of the onion thrips, Thrips tabaci. Hassadeh 74: 189-93.

Krishna Kumar N K, Krishna Moorthy P N, Kalleshwara Swamy C M and Ranganath H R. 2008. Management of thrips (Thrips tabaci Lindeman) on organically raised rose onion. Pest Management in Horticultural Ecosystems 14: 128-32.

Kubota S. 1999. Effectiveness of Beauveria bassiana against Thrips palmi on musk melons in a greenhouse. Proceedings of the Kansai Plant Protection Society 41: 69-70.

Lall B S and Singh L M. 1960. On the biology of the onion thrips Thrips tabaci (Lind.) (Thysanoptera: Thripidae). Current Science 29: 314-15.

Larentzaki K, Shelton A M, Musser F R, Nault B A and Plate J. 2007. Overwintering locations and hosts for onion thrips (Thysanoptera: Thripidae) in the onion cropping ecosystems in New York. Journal of Economic Entomology 109: 1194-1200.

Larentzaki K, Shelton A M and Plate J. 2008a. Kaolin particle film on Thrips tabaci (Thysanoptera: Thripidae) oviposition, feeding and development on onions. A lab and field case study. Crop production 27: 727-34.

Larentzaki E, Plate J, Nault B A, and Shelton A M. 2008b. Impact of straw mulch on populations of onion thrips (Thysanoptera: Thripidae) in onion. Journal of Economic Entomology 101: 1317-24.

Lewis T. 1973. Thrips: their Biology, Ecologyand Economic Importance. Academic, London, United Kingdom.

Loges V, Lemos M A, Resende L V, Menezes D, Candeia J A and Santos V F. 2004. Thrips resistance in onion cultivars and hybrids. Horticultura Brasileira 22: 222-25.

Loomans A J M, van Lenteren J C, Tommasini M G, Maini S and Riudavets J. 1995. Biological control of thrips pests: a review on thrips parasitoids. Wageningen Agric. Univ. 95: 89-201.

Lu F M. 1990. Colour preference and using silver mulches to control onion thrips, Thrips tabaci Lindeman. Chinese Journal of Entomology 10: 337-42.

Mautino G C, Bosco L and Tavella L. 2012. Integrated management of Thrips tabaci (Thysanoptera: Thripidae) on onion in north-western Italy: Basic approaches for supervised control. Pest Management Science 68: 185-93.

Mayer D F, Lunden J D and Rathbone L. 1987. Evaluation of insecticides for Thrips tabaci (Thysanoptera: Thripidae) and effects of thrips on bulb onions. Journal of Economic Entomology 80: 930-32.

McKenzie C L, Cartwright B, Miller M E and Edelson J V. 1993. Injury to onions by Thrips tabaci (Thysanoptera: Thripidae) and its role in the development of purple blotch. Environmental Entomology 22: 1266-77.

Miller J R and Cowles R S. 1991. Stimulo-deterrent diversion: a concept and its possible 
application to onion maggot control. Journal of Chemical Ecology 16: 3197-212.

Molenaar N D. 1984. Genetics, thrips (Thrips tabaci L.) resistance and epicuticular wax characteristics of non glossy and glossy onion, Allium cepa L. Dissertation Abstracts International, B-Sciences and engineering 45: 1075.

Muhammad Shakeel, Tariq Mehmood and Khokhar K M. 2006. Host plant resistance of promising onion (Allium cepa) varieties against onion thrips, Thrips tabaci Lindeman. Sarhad Journal of Agriculture 22: 477-79.

Murphy B C, Morisawa T A, Newman J P, Tjosvold S A and Parrella M P. 1998. Fungal pathogen controls thrips in greenhouse flowers. California Agriculture 52: 32-36.

Nault B A, Straub R W and Taylor A G. 2006. Performance of novel insecticide seed treatments for managing onion maggot (Diptera: Anthomyiidae) in onion fields. Crop Protection 25: 58-65.

Nault Brian A, Werling B P, Straub R W and Nyrop J P. 2011. Delaying onion planting to control onion maggot (Diptera: Anthomyiidae): Efficacy and underlying mechanisms. Journal of Economic Entomology 104: 1622-32.

North R C and Shelton A M. 1986. Colonization and interplant distribution of Thrips tabaci (Thysanoptera: Thripidae) on cabbage. Journal of Economic Entomology 79: 219-23.

Okabe K and Amano H. 1990. Attractancy of alcohols isolated from culture filtrates of Fusarium fungi for the robine bulb mite, Rhizoglyphus robini Claparede (Acari: Acaridae) in sand. Applied Entomology and Zoology 25: 397-404.

Panickar B K and Patel J R. 2001. Population dynamics of different species of thrips on chilli, cotton and pigeonpea. Indian Journal of Entomology 63: 170-75.

Pawar D B, Mote U N, Kale P N and Ajri D S. 1987. Inheritance of resistant sources for thrips in onion. Euphytica 40: 233-39.

Paulauskyte L. 1999. Most serious onion pests and search for effective control means. Sodininkyste ir Darzininkyste 18: 228-34.

Perez R P, Almaguel L, Torre E de la, Fetio, E and De la Torre E. 1989. Chemical control of Rhizoglyphus in gladioli bulbs using methyl bromide. Agrotecnia de Cuba 21: 1519.

Rao D V S and Subbaratnam G V. 1999. Seasonal incidence and population dynamics of Spodoptera exigua (Hubner) in onion. Pest Management and Economic Zoology 7: $39-45$.

Ritcey G and Mc Ewen F L. 1984. Control of onion maggot, Delia antiqua (Meigen) (Diptera: Anthomyiidae), with furrow treatments. Journal of Economic Entomology 77: $1580-84$.

Romeis J, and Ebbinghaus D. 2003. Factors accounting for the variability in the behavioral response of the onion fly (Delia antiqua) to n-dipropyl disulfide. Journal of Chemical Ecology 29: 2131-42.

Rueda A, Badenes Perez F R and Shelton A M. 2007. Developing economic thresholds for onion thrips in Honduras. Crop Protection 26: 1099-07.

Sakimura K. 1937. The life and seasonal histories of Thrips tabaci Lindeman in the vicinity of Tokyo. Oyo Dobuts Zasshi 9: 1-24.

Sastrosiswojo S. 1991. Thrips on vegetables in Indonesia. AVRDC Publication. No. 91342, pp. 12-17.

Satya Srinivas P. Anita V S and Lawande K E. 2011a. Susceptibility of onion thrips to commonly used insecticides, p.242. (In): Proceedings of National Symposium on Alliums: Current Scenario and Emerging Trends during March 2011 at Pune, Maharashtra, India.

Satya Srinivas P. Anita S B and Lawande K E. 2011c. Occurrence of thrips and predatory thrips on onion in Maharashtra. (In): Proceedings of National Symposium on Alliums: 
Current Scenario and Emerging Trends.during. March 2011 at Pune, Maharashtra, India.

Satya Srinivas P, Kaushik Banerjee and Lawande K E. 2011b. Monitoring of pesticide residues in onion bulbs in different states of India, p. 244. (In): Proceedings of National Symposium on Alliums: Current Scenario and Emerging Trends, during March 2011 at Pune, Maharashtra, India.

Satya Srinivas P, Kaushik Banerjee, Manjusha R J, Manoj S G and Lawande K E. 2012. Bioefficacy, dissipation kineticsand safety evaluation of selected insecticides in Allium cepa L. Journal of Environmental Science and Health Part B. 47: 1-10.

Saxena R C. 1981. Observations on some predators and parasites of Thrips tabaci Lind. Bulletin of Entomology 22: 97-100.

Schneider W D, Harris M O and Miller J R. 1985. Onion maggot feeding and development on heterogeneous sections of the onion bulb. Entomologia Experimentalis et Applicata 38: $151-55$.

Scott S J, McLeod P J, Montgomery F W and Hander C A. 1989. Influence of reflective mulch on incidence of thrips (Thysanoptera: Thripidae: Phlaeothripidae) in stacked tomatoes. Journal of Entomological Science 24: 422-27.

Shelton A M, Nyrop J P, North R C, Petzoldt C and Foster R. 1987. Development and use of dynamic sequential sampling programme for onion thrips, Thrips tabaci on onion. Journal of Economic Entomology 80: 1051-56.

Shelton A M, Nault B A, Plate and Zhao J Z. 2003. Regional and temporal variation in susceptibility to lambda-cyhalothrin in onion thrips in onion field of New York. Journal of Economic Entomology 96: 1843-48.

Shelton A M, Zhao J Z, Nault B A, Plate J, Musser F R and Larentzaki E. 2006. Patterns of insecticide resistance in onion thrips (Thysanoptera: Thripidae) in onion fields in New York. Journal of Economic Entomology 99: 1798-804.

Sinha A K, Sinha R B P, Ajay Kumar, Kumar A. 1993. Reaction of onion cultivars to thrips (Thrips tabaci). Journal of Applied Biology 3: 104-05.

Sinha S N, Chakraborti A K, Agnihotri N P, Jain H K and Gajbhiye V T. 1992. Field evaluation of synthetic pyrethroids against thrips, Thrips tabaci (Lind.) on onion and their residues. Indian Journal of Entomology 54: 44-47.

Soni S K and Ellis P R. 1990. Insect pests, pp. 213-71. (In): Onions and Allied Crops, Vol. II: Agronomy, Biotic Interactions, Pathology, and Crop Protection. Rabinowitch H D and Brewster J L. (Eds). CRC Press, Boca Raton, Florida, USA.

Spiegel Y, Burrows P M and Bar-Eyal M. 2003. A chemo attractant in onion root exudates recognized by Ditylenchus dipsaci in laboratory bioassay. Phytopathology 93: 127132.

Srinivas P S and Lawande K E. 2000a. Efficacy of certain botanicals in management of onion thrips pp.219. (In): Proceedings of the National Symposium on Onion-Garlic Production and Post-harvest Management Challenges and Strategies, during November 2000 at Nashik,Maharashtra, India.

Srinivas P S and Lawande K E. 2000. Economics in management of onion thrips, pp. 219. (In): Proceedings of the National Symposium on onion-Garlic Production and Postharvest Management Challenges and Strategies, during November 2000 at Nashik, Maharashtra, India.

Srinivas P S and Lawande K E. 2004. Impact of planting dates on Thrips tabaci Lindeman infestation and yield loss in onion (Allium cepa L.) Pest Management in Horticultural Ecosystem 10: 11-18.

Srinivas P S and Lawande K E. 2004a. Red spider mite-A new pest on onion and garlic. Insect Environment 10: 79-80.

Srinivas P S and Lawande K E. 2006. Maize barrier as a cultural method for management 
of thrips in onion (Allium cepa L.) Indian Journal of Agricultural Sciences 76: 16771.

Srinivas P S and Lawande K E. 2007. Seedling root dip method for protecting onion plants from thrips. Indian Journal of Plant Protection 35: 206-09.

Srinivas P S, Anil Khar, Aziz Qureshi and Lawande K E. 2007. Wild alliums as sources of resistance to Thrips tabaci. (In): Proceedings of III National Symposium on Plant Protection in Horticulture: Emerging Trends and Challenges, during March 2007 at Bengaluru, Karnataka, India.

Srinivas P S, Aziz Qureshi and Lawande K E. 2008. Growth stage susceptibility of onion (Allium cepa L.) and its role in thrips management. Indian Journal of Agricultural Sciences 78: 98-101.

Srinivasan S and Lingappa S. 1986. Dissipation of monocrotophos residues in onion crop. Pesticides 20: 31-33.

Sujay Pandey, Mishra R K, Singh A K and Srivastava D K. 2012. Bioefficacy of plant extracts, neem-based biopesticides and insect growth regulators for management of onion thrips. Biopesticides International 7: 60.

Stephen P Foster, Kevin Gorman and Ian Denholm. 2010. English field samples of Thrips tabaci show strong and ubiquitous resistance to deltamethrin. Pest Management Science 66: 861-64.

Stoner K A and Shelton A M. 1988a. Effect of planting date and timing of growth stages on damage to cabbage by onion thrips (Thysanoptera: Thripidae). Journal of Economic Entomology 81: 1186-89.

Sule A R, Ambekar J S and Nayakwadi M B. 2008. Field efficacy of newer insecticides against onion thrips (Thrips tabaci). Journal of Maharashtra Agricultural Universities 33: 281-82.

Taylor A G, Eckenrode C J and Straub RW. 2001. Seed coating technologies and treatments for onion: challenges and progress. Hort Science 36: 199-205.

Thind T S and Jhooty J S. 1982. Association of thrips with purple blotch infection on onion plants caused by Alternaria porri. Indian Phytopathology 35: 696-98.

Tomlin A D, Miller J J, Harris C R and Tolman J H. 1985. Arthropod parasitoids and predators of the onion maggot (Diptera: Anthomyiidae) in Southern Ontario. Journal of Economic Entomology 78: 975-81.

Toor R F Van, Till C M, James D E and Teulon D A J. 2004. Evaluation of UV reflective mulches for protection against thrips (Thrips tabaci) in onion (Allium cepa) crops. New Zealand Plant Protection 57: 209-13.

Torres Villa L M, Lacasa A, Bielza P and Meco R. 1994. Population dynamics of Thrips tabaci Lind. (Thysanoptera: Thripidae) on liliaceous vegetables. Boletin de sanidad Vegetal Plagas 20: 661-77.

Tu C M and Harris C R. 1988. A description of the development and pathogenicity of Entomophthora musae (Cohn) in the maggot, Delia antiqua (Meign). Agriculture, Ecosystems and Environment 20: 143-46.

Un Taek Lim, Roy G and Van Driesche. 2005. A new potential host and transmission route of Thripinema nicklewoodi, an entomogenous nematode of western flower thrips. Biological Control 33: 49-55.

Uvah I I I, and Coaker T H. 1984. Effect of mixed cropping on some insect pests of carrots and onions. Entomologia Experimentalis et Applicata 36: 159-67.

Waiganjo M M, Muriuki J and Mbugua G W. 2007. Potential of indigenous leafy vegetables as companion crops for pest management of high value legumes: A case study of Gynandropsis gynandra in Kenya. Acta Horticulturae 752: 319-21.

Walters T W and Eckenrode C J. 1996. Integrated management of onion maggot. (Diptera: Anthomyiidae). Journal of Economic Entomology 89: 1582-86. 
Waterhouse D F and Norris. 1989. Biological control: Pacific prospects-Supplemental. Australian Centre for International Agricultural research-ACIAR Monograph. 12.

Wogin M J, Ruth C B, David A J T and Melanie M D. 2010. Field response of onion thrips and New Zealand flower thrips to single and binary blends of thrips lures. Canadian Entomologist 142: 75-79.

Yousefi A, Abasifar A, Fathi Hafshejani and Jalali Sendi J. 2011. Resistance of eight Iranian onion cultivars to onion thrips (Thrips tabaci Lindeman) in the Markazi Province of Iran. African Journal of Agricultural Research 6: 4925-30.

Zezlina I and Blazic M. 2003. Testing the efficacy of different insecticides to control onion thrips (Thrips tabaci, Thysanoptera: Thripidae) in onion crops. Communications in Agricultural and Applied Biological Sciences 68: 287-90. 


\title{
Post-harvest Management and Processing
}

\author{
A.A. Murkute and Kalyani Gorrepati
}

Onion, being an essential commodity of the daily diet, creates relatively constant year-round demand. Across the globe, huge post-harvest losses to the tune of 40$50 \%$ have been reported. Attempts are being made to reduce the losses through pre- and post-harvest management practices (Adamicki, 2004; Kassali and Idowu, 2007; Hyde et al., 2011; Magomedov, 2006; Sabaragamuwa et al., 2011). The post-harvest losses mainly consist of physiological weight loss (20-25\%), sprouting $(8-10 \%)$ and decay $(10-12 \%)$. The losses during transit deteriorate the scenario further. Apart from the physiological processes that culminate into postharvest losses, pre-harvest factors causing losses include cultivation practices. Successful storage depends on the cultivar or the variety, cropping season, cultural practices, maturity of the crop at the harvest and post-harvest handling (Sidhu, 2008; Murkute, 2012). To reduce post-harvest losses, different pre- and postharvest management practices need to be standardized.

Onion is known to have natural health-promoting properties due to its rich nutritional composition. With increase in consumer awareness regarding its attributes, onion consumption is increasing day by day. This vegetable is not very convenient to cut and prepare owing to its pungency and tear-inducing effects (Siddiq et al., 2013). Its processing into ready-to-eat and ready-to-use forms would increase its consumption further. Processing of onions into different products (Fig.15.1) would allow even effective utilization of those onions that fail to meet quality standards required for the marketing (Horiuchi et al., 1999). It is utmost important to standardize and evaluate different processes for value-addition and producing processed products to improve utilization of onions, reduce their losses and stabilize market fluctuations.

\section{Pre-harvest practices}

They have been reported to be crucial for affecting storage life of onions. Sowing time, fertilizer dosage and method of application, irrigation, use of phytohormones, including growth suppressants, desiccants and metal salts, all can contribute to losses in storage. In storage, when leaf primordium develops into a green sprout, which eventually protrudes from the bulb-neck, is the principal cause of loss (Chope et al., 2006). Extended suppression of sprout growth could be achieved using Maleic Hydrazide $(\mathrm{MH})$, a synthetic sprout suppressant. However, due to carcinogenic activity of MH (Epstein et al., 1967), its use has been banned.

Pre-harvest application of ethephon was reported to reduce sprouting during 
storage (Thomas and Rankin, 1982). While fixing critical limit for minimizing storage losses, it has been concluded that sulphur (S) has a major role in reducing weight loss, followed by nitrogen $(\mathrm{N})$ and phosphorus (P). N : S ratio during crop growth (6.5-8.1) in harvested leaves (5.3) and bulbs (4.1-6.0) was found critical to reduce losses in storage. Similarly, S : P ratio in leaves of 2.4 at 63 days after transplanting was found ideal for curtailing sprouting losses (Jaggi, 2009). Lately, it has been noticed that applied sulphur did not affect sprouting, root formation, decay or development of surface discolouration or mould in storage (Forney and Jordan, 2010); rather it increased onion pungency and pyruvate content (35\%). The content of propenyl cysteine sulfoxide, the precursor of the tear-inducing lachrymatory factor, increased 10 -folds higher in S-fertilized onion during storage.

Application of $\mathrm{Zn}(10 \mathrm{~kg} / \mathrm{ha}$ as $\mathrm{Zn}$-EDTA) lowered rotting $(13.7 \%)$, sprouting $(2.1 \%)$ and physiological weight loss $(7.71 \%)$ of onions stored up to 120 days in a perforated paper packet compared with other treatments (Zn (0 and 20 $\mathrm{kg} / \mathrm{ha})$ and three levels of $\mathrm{S}(0,30$ and $60 \mathrm{~kg} / \mathrm{ha}))$ (Kumar et al., 2000). The foliar spray of $0.5 \%$ calcium nitrate $\left(\mathrm{Ca}\left(\mathrm{NO}_{3}\right)_{2}\right)$ resulted in lowest sprouting loss (14.38\%) and foliar spray of $0.5 \%$ $\mathrm{Ca}\left(\mathrm{NO}_{3}\right)_{2}+0.5 \% \mathrm{ZnSO}_{4}$ lowered rotting loss $(19.18 \%)$ after 150 days storage. Foliar spray of

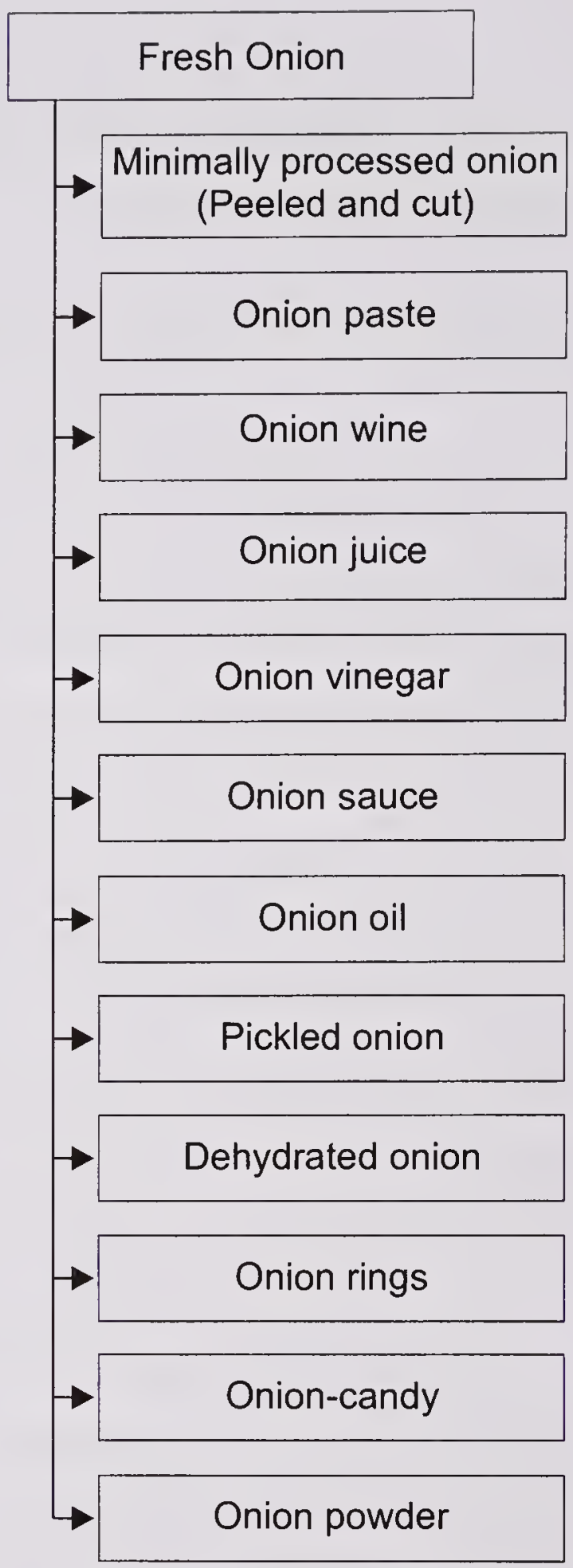

Fig.15.1 Onions- Some processed products $0.5 \% \mathrm{ZnSO}_{4}$ resulted in lowest physiological weight loss (24.78\%) and total loss $(60.1 \%)$ of bulbs at the end of 150 days of storage under ambient conditions (Shrinath et al., 2007). Organic manures, vermi-compost, poultry-manure and sheep-manure reduced post-harvest losses compared to urea application (Dhotre and Allolli, 2012).

Timely and appropriate irrigation has been strongly recommended to reduce post-harvest losses of onions. Extended irrigation before harvest results in skin splitting and promotes rotting by different fungi (Shock et al., 1998), and water deficit results in accelerated sprouting and water loss at a higher rate during storage (Rattin et al., 2011). Bulbs grown under low-soil moisture regime resulted in higher physiological weight loss and more sprouting. Maximum sprouting percentage of $25.49 \%$ was recorded in bulbs stored on the cemented floor when water applied (IW)/cumulative pan evaporation (CPE) ratio was 1.20. Application of last irrigation five days before harvesting reduced losses in storage significantly over irrigation applied just before the harvesting (Sharma et al., 2007).

Microirrigation affects storage life significantly. Losses were lower in the crop 
grown with drip irrigation than that grown with surface irrigation (Tripathi et al., 2010). Under microsprinkler irrigation regime, the crop should be irrigated on the basis of pan evaporation replenishment at $1.0 \mathrm{Ep}$ for better post-harvest attributes. Physiological weight loss at 45 days of storage was 8.42 and $9.51 \%$ in 0.60 and 1.2 Ep of irrigation, respectively, which increased to 42.80 and $29.03 \%$ after 120 days of storage with the same treatments (Kumar et al., 2007). However, physiological weight loss at 1.0 and 1.2 was Ep not significant. Highest sprouting and physiological weight losses were with (NPK) fertigation@100:50:50 kg/ ha (Kumar et al., 2006). Fertigation at $150 \mathrm{~kg} / \mathrm{ha}$ was found most desirable for micro-sprinkler irrigated onion-crop under semi-arid climate; and at $200 \mathrm{~kg} / \mathrm{ha}$, highest physiological weight loss was noticed at the end of 120 days of storage (Kumar et al., 2007). Pre-harvest applications (seedling-dip and pre-harvest spray of two calcium forms, i.e. calcium nitrate or calcium chelate) have also been found to reduce microbial decay during storage. There was significant reduction in storage-rot, i.e. black-rot (Aspergillus niger), neck-rot (Botrytis allii) and basal$\operatorname{rot}$ (Fusarium oxysporim) with the pre-harvest application of calcium (El-Neshawy et al., 2004). Improved cell-wall structure integrity observed under scanning electron microscope (SEM) was attributed to reduction in rotting due to calcium application. Different leaf desiccants as pre-harvest treatments (carfentrazone, diquat and paracquat) desiccated onion foliage well but increased bulb-rot in storage (Arboleya et al., 2005). Although, copper sulphate and pelargonic acid increased desiccation of onion-foliage; they were not sufficiently effective for field use. Pre-harvest treatment with metal-salts-calcium and potassium-also influences storage of onion (Ghoname et al., 2007). Exogenous treatment of abscisic acid (ABA) (10 $\mu$ mole/litre) restricted sprouting to $2.9 \%$ after 100 days (Chen et al., 2007). On the contrary, Chope et al. (2007a) reported that exogenous application did not increase endogenous bulb ABA concentration. Pre-harvest application of isopropyl-N (3-chlorophenyl) carbamate (CIPC) (2\%) at 75 days after planting was found to reduce sprouting significantly in kharif onion varieties-Bhima Raj and Bhima Red - after three months of storage (DOGR, 2012, 2013). Its application in rabi crop was ineffective.

\section{Post-harvest practices}

They include external application of phytochemicals as well as management practices. Treatments with ethephon, an ethylene supplier, and silver thiosulphate, an anti-ethylene compound, were carried out as post-harvest application to investigate ethylene role on sprouting of onion-bulbs (Benkeblia and SelseletAttou, 1999). It appeared that ethephon had almost no effect on sprouting, whereas silver thiosulphate slowed down sprouting. Pre-storage treatment with ethanol, which has ability to inhibit synthesis and action of ethylene, delayed rotting, sprouting and decay without any adverse effects on the quality (Qadir et al., 2007). On the contrary, continuous application of ethylene in commercial cold storages of onion was found to restrict sprouting (Johnson, 2006). Bufler (2009) substantiated that exogenous application of ethylene inhibited sprouting in onionbulbs. Exogenous ethylene and ethylene binding inhibitor, 1-methylcyclopropene (1-MCP), when applied continuously have been demonstrated to be sprout 
suppressants to onions (Downes et al., 2010). Nevertheless, both the treatments did not show any impact on rotting. Propham (CIP) or its chlorinated form chlorpropham reduced sprouting to $38 \%$ (CIP $60 \mathrm{mg} / \mathrm{litre}$ ) and 35\% (CIP $120 \mathrm{mg}$ / litre) as compared to $75 \%$ in control at $20^{\circ} \mathrm{C}$ (Benkeblia, 2004a). Post-harvest application of CIPC (hot fogging) did not control sprouting (DOGR, 2012).

Immediately after harvest, bulbs are in a natural stage of dormancy, and regrowth of the shoot can be controlled by physical influence such as temperature, gamma-irradiation and sprout-suppressant chemical treatments (Vasseur, 1991; Sinha et al., 1994). Sprouting inhibition by ionization is advantageous as it is irreversible owing to damage to meristematic cells, and does not leave any residual effects. The success of gamma-irradiation to inhibit sprouting adequately is dependent on the pre-harvest growing conditions, seasonal variations, curing period, bulb dormancy as well as storage environment/structures (Benkeblia and Varoquaux, 2003). Gamma-irradiation on some varieties indicated that it could effectively check sprouting and rotting in all onion varieties (Tripathi et al., 2011). However, no significant effect was observed on weight loss and black mould. Sulphur fumigation significantly reduced black-mould infestation. Sprouting of onion-bulbs was found only after 24 weeks when they were stored at $4^{\circ} \mathrm{C}$, and it was observed after 6 and 8 weeks when storage temperature was $10^{\circ} \mathrm{C}$ and $20^{\circ} \mathrm{C}$, respectively (Benkeblia et al., 2002). Post-harvest chemical treatment of CIP (600 $\mathrm{ppm})$ and gamma-irradiation $(0.15 \mathrm{kGy})$ on the inhibition of sprouting was as effective as chilling $\left(4^{\circ} \mathrm{C}\right)$ treatment (Benkeblia, 2004a).

Among all post-harvest management practices, curing is the most important one before storage. Curing is a high temperature process, which allows formation of strong intact outer protective skin, and closure of onion-neck (Brice et al., 1997). Albeit, curing significantly decreased onion surface from 89.5 to $84.5 \mathrm{~cm}^{2}$ and volume from 0.084 to $0.078 \mathrm{~m}^{3}$; the bulk density of freshly harvested onions with and without foliage (335 and $405 \mathrm{~kg} / \mathrm{m}^{3}$ ) increased (485 and $525 \mathrm{~kg} / \mathrm{m}^{3}$ ) significantly (Satish and Ranganna, 2002). Furthermore, curing increases hardness of onion-bulbs (9.75 to $10.5 \mathrm{~kg} / \mathrm{cm}^{2}$ ) and helps develop colour of cured bulbs. Both, wet conditions during field curing and topping before field curing increased incidence of bulb-rot (Wright and Triggs, 2004). Field curing of onion-bulbs for three days led to significantly higher marketable yield of 103.30 and $147.75 \mathrm{q} / \mathrm{ha}$ after storage with reduced losses of $15.08 \%$ and $16.9 \%$ in field curing compared to $30.78 \%$ and $32.23 \%$ losses, respectively, without curing (Sharma et al., 2007). Storage life also enhanced when well cured (10 days) onions were kept in $30 \%$ perforated brown-paper packets (Kumar et al., 2000). Enterobacter bulb decay in storage was more severe on bulbs cured at $40^{\circ} \mathrm{C}$ than those at 25,30 or $35^{\circ} \mathrm{C}$ (Schroeder 2010).

Pre-cooling has been found to maintain high quality of produce, and onions should be pre-cooled at $<4^{\circ} \mathrm{C}$ temperature within 4 to 6 hours of harvest. Hydro-cooling, forced air cooling and vacuum cooling may be used with crushed ice over the produce to maintain temperature and moisture (Adamicki, 2013). Last but not the least, it was substantiated that the weight loss was higher in onion-lots inspected regularly than those inspected at the end of the storage. Also, even a slight damage to the dry outer scales may hasten loss of water during storage (Sidhu, 2008). 


\section{Storage environment}

This has significant impact on the dormancy and the storage-life of onions (Komochi, 1990; Murkute and Gopal, 2013). Onion has two distinct optimum storage temperature conditions $-0-2^{\circ} \mathrm{C}$ and $25-30^{\circ} \mathrm{C}-$ where storage losses are lesser than other temperature regimes (Brice et al., 1997). The optimum temperature for sprouting is $10-20^{\circ} \mathrm{C}$ in dry storage. Moisture loss is greater at temperature ranging $<10^{\circ} \mathrm{C}$ and $>27^{\circ} \mathrm{C}$ (Gubb and MacTavish, 2002). In general, sprouting is inhibited by low and high temperatures, and is more pronounced at intermediate temperatures (Chope et al., 2006).

In the traditional ambient storage, lack of proper ventilation and loading height, increases storage losses in bulk storage. It is suggested that air-flow rate should be kept at $114 \mathrm{~m}^{3} / \mathrm{hr} /$ tonne of onion-bulbs for forced-air ventilation (Brice et al., 1995). Losses were reduced to $10.2 \%$ after three months storage in the forced ventilated storage structure (total flow rate $1,710 \mathrm{~m}^{3} / \mathrm{hr}$ ) from $23.7 \%$ occurring in the natural ventilated storage in Talaja Red variety (Dabhi et al., 2008). The stacking height also has effect on spoilage.

The Directorate of Onion and Garlic Research has developed different ventilated storage structures to provide optimum storage conditions (Murkute and Gopal, 2013). These are as follows.

- Top and bottom ventilated mud-plastered structure with asbestos roof

- Bottom and side ventilated structure with asbestos roof and chain-link sidewalls

- Bottom and side ventilated single-row structure with Mangalore tile roof

- Bottom and side ventilated low-cost structure with thatched-roof

- Bottom ventilated double-row structure with asbestos roof

The bottom and side ventilated structure with asbestos roof performed better than other structures with physiological weight loss up to $12-15 \%$, sprouting loss of $8-10 \%$ and decay loss of $5-8 \%$ in six months storage of rabi (i.e. May harvest) produce. The Maharashtra Government is providing $25 \%$ subsidy to farmers to construct these innovative storage structures (Murkute and Gopal, 2013).

Different onion-storage structures were evaluated for black and blue mould occurrences (Naik et al., 2008). Bottom and side ventilated single-row storage structure with thatched-roof was the best for small farmers as it showed low severity $(15-25 \%)$ by onion moulds and its cost of construction was also low. Modified bottom and side ventilated double-row storage structure with asbestos roof was the best for big farmers and traders because of its high capacity and low spoilage. The varietal difference among cultivars for mould infection up to 90 days after storage (DAS) was significant. Arka Kalyan and Arka Pitamber showed less severity $(<10 \%)$ of black mould (Aspergillus niger) till 30 DAS. Arka Kalyan remained absolutely free from blue mould (Penicillium digitatum) up to 15 DAS, and severity was up to $20 \%$ at 90 DAS, and Arka Pitambar withstood blue mould severity up to $20 \%$ till 75 DAS (Naik et al., 2008).

\section{Cold storage}

Although, innovations in the ambient storage designs have been made, there are certain limitations (Lawande and Murkute, 2011) with them. 
(i) They are vulnerable to climatic conditions, being not fully protected, and thus at least $20-25 \%$ post-harvest losses are inevitable

(ii) The losses are huge in coastal and hot-humid zones

(iii) Air circulation and humidity cannot be controlled

(iv) The capacity of the structures is only up to 100 tonnes

(v) Quality deterioration hampers export

(vi) These structures have trivial impact on supply chain and price stabilization

Use of cold storage for reducing post-harvest losses has been found a suitable alternative to ambient storage structures (Albert et al., 1979). About $70 \%$ of the bulbs stored at $1-2^{\circ} \mathrm{C}$ and $55-70 \% \mathrm{RH}$ were marketable as compared to $51 \%$ bulbs stored at the room temperature. In cold storage, roots may grow, but rot incidence was managed, particularly at $0^{\circ} \mathrm{C}$ (Iglesias et al., 1987). The severity of the rot increased with time in cold storage. The healthiest samples were those which had been air-dried for the longest time. Bulbs air-dried for 30-60 days before cold storage showed less weight loss than those without drying (Lee, 1984). The bulbs stored under cold conditions $\left(-1\right.$ to $\left.-3^{\circ} \mathrm{C}, 70-80 \% \mathrm{RH}\right)$ in trays had lower losses than those in the wooden boxes up to seven months (Pirov, 2000).

Sprouting is delayed as a response to physiological and cellular effects of low temperature. Optimum temperature $\left(-1\right.$ to $\left.0^{\circ} \mathrm{C}\right)$ and relative humidity $(65$ to $70 \%)$ are required for long-term storage (6 to 8 months) (Benkeblia, 2003). For maximum storage period and minimum losses in low temperature storage, the bulbs should be fully mature at harvest and dried until neck of the bulb is tight (Opara, 2003). The store should be properly ventilated to provide required temperature and humidity without inducing condensation of water on the surface of the bulbs. Excessive humidity in stores promote root development and rotting, while higher temperature and relative humidity lead to sprouting and development of pathological disorders (Opara 2003).

Controlled Atmosphere (CA) storage, wherein air composition of $\mathrm{CO}_{2}$ and $\mathrm{O}_{2}$ is altered using $\mathrm{N}_{2}$, has also been advocated to extend storage life of onions. $\mathrm{CA}$ storage increased pungency characteristics of cultivars (Opara, 2003). Uddin and MacTavish (2003) and Chope et al. (2007b) reported reduction in pungency in CA storage. A consumer, however, may not be able to perceive the difference, as human sensitivity ranges from 1 to $7 \mu \mathrm{mol}$. The optimum condition for storage was found to be $2 \% \mathrm{O}_{2}$ and $98 \% \mathrm{~N}_{2}$ with temperature ranging between -1 and $-3^{\circ} \mathrm{C}$, and optimum air humidity from 80 to $98 \%$. As the concentration of $\mathrm{CO}_{2}$ in the atmosphere increased from 5 to $10 \%$, incidence of physiological disorders and damage caused by Botrytis allii increased (Magomedov, 2006). Under CA storage (2-4\% $\mathrm{O}_{2}$ and $0-5 \% \mathrm{CO}_{2}$, with a relative humidity of $86-92 \%$ ), bulbs can be stored with minimum losses for 8 months. $\mathrm{CA}$ at $1 \% \mathrm{O}_{2}$ and $5 \% \mathrm{CO}_{2}$, temperature set to $2 \pm 1^{\circ} \mathrm{C}$ and $\mathrm{RH} 52$ to $87 \%$ was found superior over regular atmosphere (RA) $2 \pm 1{ }^{\circ} \mathrm{C}$, with a $\mathrm{RH}$ ranging from 58 to $75 \%$ (Poldma et al., 2012). For all cultivars, bulb dry matter and soluble solids content were higher in CA conditions compared to regular atmosphere (RA) storage. 


\section{Physiology and biochemistry}

Post-harvest losses due to weight loss and sprouting have been attributed to physiological processes that occur over the storage period. The alterations in the processes are natural phenomena owing to prevalent biotic and abiotic factors. TSS decreased sharply between 6 and 10 weeks storage kept at room temperature, but it was slight in cold stored bulbs. Pyruvic acid decreased in cold storage bulbs between 13 and 17 weeks, but did not vary at room temperature (Albert and Cuquerella, 1979). Reducing sugars, total soluble sugars and ascorbic acid contents decreased with increased storage temperatures in all cultivars (Iglesias et al., 1987). Furanui was more resistant to freezing than Kitamiki owing to high soluble solids content (Tanaka et al., 1987). Thus storage temperature affects storability by altering physico-chemical processes. Decreased peroxidase enzyme activity coincided with sprouting (Benkeblia, 2000), which was delayed in onions grown at low nitrogen supply or harvested in dry soil (Sorensen and Grevsen, 2001). Higher storage potential of light-red colour variety (cv. N 2-4-1) over dark red (Baswant 780 and Agrifound Dark Red) and white coloured (Phule Safed) varieties (Tripathi and Lawande, 2010) substantiate role of biochemical attributes interlinked with physiological processes. Biochemical properties are affected by environmental factors and have manifested differential role in storage. Therefore, scoring them as markers could be useful to assess shelf-life.

The results indicated that later the onions are harvested, lower is the content of almost all free amino acids (FAA) in the dry matter. These differences in FAA are maintained throughout in a long-term storage (Hansen, 2001). Although, the amounts of quercetin 4'-monoglucoside increased during field curing, there was no significant change in it during 5 months storage at $0^{\circ} \mathrm{C}$ and $90 \% \mathrm{RH}$ (Mogren et al., 2005). Total soluble sugars (glucose, fructose and sucrose) did not vary significantly during storage at $20^{\circ} \mathrm{C}$, but increased slightly at $4^{\circ} \mathrm{C}$ (Park et al., 2006).

Among the three major causes of post-harvest losses, sprouting, has been considered the most difficult to control. The phenomenon of sprouting after a phase of dormancy is attributed to complex physiological processes. Normally, sprouting during storage is characterized by specific changes in the development and it may be possible to extend storage duration if biochemical changes involved in the dormancy are determined (Benkeblia et al., 2002). Abscisic acid (ABA), a growth inhibitor, (Thomas and Isenberg, 1972) is believed to be associated with the dormancy of onion-bulbs (Matsubara and Kimura, 1991). Sprouting in dormant cultivar could be delayed by 35 days by soaking bulbs in $10^{-5} \mathrm{M}$ ABA aqueous solution two weeks after harvest, and $10^{-4} \mathrm{MABA}$ was required to delay sprouting in non-dormant cultivars (Yamazaki et al., 1999). The post-harvest concentration of ABA in the basal bulb sheath was found positively correlated with the number of days to sprouting in A. wakeigi Araki L. a cross between Japanese bunching onion and shallot (Yamazaki et al., 2002). ABA levels in onion-bulbs (Allium сера $\mathrm{cv}$. Sochaczewska) at harvest, after curing, and during storage were affected by growing season and bulb maturity at the harvest. On an average, highest level was recorded during storage for bulbs that were grown when lowest temperature and favourable rainfall distribution prevailed. Significantly higher ABA was 
recorded for bulbs that did not mature (90 and $50 \%$ green foliage). ABA level changed in bulbs during storage affected by weather conditions but not by bulb maturity at the harvest (Kielak et al., 2006). Chope and Terry (2008) reported bulb ABA concentration declined during storage in all cultivars with the same pattern irrespective of the initial ABA concentration (initial ABA concentration in short-storing bulbs was 2.5 -fold lesser than in long-storing bulbs). Also, storage potential of different onion cultivars was inversely related to time at which they reached a minimal ABA concentration (ca 50-120 ng/g DW).

The principal biological factor leading to onion-bulb deterioration is respiration, which increases with storage time (Benkeblia, 2004a; Chope et al., 2006). Weight loss due to water loss is a function of storage temperature and relative humidity. At high temperature and low relative humidity during storage, weight loss increases (Sidhu, 2008). Biochemical changes during storage are probably linked with respiration. A gradual change in relative composition of growth regulators occurs as the concentration of growth promoters or inhibitors rise or fall, respectively (Chope et al., 2006). $\mathrm{Q}_{10}$ coefficient was found higher at low temperature range but low at higher temperature range. The heat production was also high at higher storage temperature (Tripathi and Lawande, 2010). Onions are regarded as nonclimacteric (absence of an autocatalytic ethylene burst during ripening) with continuously low endogenous ethylene production $\left(<0.1 \mu \mathrm{L} / \mathrm{kg} / \mathrm{hr}\right.$ at $\left.0-5^{\circ} \mathrm{C}\right)$ during storage (Suslow 1998). Respiration rate of the bulb increased immediately after being treated with ethylene but to a lesser extent or not at all when treated with ethylene-binding inhibitor, 1-MCP (Downes et al., 2010).

An increased sucrose concentration acts as a trigger for release from dormancy and onset of sprouting (Benkeblia et al., 2005; Chope et al., 2007b), and metabolism of sucrose into glucose and fructose is largely temperature dependent (Benkeblia et al., 2004a; Chope et al., 2007b). A cultivar having higher fructans concentration, i.e. fructose, glucose and sucrose and a series of oligosaccharides, possesses higher storability (Chope et al., 2006). Fructo-oligosaccharides (FOS) hydrolysis is temperature independent, and storage time has more effect on higher degree of polymerization (DP) FOS than on lower DP FOS. Hydrolysis percentage of FOS was higher at $20^{\circ} \mathrm{C}$ than at $10^{\circ} \mathrm{C}$; and ranged from 47 to $58 \%$ at $10^{\circ} \mathrm{C}$, from 63 to $68 \%$ at $15^{\circ} \mathrm{C}$ and from 74 to $83 \%$ at $20^{\circ} \mathrm{C}$. This indicates that high DP FOS has shorter longevity than low DP FOS (Benkeblia et al., 2007). Field curing after lifting, leaving onions for about ten days in windrows on the field, significantly increased flavonoids without effecting onion dry weight in the edible part (Mogren et al., 2008). The decrease in sugar concentration coincided with increased sprout length; energy is required for sprout growing (Chope et al. 2007b).

Fructose concentrations of onions treated with ethylene or 1-MCP before curing were not significantly different, however, after curing concentrations were 2-fold higher compared with the control. Inhibition of sprout growth can be achieved using just a short $24 \mathrm{hr}$ treatment with ethylene or 1-MCP. However, skin thickness or permeability, which is dependent on cultivar and curing, may affect ethylene or 1-MCP influx, and therefore efficacy of sprout suppressant action (Downes et al., 2010). The discrimination for vulnerability of white onion over red onion to high rotting incidence has been attributed to the absence of anthocyanins and 
phenolic contents (Sidhu, 2008). Total antioxidant capacity increased with four months of ambient temperature and ventilated storage in Pusa White Round and Pusa Red (Patil et al., 2012).

\section{Processing and value-addition}

The changing contemporary life-style demands availability of fast food alternatives without compromising freshness and sacrifice of nutrient quality. Processing is a way to add value to the product without altering quality. Different methods of processing have been devised to suit a range of applications and needs. It is important to choose appropriate method based on the requirement.

\section{Minimally processed onion}

Minimally processed vegetables are defined as vegetables that are altered physically from its original form, yet retaining freshness. Pre-sliced fresh onions are most preferred by consumers who desire a healthy life-style and have a little time for food preparation (Brice et al., 1995) (Fig.15.2). Undesirable physiological changes (increase in respiration, etc.) occur due to minimal processing, which shortens shelf-life of minimally processed onions. Different techniques are used for increasing shelf-life. Modified atmosphere packaging (MAP) storage and controlled atmosphere (CA) storage with or without different pretreatments augment storage-life and maintain physical and nutritional characteristics of the minimally processed onions. $\mathrm{CO}_{2}$-enriched atmosphere delays onion deterioration and microbial development, particularly psychrotroph flora; $2 \% \mathrm{O}_{2} / 10 \% \mathrm{CO}_{2}$ enriched atmosphere is optimal to maintain sensory quality of diced onions (Blanchard et al., 1996). Microbial proliferation and sensory quality aspects of sliced onions (0.7-cm thickness) were tested by Liu and Li (2006) in low density polyethylene (LDPE of $30 \mu \mathrm{m}$ ) packages. Microbial shelf-life of the tested onions at 2, 4 and $10^{\circ} \mathrm{C}$ was 12,9 and 6 days, respectively, and their sensory shelf-lives were 10.5, 7 and 5 days, respectively. Different disinfectants are used to sterilize cut onions before packaging to increase shelf-life. But, it is reported that flavonoids in onions decrease by chemical disinfectant (sodium hypochlorite, amukine, hydrogen peroxide, and sodium dichloroisocyanate) due to solubility of flavonoids in immersion water. UV-C irradiation not only maintains initial flavonoid levels but also increases their levels (Perez-Gregorio et al., 2011a). Ferrer et al. (1996) studied impact of perforated films on flavonoids of shredded onions after 7 days of storage at $8^{\circ} \mathrm{C}$. The malonated anthocyanins were more stable than corresponding non-acylated pigments. The arabinosides were less stable than corresponding glucosides. Keeping potassium permanganate and activated alumina based absorbent in the diced onions package reduced ethylene, sulphur volatiles and carbon dioxide. Acceptable quality of diced onions can be kept for 10 days at $2{ }^{\circ} \mathrm{C}$ using this absorbent (Howard et al., 1994). With awareness for health concerns regarding the chemicals used to preserve quality of cut-onions, new alternatives have been studied in the recent years to find effective and environment-friendly processing techniques to ensure safety and to preserve quality. Mild heat treatment is one of the new techniques used to increase quality and firmness of sliced onions. Pre-storage heat treatment at $55^{\circ} \mathrm{C}$ for 2 min along with controlled atmosphere 


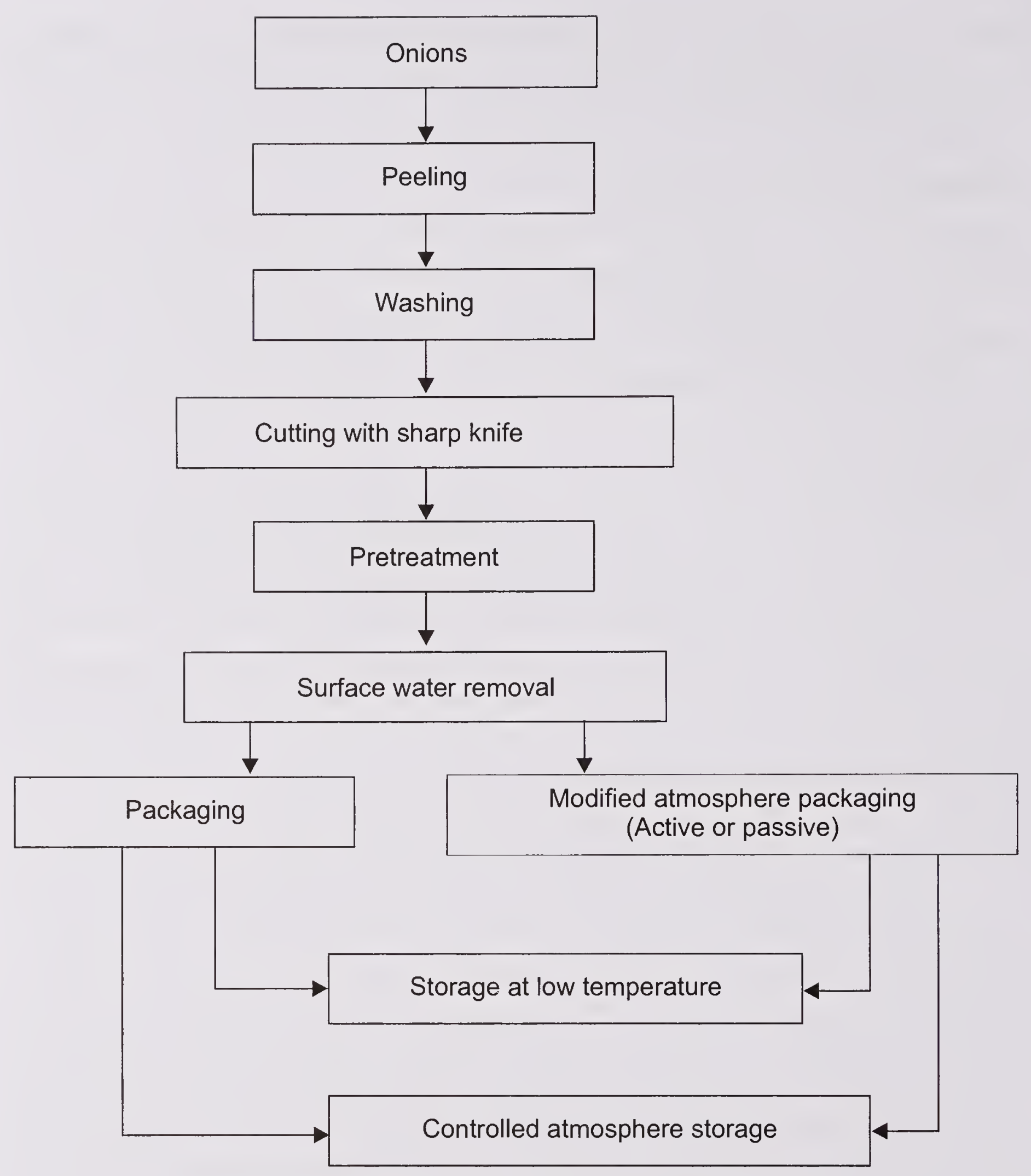

Fig. 15.2 Preparation of minimally processed onions

(CA) would increase shelf-life of minimally processed green onions to more than two weeks while stored at $5^{\circ} \mathrm{C}$. Heat treatment also controls 'telescoping' of green cut-onions (Hong et al., 2000). Onion slices can be heat treated at $50^{\circ} \mathrm{C}$ to preserve successfully antioxidant properties and colour quality for 21 days when they are to be stored storing at $4^{\circ} \mathrm{C}$ (Siddiq et al., 2013).

\section{Dehydrated onion and onion powder}

Dehydration is the oldest method of food preservation practised by mankind. It is for producing concentrated product, which would have longer shelf-life when packaged properly, and can be simply reconstituted without any substantial loss of flavour, taste, colour and aroma. Onions are generally dried from an initial moisture content of about $86 \%$ (wet basis) to $7 \%$ or less for efficient storage and processing (Sarsavadia et al., 1999). Removing moisture to this level decreases bulk to transport and also increases shelf-life. As free water is not available, 
microbial growth also is arrested on the product. Osmotic pressure exerted by the concentration of sugars and organic acids further inhibit microorganisms (Mitra et al., 2012). Different methods used for dehydration of onion are solar-drying, convective air-drying, freeze-drying, fluidized bed drying, microwave drying, vacuum drying, infrared drying and osmotic dehydration. All onion varieties are not suitable for dehydration. Specific characteristics recommended for drying are-white coloured flesh, 15-20\% total solid content, high pungency, high insoluble solids and low reducing to non-reducing sugars ratio (Mitra et al., 2012). (Fig. 15.3).

Solar-drying is the simple and low-cost drying method but due to the problem of insufficient, irregular sunshine and lack of sanitation, convection drying is used in commercial dehydration of onions (Sharma et al., 2005a). Convective drying of onions at $30^{\circ} \mathrm{C}, 50^{\circ} \mathrm{C}$ and $60^{\circ} \mathrm{C}$ has no effect on chemical components

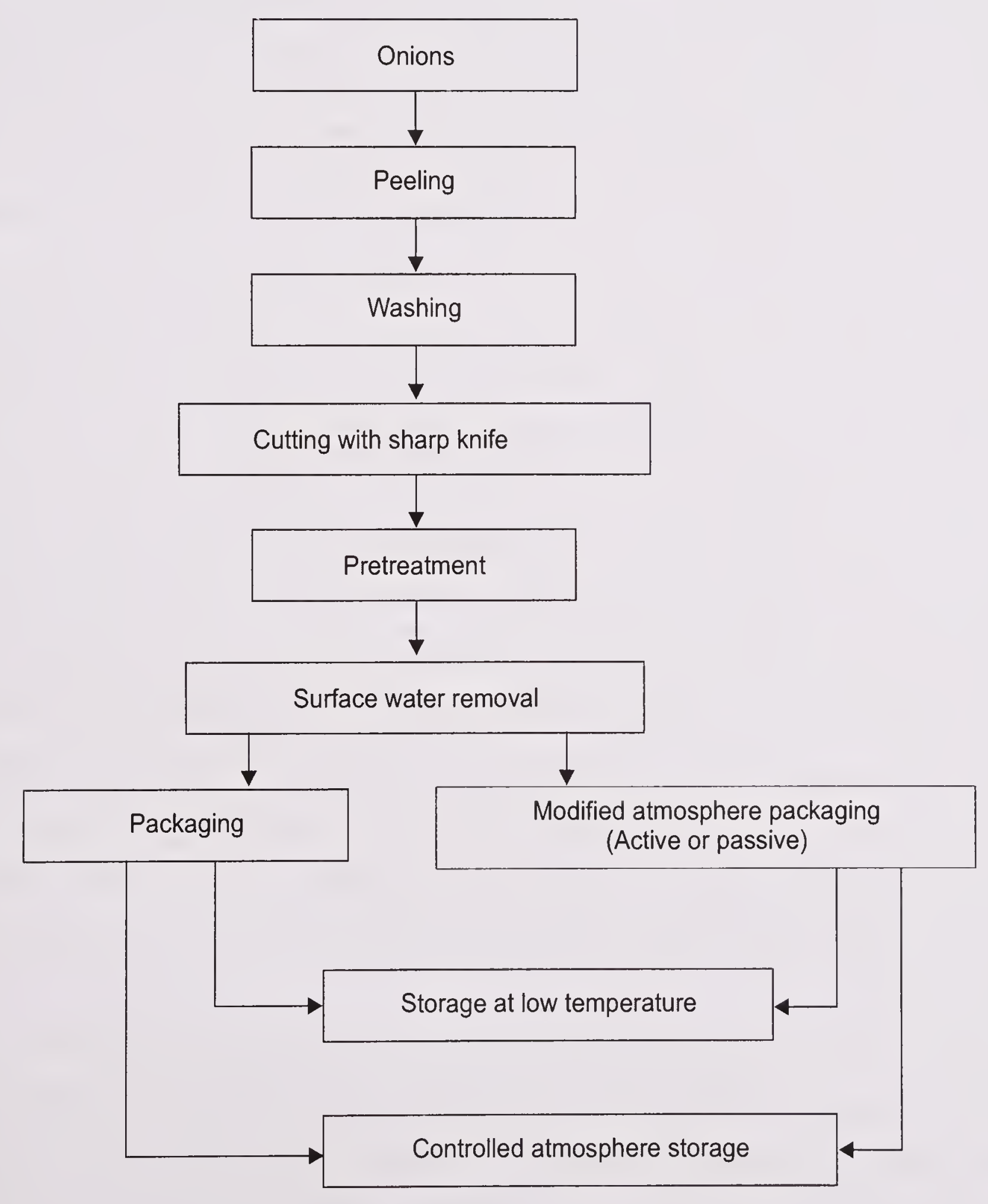

Fig.15.3 Preparation of dehydrated onion and onion powder Source: Anonymous (2013c) 
like ash, fat, protein and fibre; but sugars, acidity and vitamin $\mathrm{C}$ are influenced considerably by drying (Motaa et al., 2010). Freeze-drying increases extraction levels of total flavonols and anthocyanins, up to $32 \%$ and $25 \%$, respectively, due to change in tissue structure. All flavonoids in freeze-dried onion powder are stable up to 6 months when stored in water-tight glass bottles at room temperature in dark (Perez-Gregorio et al., 2011b). Vacuum drying gives higher drying rate, lower drying temperature and an oxygen-deficient processing environment compared to conventional methods (Wu et al., 2007; Mitra et al., 2011). There is heavy loss of thermal energy during convective drying. So an alternative has come in the form of infrared radiation (IR) drying. In IR drying, higher drying rate gives significant energy saving, and uniform temperature distribution gives better quality product (Mongpraneet et al., 2002). During IR drying, material is dried directly by absorption of IR energy. When IR is used to heat or to dry moist materials, radiation impinges on the exposed material surface, penetrates it, and energy of radiation converts into heat. Increase in infrared power at a given air temperature and velocity reduces drying time. With increased air velocity at a given infrared power and air temperature, there would be a cooling effects at the product surface; it would lead to increase in drying time (Sharma et al., 2005b). Combined electromagnetic radiation and hot-air heating is more efficient than radiation or hot-air heating alone because of their synergistic effects (Pathare and Sharma, 2006). Colour and flavour are two most important quality attributes of the dried onions. Non-enzymatic browning reaction and loss in pungency are dominating factors in quality deterioration during drying and storage. Drying conditions are to be optimized to retain maximum product quality along with process economics (Praveen Kumar et al., 2006). To reduce discolouration and browning during drying, the ratio of reducing to non-reducing sugars should be low (Mitra et al., 2012). Maximum browning in the heated onion slices occurs in the range of 0.60-0.70 water activity (Rapusas and Driscoll, 1995). Colour, flavour and texture of the fruits and vegetables can be improved by giving osmotic pretreatment prior to drying. Osmotic dehydration is the process of water removal. by immersion of water containing cellular solids in a concentrated aqueous solution during which simultaneous solid gain also takes place. Difference in the osmotic pressure between the food and its surrounding solution causes water removal, which depends upon the solution concentration, immersion time and solution temperature, sample to solution ratio and agitation or circulation of the osmotic solution. Optimum condition for osmotic dehydration for further drying of onion slices is $20 \%$ salt concentration, $28^{\circ} \mathrm{C}$ solution temperature and $1 \mathrm{hr}$ of osmosis (Sutar and Gupta, 2007).

Onion powder is a product prepared from dehydrated onions by grinding them to obtain a free-flowing powder. Onion-flakes prepared from above mentioned different methods are grounded into fine powder by using different mills to produce onion powder. Onion powder belongs to a class of food powders that are highly hygroscopic. For processing and packaging of dehydrated foods, moistureabsorption data give useful guidance. The monolayer moisture contents (moisturefree basis), corresponding to Brunauer Emmett Teller (BET) theory, which are considered as the safe minimum levels in onion powder are 2.09, 1.96 and 1.94\%, 
for freeze-dried, vacuum shelf-dried and thorough flow-dried onion powders, respectively (Debnatha et al., 2002). Onions have a characteristic taste and odour because of which many people don't like to consume them although being rich in nutrition. Hui (2004) in their published patent described a process to produce onion powder without characteristic taste and odour. This process involves freezing onions at $-20^{\circ} \mathrm{C}$ for about $24 \mathrm{hr}$ without peeling outer skin,then peeling and cutting quickly into a predetermined size, drying at $60^{\circ} \mathrm{C}$ for about $24 \mathrm{hr}$ in a drier and then grinding to 70 meshes or less.

\section{Onion paste}

Onion is one of the main ingredients in every curry preparation of Indian households. With the surge in number of working couples, people prefer to spend less and less time for food preparation. Availability of onions in the form of readyto-use paste would curtail inconvenient process of cutting onions, and thereby reduce total time for food preparation. Onion paste is convenient to use. It is a semi-solid product which retains original colour and flavour of onions (Ahmed and Shivhare, 2001). Preparation of onion paste is a simple process, but it entails proper packaging and storage conditions to retain its colour, flavour besides microbial safety.

\section{Onion pickle}

Our ancestors have explored pickling process to preserve surplus food supplies for long winters, famine and other times of need. It is a global culinary art. Pickles add a special taste to many snacks and meals. Pickles are foods soaked in different solutions that prevent spoilage. The solutions change taste and texture besides preserving foods (Fig.15.4).

In general, pickling is done in two ways, i.e., pickling in vinegar in which a few bacteria can survive because of strong acid, and pickles soaked in salt brine allowing fermentation. Fermentation encourages growth of "good" bacteria that make food less vulnerable to "bad" spoilage-causing bacteria (Anonymous, 2013a). Maintaining proper acidity is important in pickling to contain growth of microorganisms.

\section{Onion vinegar}

Onions are considered to be a promising source of vinegar as they are rich in sugar and many nutrients (Horiuchi et al., 1999). Horiuchi (2000) described an effective onion vinegar production fermentation system by a two-step fermentation system. Fu and Dong (2011a) reported a new method of vinegar production from onions (Fig.15.5). Horiuchi et al. (2004) developed a biological approach combining vinegar fermentation and composting to allow both value-addition and effective reuse of commercially unmarketable onions, i.e., pressing of onions in a mechanical juicer to give onion juice $(60 \mathrm{wt} \%)$ and onion residues (40 wt $\%$ ). The juice can be converted to onion vinegar by a two-step fermentation system. The onion residue is then utilized as a source of composting;this happens within a week. 


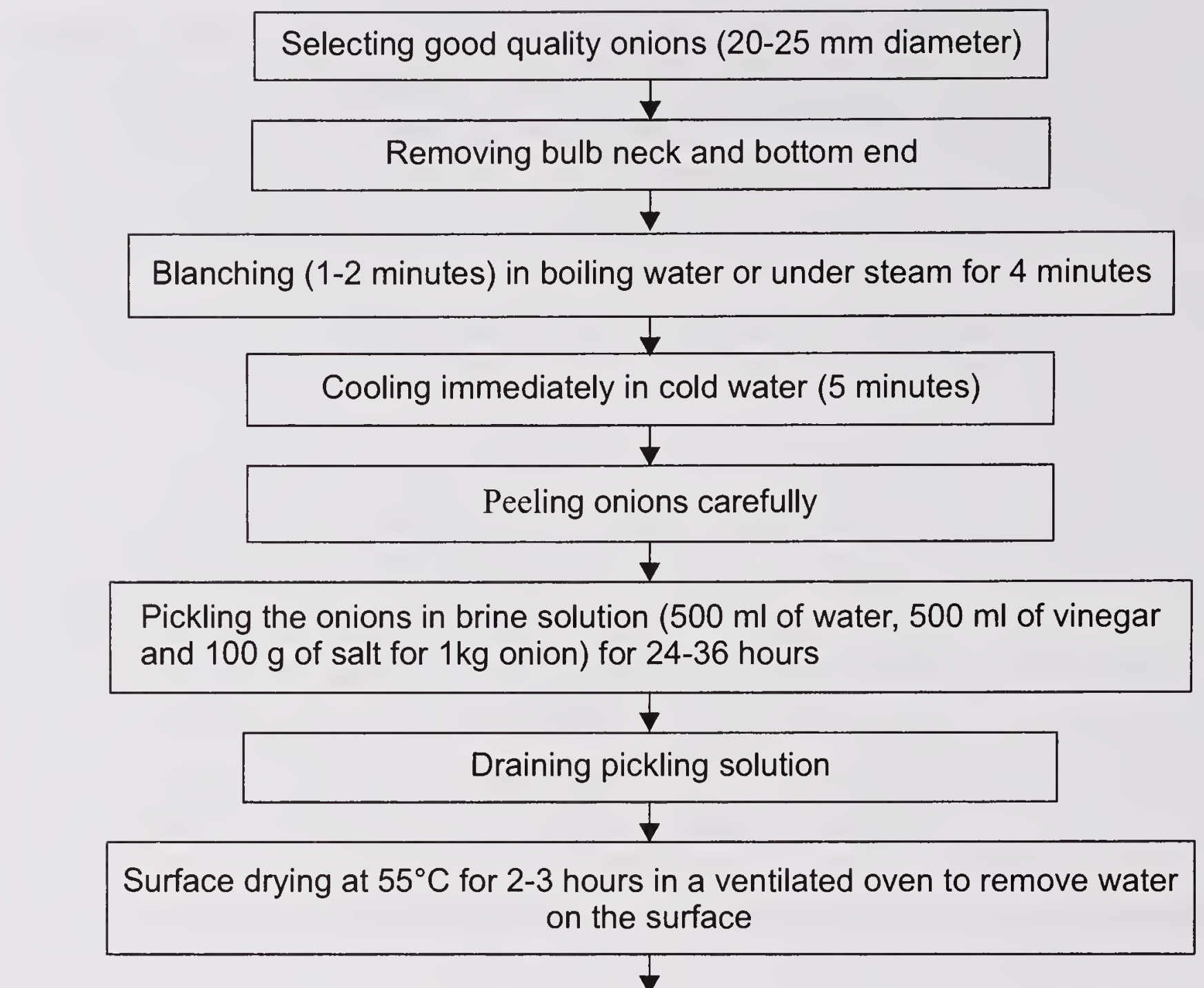

Mixing spices* with a little amount of oil and mixing it with the onions ( ${ }^{\star}$ For $1 \mathrm{~kg}$ of fermented onion $16 \mathrm{~g}$ of mustard, $13 \mathrm{~g}$ of turmeric powder, $25 \mathrm{~g}$ of sugar, $30 \mathrm{~g}$ of garlic paste, $15 \mathrm{~g}$ of chilli powder, $0.7 \mathrm{~g}$ of roasted fenugreek (methi), $300 \mathrm{ml}$ of oil

Filling the pre-sterilized jars with oil up to $1 / 5$ to of its volume and then adding the above mixture to jars containing oil, pressing the onions slightly to the bottom with the help of a spatula to eliminate air pockets

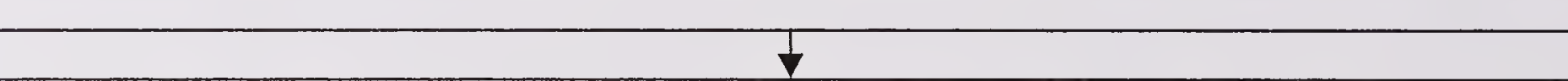

Covering onions with a thin layer of oil, leaving a headspace of $5-10 \mathrm{~mm}$

Pasteurizing the product pasteurizer for 10 minutes at $85^{\circ} \mathrm{C}$ or in boiling water for 10 minutes (Place the jars in water at $70^{\circ} \mathrm{C}$ to avoid cracking)

Cooling to ambient temperature and labelling

Fig.15.4 Onion pickle preparation Source: Anonymous (2013c)

\section{Onion oil}

It is the concentrated oil of dark-amber colour obtained by distillation of minced onions. Oil yield varies from 0.002 to $0.03 \%$ (Lawande, 2001). Onion oil can be used for imparting onion flavour to processed food without difficulty of handling a large bulk of fresh bulbs. Onion oil is also used in non-alcoholic beverages, icecreams, confectionery, baked goods, condiments, meats and pickles (Lawande, 2001). Since the last 50 years, protection of food from spoilers and pathogens has aroused a great interest, and it could be achieved by various physical and chemical 


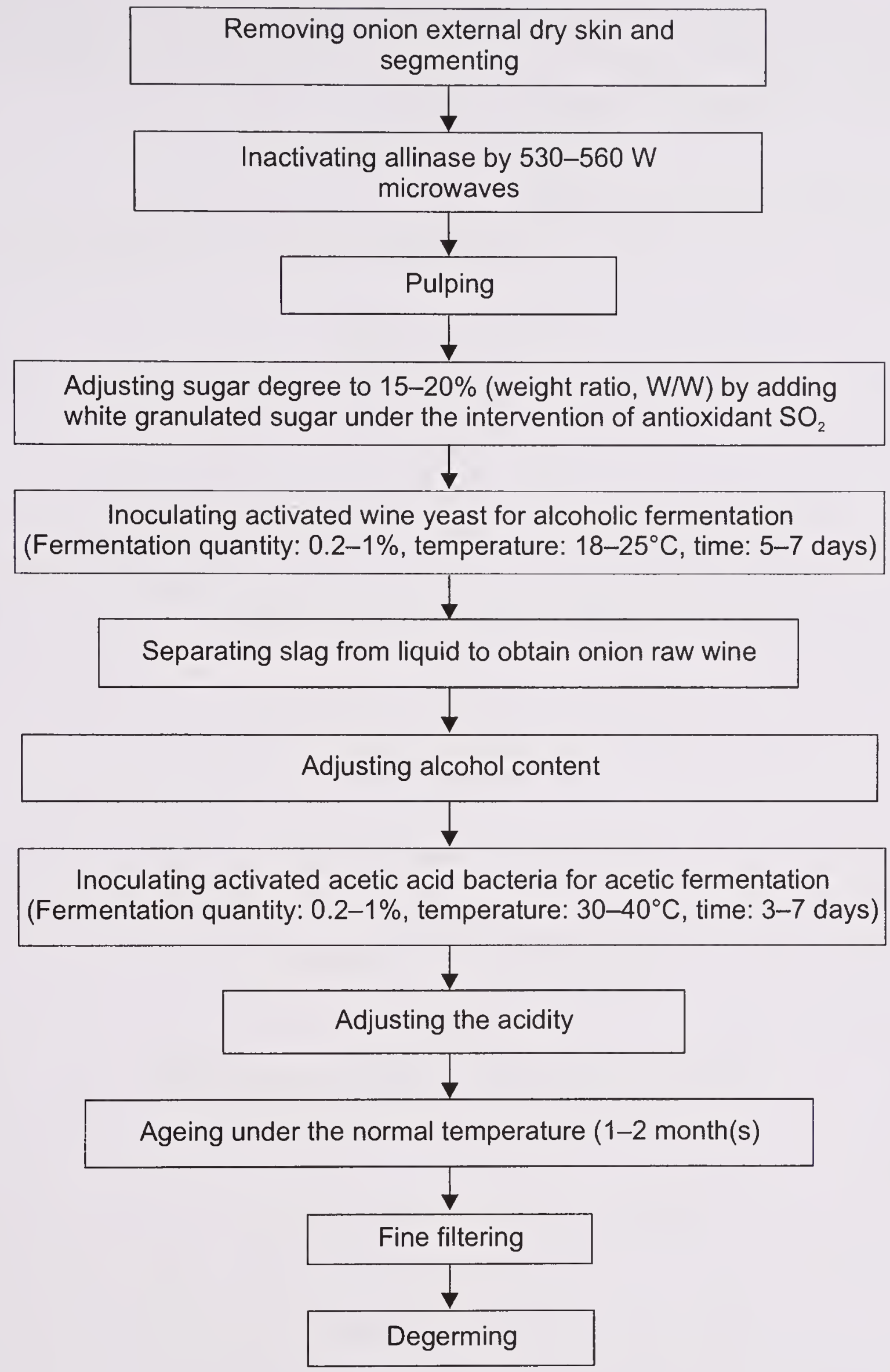

Fig.15.5 Onion vinegar preparation Source: Fu and Dong (2011a)

methods (Benkeblia, 2004b). Use of onion oil is one of the natural ways of controlling pathogens. Ye (2013) tested essential oil of Allium cepa against food spoilage and food-borne pathogenic microorganisms and its antioxidant activity. A. cepa essential oil has antimicrobial effect against tested microorganisms with minimum inhibitory concentration (MIC) and minimum bactericidal concentration (MBC) values in the range of $0.18-1.80 \mathrm{mg} / \mathrm{ml}$ and $0.54-3.6 \mathrm{mg} / \mathrm{ml}$, respectively. A method for extraction of onion oil has been developed, which has advantages of no residues, strong selectivity, less effective component destruction, simple 
and easy operation, easy reclamation of reflux extracted solvent, higher yield of oil of stable quality and high output, is time saving, with less solvent use and lower energy consumption (Dai et al., 2010).

\section{Other processed products of onion}

As onion is rich in nutrition, consumption of onion as beverage is another best way of adding onion nutrition to human body. Onion has better health benefits

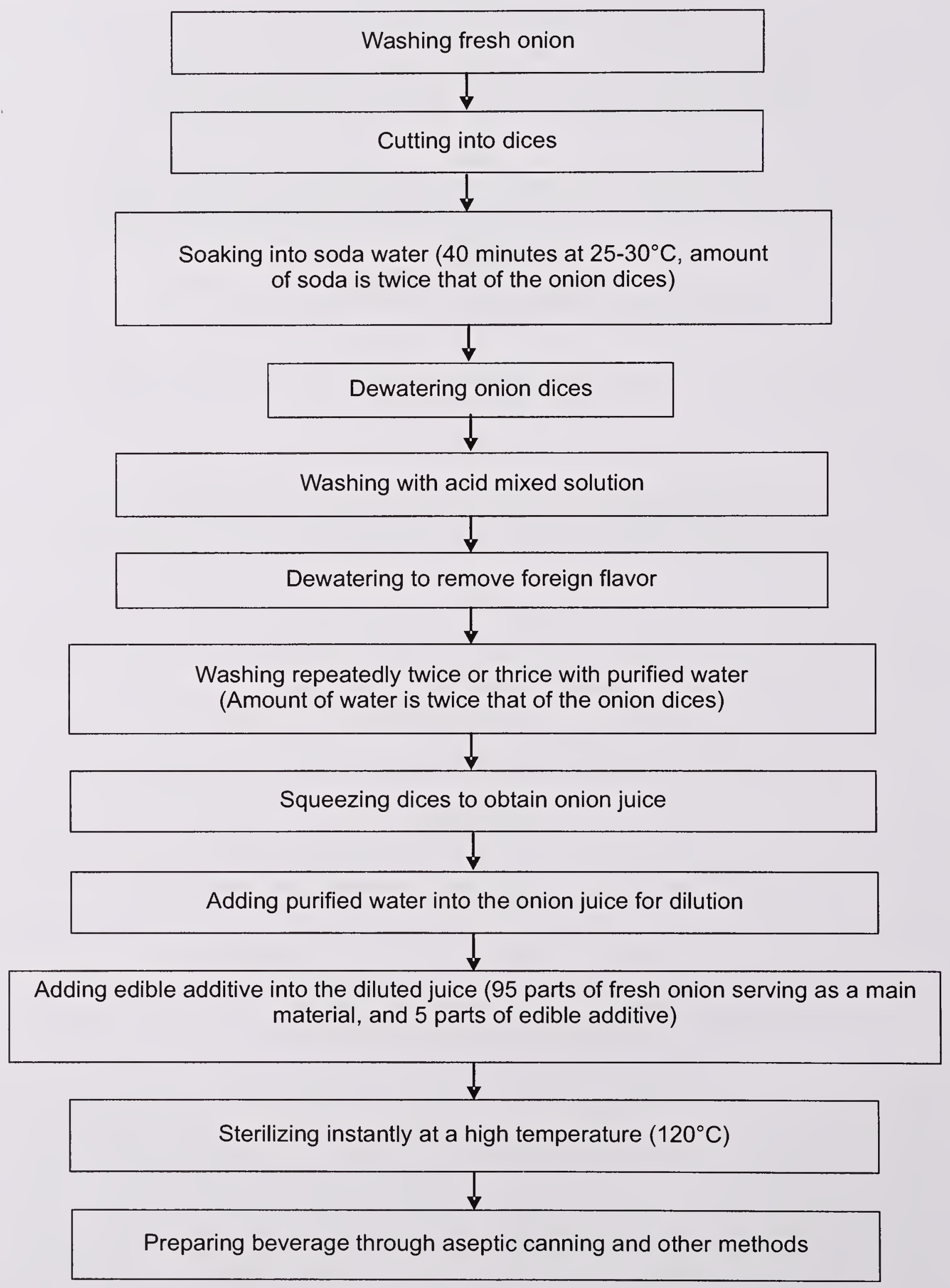

Fig.15.6 Preparation of onion-juice beverage Source: Zhang (2010) 


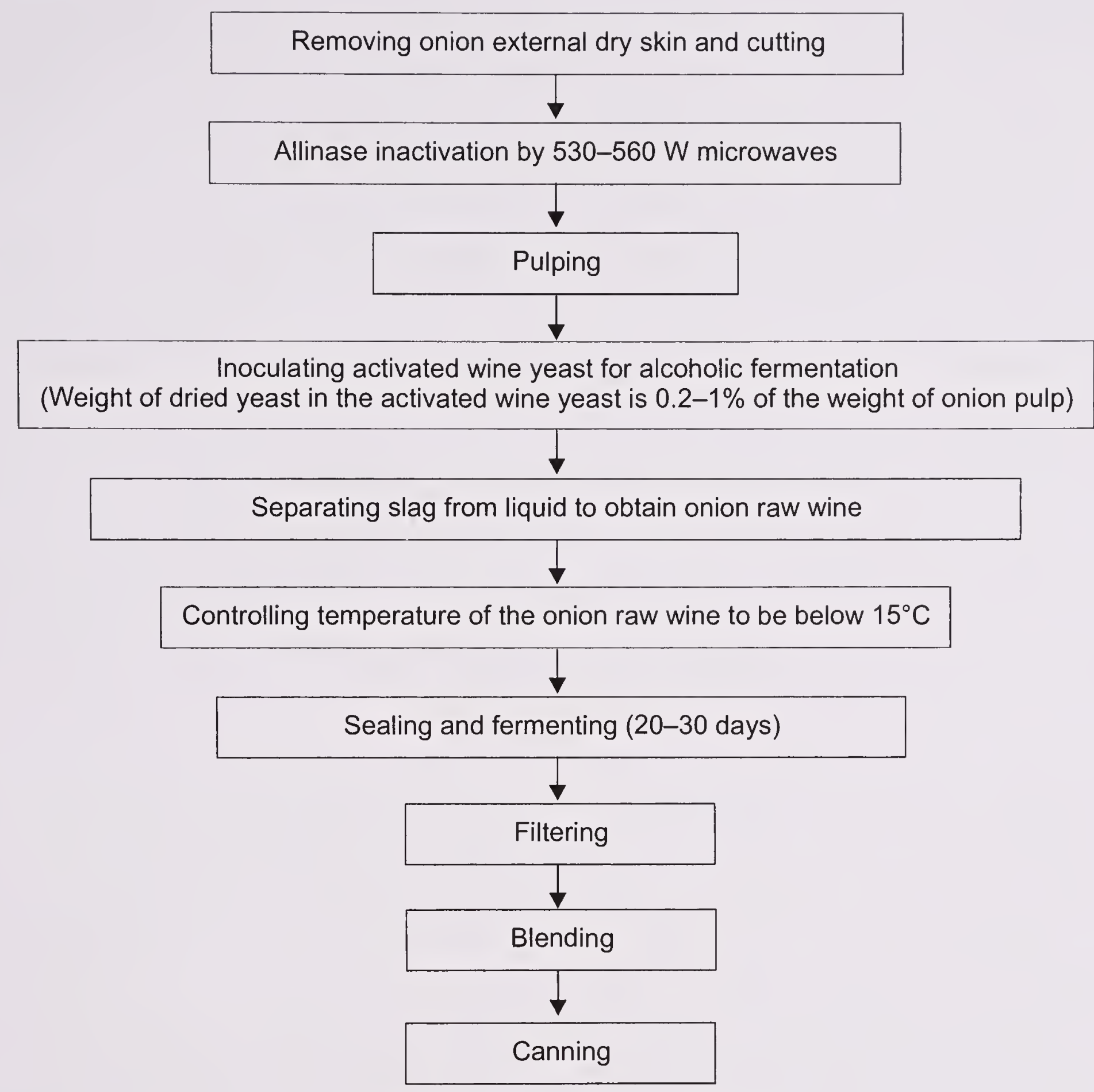

Fig. 15.7 Preparation of onion wine Source: Fu and Dong (2011b)

and healing powers. Onion juice is anti-inflammatory, blood thinner, lowers risk of blood clots, protects against lung and breast cancer, and gets rid of excess mucus from body (Anonymous, 2013b) (Fig.15.6).

Onion can be processed into onion wine through fermentation. Different fermentation parameters-time, temperature and initial sugar content-affect physicochemical and sensory properties of wine. The optimum fermentation conditions of time, temperature and initial sugar content for better alcoholic content and overall palatability of onion wine are $80-90 \mathrm{hr}, 28-32^{\circ} \mathrm{C}$ and $20-25^{\circ} \mathrm{Brix}$, respectively (Choi et al., 2013) (Fig.15.7).

In general, onion is used as one of the ingredients in the preparation of different sauces. Onion sauce is another promising processed product, which has gained popularity. Sauces can be liquid or semi-fluid, and are sometimes heterogeneous in texture with solid morsels. They often accompany dishes with little marked sensory properties such as starchy products (Avallone et al., 2008). The most well-known of all the commercially available sweet onion sauces are manufactured by Marathon Enterprises, Inc., of Englewood, N.J., under the brand SABRETT®. While 


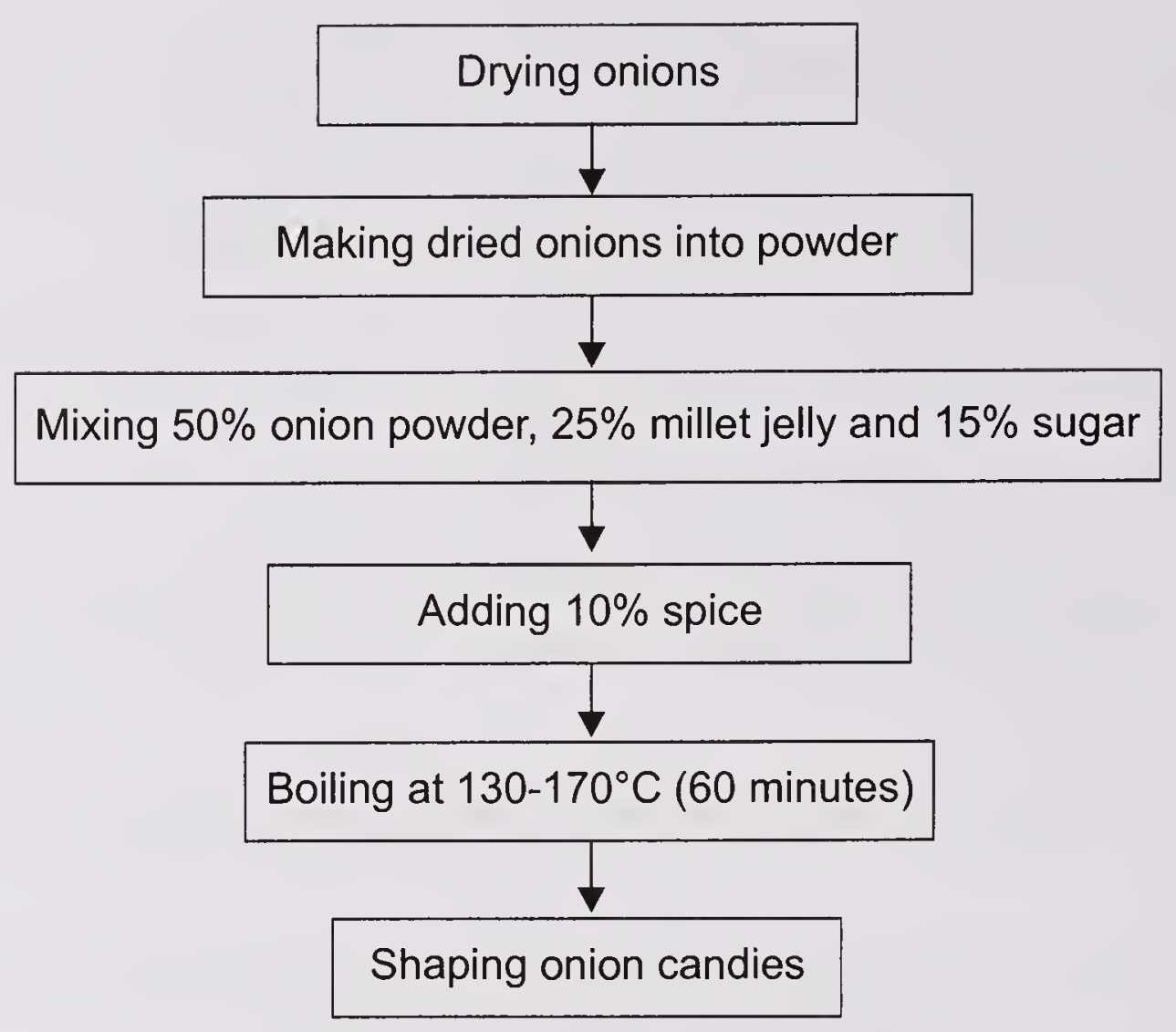

Fig.15.8 Preparation of onion -candy Source: Bork (2000)

SABRETT sweet onion sauce does very well commercially, due to its frequent packaging with a more potent hot dog, its ingredients include a significant number of chemicals (i.e. preservatives, etc.), which lead to an undesirable flavour. Joseph (2013) has developed an improved process for developing sweet onion sauce.

Onion rings is a snack product, which is an excellent appetizer and side dish. Most of the processes for the preparation of onion rings involve deep frying in oil. Because of the high oil content, consumers who are health-conscious prefer to take lesser of this. So, the new processes for the preparation of healthy onion rings by baking instead of deep frying have been evolved. Candy is the most preferred product by children. Making onion available in the form of candy would improve nutritional status of the children. Bork (2000) has developed a process for preparation of onion candy (Fig.15.8)

\section{Future Thrust}

Cultivar colour, TSS and other biochemical attributes have enormous role in storage potential of onions. By understanding mechanism of physiological processes vis-à-vis biochemical reactions, it would be easy to manage these processes towards increasing storage potential. It has been well substantiated that though physiologically onion is regarded as non-climacteric, ethylene and ethylene-binding inhibitor, 1-MCP, both can suppress onion sprouting. However, transcriptional analysis revealed that sprout suppression of onion during storage using ethylene and/or 1-MCP was mediated through differential modes of actions (Cools et al., 2011). The signal transduction pathways of both ethylene and 1MCP may unfold cascade for sprouting in onion. Further, physiological weight loss due to respiration over the period of storage is a major issue. Carbohydrate metabolism during respiration, which is a primary cause of physiological weight 
loss during storage, needs to be unraveled to provide actual insight into the complex reactions.

The pre-harvest agronomic practices-irrigation regime, fertilizer regime, application of micronutrients, diseases and insect-pests attack, harvesting indices and stage-affect onion shelf-life. Therefore, comprehensive package of practices based on agroclimatic conditions is the need of hour. Apart from pre-harvest practices, post-harvest management practices including curing and storage environment need to be standardized. Cold storage can be a viable alternative when higher cost price fluctuations in the markets are of frequent nature. Innovations in during the cold storage technology during the recent years have given an option to use cold storages for onion without irradiation. The primary R\&D endeavours have substantiated that non-irradiated onions can be stored in cold storages with appropriate ventilation facility that maintains appropriate $\mathrm{CO}_{2}$ concentration in the storage. The technology needs to be tested further for appropriate recommendations on the following operations.

- Pre-cooling temperature and schedule

- Optimum humidity with controlled effective ventilation vis-à-vis ambient temperature

- $\mathrm{CO}_{2}$ and $\mathrm{O}_{2}$ concentrations in cold storage

- Gradual cooling period after loading or conditioning

- Maximum period of storage in case of glut

- Gradual heating period before unloading or conditioning

- Re-loading temperature in case of sudden price fall in the market due to glut

Onion is one of the nutrient-affluent vegetables, which is consumed daily as an ingredient in different food products. The demand for its convenient and ready to cook or eat processed products is growing day by day. Processing of onion into different value-added processed products would lead to reduced post-harvest losses when there is a glut in the production, and would also augment value of onions and give better remuneration to farming community.

Onion storage has been found to be a multifaceted function. The innovations done in post-harvest handling and storage of onion have largely been evolved from the traditional approaches. Processing sector is limited to export. Therefore, it is high time that post-harvest handling, storage and processing of onion should be dealt with scientific and engineering dimensions. There is an urgent requirement of varieties with high storability, uniform colour, size, shape, etc. without compromising yield. Development of low-cost storage structures, preferably cold storages, would be highly valued. Entire packaging line for onions needs to be revisited to improve working efficiency. Apart from minimally processed products, powder and paste, development of blended products is also a demand of the present time.

\section{References}

Adamicki F. 2004. Methods of onion production and storage in Poland. NowosciWarzywnicze 38: 85-93. 
Adamicki F. 2005. Effects of pre-harvest treatments and storage conditions on quality and shelf-life of onions. Acta Horticulturae 688: 26-33.

Adamicki F. 2013. Internet communication. http://www.ba.ars.usda.gov/hb66/ 099onion.pdf., accessed on August 19, 2013.

Agricultural Statistics. 2012. Agricultural Statistics at a Glance 2012. Directorate of Economics and Statistics, Dept of Agriculture and Cooperation. Min of Agriculture, Govt of India.

Ahmed J and Shivhare U S. 2001. Thermal kinetics of colour degradation and storage characteristics of onion paste. Food Science and Technology 34: 380-83.

Albert A and Cuquerella J. 1979. Note on cold storage of onions, cv. Grano. Anales del Instituto Nacional de Investigaciones Agrarias, Tecnologia Agraria 5: 333-44.

Anonymous. 2013a. http://www.exploratorium.edu/cooking/pickles/pickling.html, accessed on July 15, 2013.

Anonymous. 2013b. http://www.thejuicenut.com/onion_juice__the_juice_nut.aspx, accessed on July 11, 2013.

Anonymous. 2013c. http://www.areu.mu/fruit/processing/onion\%20process.pdf, accessed on May 14, 2013.

Arboleya J E, Masabni J G, Particka M G and Zandstra B H. 2005. Identification of preharvest desiccants for use in onion production. Horticulture Technology 15: 80811.

Avallone S, Estelle-Tiemtore T W, Mouquet-Rivier C and Treche S. 2008. Nutritional value of six multi-ingredient sauces from Burkina Faso. Journal of Food Composition and Analysis 21: 553-58.

Benkeblia N. 2000. Phenylalanine ammonia-lyase, peroxidase, pyruvic acid and total phenolic variations in onion bulbs during long-term storage. Lebensmittel Wissenschaft and Technologie 33: 112-16.

Benkeblia N. 2003. Low temperature and breaking of dormancy effects on respiration rate, sugars, phenolics and peroxidase activity changes in inner buds of onion Allium cepa L Acta Agriculturae Scandinavica Section B, Soil and Plant Science 53: 16-20.

Benkeblia N. 2004a. Effect of carbamate isopropyl N-phenyl (CIP) and temperature on respiratory parameters, sprouting and rotting of onion bulb (Allium cepa L.) during storage. Vegetable Crops Research Bulletin 61: 79-89.

Benkeblia N. 2004b. Antimicrobial activity of essential oil extracts of various onions (Allium cepa) and garlic (Allium sativam). Food Science and Technology 37: 263-68.

Benkeblia N and Selselet-Attou G. 1999. Role of ethylene on sprouting of onion bulbs (Allium cepa L.) Acta Agriculturae Scandinavica Section B, Soil and Plant Science 49: 122-24.

Benkeblia N and Varoquaux P. 2003. Effects of gamma irradiation, temperature and storage time on the status of the glucose, fructose and sucrose in onion bulbs Allium cepa L. International Agrophysics 17: 1-5.

Benkeblia N, Onodera S, Yoshihira T, Kosaka S and Shiomi N. 2005. Effect of long-term storage on saccharides and fructo-oligosaccharides (FOS) of onion (Allium cepa L. cv. Tenshin) bulb. Journal of Food Technology 3: 35-40.

Benkeblia N, Shiomi N and Osaki M. 2007. Kinetics and hydrolysis parameters of total fructo-oligosaccharides of onion bulbs: effects of temperature regimes and cultivars. Journal of Food Biochemistry 31: 14-27.

Benkeblia N, Varoquaux, P, Shiomi N and Sakai H. 2002. Storage technology of onion bulbs c.v. Rouge Amposta: effects of irradiation, maleic hydrazide and carbamate isopropyl, N-phenyl (CIP) on respiration rate and carbohydrates. International Journal of Food Science and Technology 37: 169-75.

Blanchard M, Castaigne F, Willemot C and Makhlouf J. 1996. Modified atmosphere 
preservation of freshly prepared diced yellow onion. Postharvest Biology and Technology 9: 173-85.

Bork P C. 2000. Manufacturing method of onion candy. Patent publication no: KR20000017828(A).

Brice J R, Bisbrown A K J and Curd L. 1995. Onion storage trials at high ambient temperatures in the Republic of Yemen. Journal of Agricultural Engineering and Research 62: 185-92.

Brice J, Currah L, Malins A and Bancroft R. 1997. Onion Storage in the Tropics: A Practical Guide to Methods of Storage and their Selection. Chatham, UK: Natural Resources Institute. pp. 116.

Bufler G. 2009. Exogenous ethylene inhibits sprout growth in onion bulbs. Annals of Botany 103: 23-28.

Chen Q, Xi Lin H, JianJun W and XiaoHui D. 2007. Effect of exogenous abscisic acid on the dormancy of onion (Allium cepa). Journal of Nanjing Agricultural University 30: 30-33.

Choi, I, Jo D and Lee G. 2013. Monitoring of the optimum conditions for the fermentation of onion wine. Korean Journal of Food Preservation 20: 257-64.

Chope G A and Terry L A. 2008. The role of abscisic acid and ethylene in onion bulb dormancy and sprout suppression. Stewart Postharvest Review 4: 1-7.

Chope G A, Terry L A and White P J. 2006. Effect of controlled atmosphere storage on abscisic acid concentration and other biochemical attributes of onion bulbs. Postharvest Biology and Technology 39: 233-42.

Chope G A, Terry L A and White P J. 2007a. Preharvest application of exogenous abscisic acid (ABA) or an ABA analogue does not affect endogenous ABA concentration of onion bulbs. Plant Growth Regulation 52: 119-29.

Chope G A, Terry L A and White P J. 2007b. The effect of 1-methlcyclopropene (1-MCP) on the physical and biochemical characteristic of onion cv. SS1 bulbs during storage. Postharvest Biology and Technology 44: 131-40.

Cools K, Chope G A, Hammond J P, Thompson A J and Terry L A. 2011. Ethylene and 1MCP differentially regulate gene expression during onion (Allium cepa L.) sprout suppression. Plant Physiology 156: 1639-52.

Dabhi M N, Patel N C and Dhamsaniya N K. 2008. Effect of storage conditions on the quality characteristics of onion. Journal of Food Science Technology 45: 376-77.

Dai Z, Deng Z, Liao C, Ruan Z and Yin Y. 2010. Method for extracting onion oil. Patent publication no: CN101792693 (A). [Applicant: Univ Nanchang].

Debnatha S, Hemavathya J and Bhat K K. 2002. Moisture sorption studies on onion powder. Food Chemistry 78: 479-82.

Dhotre M and Allolli T B. 2012. Performance of kharif onion under the influence of nitrogen sources. Bioinfolet 9: $597-602$.

DOGR. 2012. Annual Report 2011-12. Directorate of Onion and Garlic Research, Rajgurunagar, Pune, India, pp.72.

DOGR.2013. Annual Report 2012-13. Directorate of Onion and Garlic Research, Rajgurunagar, Pune, India, pp.92.

Downes K, Chope G A and Terry L A. 2010. Postharvest application of ethylene and 1methylcyclopropene either before or after curing affects onion (Allium cepa L.) bulb quality during long term cold storage. Postharvest Biology and Technology 55: 36-44.

El-Neshawy S M, El-Korashy M, Ibrahim N A and Khalil M A. 2004. Effect of preharvest calcium applications on the incidence of onion storage rots. Egyptian Journal of Agricultural Research 82: 493-510.

Epstein S S, Andrea J, Jaffe H, Josh S, Falk H and Mantel N. 1967. Carcinogenicity of the herbicide maleic hydrazide. Nature 215: 1388-90. 
Ferrer F, Gil M I and Tomis-Barberin F A. 1996. Anthocyanins and flavonoids from shredded red onion and changes during storage in perforated films. Food Research International 29: 389-95.

Forney C F, Jordan M A, Campbell P L, Fillmore S, McRae K and Best K. 2010. Sulfur fertilization affects onion quality and flavor chemistry during storage. Acta Horticulturae 877: 163-68.

Fu P and Dong Y. 2011a. Preparation method of onion vinegar. Patent publication no: CN102154088 (A). [Applicant: Shandong Haizhibao Seafood Co Ltd].

Fu P and Dong Y. 2011b. Method for preparing onion wine. Patent publication no: CN102127504 (A). [Applicant: Shandong Haizhibao Seafood Co Ltd].

Ghoname A, Fawzy Z F, Bassiony A M, Riadand G S and Abd El-Baby M M H. 2007. Reducing onion bulbs flaking and increasing bulb yield and quality by potassium and calcium application. Australian Journal of Basic and Applied Research 1: 610-18.

Grevsen K and Sorensen J N. 2004. Sprouting and yield in bulb onions (Allium cepa L.) as influenced by cultivar, plant establishment methods, maturity at harvest and storage conditions. Journal of Horticultural Science and Biotechnology 79: 877-84.

Gubb I and MacTavish H S. 2002. Onion pre- and postharvest consideration spp.233-66. (In): Allium Crop Science: Recent Advances. Rabinowitch H D and Currah L. (Eds), CABI Publishing, Wallingford, UK.

Hansen S L. 2001. Content of free amino acids in onion (Allium cepa L.) as influenced by the stage of development at harvest and long-term storage. Acta Agriculturae Scandinavica Section B, Soil and Plant Science 51: 79-85.

Hong G, Peiser G and Cantwell M I. 2000. Use of controlled atmospheres and heat treatment to maintain quality of intact and minimally processed green onions. Postharvest Biology and Technology 20: 53-61.

Horiuchi J, Kanno T and Kobayashi M. 1999. New vinegar production from onions. Journal of Bioscience and Bioengineering 88: 107-09.

Horiuchi J, Kanno T and Kobayashi M. 2000. Effective onion vinegar production by a two-step fermentation system. Journal of Bioscience and Bioengineering 90: 289-93.

Horiuchi J, Tada K, Kobayashi M, Kanno T and Ebie K. 2004. Biological approach for effective utilization of worthless onion vinegar production and composting. Resources, Conservation and Recycling 40: 97-109.

Howard L R, Yoo K S, Pike L M and Miller-Jr G H. 1994. Quality changes in diced onions stored in film packages. Journal of Food Science 59: 110-12.

Hui H G. 2004. Production of onion powder in which characteristic taste and odour of onion is eliminated by freezing onion. Patent publication no: KR1020040093311 (A). (Applicant: Hooseng School Corp).

Hyde N D, Reeves J E and Currah L. 2011. Onion storage data from Zimbabwe: a statistical method to demonstrate end of dormancy and the onset of sprouting. Acta Horticulturae 906: $49-54$.

Iglesias I, Salcines R M and Garriga E. 1987. Effect of storage conditions on the performance of onion cultivars Red Creole C-5, Texas Early Grano Strain 502 and White Majestic. Agrotecnia de Cuba 19: 65-74.

Jaggi R C. 2009. Critical nutrient limits for minimizing storage losses in onion. Indian Journal of Horticulture 66: 344-47.

Johnson J. 2006. Onion storage revolution? The Vegetable Farmer 2: 25-26.

Johnston C S. 2009. Medicinal uses of vinegar, pp. 433-40. (In): Complementary and Alternative Therapies and the Aging Population: An Evidence-Based Approach. Watson R R. (Ed.) Elsevier's Science and Technology, USA.

Johnston C S and Gaas C A. 2006. Vinegar: Medicinal uses and antiglycemic effect. Med Gen Med 8: 61. 
Joseph P. 2013. Sweet onion sauce and method of manufacturing same. Patent: US2013004645 (Al).

Kassali R. and Idowu E O. 2007. Economics of onion storage systems under tropical conditions. International Journal of Vegetable Science 13: 85-97.

Kielak E, Grzegorzewska M and Gawronska H. 2006. Levels of abscisic acid in onion during storage and bulb storability as influenced by weather conditions during growing season and bulb maturity at harvest. Vegetable Crops Research Bulletin 64: 51-65.

Komochi S. 1990. Bulb dormancy and storage, pp. 89-111. (In): Onion and Allied Crops I. Botany, Physiology and Genetics. Rabinowitch H D and Brewster J L. (Eds). CRC Press. Boca Rattan, Florida, USA.

Kumar M, Das D K, Munish P S and Chattopadyay T K. 2000. Effect of zinc and sulphur application on the yield and post harvest life of onion (Allium cepa $\mathrm{L}$ ) as affected by different methods of storage. Advances in Plant Sciences 13: 195-200.

Kumar S, Imtiyaz M, and Kumar A. 2007. Effect of differential soil moisture and nutrient regimes on postharvest attributes of onion (Allium cepa L.) Scientia Horticulturae 112: 121-29.

Kumar S, Kumar A and Mandal G. 2006. Effect of irrigation scheduling and fertigation on storability of onion (Allium cepa) under microsprinkler irrigation regime. Indian Journal of Agricultural Sciences 76: 401-04.

Lawande K E. 2001. Onions, pp. 249-58. (In): Handbook of Herbs and Spices. Peter K V. (Ed.) Woodhead Publishing Limited and CRC Press LLC, Washington and New York, USA.

Lee W S. 1984. Studies on improvement of storability of onion bulbs. Journal of the Korean Society for Horticultural Science 25: 227-32.

Liu F and Li Y. 2006. Storage characteristics and relationships between microbial growth parameters and shelf life of MAP sliced onions. Postharvest Biology and Technology 40: $262-68$.

Magomedov R K. 2006. Production, harvesting and storage methods of onion in Russia. Vegetable Crops Research Bulletin 64: 147-54.

Matsubara S and Kimura I. 1991. Changes of ABA content during bulbing and dormancy and in vitro bulbing in onion plants. Journal of Japanese Society of Horticultural Science 59: $757-62$.

Mitra J, Shrivastava S L and Rao P S. 2012. Onion dehydration: a review. Journal of Food Science and Technology 49: 267-77.

Mitra J, Shrivastava S L and Srinivasa Rao P. 2011b. Vacuum dehydration kinetics of onion slices. Food and Bioproducts Processing 89: 1-9.

Mogren L, Gertsson U and Olsson M. 2005. Post-harvest aspects on bioactive compounds in yellow onion (Allium cepa). Acta Horticulturae 682: 535-36.

Mogren L, Gertsson U and Olsson M E. 2008. Effect of cultivation factors on flavonoid content in yellow onion (Allium cepa L.) Acta Horticulturae 765: 191-95.

Mongpraneet S, Abe T and Tsurusaki T. 2002. Accelerated drying of welsh onion by far infrared radiation under vacuum conditions. Journal of Food Engineering 55: 147-56.

Motaa C L, Lucianoa C, Diasa A, Barrocab M J and Guinea R P F. 2010. Convective drying of onion: Kinetics and nutritional evaluation. Food and Bioproducts Processing 88: $115-23$.

Murkute A A. 2012. Evaluation of onion varieties in ambient storage. DOGR News 16: $2-$ 3.

Murkute A A and Gopal J. 2013. Taming the glut. Agriculture Today 16: 28-30.

Naik M K, Raju K, Rani G S D and VeereGowda K. 2008. Evaluation of different storage structures and monitoring of storage molds in onion genotypes for managing postharvest diseases. Indian Phytopathology 61: 311-16. 
Opara L U. 2003. Onions: Post-harvest operations. AGST/FAO, pp. 16.

Park J Y, Choi M H and Kim G H. 2006. Effect of nitrous oxide on quality of onion (Allium cepa) during storage. Acta Horticulturae 699: 343-47.

Pathare PB and Sharma G P. 2006. Effective moisture diffusivity of onion slices undergoing infrared convective drying. Biosystems Engineering 93: 285-91.

Patil S, Sagar V R, Sadananda G K and Chikkanna G S. 2012. Physico-chemical constituents in onion (Allium cepa L.) during storage. Bioinfolet 9: 324-26.

Perez-Gregorio M R, Gonzalez-Barreiro C, Rial-Otero R and Simal-Gandara J. 2011 a. Comparison of sanitizing technologies on the quality appearance and antioxidant levels in onion slices. Food Control 22: 2052-58.

Perez-Gregorio M R, Regueiro J, Gonzalez-Barreiro C, Rial-Otero R and Simal-Gandara J. 2011b. Changes in antioxidant flavonoids during freeze-drying of red onions and subsequent storage. Food Control 22: 1108-13.

Pirov T T. 2000. Storability of onion varieties grown in Tajikistan. Kartofel' $-i-$ Ovoshchi 3: $27-32$.

Poldma P, Moor U, Merivee A and Tonutare T. 2012. Effect of controlled atmosphere storage on storage life of onion and garlic cultivars. Acta Horticulturae 945: 63-69.

Praveen Kumar D G, Umesh Hebbar H and Ramesh M N. 2006. Suitability of thin layer models for infrared-hot air-drying of onion slices. LWT 39: 700-15.

Qadir A, Hashinaga F and Karim M R. 2007. Effects of pre-storage treatment with ethanol and $\mathrm{CO}_{2}$ on onion dormancy. Journal of Bio-science 15: 55-62.

Rafika S B, Daami-Remadi M, Mohamed B K and Hatem C. 2006. Onion storage ability and an inventory of onion post-harvest fungi in Tunisia. Tropical Science 46: 105-12.

Rapusas R S and Driscoll R H. 1995. Kinetics of non-enzymatic browning in onion slices during isothermal heating. Journal of Food Engineering 24: 417-29.

Rattin J E, Assuero S G, Sasso G O and Tognetti J A. 2011. Accelerated storage losses in onion subjected to water deficit during bulb filling. Scientia Horticulturae 130: $25-$ 31.

Sabaragamuwa R S, Dharmasena D A N and Mannaperuma J. 2011. Optimization of environmental parameters for short-term storage of big onions and evaluation of the feasibility of controlled environmental storage. Tropical Agricultural Research 22: 356-66.

Sarsavadia P N, Sawhney R L, Pangavhane D R and Singh S P. 1999. Drying behaviour of brined onion slices. Journal of Food Engineering 40: 219-26.

Satish S V and Ranganna B. 2002. Effect of curing on the physical and mechanical properties of onion. Mysore Journal of Agricultural Sciences 36: 266-69.

Schroeder B K. 2010. Effect of postharvest onion curing parameters on enterobacter bulb decay in storage. Plant Disease 94: 1425-30.

Sharma G P, Verma R C and Pathare P B. 2005a. Thin-layer infrared radiation drying of onion slices. Journal of Food Engineering 67: 361-66.

Sharma G P, Verma R C and Pathare P. 2005b. Mathematical modeling of infrared radiation thin layer drying of onion slices. Journal of Food Engineering 71: 282-86.

Sharma P K, Kumar S, Yadav G L, Verma R and Gupta A. 2007. Effect of last irrigation and field curing on yield and post-harvest losses of rabi onion (Allium cepa). Annals of Biology 23: 145-48.

Shock C C, Feibert E B G and Saunders L D. 1998. Onion yield and quality affected by soil water potential as irrigation threshold. Hort Science 33: 188-91.

Shrinath B M, Jagtap K B and Wattamwar M J. 2007. Effect of foliar application of calcium and zinc on biochemical properties and keeping quality of onion bulb. Annals of Plant Physiology 21: 114-18.

Siddiq M, Roidoung S, Sogi D S and Dolan K D. 2013. Short communication, Total 
phenolics, antioxidant properties and quality of fresh-cut onions (Allium cepa $\mathrm{L}$.) treated with mild-heat. Food Chemistry 136: 803-06.

Sidhu A S. 2008. Storage potential of some onion and garlic cultivars: A comparative evaluation. Indian Journal of Horticulture 65: 347-48.

Sinha P, Sharma R P and Roy M K. 1994. Management of storage of rot in onion through gamma irradiation and chemicals. Journal of Food Science and Technology 31: 34143.

Sorensen J N and Grevsen K. 2001. Sprouting in bulb onions (Allium cepa L.) as influenced by nitrogen and water stress. Journal of Horticultural Science and Biotechnology 76: 501-06.

Suslow T. 1998. Onion: Dry, Recommendations for Maintaining Postharvest Quality. Department of Vegetable Crops, University of California, Davis, CA.

Sutar P P and Gupta D K. 2007. Mathematical modeling of mass transfer in osmotic dehydration of onion slices. Journal of Food Engineering 78: 90-97.

Tanaka M, Chee K and Komochi S. 1987. Studies on the storage of autumn harvested onion bulbs. V. Freezing injury of onion bulbs in storage. Research Bulletin of the Hokkaido National Agricultural Experiment Station 148: 95-105.

Thomas T H and Isenberg F M R. 1972. Hormone physiology of onion bulbs during storage. Experimental Horticulture 23: 48-51.

Thomas T H and Rankin W E F. 1982. Effect of ethephon on bulbing, Bulb necking, yield and sprouting during storage of two onion cultivars (Allium cepa L.). Journal of Horticultural Science 81: 253-62.

Tripathi P C and Lawand K E. 2010. Temperature related changes in respiration and $\mathrm{Q}_{10}$ coefficient in different varieties of onion. Progressive Horticulture 42: 88-90.

Tripathi P C, Sankar V and Lawande K E. 2010. Influence of micro-irrigation methods on growth, yield and storage of rabi onion. Indian Jovirnal of Horticulture 67: 61-65.

Tripathi P C, Sankar V, Mahajan V and Lawande K E. 2011. Response of gamma irradiation on post harvest losses in some onion varieties. Indian Journal of Horticulture 68: 55660.

Uddin M and MacTavish H S. 2003. Controlled atmosphere and regular storage-induced changes in $S$-alk(en)yl-l-cysteine sulfoxides and alliinase activity in onion bulbs (Allium cepa L. cv. Hysam). Postharvest Biology and Technology 28: 239-45.

Vasseur J P. 1991. Ionisation des produits alimentaires. (In): Tec Doc Paris, pp. 452.

Wright P J and Triggs C M. 2004. Effects of cultural practices at harvest on onion (Allium серa) bulb quality and incidence of bacterial soft rot and fungal moulds after simulated shipping. New Zealand Journal of Crop and Horticultural Science 32: 185-92.

Wu L, Orikasa T, Ogawa Y and Tagawa A. 2007. Vacuum drying characteristics of egg plants. Journal of Food Engineering 83: 422-29.

Yamazaki H, Nishijima T, Koshioka M and Miura H. 2002. Gibberellins do not act against abscisic acid in regulation of bulb dormancy of Allium wakegi. Plant Growth Regulation 36: $223-29$.

Yamazaki H, Nishijima T, Yamato Y, Hamano M, Koshioka M and Miura H. 1999. Involvement of abscisic acid in bulb dormancy of Allium wakegi Araki. II. A comparison between dormant and nondormant cultivars. Plant Growth Regulation 29: 195-200.

Ye C, Dai D and Hu W. 2013. Antimicrobial and antioxidant activities of the essential oil from onion (Allium cepa L.) Food Control 30: 48-53.

Zhang H. 2010. Onion beverage. Patent publication no: CN101708057 (A). 


\title{
Biochemistry and Nutraceutical Properties
}

\author{
Shamina Azeez and K.S. Shivashankara
}

Many claims have been made regarding the medicinal properties of the onion-it is a source of energy; acts as a stimulant and mild counter-irritant; crushed raw onion can be applied to the forehead to relieve headache. Red small onion can be used as an expectorant. Raw onion helps control coronary heart disease, thrombosis and blood pressure, and reduces cholesterol level by increasing high-density lipoproteins. Onion is also used in the treatment of anaemia, urinary disorders, bleeding piles, teeth disorders and ulcer and as platelet anti-aggregating agent (Yadav et al., 2012). Moreover, onion is antimicrobial, antioxidant, antiasthmatic, immunomodulatory and prebiotic (Crozier et al., 1997). In India, onions are also used to heal infected blisters. However, onions can cause migraine and flatulence also. Eating raw onions also lead to bad breath. In India, some people do not consume onions as they believe them being aphrodisiac. Various schools of Buddhism also advise against eating vegetables of Allium family.

Onion is used in both fresh and dried forms; dried onions are important in world trade, and are made into flaked, minced, chopped and powdered forms to add flavour in the processed food (Yadav et al., 2012).

\section{Onion Chemistry}

\section{Proximate composition}

According to the USDA National Nutrient Database for Standard Reference (2007), the nutritional composition of raw onion per $100 \mathrm{~g}$ of edible portion contains $89.11 \mathrm{~g}$ of water, $1.10 \mathrm{~g}$ of proteins, 0.10 of total lipids (fat), $0.35 \mathrm{~g}$ of ash, $9.34 \mathrm{~g}$ of carbohydrates, $4.24 \mathrm{~g}$ of total sugars and $1.7 \mathrm{~g}$ of total dietary fibre, corresponding to energy of $40 \mathrm{kcal}$. The most important minerals are potassium, calcium and selenium. Onion is a very good source of vitamins B6 and $\mathrm{C}$, chromium, biotin and fibre. They are also a
Table 16.1 Chemical composition of the onion (Sharma, 2006)

\begin{tabular}{lc}
\hline Constituents & $\begin{array}{c}\text { Nutritional value } \\
\text { (per } 100 \mathrm{~g} \text { ) }\end{array}$ \\
\hline Energy & $166 \mathrm{kcl}$ \\
Carbohydrates & $9.34 \mathrm{~g}$ \\
Sugar & $4.24 \mathrm{~g}$ \\
Dietary fibre & $1.7 \mathrm{~g}$ \\
Fat & $0.1 \mathrm{~g}$ \\
Protein & $1.1 \mathrm{~g}$ \\
Water & $89.11 \mathrm{~g}$ \\
Calcium & $23.00 \mathrm{mg}$ \\
Potassium & $146.00 \mathrm{mg}$ \\
Vitamin C & $7.40 \mathrm{mg}$ \\
Riboflavin & $0.027 \mathrm{mg}$ \\
Sodium & $4.00 \mathrm{mg}$ \\
Niacin & $0.116 \mathrm{mg}$ \\
Phosphorus & $29.00 \mathrm{mg}$ \\
\hline
\end{tabular}

Source: USDA Nutrient Database (2007) 
good source of folic acid and vitamins B1 and K (Table 16.1).

\section{Polysaccharides}

Golovchenko et al. (2012) extracted polysaccharides and reported that they contained a mixture of galactan with short-length sugar chains, pectic polysaccharides and proteinaceous material. Galacturonan and rhamnogalacturonan are the main constituents of the linear regions of the sugar chains of the pectic polysaccharides (Fig. 16.1). The ramified regions include rhamnogalacturonan-I, the side chains of the ramified region mainly contain 1, 4linked B-d-galactopyranose residues and lesser content of 1,3-linked B-dgalactopyranose and 1,5-linked <-1-arabinofuranose residues. The proteinaceous material was found partly linked to sugar chains. The structure of a watersoluble pectic polysaccharide (PS) isolated from immature onion was investigated using acid hydrolysis, methylation analysis, periodate oxidation study, and NMR studies by Patra et al. (2013), and deduced to be d-galactose, 6-O-Me-D-

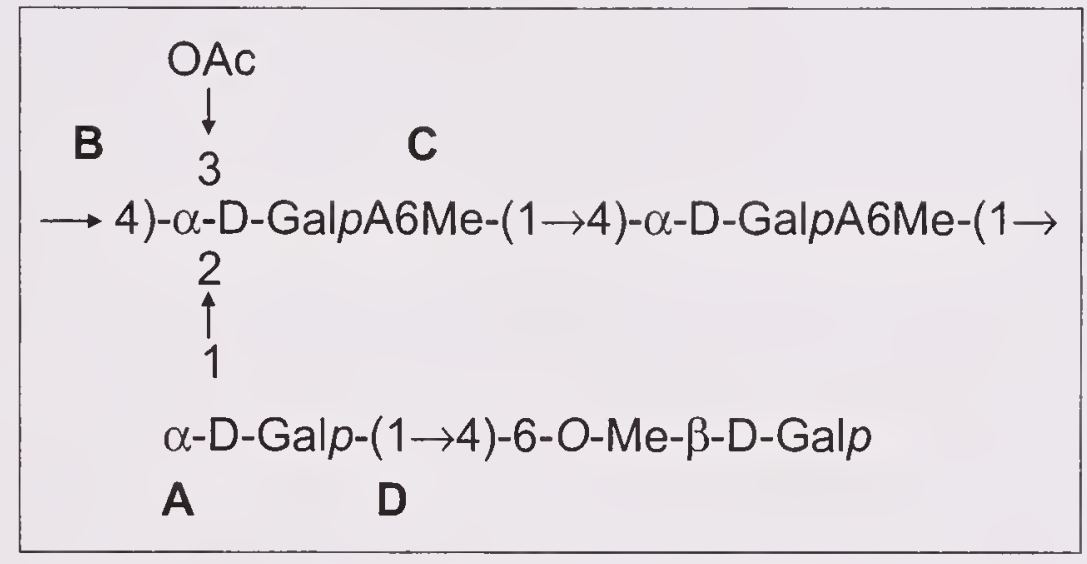

Fig. 16.1 Structure of a water-soluble pectic polysaccharide from immature onion-stick (Patra et al., 2013) galactose, 3-O-acetyl-d-methyl galacturonate and d-methyl galacturonate.

Sadeghi et al. (2013) isolated new phytochemicals from seeds of Persian leek. Two new spirostane glycosides (persicosides A and B) and four new furostane glycosides (persicosides C1/C2 and D1/D2), one cholestane glycoside (persicoside E) together with furostane glycosides (ceposides A1/A2 and C1/C2, tropeosides $\mathrm{A} 1 / \mathrm{A} 2$ and $\mathrm{B} 1 / \mathrm{B} 2$, and ascalonicoside A1/A2,) have already been described in white onion, red Tropea onion and shallot, respectively (Fig. 16.2).

\section{Phenolic acids and flavonoids}

Other constituents found in onions include phenolic acids: ellagic, caffeic, sinapic and p-coumaric acids; pectin; sterols; saponins and volatile oils. In many countries, the major sources of non-nutritive components such as dietary flavonoids are onions, apples and tea (Hertog et al., 1992). Onions contain significant amount of a flavonoid called quercetin (3,3',4',5,7-pentahydroxyflavone) (Fig. 16.3), which is two to three times more bioavailable from onions than from tea or apple (Singh, 2005). Shallots have the most phenols, six times the amount found in Vidalia onion(the variety with the lowest phenolic content); shallots also have the most antioxidant activity. Western yellow onions have most flavonoids, eleven times the amount found in Western white (the variety with the lowest flavonoid content).

The major flavonols of a mature red onion bulb are quercetin derivatives $(3,42$ O-diglucoside and 42-O-monoglucoside) (Pérez-Gregorio et al., 2011a) (Fig. 16.3), accounting for about $93 \%$ of the total flavonols ( $334 \pm 60 \mathrm{mg}$ Q per $\mathrm{kg}$, fresh weight), and are mainly responsible for IC 50 antioxidant activity of $15.84 \pm 3.73 \mathrm{~g} / \mathrm{kg}$. The 

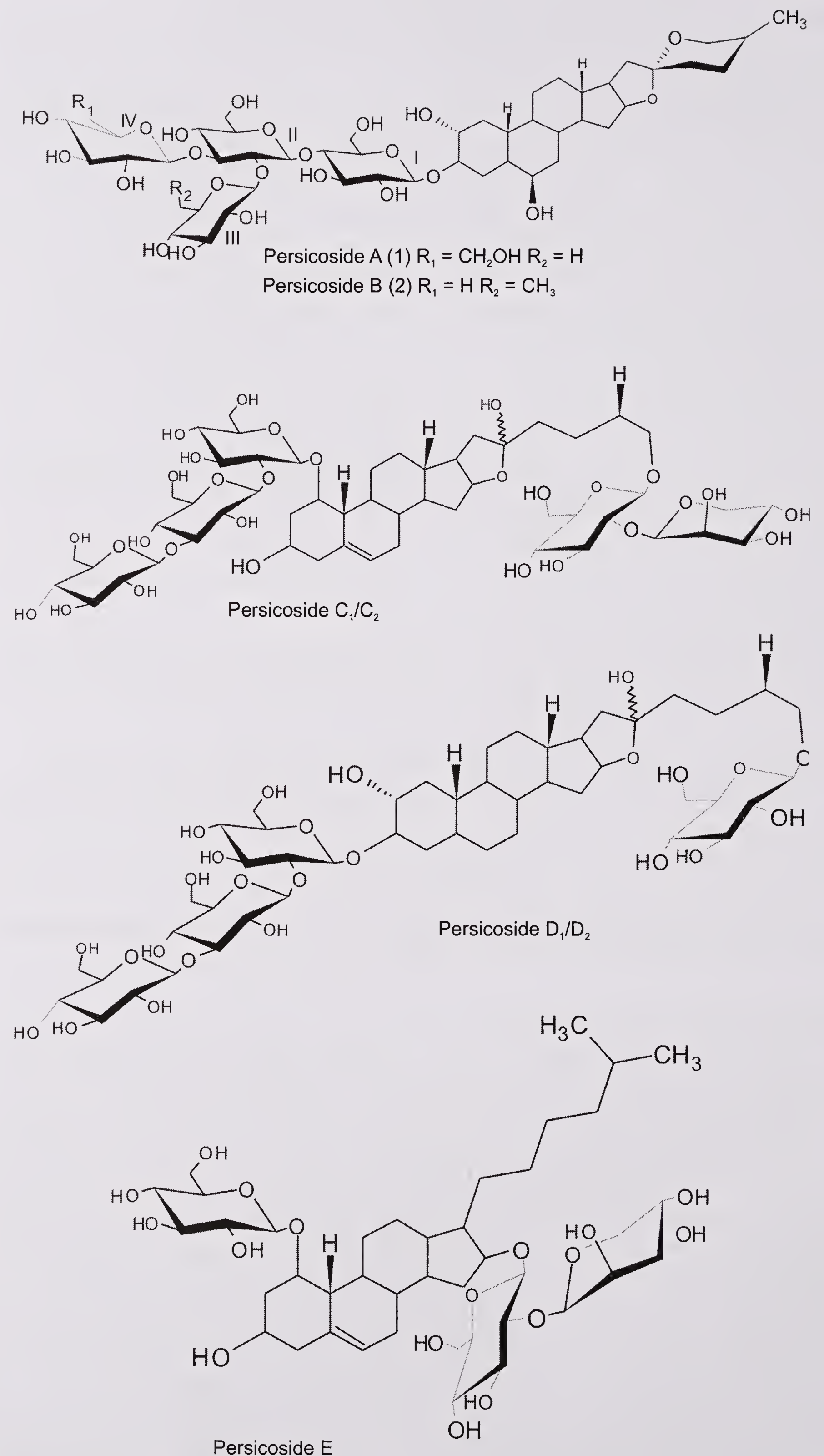

Fig. 16.2 New saponins of Allium ampeloprasum subsp. persicum (Sadeghi et al., 2013) 
<smiles>O=c1c(O)c(-c2ccc(O)c(O)c2)oc2cc(O)cc(O)c12</smiles>

Quercetin

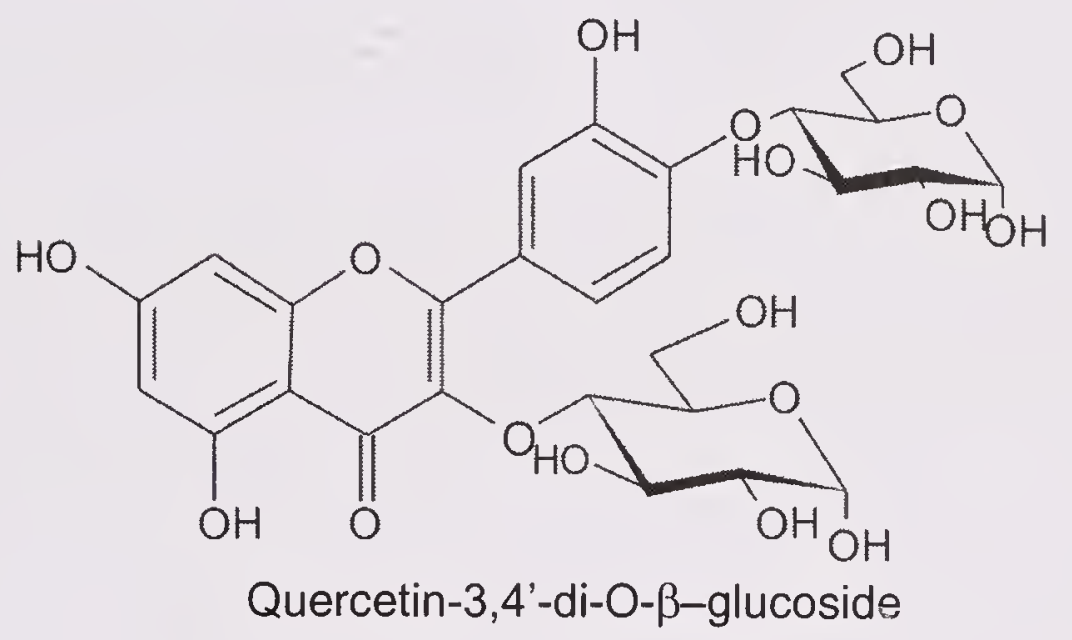

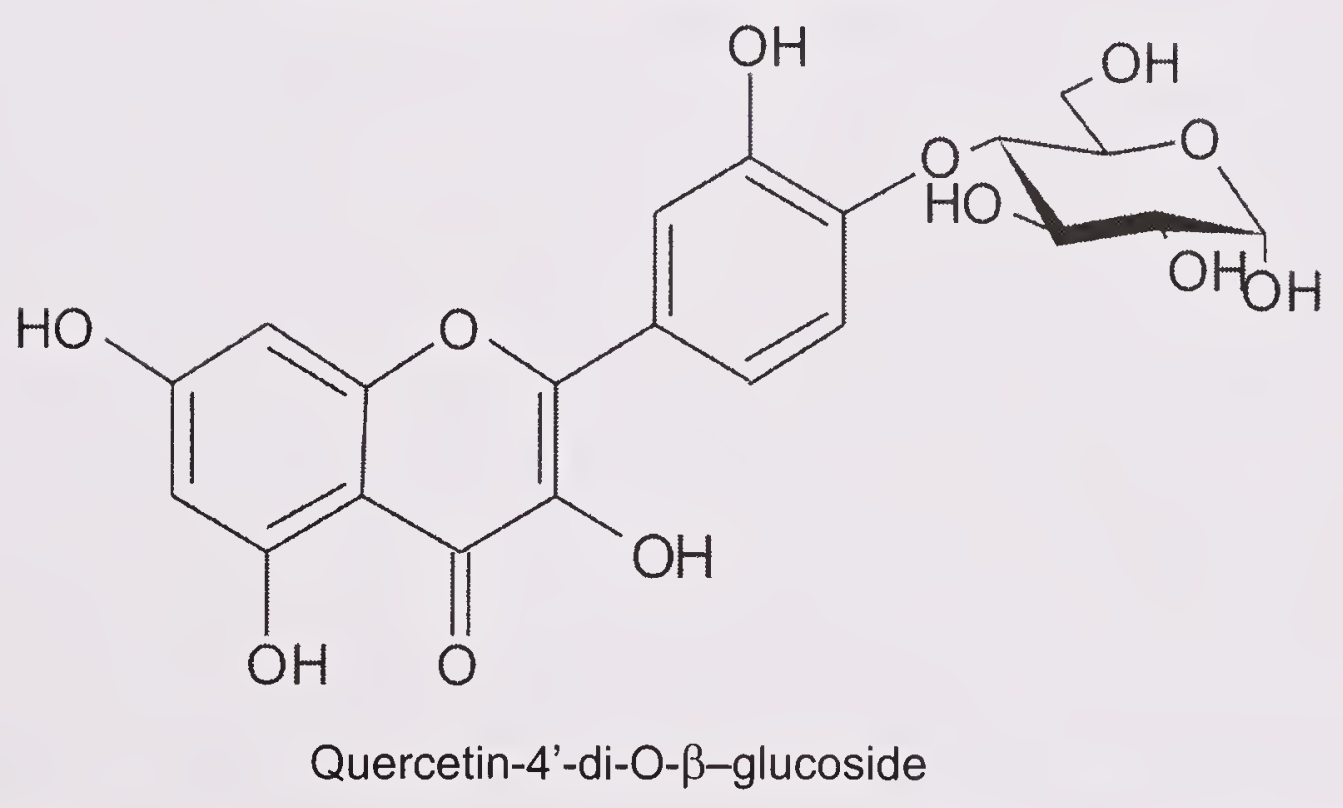

Fig. 16.3 Chemical structures of quercetin (3,3',4',5,7-pentahydroxyflavone) and its major glucosides in onion

remaining flavonol fraction (approx. 7\%) comprises 8 different components of which quercetin-3-O-glucoside and isorhamnetin-4-glucoside (Fig. 16.4) are prominent, although each contributes less than $3 \%$ of the total flavonol fraction. Instead, quercetin represents less than $1 \%$ of the total flavonols. In red onion, eight anthocyanins (which represent less than $1 \%$ of the total flavonols) are also found at a total level of $2.1 \pm 0.05 \mathrm{mg}$ cyanidin-3-glucoside per $\mathrm{kg}$ (fresh weight). Also, 4 of them (cyanidin 3-glucoside (C3g) > cyanidin 3-(622-malonylglucoside) $>$ cyanidin 3-(62 2-malonyl-laminaribioside) > cyanidin 3-laminaribioside) account for $95 \%$ of the total anthocyanins (Figs 16.5a, b, c, d). Among the eleven flavonoids characterized in onion, isorhamnetin-4'-O-galactoside was identified for the first 
time by Lee et al. (2012d). When the healthy bulb was inoculated with fungus Fusarium oxysporum, two quercetin derivatives and two isorhamnetin derivatives underwent concentration changes typical for the defence mechanism against the pathogens.

Quercetin occurs as glycosides in foods, and it is species- and cultivarspecific. In humans, quercetin undergoes extensive biotransformation to a range of metabolites (i.e. sulphate, glucuronide or methyl conjugates),<smiles>COc1cc(-c2oc3cc(O)cc(O)c3c(=O)c2O)ccc1OC1OC(O)C(O)C(O)C1O</smiles>

Fig. 16.4 Isorhamnetin-4'O-glucoside which determine its bioactivity. Primary metabolites identified in human plasma over $24 \mathrm{hr}$ after consumption of onion powder containing quercetin glycosides include quercetin sulphate, quercetin glucuronide, quercetin diglucuronide and a quercetin glutathione adduct (Lee et al., 2012c).

a Cyanidin 3-glucoside<smiles>OCC1OC(Oc2cc3ccccc3[o+]c2-c2ccc(O)c(O)c2)[C@H](O)[C@H](O)[C@H]1O</smiles>

c Cyanidin 3-(6"-malonyl-laminaribioside)<smiles></smiles>

b Cyanidin 3-(6"-malonylglucoside)<smiles>O=C(O)CC(=O)OC[C@H]1O[C@@H](Oc2cc3c(O)cc(O)cc3[o+]c2-c2ccc(O)c(O)c2)[C@H](O)[C@H](O)[C@@H]1O</smiles>

d Cyanidin 3-laminaribioside<smiles></smiles>

Fig. 16.5 Major anthocyanins in onion 


\section{Onion aroma, flavour and pungency}

Allium spp. have been classified chemotaxonomically based on the nature and abundance of thiosulphinates and related compounds (Block et al., 1992; Thomas and Parkin, 1994). Sensory appraisals of strong-flavoured onion (pungency or aroma) correlates positively with concentrations of certain non-protein sulphur amino acid compounds such as thiosulphinates, thiopropanal sulphoxide (the lachrymatory factor) and pyruvic acid (Freeman and Whenham, 1975; Crozier et al., 1997). These compounds are produced during tissue disruption and subsequent hydrolysis of S-alk(en)yl-L-cysteine sulfoxide (ACSO) by alliinase (Lancaster and Kelly, 1983; Block, 1992; Randle, 1997). Hydrolysis of ACSOs yields ammonium pyruvate and an unstable sulphenic acid, which rapidly decomposes to thiopropanal sulphoxide (Block, 1992; Thomas et al., 1992). Pyruvic acid determination is relatively simple and is used to measure Allium flavour (Abbey et al., 2001).

The principal volatile flavour component in edible and decorative species of Allium, the amino acid precursor, present in the intact tissues of A. cepa L. (onion) is S-1-propenyl-L-cysteine sulphoxides; of A. sativum L. (garlic)is S-2-propenylL-cysteine sulphoxides and of $A$. aflatunense B. Fedtschenko is S-methyl-Lcysteine sulphoxides (Freeman and Whenham, 1975).

According to Randle et al. (1995), understanding dynamics of flavour accumulation in onion and other Alliums is important for food and phytomedicinal industries for greater product standardization and characterization. They have reported that sulphur deficiency during active bulbing, resulted in dominance of ACSO flavour precursor (+)S-methyl-L-cysteine sulphoxide, and the flavour pathway was a strong sink for available $S$. At luxuriant $S$ fertility levels, trans(+)-S-(1-propenyl)-L-cysteine sulphoxide (PRENCSO) was the dominant ACSO; concentration of $\gamma$-Glutamyl peptide $(\gamma$-GP), the penultimate compound leading to ACSO synthesis, correlated with S fertility. Nearly $95 \%$ of the total bulb S could be accounted for in the measured $\mathrm{S}$ compounds at low $\mathrm{S}$ fertility. However, at the highest S treatment, only $40 \%$ of the total bulb S could be attributed to the ACSO and $\gamma$-GP, indicating that other $\mathrm{S}$ compounds were significant $\mathrm{S}$ reservoirs in onions. Concentrations of enzymatically produced pyruvic acid were most closely related to PRENCSO (trans-(+)-S-(1-propenyl)-L-cysteine sulphoxide) concentrations.

Like garlic, onion-bulbs contain significant amount of beneficial organo-sulphur compound allicin (Fig. 16.6) and its derivatives or flavonoid glycosides (Xiao and Parkin, 2002), as also the Allinase enzyme, released when an onion is cut or crushed. One of the most

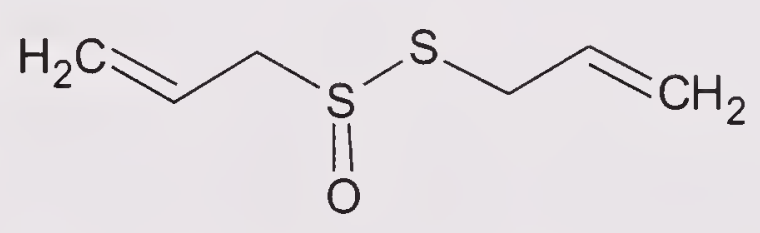

Fig. 16.6 Allicin, an organo-sulphur compound in onion intriguing questions about the flavour compounds is their role within Alliums, which is discussed at length in a review by Jones et al. (2004) - two roles ascribed are for defence against pests and predation, particularly in over-wintering bulbs, and for carbon, nitrogen and sulphur storage. In general, mild flavoured onions are reported to have poorer storage properties.

Onion flavour and pungency are attributed to its pyruvic acid content (Freeman 
and Whenham,1975). Enzyme allinase acts only on the Salk(en)yl cysteine sulphoxide precursors to produce pyruvic acid as a product of enzymatic cleavage (Randle and Bussard, 1993). Onions with low levels of pungency and sweet flavour are more popular with international consumers, and this trend is predicted to increase. Large-scale screening of onion-bulbs for pungency requires a fast and cost-efficient method. The original method<smiles>CC(=O)C(=O)O</smiles>

Pyruvic acid proposed by Schwimmer and Weston (1961), is slow and tedious, and involves use of dinitrophenyl hydrazine (DNPH), a chemical difficult to handle and very toxic. This method is not user-friendly when large quantities of samples are to be analyzed in breeding programme. Also studies by Yoo et al. (2011) have revealed that when pyruvic acid concentration is estimated by the DNPH test, fructose, a major sugar in onion juice, causes degradation of colour adduct in onion pungency test, resulting in underestimation of pyruvic acid concentration. A 96-well microplate procedure was developed for pyruvic acid analysis by Ibáñez et al. (2012) to screen a large number of onion-bulbs in breeding programmes, based on the selective reaction of p-dimethy laminobenzaldehyde with enzymatically produced pyruvic acid. With this method, which showed high correlation with spectrophotometric method, it is possible to determine pyruvic acid content in 96 onion-bulbs in just a few minutes. Russo et al. (2013) have developed a nondestructive, metal oxide sensor (MOS)-based electronic nose to discriminate three "Tropea Red Onion" PGI ecotypes from one another and common red onion, which is usually used to counterfeit it. The e-nose analysis is an artificial olfactory system, with potential for use as an innovative, rapid and specific non-destructive technique, and may provide a method to protect food products against counterfeit it.

The long-lasting presence of onion flavour in the mouth is due to the action of mouth microflora on the non-volatile flavour precursors. The key odourant for the fresh green onion tonality is ( \pm )-2-methyl-3-sulfanyl-pentan-1-ol (Fig. 16.7), and it originates from its corresponding cysteine-Sconjugate. The glutathione cycle ultimately releases volatile organic sulphur compounds (Fig. 16.8). The occurrence and concentrations of four S-(+)-alk(en)ylthio-1-cysteine

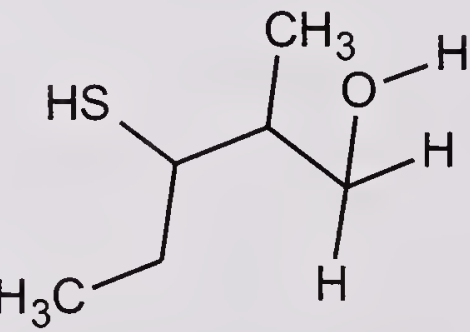

Fig. $16.7( \pm)$-2-methyl3-sulfanyl-pentan-1-ol; the key odourant in fresh green onion derivatives in onion are estimated to be $0.19 \mathrm{mg} / \mathrm{kg} \mathrm{S}$ methylthio-l-cysteine, $0.01 \mathrm{mg} / \mathrm{kg}$ S-propylthio-l-cysteine, and $0.56 \mathrm{mg} / \mathrm{kg}(\mathrm{S}$ (1-propenyllthio)-1-cysteine; concentrations which are about 3,000 times lower than isoalliin (S-(1-propenyl-S-oxo-l-cysteine). These compounds were treated with Fusobacterium nucleatum, a microorganism responsible for the formation of mouth malodour. These 1-cysteine disulphides were demonstrated to predominantly produce tri- and tetrasulfides. Isoalliin is almost entirely consumed by plant enzyme alliin lyase (EC 4.4.1.4 S-alk(en)yl-S-oxo-l-cysteine lyase) in a few seconds, but is not transformed by $F$. nucleatum. This example of flavour modulation shows that plant produces different precursors, leading to formation of the same type of volatile sulphur compounds. Whereas the plant enzyme efficiently transforms S-alk(en)yl-S-oxo-l-cysteine; mouth bacteria are responsible 
(A)

Glutathione

$\downarrow$ Methyl donor

S-methyl glutathione

Glycine $\downarrow$

Y-glutamyl S-methyl cysteine<smiles>C1CCC1</smiles>

Y-glutamyl S-methyl cysteine sulphoxide

Glutamic
acid
S-methyl cysteine sulphoxide
(B)

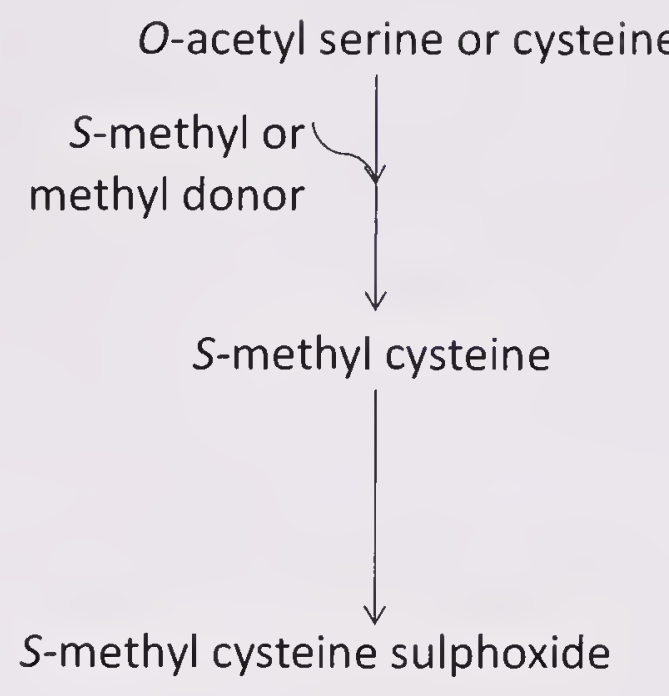

Fig. 16.8 Two proposed pathways for synthesis of Allium flavour precursors, shown for the synthesis of methyl cysteine sulphoxide. (Adapted from Granroth, 1970; Lancaster and Shaw, 1989). Pathway A (left) illustrates participation of glutathione, which is methylated, and then through loss of glycine, oxidation, and, finally, loss of the $\gamma$-glutamyl group, converted to methyl cysteine sulphoxide. Pathway $\mathbf{B}$ (right) shows an alternative route via direct methylation of $O$-acetyl serine to yield methyl cysteine sulphoxide).

for transformation of S-alk(en)ylthio-l-cysteine (Starkenmann et al., 2011a, b).

Aziz Qureshi et al. (2012) reported that increased application of selenium (Se) in a sand culture trial gave an antagonistic effect on sulphur (S) assimilation, and decreased pungency and quercetin concentration. Though Se is essential from a health point of view, its application up to $10 \mathrm{~kg} / \mathrm{ha}$ was sufficient for enriching onions without much effects on the other essential bulb-quality parameters.

\section{Lachrymatory factor in onion}

Most people experience lachrymatory smell, which is emitted when an onionbulb is cut. Among all varieties, Asian white onions have the most eye-irritating reaction. In normal onion, trans-S-1-propenyl-1-cysteine sulphoxide is transformed via 1-propenesulphenic acid into propanethial S-oxide, a lachrymatory factor (LF), through successive reactions catalyzed by alliinase and lachrymatory factor synthase (LFS) (Corzo-Martinez et al., 2007) (Fig. 16.9).

LF was identified more than 40 years ago, and LFS was identified in 2002. As LF is pungent to humans, a low-LF-producing onion would be sweet; and moreover, suppression of LF production would cause increased thiosulphinates (previously reported as "zwiebelane isomers"), which may be a precursor of health beneficial sulphur compound. After purification by recycle high-performance liquid chromatography, Aoyagi et al. (2011) established planar structure of the putative "zwiebelane isomers" and their inhibitory activities against cyclooxygenase- 1 and a-glucosidase in vitro. He et al. (2011) and Masamura et al. (2012a) have characterized LFS found in onions, which catalyses rearrangement of 1-propenesulphenic acid to (Z)-propanethial S-oxide, the onion lachrymator. Based on the type of the reaction it catalyzes, the onion LFS is classified as an isomerase, and called "sulphenic acid isomerase". Masamura et al. (2012c) 


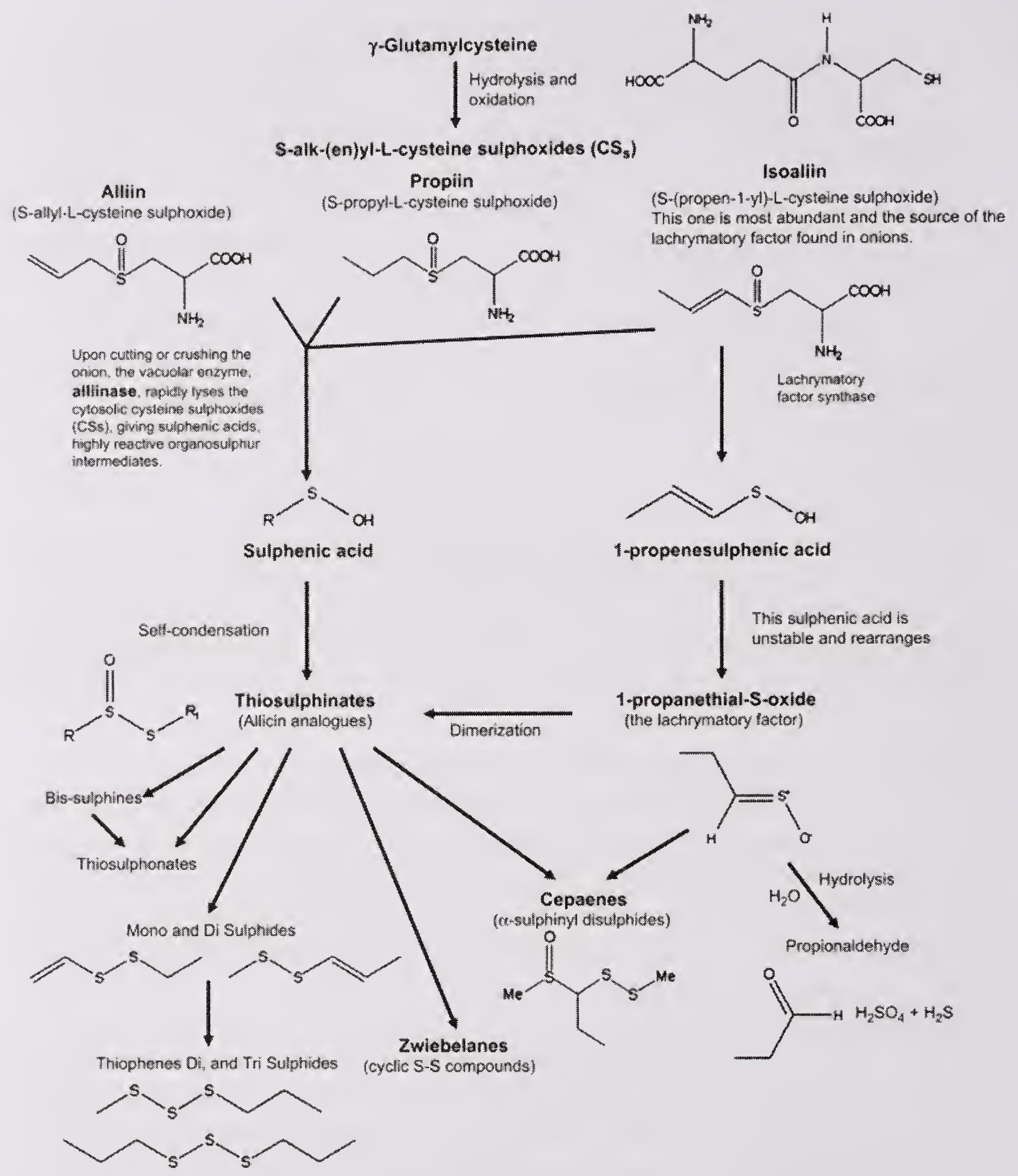

Fig. 16.9 Formation of organo-sulphur compounds during metabolic pathways in processed onion (Corzo-Martinez et al., 2007)

identified catalytic amino acid residues of $L F S$ to elucidate unique catalytic reaction mechanism of this enzyme-two amino acids (Arg71 and Glu88) were indispensable for LFS activity. LFS is an important target gene in onion breeding for both flavour intensity and health. Masamura et al. (2012b) showed that LFS genes are localized in the proximal region of the long-arm of chromosome 5.

\section{Pink discolouration of onion}

"Pinking" of onion is initiated when E-(+)-S-(1-propenyl)-1-cysteine sulphoxide is first cleaved by alliinase to yield colour developers, which react with amino acids, like valine to form pigment precursors (PPs) (Kato et al., 2013). The PPs react with naturally occurring carbonyls to form pigments. A trimeric structure 
was predicted for one of the pink pigments by these authors; which was the first report. The chemical structures of pink-red pigments produced from individual amino acids (glycine, alanine, leucine, asparagine, glutamine, tyrosine, and cystine) responsible for 'pinking' in macerated onion were tentatively elucidated by Lee et al. (2012b).

\section{Factors Affecting Nutritive Value}

\section{Stage of maturity and storage}

Nutritional composition of onions varies depending on the variety and the stage of maturity. During maturity, there is a massive export of carbohydrate reserves, total and reducing sugars from the leaves to onion-bulb (Benkeblia, 2012). Storage conditions also affect quality of onion cultivars: when 'Pusa White Round' and 'Pusa Red' were stored under ambient conditions, pungency and ascorbic acid content decreased, while total antioxidant capacity increased. 'Pusa Red' was found suitable for storage as pungency loss was least; 'Pusa White Round' was suitable for dehydration with minimum browning (Patil et al., 2012). Shallot cultivars, when stored under different atmosphere compositions, showed highest weight loss in normal atmospheric conditions but dry matter increased in $5 \% \mathrm{CO}_{2}+5 \% \mathrm{O}_{2}$ atmospheric composition. Colour of dry and fleshy scales changed depending on the cultivar and the atmosphere composition (Bajer and Gajewski, 2012).

Due to the maritime climate of the UK, onions are artificially cured in closed environments. Curing removes excess water from the outer skin, and seals neck to reduce infection and to minimize weight loss. Current curing practise involves holding onions at $28^{\circ} \mathrm{C}$ for three-six weeks, which results in a golden-brown colour appreciated by consumers. Cepaic acid, a possible oxidation product of quercetin, has been identified as a pigmented compound in the dry onion skin. Cools et al. (2012) showed for the first time that increase in brown pigmentation during curing at higher temperatures is linked to loss of quercetin glucosides, possibly by conversion into brown oxidative products.

\section{Processing effect}

Sterilization is a good method to stabilize onion by-products for use as a potential dietary fibre ingredient (Benítez et al., 2011). Physicochemical properties of onion waste change slightly with sterilization. Insoluble dietary fibre decreases and soluble dietary fibre increases with sterilization, improving soluble: insoluble ratio, decreasing oil holding capacity, cation exchange capacity and swelling capacity. The main sanitizing procedure contributing to the loss of flavonols in fresh-cut onion slices is their solubility in immersion water, followed by acidified sodium hypochlorite (Perez-Gregorio et al., 2011a). In dry decontamination treatments like UV-C irradiation, natural levels of flavonoids in fresh-cut onion slices significantly increase to $35 \%$ for flavonols and $29 \%$ for anthocyanins. This is a recommended treatment.

Freeze-drying of mature red onion bulb increases extraction of flavonoids up to $32 \%$ of flavonols and $25 \%$ of anthocyanins; freeze-dried onion powder when 
stored at room temperature, in dark, in air- and water-tight glass bottles retained stability of all flavonoids up to 6 months (Pérez-Gregorio et al., 2011b). In spite of low recovery of extractable flavonoids (quercetin 3,42-diglucoside, 42-glucoside and 3-glucoside), extraction by microwave (which induces disruptions of vacuoles and cell walls), hydrodiffusion and gravity exhibited highest antioxidant activities compared to conventional solvent extraction method (Zill-e-Huma et al., 2011b). Extraction by this new method, a modified form of solvent-free microwave hydrodiffusion and gravity technique, proved to be an efficient and environmentfriendly technique, for extraction of flavonols at the lower reactor temperature with improved alterations of tissues, in less time, and in the absence of any solvent (Zill-e-Huma et al., 2011a).

\section{Medicinal Properties of Onions}

Onion has been reported to alleviate cataract, cardiovascular disease, asthma and ulcer (Canizares et al., 2007). It is also used as an antimicrobial (Whitmore and Naidu, 2000), an anti-aggregating agent and as antioxidant (Nuutila et al.,

Table 16.2 Uses of onion in folk medicines (USDA Nutrient Database 2013)

\begin{tabular}{|c|c|}
\hline Ailments & Onion preparation \\
\hline Cough & Onion juice mixed with ginger juice and honey as an expectorant \\
\hline & $\begin{array}{l}\text { Eating raw onion or applying raw onion juice on the forehead relieves } \\
\text { cold }\end{array}$ \\
\hline Asthma & $\begin{array}{l}\text { Onion juice mixed with ginger juice, black pepper and salt or ground } \\
\text { onion with honey control asthma, and cure throat and lung problems }\end{array}$ \\
\hline Tuberculosis & Eating raw onions prevents TB infection \\
\hline Ear pain & Drops of lukewarm onion juice cures ear pain \\
\hline Eye & One drop of onion juice diluted with rose water improves eyesight \\
\hline Hysteria & $\begin{array}{l}\text { Loss of consciousness due to hysteria can be cured with the smell } \\
\text { of onions or by rubbing patients' feet with crushed onions }\end{array}$ \\
\hline Cholera & $\begin{array}{l}\text { One cup of onion juice mixed with juice of one lemon, one teaspoon } \\
\text { of ginger juice, pinch of salt (table salt or black salt) given in four } \\
\text { equal doses a day prevents cholera }\end{array}$ \\
\hline Jaundice & $\begin{array}{l}\text { Small onion cut into four pieces soaked in vinegar or lemon juice } \\
\text { taken with salt and black pepper twice a day helps cure jaundice }\end{array}$ \\
\hline Kidney stone & Onion juice mixed with sugar helps break kidney stones \\
\hline Diarrhoea & Applying onion paste on navel region helps cure diarrhoea \\
\hline Nose bleed & Few drops of onion juice applied to nose \\
\hline Skin diseases & $\begin{array}{l}\text { Onion mixed with turmeric powder and mustard oil, heated on fire } \\
\text { and applied on abscesses, helps drain out pus. Onion-juice ( } 1 / 4 \text { cup) } \\
\text { mixed with water (one cup) used to wash wounds etc., and applying } \\
\text { a dressing of the same, acts as a disinfectant and relieves itching }\end{array}$ \\
\hline & Eating raw onions in summer reduces chances of heat strokes \\
\hline Menstrual disorders & $\begin{array}{l}\text { Onion juice mixed with gur taken regularly helps relieve menstrual } \\
\text { disorders }\end{array}$ \\
\hline Dental problems & $\begin{array}{l}\text { Eating raw onion prevents bacterial growth in the mouth, stops dental } \\
\text { decay, helps cure dental problems }\end{array}$ \\
\hline Insomnia & $\begin{array}{l}\text { Onion juice ( } 1 \text { tsp) mixed with milk or honey taken at bed-time induces } \\
\text { sleep }\end{array}$ \\
\hline Arthritis & Rubbing onion juice with sesame oil cures arthritis \\
\hline
\end{tabular}


2003). It is also known to enhance reproduction, improve growth performance (body weight gain, feed consumption, feed conversion) and delay ageing, which are attributed to phenolic compounds (flavonoids, anthocyanins, phenolic acids and flavonols), organosulphur compounds, vitamins and minerals (Teyssier et al., 2001; Furusawa et al., 2003; Kamal and Daoud, 2003; Ismail et al., 2003; Wang et al., 2005) (Table 16.2). Millet et al. (2012) found that compared to aqueous and methanolic extracts, lactic-acid fermented aqueous extracts, which lack usual onion flavonoid profile, were most bioactive in assays such as antibacterial, antigenotoxic and antiproliferative activities. Fresh

Table 16.3 Phytochemicals in onion-bulbs (mg/100 g fresh weight) (USDA website)

\begin{tabular}{lcc}
\hline Phytochemical & Red onions & White onions \\
\hline Cyanidin & 3.19 & $\mathrm{Nil}$ \\
Delphinidin & 4.28 & $\mathrm{Nil}$ \\
Peonidin & 2.07 & $\mathrm{Nil}$ \\
Quercetin & 39.21 & 7.30 \\
Isorhamnetin & 3.41 & 0.85 \\
Myrcetin & 2.70 & $\mathrm{Nil}$ \\
\hline
\end{tabular}
white onions contain higher quantities of bioactive compounds (polyphenols, flavonols, flavonoids, anthocyanins and tannins) than onions boiled for $10 \mathrm{~min}$. (Heeim et al., 2012). Boiling also led to decrease in bioactivity; however, fresh and boiled (for $10 \mathrm{~min}$ ) white onions can be considered as a functional food with high antioxidative and antiproliferative activities. Onion, being a rich source of many phytochemicals, as enumerated above, has many health promoting effects, and is considered to be a major nutraceutical. Composition of some of the flavonoids, anthocyanidins, total flaovonoids, phenols and antioxidant capacity is given in Tables 16.3 and 16.4.

Table 16.4 Total phenols, flavonoids, antioxidant activity, ferric-reducing property (FRP) and DPPH (radical scavenging activity) of white, yellow and red onions

(Shivashankara and VeereGowda, 2005)

\begin{tabular}{llcccc}
\hline Genotypes & Colour & Phenol & TF & FRAP & DPPH \\
\hline JNDW 85 & White & 51.34 & 2.94 & 8.08 & 23.62 \\
PKV Selection & White & 65.88 & 2.33 & 7.65 & 19.24 \\
Pb White & White & 74.39 & 2.16 & 8.08 & 27.49 \\
Phule Suvarna & Yellow & 76.61 & 3.85 & 30.21 & 30.32 \\
Arka Pitamber & Yellow & 79.06 & 4.93 & 31.91 & 25.74 \\
Arka Niketan & Light red & 88.76 & 4.75 & 23.46 & 30.23 \\
INDAM DR1 & Red & 91.32 & 4.71 & 27.11 & 29.56 \\
Arka Kalyan & Red & 89.85 & 5.01 & 31.53 & 49.98 \\
Agrifound Rose & Deep red & 123.71 & 6.54 & 38.95 & 47.66 \\
Arka Bindhu & Deep red & 108.23 & 6.15 & 51.41 & 41.48 \\
\hline
\end{tabular}

\section{Antioxidant effects}

Oxidative stress can increase risk of degenerative diseases and off-set premature aging related complications. The antioxidant compounds-polyphenols, anthocyanins, sulphur-containing compounds, vitamins and minerals-have been described in onion and garlic as powerful quenchers of singlet, hydroxyl and peroxyl radicals (Block et al., 1994; Prasad, 1995; Suh et al., 1999; Nuutila et al., 2003; Ly et al., 2005). Ascorbic acid present in the green onion plays a fundamental role in plant antioxidant response towards $\gamma$-radiation exposure, while polyphenols 
remain largely unchanged, as has been revealed from oxygen radical absorbance capacity, employing pyrogallol red (Jimenez et al., 2011).

Xue et al. (2011) reported three phenolic compounds in onion peel-two known compounds, quercetin and quercetin 32-O- $\beta$-d-glucopyranoside (Q32 G), and one novel compound, quercetin 3-O- $\beta$-d-glucopyranoside- $(4 \rightarrow 1)-\beta$-d-glucopyranoside (Q3M). Quercetin shows highest antioxidative activity, and Q3M is with the strongest anti-aging activity among these flavonoids, which may be related to its high hydrophilicity.

Red onions have higher flavonoids, anthocyanins, total phenols and FRAP and DPPH activities as compared to yellow and white onions. Red and yellow onions have significantly higher antioxidative and antipropliferative activities than white onions (Yang et al., 2004). Red onion-peel is good and easily accessible source of nutraceutical compounds with significant antioxidant and antimutagenic properties, mainly due to the presence of polyphenols (ferulic, gallic, protocatechuic acids, quercetin and kaempferol) (Singh et al., 2009) and induction of plasma SOD and GPx activities and inhibition of liver lipid peroxidation (Lee et al., 2012a).

Lu et al. (2011) standardized use of mid-infrared spectroscopy to predict total antioxidant capacity of vegetables, including onions and shallots, and this provides a rapid and precise alternative to traditional wet chemistry analysis.

\section{Immunomodulatory effects}

Administration of Welsh onion green leaves (WOE) to mice showed a concentration-dependent inhibition on paw edema development after carrageenan treatment, closely attributing to decreased levels of tissue NO and tumor necrosis factor-a (TNF-a). Further evidence for WOE's protection was shown by reduction of lipid oxidation and increase of antioxidant enzyme activities, including catalase, superoxide dismutase and glutathione peroxidase in vivo. Further, WOE also decreased number of acetic acid-induced writhing responses and formalin-induced pain in the late phase in mice. Thus, WOE might have served as a natural source of anti-inflammatory compounds (Wang et al., 2013). Supplementary onion extract enhanced humoral immune response in White Leghorn chickens; macrophages exhibited superior microbicidal activity and ROS production, likely to be attributed to high flavonoid contents (Hanieh et al., 2012).

\section{Anticancer effects}

Preliminary studies have indicated that increased consumption of onions reduces risk of gastric and head and neck cancers (Dorant et al., 1996). These antitumor and anticancer effects are attributed to organosulphur compounds (Block, 1994, 1997; Stavric, 1997), which reportedly increased activities of carcinogen detoxifying enzymes like quinine reductase and glutathione transferase in gut, liver, kidney, lungs, urinary bladder and spleen tissues of rats (Munday and Munday 2001). Onion extracts are reported to prevent brain edema and brain blood barrier hyperpermeability (Hyun et al., 2013). Extracts of onion inhibited estrogen biosynthesis in human ovarian cells, an important strategy in treating breast cancer (Lu et al., 2012). 


\section{Protection against cardiovascular diseases}

Onion and its extract are reportedly effective against cardiovascular diseases, because of their hypocholesterolemic, hypolipidemic, anti-hypertensive, antidiabetic, antithrombotic and anti-hyperhomocysteinemia effects. Liver abnormalities in rats fed with cholesterol-containing diet were corrected by supplementation with garlic, followed by red and white onions (Gorinstein et al., 2011).

Onion diallyl sulphides (diallyl sulphide, diallyl disulphide, diallyl trisulphide) and thiosulfinates (methyl methane-TS, propyl propane-TS and 2-propenyl 2propene-TS (allicin)) reduce risk of cardiovascular diseases by reducing erythrocyte and platelet oxidation and platelet aggregation (Briggs et al., 2000; Chan et al., 2002). Mechanism for antiplatelet effect of onion may, at least partly, involve inhibition of arachidonic acid release from platelets, thromboxane A2 synthase inhibition and $\mathrm{TXA}_{2} / \mathrm{PGH}_{2}$ receptor blockade (Moon et al., 2000). Onion was found to have more favourable effect on the inhibition of thromboxane B2 in diabetic rats (Jung et al., 2002).

Rapidly dried onion powder (OP) prepared from outer layers (second to fourth scale leaves from the surface) of onion-bulbs was effective in decreasing risk of arteriosclerosis in rats fed with high-fat diet as the result of the content of quercetin derivatives (Hamauzu et al., 2011). Onion-peel extract changes expression of genes associated with cholesterol metabolism in favour of lowering blood LDLcholesterol and enhancing HDL-cholesterol through increasing mRNA abundance of LDL receptor and ATP-binding cassette transporter Al genes (Lee et al., 2012f). The anti-thrombotic effects of onion powder extract may also occur as a result of restricting induced expression of tissue factor via down-regulating mitogenactivated protein kinase activation upon coagulation stimulus, leading to prolongation of time for arterial thrombosis (Lee et al., 2013).

Formation of cholesterol gallstones in gallbladder is controlled by procrystallizing and anticrystallizing factors present in the bile. Dietary garlic and onion have anti-lithogenic potential by beneficial modulation of biliary cholesterol saturation index. These Allium spices also influence cholesterol nucleating and anti-nucleating protein factors, which contribute to their antilithogenic potential (Vidyashankar et al., 2010). In mice fed with high cholesterol diet, fenugreek, onion and their combination reduced incidence of cholesterol gallstones, with attendant reduction in total cholesterol, cholesterol/phospholipid ratio content in the serum, liver and bile; reduced fat accumulation in liver and inflammation of gallbladder membrane (Reddy and Srinivasan, 2011).

Whole, quarters and crushed onions lost their in-vitro anti-platelet activity after 30,20, and $10 \mathrm{~min}$. of oven heating, respectively. The longer retainment of antiplatelet activity in intact bulbs was attributed to a later alliinase inactivation. In fact, extensively cooked onions may stimulate rather than inhibit platelet aggregation (Cavagnaro and Galmarini, 2012).

\section{Antiobesity effect}

Moon et al. (2013) demonstrated that the antiobesity effects of quercetin-enriched onion peel extract (OPE) are through suppression of pre-adipocyte differentiation 
and inhibition of adipogenesis. They found that lipid accumulation and triglyceride contents in 3T3-L1 preadipocytes cells were markedly suppressed by OPE; mRNA levels of activating protein (AP2) were down-regulated and those of carnitine palmitoyl transferase- $1 \alpha(\mathrm{CPT}-1 \alpha)$ and fatty acid binding protein 4 were upregulated. Peroxisome proliferator-activated receptor ã mRNA levels were downregulated in epididymal fat of OPE, and significant down-regulation of CCAAT/ enhancer binding protein mRNAlevels in OPE was also observed. The mRNA levels of CPT- $1 \alpha$ and uncoupling protein- 1 were up-regulated by the OPE, while those of fatty acid synthase and acetyl-CoA carboxylase were down-regulated.

\section{Antimicrobial properties}

Green onion extract had significant antilisterial effect against Listeria monocytogenes cocktail in retail milks (full-fat milk, fat-free milk, nano-calcium milk and nano-iron milk). Combination of green onion extract and nisin resulted in synergistic antilisterial activity, thus indicating potential application of combining these as antilisterial agents in the food industry (Yan et al., 2011).

Ye et al. (2013) found that the essential oil of onion may be a new potential source of natural antimicrobial agent against food-borne pathogenic microorganisms and antioxidant agents for application in food systems. Persicosides A and B, novel spirostane glycosides isolated from the seeds of Persian leek, showed high antifungal activity against pathogens-Penicillium italicum, Aspergillus niger, Trichoderma harzianum and Botrytis cinerea-highlighting positive effect of the spirostane skeleton on the antifungal activity.

Three saponins-ceposide A, ceposide B, and ceposide C-isolated from the bulbs of white onions, are found to have antifungal activity which increases with their concentration and varies in the following descending order: ceposide $\mathrm{B}>$ ceposide $\mathrm{A}>$ ceposide $\mathrm{C}$. There was a significant synergism in antifungal activity of three ceposides against Botrytis cinerea and Trichoderma atroviride (Lanzotti et al., 2012).

A fructan (composed of terminal and 2,1-linked B-d-Fruf residues with 1,6linked $B$-d-Glcp residues; molecular weight $1.5 \times 10^{3}$ ), which acts as an antiinfluenza A virus material, has been isolated from the hot-water extract of green leafy part of Welsh onion (Lee et al., 2012e). Although fructan did not show antiinfluenza A virus activity in vitro, it demonstrated an inhibitory effect on the virus replication in vivo, when it was orally administered to mice. In addition, the polysaccharide enhanced production of neutralizing antibodies against influenza A virus. Thus, the authors opine that antiviral mechanism of the polysaccharide is dependent on the host-immune system, i.e. enhancement of the host immune function is achieved by administration of polysaccharide.

Methanolic and ethanolic extracts of onion-bulbs, which contain secondary metabolites, saponins, tannins, alkaloids, cyanogenic glycosides and flavonoids, are inhibitory to Staphylococcus aureus, B. subtilis and P. aeruginosa (Bello et al., 2013).

\section{Traditional remedies using onion}

Onion has been used for thousands of years for various conditions, including 
insomnia, wound-healing and baldness. A traditional Maltese remedy for seaurchin wounds is to tie half a baked onion to afflicted area overnight. Similarly, in Bulgaria a half-baked onion with sugar is placed over the finger and fingernail in case of inflammation. Raw onion can also reduce swelling due to bee-stings. In the United States, products containing onion extract are used in the treatment of topical scars. Though some studies have found these remedies ineffective, others find them as anti-inflammatory or bacteriostatic. Onion may be beneficial for women, who are at increased risk for osteoporosis as they go through menopause, by destroying osteoclasts. An American chemist has stated that pleiomeric chemicals in onions have the potential to alleviate or prevent sore-throat. Onion in combination with jaggery has been widely used as a traditional household remedy for sore-throat in India. Tying an onion near the light repels mosquitoes, and keeping a white onion prevents snakes from entering the house.

African medicine: In south-eastern Morocco, onion is popularly used to treat diabetes and hypertension.

Arab medicine: Onions have been combined with eggs and sesame oil to cure coughs and colds and to relieve sore-throat. Onion juice as eardrops is used to treat ear infection as well as deafness.

Ayurveda: Onion is used for relieving earache, cardiovascular disorders and bleeding hemorrhoids. For the latter condition, an ounce of onion crushed in water and two ounces of sugar is prescribed twice daily. A paste of mustard oil, turmeric and onion juice has also been used. Honey and onion juice mixed in equal amounts is used to treat coughs. Onion has also been used as an aphrodisiac, although strict practitioners may avoid them, as they might increase desire. Hing is generally used as a substitute here. According to Karta Purkh Singh Khalsa's book, 'The Way of Ayurvedic Herbs', the famed Yogi Bhajan once said, "I said, in this universe, in Ayurveda, the basic method of healing, there are only three things: ginger, garlic, onion. These are called Triyajhad, three roots." This combination is ideal for spinal issues. Raw, chopped onion is believed to be a "cure-all" herb with rejuvenating capabilitiesand to promote longevity if consumed regularly. For fever, an infusion of onion and tulsi cooked in coconut oil is applied to the head.

Caribbean medicine: In the Bahamas, cold is treated by placing an onion slice in shoe near the heel. Onion is used with honey to treat respiratory disorders such as bronchitis and catarrh in the Dominican Republic. In Haiti, headaches are relieved by placing sliced onions on the head. In Trinidad, onion decoctions are made for coughs, colds and tuberculosis. In Curaçao, tinnitus and earache are treated using neck of the onion as a plug.

Central/South American medicine: In Bolivia, onion-bulbs are eaten for curing respiratory disorders, kidney disorders (kidney stones) and urinary disorders, and as a sleep aid and anti-inflammatory. Candied onions are used for cough and respiratory disorders (pertussis). Onion skin tea has also been used to treat respiratory disorders such as laryngitis with vocal loss in both Peru and Bolivia. In Nicaragua, the Garifuna supposedly ingest onion juice for respiratory disorders and parasitic infections (particularly intestinal parasites).

Chinese medicine: Onion is used in Chinese medicine to regulate qi, improve circulation, warm body, treat respiratory disorders (loosen phlegm) and as an 
appetite stimulant and sleep aid. Abdominal pain associated with parasitic infections may be treated using one tablespoon each of green onion juice and sesame oil daily. Ulcers are treated using 2-3 tablespoons of green onion juice with brown sugar and hot-water twice daily.

European medicine: Onions are used in Italian traditional medicine for chilblains and wound healing. In Russia, vinegar-boiled onion is applied to treat skin conditions such as corns. During World War II, Russian soldiers used onions as an antiseptic. In Spain, onion is used to treat deafness and tinnitus.

Japanese medicine: In Japan, a cut onion is placed under a pillow as a supposed sleep-aid.

Modern (Western) herbal medicine: In modern herbal medicine, onion has been used for hypercholesterolemia and hypertension.

Veterinary medicine: Secondary sources suggest that onions are allegedly toxic to animals. (Source: www.naturalstandard.com)

It is stated that the above are only claims and further study is needed before definitive conclusions may be drawn about onion's effectiveness for the treatment of these or any other conditions. Some of the common ailments and the onion preparations used for their control are given in Table 16.2.

\section{Value-addition in Onion}

\section{Onion supplementation in food}

Processing of onion produces a large amount of discards, mainly skins. The soluble extracts of selected onion varieties (Pearl, Red, Yellow and White) have a higher phenolic content and antioxidant activity than insoluble-bound extracts, exhibited notable inhibition of LDL cholesterol oxidation, DNA scission and COX2 expression at concentrations as low as $5 \mu \mathrm{g} / \mathrm{ml}$. Pearl onion skin phenolics exhibited the highest activities among the tested onion varieties (Albishi et al., 2013).

Studies by Swieca et al. (2013) showed that when different types of breads were enriched with onion skin, phenolic contents and antiradical abilities increased moderately. Fortification also influenced protein digestibility (a reduction from $78.4 \%$ for control breads to $55 \%$ for breads with a $4 \%$ supplement), due to the presence of indigestible and other bread proteins-flavonoid complexes. Thus supplementation was found to have multiple effects on food quality and prohealth properties.

\section{Increasing bioavailability of iron and zinc}

Among the flavonoids in both red and yellow onions, myricetin was the most bioaccessible after digestion, suggesting that antioxidant activity of yellow and red onions was stronger in the outer layer than in the inner layer; a strong correlation is found between antioxidant activity and total phenolic contents (Shim et al., 2011). Gautam et al. (2011) have reported increased bioaccessibility of iron in specific grains, when used with combinations of onion-carrot, and onionamaranth. Also, amchur-onion had additive effects on zinc bioaccessibility. These observations are useful in evolving dietary strategies to maximize bioavailability 
of minerals from grains. In onion powder, quercetin occurs as quercetin 3,4'-Oglucoside and 4'-O-glucoside, which can be analysed in human plasma using 96well SPE and LC-(ESI)MS/MS. Consumption of onion peel powder led to faster absorption, higher concentration, and greater bioavailability of quercetin (Lee and Mitchell, 2012).

\section{References}

Abbey L, Aked J and Joyce D C. 2001. Discrimination amongst Alliums using an electronic nose. Annals of Applied Biology 139: 337-42.

Albishi T, John J A, A1-Khalifa A S and Shahidi F. 2013. Antioxidant, anti-inflammatory and DNA scission inhibitory activities of phenolic compounds in selected onion and potato varieties. Journal of Functional Foods 5(2): 930-39.

Aoyagi M, Kamoi T, Kato M, Sasako H, Tsuge N and Imai S. 2011. Structure and bioactivity of thiosulfinates resulting from suppression of lachrymatory factor synthase in onion. Journal of Agricultural and Food Chemistry 59(20): 10893-900.

Azizqureshi A, Eknathlawande K, Balasabpatil V and Sibimani. 2012. Relationship between selenium and sulphur assimilation and resultant interaction on quality parameters in onion. Communications in Soil Science and Plant Analysis 43(12): 1625-31.

Bajer M T and Gajewski M. 2012. The effect of CA storage on quality parameters of shallot (Allium ascalonicum L.) bulbs. Acta Horticulturae 934.

Bello O S, Olaifa F E, Emikpe B O and Ogunbanwo S T. 2013. Potentials of walnut (Tetracarpidium conophorum Mull. Arg) leaf and onion (Allium cepa Linn) bulb extracts as antimicrobial agents for fish. African Journal of Microbiology Research 7(19): 2027 33.

Benítez V, Mollá E, Martín-Cabrejas M A, Aguilera Y, López-Andréu F J and Esteban R M. 2011. Effect of sterilization on dietary fibre and physico-chemical properties of onion by-products. Food Chemistry 127(2): 501-07.

Benkeblia N. 2012. Accumulation of total and reducing sugars in the green leaves and bulb tissues during growing and bulbing of onion (Allium cepa L.) Acta Horticulturae 932.

Block E. 1994. Flavorants from garlic, onion, and other alliums and their cancer preventive properties, pp. 84-96. (In): Food Phytochemicals for Cancer Prevention I. Fruits and Vegetables. Huang M.-T, Osawa T, Ho Ch-T and Rosen R T. (Eds). [ACS Symposium Series 546, American Chemical Society, Washington, USA].

Block E, Calvey E M, Gillies J Z and Uden P. 1997. Peeling the onion, pp. 1-30. (In): Functionality of Food Phytochemicals. Johns T and Romeo J T. (Eds). Plenum Press, New York, USA.

Block E, Naganathan S, Putman D and Zhao S H. 1992. Allium chemistry: HPLC analysis of thiosulfinates from onion, garlic, wild garlic (ramosoms), leek, scallion, shallot, elephant (great-headed) garlic, chive, and Chinese chive. Uniquely high allyl to methyl rations in some garlic samples. Journal of Agricultural and Food Chemistry 40: 241830.

Briggs W H, Xiao H, Parkin K L, Shen C and Goldman I L. 2000. Differential inhibition of human platelet aggregation by selected Allium thiosulfinates. Journal of Agricultural and Food Chemistry 48(11): 5731-35.

Canizares P, Gracia I, Gómez L A, Martín De Argila C, Boixeda D, Garcia A, CorzoMartínez M, Corzo N and Villamiel M. 2007. Biological properties of onions and garlic. Trends in Food Science and Technology 18: 609-25.

Cavagnaro P F and Galmarini C R. 2012. Effect of processing and cooking conditions on 
onion (Allium cepa L.) induced antiplatelet activity and thiosulfinate content. Journal of Agricultural and Food Chemistry 60(35): 8731-37.

Chan K-c, Hsu C-c and Yin M-c. 2002. Protective effect of three diallyl sulphides against glucose-induced erythrocyte and platelet oxidation, and ADP-induced platelet aggregation. Thrombosis Research 108: 317-22.

Cools K, Chope G A and Terry L A. 2012. Do quercetin glucosides govern skin colour changes in brown onion (Allium cepa L.) bulbs during curing? Acta Horticulturae 934.

Crozier A, Lean M E J, McDonald S M and Black C. 1997. Quantitative analysis of the flavonoid content of commercial tomatoes, onions, lettuce, and celery. Journal of Agriculture and Food Chemistry 45: 590-95.

Dorant E, van den Brandt P A, Goldbohm R A and Sturmans F. 1996. Consumption of onions and a reduced risk of stomach carcinoma. Gastroenterology 110: 12-20.

Freeman G G and Whenham R J. 1975. A survey of volatile components of some Allium species in terms of $\mathrm{S}$-alk(en)yl-L-cysteine sulphoxides present as flavour precursors. Journal of Science of Food and Agriculture 26: 1869-86.

Furusawa M H, Tsuchiya M, Nagayama T, Tanaka K, Nakaya and Iinuma M. 2003. Antiplatelet and membrane rigidifying flavonoids in browning scale of onion. Journal of Health Science 49: 475-80.

Gautam S, Patel K and Srinivasan K. 2011. Promoting influence of combinations of amchur, B-carotene-rich vegetables and Allium spices on the bioaccessibility of zinc and iron from foodgrains. International Journal of Food Sciences and Nutrition 62(5): 518-24.

Golovchenko V V, Khramova D S, Ovodova R G, Shashkov A S and Ovodov Y S. 2012. Structure of pectic polysaccharides isolated from onion Allium cepa L. using a simulated gastric medium and their effect on intestinal absorption. Food Chemistry 134(4): 181322.

Gorinstein S, Leontowicz H, Leontowicz M, Najman K, Bielecki W, Ham K-S, Kang S-G, Paredes-Lopez O, Martinez-Ayala A L and Trakhtenberg S. 2011. Aorta and liver changes in rats fed cholesterol-containing and raw vegetable-supplemented diets: experiments in vitro and in vivo. Journal of Agricultural and Food Chemistry 59(13): 7441-51.

Hamauzu Y, Nosaka T, Ito F, Suzuki T, Torisu S, Hashida M, Fukuzawa A, Ohguchi M and Yamanaka S. 2011. Physicochemical characteristics of rapidly dried onion powder and its anti-atherogenic effect on rats fed high-fat diet. Food Chemistry 129(3): 810 15.

Hanieh H, Narabara K, Tanaka Y, Gu Z, Abe A and Kondo Y. 2012. Immunomodulatory effects of Alliums and Ipomoea batata extracts on lymphocytes and macrophages functions in white leghorn chickens: in vitro study. Animal Science Journal 83(1): 6876.

He Quan, Kubec Roman, Jadhav A P and Musah R A. 2011. First insights into the mode of action of a "Lachrymatory Factor Synthase"-Implications for the mechanism of lachrymator formation in Petiveria alliacea, Allium cepa and Nectaroscordum species. Phytochemistry 72(16): 1939-46.

Heeim M, Kyung-sikham Y-s, Seong-gookkang, Buk-guheo, Hannaleontowicz, Marialeontowicz, Jaceknamiesnik, Kasianajman and Shelagorinstein. 2012. Effects of cooking on the bioactivity of lotus roots and white onions. International Journal of Food Properties 15(1): 49-59.

Hertog M G L, Hollman P C H and Venema D P. 1992. Optimization of quantitative HPLC determination of potentially anticarcinogenic flavonoids in vegetables and fruits. Journal of Agriculture and Food Chemistry 40: 1591-98.

Hyun S-W, Park M J S W, Kim E J and Jung Y-S. 2013. Onion (Allium cepa) extract 
attenuates brain edema. Nutrition 29: 244-49.

Ibáñez F, Rezano A, Fredes A, Rodríguez G, Reggio A and Vilaró F. 2012. Development of a rapid microplate assay for determining pungency in onion breeding program. Acta Horticulturae 935.

Ismail A M, Sedki A A and Abdallah A G. 2003. Influence of black seed, garlic and onion supplementation on reproductive performance in rabbit. Egyptian Journal of Agricultural Research 81: 1193-1205.

Jimenez L, Alarcf E, Trevithick-Sutton N C, Gandhi N and Scaiano J C. 2011. Effect of $\gamma$ radiation on green onion DNA integrity: role of ascorbic acid and polyphenols against nucleic acid damage. Food Chemistry 128(3): 735-41.

Jones M G, Hughes J, Tregova A, Milne J, Tomsett A B and Collin H A. 2004. Biosynthesis of the flavour precursors of onion and garlic. Journal of Experimental Botany 55(404): 1903-18.

Jung Y-S, Kim M H, Lee S H, Baik E J, Park S W and Moon C-H. 2002. Antithrombotic effect of onion in streptozotocin-induced diabetic rat. Prostaglandins, Leukotrienes and Essential Fatty Acids 66: 453-58.

Kamal A and Daoud J. 2003. Effect of onion and/or garlic as feed additive on blood, tissue constituents and growth performance in Muscovy Ducks. Veterinary Medicine Journal 51: 161-75.

Kato M, Kamoi T, Sasaki R, Sakurai N, Aoki K, Shibata D and Imai S. 2013. Structures and reactions of compounds involved in pink discolouration of onion. Food Chemistry 139(1-4): 885-92.

Lancaster J E and Kelly K E. 1983. Quantitative analysis of the S-alk(en)yl-L-cysteine sulphoxides in onion (Allium cepa L.) Journal of Science of Food and Agriculture 34: 1229-35.

Lanzotti V, Romano A, Lanzuise S, Bonanomi G and Scala F. 2012. Antifungal saponins from bulbs of white onion, Allium cepa L. Phytochemistry 74: 133-39.

Lee B, Jung J-h and Kim H-s. 2012a. Assessment of red onion on antioxidant activity in rat. Food and Chemical Toxicology 50(11): 3912-19.

Lee E J, Rezenom Y H, Russell D H, Patil B S and Yoo K S. 2012b. Elucidation of chemical structures of pink-red pigments responsible for 'Pinking' in macerated onion (Allium cepa L.) using HPLC-DAD and Tandem Mass Spectrometry. Food Chemistry 131(3): 852-61.

Lee $\mathbf{J}$ and Mitchell A E. 2012. Pharmacokinetics of quercetin absorption from apples and onions in healthy humans. Journal of Agricultural and Food Chemistry 60(15): 3874 81.

Lee J, Ebeler S E, Zweigenbaum J A and Mitchell A E. 2012c. UHPLC-(ESI)QTOF MS/ MS profiling of quercetin metabolites in human plasma post consumption of apple sauce enriched with apple peel and onion. Journal of Agricultural and Food Chemistry 60(34): 8510-20.

Lee J H, Lee S J, Park S, Jeong S W, Kim C Y, Jin J S, Jeong E-d, Kwak Y-s, Kim S T, Bae D W, Kim G-s and Shin S C. 2012d. Determination of flavonoid level variation in onion (Allium cepa L.) infected by Fusarium oxysporum using liquid chromatographytandem mass spectrometry. Food Chemistry 133(4): 1653-57.

Lee J-B, Miyake S, Umetsu R, Hayashi K, Chijimatsu T and Hayashi T. 2012e. Antiinfluenza A virus effects of fructan from Welsh onion (Allium fistulosum L.) Food Chemistry 134(4): 2164-68.

Lee S-M, Moon J, Chung J H, Cha Y-J and Shin M-J. 2013. Effect of quercetin-rich onion peel extracts on arterial thrombosis in rats. Food and Chemical Toxicology 57: 99105.

Lee S-M, Moon J, Do H J, Chung J H, Lee K-h, Cha Y-j and Shin M-j. 2012f. Onion peel 
extract increases hepatic low-density lipoprotein receptor and ATP-binding cassette transporter A1 messenger RNA expressions in Sprague-Dawley rats fed a high-fat diet. Nutrition Research 32(3): 210-17.

Lu D-F, Yang L-J, Wang F and Zhang G-1. 2012. Inhibitory effect of luteolin on estrogen biosynthesis in human ovarian granulosa cells by suppression of aromatase (CYP19). Journal of Agricultural and Food Chemistry 60(34): 8411-18.

Lu X, Wang J, Al-Qadiri H M, Ross C F, Powers J R, Tang J and Rasco B A. 2011. Determination of total phenolic content and antioxidant capacity of onion (Allium cepa) and shallot (Allium oschaninii) using Infrared Spectroscopy. Food Chemistry 129(2): 637-44.

Ly T N, Hazama C, Shimoyamada M, Ando H, Kato K and Yamauchi R. 2005. Antioxidative compounds from the outer scales of onion. Journal of Agricultural and Food Chemistry 53: $8183-89$.

Masamura N, Aoyagi M, Tsuge N, Kamoi T and Imai S. 2012a. Proton transfer in a reaction catalyzed by onion lachrymatory factor synthase. Bioscience, Biotechnology, and Biochemistry 76(9): 1799-1801.

Masamura N, Mccallum J, Kenel F, Pither-joyce M, Khrustaleva L, Suzuki G, Mukai Y, Yamauchi N and Shigyo M. 2012b. Genome organization of gene encoding lachrymatory factor synthase in Allium cepa. Acta Horticulturae 969.

Masamura N, Ohashi W, Tsuge N, Imai S, Anri Ishii-nakamura, Hirota $\mathrm{H}$, Nagata $\mathrm{T}$ and Kumagai H. 2012c. Identification of amino acid residues essential for onion Lachrymatory Factor Synthase activity. Bioscience, Biotechnology and Biochemistry 76(3): 447-53.

Millet A, Lamy E, Jonas D, Stintzing F, Mersch-Sundermann V and Merfort I. 2012. Fermentation enhances biological activity of Allium cepa bulb extracts. Journal of Agricultural and Food Chemistry 60(9): 2148-56.

Moon C H, Jung Y S, Kim M H, Lee S.H, Baik E J and Park S W. 2000. Mechanism for antiplatelet effect of onion: AA release inhibition, thromboxane $\mathrm{A}_{2}$ synthase inhibition and $\mathrm{TXA}_{2} / \mathrm{PGH}_{2}$ receptor blockade. Prostaglandins, Leukotrienes and Essential Fatty Acids 62: 277-83.

Moon J, Do H-J, Kim O Y and Shin M-J. 2013. Antiobesity effects of quercetin-rich onion peel extract on the differentiation of 3T3-L1 preadipocytes and the adipogenesis in high fat-fed rats. Food and Chemical Toxicology 58: 347-54.

Munday R and Munday C M. 2001. Relative activities of organosulfur compounds derived from onions and garlic in increasing tissue activities of quinone reductase and glutathione transferase in rat tissues. Nutrition and Cancer 40(2): 205-10.

Nuutila A M, Puupponen-Pimiä R, Aarni M and Oksman-Caldentey K M. 2003. Comparison of antioxidant activity of onion and garlic extracts by inhibition of lipid peroxidation and radical scavenging activity. Food Chemistry 81: 485-93.

Patil S, Sagar V R, Sadananda G K and Chikkanna G S. 2012. Physico-chemical constituents in onion (Allium cepa L.) during storage. Bioinfoletters 9(3).

Patra P, Sen I K, Bhanja S K, Nandi A K, Samanta S, Das D, Devi K S P, Maiti T K and Islam S S. 2013. Pectic polysaccharide from immature onion stick (Allium cepa): Structural and immunological investigation. Carbohydrate Polymers 92(1): 345-52.

Perez-Gregorio M R, Gonze1 C lez-Barreiro R, Rial-Otero J and Simal-Gendara. 2011a. Comparison of sanitizing technologies on the quality appearance and antioxidant levels in onion slices. Food Control 22(12): 2052-58.

Pérez-Gregorio M R, Regueiro J, González-Barreiro C, Rial-Otero R and Simal-Gándara J. 2011b. Changes in antioxidant flavonoids during freeze-drying of red onions and subsequent storage. Food Control 22(7): 1108-13.

Prasad K, Axdal V A, Yu M and Raney B L. 1995. Antioxidant activity of allicin, an active 
principle in garlic. Molecular Cell Biochemistry 148: 183-89.

Randle W M. 1997. Onion flavour chemistry and factors influencing flavour intensity, pp. 41-44. (In): Spices: Flavour Chemistry and Antioxidant Properties. Risch S J and Ho C T. (Eds). Washington D.C.: American Chemical Society.

Randle W M and Bussard M L. 1993. Pungency and sugars of short-day onions as affected by sulfur nutrition. Journal of American Society of Horticultural Science 118(6): 76670.

Randle W M, Lancaster J E, Shaw M L, Sutton K H, Hay R L and Bussard M L. 1995. Quantifying onion flavor compounds responding to sulfur fertility-sulfur increases levels of alk(en)yl cysteine sulfoxides and biosynthetic intermediates. Journal of American Society of Horticultural Science 120 (6): 1075-81.

Reddy R R L and Srinivasan K. 2011. Dietary fenugreek and onion attenuate cholesterol gallstone formation in lithogenic diet fed mice. International Journal of Experimental Pathology 92(5): 308-19.

Russo M, di Sanzo R, Cefaly V, Carabetta S, Serra D and Fuda S. 2013. Non-destructive flavour evaluation of red onion (Allium cepa L.) ecotypes: An electronic-nose-based approach. Food Chemistry 141(2): 896-99.

Sadeghi M, Zolfaghari B, Senatore M and Lanzotti V. 2013. Spirostane, furostane and cholestane saponins from Persian leek with antifungal activity. Food Chemistry 141(2): 1512-21.

Schwimmer S and Weston W J. 1961. Enzymatic development of pyruvic acid in onions as a measure of pungency. Journal of Agricultural Chemistry 9: 301-04.

Shim S-M, Yi H-L and Kim Y-S. 2011. Bioaccessibility of flavonoids and total phenolic content in onions and its relationship with antioxidant activity. International Journal of Food Sciences and Nutrition 62(8): 835-38.

Shivashankara K S and VeereGowda R. 2005. Total antioxidant and radical scavenging capacities of white, yellow and red onion types, pp. 63-71. (In): Proceedings of National Conference on Alliums: Importance, Cultivation, Commercialization and Pharmacotherapeutic Properties of Garlic, Onion and Ornamental Alliums, held during 24-25 Feb. 2005 at Varanasi, India.

Sharma R. 2006. Home treatment by onion, pp. 27-30. (In): Herbal Remedies. Lotus Press, New Delhi, India.

Singh S. 2005. Onions for your health. www.yobserver.com. Access date November 10, 2009.

Singh B N, Singh B R, Singh R L, Prakash D, Singh D P, Sarma B K, Upadhyay G and Singh H B. 2009. Polyphenolics from various extracts/fractions of red onion (Allium cepa) peel with potent antioxidant and antimutagenic activities. Food and Chemical Toxicology 47: 1161-67.

Starkenmann C, Niclass Y and Cayeux I. 2011a. Occurrence of 1-glutamyl-S-(1-hydroxy2-methyl-3-pentanyl)-1-cysteine and S-(1-ethyl-3-hydroxy-2-methylpropyl)-1-cysteine in fresh and processed Allium cepa L. cultivar. Flavour and Fragrance Journal 26(6): $378-84$.

Starkenmann C, Niclass Y and Troccaz M. 2011b. Nonvolatile S-alk(en)ylthio-l-cysteine derivatives in fresh onion (Allium cepa L. cultivar). Journal of Agricultural and Food Chemistry 59(17): 9457-65.

Stavric B. 1997. Chemopreventive agents in foods, pp. 53-87. (In): Functionality of Food Phytochemicals. Johns T and Romeo J T. (Eds) Plenum Press, New York, USA.

Suh H J, Lee J M, Cho J S, Kim Y S and Chung S H. 1999. Radical scavenging compounds in onion skin. Food Research International 32: 659-64.

Swieca M, Gawlik-Dziki U, Dziki D, Baraniak B and Czyz J. 2013. The influence of protein-flavonoid interactions on protein digestibility in vitro and the antioxidant quality 
of breads enriched with onion skin. Food Chemistry 141 (1): 451-58.

Teyssier C, Amiot M J, Mondy N, Auger J, Kahane R and Siess M H. 2001. Effect of onion consumption by rat on hepatic drug metabolizing enzyme. Food and Chemical Toxicology 39: 981-87.

Thomas D J and Parkin K L. 1994. Quantification of alk(en)yl-L-cysteine sulfoxides and related amino acids in alliums by high-performance liquid chromatography. Journal of Agricultural and Food Chemistry 42: 1632-38.

Thomas D J, Parkin K L and Simon P W. 1992. Development of a simple pungency indicator test for onions. Journal of Agricultural and Food Chemistry 60: 499-504.

USDA, U.S. Department of Agriculture, Agricultural Research Service. 2007. http:// www.ars.usda.gov/ba/bhnrc/ndl.

USDA, US. Department of Agriculture database for the flavonoid content of selected foods, release 3.1 (December 2013). http://www.ars.usda.gov/nutrientdata

Vidyashankar S, Sambaiah K and Srinivasan K. 2010. Effect of dietary garlic and onion on biliary proteins and lipid peroxidation which influence cholesterol nucleation in bile. Steroids 75(3): 272-81.

Wang B, Chen J, Liang Y and Duh P. 2005. Effect of Welsh onion on oxidation of low density lipoprotein and nitric oxide production in macro phase cell line RAW.264.7. Food Chemistry 91: 47-155.

Wang B-S, Huang G-J, Lu Y-H and Chang L-W. 2013. Anti-inflammatory effects of an aqueous extract of Welsh onion green leaves in mice. Food Chemistry 138 (2-3): 75156.

Whitmore B B and Naidu A S. 2000. Thiosulfinates, pp. 349. (In): Natural Food Antimicrobial Systems. Naidu A S. (Ed.) CRC Press, Boca Raton, USA.

Xiao H and Parkin K L. 2002. Antioxidant functions of selected Allium thio sulfinates and S-alk(en)yl-1-cysteine sulfoxides. Journal of Agricultural and Food Chemistry 50: 2488-93.

Xue Y-L, Ahiko T, Miyakawa T, Amino H, Hu F, Furihata K, Kita K, Shirasawa T, Sawano Y and Tanokura M. 2011. Isolation and Caenorhabditis elegans lifespan assay of flavonoids from onion. Journal of Agricultural and Food Chemistry 59 (11): 5927-34.

Yadav A, Singh S K and Kumar N. 2012. Nutritional and medicinal value of onion. Annals of Horticulture 5(2): 308-14.

Yan M, Li C-W and Hsieh Y-H. 2011. Synergistic inhibition of Listeria monocytogenes by nisin and green onion extract. Journal of Food Safety 31(4): 505-10.

Yang J, Meyers K J, van der Heide J and Liu R H. 2004. Varietal differences in phenolic content and antioxidant and antiproliferative activities of onions. Journal of Agricultural and Food Chemistry 52(22): 6787-93.

Ye C-L, Dai D-H and Hu W-L. 2013. Antimicrobial and antioxidant activities of the essential oil from onion (Allium cepa L.) Food Control 30(1): 48-53.

Yoo K S, Lee E J and Patil B S. 2011. Underestimation of pyruvic acid concentrations by fructose and cysteine in 2,4-Dinitrophenylhydrazine-mediated onion pungency test. Journal of Food Science 76(8): C1136-42.

Zill-e-Huma Vian M A, Fabiano-Tixier A-S, Elmaataoui M and Chemat F. 2011a. A novel idea in food extraction field: Study of vacuum microwave hydrodiffusion technique for by-products extraction. Journal of Food Engineering 105(2): 351-60.

Zill-e-Huma Vian M A, Fabiano-Tixier A-S, Elmaataoui M, Dangles O and Chemat F. 2011b. A remarkable influence of microwave extraction: Enhancement of antioxidant activity of extracted onion varieties. Food Chemistry 127(4): 1472-80. 


\section{Marketing and Export}

T.M. Gajanana and D.Sreenivasa Murthy

Onion is the only vegetable that is exported in large quantities from India. It is unlike many vegetables, which are with major share in the world production, but contribute lesser in terms of foreign exchange earnings. At the same time, onion is one of the most market-sensitive commodities, which create ripples in the trade and also in the political circles. Increase in the price of onions affects the consumer by way of an increase in budget or reallocation in food-consumption budget, while a decrease in its price lowers cost of cultivation and affects the producer. Apart from this price sensitiveness, the other major domestic marketing constraints are post-harvest losses and high price spread, leading to dwindling producer share in the consumer rupee. Keeping these in view, a detailed analysis has been attempted on the marketing and export potential of onions in this chapter. The chapter covers growth pattern, marketing practices, price analysis, post-harvest losses in domestic- and export-oriented onions, export performance, potential importers, and cost and constraints in export of onions.

\section{Domestic Market}

\section{Growth in production}

It was examined from 1991-92 to 2011-12 as well as decade-wise separately. To examine historical and recent trends of onion production in India, secondary data of the area under cultivation and yield of onion have been used. Compound growth rate $(\%)$ in area, production, productivity and export of onion was worked out using the following functional form of growth function.

$$
y=a b^{t} e^{u}
$$

where

$\mathrm{y}$ is the production/area/yield/export of onion

$\mathrm{t}$ is the time trend

a is the intercept

$\mathrm{b}=(1+\mathrm{r})$ and $\mathrm{r}$ is the growth rate

$\mathrm{u}$ is the error term

By transforming expression (1) into semi log form

$$
\operatorname{Ln} y=\operatorname{Ln} a+t \operatorname{Ln} b+u \text {... (2) }
$$

Ln a and Ln b are obtained by application of ordinary least square (OLS) procedure to equation (2) and the growth rate (r) is computed as below.

$$
r=(\text { anti } \log \text { of } \operatorname{Ln} b-1)^{*} 100
$$


There was an impressive growth of $8.28 \%$ per annum in production during 199192 to $2011-12$, and it was noticed that area-led growth $(6.01 \%)$ was more predominant than productivity-led growth (2.48\%) (Table17.1). Estimation of growth rates separately for two decades to facilitate detailed analysis indicates that the period from 2001-02 to 2011-12 showed nearly four-fold higher growth rate in production than the period 1991-92 to 2000-01. The growth in area during these two periods was 4.52 and $8.84 \%$, respectively, which suggests that more area was brought under onion cultivation during the last decade due to profitability of cultivation and good prospects for export. As regards the productivity growth, it is clear that the latter period achieved a significant growth of nearly $5 \%$ while the former showed negative growth $(-0.79)$. Improvement in productivity in the latter period is attributed mainly to release of high-yielding varieties/hybrids as well as adoption of improved production and protection technologies.

Table 17.1 Pattern of growth in onion area, production and productivity

\begin{tabular}{lcccl}
\hline \multirow{2}{*}{ Period } & \multicolumn{3}{c}{ Growth rate (\%) } & Pattern of growth \\
\cline { 2 - 4 } & Area & Production & Yield & \\
\hline $1991-2001$ & 4.52 & 3.69 & -0.79 & Area-led growth \\
$2001-2012$ & 8.84 & 14.24 & 4.97 & Area- and yield-led growth \\
$1991-2012$ & 6.01 & 8.64 & 2.48 & Area- and yield-led growth \\
\hline
\end{tabular}

\section{Marketing of onion: a case study in Karnataka}

For examining marketing issues like marketing channels, post-harvest losses and price spread primary data were collected directly from all stakeholders participating in the onion-marketing processes. The primary data were collected through survey method in Karnataka, as the state is one of the major onion-growing states, next only to Maharashtra, accounting for $15.18 \%$ of the area and $14.25 \%$ of the production, with a structured schedule for farmers, retail and wholesale traders and other market functionaries. Onion harvested in Gadag is marketed to distant markets like Bengaluru and hence, Bengaluru market was selected to study marketing practices and also to assess losses at the market level.

Marketing channel: After harvest, onion is left in the field for two days, and de-topping is done at the heaping yard. The de-topped onions are dried in the open for 5 days. After drying, onions are packed in gunny-bags. While field sale was the major marketing channel followed, some farmers

Table 17.2 Marketing cost and returns of the producer ( $₹ / 50 \mathrm{~kg})$

\begin{tabular}{lr}
\hline Items of cost & Cost (₹) \\
\hline Harvesting & 20.00 \\
De-topping & 12.00 \\
Packing material & 12.00 \\
Bagging & 2.00 \\
Loading and transportation & 50.00 \\
Unloading and weighing & 4.00 \\
Total cost & 100.00 \\
Cost of post-harvest losses $(10.43 \%)$ & 32.85 \\
Total cost & 132.85 \\
Price realized & 314.77 \\
Net price realized & 181.92 \\
\hline
\end{tabular}

Source: Gajanana et al. (2010) 
sold onions in the distant markets like Bengaluru through commission agents. For distant market sale, onions in gunny-bags 1 of $50 \mathrm{~kg}$ are transported in trucks. 2 Costs and returns associated with the distant market sale of onion in Bengaluru were worked out.

Costs and returns of the market 3 intermediaries: Cost of marketing $50 \mathrm{~kg}$ of onions worked out to be ₹ 132.85 , consisting of harvesting (15.05\%), de-topping (9.03\%), packing material and bagging (10.54\%), loading and transportation $(37.64 \%)$, unloading and weighing $(3.01 \%)$ and postharvest losses $(24.73 \%)$ (Table 17.2). On an average, farmers realized a net price of ₹ 181.92 .

Retailers incurred a cost of ₹ 357.70 , consisting of loading $(0.56 \%)$, commission $(5.28 \%)$, transportation $(3.67 \%)$ and postTable 17.3 Cost and returns of the retailer

\begin{tabular}{llc}
\hline Particulars & Cost $(₹ / 50 \mathrm{~kg})$ \\
\hline 1 & Purchase price & 314.77 \\
2 & Marketing cost & \\
& Loading & 2.00 \\
& Commission & 18.89 \\
& Transport & 13.14 \\
& Total marketing cost & 33.43 \\
3 & Total cost $(1+2)$ & 348.20 \\
& Cost of post-harvest & 9.50 \\
& losses $(2.12 \%)$ & 357.70 \\
\hline
\end{tabular}

Table 17.4 Price spread in marketing of onions

\begin{tabular}{lrr}
\hline Particulars & \multicolumn{2}{c}{ Price spread } \\
\cline { 2 - 3 } & $₹ / 50 \mathrm{~kg}$ & $\%$ \\
\hline Net price received by farmers & 181.92 & 39.93 \\
Post-harvest losses at the & 32.85 & 7.21 \\
$\quad$ field level & & \\
Marketing cost of producers & 100.00 & 21.95 \\
Retailer's cost & 33.43 & 7.33 \\
Post-harvest losses at retail level & 9.50 & 2.08 \\
Retailer's margin & 98.00 & 21.50 \\
Consumer's price & 455.50 & 100.00 \\
\hline
\end{tabular}
harvest losses $(2.66 \%)$ besides the purchase price (Table 17.3). They realized a net price of ₹ 97.80 for $50 \mathrm{~kg}$ of onions.

Marketing efficiency: The producer share was very low, only $40 \%$ (Table 17.4). It may be noted that the marketing system for onions has not been as efficient as its efficiency index was less than 1.00 at 0.78 (Table 17.5). In this context, post-harvest losses and their impact on marketing efficiency was studied.

Efficiency of the marketing system was analysed normally using standard formula of Acharya and Agarwal (2001). This formula was later modified by

Table 17.5 Efficiency in marketing of onions

\begin{tabular}{lc}
\hline Efficiency parameters & Efficiency parameter values \\
\hline Producer's share $(\%)$ & 39.93 \\
Marketing cost $(\mathrm{MC})(₹ / \mathrm{kg})$ & $2.66(3.51)^{\star}$ \\
Intermediaries margin $(\%)$ & 21.50 \\
Post-harvest loss (PHL) $(\%)$ & 9.29 \\
Marketing efficiency (ME) index & $0.78(0.66)^{\star \star}$
\end{tabular}

${ }^{\star} \mathrm{MC}$ Marketing cost after inclusion of PHL as an item of cost, ${ }^{\star \star} \mathrm{ME}$ after inclusion of PHL as $\mathrm{MC}$ 
Sreenivasa Murthy et al. (2004) by including post-harvest losses as an item of cost, as is given below.

$$
\mathrm{ME}=\frac{\mathrm{NP}_{\mathrm{F}}}{\mathrm{MC}+\mathrm{MM}+\mathrm{PHL}}
$$

where ME $=$ Marketing efficiency index

$\mathrm{NP}_{\mathrm{F}}=$ Farmer's net price

$\mathrm{MC}=$ Marketing cost of the intermediaries

$\mathrm{MM}=$ Marketing margin of the intermediaries

PHL $=$ Post harvest loss during marketing

Post-harvest losses: A case study in Karnataka: Like other vegetables, onion is also subject to losses at different stages of handling after the harvest. These losses will have implications on the efficiency of the marketing system. Keeping in view the losses that occur at different stages of handling, post-harvest losses (PHL) were estimated along with the causes in Karnataka as per the procedures highlighted in Gajanana et al. (2010).

Big onion: Post-harvest loss was estimated in one of the major onion-producing districts of Gadag in Karnataka. The PHL was estimated from 47 fields of onions in the district to assess losses during preparation of onions for the market, particularly during sorting and packing. The transit loss from production centre to destination centre was estimated at Bengaluru market, immediately after arrivals. Losses occurring at the retail level were assessed from 27 retailers of onions in Bengaluru. Simple averages and percentages are used for PHL estimation. The following channel was used for the estimation: Producer $\rightarrow$ Commission Agent $\rightarrow$ Retailer $\rightarrow$ Consumer.

The field level loss was observed to be $10.43 \%$, consisting of rot $(7.5 \%)$, skin out $(0.17 \%)$, doubles/splits $(2.99 \%)$ and sprouts $(0.11 \%)$. C grade produce (double and small), which fetches only one-third the price, was observed to be $7.98 \%$ thereby suggesting that there is a need to standardize production practices for better quality onions. Atibudhi (1997) observed a field level loss of 13.75\%; consisting of weight loss $(8.71 \%)$, spoilage of bulbs $(4.29 \%)$ and sprouting $(0.75 \%)$. It may be noted that farmers did not have the storage facility and had to transport to distant markets immediately after drying of onions in heaps. In another study by Kishor Kumar et al. (2006), the estimated field level loss was observed to be $6.21 \%$, and storage loss (decay, sprouting, de-scaling and rooting) was about $50 \%$ of this loss, as farmers had adopted traditional-heap method of storage.

There existed a significant positive association $(\mathrm{r}=0.35)$ between the field level loss and the acreage under onions, thereby indicating that more area under onions would dilute efforts towards proper crop management. It was further indicated by the regression analysis that an increase in area by one acre would bring about $1.05 \%$ increase in field-level loss. Production of onion per hectare had a positive and significant relationship with field-level losses of onions farmer would not be able to pay full attention to post-harvest operations when large quantity is produced, and the limited managerial skills lead to higher losses(Kishor Kumar et al., 2006). 
After harvest and curing, onions grown in Gadag are transported to Bengaluru market. Retailers buy onions from farmers through commission agents at the market place. Information on losses at the retail level was collected from retailers. At the retail level the loss was observed to be $2.12 \%$; consisting of rot $(1.52 \%)$, peel $(0.49 \%)$ and sprouts $(0.11 \%)$. Pathological investigation of the sampled lots of rotten onion-bulbs indicated that rotting of bulbs at the field level was mainly due to soft-rot (Erwinia carotovora var. carotovora), black-rot (Aspergillus niger var. Tieghem) and bulb-rot due to Sclerotium sp. For managing post-harvest diseases, curing of the harvested onions in the field for two days and then further drying in the shade for 10-15 days before storage is effective. Care should be taken to avoid injury to bulbs during post-harvest handling. For controlling black mold (A. niger), the crop should be sprayed with Carbendazim (0.2\%) 10-15 days before harvesting and for white-rot (Sclerotium rolfsii), seed treatment with Thiram ( $4 \mathrm{~g} / \mathrm{kg}$ of seeds) and drenching of the soil with Mancozeb $(0.25 \%)$ are recommended.

Post-harvest losses (PHL) account for about 9\% of the consumer's price in the marketing channel. As PHL increases the cost of marketing, it also has an impact on the marketing efficiency. Price spread was observed to be $60 \%$, which without the PHL, would have been just 51\%. If PHL is also included as an item of cost of marketing, efficiency of the already inefficient marketing system further lowers. It may, therefore, be inferred that efforts are needed to reduce losses during postharvest handling of onions to improve efficiency of the marketing system.

Export-oriented rose onion: Its post-harvest losses at the field level were estimated from 47 onion harvesting/harvested fields in Kolar and Chikkaballapura districts in Karnataka and at the exporters' level from 14 exporters in Chennai.

As pointed out earlier, production practices are not standardized; this results in more number of splits and very small bulbs, which do not meet export standards. Hence, efforts were made to assess post-harvest losses in rose onion, exclusively grown for export, in the study area to understand the extent and the cause of losses. Kolar and Chikkaballapur districts are the main rose onion-producing areas in Karnataka. It was observed that the growers were mostly of small and marginal categories with a holding size of less than 2 ha. Average area under rose onion was observed to be 0.5 ha. Rose onion growers in the area follow Field Sale for marketing of onions. Onion cultivation is not so well organized, though a sort of unwritten contract between the traders and the farmers exist. Onions grown in the area are bought by traders in the field itself and sold to exporters in Chennai. Thus, marketing channel followed is: Farmers $\rightarrow$ Local Traders $\rightarrow$ Exporters. Losses occurring in this channel and their causes were studied.

In rose onion in Kolar and Chikkaballapur districts, total field level loss (due to sorting) was $16.51 \%$; consisting of very small (4.17\%), doubles/splits and rotten bulbs $(8.64 \%)$ and physiological loss in weight during storage was $3.70 \%$. Field level losses in Bagepalli were significantly lesser than Chintamani; due to less percentage of doubles/splits in Bagepalli area.

At the exporter's level, onions brought from the farmers' fields are sorted based on the size into less than $27 \mathrm{~mm}$ and more than $27 \mathrm{~mm}$. Losses at exporters' level assessed in Chennai were mainly due to sorting, which worked out to $7.13 \%$. In 
less than $27 \mathrm{~mm}$ onions, loss was $3.36 \%$, consisting of soiled bulbs and very small damaged bulbs. In case of more than $27 \mathrm{~mm}$ onions, sorting loss was $3.77 \%$; consisting of doubles and skin-out bulbs.

Losses occurring at the field level (16.51\%) and at the exporters' level (7.13\%) together accounted for $23.64 \%$. It therefore indicates that there is a need to standardize production practices so as to have lesser splits/doubles and very small bulbs to meet export criteria.

\section{Major onion markets and price analysis}

There are reports that onion trade is domestically in more than 100 markets in India (The National Horticulture Research and Development Foundation, NHRDF). Recent look at the total arrivals in these markets shows that the arrivals increased from 4,617 thousand MT in 2008-09 to 6,040 thousand MT in 200910 , and then declined to 5,897 thousand MT in 2010-11. The latest decline was due to drought. The total arrivals in these markets together are not a true representation of the total production in a particular season due to cross arrivals from one market to another market, and hence there is duplicity of recording quantum of arrivals. Arrivals do not include self consumed or sold in the villages/ towns. The arrivals in the top 50 markets accounted for around $95 \%$ of the total arrivals in all these markets for which data were available. The share of the top ten markets was nearly 55\%. Maharashtra alone accounted for 24 of the top 50 markets, followed by six in Gujarat, four in Karnataka, and three each in Rajasthan and Uttar Pradesh.

An attempt has been made to analyze the major onion markets and about seasonality of arrivals and prices; for which data were collected from the secondary sources(The secondary data were collected from Ministry of Agriculture and Agriculture Marketing Departments of different states).

\section{Region-wise price analysis}

To analyze price and spatial market integration among different markets, weekly wholesale real prices of onion from 30 major onion markets, including Mumbai, Delhi, Kolkata, Chennai and Bengaluru, published in Horticulture Information Service of National Horticultural Board were collected for the period from January 1991 to September 2007. However, data were not available for all weeks/years in 30 markets, and hence, only 23 major markets were analyzed (Figs 17.1, 17.2). Twenty-three major markets for which complete data were available were grouped into four regions as follows.

(i) Eastern regions : Bhubaneswar, Kolkata, Guwahati and Patna

(ii) Western region : Ahmedabad, Bhopal, Mumbai, Nagpur, Pune, Surat

(iii) Northern region: Chandigarh, Delhi, Jammu, Jaipur, Kanpur, Srinagar, Agra

(iv) Southern region : Bengaluru, Hyderabad, Chennai, Madurai and Thiruvananthapuram

Data of weekly wholesale real prices of onions, which were averaged to the year for different states, are presented in Table17.6. Data indicate a large volatility in onion price in every market over the years. Onion price is also found volatile across time due to supply shocks, perishable nature, vagaries of monsoon, change 


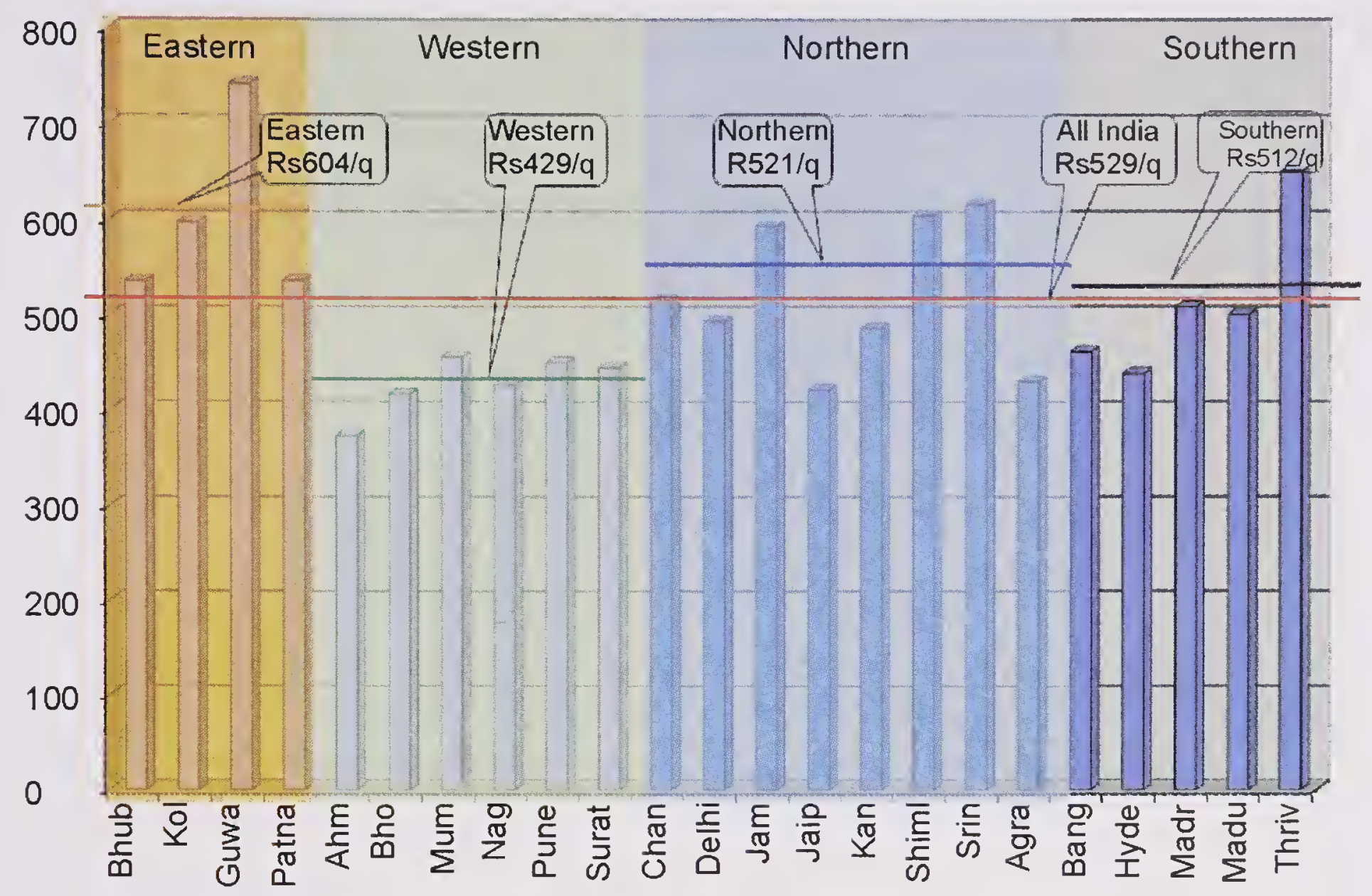

Fig. 17.1 Price relationships of different markets in India -Average prices of onion, 1991 to 2007

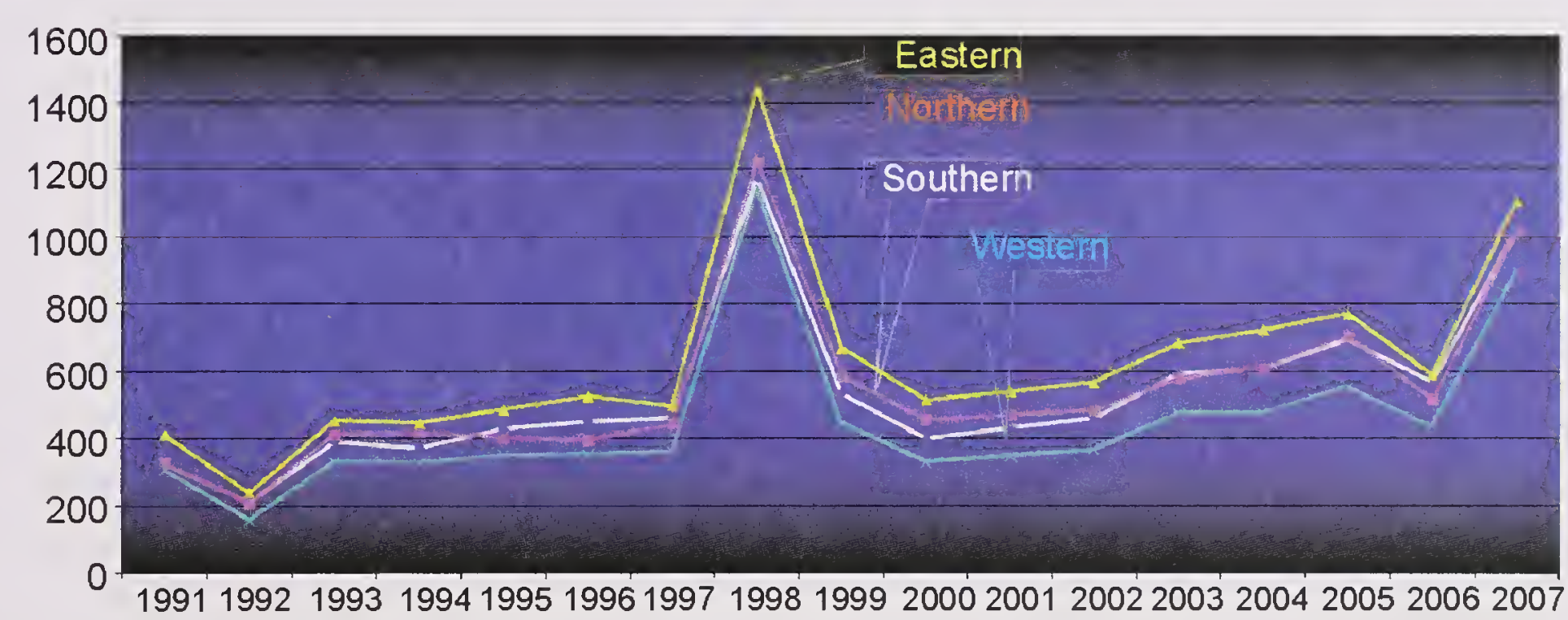

Fig.17.2 Price relationships between the different regions in India

in international scenario, etc. Except for the years 1998 and 2007, the trend in each of the market was gradual and steady.

The aggregation of the prices of onion at the national level indicated that the triennium average price of ₹ 312/q in January 1991 increased to ₹ 735/q for the triennium ending 2007. The details on the aggregation of the average wholesale real price of onion per quintal for four regions as well as of national average are given in Table 17.7. The lowest prices of onions were observed in Western region markets, where the distance between the producing areas and the markets was minimum. As the onions move to different markets during and after harvesting, cost of the onions increases, and this results in higher wholesale prices in distant markets like Jammu, Kolkata, Guwahati, etc. For instance, the average price of onions in the western markets (where the production regions are located) during 


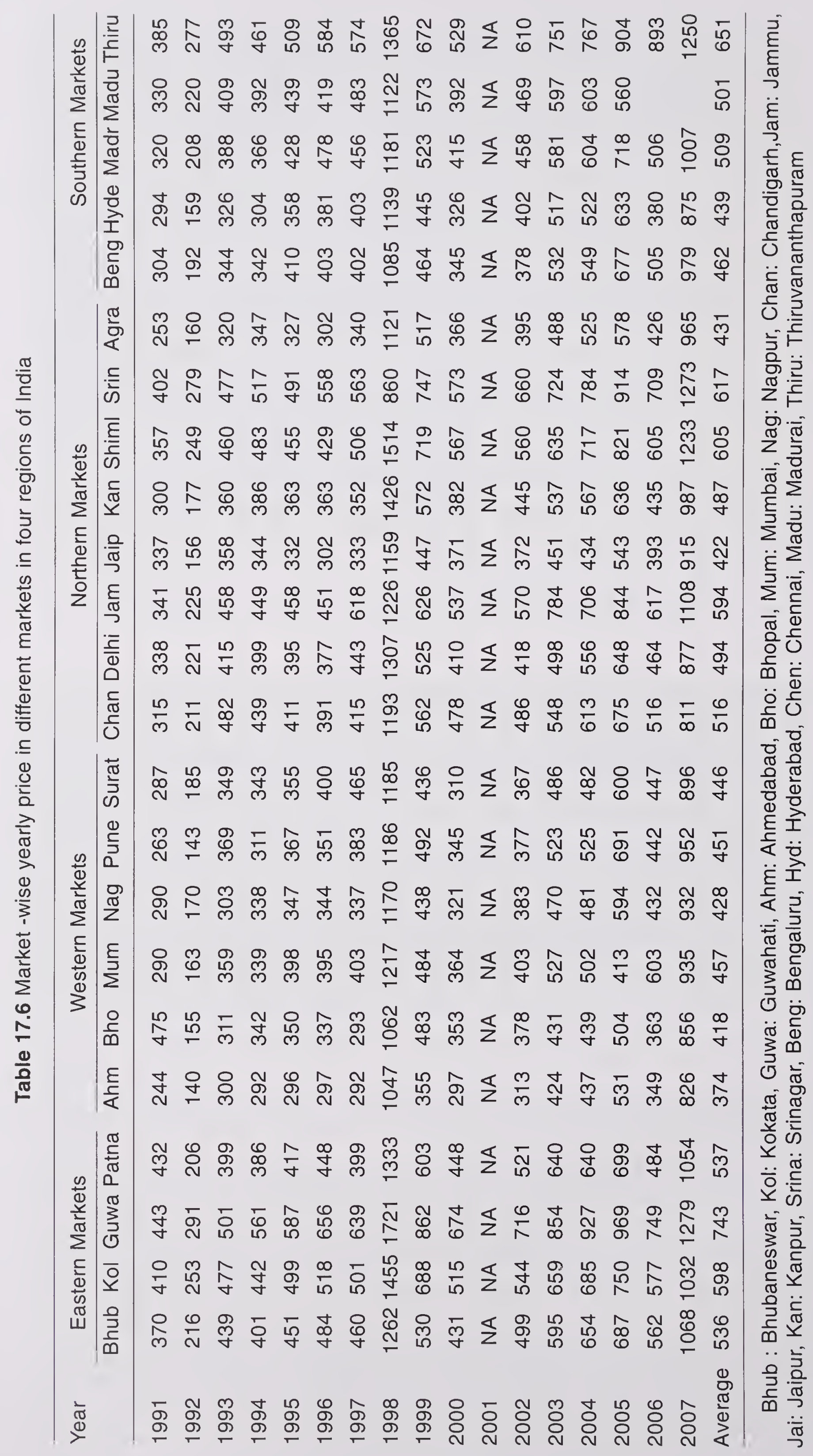


Table 17.7 Region -wise average price of onions from1991 to 2007 (₹/q)

\begin{tabular}{lrrrrr}
\hline Year & South & North & East & West & All India \\
\hline 1991 & 327 & 330 & 414 & 308 & 338 \\
1992 & 211 & 210 & 241 & 159 & 202 \\
1993 & 392 & 416 & 454 & 332 & 396 \\
1994 & 373 & 420 & 448 & 328 & 391 \\
1995 & 429 & 404 & 488 & 352 & 411 \\
1996 & 453 & 397 & 526 & 354 & 420 \\
1997 & 464 & 446 & 500 & 362 & 437 \\
1998 & 1,178 & 1,226 & 1,443 & 1,145 & 1,232 \\
1999 & 535 & 589 & 671 & 448 & 555 \\
2000 & 401 & 461 & 517 & 332 & 424 \\
2001 & NA & NA & NA & NA & NA \\
2002 & 464 & 488 & 570 & 370 & 466 \\
2003 & 596 & 583 & 687 & 477 & 576 \\
2004 & 609 & 613 & 726 & 477 & 596 \\
2005 & 698 & 707 & 776 & 555 & 678 \\
2006 & 571 & 521 & 593 & 439 & 521 \\
2007 & 1,028 & 1,021 & 1,109 & 900 & 1,005 \\
Average & 512 & 521 & 604 & 429 & 509 \\
\hline
\end{tabular}

September 2007 was ₹ 900/q compared to the wholesale price of ₹ 1,021 in the northern markets, ₹ $1028 / \mathrm{q}$ in the southern markets and ₹ 1109 in the eastern markets. These higher prices were in the order of 13,14 and $23 \%$ in these markets, respectively. The price difference across these markets is mainly due to transportation and transaction costs.

Market correlation: Correlations between weekly prices of onions for major 23 markets were estimated and the results are given in Table17.8. The relationship between prices of different markets was found strong and significant. This indicates the near perfect relationship in the movement of prices in different markets. However, the relationship between Jammu and Kashmir markets with other markets, though found significant, was not near perfect as values ranged between 0.4 and 0.6 .

Onion price analysis during the last five years: A brief status report on onions (NHRDF, 2013) analysed the status of their production and marketing in India. According to this, the movement of average arrivals of last five years in the major consuming markets of Mumbai, Delhi, Kolkata and Chennai was almost same, except Kolkata, where arrivals fluctuated because of the export demand of Bangladesh through Kolkata arriving from Maharashtra (by rail) and from Karnataka (by road). In producing markets of Lasalgaon, Pimpalgaon, Bengaluru and Pune, arrivals were more from December to March because the produce harvested in these months was not for storage and was to be brought to the market. In Karnataka, major harvesting of kharif crop takes place in October and November.

In both consuming and producing markets, prices start increasing from October/ November and would remain at a higher level till January/February. During these months, demand for onion emanates from northern, southern and eastern states (non-kharif onion-producing regions), and this has to be met from the supply of onion from the kharif onion-producing states of Maharashtra, Gujarat, Rajasthan 


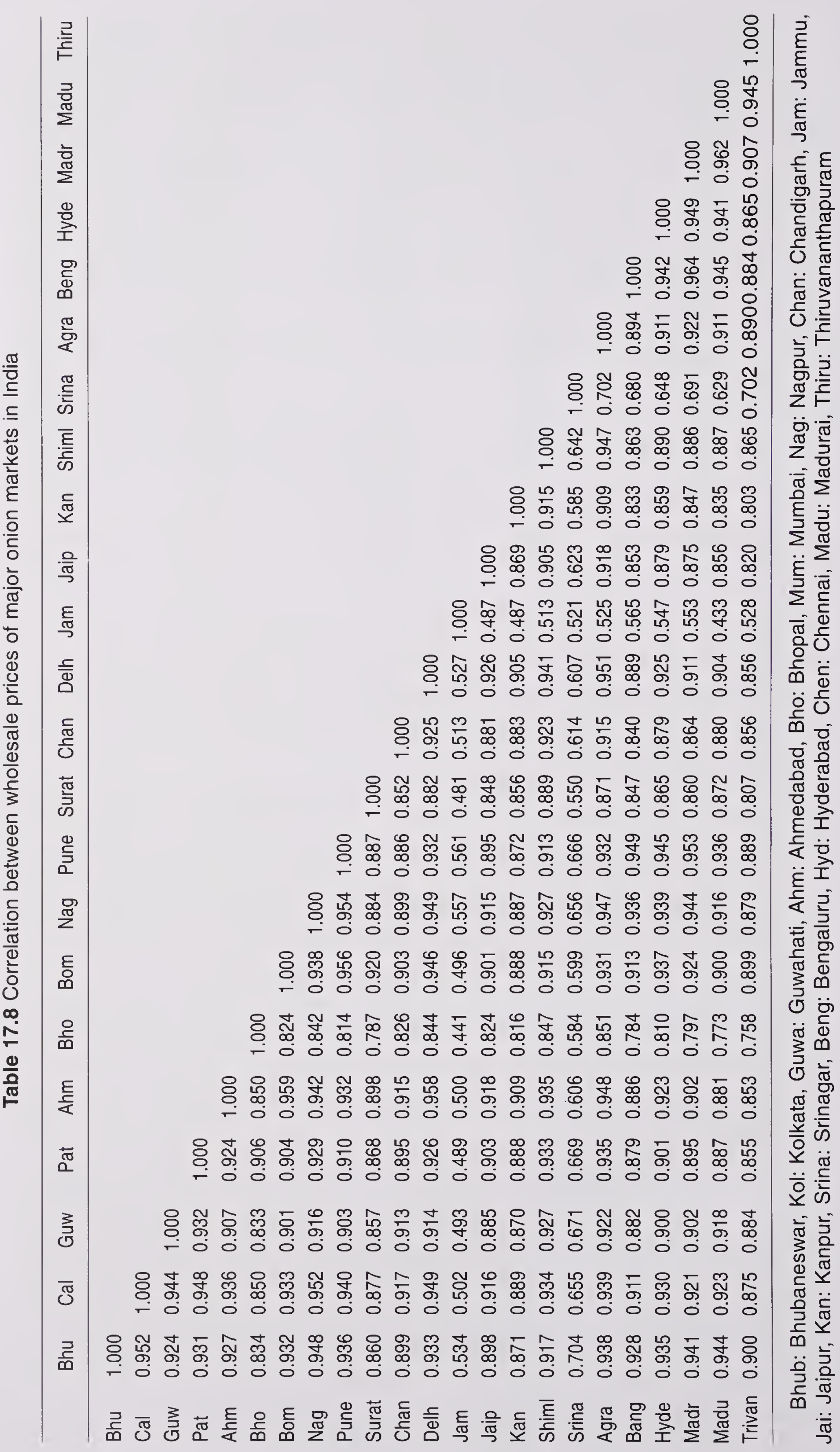


and Karnataka. Because of higher domestic prices, the export is normally lesser during these months.

Market integration-A case study of five major markets: Markets are said to be spatially integrated if price changes in one market it is fully reflected in the alternative market. Prices in spatially integrated markets are determined simultaneously at various locations, and information of any change in price in one market is transmitted to other markets. Markets that are not integrated may convey inaccurate price signal that may distort producers marketing decision and contribute to inefficient product movement, and traders may exploit market and benefit at the cost of producers and consumers. Based on the information of the extent of market integration, government can formulate policies of providing infrastructure and information regulatory services to avoid market exploitation.

Spatial market integration is analyzed by estimating price relationship between spatially separated markets using the Equation given below.

$$
\bar{\Delta} y_{t}=\mu+\left(\beta_{1}-1\right)\left(\mathrm{y}_{\mathrm{t}-1}-\lambda x_{t-1}\right)+\gamma_{0} \Delta \mathrm{x}_{\mathrm{t}}+\varepsilon_{\mathrm{t}}
$$

Where $y_{t}$ and $x_{t}$ are prices in two spatially separated markets, $\mu$ is intercept, $\beta_{1}$ is parameter that measures the speed of adjustment to long-run equilibrium, $\gamma_{0}$ is slope on $\Delta x_{t}, \lambda$ is market integration parameter. If the two markets are perfectly spatially integrated, the parameter $\lambda$ is one or near to one.

An attempt has been made in the present study to examine how Bengaluru market is integrated with other major metropolitan cities. Care was taken that each market from each zone was selected, and the details are as follows.

1. Bengaluru market with Pune (western market), Delhi (northern market), Chennai (southern market-Nearest market) and Kolkata (eastern marketFarthest market)

2. Chennai market with Pune (western market), Delhi (northern market), Bengaluru (southern market-Nearest market) and Kolkata (eastern marketFarthest market)

3. Mumbai market with Pune (western market), Delhi (northern market), Bengaluru (southern market-Nearest market) and Kolkata (eastern marketFarthest market)

4. Delhi market with Pune (western market), Chandigarh (northern market), Bengaluru (southern market-Nearest market) and Kolkata (eastern marketFarthest market)

5. Kolkata market with Pune (western market), Delhi (northern market) and Bengaluru (southern market-Nearest market)

The results of the market integration between Bengaluru market and other major markets, viz. Pune, Delhi, Chennai and Kolkata are presented in Table 17.9. The market integration equation was found highly significant as the $R^{2}$ values for all four equations were more than $92 \%$.

In the regression of Bengaluru on Chennai, the estimated value of $\lambda$ was near to one, i.e. 0.9413 indicating that the price change in Chennai was almost fully reflected in Bengaluru. The estimated market integration parameter $\lambda=0.8310$ for the regression of Bengaluru on Pune, 0.7712 for Delhi on Bengaluru and 0.7024 for Bengaluru on Kolkata was observed. These results indicate strong 
Table 17.9 Spatial price relationships between Bengaluru and other onion markets

\begin{tabular}{|c|c|c|c|c|c|c|}
\hline $\begin{array}{l}\text { Dependent } \\
\text { variable }\end{array}$ & $\begin{array}{l}\text { Independent } \\
\text { variable }\end{array}$ & $\begin{array}{c}\text { Intercept } \\
\mu\end{array}$ & $\begin{array}{c}\text { Adjustment } \\
\text { parameter } \\
\beta\end{array}$ & $\begin{array}{l}\text { Slope on } \quad \gamma 1 \\
\quad \Delta x \\
\gamma 0\end{array}$ & $\begin{array}{c}\text { Market } \\
\text { integration } \\
\text { parameter } \lambda\end{array}$ & $\mathrm{R}^{2}$ \\
\hline \multicolumn{7}{|l|}{ Bengaluru } \\
\hline & Pune & 30.306 & 0.6729 & $0.5327-0.2609$ & 0.8310 & 0.9488 \\
\hline & Chennai & -5.464 & 0.6090 & $0.6666-0.2985$ & 0.9413 & 0.9536 \\
\hline & Kolkata & 12.684 & 0.7643 & $0.2870-0.1214$ & 0.7024 & 0.9225 \\
\hline & Delhi & 15.747 & 0.8312 & $0.4390-0.3088$ & 0.7712 & 0.9303 \\
\hline \multicolumn{7}{|l|}{ Chennai } \\
\hline & Pune & 32.306 & 0.6929 & $0.5927-0.3452$ & 0.8426 & 0.92 \\
\hline & Bengaluru & 12.684 & 0.7643 & $0.2870-0.1214$ & 0.9500 & 0.95 \\
\hline & Kolkata & 11.684 & 0.8643 & $0.3456-0.3224$ & 0.7424 & 0.91 \\
\hline & Delhi & 17.747 & 0.7312 & $0.5567-0.2345$ & 0.7963 & 0.94 \\
\hline \multicolumn{7}{|l|}{ Mumbai } \\
\hline & Bengaluru & -7.956 & 0.649 & $0.4356-0.3256$ & 0.8310 & 0.916 \\
\hline & Kolkata & 13.562 & 0.8643 & $0.4156-0.3224$ & 0.7924 & 0.931 \\
\hline & Delhi & 14.256 & 0.7312 & $0.4568-0.2345$ & 0.8545 & 0.904 \\
\hline \multicolumn{7}{|l|}{ Delhi } \\
\hline & Pune & 15.465 & 0.6349 & $0.5623-0.3352$ & 0.8656 & 0.892 \\
\hline & Bengaluru & 8.562 & 0.557 & $0.6456-0.5256$ & 0.6953 & 0.913 \\
\hline & Kolkata & 11.223 & 0.5864 & $0.5415-0.4224$ & 0.8324 & 0.823 \\
\hline & Chandigarh & 11.003 & 0.6731 & $0.5568-0.3345$ & 0.9246 & 0.923 \\
\hline Rulkdid & Pune & 15.465 & 0.6349 & $0.5623-0.3352$ & 0.8256 & 0.903 \\
\hline & Bengaluru & 12.684 & 0.7643 & $0.2870-0.1214$ & 0.7024 & 0.921 \\
\hline & Delhi & 11.223 & 0.5864 & $0.5415-0.4224$ & 0.8624 & 0.895 \\
\hline
\end{tabular}

spatial market integration among markets, which are nearer (Bengaluru and Chennai), and this becomes weaker with distant markets (Bengaluru-Pune, Bengaluru-Delhi and Bengaluru-Kolkata).

Market integration of Chennai market with other regional markets indicated that the model was found highly significant as suggested in the high $\mathrm{R}^{2}$ values $(0.91$ to 0.95) in all equations, viz. Chennai with Bengaluru, Delhi, Pune and Kolkata. This indicates that the fitted models sufficiently explain the variations in the model. The estimated coefficients (market integration) of these four models were also found significant at $1 \%$ or $5 \%$ level. In the regression of Chennai on Bengaluru, the estimated value of ' 1 ' was near to one, i.e. 0.95 indicating that the price change in Chennai was almost fully reflected in Bengaluru. A change of ₹ 1.00 in onion price in Chennai brought about ₹ 0.95 change in onion price in Bengaluru. The reverse estimation of market integration as reported earlier was also the same, indicating that the fitted model was consistent with the markets as regards to the coefficients.

The estimated market integration parameter ' 1 ' was 0.8426 in the regression for Chennai on Pune, 0.7963 for regression of Chennai on Delhi and 0.7424 for regression of Chennai on Kolkata. These results show strong spatial market integration among markets, which were nearer (Bengaluru and Chennai), and weaker for markets located at distant places (Bengaluru-Pune, Bengaluru-Delhi and Bengaluru-Kolkata). 
The market integration models of Mumbai market with other markets also exhibited very high $\mathrm{R}^{2}$, indicating goodness of the fit of the models. The market integration coefficients were also found significant. The highest market integration of Mumbai market was found with Pune market with near perfect integration. Almost $95 \%$ of the change in price in Mumbai market was reflected in Pune market. The extent of change in prices in Delhi due to change in Mumbai market was only about $85 \%$. As regards with the southern market Bengaluru, this integration value was 0.8310 and with the distant market Kolkata, the extent of translation of change was lowest with ' $\mathrm{l}$ ' at 0.7924 . Thus, the trend expressed here is as per the expected lines.

Delhi is one of the major markets in India for onions. The supply mostly comes from production centres of the western belt. The fitted model of market integration for regression of Delhi on Bengaluru, Pune, Chandigarh and Kolkata had high $\mathrm{R}^{2}$ values indicating that fitted models sufficiently explained the variation. The coefficients of all the models were also found significant suggesting that the market integration coefficients also had significant relationships.

The highest market integration coefficient was found between Delhi and Chandigarh; indicating that they had very strong relationships regarding price movement. This was followed between Delhi and Pune and Delhi and Kolkata. Bengaluru being the distant market, the extent of relationship was relatively weaker as compared to other markets.

Kolkata located farther away from the production regions, gets onion supply from the western and eastern regions. The fitted models sufficiently explain the relationship as indicated in high $\mathrm{R}^{2}$ values. The values ranged from 0.895 to 0.941 . The coefficients of all the four models were also found significant indicating that the market integration coefficient was strong and positive. The highest market integration value 1 was found between Kolkata and Delhi market, suggesting that ₹ 1 change in price in Kolkata caused a change of ₹ 0.86 in Delhi market. The 1 value for Kolkata and Bengaluru market and Kolkata and Pune market was 0.7024 and 0.8256 , respectively.

\section{Price stabilization}

The decline in production of onions during bad years affects availability for domestic consumption, which may many times lead to sensitive social, political and economical unrest in the country. The impact of such a situation is well documented, and the following measures/suggestions have been indicated to minimize impact during such a crisis, which may act as a price-stabilization mechanism.

- Strict vigil on the distribution system of the onions, especially on hoarding or black marketing at the distributor level.

- Exploring ways to bring withheld stock by the farmers.

- During the years of less production, a regular mechanism for forecasting and distribution system needs to be developed, and put into preventive action at an earliest possible situation.

- As the problem is recurring, strengthening of the existing storage systems needs to be taken up on the priority so as to supply produce throughout the 
year. Even the storage at the local production areas need to be explored to help farmers.

- Proper distribution network needs to be developed for timely availability of onions in different places in sufficient quantities.

- Ensure more availability of onions for domestic consumption by moderating export of onions.

- Augment present availability with imports.

- On the supply side, development of hybrids/high-yielding varieties resistant to moisture stress and adoption of modern production methods to increase production are essential.

- Efforts to identify and reduce post-harvest losses in onion are needed as these would ensure more availability without any additional cost.

\section{Export Market}

Big (Bellary/Nashik Red) onion and Rose onion are the major types of fresh onions exported from India. Indian onions are exported to about 45 countries in the world. The National Agricultural Cooperative Marketing Federation of India Ltd (NAFED) has been the sole Canalizing Agent for export of onions from India. However, since 1999, twelve more agencies have been added with the overall monitoring by the NAFED. The NAFED is responsible for fixing minimum export price (MEP) of onions, which is done on a monthly basis. Factors such as market trends, world prices and domestic prices, and margins are considered while arriving at the MEP of onions (Mathur, 2001). The latest decision of the GoI to hike MEP is a measure to contain domestic prices by discouraging export.

\section{Share of export in domestic production}

During the last two decades (TE 1993-94 to TE 2011-12), there has been an impressive growth both in domestic production $(8.64 \%)$ and in export $(9.28 \%)$ of onions from India. It may be noted from Table 17.10 that the share of export in domestic production has been hovering around $9 \%$. During the previous decade (1980-81 to 1993-94), the share of export in the domestic production increased mainly due to higher export growth compared to growth in domestic production (Sreenivasa Murthy and Subrahmanyam, 1999). The sudden decline in the share of
Table 17.10 Share of export of onions in the domestic production

\begin{tabular}{lrrr}
\hline Year & $\begin{array}{c}\text { Production } \\
\text { Q (tonnes) }\end{array}$ & $\begin{array}{c}\text { Export } \\
\text { Q (tonnes) }\end{array}$ & $\begin{array}{r}\text { Export } \\
\text { Share } \\
(\%)\end{array}$ \\
\hline TE 1993-94 & 3693966.67 & 372694.07 & 10.09 \\
TE 1995-96 & 4040833.33 & 369801.00 & 9.15 \\
TE 1998-99 & 4376666.67 & 325351.47 & 7.43 \\
TE 2001-02 & 4957566.67 & 348526.20 & 7.03 \\
TE 2004-05 & 6079233.33 & 760620.13 & 12.51 \\
TE 2007-08 & 11331800.00 & 1115828.77 & 9.85 \\
TE 2011-12 & 14929366.67 & 1385723.67 & 9.28 \\
CGR (1991- & 8.64 & 9.28 & \\
2012 (\%) & & & \\
\hline
\end{tabular}

Data Source: NHB Horticulture Data Base; APEDA Export Statistics

export during TE 1998-99 was owing to the ban imposed on the onion export because of the steep rise in domestic onion prices. 


\section{Growth and stability of Indian onion export}

Export of onion grew at $9.28 \%$ in quantity and $15.22 \%$ in value of exports during the last two decades (Table 17.11). Export of onion during the second decade (20012012) registered a higher growth of $11.17 \%$ in quantity and $20.67 \%$ in value; though the performance in Table 17.11 Growth in export of onions the previous decade was not satisfactory.

Coefficient of variation (CV) is normally used to measure instability. Since time series data contain the trend element, it is suggested to use coefficient of variation around the trend $(\mathrm{CVt})$ instead of simple $\mathrm{CV}$. The appropriateness of CVt over CV was suggested by Nadakarni (1971). Further, Cuddy and Della (1978) developed an index of instability $\left(\mathrm{CVt}=\mathrm{CV}\right.$ " $\left.1-\mathrm{R}^{2}\right)$, where $\mathrm{R}^{2}$ is obtained from the trend equation. This index is used to assess instability associated with the export of onion to different countries. It is interesting to note that the high growth as cited above was associated with

less instability $(\mathrm{CVt}=20-22 \%)$.

Table 17.12 Identification of potential importers of onions from India-Growth and Instability

\section{Major international markets for Indian onion}

A three-dimensional analysis of growth, import share and instability was used to identify potential markets for Indian onions. The results are presented in Tables 17.12 and 17.13. Trend in export of onion to major importers is shown in Figs 17.3 and 17.4.

Malaysia registered high growth (10-15\%) with less instability (17$37 \%$ ) during 1993-2012 and its

\begin{tabular}{lcr}
\hline Period & \multicolumn{2}{c}{ CGR (\%) } \\
\cline { 2 - 3 } & Quantity & Value \\
\hline $1991-2001$ & -3.81 & 4.05 \\
$2001-2012$ & 11.17 & 20.67 \\
$1991-2012$ & 9.28 & 15.22 \\
\hline
\end{tabular}

Table 17.13 Identification of potential importers of onions from India-Import share (1993-2012)

\begin{tabular}{|c|c|c|c|c|c|c|}
\hline \multirow[t]{3}{*}{ Countries } & \multicolumn{6}{|c|}{ Import share (\%) } \\
\hline & \multicolumn{2}{|c|}{ TE 1995-06 } & \multicolumn{2}{|c|}{ TE 2006-07 } & \multicolumn{2}{|c|}{ TE 2011-12 } \\
\hline & $Q$ & V & Q & V & Q & V \\
\hline Malaysia & 21.10 & 23.48 & 22.00 & 17.04 & 21.67 & 23.73 \\
\hline Sri Lanka & 14.11 & 14.10 & 10.87 & 10.46 & 9.88 & 9.49 \\
\hline UAE & 32.08 & 26.77 & 14.11 & 13.44 & 11.09 & 9.97 \\
\hline Bangladesh & 11.62 & 10.04 & 35.62 & 27.03 & 34.31 & 34.38 \\
\hline Bahrain & 1.13 & 1.05 & 2.01 & 1.93 & 0.91 & 0.78 \\
\hline Singapore & 10.84 & 15.83 & 1.75 & 1.66 & 1.87 & 1.80 \\
\hline
\end{tabular}




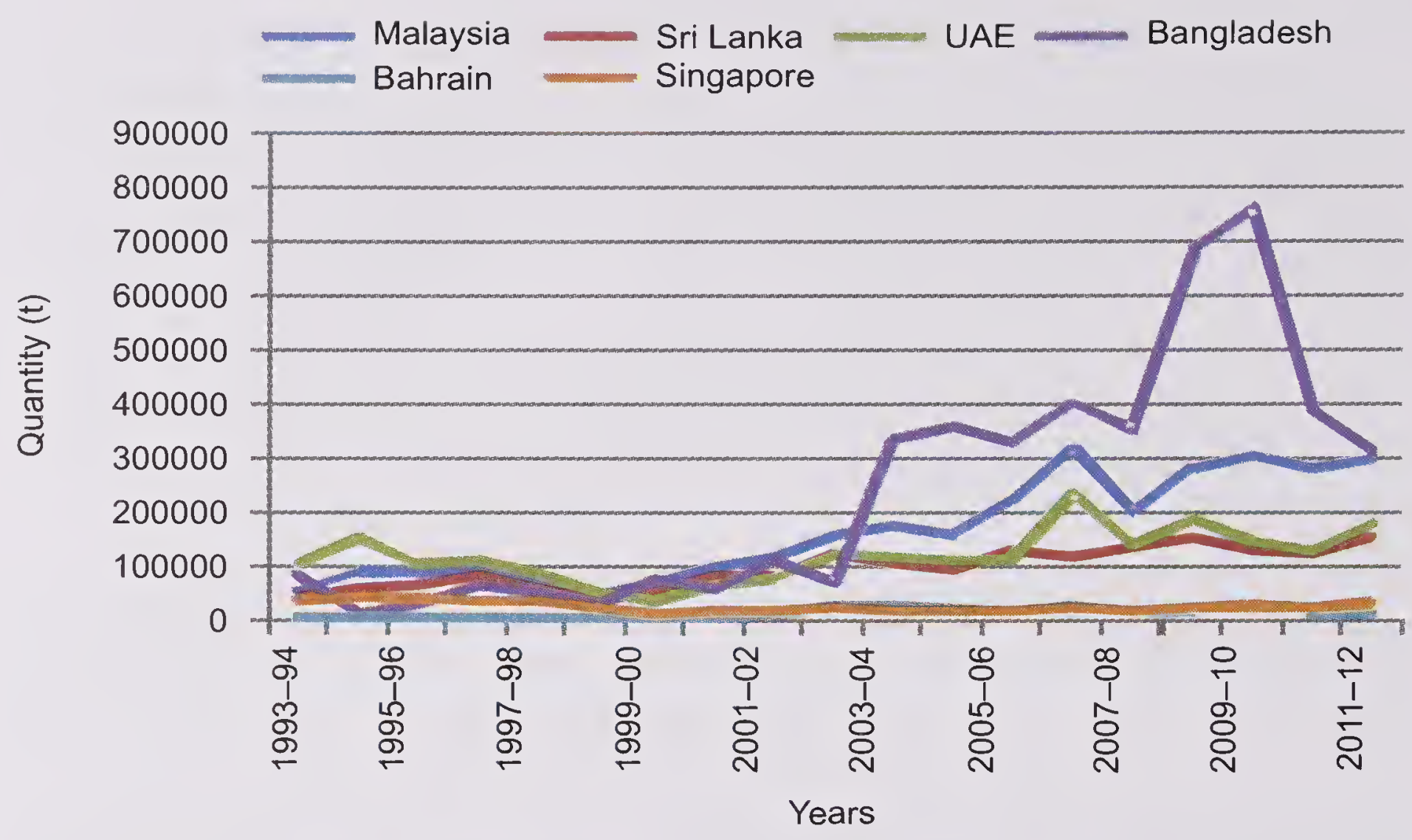

Fig. 17.3. Onion exports from India to different countries

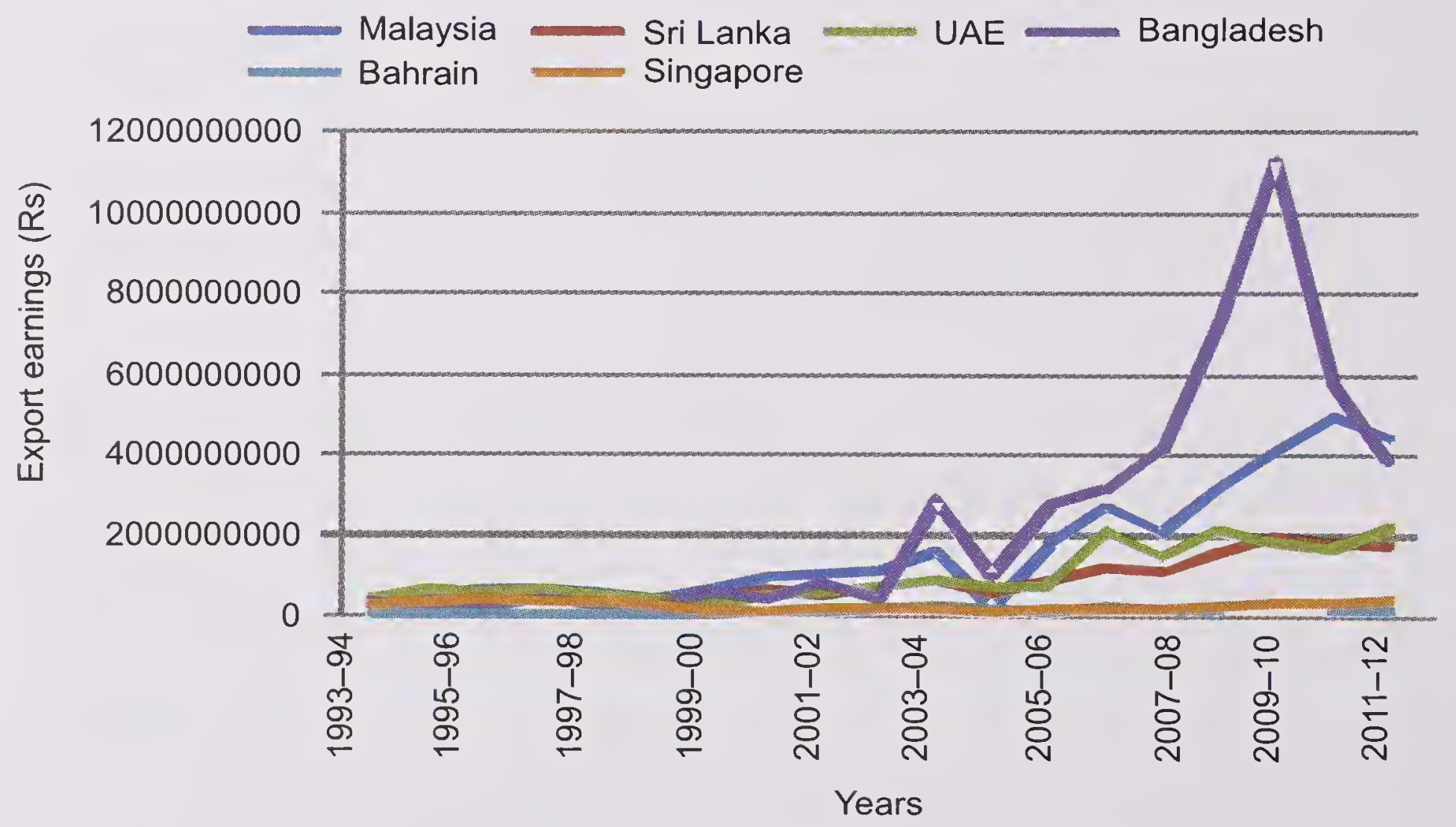

Fig. 17.4 Onion export earnings from different countries

share hovered around 22\%. Sri Lanka registered high growth (7-12\%) and the growth was found almost stable (15\%) and a slight decline in its share from 14\% during TE 1995-96 to around 10\% during TE 2011-12 was observed. It is interesting to note that Bangladesh is emerging as a major importer of onions from India with a very high growth (20-28\%) but with slightly higher instability also (34-38\%). As regards the import share, there was a threefold increase in the share of Bangladesh during mid-nineties to TE 2011-12. High growth in export of onion to Bahrain was associated with high instability and its share was very 
low $(1-2 \%)$. It is disturbing to note that the share of the earlier dominant importers, UAE and Singapore have, of late, come down drastically. In fact, the share of UAE has come down from 26-32\% during the mid-nineties to around $10 \%$ during the TE 2011-12. In case of Singapore, there has been a significant decline in its share from more than $10 \%$ to less than $2 \%$ during the same period.

It is desirable to have high growth with stability for a country to be a potential market for Indian onions. Based on the increasing share and high growth with slight instability, Malaysia, Sri Lanka and Bangladesh may be considered potential markets for onions from India. Further, UAE may continue to be an important market for India. Khunt et al. (2008) and Reddy et al. (2013) based on the nominal protection coefficients (NPC), observed that export of onion, in general, has been competitive with the nominal protection coefficient NPC hovering around 0.8 . However, to understand as to whether this holds good and if export is really profitable at the individual exporter's level, an attempt was made to work out costs and returns associated with export of onion from different ports.

Cost of exports: Big (Bellary/Nashik Red) onion from Mumbai port: Bangladesh, Malaysia, Nepal, Dubai and Sri Lanka are the major destinations for onions from Mumbai port. Cost of export of onion from Mumbai port to Dubai worked out to ₹ 3,242/tonne, consisting of packing ( $₹ 757$ ), transport from field to pack house ( $₹ 757$ ), from pack house to port ( $₹ 231$ ), C\&F charges ( $₹ 147$ ), SPS, NOC and documentation charges (₹ 69), terminal handling charges (THC) (₹ 255) and freight (₹ 1703). With a purchase price of $₹ 7,000 /$ tonne, the cost of export worked out to ₹ 10,242 /tonne. Export margin varied from ₹ 1,000 to $₹ 1,500$ / tonne. Export realization depends to a great extent on the international prices.

Big (Bellary/Nashik Red) onion from Chennai port: Big (Bellary Red) onions $(35-45 \mathrm{~mm})$ are exported from Chennai port to Malaysia, Singapore, Sri Lanka, Brunei and the Philippines. Malaysia accounts for $60 \%$ of onion exported from Chennai port. The cost of export of onion to Malaysia worked out to ₹ 2,670/ tonne, consisting of packing material like nylon-mesh bag ( $₹ 400 /$ tonne), other packing materials like pallet, thread etc. ( $₹$ 350/tonne), labour charges ( $₹ 400 /$ tonne), transportation, field to port and port to port (₹ 1,140/tonne), other costs like NOC, documentation, etc ( $₹ 1,140 /$ tonne), freight and terminal handling charges (₹ 380/tonne). With the purchase price of ₹ 6,000/tonne, cost of export of big onion to Malaysia worked out at ₹ 8,670/tonne. Export realization varied from ₹ 10,000 /tonne to ₹ $13,000 /$ tonne and the net realization worked out at ₹ 1,330 ₹ 4,330/tonne.

Rose onion from Chennai port: Rose onion is grown exclusively for export. It does not have a domestic market. Rose onion grown in Karnataka, Andhra Pradesh and Tamil Nadu is exported from Chennai port to Malaysia, Singapore, Indonesia, Sri Lanka, Brunei and the Philippines. Malaysia accounts for $90 \%$ of export. Export earnings from Rose onion were to the tune of ₹ 45 crore in 2006-07. During 2010-11, exports stood at 22,346.49 tonnes, valued at ₹ 59.55 crore.

Information on cost and constraints in export of rose onion was obtained from 14 exporters based in Chennai. The cost of export of Rose onion from Chennai to Malaysia worked out at ₹ 4,700/tonne, consisting of packing material like bamboobaskets and net (₹ 1,240/tonne), other packing materials like pallet, thread, etc 
( $₹$ 350/tonne), labour charges ( $₹ 400 /$ tonne), transportation, field to port and port to port ( $₹ 1,140$ /tonne), other costs like NOC, documentation etc ( $₹ 1,140$ /tonne), freight and terminal handling charges ( $₹ 470 /$ tonne). With the purchase price of ₹ 10,000 /tonne, the cost of export of rose onion to Malaysia worked out at ₹ 14,700/ tonne. Export realization varied from ₹ $17,400 /$ tonne to ₹ $24,000 /$ tonne with a net profit of ₹ 2,700-₹ 9,300/tonne.

\section{Constraints in exports}

Constraints in export of big onion

- Only $30-40 \%$ is of exportable quality.

- Poor infrastructure facility for export, especially road, storage, transport etc.

- Onion is not covered under ECGC-insurance.

- Time-lag between port and destination due to lack of direct vessels.

- Non-tariff barrier in the form of fumigation of onion cargo.

- China is emerging as an important competitor for onions in the international market.

- Withdrawal of LC hinders proper transaction as there are cases of payment defaults.

- Cargo to reach the port well in advance (2 days), before the vessel leaves.

- Frequent export bans are bottlenecks for exporting onions.

\section{Constraints in export of rose onions}

- Production practices to be standardized so as to have lesser splits and very small bulbs.

- Grading is not done at farmers' fields level itself.

- Proper storage/godown facility is not available at the production centre.

- LC to be re-introduced for proper transaction.

- Cargo has to reach the port two days before the ship leaves.

- Only one foot of the container door is opened.

- SPS certification is needed for fumigation of onion cargo.

- Competition from China, Myanmar (Burma), Indonesia, Thailand and the Philippines.

- Rose onion is grown exclusively for export, and hence export ban on onions should not be applicable to rose onion-KAPPEC is making efforts with GoI to have a separate HS Code for rose onions.

\section{Marketing of onions: India vis-à-vis China}

The global scenario of onion production and export is given in Chapter 1. The order of preference for onions in the traditional markets in the descending order is India, Pakistan, Iran, Egypt and China. The demand for Indian onions, especially in the Asian countries, is more than the Chinese onions; as the yellow coloured Chinese onions are apparently less tasty. Further, the hybrid Chinese onions are bigger compared to the Indian onions. Customers in these countries turn to the Chinese products only during the time of higher price of Indian onions.

Of late, China is attempting to diversify its export market to the traditional 
importers of Indian onions. Since the last three to four years, it is reported that China has started promoting one of its varieties in these markets, which is similar to Indian onions in colour. However, it has been reported that their taste and shape are different due to different weather and soil conditions.

One of the considerations which make Indian onion export still advantageous in the near future is that onions from no other country can beat Indian onions in taste and other quality parameters. Secondly, price advantage; at present the difference between Indian onions and those from other exporting countries is more than \$100/tonne in the international markets. China can enter into Indian traditional export markets only if the onions from India become too expensive during June to September in the domestic market, making exports difficult. And finally, the peak season for export of Indian onions is from January to March, when hardly any country, barring Egypt, which offers a small quantity, is represented in the market.

\section{Future Strategies}

It may be concluded from the foregoing discussion that the total post-harvest losses (PHL) worked out at $12.55 \%$ consist of $10.43 \%$ at the field level and $2.12 \%$ at the retail market level. At the field level, losses were mainly due to rotting of bulbs and occurrence of doubles/splits. At the retail market level also, rotting of bulbs, skin-out bulbs and to some extent sprouting are the main reasons for losses. Some suggestions for the management of these losses are as follows.

Management of post-harvest diseases: Curing of the harvested onions in the field for two days and then further drying in the shade for 10-15 days should be taken up before transportation. Care should be taken to avoid injury to bulbs during post-harvest handling. For the control of diseases like rots, the recommended treatments should be followed.

Development of varieties/hybrids resistant to diseases: Research has been initiated in this direction at the Indian Institute of Horticultural Research (IIHR), Bengaluru, Directorate of Onion and Garlic Research (DOGR), Pune, and National Horticultural Research and Development Foundation (NHRDF), Nashik. Many varieties of onions-Arka series, Bhima series, Agrifound series-have been released from these institutes. For example, 'Arka Kalyan' and 'Arka Pragathi' varieties developed at the IIHR, Bengaluru, were found superior to local varieties and they were less susceptible to rots. By adoption of these varieties, losses due to rotting of bulbs could be reduced to a great extent, thereby making available more number of bulbs for market (R. VeereGowda, IIHR, Bengaluru 2013, Personal Communication). The analysis of impact of Arka Kalyan variety by Krishi Vigyan Kendra (KVK), Hulkoti, indicated that it ranked first in bulb colour and shape, keeping quality, resistance to purple-blotch disease, marketability and yield. However, the only problem with this is the longer duration of 100-120 days (K.T. Patil, KVK, Kulkoti 2010, Personal Communication).

Adoption of better production and post-harvest practices: Adoption of better production and post-harvest practices would help the producers to bring better quality produce to the market to earn higher returns. Further, only rabi onions are 
suitable for storage and hence all the kharif onions are to be sold immediately after harvest. Post-harvest curing and proper drying of the kharif onions is a must for getting better market price.

Infrastructure facilities: Bad condition of roads, inadequate and improper storage, inadequate transport, etc. need to be addressed to minimize losses during post-harvest handling of onions. Improved storage facilities, packing and transportation facilities would reduce losses to a considerable extent.

It may also be concluded that the growth in export of onions has been good but this growth is associated with instability. To meet domestic and export market requirements, domestic production needs to be increased through enhanced productivity. Export of onions also has many constraints which need immediate attention of the Government, researchers and policy-makers. For improving export performance of onions from India to different countries following are the suggestions.

Development of varieties/hybrids suitable for export: Research has been initiated to meet export requirements at institutes like Indian Institute of Horticultural Research (IIHR), Bengaluru, Directorate of Onion and Garlic Research (DOGR), Pune, and National Horticultural Research and Development Foundation (NHRDF), Nashik. Many varieties of onions have been released from these institutes for export oriented cultivation. For example, 'Arka Bindu' variety of Rose onion developed at the IIHR, Bengaluru, was found to be superior to local varieties and by adopting this variety, number of splits/doubles and very small bulbs can be reduced to a great extent, thereby making available more number of bulbs for export.

Japanese, American and European markets require big sized $(70-80 \mathrm{~mm})$ yellow onions. So far, India has not been able to export yellow onions to these markets. Efforts are needed to develop yellow onion varieties/hybrids to suit the export requirements. Yellow onion varieties like 'Arka Pitambar' developed at IIHR, Bengaluru need to be improved to meet the export requirement. Considering the opportunities and potential of yellow onion, DOGR organizes programmes for identification of suitable varieties and hybrids, suitability of season and standardization of production technologies. The Directorate has recommended Mercedes, Couger, Linda Vista varieties/hybrids for growing from SeptemberFebruary. The trials conducted on BBF with drip irrigation indicated the yield potential up to 50 tonnes/ha as against 13 tonnes/ha as national average. This successful technology has been transferred to farmers' fields in Pune and Nashik districts who are convinced about the high productivity and quality. The trial consignments of yellow onion organized for export to Germany through private traders indicated a promising chance for enhancing export to European Union countries. Finalization of forward linkages and trans-shipment with established backward linkages, can help in developing export market to the tune of 2-3 lakh tonnes (DOGR website).

Adoption of better production and post-harvest practices: Adoption of better production and post-harvest practices developed at the above research institutes would help producers to bring better quality produce to the market- - both domestic and international-and thereby fetch them better returns. 
Need to support growing and export of 'Rose onion': Since Rose onion is grown exclusively for export and since it does not have domestic market, there is a need to have a separate HS Code for Rose onion so that export ban imposed on onions is not applicable to this. Further, organized production of Rose onion is crucial as majority of the growers are small and marginal.

Re-introduction of $L C$ : Payment default and other associated problems in onion export call for re-introduction of LC. Exporters are of the view that NAFED, the Canalizing Agent may issue LC while issuing NOC.

\section{References}

Acharya S S and Agarwal N L. 2001. Agricultural Marketing in India. Third Edition, Oxford \& IBH Publishing Company, New Delhi, India.

Anonymous. 2012a. NHB Horticulture Data Base, 2011-12, Gurgaon, New Delhi,India. Anonymous. 2012b. Export Statistics for Agro and Food Products, India, 2011-12, APEDA, New Delhi, India.

Atibudhi H N. 1997. An estimation of post harvest loss and its management in Nawapada District of Orissa. Indian Journal of Agricultural Marketing 11(1,2): 26-30.

Cuddy and Della V. 1978. Measuring instability in time series data. Oxford Bulletin of Economics and Statistics 40(1): 79-85.

Gajanana T M, Sreenivasa Murthy D, Sudha M and Dakshinamoorthy V. 2009. Onion export and constraints-an economic appraisal (Kannada). Krishi Pete 35(4):16-19.

Gajanana T M, Sreenivasa Murthy D, Sudha M and Dakshinamoorthy V. 2011. Problems and prospects of export of Rose onion from India (in Hindi). Bagwani 4: 62-65.

Gajanana T M, Sudha M, Saxena A K and Dakshinamoorthy V. 2010. Post harvest handling, marketing and loss assessment of onion in Karnataka, India - an economic analysis, pp. 1527-32. (In): Proceedings of International Conference on Horticulture, held during 9-12 November 2009 at PNASF, Bengaluru, Karnataka, India.

Khunt K A, Gajipara H M and Venkaria S B. 2008. Export potential and barriers in export of onion from Gujarat. Indian Journal of Agricultural Marketing 122(1): 128-40.

Kishor Kumar D, Basavaraja H and Mahajanshetty S B. 2006. An economic analysis of post harvest losses in vegetables in Karnataka. Indian Journal of Agricultural Economics 61(1): 134-46.

Mathur V C. 2001. Export potential of onion: A Case Study of India. (In): Regional workshop on Commodity Export Diversification and Poverty Reduction in South and South-East Asia, during 3-5 April 2001, organized by UNCTAD in cooperation with ESCAP. Bangkok, Thialand.

Nadakarni M V. 1971. Yield uncertainty in Maharashtra agriculture. Indian Journal of Agricultural Economics 24: 327-33.

NHRDF. 2013. A Brief Status Report on Onion Production in India, pp.1-9

Reddy H N M, Chinnappa Reddy B V and Pradeepa Babu B N. 2013. Export performance of Indian onion: an econometric analysis. Research Journal of Agricultural Sciences 4(3): 423-27

Sreenivasa Murthy D and Subrahmanyam K V. 1999. Growth and instability in exports of onion from India. Indian Journal of Agricultural Marketing 13(3): 21-27.

Sreenivasa Murthy D, Gajanana T M and Sudha M. 2004. Post harvest loss and its impact on marketing cost, margin and efficiency: a study on grapes in Karnataka. Indian Journal of Agricultural Economics 59(4): 772-86. 


\section{Onion Production and Price Volatility: Implications for Technology and Policy}

Ramesh Chand, Raka Saxena and Sanjay Chayal

Agricultural production as well as food consumption in India are witnessing profound changes. Production is becoming increasingly commercialized accompanied by diversification towards high-value commodities. Demand diversification, market development, increasing liberalization and global interfaces and monetization of economy are aiding this process. Changes in food demand are the result of improved per capita income of consumers, rising urbanization, changing life-style and food preferences of the society. Changes in demand pattern of the societies have altered the demand-price linkages and responsiveness of the market price to fluctuations in demand. Lack of assimilation of these changes, for which, market and prices are exhibiting high level of volatility is disappointing for policy-makers. Price volatility is exacerbated by lack of appropriate policy regarding consumption patterns and technological interventions. As a consequence, so called, minor commodities in consumption basket, like onions, often cause major shocks to prices to farmers, to consumers as well as to overall price stability.

This chapter is an attempt to understand nature of changes in demand for onions and their implications on price and production of onions. It also examines changes in production and prices of onions in yesteryears to understand recent price shocks in the onion market. This is followed by suggestions to check price shocks and to bring in stability in onion markets. The analysis is based on the secondary data on area, production, productivity, market arrivals, market prices and exports obtained from various sources like Centre of Monitoring Indian Economy (CMIE) publications, National Horticulture Board, AGMARKNET website, etc.

\section{Changes in production pattern}

The onion production in India has consistently increased during the last three decades (Fig.18.1). This entire period can be divided in two phases. The first phase from 1980-81 to 2002-03 witnessed gradual increase in production, driven largely by area expansion. In this period, area under onion cultivation doubled, from 0.25 million hectares to 0.5 million hectares, and the production also doubled (refer to 2003-04). However, the yield level remained stagnant at 100 quintals per hectare. After 2002-03, all the three dimensions of the production witnessed exponential growth. Area under onion cultivation doubled in a decade, productivity increased by about $50 \%$ and production almost tripled. Netting-out the population growth, production of onion in India showed an increase from $4.56 \mathrm{~kg} /$ person/ year in the biennium 2000-01 and 2001-02 to $13.97 \mathrm{~kg} /$ person/year in the biennium 

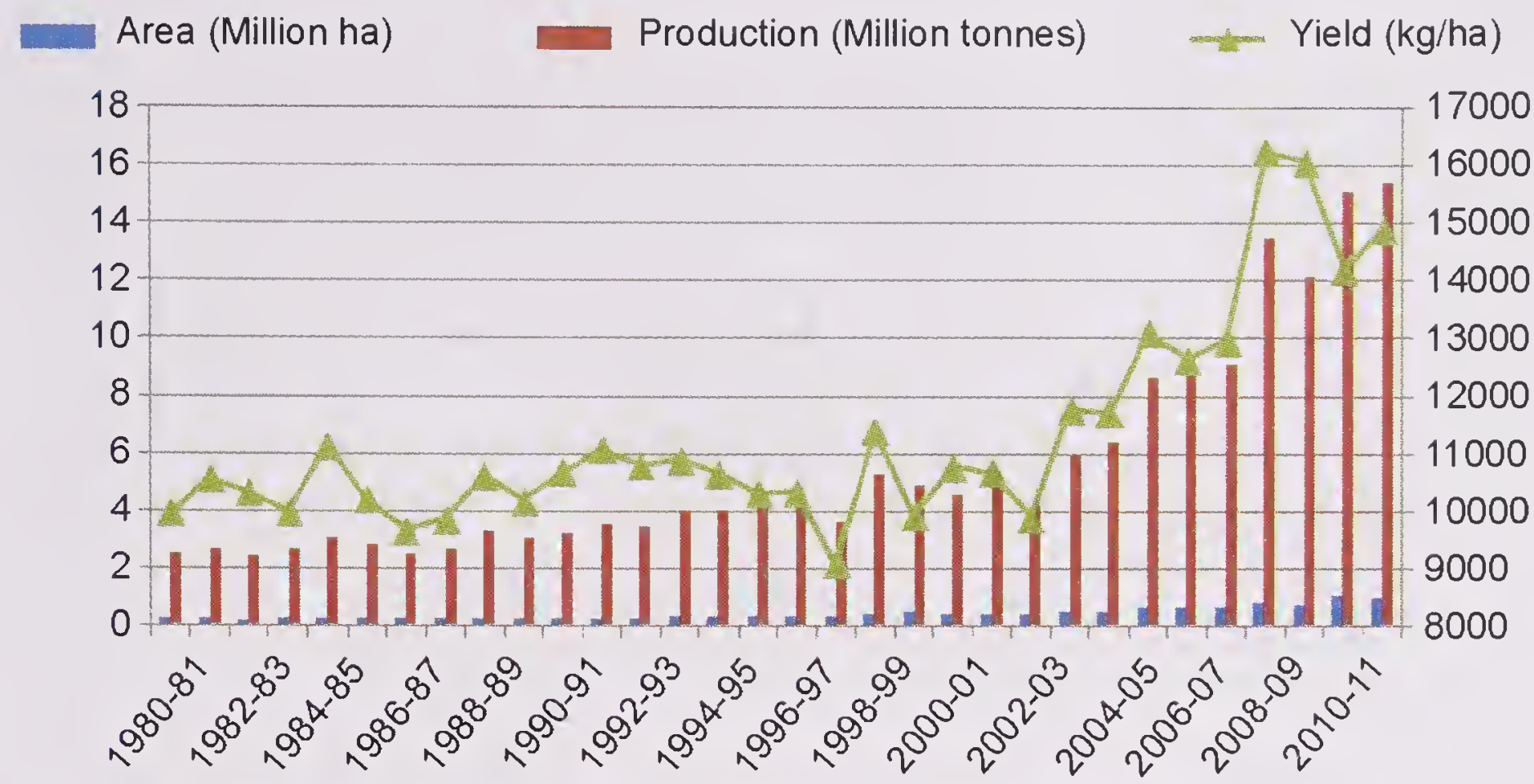

Fig. 18.1 Trends in area, production and productivity of onion in India

2011-12 and 2012-13.

Spectacular increase in onion production in 2012-13 increased its per capita domestic availability and consumption, and it also helped raising onion export from India from 330 thousand metric tonnes in 2000 to 1,822 thousand metric tonnes in 2012-13.However, like many other agricultural commodities, onion production in the country faces deviations from the trend or normal production. This often leads to price shocks and disruption in exports. Thus, despite being surplus nation, the country has to resort to costly imports in adverse situations. This instability in production forces the country to take abrupt decisions to sometimes curb export, and this in a way affects the reputation of India as a reliable supplier in the overseas markets.

\section{Regional pattern of onion production}

Unlike other agricultural commodities, onion production does not have any geographical clustering. Currently, close to $70 \%$ of the total onion produced in the country comes from Maharashtra, Karnataka, Madhya Pradesh, Gujarat and Bihar. Maharashtra is the highest onion- producing state in India, contributing approximately $30 \%$ of the share in total production (see Fig.2.1, Chapter 2).

Maharashtra has been the largest onion- producing state, followed by Karnataka (Fig. 18.2). Surprisingly, the production in Karnataka declined during the last five years (2007-2012). In general, production pattern witnessed increasing trend during the last five years; except in the year 2009-10 when onion production dropped owing to cyclone and unseasonal rains in Maharashtra, Gujarat and Karnataka. There was a drop in onion production in Maharashtra by $20 \%$ compared to the previous year. It can be seen that Madhya Pradesh remained the $5^{\text {th }}$ largest onion-producing state in the four consecutive years, starting from 2007-08 to 2010-11. But it became $3^{\text {rd }}$ in 2011-12, with an increase of $91 \%$ compared to the previous year. The reason for such an increase was expansion in onion area by more than $50 \%$ and noticeable, of more than $25 \%$, of productivity increase.

It is important to mention that regional concentration of onion production in 


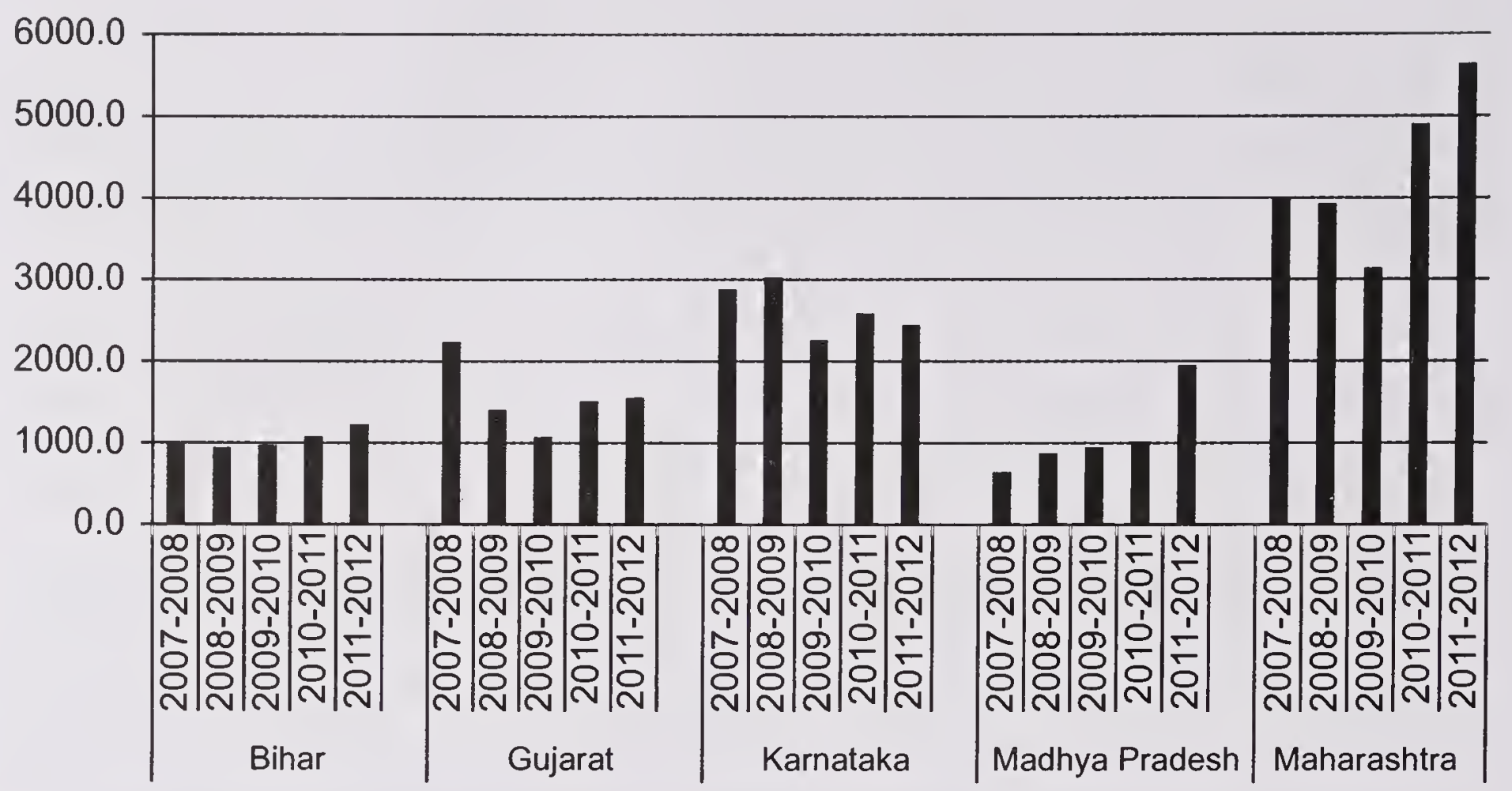

Fig. 18.2 Changes in production pattern of major onions-producing states (in '000 tonnes)

the country has increased during the past three decades, though with fluctuations. Five major producing states-Maharashtra, Karnataka, Gujarat, Madhya Pradesh and Bihar-together produced around $55 \%$ of the total production in 1980-81, but this declined to $50 \%$ in $1987-88$ (Fig 18.3). The volatility in regional concentration was relatively higher during $1987-88$ to $2000-01$. Between 200001 and 2012-13, the regional concentration increased from 64 to $69 \%$ with some peaks and troughs in between.

Onion production has risen from below 5.5 million tonnes till 2002-03 to above 15 million tonnes during the last three years. And the country experienced annual growth rate of $13.36 \%$ in onion production since $2000-01$. No other food crop in India has shown this type of spectacular growth in the recent past. However,

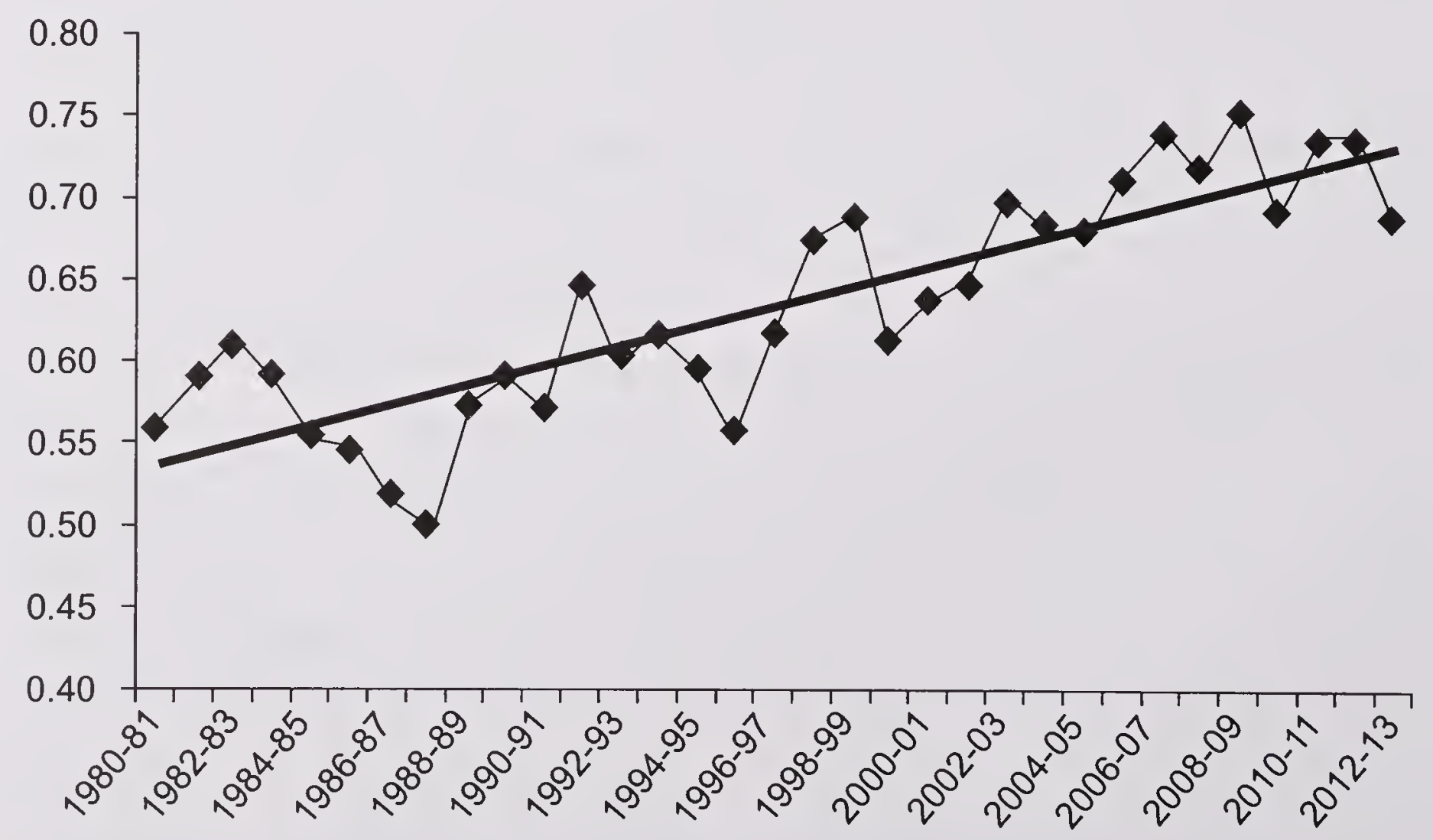

Fig. 18.3 Regional concentration in onion production (share of five major producing states) Source: Office of the Economic Adviser, Gol. 
domestic and overseas demand for onions seems to be outpacing growth in production. Per capita availability of onion increased from $4.0 \mathrm{~kg}$ in 2002-03 to $12.6 \mathrm{~kg}$ in 2012-13; witnessing an increase of $12 \%$ every year. This growth in per capita demand for onions reflects mind boggling preference of Indian consumers for onion.

Table 18.1 gives information on the changes in household consumption pattern of onion in India. The data were obtained from various rounds of the National Sample Survey Office (NSSO). Per capita onion consumption among rural households witnessed highly impressive growth during 1993-94 and 2009-10; and it increased by $61 \%$. Due to changing life-style and dietary patterns, onion consumption among urban households is usually higher than rural households. Onion consumption in urban households also experienced high growth of $53 \%$ during 1993-94 and 2009-10.

Table 18.1 Consumption pattern of onions in rural and urban households

\begin{tabular}{lcccc}
\hline Round & Sector & $\begin{array}{c}\text { Quantity per } \\
\text { 30 days (kg) }\end{array}$ & $\begin{array}{c}\text { Value per } \\
30 \text { days (₹) }\end{array}$ & $\begin{array}{c}\text { \% share in food, } \\
\text { monthly per capita } \\
\text { expenditure } \\
\text { (MPCE) }\end{array}$ \\
\hline $1993-94$ & Rural & 0.46 & 2.21 & 1.24 \\
$1999-00$ & Rural & 0.58 & 3.68 & 1.27 \\
$2004-05$ & Rural & 0.56 & 3.97 & 1.29 \\
$2009-10$ & Rural & 0.74 & 10.89 & 1.82 \\
$1993-94$ & Urban & 0.56 & 2.88 & 1.15 \\
$1999-00$ & Urban & 0.72 & 4.77 & 1.16 \\
$2004-05$ & Urban & 0.72 & 5.06 & 1.13 \\
$2009-10$ & Urban & 0.85 & 13.34 & 1.51 \\
\hline
\end{tabular}

Source: National Sample Survey Office, Various Rounds

If we account for onion consumption outside home, consumption level and its growth would be much higher than the household level data. Large expansion of eating joints, outside eateries, snack corners, restaurant in the recent years has added considerably to increase per capita onion consumption, as onion being the main ingredient that attracts consumers to spicy food.

According to an estimate of the NCAER, price elasticity of demand for onion is as low as 0.1 . This implies rigidity in consumers' demand for onion. It seems the Indian consumers consider onion consumption as a much stronger necessary good than the staple food. As onion is an integral ingredient of Indian curry, it is difficult to imagine acceptance of food without onions. Over the years, onion has replaced its substitute spices, as they have turned much costly. This further explains low price elasticity of demand for onion, which implies that $10 \%$ increase in price can result only in $1 \%$ decline in demand for onion. This also implies that $10 \%$ shortfall in onion supply causes $100 \%$ increase in its price. 


\section{Onion price behaviour}

Agricultural prices are influenced by umpteen number of factors, ranging from to social, economic, policy, market, trade, etc.The food inflation in recent years has remained stubbornly high, which has been causing a serious concern. In the case of products like onion, potato, tomato and some other horticultural products, prices have shown steep rise and also sharp fall even within a short span. The volatility has turned much more severe after the year 2009.

Behaviour of onion prices in the recent years can be captured from the monthly wholesale price indices (WPI) of onion (Fig.18.4).Compared to the WPI of food and non-food articles, the onion WPI has witnessed a highly volatile trend. In recent times, the volatility has become even much more severe and is getting explosive.

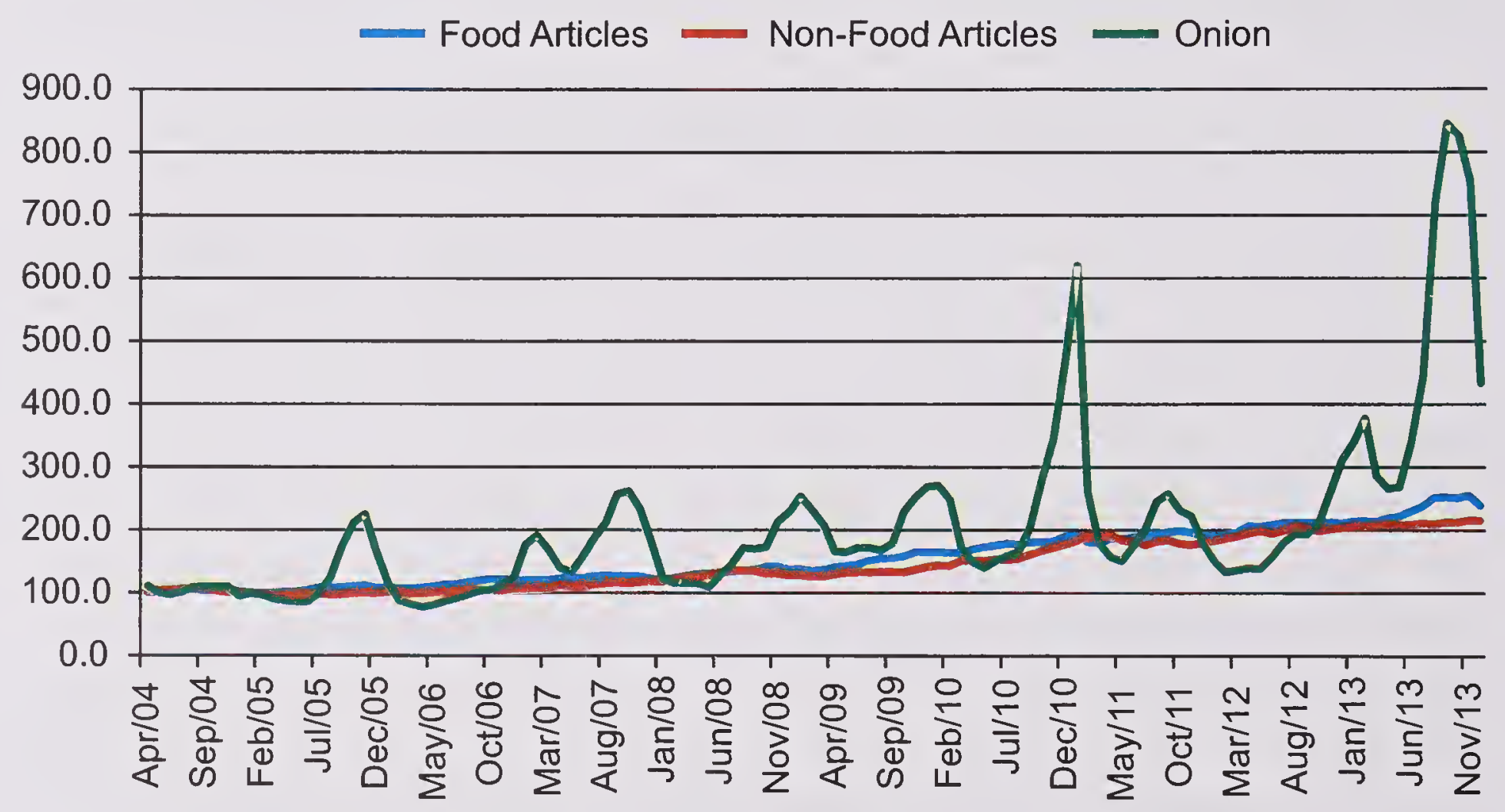

Fig. 18.4 Trends in wholesale price index of food, non-food and onion

Like any other agricultural commodity, onion production in India is also affected by rainfall, which in turn, affects the market arrivals and prices. The year 200910 was a bad year in India from agricultural perspective, which resulted in a decline of about $10 \%$ in onion production. Its impact was immediately visible in the market prices, and the onion WPI reached the historical peak of 619 (base 2004-05=100). After 2009, the onion WPI dipped below the general WPI of food and non-food articles. Sensitivity of onion prices to small variations in supply is evident from the fact that during the last 10 years, onion price shocks have hit the country thrice. In 2013, the country experienced more intense onion crisis, which has been described in details in the subsequent section.

\section{Understanding onion price crisis of 2013}

It has already been indicated that Maharashtra accounts for more than $30 \%$ of the share of the total production of onion in the country. The major onion markets in Maharashtra govern entire trade and affect price situation across the country. Therefore, it becomes important to understand the price and arrival behaviour of the leading onion- producing state, Maharashtra, in the country (Fig.18.5).The 


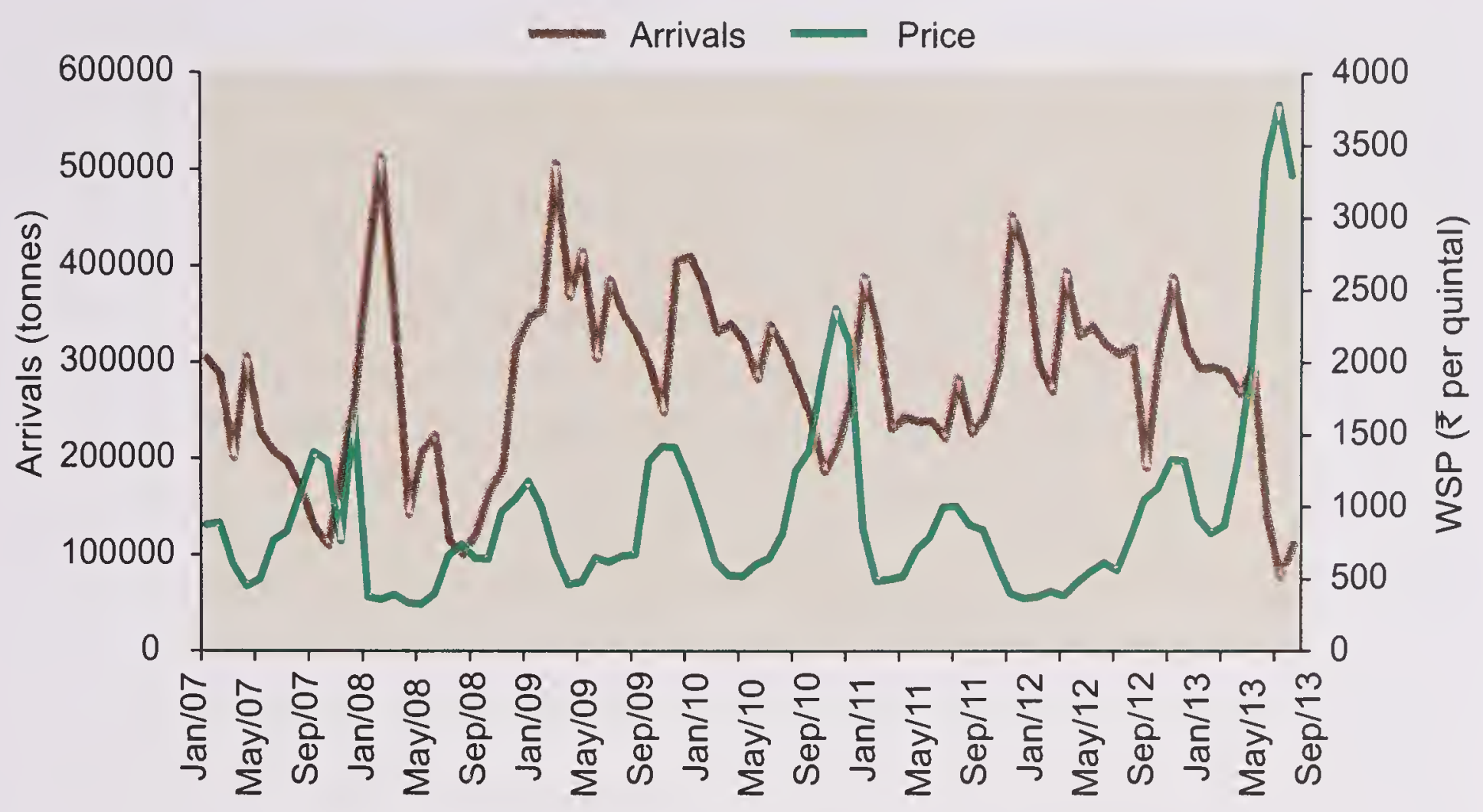

Fig. 18.5 Arrival and price pattern of onion in Maharashtra

arrival pattern indicates that peaks in the market arrivals are getting reduced whereas the spikes in prices are becoming steeper. These patterns may be due to many reasons. One, it could be due to increase in storage capacity of producers and their decision to stagger sales to take advantage of increased prices in the lean season. Thus, farmers holding back produce during below normal production, results in still lower market arrival, which leads to higher increase in prices. Two, it could also be due to manipulation of market by wholesale buyers and big traders.

The WPI of onion in the country and prices in Maharashtra behave in a quite similar fashion. One may infer that the state price signals reach other markets too and affect prices in other markets.

The arrivals in Maharashtra started declining from January 2013, the trend continued (except April 2013) and the gap widened to a great extent in August 2013 as compared to the previous year (Fig.18.6). Further, a sharp decline in September 2013 added to crisis, and its impact on prices was clearly visible.

$\square 2012 \square 2013$

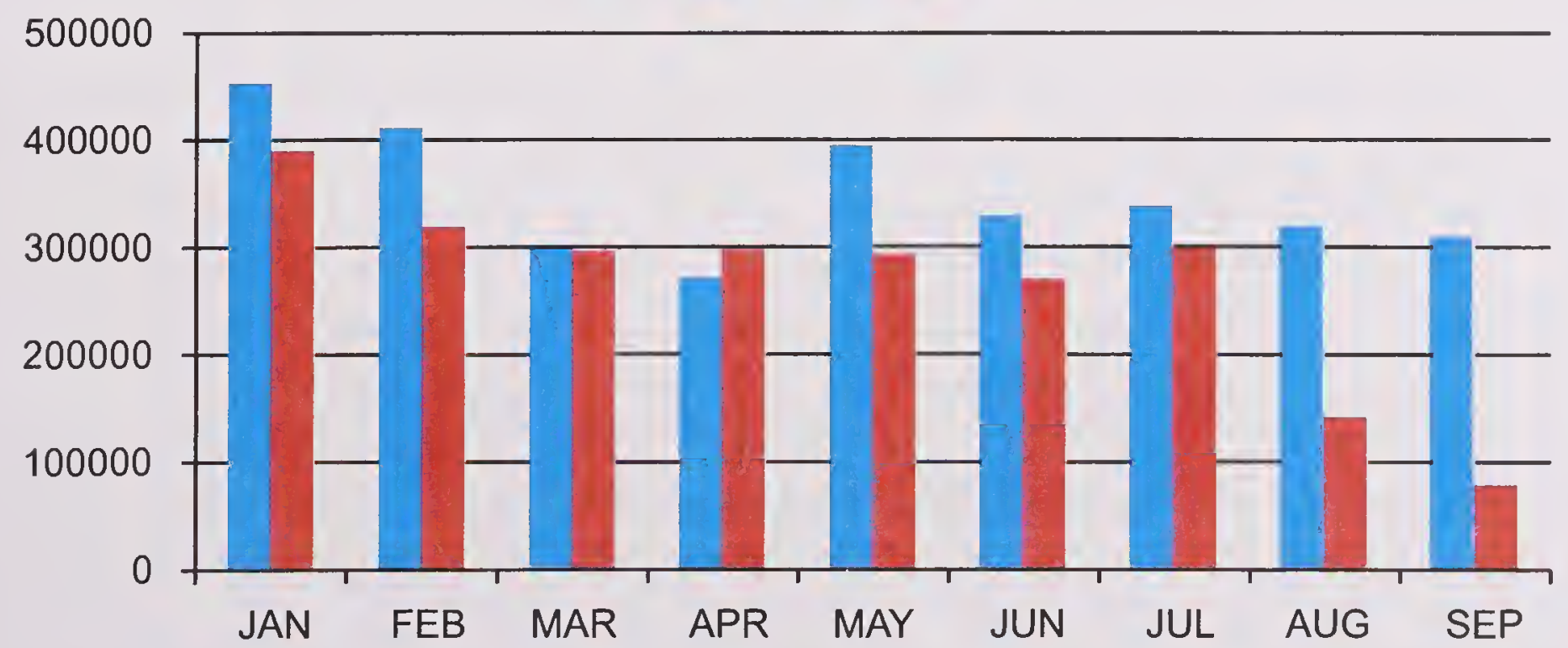

Fig. 18.6 Comparison in month-wise arrivals (tonnes) of onion in Maharashtra, 2012 and 2013 
A peek into the present crisis reveals that adequate and clear signals were available as early as in the months of May-June ofthe coming price shock, and these have been exploited by onion traders under a clear strategy. Advanced estimate about onion production in March 2013 indicated that production in 201213 at the country level would be lower by $4 \%$ as compared with the previous year. Private traders could understand its implications and started procuring onion in a big way by offering higher price to producer-sellers. Market arrivals of onion in three post-harvest months of rabi crop (April to June 2013) in 32 markets of the country including those in Maharashtra were in fact $24 \%$ higher than the previous year. As the supply from farmers dried up, the market arrivals beyond June were to be determined by the stocks released by onion-traders. Market arrivals in July and August were lower by 17 and $22 \%$ compared to the previous year. This reduced supply, raised year on year market prices in 32 markets in July and August by $186 \%$ and $293 \%$, respectively, compared to year 2012. It happened according to the expectation of the traders as well as what is implied by the price elasticity of demand. Then, it completely came in the hands of traders to dictate prices by calibrated release of stocks with them. Here, it is pertinent to point out that the decrease in production of onion was responsible for increase in price of onion only to a small extent; predominant part was owing to withdrawal of onions from the market by the traders.

It is ironical that India faces frequent and severe onion price shocks despite record growth in its production in the country. The present onion crisis is a consequence of our neglect of response to put in place effective mechanism to prevent the crisis or reduce its severity. Every time we face abnormal rise in onion price, we attribute it to unfavourable weather and exploitation of situation by traders and so called cartelization, hoarding etc. and forget about it when prices roll back to normal. We have been treating such shocks as inevitable rather than seeking a solution to avoid their recurrence.

\section{Future Strategies}

There are following three ways to stabilize supply and prices.

1. Stabilisation through stocks:Stabilization through stock requires purchase of onion during normal or above normal production and liquidating the stock in the event of shortfall in production. This type of stabilization in supply requires market intervention by public sector parastatal like NAFED. Besides physical stabilization, it would also keep a check on exploitation and market manipulation by the private trade. There should be constant monitoring of prices and market arrivals by some agency of the Central Government, which should also give advance information to government about implications of supply fluctuation on prices, like early warning system of the FAO. This should be followed by appropriate and early action based on the market intelligence to regulate trade like liberalizing import, restriction on export and check on hoardings.

2. Stabilization through trade: It needs to be remembered that private trade is 
benefited by price variations and volatility, and their interest is against price stabilization. One also cannot expect private sector, involved in domestic trade of onion, to arrange import to augment domestic supply as this would involve larger reduction in gains from domestic sales than gains from imports. The anecdotal evidence indicates as if Indian onion traders have tacit understanding and some sort of cartelization and they are involved in price discrimination, under which, they are charging lower price in overseas markets and higher price in domestic market like a monopolist. Therefore, public sector agency like the NAFED has a crucial role in price stabilization through domestic operations as well as through trade. Such institutions cannot be created at the time of crisis - they have to be there before the crisis.

3. Stabilization through regional or temporal spread of onion cultivation: The third measure relates to seasonal spread in onion cultivation and technology. As the production of onion is concentrated in a few pockets, the instability in production can be reduced by diluting regional concentration of onion production and by extending its cultivation beyond present seasons and geographic areas. Both these options require technological interventions. The suitable varieties need to be developed to suit various agro-climatic conditions so that geographical and seasonal span of the onion-crop can be expanded.

If India doses not take the three measures listed above, it is going to face recurrent price crisis in onions.

\section{References}

NSSO. Key Indicators of Household Consumer Expenditure in India, 1993-94, 1999-00, 2004-05, 2009-10, National Sample Survey Office,Ministry of Statistics and Programme Implementation, Government of India, New Delhi, India.

NCAER. 2012. Price and Competition Issues in the Indian Market for Onions. National Council of Applied Economic Research, New Delhi, India. 


\section{Contributors}

Agrawal, Suresh O. Bejo Sheetal Seeds Pvt. Ltd.

Bejo Sheetal Corner, Mantha Road

Jalna (Maharashtra) 431203

Email: bejosheetal@ hotmail.com

Anandhan, S.

ICAR-Directorate of Onion and Garlic Research Rajgurunagar, Pune (Maharashtra) 410505

Email: anandhans@gmail.com

Aswath, C.

ICAR-Indian Institute of Horticultural Research Hessaraghatta, Bengaluru (Karnataka) 560089

Email: aswathiihr@gmail.com

Azeez, Shamina

Chayal, Sanjay

Gajanana, T.M.

Ganeshamurthi, A.N.

Gawande, S.J.

Gopal, J.

Gorrepati Kalyani

Gupta, A.J.
ICAR-Indian Institute of Horticultural Research Hessaraghatta, Bengaluru (Karnataka) 560089

Email: shamina@iihr.ernet.in

ICAR-National Institute of Agricultural Economics and Policy Research

D.P.S. Marg, Pusa, New Delhi 110012

Email: chayalsanjaysitaram@gmail.com

ICAR-Indian Institute of Horticultural Research Hessaraghatta, Bengaluru (Karnataka) 560089

Email: gajanana@iihr.ernet.in

ICAR-Indian Institute of Horticultural Research Hessaraghatta, Bengaluru (Karnataka) 560089

Email: angmurthy@iihr.ernet.in

ICAR-Directorate of Onion and Garlic Research Rajgurunagar, Pune (Maharashtra) 410505

Email: sureshgawande75@gmail.com

ICAR-Directorate of Onion and Garlic Research Rajgurunagar, Pune (Maharashtra) 410505

Email: jai_gopal@ rediffmail.com; director.dogr@icar.gov.in

ICAR-Directorate of Onion and Garlic Research Rajgurunagar, Pune (Maharashtra) 410505

Email: kalyanigorrepati@gmail.com

ICAR-Directorate of Onion and Garlic Research Rajgurunagar, Pune (Maharashtra) 410505

Email: guptaaj75@yahoo.co.in 
Gupta, R.P.

Krishna Kumar, N.K.

Lawande, K.E.

Mahajan, Vijay

Murkute, A.A.

Negi, K.S.

Palaniappan, $\mathbf{R}$.

Paramaguru, $\mathbf{P}$.

Pathak, C.S.

Pugalendhi, L.

Raghuram Muktha

Ramesh Chand
National Horticultural Research and Development Foundation Chitegaon Phata, Nashik-Aurangabad Road

Nashik (Maharashtra) 422003

Email:rpgupta5@yahoo.com

Division of Horticulture Science

Indian Council of Agricultural Research

New Delhi 100012

Email: ddghort@icar.org.in

Lakshmana Reddy, D.C. ICAR-Indian Institute of Horticultural Research

Hessaraghatta, Bengaluru (Karnataka) 560089

Email: dclreddy@gmail.com

Flat No. 7, Nisarg Phase-2, Kaspate Wasti, Wakad

Pune (Maharashtra) 411057

Email: kelawande2011@gmail.com

ICAR-Directorate of Onion and Garlic Research

Rajgurunagar, Pune (Maharashtra) 410505

Email: vijbmaha@yahoo.com

ICAR-Central Citrus Research Institute

Shankar Nagar P.O., Nagpur (Maharashtra) 440010

Email: ashutoshmurkute@gmail.com

Regional Station

ICAR-National Bureau of Plant Genetic Resources

Bhowli, Nanital, Uttarakhand

Email: ksnegi1960@gmail.com

ICAR-Indian Institute of Horticultural Research

Hessaraghatta, Bengaluru (Karnataka) 560089

Email: rampal2k@gmail.com

Department of Spices and Plantation Crops

Tamil Nadu Agricultural University

Coimbatore (Tamil Nadu) 641003

Email: paramagurup@yahoo.co.in

Nath Seeds Ltd.

Nath Road, P.B. No. 518, Aurangabad (Maharashtra) 431005

Email: chandra.pathak@nathseeds.com

Tapioca and Castor Research Station

Yethapur, Salem (Tamil Nadu) 639119

Email: hortmvelu@yahoo.com

Maharashtra Hybrid Seeds Company Ltd.

Bettanagere Village, Huskur Post, Dasanapura Hobli

Bengaluru North Taluk (Karnataka) 562123

Email: Muktha.Raghuram@mahyco.com

ICAR-National Institute of Agricultural Economics and Policy Research

D.P.S. Marg, Pusa, New Delhi 110012

Email: rc@ncap.res.in 
Ravi, K.S.

Sankar, V.

Saxena, Raka

Sharma, H.P.

Shekar Mahesh

Shivashankara, K.S.

Sreenivasa Murthy, D.

Sreenivasa Rao, E.

Srinivas, P.S.

Thangasamy, A.

Tripathi, P.C.

VeereGowda, $R$.

Velmurugan, $M$.
Maharashtra Hybrid Seeds Company Ltd.

Bettanagere Village, Huskur Post, Dasanapura Hobli

Bengaluru North Taluk (Karnataka) 562123

Email: ravi.kankanallu@mahyco.com

Regional Station, ICAR-Indian Institute of Horticultural Research

Chettalli (Karnataka) 571248

Email: skar_hort@yahoo.com

ICAR-National Institute of Agricultural Economics and Policy Research

D.P.S. Marg, Pusa, New Delhi 110012

Email: rakasaxena@ncap.res.in

National Horticultural Research and Development Foundation

Chitegaon Phata, Nashik-Aurangabad Road

Nashik (Maharashtra) 422003

Email: nasik@nhrdf.com

Maharashtra Hybrid Seeds Company Ltd.

Bettanagere Village, Huskur Post, Dasanapura Hobli

Bengaluru North Taluk (Karnataka) 562123

Email: mahesh.shekar@mahyco.com

ICAR-Indian Institute of Horticultural Research

Hessaraghatta, Bengaluru (Karnataka) 560089

Email: shiva@iihr.ernet.in

ICAR-Indian Institute of Horticultural Research Hessaraghatta, Bengaluru (Karnataka) 560089 Email: srinivasiihr@yahoo.co.in

ICAR-Indian Institute of Horticultural Research Hessaraghatta, Bengaluru (Karnataka) 560089 Email: esrao@iihr.res.in

ICAR-Directorate of Oilseeds Research

Hyderabad (Telangana) 500030

Email: pssrinivas@dor-icar.org.in

ICAR-Directorate of Onion and Garlic Research Rajgurunagar, Pune (Maharashtra) 410505

Email: astsamy@yahoo.co.in

Regional Station

ICAR-Indian Institute of Horticultural Research

Chettalli (Karnataka) 571248

Email: prakaashtripathii2000@yahoo.co.in

ICAR-Indian Institute of Horticultural Research Hessaraghatta, Bengaluru (Karnataka) 560089

Email: gowdadrv@yahoo.com

Tapioca and Castor Research Station Yethapur, Salem (Tamil Nadu) 639119

Email: hortmvelu@yahoo.com 


\section{Subject Index}

abiotic factors 226

acervuli of Colletotrichum

gloeosporioides 203

ACSO 277

Aggregatum Group 30

Aggregatum Onion 104

Aggregatum Onion and Shallots 104-20

aggregatum onion cultivation 104, 113

Agrobacterium strains 126

Agrobacterium-mediated DNA delivery

systems 125

Agrobacterium-mediated transformation

126

agronomic characters, desirable 63

Agronomic Traits, genetics of 57

Ain-i-Akbari 2

alkaline soil 146

Allexivirus 212, 219

Allicin 26, 277

allicin content 26

Allinase enzyme 277

Allium ampeloprasum 4

Allium ampeloprasum subsp. persicum 274

Allium asarense 2

Allium cepa var. ascalonicum 114

Allium cepa, idiogram of 56

Allium fistulosum 4, 73

Allium germplasm 40

Allium hookeri 45

Allium oschaninii 2, 33

Allium species in subsect. cepa 32

Allium species introduced 41

Allium species used as vegetables 114

Allium species, nutrient composition of 115

Allium vavilovii 2,33

Allium stracheyi 45

Allium, infrageneric classification in 33

Allium-growing states/regions 40

alluvial soils 146

Alternaria porri 70 amplified fragment length polymorphism 127

Annual method 177

anthocyanidin synthase 131

anthocyanin synthesis pathway 131

anthocyanins 275,276

Anthracnose 9, 202

anthracnose, severity of 204

anthracnose, symptoms of 203

antibiotic markers 126

Anticancer effects 284

antihelmintic 116

anti-inflammatory 116

Antimicrobial properties 286

Antiobesity effect 285

antioxidant activity 273

antioxidant capacity 255

Antioxidant effects 283

anti-shattering chemical 96

antispasmodic 116

aphrodisiac 272

area, production and productivity, statewise 10

arrhenotoky 226

Arrival and price pattern 321

artificial neural networks forecasting models 228

Atharvaveda 2

autocatalytic ethylene burst 254

Azadirachtin-based formulations 232

Azospirillum 107

backcross method 89

Barrier cropping 20

Basal-rot 71

basal-rot resistance 57

Bhagavad Gita 2

Biennial method 177

bioavailability of iron and zinc 288

Biochemical properties 253 
Biochemistry and Nutraceutical

Properties 272-94

biodiversity assessment and germplasm conservation 39

biofertilizers $18,170,171$

Biological control 230

biological yield 147

Biomass development 5

Biosystematics 33

Biosystematics, Botany and Genetic

Resources 30-55

Biotechnology 16, 121-44

biotic stresses 19

Bioversity International 38

bolting, resistance to 43

Botrytis allii 71

Breeding for export 69

Breeding for Hybrid Technology 82-103

Breeding for processing quality 69

Breeding for production 66

Breeding for quality 67

Breeding for resistance 70

Breeding Methods 58

Breeding Objectives 66

bridging species 73

broad-based furrow 153

broadcasting 21

Bromoviridae 215

Bulb mites 235

bulb planting, time of 178

bulb respiration 26

bulb storage facility 187

bulb yield, marketable 91

bulbing stage 20

bulb-rotting 9

Bullock-drawn implements 157

Bunyaviridae 212, 214

CA storage 252

canned onions 24

CAPS markers 133

cardiovascular diseases 285

cardiovascular problems 1

Centre for Genetic Resources at Wageningen 38

Centre for the Conservation and Breeding of the Agrodiversity 38

centre of origin 3

centromeric position 56

Certification standards for seed production 180 certification, Problems in 183

chalcone isomerase 68,131

Charak 2

Charak Samhita 1

Chemical composition 272

Chemical control 232

chemical disinfectant 255

chemical fertilizers 18, 169

Chemicals for producing male-sterile lines 85

Chemistry 272

Chinese gardens 1

Chinese medicine 1

Chinese national germplasm resources bank 38

Chinese travelers' memoirs 2

chives 34

chlorophyll deficient 57

chlorotic lesions 212

Chromosome doubling 124

chromosome doubling, induced 86

Chromosome symmetry 56

chute-type feeding unit 22

Classification 192

cleaved amplified polymorphic sequences 127

CMS, restoration of 57

$\mathrm{CO}_{2}$-enriched atmosphere 255

coefficient of variation, genotypic 104

coefficient of variation, phenotypic 104

Cold storage 26, 251

cold storage technology, low-cost 27

cold storages, commercial 249

Cold-storage technology 26

Colour improvement 131

Commercial wild species 46

Common Onion Group 30

common onion 104

Conidia of Stemphylium vesicarium 201

Conidiophores 201

constraints in export of onions 295

contigs 130

controlled atmosphere 255

Controlled Atmosphere (CA) storage 252

convective air-drying 257

conventional breeding 27

conventional insecticides 232

Convergence Breeding 97

country onion 104

crop geometry 17

Crop residues and green manure 171 
Crop rotation 156

Cropping sequence and intercropping 17 cropping sequences 156

Cropping systems 155

Crop-weed competition 153

cultivated area 25

Cultivation 117

Cultural practices for onion-seed production 178

Culture medium 123

cumulative pan evaporation 248

cumulative thrips days 228

Cutworm 235

cytological model system 56

Cytology 56

cytoplasmic genomes 73

cytoplasmic male sterility 132

cytoplasmic male-sterile lines 82

cytoplasmic sterility 82

cytoplasmic sterility factor S 82

Cytoplasmic-genic male-sterility system 83

Damping-off 206

dehydrated onion $24,256-58$

Dehydration 112

deploidization 97

deuterotoky 226

Development of A and B lines 88

Development of varieties/hybrids resistant to diseases 313

developmental stages 147, 166

DH inbreds 125

diced onions 255

dihaploid 86

dihydroflavonol 4-reductase 68,131

dinitrophenyl hydrazine 278

Direct Antigen Coating Enzyme Linked Immunosorbent Assay 215

Direct seed sowing 21

Direct seeding 148

Disease and pest resistance 26

Diseases and insect-pests management 180 diuretic 116

diversity analysis $121,129,130$

DNA fingerprinting 130

DNA markers 127

Double Antibody Sandwich Enzyme

Linked Immunosorbent Assay 213

doubled haploid line 131

doubled-haploids 121

Doubled-haploids production 122
Downy mildew 205

dried onion powder 285

drip irrigation 19,152

Drying and curing 109

dwarf seed stalk 57

Economic threshold levels 232

Egyptian ground onion 104

electrical cabinet-drying 24

embryo degeneration 123

entomopathogenic nematode 231, 234

Entomopathogens 231

ethylene binding inhibitor 249, 254

exotic hybrid varieties 26, 93

Explant selection 123

Export Market 308

Export of seed 195

export requirements 176

Export to European countries 6

export,share of, in domestic production 308

export-oriented onions 295

Export-oriented rose onion 299

Ex-situ conservation of wild Allium species 41

$\mathrm{F}_{1}$ hybrid scheme 89

$\mathrm{F}_{1}$ hybrid seeds, production of 184

$\mathrm{F}_{1}$ hybrids 94

Family selection 63

Farm mechanization 21

Fertigation 18, 107, 152

Fertilization 150

fertilization, General recommendations of 150

fertilizer application, time of 169

fertilizer recommendations 162

fertilizer-N recovery 169

field genebank 41

Field inspection 180

fingerprinting of Alliums 129

flakes 24

flavonoids 273

flavonols 273

flavour 46

flavour and pungency 277

flood irrigation 229

flower-bearing stalks 212

fluidized bed drying 257

folk medicines, onion in 282

food-borne pathogenic microorganisms 261 
Frankliniella occidentalis 225

free amino acids 253

freeze-drying 257

fructans 111

Fungal Diseases 197-211

Fusarium basal-rot 207

Fusarium oxysporum 71

Galacturonan 273

galanthum-cytoplasmic (GC) populations 84

garlic mosaic virus 40

gene centre, Mediterranean 3

gene centre, South-west Asian 2

general combining abilities 92

genes, introgression of 27

genetic base 40

genetic centre of origin 2

Genetic factors 122

Genetic mapping 73

genetic resource, for processing 42

genetic resources 36,37

genetic resources, utilization for 42

genetic traits 127

Genetic transformation in Allium 125

genetically heterogeneous 4

Genetics and Breeding of Open-pollinated

Varieties 56-81

genomic resources in Alliums 128

genotypes 83

genotypic factors 123

geographical variations and population

fluctuation 226

germplasm accessions 40

germplasm for food Alliums 45

Germplasm resources in India 39, 230

GIS-based modelling 227

Global export 5

Global scenario 4

glucosides 275

Grading of bulbs 23

Grading precision 23

Grassy refuge stripes 234

greenhouse cage experiments 73

Groundnut bud necrosis virus 212, 214

Growth and developmental stages 146

Gupta period 2

gynogenesis 86,123

gynogenic embryo, Origin of 124

gynogenic embryos 124 hand-grading 23

Hand-operated onion-grader 23

Haploidy 86

Harvesting 108

Harvesting and curing 183

health-promoting properties 247

Hedonic scale 24

herbicide application 155

herbicides use 154

Heterorhabditis 230

heterosis 91

Heterosis and combining ability 90

heterosis breeding programme 93

homozygous recessive 84

Host range 214, 216

Host resistance 230

Hybrid Breeding 87

Hybrid onion 192, 194

hybrid vigour 82

hybridization 82

hybrids 26

hygromycin 126

Ilarvirus 215

Immunomodulatory effects 284

Improved varieties 192

inbreeding depression 65

Indian gene centres 34

indigenous germplasm 90

infrared drying 257

inhibitor-promoter interaction 111

Insect and Nematode Pests 223-46

insect-pests infesting bulb 223

insecticides, registered 235

insecticides, alternative to 232

In-silico mining of markers 130

in-situ hybridization 74

Institutions working on onion 12

Integrated Disease Management 27

Integrated nutrient management 17, 27

Integrated Pest Management 27

Integrated plant nutrient system 170

integrated weed management practices 155

inter simple sequence repeat 127

intercalary C-band pattern 56

Intercropping 229

Intermediate long-day conditions 5

international germplasm repositories 39

in-vitro collection 38

in-vitro culture 121,124

in-vitro haploid production 86 
in-vitro repository 41

Irrigation 18

Irrigation and aftercare 179

Irrigation requirement 18

Isolation distance 25, 187, 193

isorhamnetin-4'-O-galactoside 275

ISSR 127

kanamycin 126

Kharif production technology 27

Lachrymatory factor 279

lachrymatory factor synthase 127, 279

lachrymatory smell 279

Land preparation 117, 148, 178

Landraces of onion and garlic 42

leaf nutrient content 168

Leaf-feeding insect-pests 223

Leaves shape 32

leek 34

Lepidopteran pests 235

Lesion nematode 237

Line $\times$ tester 91

lithontripic properties 116

live-barriers 229

long-day bulbing character 34

Long-day conditions 5

low productivity, Reasons for 25

low-cost drying method 257

low-density genetic map of onion 133

maintainer lines 84-87, 89

Maintenance breeding 87

major nutrients, General effects of 150

male fertility, restoration of 85

male sterile 87

male-sterile lines, exotic 90

male sterility 82

male sterility, Chemically-induced 85

male sterility, use of 82

Male-sterile plants 83

male-sterility gene 83

Male-sterility nuclear gene 57

malonated anthocyanins 255

Manual harvesting 22

manual sowing 21

Manures and fertilizers 179

marker systems 127

marketable onion-bulb 18

Marketable yield of $F_{1}$ hybrids 94

Marketing 296, 297, 312
Marketing and Export 295-315

Marketing channel 296

Marketing cost and returns 296

Marketing efficiency 297

Marketing of onions 312

markets, Major, onion 300

markets for Indian onion 309

mass selection 61,82

maturity, Stage of 281

Mechanization 27

medicinal properties $114,272,282$

medicinal use 46

Mediterranean cultivars 44

meristematic cells 250

metabolic pathways 280

methylation analysis 273

Microirrigation 152, 153, 248

microirrigation systems 229

Micronutrients 151

micronutrients, deficiency of 167,168

microsatellite markers 129

microsatellite or simple sequence repeat 127

micro-sprinkler irrigation 249

micro-sprinklers 153

microwave drying 257

mineral fertilizers 163

Minimally processed onion 255

minimum bactericidal concentration 261

minimum inhibitory concentration 261

Minimum seed certification standards for onion hybrids 182

Miticides 236

mitochondrial heteroplasmy 85

Modern concept 1

Modified atmosphere packaging 255

Moisture stress 152

Molecular Breeding 127

Molecular marker-assisted selection 131

molecular markers 85, 121, 129, 132, 134

Morphology 32

Motorized onion-grader 23

mud-plastered structure 251

Mulching 155

multicellular endosperm 124

multiplier onion $24,104,176$

multiplier onion, seed production of 184

Nashik Red 311

National Active Germplasm Site 40

National Agrobiodiversity Centre,

Republic of Korea 38 
neck thickness 91

Neck-rot 71

Neck-rot resistance 71

necrotic lesions 215

Negative nutrient balance 162

Nematode pests 223

Nematodes 223, 236

nematodes, plant-parasitic 236

Nitrogen-management practices 164

Non-enzymatic browning reaction 258

non-insect pests 223

non-restoring allele 84

non-traditional growing areas 40

nuclear inclusion protein 219

nuclease inhibitor 125

nucleocapsid 213,215

$\mathrm{N}$-use efficiency 169

Nutrient application guidelines 150

nutrient audits 162

nutrient balance 162

Nutrient budgeting 162

Nutrient composition 116

nutrient inputs 162

Nutrient Management 162-75

nutrients, Management of 163

nutritional composition 247

Nutritive Value, Factors Affecting 281

oignon 2

Onion adaptation in India 34

Onion diallyl sulphides 285

Onion fly (maggot) 234

onion fly, parasites on 234

Onion paste 259

Onion pests 224

Onion pickle 259,260

onion powder $24,256-58$

Onion price behaviour 320

Onion R\&D in India-Status and

Prospects 9-29

onion residue 259

onion rings 24

onion salt 24

Onion sauce 263

Onion Seed Industry and Trade 191-96

onion thrips 20,73, 213, 224

Onion thrips, Seasonal incidence of 227

Onion vinegar 259

onion wine 263

onion yellow dwarf virus $217,219,220$

onion, processed products of 262
Onion-flakes 258

onion-growing areas 228, 237

onion-growing states 9

onion-importing countries 6

onion-juice 262

onion-producing countries 4

onion-storage structures 251

open-pollinated family breeding scheme 64

open-pollinated varieties $25,56,82$

open-pollination breeding methods 63

Organic farming 170

organic farming, scope for 233

Organic manures 162,170

Organogenesis 121

Origin and distribution 2

Origin, history and distribution 1-8

osmotic dehydration 257,258

Ovary culture 86

ozone damage resistance 57

Packaging 109

packing materials 23

Palandu 104

parasitoid 231

parental inbred line 90

Parental lines 63

Pattern of growth in onion 296

PCR-based molecular marker 131

pectic polysaccharides 273

Pedigree selection 65

perforated paper packet 248

Performance of $F_{1}$ hybrids 92

periodate oxidation 273

Perithecia 201

Pest and disease management 19

Pesticide residues 233

Phenolic acids 273

phenolic compounds 284

phenolic contents 255

phenotypic performance 61

pheromone trap 235

phosphinothricin 126

Phosphobacteria 107

phosphomannose isomerase 127

physico-chemical processes 253

phytochemicals 249,283

phytohormones 247

pickling in vinegar 259

pickling without fermentation 111

Pink discolouration 280

Pink root 208 
pink-root resistance 57

plant analysis 163

plant explorations 40

Plant regeneration 121

planting dates, impact of 227

plant-nutrient requirement 163

Policy issues 195

pollen lines 87

pollen mother cell 83

polymerase chain reaction 84

polymorphisms in chloroplast DNA 84

polyphagous 225

Polysaccharides 273

polyvinyl acetate 96

post-harvest diseases, Management of 313

Post-harvest handling and storage 22

post-harvest losses 247, 252, 298

Post-harvest Management and Processing 247-71

post-harvest management practices 247

post-harvest operations 16

post-harvest period 110

post-harvest practices 313

post-harvest storage-life 153

Post-harvest technology 108

Potassium balance 166

Potassium requirement 166

potato onion 104

potential production areas 7

Potyvirus 217

Pre-breeding for disease and pest resistance 73

precision irrigation 152

Precision technology 157

Predatory mite 231

prediction models 227

pre-harvest cultural practices 22

Pre-harvest practices 247

premature bolters 186

PRENCSO 277

price analysis 300

Price stabilization 307

Price volatility 316

processed onion 280

Processing 111

Processing and value-addition 26

Processing effect 281

processing industries 26

processing units 26

Production of quality seed 113

production pattern 316,318
Production technologies 16

Production Technology 145-61

production, kharif onion, interventions for 21

productivity 25

promising lines 63

Propham 250

protandrous 32

Protease inhibitors 230

proteinaceous material 273

Protoplast fusion 125

Proximate composition 272

pungent varieties 71

purple-blotch 40, 70, 197, 225

purple-blotch, symptoms of 198

P-use efficiency 165

pyruvic acid 26

pyruvic acid content 277

QTL mapping 134

quality onion-seeds 176

Quality traits 131

quercetin 275

quercetin derivatives 273

Raising onion-crop 148

random amplified polymorphic DNA 127

Recurrent selection 65

Red spidermite 236

Reference Collection,taxonomic 38

refrigerated containers 26

regional or temporal spread of onion

cultivation 323

Region-wise price analysis 300

regular atmosphere (RA) storage 252

resistant genes 26

Response to sulphur 167

restriction fragment length polymorphism 127

Reverse Breeding 96

RFLP markers 133

rhamnogalacturonan 273

Rigveda 2

Root plate 236

Root-knot nematode 237

rose onion $70,233,311$

rose onions, constraints in export of 312

Rymovirus 212, 220

S-1-propenyl-L-cysteine sulphoxides 277 saponins 273,274 
SCAR marker 133

S-cytoplasm 83

secondary centre 3

Seed Availability 185

Seed Corporation 191

seed genebank 41

seed germination, influence of salinity on 45

Seed priming and nursery management 16

Seed Production 113, 176-90

Seed Production Technology 177

seed production, constraints in 186, 193

Seed Production, cost of 184

seed production, standards of 187

Seed quality 192

seed replacement rate 194

Seed requirement 185, 191

seed storage 187

Seedling transplanting 17

seedlings, Well-hardened 151

seed-production pockets 187,188

seed-production technologies 193

seed-setting types 104

Seed-to-seed 177

seed-to-seed cycles 89

Selectable markers 126

Selection intensity 61

Selection of bulbs 178

Selfing and massing technique 62

sensor-based technologies 157

sequence characterized amplified region 127

sequencing technologies 127

Sets planting 149

Sets technology 21

Sex pheromones 235

sex-linked markers 132

shallot $30,34,114$

shallot collection centres 37

shallow root system 154

shelf-life 24, 111

Short-day conditions 5

short-day onion 89

short-day onion hybrids 89

Shusruta 1, 2

single nucleotide polymorphism 127, 133

Single-cross/three-way hybrids 90

singletons 130

skin types 40

Soil testing 163

soil-borne pest 237 soils for cultivation 145

soil-water potential 152

solar-drying 24,257

solarization 155

somatic embryogenesis 121

Sources of resistance for diseases and insect-pests 70

Spatial price relationships 306

species diversity 39

specific combining abilities 92

sprinkler irrigation 153, 229

Sprout activation 111

Sprouting 109

sprout-suppressant chemical treatments 250

SSRs, Development of 128

stagnation in productivity 191

Standard Material Transfer Agreement 38

State Seeds Corporations 191

Stem and bulb nematode 237

Stemphylium-blight 40, 72

Stemphylium-blight, symptoms of 200

Sticky traps 228

Stimulo-deterrent-diversion 235

Storage 26, 110

Storage environment 251

storage facilities 193

storage methods 111

Storage of mother-bulbs 177

structures 23

sulphur deficiency 277

Sumerian report 1

sun-dried flakes 24

sweet flavour 278

Sweet onions 44

Symptoms of different pests 224

synthetic pyrethroid 236

Synthetic varieties 62,63

synthetic variety development 63

systemic insecticides 214

Taxonomy 30

T-cytoplasm 83

T-cytoplasmic male-sterile inbred line 84 teardrop-shaped bulbs 116

tearless onions 127

temperate germplasm 36

Tetranychid mite 236

thelytoky 226

therapeutic effects 1

thick-necked bulbs 58

thiopropanal sulphoxide 277 
thiosulphinates 277

Thripidae 224

Thrips 72, 224

thrips, peak flights of 228

thrips, resistant sources identified for 230

Thysanoptera 224

tissue culture 121

Tobacco streak virus 212, 215

tomato spotted wilt virus 225

Tospovirus 212, 214

tractor-drawn implements 157

trade 4, 5

Traditional remedies using onion 286

Transcriptase Polymerase Chain Reaction 214

Transformation 125

transgenic development 121

Transgenic plants 127

Transplanting 148

Transportation 112

True shallots 114

TSS 109

Twister 202

vacuum drying 257

value-added nutritionally rich products 27

value-addition 255,288

varietal identification 129

Varietal improvement 13

varietal improvement programme 13
Varieties 1, 14, 116, 176

Varieties of aggregatum onion 105

varieties released worldwide 59

varieties, Multiplier onion 9

Vedic period 2

Vegetable Germplasm Bank of Zaragoza 38

ventilated storage structures 23,251

Viral diseases 212-222

Virus diagnosis 213,215,216,218,221

virus particle 217

Water requirement 151

Wax crystals 73

Weed control 154

Weed management 19, 108, 153, 179

weeds, types of 153

Western White 273

Western yellow onions 273

white onion varieties 69

White onions 24

wholesale price indices 320

wild Allium species 34, 40

wild species 40

wild species, exotic 40

wild species, lesser-known 34

Yajurveda 2

yellow dwarf virus 212 



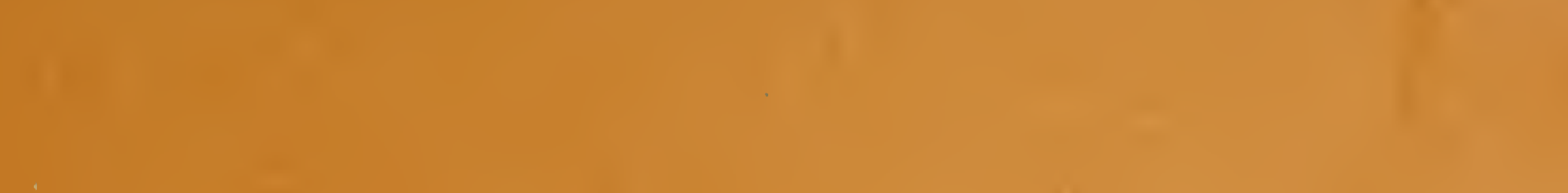

(1)

1

.

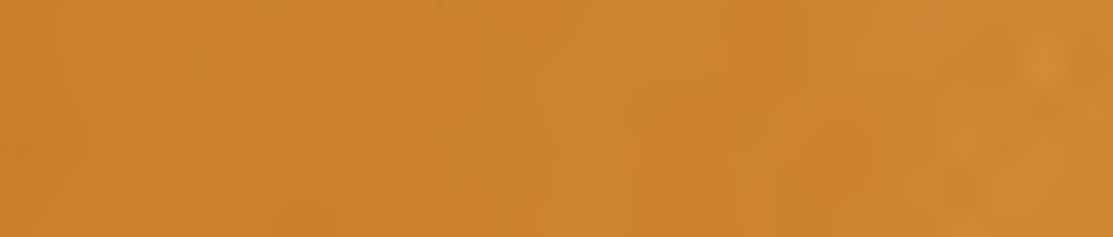

; a

1)

n

? 
THE ONION

The name "onion" originated from the Latin name unio, meaning oneness or unity, or a kind of single onion. A native of Central Asia, onion is now grown in more than 140 countries under temperate to tropical conditions. In India, onions have been adapted from very early times, before Christian era. Maharashtra, Karnataka, Gujarat, Bihar, Madhya Pradesh and Rajasthan are the main oniongrowing states in the country. Barring north-eastern states and Kerala, basically all states grow onion. A crop of high culinary importance in daily diet creates ripples in political circles when consumers face shortage of onion and market price goes high.

'The Onion' covers all aspects of the crop from its origin to marketing. In its eighteen chapters written by experts in the respective fields of onion, this monograph reviews status and prospects of onion research and development. It covers genetic resources, genetics, biotechnology, breeding, crop production, crop protection, seed production, physiology, biochemistry, processing and storage as well as price volatility aspects of onion. Each chapter presents complete information from historical aspects to latest times, supported by data, illustrations and references. Readers will find all information on onion in one spine in this book. This publication hopefully would be a source of rich information for students and researchers, and would be of great value for farmers and entrepreneurs alike.
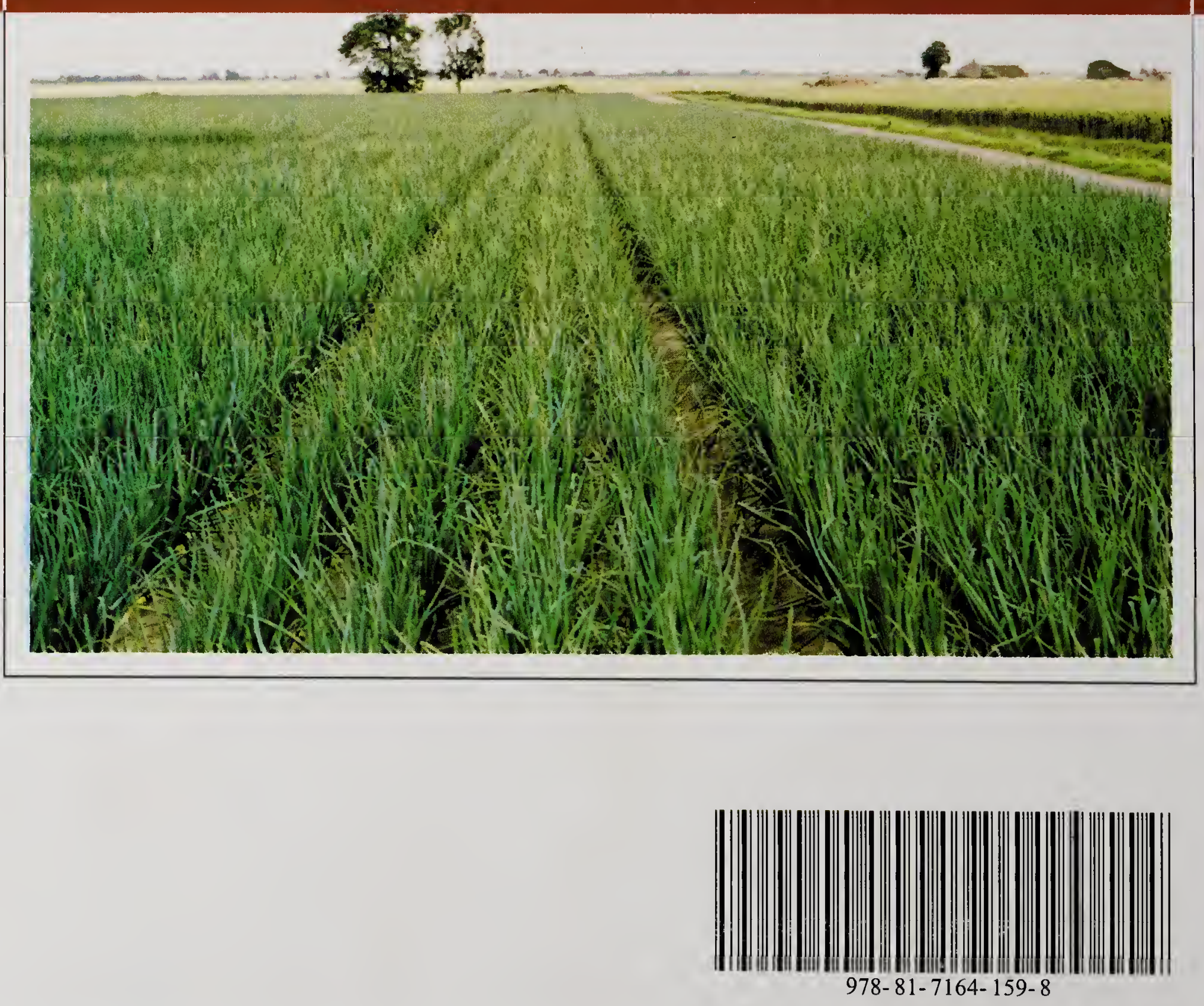